\title{
Stemmen zonder last : de functie van het vrije mandaat in het hedendaagse staatsrecht
}

Citation for published version (APA):

Kleijkers, R. M. M. (1993). Stemmen zonder last : de functie van het vrije mandaat in het hedendaagse staatsrecht. [Doctoral Thesis, Maastricht University]. Datawyse / Universitaire Pers Maastricht. https://doi.org/10.26481/dis.19931028rk

Document status and date:

Published: 01/01/1993

DOI:

10.26481/dis.19931028rk

Document Version:

Publisher's PDF, also known as Version of record

\section{Please check the document version of this publication:}

- A submitted manuscript is the version of the article upon submission and before peer-review. There can be important differences between the submitted version and the official published version of record.

People interested in the research are advised to contact the author for the final version of the publication, or visit the DOI to the publisher's website.

- The final author version and the galley proof are versions of the publication after peer review.

- The final published version features the final layout of the paper including the volume, issue and page numbers.

Link to publication

\footnotetext{
General rights rights.

- You may freely distribute the URL identifying the publication in the public portal. please follow below link for the End User Agreement:

www.umlib.nl/taverne-license

Take down policy

If you believe that this document breaches copyright please contact us at:

repository@maastrichtuniversity.nl

providing details and we will investigate your claim.
}

Copyright and moral rights for the publications made accessible in the public portal are retained by the authors and/or other copyright owners and it is a condition of accessing publications that users recognise and abide by the legal requirements associated with these

- Users may download and print one copy of any publication from the public portal for the purpose of private study or research.

- You may not further distribute the material or use it for any profit-making activity or commercial gain

If the publication is distributed under the terms of Article $25 \mathrm{fa}$ of the Dutch Copyright Act, indicated by the "Taverne" license above, 


\section{STEMMEN ZONDER LAST}

De functie van het vrije mandaat in het hedendaagse staatsrecht 


\section{Promotoren:}

Prof. mr. C. Flinterman

Prof. mr. F.A.M. Stroink

Beoordelingscommissie:

Prof. mr. A.Q.C. Tak, voorzitter

Prof. mr. E.C.M. Jurgens

Prof. mr. D.J. Elzinga (Rijksuniversiteit Groningen) 


\section{INHOUDSOPGAVE}

1 INLEIDING

1.1 Controverses over vertegenwoordiging in het staatsrecht

1.2 Burke's (liberale) theorie van de representatieve democratie

1.3 De liberale theorie als constitutionele norm in het Nederlandse staatsrecht

1.4 De bezwaren van de liberale theorie

1.5 Probleemstelling en opzet van het onderzoek

2 THEORIEEN OVER STAATSRECHTELIJKE VERTEGENWOORDIGING

2.1 Inleiding

2.2 Juridische betekenissen van het begrip vertegenwoordiging

2.3 Staatsrechtelijke vertegenwoordiging

2.4 Het ontstaan van het staatsrechtelijke vertegenwoordigingsbegrip

2.5 Vertegenwoordiging in het staatsrecht: Burke's paradigma

2.6 Staatsrechtelijke vertegenwoordiging op het Europese vasteland

2.7 Een nieuwe mandaatstheorie

2.8 Theorieën: politicologische benadering 
VERTEGENWOORDIGING IN NEDERLAND

3.1 Inleiding

3.2 De staatkundige situatie rond 1581

3.3 De functie van de Gewestelijke Staten

3.3.1 De Gewestelijke Staten in de Republiek

3.4 De positie van de Staten-Generaal

3.5 De ontwikkeling van het gebod van last

en ruggespraak

3.5.1 Vormgeving van de instucties

3.5.2 De inhoud van de instructies

3.6 De invloed van het gebod op het besluitvormingsproces

3.6.1 De Republiek in verval

3.7 Van gebod naar verbod: de Bataafse Republiek

3.8 Staatsrechtelijke vertegenwoordiging 1814-1848

3.9 Grondwet 1848

3.10 Staatsrechtelijke vertegenwoordiging 1848-1900

3.11 Staatsrechtelijke vertegenwoordiging 1900-1945

3.12 Staatsrechtelijke vertegenwoordiging na 1945

4 DE ONAFHANKELIJKHEID VAN DE VOLKSVERTEGENWOORDIGER IN DUITSLAND

4.1 Inleiding

4.2 De ontwikkeling van het vrije mandaat in het Duitse staatsrecht

4.2.1 Het Duitse rijk in de 19e eeuw

4.2.2 De Republiek van Weimar en het Hitlerregime

4.2.3 Duitsland na de Tweede Wereldoorlog 149

4.3 De norm van art. 20 GG

4.4 De onafhankelijke volksvertegenwoordiger: art. $38 \mathrm{GG}$

4.4.1 Vertreter des ganzen Volkes 
4.5 De rol van de politieke partijen: art. $21 \mathrm{GG}$

4.5.1 Historische ontwikkeling van de politieke partijen

4.5.2 Het begrip 'politieke partij'

4.5.3 De functie van de politieke partij

4.5.4 De positie van de fracties

4.6 Partijenstaat versus representatieve democratie:

het Spannungsverhältnis tussen art. 21 en art. 38 GG

5 DE ONAFHANKELIJKHEID VAN DE

VOLKSVERTEGENWOORDIGER IN HET VERENIGD KONINKRIJK

5.1 Inleiding

5.2 Beginselen en bronnen van het Britse staatsrecht

5.3 De ontwikkeling van het vrije mandaat in het Britse staatsrecht

5.3.1 Ontstaan van het Engelse parlement

5.3.2 Opkomst parlementair stelsel

5.3.3 Het Verenigd Koninkrijk in de 19e eeuw

5.4 De vertegenwoordigingsgedachte in het Britse staatsrecht: de mandate doctrine

5.5 De relatie tussen de MP en de centrale en parlementaire partijorganisatie

5.5.1 De rol van de centrale partijorganisatie

5.5.2 De Whips en the whip

5.6 De relatie tussen de MP en zijn lokale partij en kiezers

5.6.1 Constituency surgery

\section{HET VRIJE MANDAAT IN HET HEDENDAAGSE STAATSRECHT}

6.1 Inleiding

6.2 Onafhankelijkheid als constitutionele norm 
6.3 Beperkte onafhankelijkheid als staatkundige praktijk

6.3.1 Relatie volksvertegenwoordiger - kiezer $\quad 2.50$

6.3.2 Relatie volksvertegenwoordiger politieke partij

6.3.3 Relatie volksvertegenwoordiger - fractie

6.4 De betekenis van het vrije mandaat voor het Nederlandse staatsrecht nader beschouwd

6.4.1 Huidige betekenis: de restfunctie van het verbod van last

6.5 De meerwaarde van het vrije mandaat in het staatsrecht

6.5.1 Meer dan een restfunctie

274

6.5.2 De praktische waarde van de functies 


\section{INLEIDING}

\subsection{Controverses over vertegenwoordiging in het staatsrecht}

Vertegenwoordiging is een machtsinstrument. Zeker wanneer een vertegenwoordiging zich manifesteert als volksvertegenwoordiging is dit het geval. Een kleine groep (de vertegenwoordigers of afgevaardigden) wordt aangewezen door een grotere groep om deel te nemen aan de wetgevende en/of bestuurlijke activiteiten van een staat. Een dergelijke vertegenwoordiging, veelal aangeduid als politieke of staatsrechtelijke vertegenwoordiging, beperkt de macht van het bestuur, maar ook die van de bestuurden. Zij vormt het intermediair tussen bestuur en bestuurden, door parlementaire rechten en gebruiken toegerust met eigen machtsmiddelen. Zo beschouwd is vertegenwoordiging een "institutional technique by which power is structured in a political society".

Over deze vorm van vertegenwoordiging bestaat een aantal uitgebreide controverses. $\mathrm{Zo}$ is er grote verdeeldheid en onduidelijkheid over de inhoud van het begrip. Vaak wagen auteurs zich zelfs in het geheel niet aan een poging een (duidelijke) definitie te vinden. ${ }^{2}$

Zonder voorbij te willen gaan aan de problemen rond de definiëring van het begrip ${ }^{3}$, staat in dit proefschrift een andere controverse over vertegenwoordiging in het staatsrecht centraal. Deze betreft de relatie tussen volksvertegenwoordigers en vertegenwoordigden: moeten eerstgenoemden

1. N.L. Schwartz, The blue guitar: political representation and community, Chicago 1988, p. 23.

2. Zo wijdt J.S. Mill, een van de meest invloedrijke $19 \mathrm{e}$ eeuwse theoretici over het algemeen kiesrecht, een heel boek (Considerations concerning representative government, Londen 1861) aan 'representative government' zonder daarbij het begrip 'representation' te definiëren of een verband te leggen tussen beide begrippen.

3. Zie hiervoor $\S 2$ en $\S 3$ van het volgende hoofdstuk. 
zich richten naar de wensen van de laatsten en daarom onderworpen worden aan bindende mandaten en instructies? Of dienen zij bij hun optreden als vertegenwoordigers juist naar eigen inzicht te handelen? Dit is "undoubtedly the central classic controversy in the literature of politica! representation". ${ }^{4} \mathrm{Zij}$ staat bekend als de delegate - trustee controversy.

In de 'delegate'-opvatting worden de volksvertegenwoordigers gezien als lasthebbers die geacht worden te handelen naar de uitdrukkelijke instructies van hun achterban. $\mathrm{Zij}$ beschikken dus over een bindend mandaat. In haar meest extreme variant betekent deze opvatting dat de volksvertegenwoordigers hun bijdragen in het vertegenwoordigend lichaam tot het verwoorden van deze instructies dienen te beperken. Zij functioneren dan letterlijk als spreekbuis voor de opvattingen van degenen die zij vertegenwoordigen en ontlenen hun bestaansrecht slechts aan het gegeven dat hun achterban zelf niet in het vertegenwoordigend lichaam aanwezig kan of wil zijn.

Minder extreem is de variant van de 'delegate'-opvatting waarin het de afgevaardigden tot op zekere hogere is toegestaan naar hun eigen oordeel en inzichten te handelen, mits zij daarbij de belangen van hun achterban voor ogen houden. Deze gedeeltelijke handelingsvrijheid wordt hen gegeven omdat het nu eenmaal onmogelijk is voor elk onderwerp waarmee zij bij hun werkzaamheden worden geconfronteerd, instructies te geven. Evenmin kan van de vertegenwoordigden worden verwacht dat hun denkbeelden dusdanig uniform zijn dat steeds tot een eensluidende instructie kan worden gekomen. Maar ook in deze variant blijft het kernpunt dat als door de vertegenwoordigden instructies zijn gegeven, deze de opstelling van de afgevaardigden in het vertegenwoordigend lichaam behoren te bepalen. ${ }^{5}$ Aan deze variant is verwant de opvatting waarin de afgevaardigden enige handelingsvrijheid hebben zolang zich geen nieuwe of controversiële onderwerpen aandienen. Wanneer dit wel het geval is, worden zij geacht met hun achterban overleg te plegen alvorens hun standpunten in het vertegenwoordigend lichaam kenbaar te maken. De instructies die zij in dit overleg krijgen dienen zij op te volgen; wanneer zij dit niet doen behoren zij af te treden. ${ }^{6}$

4. H.F. Pitkin, The concept of representation, Berkely 1967, p. 145.

5. Vergl. P.E. Converse/R. Pierce, Political representation in France, Cambridge 1986, p. 493.

6. Vergl. Pitkin, a.w., p. 146. 
De tegenpool van de 'delegate'-opvatting, de 'trustee'-opvatting, ziet de leden van een vertegenwoordigend lichaam niet als lasthebbers van hun kiezers, maar als onafhankelijke gevolmachtigden. Zij beschikken over een vrij mandaat. De meest extreme variant van deze opvatting ontkent het bestaan van een relatie tussen vertegenwoordigers en vertegenwoordigden; deze laatsten zijn slechts "an administrative recruitment device to find a few good men".? De vertegenwoordigers worden gezien als de experts; het vervullen van de taken van het vertegenwoordigend lichaam wordt te complex geacht voor de gemiddelde burger. ${ }^{8}$ Op grond van deze superioriteit hebben de afgevaardigden geen enkele verplichting ten opzichte van hun kiezers; zelfs aan uitdrukkelijke verkiezingsbeloften kunnen zij niet worden gehouden. ${ }^{9}$

De minder extreme en daarom meer gangbare interpretatie van de 'trustee'opvatting gaat uit van een relatie tussen de afgevaardigden en hun achterban waarin de eigen verantwoordelijkheid en handelingsvrijheid van eerstgenoemden overheersen. Deze variant heeft zijn bekendheid vooral te danken aan de Whigs, in de $17 \mathrm{e}$ en $18 \mathrm{e}$ eeuw de meest invloedrijke politieke beweging binnen het parlement van het Verenigd Koninkrijk. De onafhankelijkheid van de afgevaardigden in het parlement vormde een belangrijk element van hun staatkundige opvattingen. Na de Reform Act van 1832 verdwenen de Whigs uit het Britse parlement, maar de meeste elementen van hun staatsleer bleven in de Britse constitutie behouden en werden overgenomen in de staatsleren van andere politieke stromingen in het Verenigd Koninkrijk. ${ }^{10}$ Ook in de constituties van een groot aantal andere westerse staten hebben de opvattingen van de Whigs hun sporen nagelaten. ${ }^{11}$

7. Converse/Pierce, a.w., p. 493.

8. Vergl. Pitkin, a.w., p. 147.

9. Idem, p. 146.

10. Vergl. A. Young, The reselection of MPs, Londen 1983, p. 19; S.H. Beer, Modern British politics. Parties and pressure groups in the collectivist age, 3e druk, Londen 1982, p. 19.

11. Dat geldt niet alleen voor hun opvattingen over de rol van de volksvertegenwoordigers; vergl. Schwartz, a.w., p. 5. 


\subsection{Burke's (liberale) theorie van de representatieve democratie}

De persoon die op het punt van de 'trustee'-opvatting geldt als de belichaming van de opvattingen van de Whigs is de Britse staatsman en politiek filosoof Edmund Burke (1729-1797). Burke is in de geschiedenis een ambivalente waardering ten deel gevallen. Aan de ene kant staat hij te boek als een gematigd progressief hervormer die zich in zijn geschriften en toespraken afzette tegen de vergaande invloed van het Britse hof op het $18 \mathrm{e}$ eeuwse parlement, die de wijze waarop het Britse imperialisme zich manifesteerde in de Verenigde Staten, Ierland en India afwees en die zich een vurig voorstander toonde van godsdienstvrijheid en parlementaire hervormingen. ${ }^{12}$ Aan de andere kant staat hij echter ook bekend als aartsconservatief vanwege zijn ondemocratische en reactionaire opvattingen waarin hij zich aanhanger toonde van de gevestigde hiërarchische structuren in de Britse maatschappij, waarin hij het standpunt huldigde dat bestaande wetten, gewoonten en (voor)rechten van de adel dienden te worden gerespecteerd en waarin hij de maatschappij zag als een "organism embodying a divinely-given moral order". ${ }^{13}$

De tegenstrijdigheden in Burke's opvattingen zijn voor een deel te verklaren doordat hij in zijn werken niet poogde tot een allesomvattende politieke theorie te komen; zijn doel was veeleer gericht op het naar voren brengen van in de praktijk bruikbare theorieën. ${ }^{14}$ Daardoor kon het voorkomen dat enkele van zijn denkbeelden niet geheel met elkaar in overeenstemming waren te brengen. Dat Burke's denkbeelden soms in hoge mate volstrekt aan elkaar tegengesteld zijn, en elkaar zelfs op sommige punten lijken uit te sluiten, heeft echter een andere reden. Deze is gelegen in Burke's afkeer van de Franse revolutie en haar denkbeelden en zijn angst dat de revolutionaire tendensen in Frankrijk naar het Verenigd Koninkrijk zouden overslaan. De geschriften waarin hij deze opvattingen uiteenzet, Reflections on the Revolution in France uit 1790 en het een jaar later geschreven $A n$ Appeal from the New to the Old Whigs, zijn de hoofdoorzaak van de deels

12. Vergl. B.W. Hill, Edmund Burke. On government, politics and society, Brighton 1975, p. 7; C.B. Macpherson, Burke, Oxford 1980, p. 3.

13. Macpherson, a.w., p. 4. Zie ook: G.H. Sabine/Th. L. Thorson, A history of political theory, $4 \mathrm{e}$ druk, Hinsdale 1973, p. 557/558.

14. Vergl. Hill, a.w., p. 8. 
negatieve waardering die hem ten deel is gevallen. ${ }^{15}$ Met name Reflections heeft verbazing gewekt vanwege de reactionaire toonzetting; volgens sommigen was Burke niet toerekeningsvatbaar toen hij het werk schreef en moet een oordeel erover met de nodige afstandelijkheid ten opzichte van zijn eerdere werk gegeven worden. ${ }^{16}$

Dat eerdere werk is reden voor een meer positieve waardering van Burke's denkbeelden. Zo is hij de eerste die het belang van de vorming van politieke partijen onderkent, al heeft hij daarbij vooral het oog op de (functie van) partijvorming binnen het parlement. Zijn grootste verdienste voor het hedendaagse staatsrecht betreft echter zijn opvattingen over de relatie tussen kiezers en gekozenen en de eigen verantwoordelijkheid die laatstgenoemden binnen deze relatie hebben. Door zijn opvattingen over vertegenwoordiging in het staatsrecht -en ook de wijze waarop hij deze verwoordde- geldt Burke als de vormgever van de liberale theorie van de representatieve democratie, hoewel hij bepaald niet de eerste was die deze theorie verkondigde en haar zeker niet zelf als liberaal zou hebben betiteld. ${ }^{17}$ Burke's theorie van de representatieve democratie bevat een drietal kenmerken. Allereerst worden de volksvertegenwoordigers niet gezien als lasthebbers ('delegates') maar als gevolmachtigden ('trustees') van hun kiezers. Voorts worden zij geacht -in samenwerking met het bestuur- het algemeen belang van de natie te behartigen en niet het bijzondere belang van de kiezers of een groep kiezers. De exacte inhoud van dit algemeen belang laat zich moeilijk bepalen en kan van geval tot geval verschillen. Maar in ieder geval is de invulling van dit begrip onverenigbaar met de exclusieve vertegenwoordiging door de afgevaardigden van belangen van bepaalde (bevolkings)groepen of individuen. Een derde kenmerk is het

15. E. Burke, Reflections on the revolution in France and on the proceedings in certain societies in London relative to that event, in: The works of the Right Honourable Edmund Burke, deel 4, Londen 1906/1907; An appeal from the new to the old Whigs in consequence of some late discussions in parliament relative to the reflections on the French revolution, in: Works, a.w. (deel 5). Hoewel in dit laatste werk in de derde persoon enkelvoud over Burke gesproken wordt, staat buiten twijfel dat Burke hier zelf aan het woord is, ter verdediging van de kritiek die hem binnen zijn eigen partij ten deel was gevallen naar aanleiding van het verschijnen van de Reflections.

16. Vergl. Macpherson, a.w., p. 4.

17. Zie hieronder, hoofdstuk 2. 
vertrouwen in de rede. In het parlement komen de volksvertegenwoordigers bijeen om op basis van uitwisseling van gedachten tot besluitvorming te komen. Deze besluitvorming komt niet yoort uit de wil of de opvattingen van de kiezers, maar uit redelijk parlementair overleg. Deze kenmerken brengen met zich mee dat de volksvertegenwoordigers ten opzichte van hun kiezers een vrij mandaat hebben teneinde hun onafhankelijkheid te garanderen. ${ }^{18}$

Burke's opvattingen over vertegenwoordiging zijn in de $19 \mathrm{e}$ eeuw geleidelijk in de meeste westerse landen tot constitutionele standaard verheven. Als zodanig zijn zij ook in de 20 e eeuw van waarde. Nog steeds is het vrije mandaat als waarborg voor de ongebondenheid van de individuele volksvertegenwoordiger een belangrijke factor in het hedendaagse staatsrecht.

\subsection{De liberale theorie als constitutionele norm in het Nederlandse staatsrecht}

Ook in het Nederlandse staatsrecht is de liberale theorie van de representatieve democratie nog steeds het ijkpunt voor de relatie tussen kiezers en gekozenen. Die relatie lijkt in hoge mate nog bepaald te worden door de invulling die de grondwetgever bij de vorming van het Koninkrijk der Nederlanden daaraan gegeven heeft. De vele veranderingen die zich sindsdien op het constitutioneel vlak hebben voorgedaan, hebben niet of nauwelijks hun weerslag in de Grondwet gevonden. Het lijkt zelfs alsof de grondwetgever sinds de ingrijpende en fundamentele wijziging van de grondwet in 1848 (!) de opvatting huldigt dat de Grondwet een voldoende stevig fundament is voor de ontwikkeling van een gezond staatkundig leven; een ontwikkeling die direct of indirect wordt genormeerd door het constitutionele geschreven recht. ${ }^{19}$ De begrippen en de instellingen van dat constitutionele geschreven recht zijn in ieder geval sinds de $19 \mathrm{e}$ eeuw niet wezenlijk veranderd of aangepast. Daarmee is niet gezegd dat er geen veranderingen of aanpassingen hebben plaatsgevonden. Dat is -zoals

18. Vergl. J.J.A. Thomassen, Politieke representatie, in: J.J.A. Thomassen (red.), Hedendaagse democratie, Alphen aan den Rijn 1991, p. 170/171.

19. Vergl. A.H.M. Dölle, Over ongeschreven staatsrecht, Groningen 1988, p. 15. 
gezegd- wel degelijk het geval. De begrippen en instellingen van het constitutionele recht hebben sinds 1848 herhaaldelijk verandering c.q. aanpassing ondergaan, echter zonder dat de grondwetgever daar expliciet uitdrukking aan heeft gegeven. Het lijkt alsof de grondwetgever "er zich nog altijd mee tevreden stelt, daarvan zo min mogelijk te zeggen en het oude jargon en de oude begrippen en termen heeft aangehouden alsof de zaak op dezelfde voet ware voortgezet". ${ }^{20}$ Deze constatering van Donner uit 1961, een jaar later min of meer herhaald door Van der Hoeven ${ }^{21}$, heeft ook na de jongste grondwetsherzieningen nauwelijks aan betekenis verloren.

Donners constatering is ook van toepassing op de positie van de leden van die organen binnen het constitutionele recht die geacht moeten worden het Nederlandse volk te vertegenwoordigen. Het grondwettelijk en kieswettelijk recht lijken op dit punt nog steeds dezelfde betekenis te hebben als in de vorige eeuw: de vrije keuze van de kiezer en de ongebondenheid van de volksvertegenwoordiger vormen op het eerste gezicht ook in de tegenwoordige tijd nog het hart van de vertegenwoordigende kiezersdemocratie. ${ }^{22}$ Naar de letter van de Grondwet heeft de individuele volksvertegenwoordiger daarom nog steeds een vrij mandaat en is zijn onafhankelijkheid absoluut. ${ }^{23}$ De leden van de Staten-Generaal vertegenwoordigen het gehele Nederlandse volk (art. $50 \mathrm{Gw}$.), en om te voorkomen dat zij daarbij athankelijk (kunnen) worden van een bepaald, al dan niet in een organisatorisch

20. A.M. Donner, De plaats van de Staten-Generaal in het hedendaagse staatsrecht (Preadvies Calvinistische Juristenvereniging 1961), in: Tussen het echte en het gemaake, Zwolle 1986, p. 125.

21. "Terwijl (...) de scheppers van de grondwet een bepaald beeld voor ogen stond van het politieke en sociale krachtenveld, en zij hun arbeid richtten op een daarop aansluitende institutionalisering, treden in de loop des tijds ook hier structuurveranderingen op, waardoor de door de grondwet geschapen instellingen en de daaraan gegeven organisatie, zoals deze door de grondwetgever waren gedacht, geleidelijk minder goed op de politieke en sociale werkelijkheid aansluiten." (J. van der Hoeven, De waarde van de grondwet, Zwolle 1962, p. 19).

22. D.J. Elzinga, Partijbinding en politieke moraliteit, in: R.A. Koole (red.), Het belang van politieke partijen, Groningen 1984, p. 165.

23. Bij het zelfstandig namwoord volksveriegenwoordiger en het bijbehorende bezittelijk voornaamwoord zijn moeten in dit boek ook volksvertegenwoordigster en het bijbehorende haar worden gelezen. 
verband opererend gedeelte daarvan dienen zij te stemmen zonder last (art. 67 lid $3 \mathrm{Gw}$.). Het innemen van een bepaald standpunt in de vergadering van de Staten-Generaal mag dus niet geschieden wanneer die standpuntbepaling berust op een opdracht die de leden van de Staten-Generaal daartoe van een of meer anderen hebben ontvangen. Tot aan de grondwetsherziening van 1983 kende dit verbod een ruimere omschrijving, in die zin dat het de leden van de Staten-Generaal eveneens verboden was met anderen overleg (ruggespraak) te plegen. ${ }^{24}$ Art. 129 lid $6 \mathrm{Gw}$. bevat het lastverbod voor leden van de provinciale staten en van de gemeenteraad.

De bepaling dat de Staten-Generaal het gehele Nederlandse volk vertegenwoordigen neemt in de Grondwet een prominente plaats in. In de opeenvolgende grondwetten van het Koninkrijk der Nederlanden is zij steevast terug te vinden aan het begin van het hoofdstuk over de StatenGeneraal. Het artikel stelt de norm voor het optreden van de leden van de Staten-Generaal: zij dienen de belangen van het gehele volk te behartigen en mogen geen vertegenwoordigers zijn van deelbelangen of groepen van personen. De volksvertegenwoordigers hebben
"een opdracht tot handelen en besluiten voor degenen die dat zelf niet kunnen omdat zij te veel in aantal zijn, te verspreid wonen, niet deskundig genoeg zijn en, vooral, wel wat anders te doen hebben. Krachtens die opdracht geeft de medewerking van de volksvertegenwoordiging aan de wet verhoogd gezag en haar toezicht inhoud aan de eis van verantwoordelijke regering en verantwoordelijk bestuur. ${ }^{25}$

De bepaling van het verbod van last en ruggespraak neemt in de Grondwet een minder prominente plaats in. $\mathrm{Zij}$ is nauw verbonden met de grondwettelijke bepaling betreffende de eed (c.q. belofte) die de leden van de StatenGeneraal moeten afleggen. In alle grondwetten van het Koninkrijk gaat de bepaling van het verbod van last en ruggespraak dan ook aan die van de eed vooraf. ${ }^{26}$ Daarnaast is zij ook nauw verwant met die van art. $50 \mathrm{Gw}$.: zij houdt de voorwaarde in die moet bewerkstelligen dat de Staten-Generaal

24. Laatstelijk art. $96 \mathrm{Gw}$. 1972: "De leden stemmen zonder last of ruggespraak met hen, die benoemen."

25. C.W. van der Pot/A.M. Donner, Handboek van het Nederlandse staatsrecht, $12 \mathrm{e}$ druk, bewerkt door L. Prakke (e.a.), Zwolle 1989, p. 421.

26. Een uitzondering vormt de Grondwet van 1814 , waarin beide bepalingen in één artikel waren opgenomen. 
inderdaad het gehele Nederlandse volk vertegenwoordigen. ${ }^{27}$ De verbodsbepaling maakt de bepaling van art. $50 \mathrm{Gw}$. dus pas echt effectief. De leden van de Staten-Generaal kunnen alleen dan daadwerkelijk het gehele Nederlandse volk vertegenwoordigen wanneer zij van niemand afhankelijk zijn. Beide bepalingen vinden hun basis in de gedachte dat de StatenGeneraal als één onafhankelijk orgaan optreden, waarvan de leden moeten trachten "die ongrijpbare grootheden, de 'volkswil' en 'het algemeen belang', te vinden en te verdedigen". ${ }^{28}$ Daarmee vormen zij de constitutionele bevestiging van de liberale theorie van de representatieve democratie in Nederland.

\subsection{De bezwaren van de liberale theorie}

Hoewel de liberale theorie van de representatieve democratie reeds lange tijd constitutionele erkenning geniet, kan niet gezegd worden dat zij geheel zonder bezwaren is en in de praktijk in alle opzichten voldoet. Er zijn twee gebreken te onderscheiden. Het eerste gebrek is inherent aan de betekenis die sinds het einde van de $17 \mathrm{e}$ eeuw aan het vertegenwoordigingsbegrip in het staatsrecht gegeven wordt. Het wezen van vertegenwoordiging is dat iets wat niet tegenwoordig is toch in zekere zin tegenwoordig wordt gemaakt. ${ }^{29}$ Ook de geschiedenis van dit begrip wijst daarop. Vroeger betekende vertegenwoordigen tegenwoordig zijn; het synoniem representeren is afgeleid van het Latijnse werkwoord 'repraesentare', dat aanschouwelijk maken, voor iemand brengen, (ver)tonen betekent. In Engeland, waar het staatsrechtelijke vertegenwoordigingsbegrip zich voor het eerst in zijn moderne gedaante manifesteerde, maakte het werkwoord 'to represent' een zelfde ontwikkeling door. Rond 1380 betekende het werk-

27. Tweede Kamer 1978-1979, 14 222, nr. 6, p. 6.

28. Donner, a.w. p. 128.

29. Vergl. onder meer: Pitkin, a.w., p. 8/9; G. Leibholz, Das Wesen der Repräsentation und der Gestaltwandel der Demokratie im 20. Jahrhundert, 3e druk, Berlijn 1966, p. 26; A. Hoogerwerf, De geachte afgevaardigde. Over de veriegenwoordigende rol van her parlementslid, Meppel 1958, p. 5. 
woord slechts 'to bring into presence'. ${ }^{30}$ Geleidelijk kreeg het de betekenis van het staan van het deel voor het geheel, het vervangen van velen door éen en het weerspiegelen van een geheel volk in een parlement. ${ }^{31}$ In deze laatste betekenis is tevens de problematiek van het vertegenwoordigen tot uitdrukking gebracht. De mogelijkheid van afstand en spanning tussen vertegenwoordiger en vertegenwoordigde is in het woord vertegenwoordigen voelbaar. In de woorden van Van der Burg: "Vertegenwoordiging brengt noodzakelijk een zekere afstand, een zekere vervreemding tussen kiezer en gekozene mee". ${ }^{32}$

Deze vervreemding tussen kiezer en gekozene manifesteert zich in feite reeds vanaf het moment dat de liberale theorie van de representatieve democratie constitutioneel gemeengoed is geworden. Toch wordt zij echter pas in de $2 \mathrm{e}$ helft van de $20 \mathrm{e}$ eeuw in toenemende mate als een bezwaar ervaren. In deze periode zijn de kiezers meer interesse gaan vertonen in het functioneren van de volksvertegenwoordiging. Zij willen hun rol niet meer beperkt zien tot het regelmatig uitbrengen van hun stem, maar ook tussentijds een zekere mate van participatie hebben. Als gevolg van deze grotere betrokkenheid bij de besluitvorming wensen de kiezers meer controlemogelijkheden en inspraak; ze zijn mondiger geworden en verwachten, zeker wanneer zij zich hebben georganiseerd in belangengroepen, dat de volksvertegenwoordiger bij het bepalen van zijn standpunt rekening zal houden met hun wensen. Aan deze verwachting wordt in de praktijk door de volksvertegenwoordigers niet of nauwelijks voldaan, waardoor de onvrede van de kiezers blijft bestaan.

Deze onvrede wordt nog vergroot door het tweede gebrek dat aan de liberale theorie van de representatieve democratie kleeft: de onmiskenbaar belangrijke rol die de politieke partijen in het huidige staatsbestel vervullen

30. Zie uitvoeriger over de historische ontwikkeling van het begrip: Pitkin, a.w., pp. 241-252, alsmede H.R. Nord, Historische ontwikkeling en beteekenis van de representatiegedachte in het staatsrech, Leiden 1941, hfdst. 1 .

31. Vergl. Hoogenwerf, a.w., p. 5: Nord, a.w., pp. 1-3.

32. F.H. van der Burg, Overheid en onderdaan in een representatieve democratie (preadvies VAR), Haarlem 1970, p. 6 en dez., Representatie en participarie, Deventer 1973, p. 6. Zie ook Pitkin, a.w., p. 9, die in dit verband spreekt van een "fundamental dualism" dat van het begrip vertegenwoordigen deel uit maakt. 
laat zich moeilijk met de theorie in overeenstemming brengen. De eis van onafhankelijkheid van de volksvertegenwoordiger zoals die in de liberale theorie van de representatieve democratie naar voren komt, blijkt in praktijk door het functioneren van de politieke partijen in vergaande mate beperkt te zijn. Vooral in de relatie tot zijn eigen partij en fractie lijkt er voor de volksvertegenwoordiger weinig onathankelijkheid te resteren. Door de ontwikkeling van de politieke partijen met hun hiërarchische organisatie, de steeds gedetailleerder wordende verkiezings- en partijprogramma's (die de aspirant-volksvertegenwoordigers doorgaans van te voren dienen te onderschrijven), de strikt geformuleerde regeeraccoorden en de vergaande fractie-invloed op de individuele volksvertegenwoordiger, is deze juist zeer afhankelijk geworden van zijn partij en fractie. In een enkel geval is deze afhankelijkheid als dusdanig vergaand ervaren dat een beroep op de rechter werd gedaan teneinde de onafhankelijkheid van de volksvertegenwoordiger ten opzichte van zijn partij en fractie te herstellen. ${ }^{33}$

De constitutionele norm dat de kiezer beslist over de aanwijzing van volksvertegenwoordigers gaat schuil achter de praktijk, waarin de politieke partijorganisatie de kandidaatstelling en het verkiezingsproces beheerst en waarin de partijstandpunten prevaleren boven de opvattingen van de kiezers. De kiezer stemt op de lijst of op een bepaalde kandidaat van een politieke partij. De facto is het dus niet de kiezer, maar de partijorganisatie die de (potentiële) volksvertegenwoordiger aanwijst. ${ }^{34}$ Hoewel de Grondwet ook thans geen enkele indicatie in deze richting geeft, heeft zich een verschuiving voorgedaan van kiezersdemocratie naar partijendemocratie. Een verschuiving die de vraag opwerpt of de volksvertegenwoordiger nog wel geacht kan worden een vertegenwoordiger van de kiezers (c.q. het volk) te zijn,. of dat hij slechts een vertegenwoordiger van zijn partij geworden is.

Vooral op centraal niveau is de verschuiving van kiezersdemocratie naar partijendemocratie significant. Recent onderzoek heeft aangetoond dat de meerderheid van de leden van de Tweede Kamer zich niet primair als volksvertegenwoordiger in de letterlijke betekenis van het woord beschouwt: bijna tweederde ziet zich in de eerste plaats als vertegenwoordiger

33. Zie hierover hoofdstuk 6.

34. Vergl. Elzinga, Partijbinding en politieke moraliteit, a.w., p. 165. 
van (de kiezers van) zijn politieke partij..$^{35}$ Deze rolopvatting wordt vooral door kamerleden aan de linkerzijde van het politieke spectrum aangehangen. Naast de -grondwettelijk vastgelegde- relatie tussen gekozene en kiezer, heeft de staatkundige praktijk gezorgd voor een (innige) relatie tussen gekozene en partij. De Staten-Generaal hebben hun zelfstandige positie verloren en zijn een registratie-forum geworden van in fractieverband genomen beslissingen. Deze ontwikkeling heeft geleid tot een ingrijpende positieverandering van de individuele volksvertegenwoordiger. Niet langer vormen zijn eigen oordeel en inzicht de doorslaggevende maatstaven voor de te nemen beslissingen, maar de opvattingen van zijn partij en zijn fractie in het parlement. ${ }^{36}$ In het eerdergenoemde onderzoek onder leden van de Tweede Kamer verklaarde slechts $11 \%$ bij stemmingen de eigen mening te zullen laten prevaleren wanneer deze zou afwijken van het fractiestandpunt. ${ }^{37}$ Het automatisch volgen van het fractiestandpunt wordt door $20 \%$ van de leden van de Tweede Kamer als uitgangspunt voor het stemgedrag gezien. De meeste leden laten het stemgedrag echter van de omstandigheden afhangen. Vooral het geweten wordt gezien als een omstandigheid die incidenteel en bij voorkeur met medeweten van de fractie c.q. de leiding daarvan- het laten prevaleren van de eigen mening toelaatbaar maakt. Wanneer er geen gewetenszaken in het geding zijn wordt door de leden van de Tweede Kamer als vuistregel genomen dat de fractiemening moet worden gevolgd. ${ }^{38}$

Deze ontwikkelingen hebben tot veel kritiek op het huidige staatsbestel in het algemeen en het functioneren van de volksvertegenwoordiging in het bijzonder geleid. De pogingen die sinds de jaren zestig zijn ondernomen om de vergaande vervreemding tussen de burger en de politiek en groei-

35. J.J.A. Thomassen/M.L. Zielonka-Goei, Het parlement als volksvertegenwoordiging, in: J.J.A. Thomassen/M.P.C.M. van Schendelen/M.L. Zielonka-Goei (red.), De geachte afgevaardigde ... Hoe kamerleden denken over het Nederlandse parlement, Muiderberg 1992, p. 199 en p. 221. Zie ook: M.L. Zielonka-Goei, Werk in uitvoering: taken en werkzaamheden van kamerleden, in: Thomassen/Van Schendelen/Zielonka-Goei, a.w., p. $54 / 55$.

36. Vergl. D.J. Elzinga, De politieke partij en het constiturionele recht, Nijmegen 1982, p. 6.

37. M.P.C.M. van Schendelen, Fracties en kamercommissies, in: Thomassen/Van Schendelen/Zielonka-Goei, a.w., p. 82.

38. Idem, p. 83. 
ende onvrede over de relatie tussen kiezer en gekozene tegen te gaan, hebben vooralsnog tot weinig concrete verbeteringen geleid. Nog steeds voeren de geluiden van onvrede de boventoon. Ook vanuit het parlement zelf wordt betoogd dat de volksvertegenwoordigers (c.q. een belangrijk deel daarvan) zijn verworden tot stemvee en carrière-jagers:

"(...) de fractieleden van het CDA in Tweede Kamer zijn toch tot stemvee verklaard? $\mathrm{Zij}$ volgen blindelings hun fractievoorzitter en die volgt weer blindelings de premier. (...) Voor veel CDA-leden is de Tweede Kamer het voorportaal van een verdere carrière in de overheidssfeer. Om maatschappelijk voonit te komen heeft het geen enkele zin de macht, de dragers ervan, tegen je in het harnas te jagen. Wat doe je dus? Je stelt je buitengewoon loyaal op en voor het overige houd je je gedeisd. ${ }^{39}$

\subsection{Probleemstelling en opzet van het onderzoek}

Uit het bovenstaande kan worden afgeleid dat er een grote discrepantie bestaat tussen de grondwettelijk geboden onafhankelijkheid van de volksvertegenwoordiger en de politieke praktijk, die van die onafhankelijkheid weinig heeft overgelaten. De bepalingen van de artt. 50 en 67 lid 3 Gw. lijken in de praktijk van weinig waarde te zijn. Met name de ontwikkelingen in de relatie tussen volksvertegenwoordiger en partij en de daarin vervatte mogelijkheid dat partijbelang gesteld gaat worden boven het algemeen belang, brengt het gevaar met zich dat de grondwettelijke voorschriften verworden tot een lege huls. ${ }^{40}$ De onafhankelijkheid van de volksvertegenwoordiger, zoals tot uitdrukking gebracht in het vereiste van het vrije mandaat, is thans niet meer dan een residu van hetgeen in de vorige eeuw werd beoogd..$^{41}$

De discrepantie tussen theorie en praktijk manifesteert zich niet alleen in Nederland, maar in elke staat waar de liberale theorie van de representatieve democratie onderdeel vormt van de constitutie. De waardevermin-

39. Aldus A. Kaland, (toenmalig) voorzitter van de CDA-Eerste Kamerfractie in een interview in HP/De Tijd, 18 oktober 1991, p. 23.

40. C.A.J.M. Kortmann, De Grondwetsherzieningen 1983 en 1987, 2e druk, Deventer 1987, p. $198 / 199$.

41. D.J. Elzinga/C. Wisse, De parlementaire fracties (Nederlands Parlementsrecht, deel 5), Groningen 1988, p. 169. 
dering van de betekenis van het vrije mandaat is daarom een universeel probleem. Hoewel de liberale theorie niet meer lijkt te passen in het moderne staatkundig bestel waarin aan politieke partijen en hun fracties in de vertegenwoordigende lichamen een belangrijke rol is toebedeeld, is zij opmerkelijk duurzaam gebleken. Vooral in situaties waarin er sprake is van een (dreigend) conflict tussen volksvertegenwoordigers en hun achterban weet het vrije mandaat zich verzekerd van een ruime aandacht.

Dit onderzoek richt zich op het bestaanrecht van het vrije mandaat in het hedendaagse staatsrecht. Het beoogt na te gaan welke functies (zowel normatief als feitelijk) thans nog aan het vrije mandaat kunnen worden toebedacht. Dit proefschrift richt zich daarmee op de tegenwoordige verhouding tussen leden van volksvertegenwoordigende organen enerzijds en hun kiezers en partijen anderzijds, toegespitst op de mate van onafhankelijkheid voor de volksvertegenwoordigers. Het gaat, met andere woorden, om de staatsrechtelijke positie van de individuele volksvertegenwoordiger. De onafhankelijkheid van de individuele volksvertegenwoordiger ten opzichte van anderen vormt bij de plaatsbepaling van die staatsrechtelijke positie een essentieel, zoniet het doorslaggevend element. Zijn taak, het vertegenwoordigen van het volk -criterium daarvoor is het ongrijpbare algemeen belang- kan hij alleen dan naar behoren uitoefenen wanneer hij niet afhankelijk is van anderen. Een onathankelijke opstelling is daarnaast ook noodzakelijk voor het effectief functioneren van het totaal van de volksvertegenwoordigers, het parlement. Aan de andere kant impliceert de liberale theorie dat volkswertegenwoordigers bepaalde verplichtingen ten opzichte van hun kiezers hebben en tot op zekere hoogte aan hen verantwoording schuldig zijn. De aard en omvang van hiervan wordt bepaald door de politieke cultuur in een staat en door de inrichting en ontwikkeling van het vertegenwoordigend lichaam waarvan de volksvertegenwoordigers deel uit maken. Bovendien kan een democratie in de huidige constellatie ook niet functioneren zonder het intermediair van de politieke partij, terwijl het effectief functioneren van het parlement gediend is met het bestaan van, en het werken in fracties.

De huidige functie van het vrije mandaat in het staatsrecht moet binnen deze randvoorwaarden worden gezocht. Allereerst zal in hoofdstuk 2 het begrip vertegenwoordiging, toegespitst op het staatsrechtelijke vertegenwoordigingsbegrip, aan de orde worden gesteld. Dit theoretisch kader van de huidige staatsrechtelijke positie van de volksvertegenwoordigers is vooral historisch bepaald. Bepaalde ontwikkelingen hebben denkbeelden en 
voorstellingen opgeroepen die op hun beurt de gang van zaken weer hebben beïnvloed. De verschillende perioden staan daarom niet los van elkaar, maar kunnen worden voorgesteld als een ontwikkeling naar de huidige situatie. Hoofdstuk 3 bevat daarom een beschrijving van de ontwikkeling in Nederland van de relatie tussen volksvertegenwoordiger en kiezer en tussen volksvertegenwoordiger en partij door de eeuwen heen. Aan de hand van een beschrijving van het besluitvormingsproces onder de Republiek der Verenigde Nederlanden wordt aangegeven waarom hier te lande indertijd gekozen is voor het verbod van last en ruggespraak als waarborg voor de onafhankelijkheid van de individuele volksvertegenwoordiger. Tevens zal worden nagegaan welke functie sindsdien aan het vrije mandaat is toegekend. De hoofdstukken 4 en 5 bevatten een soortgelijke beschrijving voor het Duitse en Britse staatsbestel. Voor de beschrijving van deze stelsels is gekozen vanwege de vele overeenkomsten (voor wat betreft Duitsland) en de vele verschillen (voor wat betreft het Verenigd Koninkrijk) met het Nederlandse stelsel. Daarnaast is beschrijving van de staatsrechtelijke positie van de individuele volksvertegenwoordiger in Duitsland interessant vanwege de grondwettelijke erkenning van de rol van de politieke partijen in het staatsbestel. Het slothoofdstuk tenslotte zal dieper ingaan op de functies die thans aan het vrije mandaat kunnen worden toegekend.

Opmerking verdient tenslotte dat het accent in dit onderzoek ligt op de beschrijving van de staatsrechtelijke positie van volksvertegenwoordigers op centraal niveau, en dan vooral nog die van rechtstreeks gekozen volksvertegenwoordigers. Mutatis mutandis geldt hetgeen hieronder wordt opgemerkt echter ook voor de leden van de volksvertegenwoordigende lichamen op provinciaal en gemeentelijk niveau. 
1

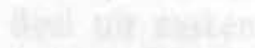

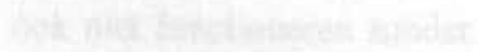

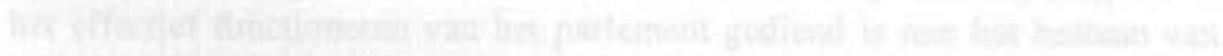

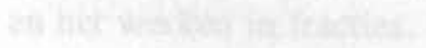

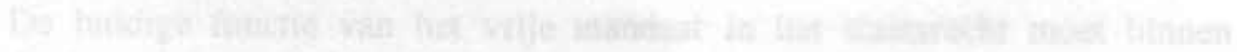

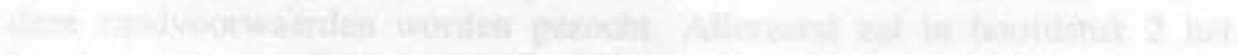

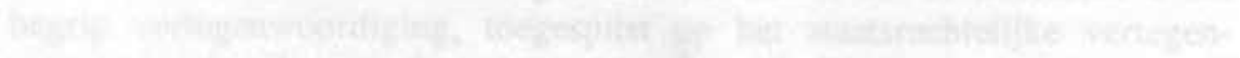

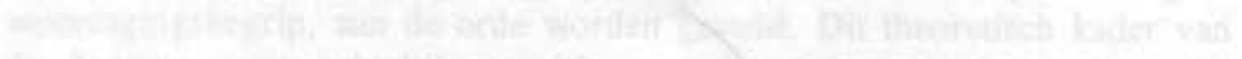

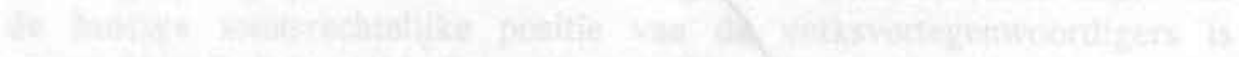
Whane 


\section{THEORIEEN OVER STAATSRECHTELIJKE: VERTEGENWOORDIGING}

\section{$2.1 \quad$ Inleiding}

Er bestaat een grote verscheidenheid aan opvattingen over de afbakening en de invulling van het begrip vertegenwoordiging. Niet ten onrechte verklaart Van Schendelen de uitspraak van Augustinus over het begrip tijd ("ieder weet precies wat ermee bedoeld wordt - tot hij gevraagd wordt het uit te leggen") mede van toepassing op het begrip vertegenwoordiging. ${ }^{1}$ Deze verscheidenheid wordt in de eerste plaats veroorzaakt doordat het begrip zich manifesteert op alle terreinen van het leven. Maar ook wanneer de betekenis wordt beperkt tot én terrein -het juridischeblijft de verscheidenheid nog groot.

Het is daarom noodzakelijk aandacht te besteden aan de diverse betekenissen van het begrip vertegenwoordiging, met name waar het de juridische betekenissen betreft. Deze juridische betekenissen van het begrip komen in paragraaf 2 aan de orde; in paragraaf 3 wordt vervolgens uitvoeriger ingegaan op een van deze juridische betekenissen van het begrip vertegenwoordiging. Dit is de vertegenwoordigingsfiguur die in dit werk centraal staat, de staatsrechtelijke vertegenwoordiging zoals die in verschillende mandaatstheorieën gestalte heeft gekregen. De paragrafen 4 en 5 zijn aan het ontstaan van deze vertegenwoordigingsfiguur gewijd, waarbij in paragraaf 5 vooral de rol van Burke daarbij belicht wordt. Zijn invloed op het ontstaan van de bekendste vorm van staatsrechtelijke vertegenwoordiging, het vrije c.q. representatieve mandaat, is onmiskenbaar. De volgende paragraaf gaat in op de verspreiding van de theorie van het vrije mandaat op het continent. Hoewel deze vorm van staatsrechtelijke vertegenwoordiging de meeste constitutionele erkenning heeft gekregen staat hij, zoals in hoofdstuk 1 reeds werd aangegeven, op gespannen voet met de moderne staatkundige praktijk. In paragraaf 7 wordt daarom een theorie opgevoerd die beoogt deze spanning te verminderen. Paragraaf 8 tenslotte vormt een

1. M.P.C.M. van Schendelen, Over vertegenwoordiging en democratisch bestuur, Namens 1986, p. 2. 
kleine excursie naar theorieẻn over staatsrechtelijke vertegenwoordiging buiten het staatsrechtelijke gebied.

\subsection{Juridische betekenissen van het begrip vertegenwoordiging}

In het huidige spraakgebruik heeft het begrip vertegenwoordigen volgens Van Dale een drietal betekenissen" ${ }^{2}$ :

1) optreden, handelen voor en in naam van een ander die daartoe opdracht of machtiging verleend heeft;

2) de voorstelling van iets oproepen, er het beeld of de uitdrukking van zijn;

3) equivalent zijn met, uitmaken.

Deze betekenissen van het begrip zijn niet meer dan zeer algemeen gestelde omschrijvingen die gelden voor het gehele maatschappelijke leven. Teneinde het begrip in een juridische context te kunnen gebruiken, is het noodzakelijk een wat specifieker vertegenwoordigingsbegrip te hanteren. ${ }^{3}$ Probleem daarbij is echter dat er niet zoiets als de juridische context bestaat, in die zin dat de betekenis van het begrip al naargelang de specifieke (juridische) omstandigheden kan verschillen. Vertegenwoordiging als zodanig is dan ook nergens in de wet geregeld. ${ }^{4}$ De belangrijkste vertegenwoordigingsfiguur is de privaatrechtelijke vertegenwoordiging krachtens volmacht van titel 3 boek 3 BW. ${ }^{5}$ Volmacht is de bevoegdheid die de volmachtgever aan een ander, de gevolmachtigde, verleent, om in zijn

2. Van Dale's Groot Woordenboek der Nederlandse taal, 11e druk, Utrecht/ Antwerpen 1984.

3. In navolging van het gangbare juridische en politieke taalgebruik worden hieronder de begrippen representatie en vertegenwoordiging als synoniemen opgevat en door elkaar gebruikt, ook al kan aan het begrip representatie een zekere antiquiteitswaarde niet worden ontzegd; vergl. F.H. van der Burg, Representatie, in: Werkboek staatkunde 1984-1985, Leiden 1984, p. 141.

4. Vergl. A.R. Bloembergen, Vertegenwoordiging, 3e druk, Alphen aan den Rijn 1986, p. 10: "Noch in de wet, noch in de doctrine bestaat in ons land een behoorlijk ontwikkelde algemene leer van de vertegenwoordiging. "

5. Zie over de maatschappelijke betekenis van de volmacht: Bloembergen, a.w., p. $18 / 19$. 
naam rechtshandelingen te verrichten (art. 3:60 lid 1 BW) ${ }^{6}$. Hierdoor wordt de gevolmachtigde niet gebonden. De rechtsgevolgen die als gevolg van de rechtshandelingen van de gevolmachtigde intreden, treffen de volmachtgever, mits de gevolmachtigde handelde binnen de grenzen van zijn bevoegdheid (art. 3:66 lid 1 BW). Kenmerkend voor de volmacht is de verlening ervan: een eenzijdige rechtshandeling die de volmachtgever tot de gevolmachtigde richt. De wilsverklaring van de volmachtgever bepaalt de inhoud en de omvang van de volmacht. Tenzij de wet het tegendeel bepaalt, is de volmachtverlening vormvrij. Zij kan zowel uitdrukkelijk als stilzwijgend geschieden. De volmachtverlening werkt niet privatief: de volmachtgever behoudt volledig zijn bekwaamheid en bevoegdheid ten aanzien van al zijn vermogensbestanddelen en heeft dus nog steeds de mogelijkheid zelf de bewuste rechtshandelingen te verrichten. ${ }^{7}$

De volmachtverlening dient te worden onderscheiden van lastgeving. Dit laatste is een overeenkomst van opdracht waarbij de ene partij, de lasthebber, zich jegens de andere partij, de lastgever, verbindt voor rekening van de lasthebber een of meer rechtshandelingen te verrichten (art. 7:414 BW). Bij volmachtverlening krijgt de gemachtigde vertegenwoordigingsbevoegdheid zonder dat daarmee een verplichting tot handelen ontstaat; bij lastgeving daarentegen ontstaat deze verplichting wel. ${ }^{8}$ Dit neemt niet weg dat bij volmachtverlening de bevoegdheid om in naam van een ander rechtshandelingen te verrichten en de verplichting om deze bevoegdheid uit te oefenen, vaak samen zullen vallen. ${ }^{9}$ Daarnaast ontstaan bij lastgeving

6. Het privaatrecht kent nog andere vertegenwoordigingsfiguren, zoals de wettelijkè vertegenwoordiging van onbekwamen en de vertegenwoordiging van een rechtspersoon door haar bestuurders; deze blijven hier buiten beschouwing omdat zij in tegenstelling tot volmacht en lastgeving weinig tot geen affiniteit met het staatsrechtelijke vertegenwoordigingsbegrip bebben. Dit geldt eveneens voor de vertegenwoordiging bij andere daden dan rechtshandelingen, zoals onrechtmatige daden. Zie voor een meer uitgebreide opsomming van privaatrechtelijke vertegenwoordigingsfiguren: C. Asser/W.C.L. van der Grinten, De vertegenwoordiging, deel 1, 7e druk, Zwolle 1990, pp. 13-15.

7. Zie Asser/Van der Grinten, a.w., p. 62; Jac. Hijma/M.M. Olthof, Compendium van het Nederlands vermogensrecht, 4e druk, Deventer 1990, p. 47.

8. Vergl. Bloembergen, a.w., p. 18.

9. Vergl. Hijma/Olthof, a.w., p. 46. 
slechts rechten en plichten tussen lastgever en lasthebber, terwijl bij volmachtverlening juist vooral rechten en plichten tussen de volmachtgever en een derde ontstaan.

De wettelijke bepalingen omtrent volmacht zijn gegeven voor vermogensrechtelijke handelingen. Niettemin kunnen zij ook van toepassing zijn buiten het vermogensrecht. Analoge toepassing van de regels ontrent de volmacht is geboden indien de wet niet in een andere richting wijst en de aard van de rechtshandeling of de rechtsbetrekking zich daartegen niet verzet (art. 3:78 $\mathrm{j}^{\circ}$ art. 3:79 $\mathrm{BW}$ ). Zo kent het privaatrecht in art. 1:66 BW (het huwelijk met de handschoen) een zeer bijzondere, buiten het vermogensrecht gelegen vertegenwoordigingsfiguur waarbij de wettelijke bepalingen omtrent de volmacht voor een deel van toepassing zijn. Daarnaast zijn ook buiten het (materiële) privaatrecht vertegenwoordigingsfiguren aan te wijzen die enige gelijkenis vertonen met de privaatrechtelijke vertegenwoordigingsfiguur krachtens volmacht, zoals de processuele vertegenwoordiging in het burgerlijk proces, het strafproces en het administratief proces. ${ }^{10}$

De meeste niet-privaatrechtelijke vertegenwoordigingsfiguren worden echter veelal door eigen rechtsregels beheerst. Dit geldt vooral voor het (materiële) publiekrecht. " Hierin bestaat een grote verscheidenheid aan vertegenwoordigingsfiguren. Zo bestaat er bijvoorbeeld een vertegenwoordigingsrelatie tussen een publiekrechtelijk lichaam (gemeente, provincie) en haar organen (ambten). Deze vertegenwoordigingsfiguur is terug te voeren op de omstandigheid dat het publiekrechtelijk lichaam zelf niet kan handelen; het is gelijk te stellen met de hierboven genoemde (privaatrechtelijke) vertegenwoordiging van rechtspersonen door hun bestuurders. ${ }^{12}$

Daarnaast is er een vertegenwoordigingsfiguur in de relatie tussen de ambten onderling. Hieronder vallen niet alleen de relaties tussen het algemeen bestuur (gemeenteraad, Provinciale Staten) en het dagelijks bestuur (college van B \& W; Gedeputeerde Staten), maar ook die tussen

10. Zie hijvoorbeeld art. $133 \mathrm{Rv}$.; art. $270 \mathrm{~Sv}$.; art. $38 \mathrm{j}^{\circ}$ art. 39 en art. $78 \mathrm{j}^{\circ}$ art. 80 Wet RvS.

11. Vergl. P.W.A. Immink, Politieke verregenwoordiging. Een begripsverkenning, in: Verspreide geschrifien, Groningen 1967, p. 167.

12. Zie noot 6 . 
het algemeen bestuur en door hem ingestelde commissies. ${ }^{13}$ Het dagelijks bestuur wordt (grotendeels) benoemd uit, en door het algemeen bestuur. Het vertegenwoordigt daarmee in zekere zin dat algemeen bestuur, hoewel het ook eigen bevoegdheden opgedragen kan krijgen. Algemene regels voor deze vertegenwoordigingsfiguur zijn moeilijk te geven omdat belangrijke verschillen bestaan tussen provinciaal en lokaal niveau. ${ }^{14}$

Ook binnen een ambt zelf is een vertegenwoordigingsfiguur te onderscheiden. Dit is terug te voeren op het verschil tussen ambtsdrager en ambt. De natuurlijk persoon die op een bepaald moment het ambt bekleedt (de ambtsdrager), vertegenwoordigt het ambt bij het uitoefenen van de overheidsbevoegdheden die aan dat ambt verbonden zijn.

Van geheel andere orde is de vertegenwoordigingsfiguur die ontstaat bij mandaatverlening. Hierbij verleent een bestuursorgaan aan een ander de bevoegdheid in zijn naam besluiten te nemen. ${ }^{15}$ Het gaat hier dus om mandaat van bestuursbevoegdheden. Daarnaast bestaat nog de -vrij zeldzame en staatsrechtelijk allerminst zuivere- figuur van mandaat van wergevingsbevoegdheden. Beide mandaatsfiguren dragen een vertegenwoordigingselement in zich. Wanneer het mandaatsbegrip wordt afgezet tegen het delegatiebegrip, is het vertegenwoordigingsaspect zelfs het meest essentile kenmerk van het mandaat. ${ }^{16} \mathrm{Waar}$ bij delegatie de delegataris een bevoegdheid van de delegans overneemt, handelt bij mandaat de mandataris namens de mandans; hij oefent een bevoegdheid van de laatste uit. De bevoegdheid zelf blijft echter bij de mandans berusten; de mandans draagt de verantwoordelijkheid voor hetgeen de mandataris in zijn naam doet, mits het besluit van mandataris binnen de grenzen van diens bevoegdheid is genomen. ${ }^{17}$ Daarmee is het mandaat verwant aan de vertegenwoordigingsfiguur in het privaatrecht, met name aan vertegenwoordiging door volmacht, al wordt het in beginsel niet door het privaatrecht, maar door eigen,

13. Vergl. G.H. Hagelstein, Het vertegenwoordigingsprincipe in de Wet Gemeenschappelijke Regelingen, Namens 1986, p. 381/382.

14. Hierover uitvoeriger: Hagelstein, a.w., p. 382.

15. Dit is de definitie die het voorontwerp van de Algemene Wet Bestuursrecht (derde tranche) in art. 1A.1.1.1. aan mandaatverlening geeft.

16. In dezelfde zin: Algemene bepalingen van administratief recht (rapport ABAR), 5e druk, Alphen aan den Rijn, 1984 p. 40. Zie ook: H.D. van Wijk/W. Konijnenbelt, Hoofdstukken van administratief recht, Ge druk, Culemborg 1988, p. 66 (noot 70).

17. Vergl. art. 1A.1.1.3. AWB. 
tot aan de invoering van de Algemene Wet Bestuursrecht niet in de wet neergelegde administratiefrechtelijke regels beheerst. ${ }^{18}$ Een andere overeenkomst met de volmachtfiguur is dat ook van het mandaat geen privatieve werking uitgaat: de mandans kan zijn gemandateerde bevoegdheid incidenteel ook zelf uitoefenen zonder dat hij daarvoor een gegeven mandaat moet intrekken. ${ }^{19}$ In dezelfde lijn ligt de bevoegdheid van de mandans om de mandataris niet alleen algemene, maar ook bijzondere aanwijzingen te geven. ${ }^{20}$

In dit proefschrift staat een andere vertegenwoordigingsfiguur centraal: de vertegenwoordigingsrelatie tussen de kiezers en hun vertegenwoordigers in algemene vertegenwoordigende lichamen. Deze vorm van publiekrechtelijke vertegenwoordiging zal hier verder worden aangeduid als staatsrechtelijke vertegenwoordiging. Deze vertegenwoordigingsfiguur vormt een afzonderlijke categorie van vertegenwoordiging met een aantal geheel eigen kenmerken. Het is een vertegenwoordigingsfiguur sui generis dat zich in een groot aantal opzichten van de bovengenoemde vormen van vertegenwoordiging onderscheidt. Bij staatsrechtelijke vertegenwoordiging is de vertegenwoordiging (tegenwoordig) onverbrekelijk verbonden met publiekrechtelijk geregelde verkiezingen door de vertegenwoordigden; bij de overige vormen van vertegenwoordiging is dat niet het geval. Bij privaatrechtelijke vertegenwoordiging en ook bij mandaat van bestuursbevoegdheden worden instructies (last en ruggespraak) van oudsher algemeen aanvaard c.q. nodig geoordeeld; bij staatsrechtelijke vertegenwoordiging wordt over de toelaatbaarheid van instructies verschillend gedacht.

Een ander verschil tussen de staatsrechtelijke vertegenwoordiging en andere vormen van vertegenwoordiging is dat bij de laatste categorie de vertegenwoordiger optreedt tegenover derden, terwijl dat bij staatsrechtelijke vertegenwoordiging formeel niet het geval is: in Nederland vertegenwoordigen de Staten-Generaal het Nederlandse volk tegenover het Nederlandse volk zelf. ${ }^{21}$ Daarnaast heeft staatsrechtelijke vertegenwoordiging privatieve werking: er is geen plaats voor eigen optreden (c.q. ingrijpen)

18. Vergl. Bloembergen, a.w., p. 7. Uitvoeriger over de verschillen en overeenkomsten tussen mandaat en volmacht: G.R.J. de Groot/A.A. van Rossum, Mandaat en volmacht, RM Themis 1993, pp. 127-141.

19. Art. 1A.1.1.7 AWB.

20. Art. 1A.1.1.6 lid 1 AWB.

21. Vergl. Van der Burg, Werkboek staatkunde, a.w., p. 143. 
van de vertegenwoordigde(n), terwijl daar bij de overige vormen van vertegenwoordiging meestal wel plaats voor is.

\subsection{Staatsrechtelijke vertegenwoordiging}

Het begrip staatsrechtelijke vertegenwoordiging is minder gangbaar dan zijn synoniem politieke vertegenwoordiging, dat vooral in politicologische en buitenlandse geschriften gebruikt wordt. Volgens Nord is vertegenwoordiging in staatsrechtelijke zin aanwezig wanneer de invloed op de staatszaken, die aan een aantal onderdanen is toegekend, door een kleiner aantal uit hun midden wordt uitgeoefend. ${ }^{22}$ Waaraan laatstgenoemde groep de bevoegdheid ontleent om als vertegenwoordiging op te treden, is daarbij in principe niet van belang. Met andere woorden: het hoeven noodzakelijkerwijs niet verkiezingen te zijn waaraan deze groep de legitimatie ontleent, evengoed kan deze bijvoorbeeld zijn gegrond op een natuurlijk of een goddelijk recht. Vertegenwoordiging en verkiezing vallen niet per definitie samen; verkiezingen zijn slechts een middel om tot vertegenwoordiging te komen. ${ }^{23}$

Dit komt ook tot uiting in de door de politicoloog Birch gehanteerde omschrijving. Birch gebruikt de term (politieke) vertegenwoordiging voor vertegenwoordigers die via gewoonte of wet binnen een bepaald regeringsstelsel de status of de rol van vertegenwoordiger hebben. ${ }^{24}$ Daar echter de meeste twistpunten over politieke vertegenwoordiging de keuze en functies van gekozen leden van een (volks)vertegenwoordigend lichaam tot onderwerp hadden, reserveert Birch het begrip politieke vertegenwoordiging voor deze categorie. De typering van gekozen leden van een (volks)vertegenwoordigend lichaam als vertegenwoordigers ziet hij als een gespecialiseerd gebruik van de term vertegenwoordiging, die niet exact overeenkomt met andere betekenissen van het hegrip. De wezenlijke karakteristiek

22. H.R. Nord, Historische ontwikkeling en beteckenis wan de representatiegedachte in het staatsrecht, Leiden 1941, p. 21.

23. Vergl. Nord, a.w., p. 20. Zie ook: J.R. Pennock, Political representation: an overview, in: J.R. Pennock/J.W. Chapman, Representation, New York 1968, pp. 6-8.

24. A.H. Birch, Representation, Londen 1971, p. 18. 
van deze personen is de wijze van hun selectie, niet hun gedrag, eigenschappen of symbolische waarde. ${ }^{25}$

Staatsrechtelijke vertegenwoordiging waarbij het vertegenwoordigend lichaam door (directe) verkiezingen door (het merendeel van) de onderdanen tot stand komt, wordt door Nord eigenlijke vertegenwoordiging genoemd ter onderscheiding van de oneigenlijke vertegenwoordiging waarbij dit niet het geval is ${ }^{26}$ Tegen deze onderscheiding is aangevoerd dat zij niet correct is, omdat zij te zeer aan een bepaalde historische constellatie is gebonden. ${ }^{27}$ Toch is zij van enige waarde omdat daarmee tot uitdrukking wordt gebracht dat voor staatsrechtelijke vertegenwoordiging verkiezingen niet noodzakelijk zijn. Daarnaast is het onderscheid zinvol ten opzichte van de andere vormen van vertegenwoordiging in het publiekrecht waarbij doorgaans eveneens geen sprake is van verkiezingen.

Naast deze politieke of staatsrechtelijke vertegenwoordiging onderscheidt Birch nog andere betekenissen van het begrip vertegenwoordiging, de nietpolitieke vertegenwoordiging. Als de belangrijkste verschijningsvormen van de term vertegenwoordiger in deze betekenis onderscheidt hij:

a. een agent of woordvoerder die handelt ten behoeve van zijn principaal. De functie van de vertegenwoordiger is het verwezenlijken van zekere doeleinden, opgesteld door de principaal. De mate waarin deze doeleinden worden bereikt, is een criterium voor succesvolle vertegenwoordiging. Birch noemt dit delegated representation. ${ }^{23}$

b. een persoon die sommige karakteristieken deelt van een groep personen. De vertegenwoordiging als geheel vormt zo een 'representative sample': een deelverzameling van de relevante bevolking, gekozen door statistische methoden, dusdanig dat de belangrijkste karakteristieken van de bevolking hierin zijn weerspiegeld. Daar een vertegenwoordigend lichaam, in deze zin, ideaal samengesteld zou zijn als het een microcosmos van de grotere maatschappij zou zijn, noemt Birch dit soort vertegenwoordiging microcosmic representation. ${ }^{20}$

c. een persoon die de identiteit of hoedanigheid van een groep personen symboliseert. De vertegenwoordiger fungeert dan als een concrete beli-

25. Vergl. Birch, Representation, a.w. p. 19/20.

26. Nord, a.w., p. 20.

27. Vergl. Immink, a.w., p. 167.

28. Birch, Representation, a.w., p. 15.

29. Idem, p. 17. 
chaming van een groep of categorie personen. Deze categorie noemt Birch symbolic representation. ${ }^{30}$

Er kan niet ontkend worden dat gekozen volksvertegenwoordigers ook vertegenwoordigers in een of meer bovengenoemde algemene, niet-politieke toepassingen van het begrip vertegenwoordiging kunnen zijn. Met name de eerste twee niet-politieke betekenissen van de term vertegenwoordiger, zoals door Birch gebruikt, worden in de debatten betreffende de positie van gekozen vertegenwoordigers veelvuldig aangehaald. Zo zijn de betekenis en houdbaarheid van instructies en mandaten een steeds terugkerend thema geweest in het voortdurend debat over staatsrechtelijke vertegenwoordiging. Beweerd is dat gekozen vertegenwoordigers een plicht hebben te handelen als agenten voor hun kiezers; er zijn staten waar deze opvatting in sommige periodes het overheersende standpunt is geweest. Daar tegenover hebben anderen de noodzaak benadrukt dat gekozen vertegenwoordigers moeten handelen naar hetgeen zij het beste vinden voor de natie als geheel, terwijl andere schrijvers weer hebben benadrukt dat de eerste plicht van een gekozen vertegenwoordiger is de opvattingen van zijn partij te steunen. ${ }^{31}$

Een ander steeds terugkerend thema in dit debat is de opvatting dat de gekozen vertegenwoordigers idealiter dezelfde kenmerken zou moeten hebben als hun kiezers, zodat de vergadering van het vertegenwoordigend lichaam een sociale microcosmos zou zijn van het volk. De voorstanders van dit standpunt hebben erop gewezen dat een vergadering geen juiste vertegenwoordiging van het volk kan zijn als haar sociale samenstelling opvallend verschilt met die van het kiezerscorps. ${ }^{32}$

Symbolische vertegenwoordiging heeft daarentegen in het debat een veel minder prominente rol gespeeld, hetgeen door Birch wordt verklaard uit het feit dat deze vorm van vertegenwoordiging nauwelijks is onderzocht. ${ }^{33}$ Dat sluit niet uit dat in vele politieke situaties de verkiezing of aanwijzing van een vertegenwoordiger van een minderheidsgroepering een betekenis heeft die ver uit gaat boven de werkelijke macht die hij geniet, ondat hij

30. Idem, p. $17 / 18$.

31. Zoals in $\$ 1$ van hoofdstuk 1 reeds werd aangestipt zijn ook andere standpunten bij dit debat mogelijk: zie H.F. Pitkin, The concept of representation, Berkeley 1967, p. 146.

32. Vergl. A.C.P. van den Broek, Recallrecht in het licht van de representatic, 's-Gravenhage 1978, p. 16.

33. Birch, Representation, a.w., p. 21. 
de erkenning van de politieke rechten van de betrokken groep in kwestie symboliseert.

\subsection{Het ontstaan van het staatsrechtelijke vertegenwoordigingsbegrip}

Staatsrechtelijke vertegenwoordiging kent een relatief korte ontstaansgeschiedenis. Het verschijnsel gaat niet terug tot de directe democratie van de oudheid, maar tot het feodalisme van de late middeleeuwen waarin de macht van de vorst c.q. landsheer steeds meer beperkt raakte dooi zijn afhankelijkheid van de instemming en de financiële steun van zijn vazallen. Doordat de agrarische matschappij van de vroege middeleeuwen door de opkomst van handel en steden werd doorbroken, ontstond in de dertiende eeuw in Europa het maatschappelijk standenbestel: de feodale staat groeide uit tot standenstaat. ${ }^{34}$ Door haar economische macht wist de burgerij zich een plaats te veroveren naast de geestelijke en wereldlijke vazallen. Door veranderingen in de samenleving verdwenen de individuele vazallen om plaats te maken voor collectieve standen: de geestelijkheid, de adel en de steden. Evenals bij het feodale verdrag tussen leenheer en leenmannen werd de verhouding tussen landsheer en standen geregeld door een verdrag met wederzijdse rechten en plichten. De vorst was verplicht de bestaande rechten van de standen te eerbiedigen; wanneer hij zich niet aan het verdrag hield hadden de standen het recht van opstand. De maatschappelijke functie van de standen bestond in het behartigen van de geestelijke, militaire en economische belangen van het land. Hieruit vloeiden hun politieke rechten voort; tot het toestaan van belastingen (beden) en voor overleg in belangrijke kwesties werden zij bijeengeroepen in de curia, de vorstelijke of landsheerlijke raad, welke bijeenkomst standenvergadering of Staten werd genoemd. ${ }^{35}$

Zo onstond een vorm van vertegenwoordiging waarin de vorst, door geldnood gedreven, overging tot het uitnodigen van vertegenwoordigers van de standen en de regio's van het land. Het doel hiervan was hun instemming te verkrijgen voor door hem voorgestelde maatregelen, die

34. Vergl. C.H.E. de Wit. De strijd tussen aristocratie en democratie in Nederland, 1780-1848, Heerlen 1965, p. 15.

35. Idem. 
vooral gelegen waren op het gebied van de belastingen. Dit principe vond zijn wortels in een uit het Romeinse recht overgeleverd beginsel uit het Corpus Juris, Quod omnes tangit ab omnibus approbetur (wat alle betrokkenen aangaat, moet door alle betrokkenen goedgekeurd worden), dat zo werd uitgelegd dat matregelen van de vorst eerst aan de betrokkenen mochten worden opgelegd wanneer deze hun instemming met de maatregelen hadden betuigd. ${ }^{36}$ De vertegenwoordigers kwamen niet zozeer bijeen om te beraadslagen over het nationale regeringsbeleid, als wel om de belangen van hun stand te verdedigen ten opzichte van de vorst.

De relatie tussen deze vertegenwoordigers en hun committenten werd geheel beheerst door regels van privaatrecht; de ontstaansgeschiedenis van het moderne staatsrechtelijke vertegenwoordigingsbegrip is daarom nauw met het privaatrechtelijke vertegenwoordigingsbegrip verbonden. Toen het vertegenwoordigingsbegrip in het staatkundig leven ontstond, werd dit geheel volgens privaatrechtelijke beginselen geconstrueerd. De eerste 'volks'vertegenwoordigers werden gezien als lasthebbers, die voor de uitvoering van hun opdracht aan hun committenten verantwoording schuldig waren; zij traden op als procureurs van een privaatrechtelijke groep (de standen), niet van een staatkundige eenheid. ${ }^{37}$ Handelingen, die door de vertegenwoordigers met derden (de vorst) werden aangegaan, werden geacht door de lastgever (de standen) te zijn verricht. Wanneer de vertegenwoordiger naar de mening van de lastgever zijn taak niet goed uitoefende, kon hij door de lastgever worden teruggeroepen of uit zijn vertegenwoordigingsbevoegdheid worden ontzet.

Deze vertegenwoordigingstiguur groeide geleidelijk uit tot een theorie waarin bovengenoemde privaatrechtelijke aspecten werden getransformeerd tot een staatsrechtelijke theorie, de theorie van het gebonden c.q. imperatief mandaat. Volgens deze theorie is de afgevaardigde een lasthebber; hij ontvangt zijn last van de kiezersgroep die hem heeft aangewezen. De theorie van het imperatief mandaat gaat uit van de gedachte dat leder lid van de natie de drager is van een quotum van de soevereiniteit, waarvan de

36. Vergl. F.H. van der Burg, 'Quod omnes tangit ab omnibus approbetur', in: M.C. Burkens/R. Crince Le Roy, Burger en overheid, 's-Gravenhage 1984, p. 66/67; M. Prestwich, English politics in the thirteenth century, Basingstroke 1990, p. 19.

37. Nord, a.w., p. 36. 
grootte bepaald wordt door het aantal individuen dat de natie vormt. De leden oefenen hun recht uit door deel te nemen aan de verkiezingen en door een afgevaardigde te benoemen. Bijgevolg kan de afgevaardigde zijn macht slechts krijgen van degenen die hem hebben aangewezen en aangezien de afgevaardigde geen cessionaris wordt van de soevereiniteit -die blijft immers berusten bij de kiezers- kan hij slechts hun lasthebber zijn. $\mathrm{Hij}$ is geenszins lasthebber van de natie als geheel; dat is slechts een fictie. $\mathrm{Hij}$ is lasthebber van de groep kiezers, die hem heeft benoemd. ${ }^{38}$ Deze theorie impliceert dat, aangezien elke lastgever zijn mandaat kan beperken, ook de kiezers van te voren de houding kunnen bepalen die hun afgevaardigde zal moeten aannemen en hem daarom ook instructies kunnen geven. Gaat de afgevaardigde-lasthebber zijn instructies te buiten, dan bindt hij in elk geval zijn kiezers niet, terwijl hij eventueel kan worden teruggeroepen.

De middeleeuwse vertegenwoordigingsfiguur is geleidelijk vervangen door een nieuw vertegenwoordigingsbegrip dat de afgevaardigden opvat als de vertegenwoordigers van de gehele natie. Het privaatrechtelijk karakter van de standenvertegenwoordiging gaat verloren; alle afgevaardigden worden geacht gezamenlijk een taak te verrichten in het algemeen belang; zij komen niet meer op voor de subjectieve rechten en belangen van de eigen stand.

De bakermat van de theorieën over deze nieuwe vertegenwoordigingsfiguur ligt in het 17e eeuwse Engeland: van alle parlementen en standenvergaderingen is het Britse parlement het eerste waar onder de leden het besef ontstaat een natie te vertegenwoordigen. ${ }^{39}$ Een eeuw voordat als gevolg van de speech van Burke in Bristol het nieuwe vertegenwoordigingsbegrip tot de nieuwe maatstaf voor de relatie tussen de afgevaardigde in een vertegenwoordigend lichaam en zijn kiezers zal uitgroeien, worden er theorieën verkondigd die hiervan een voorloper zijn. Enkele hebben zelfs een groter democratisch en vooruitstrevend vermogen dan de theorie die een eeuw later door Burke wordt verkondigd en uiteindelijk geaccepteerd zal raken.

38. Idem, p. 107/108.

39. Vergl. H.H. Zwager, De motivering van het algemeen kiesrecht in Europa, Groningen 1958, p. 29. 
Een eerste aanzet wordt gegeven door een relatief onbekende beweging, de Levellers genaamd. ${ }^{40}$ Deze groep, bestaande uit legerofficieren en burgers, vormt voor korte tijd (met name tussen 1640 en 1650) een politieke beweging avant la lettre, waarvan de denkbeelden in vele opzichten anticiperen op de 'revolutionaire' denkbeelden aan het einde van de $18 \mathrm{e}$ en het begin van de $19 \mathrm{e}$ eeuw. De Levellers waren voorstanders van een onafhankelijk parlement, dat zij als de vertegenwoordiger van het volk zagen. Zij erkenden dat aan elk individu bepaalde grondrechten toekwamen, die het parlement niet mocht beperken. In hun visie, uiteengezet tijdens de Putney debates in oktober 1647, berustte de soevereiniteit bij het volk en niet bij het parlement zelf, zoals in deze periode herhaaldelijk door anderen werd gesteld. Het parlement ontleende volgens de Levellers zijn gezag aan een delegatieopdracht van het volk. ${ }^{41}$ Daarom was het parlement vertegenwoordiger van het gehele volk en niet van een bepaald gedleelte daarvan. Ten tijde van de Levellers was de afgevaardigde in het Lagerhuis niet meer dan een gedelegeerde namens de gemeenschap die hem had afgevaardigd; zijn taak bestond uit het al dan niet goedkeuren van belastingmaatregelen en wetten, voorgesteld door de vorst. De Levellers wensten het recht om deze afgevaardigden te kiezen uitgebreid te zien tot de gehele mannelijke bevolking, zodat zij het gehele volk zouden vertegenwoordigen. ${ }^{42}$ Dat een dergelijke taakverandering ook een verandering in de relatie tussen kiezer en gekozene kon impliceren, werd door hen niet ingezien. De Levellers bleven vasthouden aan de uit de middeleeuwen stammende opvatting dat de volksvertegenwoordiger als agent van zijn kiezer moest optreden.

De opvattingen van de Levellers vonden weinig weerklank. Met het verdwijnen van het leger na de Glorious Revolution van 1688 , verdwenen

40. Zie hierover o.m. A.H. Birch, Representaive and responsible government, $7 \mathrm{e}$ druk, Londen 1979, pp. 35-38; C.B. Macpherson, The political theory of possessive individualism, 13e druk, Oxford 1990, pp. 107-159; G.H. Sabine/Th. L. Thorson, A history of political theory, 4e druk, Hinsdale 1973, pp. 442-449; Zwager, a.w., pp. 29-36.

41. Vergl. Sabine/Thorson, a.w., p. 449; Birch, Representation, a.w., p. 37.

42. Na de Putney-debatten hebben de Levellers hun opvattingen over het algemeen kiesrecht enigszins bijgesteld door enkele kiesrechtuitsluitingen te formuleren; vergl. Zwager, a.w., p. 35. Uitvoeriger over de ontwikkeling in de opvattingen over het kiesrecht bij de Levellers: Macpherson, The political theory of possessive individualism, a.w., pp. 107-136. 
ook de Levellers. Zij verdienen echter vermelding omdat zij de eerste beweging in het Verenigd Koninkrijk (lees: Engeland) waren die naar voren kwamen met een theorie over "popular sovereignty in an unambiguous form". ${ }^{43}$

Vermelding verdient voorts Lord Shaftesbury (1621-1683), de leider van de parlementaire oppositie tegen de restauratie van de Stuarts. Ook hij stelde dat het doel van het parlement was gelegen in het vertegenwoordigen van de gehele natie. Hij verbond hieraan echter niet de consequentie dat dit diende te leiden tot een algemeen kiesrecht. Algemeen kiesrecht was een niet te verwezenlijken ideaal. Het volk was volgens Shaftesbury te vatbaar voor invloeden van buitenaf om een eventuele taak als kiezer op adequate en geloofwaardige wijze te vervullen. De vertegenwoordiging van het volk diende daarom te geschieden door het verbeteren van de afwijkingen van het bestaande stelsel van vertegenwoordiging. Dit stelsel moest dusdanig gewijzigd worden dat voor de uitoefening van het actief en passief kiesrecht slechts die mannen in aanmerking zouden komen die genoeg bezit hadden om in volstrekte onafhankelijkheid hun taak te kunnen vervullen. ${ }^{4}$ Deze gedachte van 'representation of the property' zou door velen -waaronder John Locke (1632-1704), de secretaris en huisarts van Shaftesburyworden overgenomen en zou een belangrijk bestanddeel worden van de theorie over staatsrechtelijke vertegenwoordiging van de Whigs (zie hieronder).

In hetzelfde tijdsgewricht als dat van Shaftesbury werd door Algernon Sidney (1622-1683) in zijn Discourses concerning government (geschreven rond 1680) de basis gelegd voor de nieuwe opvattingen over de relatie tussen kiezer en gekozene. Sidney stelde zich op het standpunt dat een eenmaal gekozen afgevaardigde zijn eigen opvattingen diende te volgen en niet die van zijn kiezers. Volgens Sidney was de wetgevende macht van het parlement afgeleid van het volk. Alle staatsmacht (c.q. elke uiting daarvan) was naar zijn oorsprong op het volk terug te leiden; de macht van het volk kende geen grenzen. De afgevaardigden in het parlement ontleenden hun

43. Birch, Representative and responsible government, a.w., p. 35 .

44. De opvattingen van Shaftesbury zijn weergegeven bij P.A. Gibbons, Ideas of political representation in Parliament, 1660-1832, Oxford 1914, pp. 1416. 
gezag aan het volk, vandaar dat Sidney de mogelijkheid van instructies erkende. ${ }^{45}$ Toch vond hij dat de afgevaardigde idealiter geen lasthebber van zijn kiezers diende te zijn: het beste bewijs van de ongelimiteerde macht van het volk is juist dat dit vertrouwt op de wijsheid en trouw van zijn afgevaardigden door dezen juist geen beperkingen ten aanzien van hun functioneren in de weg te leggen. ${ }^{46}$ Omdat ten tijde van verkiezingen niemand kan voorzien welke maatregelen tijdens een regeerperiode genomen moeten worden, moet het de afgevaardigden worden toegestaan om naar eigen goeddunken te handelen. En hoewel het de afgevaardigden misschien wel gelegen komt om naar de opvattingen van hun kiezers te luisteren, zijn zij niet verplicht deze opvattingen daadwerkelijk over te nemen en in het parlement als de hunne te verkondigen. ${ }^{47}$ Het parlement is volgens Sidney

"(...) not a congress of ambassadors of different bodies; for the powers of the cities, counties and boroughs of England are regulated by the general law to which they all have consented, and by which they are all made members of one political body. This obliges them to proceed with their delegates in a manner different from that which is used in the United Netherlands, or in Switzerland. So that it is not for Kent, Sussex, Lewis or Maidenstone, but for the whole nation that the members chosen in those places are sent to service in Parliament. ${ }^{48}$

De opvattingen van Sidney werden vanaf het einde van de $17 \mathrm{e}$ eeuw op gezette tijden in het parlement door de Whigs verwoord. ${ }^{49}$ De Whigs, de voorgangers van de liberale partij, waren een van de twee politieke bewegingen die op dat moment in het parlement actief waren. Tegenover de Whigs stonden de Tories, de voorgangers van de conservatieve partij. Het lidmaatschap van deze groeperingen berustte meer op traditie, persoonlijke voorkeur en rivaliteiten dan op politieke voorkeur of overtuiging. Hoewel noch de Whigs noch de Tories als politieke partijen in de huidige betekenis

45. A. Sidney, Discourses concerning government, 3e druk, Londen 1751, p. 453.

46. Idem, p. 454.

47. Idem, p. 451.

48. Idem.

49. Zie de voorbeelden genoemd door Gibbons, a.w., p. 22/23. Zie ook: E. Porritt/A.G. Porritt, The unreformed House of Commons: parliamentary representation before 1832, deel 1, Cambridge 1903, p. 271. 
van het woord beschouwd kunnen worden, waren het toch redelijk hechte groepen.

Ook in het Verenigd Koninkrijk bestond nog geen algemeen geaccepteerde theorie over staatsrechtelijke vertegenwoordiging. Ten aanzien van de opvattingen over de rol van het parlement en de daarmee samenhangende relatie tussen kiezer en gekozene stonden Tories en Whigs lijnrecht tegenover elkaar. De Tories kunnen worden beschouwd als de voorstanders van het traditionele systeem van staatsrechtelijke vertegenwoordiging waarin de taak van de afgevaardigde bestond uit het behartigen van de belangen van zijn kiezers (c.q. het district of de regio). Het algemeen belang was in deze opvatting geen zaak van de afgevaardigden in het parlement, maar een aangelegenheid van vorst. ${ }^{50}$ Volgens de Tories was voor het totstandkomen van een wet de toestemming vereist van zowel de vorst (aan wie het wetgevingsinitiatief toekwam, als onderdeel van zijn prerogatieven), de adel en de burgers (de Commons). De adel was op persoonlijke titel in het Hogerhuis aanwezig; zij 'vertegenwoordigden' zichzelf. De Commons waren daarentegen niet zelf in staat hun taak te verrichten. Vandaar dat zij geacht werden om door "their attorneys with large general powers" ${ }^{51}$ hun toestemming tot een wet te hebben gegeven. Het besluit van deze vertegenwoordigers was bindend voor alle burgers. In deze opvatting waren de afgevaardigden in het Lagerhuis gedelegeerden van hun kiezers. Voor de relatie tussen kiezer en gekozene impliceerde dit dat de Tories bleven vasthouden aan de (oude) theorie van het imperatief mandaat.

De opvatting dat de afgevaardigde lasthebber van de kiezers is werd afgewezen in de theorie van de Whigs zoals deze in de loop van de $18 \mathrm{e}$ eeuw definitief gestalte krijgt. De Whigs kunnen worden beschouwd als de grondleggers van het moderne vertegenwoordigingsbegrip. In de opvattingen van de Whigs waren de leden van het parlement noch gedelegeerde vertegenwoordigers, noch microcosmische vertegenwoordigers, noch symbolische vertegenwoordigers. Zij werden gezien als gekozen vertegenwoordigers wier taak niet primair is het behartigen van de belangen van hun kiezers, maar de belangen van het volk als geheel, naar wat volgens

50. Vergl. S.H. Beer, Modern British Politics. Parties and pressure groups in the collectivist age, 3e druk, Londen 1982, pp. 6-9.

51. Gibbons, a.w., p. 25. 
hun persoonlijk oordee! het beste is. ${ }^{52} \mathrm{Zij}$ zijn geen vertegenwoordigers van deelbelangen, maar dienen het algemeen belang van de natie te behartigen. Wat dit algemeen belang precies inhoudt is moeilijk te bepalen en zal van geval tot geval bekeken moeten worden; in ieder geval sluit het uit dat uitsluitend belangen van bepaalde groepen van de natie worden vertegenwoordigd.

In het vertegenwoordigend lichaam, het parlement, komen de vertegenwoordigers van het volk bijeen om door uitwisseling van argumenten en met inachtneming van het algemeen belang tot een rationele oplossing van de hen voorgelegde vraagstukken te komen. Het parlement is in deze visie vooral een overlegorgaan, dat de gehele natie vertegenwoordigt. De beslissingen van dit orgaan zijn niet "a mere aggregation of sectional demands". ${ }^{53}$ De gekozen volksvertegenwoordiger wordt gezien als een onafhankelijk vormgever van het nationaal beleid; het vertegenwoordigend lichaam is een publieke autoriteit waarvan de macht wordt gelegitimeerd door de verkiezing van haar leden, ook al hebben deze leden geen verplichting instructies van hun kiezers te aanvaarden.

Toch gingen ook de Whigs in hun opvattingen niet zover dat iedereen in aanmerking diende te komen om het kiesrecht uit te oefenen. Integendeel, achterliggende gedachte bij hun theorie was juist te verzekeren dat "voters should be men of such character and property as to be independent of outside influence" 54 , een gedachte die reeds door Shaftesbury was verwoord. Dit element is bijvoorbeeld te herkennen in de opvattingen van Blackstone, een tijdgenoot en geestverwant van Burke. In zijn opvattingen komt sterk tot uiting dat alleen de besten (te selecteren door een 'property qualification') geschikt zijn om naar het Lagerhuis afgevaardigd te worden. Hij verklaart zich weliswaar, in navolging van Sidney, in beginsel een voorstander van algemeen kiesrecht, maar alleen wanneer het waarschijnlijk zou zijn dat iedere kiezer zijn stem vrij kon uitbrengen. Nu dat niet het geval is bij "persons of indigent fortunes, or such as are under the immediate dominion of others"ss, is het noodzakelijk dat er eisen aan de uitoefening van het kiesrecht worden gesteld, waarbij diegenen die niet geacht

52. Vergl. Birch, Representation, a.w., p. 37.

53. Idem, p. 38.

54. Gibbons, a.w., p. 14.

55. W. Blackstone, Commentaries on the laws of England, deel 1 (Of the rights of persons), 20e druk, Londen 1841 (oorspr. uitgave 1765), p. 167. 
kunnen worden een eigen wil te bezitten van het kiesrecht worden uitgesloten "in order to set the more independent members of society on an equality one with the other". ${ }^{56}$ De toenmalige Engelse constitutie voldeed in dit opzicht niet, vandaar dat er volgens Blackstone een ingrijpende wijziging nodig was teneinde "a more complete representation of the people" te verwezenlijken.

Ten aanzien van de relatie tussen kiezer en gekozene was Blackstone even duidelijk als Sidney en (na hem) Burke. Hij erkende het recht van de kiezers om advies te geven, maar dit advies mocht volgens hem nooit bindend zijn voor het stemgedrag en het overig functioneren van de afgevaardigde in het vertegenwoordigend lichaam:

"(...) every member, though chosen by one particular district, when elected and returned serves for the whole realm. For the end of his coming thither is not particular, but general: not barely to advantage his constituents, but for the common whealth (...). And therefore he is not bound, like a deputy in the united provinces, to consult with, or take the advice, of his constituents upon any particular point, unless he himself thinks it proper and prudent to do so. ${ }^{.57}$

\subsection{Vertegenwoordiging in het staatsrecht: Burke's paradigma}

De opvattingen van de Whigs over de taak van het parlement en de opstelling van de individuele volksvertegenwoordiger daarin, had een belang dat uitging boven hun betekenis voor de ontwikkeling van het staatkundig bestel van het Verenigd Koninkrijk: zij omvatten een geheel nieuw concept ten aanzien van het denken over staatsrechtelijke vertegenwoordiging. Niet alleen in het Verenigd Koninkrijk, maar ook in vele andere westerse staten zou deze liberale theorie van de representatieve democratie uitgroeien tot een van de belangrijkste constitutionele beginselen. Dat is voor een groot deel de verdienste van Edmund Burke geweest. Ook in zijn tijd hadden de opvattingen van de Tories allerminst aan invloed ingeboet; zoals in hoofdstuk 1 reeds werd aangegeven is Burke echter degene aan wie de eer toekomt met zijn opvattingen, hoewel allerminst

56. Idem.

57. Blackstone, a.w., p. $154 / 155$ (cursivering in origineel). 
origineel, de strijdvraag in het voordeel van de opvattingen van de Whigs te beslissen.

In november 1774 werd Burke op het laatste moment uitgenodigd zich kandidaat te stellen voor een van de twee vacante Lagerhuiszetels van de stad Bristol. De uit lerland afkomstige Burke was in Bristol volslagen onbekend. Onder de andere kandidaten bevond zich een inwoner van de stad die zich bereid verklaarde elke instructie die hij van zijn kiezers zou ontvangen, uit te voeren. Deze persoon werd samen met Burke gekozen als parlementslid voor Bristol. Nadat hij gekozen was, hield Burke de rede die beroemd zou worden vanwege de daarin verkondigde opvattingen over de relatie tussen kiezer en gekozene. ${ }^{58}$ Deze speech is de belangrijkste bron van Burke's opvattingen op het punt van de relatie tussen kiezers en gekozenen, al heeft slechts een klein gedeelte ervan op deze problematiek betrekking. Het grootste deel van de speech handelt over de noodzaak van parlementaire hervormingen, waarvan Burke allerminst een voorstander was. In zijn speech onderscheidt Burke impliciet twee verschillende dimensies van de relatie tussen gekozene en kiezer. De eerste ziet op de manier (de stijl) van vertegenwoordiging door de afgevaardigde: doet hij dit al als 'delegate', gebonden aan een imperatief mandaat, of als 'trustee', zelfstandig beslissend over de hem voorgelegde zaken. Deze dimensie komt neer op de vraag of de volksvertegenwoordiger de wil van de kiezer dan wel zijn eigen oordeel moet volgen. De tweede dimensie van de relatie heeft betrekking op het doel (de focus) van de vertegenwoordiging: moet de afgevaardigde bij zijn (wetgevende) werkzaamheden primair het landsbelang (c.q. het algemeen belang) behartigen of dient hij slechts het belang van zijn kiezers (c.q. zijn district) voor ogen te houden. ${ }^{59}$

58. E. Burke, Speech to the electors of Bristol (3 november 1774), in: The works of the Right Honourable Edmund Burke (deel 2), Londen 1906/1907, pp. 159-166. Zie hierover o.m.: Pitkin, a.w., pp. 168-189; Sabine/Thorson, a.w., pp. 558-561; Beer, a.w., pp. 9-13; Nord, a.w., p. 64/65; Porrit, a.w., p. 271.

59. Vergl. V. Bogdanor, Introduction, in: dez. (ed.), Representatives of the people? Parliamentarians and constituents in western democracies, Aldershot 1985 , p. 3. Zie over de begrippen 'stijl' en 'focus' van vertegenwoordiging verder $\$ 8$ van dit hoofdstuk. 
Burke geeft allereerst zijn zienswijze over de vraag wiens opvattingen bij de vervulling van de parlementaire werkzaamheden door de afgevaardigde dienen te prevaleren. Na verwijzing naar de uitspraak van zijn collegaafgevaardigde dat deze positief staat tegenover dwingende instructies van de kiezers, vervolgt hij met te zeggen dat

"(..) it ought to be the happiness and glory of a representative to live in the strictest union, the closest correspondence, and the most unreserved communication with his constituents. Their whishes ought to have great weight with him; their opinion high respect; their business unremitted attention. It is his duty to sacrifice his repose, his pleasures, his satisfactions, to theirs; and above all, ever, and in all cases to prefer their interest to his own. But his unbiassed opinion, his mature judgment, his enlightened conscience, he ought not to sacrifice to you; to any man, or to any set of men living. These he does not derive from your pleasure; no, nor from the law and constitution. They are a trust from Providence, for the abuse of which he is deeply answerable. Your representative owes you, not his industry only, but his judgment; and he betrays, instead of serving you, if he sacrifices it to your opion. ${ }^{\text {"60 }}$

Bij bestuur en wetgeving doet volgens Burke de wil van bepaalde personen niet ter zake; wanneer dat wel het geval zou zijn, zou zonder meer de wil van de kiezers de doorslaggevende factor moeten zijn. ${ }^{61}$ Bestuur en wetgeving zijn echter

"(...) matters of reason and judgment, and not of inclination; and what sort of reason is that, in which the determination precedes the discusion; in which one set of men deliberate, and the other decide; and where those who form the conclusion are perhaps three hundred miles distant from those who hear the arguments? ${ }^{\text {nt2 }}$

Dat neemt echter niet weg dat de kiezer zijn wil niet aan de afgevaardigde duidelijk mag maken; het gaat er echter om op welke wijze hij dit doet:

"To deliver an opinion is the right of all men; that of constituents is a weighty and respectable opinion, which a representative ought always to rejoice to hear; and which he ought always most seriously to consider. But authoritative instructions, mandates

60. Burke, Speech, a.w., p. 164.

61. Idem.

62. Idem, p. 165. 
issued, which the member is bound blindly and implicitly to obey, to vote, and to argue for, though contrary to the clearest conviction of his judgment and conscience, -these are things utterly unkown to the laws of this land, and which arise from a fundamental mistake of the whole order and tenor of our constitution. ${ }^{13}$

Daarop laat hij de beroemdste passage van zijn speech volgen, waarbij hij letterlijk nogal dicht bij Sidney en, in mindere mate, Blackstone in de buurt komt:

"Parliament is not a congress of ambassadors from different and hostile interests; which interests each much maintain, as an agent and advocate, against other agents and advocates; but Parliament is a deliberative assembly of one nation, with one interest, that of the whole; where, not local purposes, not local prejudices ought to guide, but the general good, resulting from the general reason of the whole. You choose a member, indeed; but when you have chosen him, he is not a member of Bristol, but he is a member of parliament. If the local constituent should have an interest, or should form an hasty opinion, evidently opposite to the real good of the rest of the community, the member for that place ought to be as far, as any other, from any endeavour to give it effect. " ${ }^{\text {"At }}$

Burke's speech was in de eerste plaats gericht op het voorkomen van hervormingen van het bestaande parlementair stelsel van het Verenigd Koninkrijk. Zoals wel vaker voerde Burke historische precedenten aan om te betogen dat een imperatief mandaat onbekend was "to the laws of the land". Dit met het doel de kiezers in Bristol, die bekend stonden om hun radicale opvattingen op dit punt, te waarschuwen. De andere afgevaardigde namens Bristol deelde deze opvattingen. Burke vreesde dat hij gedwongen zou worden zich uit te spreken voor radicale hervormingen, op welke ook in Bristol steeds vaker werd aangedrongen, terwijl hij zich juist daartegen verzette. ${ }^{65}$ Het kernpunt van zijn opvattingen was de verdediging van de bestaande maatschappij en de daarin gevestigde hiërarchie en gewoonten. Als hij al veranderingen voorstond, dan waren die er op gericht het systeem te verbeteren, maar niet om ingrijpende veranderingen aan te brengen: "Burke's theory (...) is typical of a conservatism, which, without

63. Idem (cursivering in origineel).

64. Idem (cursivering in origineel).

65. Vergl. A. Young, The reselection of MPS, Londen 1983, p. 18. 
being sufficiently obscurantist to regret past developments, yet looks askance at all future progress and desires nothing better than to be left in the peaceful possesion of what has been already gained". ${ }^{60}$

Met het oog op dit conservatisme is het logisch dat Burke een grote waarde toekende aan de constitutie van het Verenigd Koninkrijk: deze had in het verleden haar waarde bewezen en bood thans in het algemeen voldoende waarborgen tegen een overvloed aan invloed van de vorst, een ander belangrijk motief in Burke's denkbeelden. ${ }^{67}$ Burke zag de constitutie als "an institution of almost superhuman ingenuity, which exists solely to bring the general will into action and record its decrees." ${ }^{68}$

De constitutie ging er, in de visie van Burke, niet van uit dat iedereen (c.q. het mannelijk deel van de bevolking) stemrecht toekwam; de 'general will' was te ondefinieerbaar om op die manier tot uitdrukking gebracht te worden. Daarnaast was het grootste deel van het volk te onbekwaam om te beslissen over de (details van de) wetten. Net zoals Shaftesbury en Blackstone voor hem, stelde Burke dat de 'general will' weliswaar diende te prevaleren, maar dat dit niet betekende dat het formuleren van die wil een zaak zou zijn van een "general assembly of the people, or (...) a congress of delegates as an organ to voice that will." ${ }^{\circ}$ Voor Burke bestond er geen directe relatie tussen het volk en de afgevaardigde in het Lagerhuis:

"For it is not the derivation of the power of that house from the people, which makes it in a distinct sense their representative. The king is the representative of the people; so are the lords, so are the judges. They are all trustees for the people, as well as the commons; because no power is given for the sole sake of the holder; and although government certainly is an institution of divine autho-

66. Gibbons, a.w., p. $38 / 39$.

67. Zie bijwoorbeeld E. Burke, Reflections on the revolution in France and on the proceedings in certain societies in London relative to that event, in: Works, a.w., deel 4, p. 63, waar hij spreekt over "a constitution, whose merits are confirmed by the solid test of long experience, and an increasing public strength and national prosperity".

68. Gibbons, a.w., p. 36.

69. Idem; zie ook Zwager, a.w., p. 76. 
rity, yet its forms, and the persons who administer it, all originate

from the people. ${ }^{20}$

Dat een afgevaardigde zijn status ontleent aan het volk, is daarom geen onderscheidend criterium voor de bepaling van diens taak: alle overheidsorganen kennen een dergelijke oorsprong van hun status.

"The virtue, spirit and essence of a House of Commons consists in its being the express image of the feelings of the nation. It was not instituted to be a controul upon the people (...). It was designed as controul for the people. "7h

Ook op het gebied van de staatsrechtelijke vertegenwoordiging had de constitutie van het Verenigd Koninkrijk haar waarde volgens Burke bewezen:

"I shall only say here, in justice to that old-fashioned constitution, under which we have long prospered, that our representation has been found perfectly adequate to all the purposes for which a representation of the people can be desired or devised. " 72

Staatsrechtelijke vertegenwoordiging stond in de staatsopvatting van Burke en de andere Whigs gelijk aan virtual representation. In deze optiek bestond het rijk niet uit individuen, maar was het een verzameling van interessegroepen, ieder met een eigen belang dat doorgaans diametraal tegenover het belang van de andere groepen stond. Voor Burke was vertegenwoordiging dan ook vooral vertegenwoordiging van die belangen: 'representation of interests'. ${ }^{73}$ Dat er in (met name) de noordelijke steden grote bevolkingsgroepen niet in het parlement waren vertegenwoordigd, deed voor Burke daarom ook niet terzake. Birmingham mocht dan geen afgevaardigden hebben, maar Bristol had deze wel. En Bristol was, als kiesdistrict, in de visie van Burke niet de stad Bristol, maar ook de exponent van de plaatsen waarin vooral de belangen van de handel voorop stonden. Tot die plaatsen behoorde ook Birmingham. De afgevaardigden uit Bristol waren dus niet afgevaardigden namens Bristol, maar afgevaardigden namens de handel.

70. E. Burke, Thoughts on the cause of the present discontents (1770), in: Works, a.w., deal 2, p. 50.

71. Idem, p. 50/51 (cursivering in orgineel).

72. Burke, Reflections, a.w., p. 61.

73. Vergl. Pitkin, a.w., hfdst. 8, m.n. pp. 173-189. 
Door de belangentegenstellingen tussen de verschillende interessegroepen zou in een vergadering van deze groepen nooit een algemene wil kunnen ontstaan: het belang van een van de groepen zou steeds prevaleren. Dit laatste werd nu echter, in Burke's opvattingen, door de constitutie van het Verenigd Koninkrijk verhinderd. Deze zou bewerkstelligen dat de verschillende belangen van het land, zoals die door de verschillende kiezers(groepen) tot uitdrukking werden gebracht, tot én algemeen belang werden samengesmolten.

Doel van het systeem van virtual representation was het rekening houden met het belang van een bepaalde groep; het betekende echter niet het (actief) propageren van dit belang. ${ }^{74}$ Dat laatste was immers juist de taak van de gedelegeerde afgevaardigde in de door de Tories aangehangen theorie van het imperatief mandaat. In de ogen van de Whigs was de afgevaardigde een gekozen volksvertegenwoordiger met als tak het algemeen belang te behartigen, met de aantekening dat hij oog diende te hebben voor de belangen van zijn interessegroep.

In deze optiek bestond echter ook nog steeds het gevaar dat het parlement vooral een congres van afgezanten namens de diverse belangengroepen zou worden. Om dit te voorkomen stelde Burke zich op het standpunt dat elk lid van het parlement zich diende te onttrekken aan eventuele instructies van hun kiezers. De opvattingen van de kiezers dienden slechts evenveel waarde toe te komen dan die van elk willekeurig andere persoon (zolang die maar 'respectable and intelligent' was). Bij stemmingen diende de afgevaardigde zich te laten leiden door zijn eigen oordeel en geweten en vooral door wat hij zag als het algemeen belang van het land. ${ }^{75}$

Toch was de onafhankelijkheid van de individuele volksvertegenwoordiger niet absoluut. Enige verantwoordelijkheid van de afgevaardigde ten opzichte van de kiezer oordeelde Burke noodzakelijk. In zijn speech zijn daartoe enkele aanzetten te vinden. De binding tussen kiezer en gekozene ging voor Burke zo ver dat hij, als een van de eersten, aandrong op openbaarheid van de debatten in het Lagerhuis. Ook pleitte hij voor het bijhouden van lijsten waarop het stemgedrag van de afgevaardigden aangegeven werd, zodat de kiezers beter in staat zouden zijn hun afgevaardigden te beoordelen. ${ }^{76} \mathrm{Om}$ voldoende tegenwicht te bieden tegen de macht van de vorst, moest het

74. Vergl. Birch, Representation, a.w., p. 51.

75. Vergl. Gibbons, a.w., p. 37.

76. Burke, Present Discontents, a.w., p. 75. 
parlement dicht bij het volk staan. Dit zou enerzijds de afgevaardigden in staat stellen zich te weer te stellen tegen de overredingskracht van ministers en anderzijds de kiezers beter in staat stellen een eventueel minder goed functioneren van 'hun' afgevaardigde op te merken.

Burke's opvatting over de relatie tussen kiezers en gekozenen zou in de $19 \mathrm{e}$ eeuw de gangbare standaard worden voor de vormgeving van de relatie tussen een lid van het vertegenwoordigend lichaam en zijn kiezers. In de ongeschreven constitutie van het Verenigd Koninkrijk was het een van de weinige elementen die teruggingen tot de $18 \mathrm{e}$ eeuw; andere West-Europese staten, Frankrijk voorop, zouden het beginsel van de onafhankelijkheid van de individuele volksvertegenwoordiger en zijn taak om het algemeen belang te dienen, in hun grondwet opnernen. Dit zou bekend worden als de theorie van het vrije mandaat.

Volgens deze theorie is de natie de draagster van de soevereiniteit. Zij geeft de opdracht aan een andere persoon, het parlement, om die soevereiniteit in haar naam uit te oefenen. Er is een daadwerkelijk mandaat, waarbij twee partijen zijn: de natie (de mandans) en het parlement (de mandataris). Het resultaat van deze lastgeving is een vertegenwoordiging in die zin, dat de wilsuiting van het parlement beschouwd wordt als te zijn uitgegaan van de natie, en geacht wordt dezelfde gevolgen te hebben. ${ }^{n}$ In deze theorie gaat dus de macht en niet de wil van de vertegenwoordigde op de vertegenwoordiger over. Deze laatste krijgt geen opdracht, maar een volmacht; hij beslist zelf hoe hij het beste de belangen van zijn kiezers kan dienen en is daarbij niet gebonden aan eventuele instructies.

Dat betekent echter niet dat de afgevaardigden geheel naar willekeur mogen beslissen. Het-parlement als geheel is verantwoording verschuldigd aan het kiezerscorps als geheel. De grondslag voor deze relatie is gelegen in het mandaat dat het parlement heeft ontvangen. Het doel van de verkiezingen is juist een waarderingsoordeel uit te spreken over de wijze waarop de vertegenwoordigers zich van hun taak hebben gekweten.

In de theorie van het imperatieve mandaat zijn de afgevaardigden de lasthebbers van hun kiezers. Zij zijn de dragers van het subjectieve recht om dat deel van de soevereiniteit, dat aan hun kiezers toebehoort, onder hun controle uit te oefenen. In de theorie van het vrije mandaat is de oplossing minder eenvoudig: het parlement in zijn geheel ontvangt een mandaat (dus

77. Nord, a.w., p. 113/114. 
niet de individuele volksvertegenwoordiger). De afgevaardigden worden in feite door het parlement 'geabsorbeerd': juridisch zijn zij niets, alleen het parlement als geheel heeft een wil, een juridische bevoegdheid. Maar eigenlijk zijn en doen de afgevaardigden alles. ${ }^{78}$

\subsection{Staatsrechtelijke vertegenwoordiging op het Europese vasteland}

De opvattingen van de Whigs over staatsrechtelijke vertegenwoordiging werden door de geschriften van Montesquieu over het vasteland verspreid. Montesquieu was erg gecharmeerd van het Engelse staatsbestel; naar Engels voorbeeld zag hij het parlement niet als een instelling ter bescherming van het volk tegen vorstelijke willekeur. De scheiding van de drie staatsmachten impliceert reeds dat deze zelfstandig zijn en door zelfstandige organen worden uitgeoefend. Het parlement is dus ook een zelfstandig orgaan, door middel waarvan het volk de hem toekomende wetgevende macht uitoefent. Dat het volk deze macht aan een klein aantal burgers, verzameld in het parlement, heeft overgedragen vindt Montesquieu niet bezwaarlijk omdat er nu eenmaal geen andere mogelijkheid is. Een van de meeste essentiële opgaven van een parlement -het woord zegt het reeds- is de gezamenlijke beraadslaging. Dit maakt staatsrechtelijke vertegenwoordiging noodzakelijk:

"Le grand avantage des représentants, c'est qu'ils sont capables de discuter les affaires. Le peuple n'y est point du tout propre; ce qui forme un des grands inconvéniens de la démocratie. ${ }^{" 79}$

Ook het vereiste van de vrijheid van de vertegenwoordigers wordt bij Montesquieu ingegeven door praktische motieven. De vertegenwoordigers moeten niet gebonden zijn aan instructies van hun kiezers. Weliswaar zou door binding aan instructies de stem van de vertegenwoordigers het meest met die van de natie overeenkomen, maar aan de andere kant zou dit tevens leiden tot veel uitstel. Het zou elke afgevaardigde de macht geven om het parlement afzonderlijk te controleren en in spoedeisende en belangrijke staatszaken zou de daadkracht van de natie kunnen worden belemmerd

78. Vergl. Van den Broek, a.w., p. 20; Nord, a.w., p. 114.

79. Montesquieu, De l'esprit des loix (deel 2), Parijs 1955, p. 67. 
door een grillige inval van een enkele afgevaardigde. ${ }^{80}$ In het parlement moet met vrucht gediscussieerd kunnen worden; vandaar dat Montesquieu een imperatief mandaat verwerpt. Maar het verwerpen van het imperatief mandaat betekent ook, dat de afgevaardigde niet meer als een vertegenwoordiger van plaatselijke belangen wordt gezien. De afgevaardigde in het parlement is een vertegenwoordiger van de gehele natie, van het volk, die zijn positie ontleent aan het vertrouwen dat hij het landsbelang naar zijn beste weten zal behartigen.

Montesquieus standpunt dat het volk niet zelf wetten kan maken en dat dus moet overlaten aan zijn vertegenwoordigers, is een zuiver praktische overweging. Het vormt een scherpe tegenstelling tot de sterk theoretische argumenten van Rousseau, die vasthield aan de onvervreemdbare volkssoevereiniteit en geen vertegenwoordiging daarvan door afgevaardigden uit het volk aanvaardde, zelfs niet mogelijk achtte. Beiden zijn van mening dat het volk de wetgevende macht moet uitoefenen; waar Montesquieu vertegenwoordiging daarbij als noodzalak zag, stelde Rousseau dat het volk die functie nooit uit handen kan geven als het zijn vrijheid liefheeft. Hieruit leidde hij af dat de afgevaardigden van het volk niet zijn vertegenwoordigers (kunnen) zijn: de afgevaardigden zijn slechts lasthebbers, zij kunnen geen onherroepelijke besluiten nemen. ${ }^{81}$ Dit is een terugkeer naar het imperatief mandaat, zij het in een andere vorm dan voorheen onder de standenvergaderingen. De afgevaardigden van de standen hadden slechts als taak te waken voor de belangen van hun stand en niet om mee te werken

80. Idem. Deze beschrijving van een gefrustreerd besluitvormingsproces vertoont nogal wat overeenkomsten met het dat moment geldende in de Republiek der Verenigde Nederlanden (zie hoofdstuk 3). Opvallend is echter dat Montesquieu de op dat moment geldende praktijk van het gebod van last en ruggespraak in het stelsel van besluitvorming in de Republiek billijkt: als de afgevaardigden in een parlement een stand ("un corps de peuple") vertegenwoordigen, moeten zij door hun committenten verantwoordelijk gehouden kunnen worden. Het feit dat hij deze praktijk billijkt, impliceert overigens niet dat Montesquieu voorstander was van dit stelsel van besluitvorming als geheel; dat zijn voorkeur naar een ander -toenmaligstelsel van besluitvorming uitging, mag wel als bekend worden verondersteld.

81. J.-J. Rousseau, Du contract social ou principes du droit politique, Amsterdam 1762, boek 3, hfdst. 15 . 
aan het vaststellen van de op het algemeen belang van het volk gerichte 'volonté générale'. 82

Op het Europese vasteland nam de theorievorming over de aard van het mandaat van de volksvertegenwoordiger vooral ten tijde van de Franse revolutie een hoge vlucht. Aan de ene kant bestond de opvatting die de natie, in navolging van Rousseau, zag als een atomistische verzameling van individuen. Het volk mag de wetgevende macht niet aan anderen overdragen wil het zijn soevereiniteit niet verliezen. Daarom moeten de afgevaardigen in het parlement niet anders zijn dan de spreekbuizen van hun kiezers. Dat is de theorie van het imperatief mandaat, in de Assemblée Nationale vooral door Pétion de Villeneuve verwoord. Hij werd daarin gesteund door de tot dan toe geldende praktijk in het Franse parlement, waar de afgevaardigden zich vooral als vertegenwoordigers namens een van de drie standen beschouwden en niet van de natie. ${ }^{83}$

Hiertegenover stelden onder anderen Sieyess en Talleyrand de theorie van het vrije mandaat. $\mathrm{Zij}$ beseften dat een volk alleen door vertegenwoordiging kan handelen. Het volk wordt pas handelingsbekwaam als het bij verkiezing de besten, kundigsten en verlichtsten uit zijn midden aanwijst om voor de natie te handelen, zo redeneerden zij. Hun opvatting zou uiteindelijk door de Assemblée Nationale worden overgenomen. In de vergadering van 8 juli 1789 werd definitief met het imperatief mandaat gebroken toen de afgevaardigden op voorstel van Sieyes besloten de cahiers, waarin de instructies van hun committenten stonden opgetekend, terzijde te leggen en zelfstandig te beraadslagen en te besluiten. ${ }^{84}$ De constitutie die door de vergadering werd opgesteld en in september 1791 van kracht werd, verwoordde dit besluit als volgt:

82. Vergl. Nord, a.w., p. 84.

83. Vergl. Zwager, a.w., p. 47.

84. Zie over dit besluit en de discussies die hieraan voorafgingen o.m. P.A. Ramaer, De verhouding der volksvertegenwoordigers tot hunne committenten in de constitutionele monarchie, Leiden 1868, pp. 119-127 en J. d'Aulnis de Bourouill, De imperatieve mandaten der volksvertegenwoordigers, Themis 1882, pp. 422-429. 
"Les représentants nommés dans les départements ne seront pas représentants d'un département particulier, mais de la nation entière, et il ne pourra leur être donné aucun mandat. " 85

Bovengenoemd besluit van 8 juli 1789 van de Assemblée Nationale markeert de definitieve vestiging van de moderne staat op het Europese vasteland. ${ }^{86}$ Daar de nieuwe opvattingen over de rol van de volksvertegenwoordiging werden geïncorporeerd in het gedachtengoed van de Franse revolutie, duurde het niet lang vooraleer deze opvattingen tot andere landen zouden doordringen en ook daar constitutionele erkenning zouden krijgen. Voor de oude middeleeuwse, privaatrechtelijke standenvertegenwoordiging, waarin de vertegenwoordigers waren gebonden aan een imperatief mandaat, was geen plaats meer. Maar het beginsel van de lastgeving bleef behouden in die zin dat het vrije mandaat een nieuwe lastgeving vooronderstelde, die door de natie aan het parlement zou zijn gegeven.

\subsection{Een nieuwe mandaatstheorie}

De theorievorming over staatsrechtelijke vertegenwoordiging wordt beheerst door uit vorige eeuwen overgeleverde begrippen en is daardoor enigszins achterhaald. De staatkundige praktijk is de vertegenwoordigingstheorieën vrijwel steeds vooruit gegaan en gebleven. De uitbreiding van het kiesrecht, de opkomst en groei van de politieke partijen, de sterker wordende partij- en fractiediscipline, de uitbreiding van het aantal taken van de overheid en de daarmee gepaard gaande groei van de institutionele macht zijn ontwikkelingen die, met uitzondering van het eerstgenoemde aspect, voor de 20e eeuw niet waren voorzien. Tot die tijd had de overheid slechts een beperkte taak: het waren vooral de zgn. klassieke taken van de overheid (buitenlandse zaken, defensie, handhaving van de openbare orde) die door de het parlement werden 'gecontroleerd'. Het parlement was, zoals Burke zou stellen, inderdaad niet meer dan een beraadslagende vergade-

85. Titre III, chap. 1, sect. 3, art. 7. De constitutie van 1795 bevatte in art. 52 een bepaling van gelijke strekking.

86. Vergl. J.T. Buijs, De zelfstandigheid van het staatsrecht (rede 1876), in: Studiën over staatkunde en staatsrecht, deel 2, Amhem 1895, p. 497. 
ring, nu wetgeving in deze tijd een gering aandeel had binnen de parlementaire werkzaamheden.

Toch is het Burke geweest die reeds gewezen heeft op het belang van de rol van politieke partijen in het staatsbestel. In een tijd waarin partij- en factievorming in het algemeen als hoogst ongepast werden beschouwd, was hij een van de eersten die het belang van politieke partijen onderkende. In dit opzicht kan Burke worden gezien als de "first major theorist of party". ${ }^{87}$ Zijn werk Thoughts on the cause of the present discontents is een pleidooi voor partijvorming en de voordelen hiervan, al heeft hij vooral het oog op partijvorming binnen het parlement. In dit werk gebruikt hij ook de veel geciteerde definitie van het begrip politieke partij:

"Party is a body men united for promoting by their joint endeavours the national interest upon some particular principle in which they are all agreed. ${ }^{88}$

Partijvorming was volgens Burke noodzakelijk voor het ontdekken en tegengaan van de toenmalige "unconstitutional designs", die voor hem vooral gelegen waren in de te grote macht en invloed van het Britse hof op de afgevaardigden in het House of Commons:

"Whilst men are linked together, they easily and speedily comnunicate the alarm of any evil design. They are able to fathom it with common counsel, and to oppose it with united strenght. ${ }^{89}$

De noodzaak om tot partijvorming over te gaan en een gemeenschappelijk standpunt in te nemen over staatszaken betekende volgens Burke echter allerminst dat de afgevaardigden in het Lagerhuis hun onafhankelijkheid dienden op te geven. Partijvorming en het volgen van de partijlijn zou nooit zover mogen gaan dat de afgevaardigden zouden worden gedwongen af te wijken van hun eigen opvattingen; wanneer de eigen opvattingen van een afgevaardigde in het Lagerhuis fundamenteel zou verschillen met die van een partij, moest hij zich niet aansluiten of een andere partij zoeken. ${ }^{90}$

Zeker in het tijdsgewricht van Burke is het bij enkele bescheiden aanzetten tot partijvorming gebleven. In het Verenigd Koninkrijk waren, zoals

87. Deze omschrijving is van I. Kramnick, The rage of Edmund Burke. Portrait of an ambivalent conservative, New York 1977, p. 112.

88. Burke, Present Discontents, a.w., p. 82.

89. Idem, p. 78.

90. Idem, p. 84 en p. 85. 
hiervoor reeds werd aangeven, weliswaar al langer politieke bewegingen actief, maar evenals op het Europese vasteland manifesteren ook hier de politieke partijen als zodanig zich eerst vanaf het midden van de vorige eeuw. ${ }^{91}$ Het bestaansrecht van politieke partijen was toen nog erg omstreden; partijvorming werd gezien als een gevaar voor de op nationale eenheid gerichte besluitvorming. ${ }^{92}$ Vooral door de geleidelijke uitbreiding van het kiesrecht werd een herbezinning op functie van de politieke partijen noodzakelijk. De liberale staat, waarin het actief staatsburgerschap nog uitsluitend toekwam aan de sociaal-economische bovenlaag veranderde geleidelijk in een moderne (massa)democratie, waarin deze onderscheiding is weggevallen en het gehele volk zich door zijn organisaties laat gelden. Daartoe behoren in de eerste plaats de politieke partijen gerekend te worden. Van de oorspronkelijke, min of meer vrijblijvende groepsvorming binnen het parlement blijft weinig over: de politieke partijen groeien uit tot buitenparlementaire organisaties wier doel is zoveel mogelijk kiezers aan zich te binden, teneinde in het parlement de partijstandpunten te kunnen verwezenlijken. De partijvorming binnen het parlement wordt hierdoor versterkt: de facties groeien uit tot streng gedisciplineerde fracties.

Deze ontwikkeling heeft sommigen doen spreken van een terugkeer naar het imperatief mandaat, maar dan in een nieuwe gedaante. Het imperatief mandaat gaat nu niet meer uit van de kiezers maar van de politieke partijen. Niet de individuele volksvertegenwoordiger vormt in volstrekte zelfstandigheid de volkswil en geeft aan deze volkswil uiting, maar de partijen doen dat voortaan in zijn plaats. De individuele volksvertegenwoordiger vertegenwoordigt niet meer het gehele volk, maar alleen de partij die hem gekandideerd heeft. De partij-discipline is immers zo strak geworden, dat niet meer beweerd kan worden dat de individuele volksvertegenwoordiger nog volgens eigen overtuiging en geweten zijn stem in het parlement bepaalt. De afgevaardigden zijn slechts lasthebbers van de politieke partijen. Deze laatste stelling is gebaseerd op de door Leibholz verkondigde

91. Op de partijvorming in de in dit proefschrift besproken landen zal in de afzonderlijke hoofdstukken uitvoeriger worden ingegaan.

92. Vergl. D.J. Elzinga, De politieke partij en het constitutionele recht, Nijmegen 1982, p. 23; J.J.A. Thomassen, Politicke representatie, in: J.J.A. Thomassen (red.), Hedendaagse democratie, Alphen aan den Rijn 1991 , p. 181. 
theorie van de partijenstaat. ${ }^{93}$ In deze theorie ziet hij de positie van de individuele volksvertegenwoordiger als:

"(...) meist nichts anderes mehr als an die Weisungen der Parteien und deren Honorationen gebundene Funktionäre, die von den Wählern auch nur als angehörige einer bestimmten politischen Partei in das Parlement gewählt werden ". ${ }^{94}$

Hoewel op de theorie van de partijenstaat nogal wat kritiek mogelijk is ${ }^{95}$, heeft zij wel oog voor de veranderende functie van het parlement en doet zij een poging deze verandering te verklaren.

Bovengenoemde ontwikkelingen en het daarmee gepaard gaande verlies van de zelfstandigheid van de individuele volksvertegenwoordiger heeft tot een derde mandaatstheorie geleid; de theorie van het electorale mandaat. ${ }^{96}$ Hier verleent het volk geen mandaat aan de volksvertegenwoordigers, maar aan de politieke partijen. Deze verlenen op hun beurt een mandaat aan de individuele volksvertegenwoordiger. Het mandaat verleend door het volk is in feite een kruising van lastgeving en machtiging: aan de ene kant rust op de politieke partijen de verplichting hun verkiezingsprogramma zoveel mogelijk in het te voeren beleid te verwezenlijken, terwijl anderzijds aan de partijen een redelijke behoefte aan bewegingsvrijheid niet mag -en gezien de staatkundige verhoudingen veelal ook niet kan- worden ontzegd. ${ }^{97}$ Het mandaat dat de politieke partij vervolgens aan de individuele volksvertegenwoordiger verleent, is in hoge mate een lastgeving: nu de individuele volksvertegenwoordiger kandidaat is gesteld door de partij en op het op het partijprogramma gebaseerde verkiezingsprogramma verkozen is, moeten de partijstandpunten in het parlement zoveel mogelijk worden

93. G. Leibholz, Das Wesen der Repräsentation und der Gestaltwandel der Demokratie im 20. Jahrhundert, 3e druk, Berlijn 1966, pp. 98-123.

94. Idem, p. 99.

95. Zie bijvoorbeeld: Elzinga, a.w., pp. 8-16; Thomassen, a.w., p. 181/182 en C.W. van der Pot/A.M. Donner, Handboek van het Nederlandse staatsrecht, 12e druk, bewerkt door L. Prakke (e.a.), Zwolle 1989, p. 422/423.

96. Hierover: Birch, Representation, a.w., pp. 97-100; Van den Broek, a.w., p. 19/20. Zie ook: A. Hoogerwerf, De geachre afgevaardigde. Over de vertegenwoordigende rol van het parlementslid, Meppel 1968, p. 15/16.

97. Vergl. E.H. s'Jacob, Representatie en mandaat in het politiek bestel, Groningen 1966, p. 17. 
gesteund; hun persoonlijke opvattingen zijn daarbij grotendeels irrelevant. ${ }^{98}$

De theorie van het electorale mandaat gaat uit van de realiteit van het politieke leven in de moderne staat, met al haar overlappende tegenstellingen, complexe problemen en issues en een veelheid van factoren die op de politieke besluitvorming inwerken. In een dergelijke omgeving moet de vertegenwoordiger tegelijk meegaand èn onafhankelijk zijn, luisteren naar de kiezers en tevens een eigen oordeel hebben, losse issues èn de grote lijn in het oog houden, met de kiezers van mening durven en kunnen verschillen, zonder dat dit tot permanente onenigheid leidt. Binnen deze voorwaarden moet de vertegenwoordiger functioneren, handelen en werken: vertegenwoordiging is voor beide partijen een openbaar en geïnstitutionaliseerd proces. Waar de nadruk in de relatie precies wordt gelegd is van vele factoren afhankelijk en zal van situatie tot situatie verschillen. Er behoeft niet een voortdurende verantwoording te zijn, maar een potentiële bereidheid tot verantwoording behoort aanwezig te zijn." Gezegd kan daarom worden dat ook onder de theorie van het electoraal mandaat in praktijk het vereiste dat een volksvertegenwoordiger zoveel mogelijk in onafhankelijkheid tot zijn beslissingen moet komen, voorop staat. De afgevaardigde is deel van "a body which is responsible for the interest of the country at large, and, though he is influenced by the whishes and views of his constituents and by the action of his party, he does not surrender his right of independent judgement." 100

De mandaatstheorieën vormen de belangrijkste categorie theorieën over staatsrechtelijke vertegenwoordiging. ${ }^{101}$ Alleen van deze theorieën kan worden gezegd dat zij enige constitutionele erkenning hebben gekregen. Dat geldt vooral voor de theorie van het vrije mandaat, dat in vrijwel alle westerse landen op de een of andere wijze in de constitutie verankerd is. De theorie van het electoraal mandaat is weliswaar meer in overeenstem-

98. Vergl. Birch, Representation, a.w., p. 98; Van den Broek, a.w., p. 20.

99. Vergl. J. Kooiman, Over de Kamer gesproken, 's-Gravenhage 1976, p. 95.

100. C.P. Ilbert, Parliament. Its history, constiturion and practice, 3e druk, bewerkt door C. Carr, Londen 1948, p. 141.

101. Voor de Tweede Wereldoorlog hebben nog enkele andere theoricēn een bescheiden- rol gespeeld, met name in Duitsland en Frankrijk; zie hierover Nord, a.w., pp. 116-130. Thans zijn deze echter van geen enkel belang meer. 
ming met de praktijk, maar heeft weinig constitutionele erkenning gekregen; alleen in het Verenigd Koninkrijk zijn elementen van deze theorie in de constitutie terug te vinden. ${ }^{102}$ In Duitsland is dit, ondanks de grondwettelijke erkenning van de rol van de politieke partijen in het staatsbestel, niet het geval; de afgevaardigde in de Bondsdag heeft, net als zijn Nederlandse collega, vooral een vrij mandaat. ${ }^{103}$ De theorie van het imperatieve mandaat is, zoals hiervoor reeds werd aangegeven, thans eigenlijk niet meer dan een constitutionele antiquiteit.

\subsection{Theorieën: politicologische benadering}

Het kernpunt bij de theorie van het vrije mandaat en zijn tegenhanger, de theorie van het imperatief mandaat, is de mate waarin de individuele leden van een volksvertegenwoordiging hun gedrag laten bepalen door de wil van de kiezers. In dit opzicht hebben deze theorieën vooral een normatief karakter omdat zij een uitspraak doen over de wijze waarop de volksvertegenwoordiger zich ten opzichte van zijn kiezers dient te gedragen en weinig empirisch van aard zijn. De mandaatstheorieën zijn dan ook niet boven kritiek verheven. Vooral door politicologen is betoogd dat de mandaatstheorieën -behoudens de theorie van het electoraal mandaatte weinig oog hebben voor de wijze waarop de vertegenwoordiger zich in praktijk gedraagt.

Zo stelt Hoogerwerf dat de mandaatstheorieën -waarbij hij zich overigens beperkt tot de theorieën van het imperatieve en het vrije mandaat, door hem lastgevingsmodel respectievelijk machtigingsmodel genoemd- de aandacht te eenzijdig op de besluitvorming binnen het parlement richten en voorbijgaan aan het feit dat een parlement ook een beraadslagend lichaam is. Dit verwijt is nogal merkwaardig, nu deze theorieën zijn ontstaan in een periode waarin de parlementen juist vooral een beraadslagende functie hadden. Volgens Hoogerwerf is de relatie tussen volksvertegenwoordiger en vertegenwoordigde niet alleen een kwestie van besluitvorming, maar ook een kwestie van raadpleging vooraf en het afleggen van verantwoording achteraf. ${ }^{104}$ Door de aandacht te eenzijdig op de besluitvorming te

102. Zie hiervoor $\$ 4$ van hoofdstuk 5 .

103. Zie hiervoor $\$ 6$ van hoofdstuk 4 .

104. Hoogerwerf, a.w., p. 10. 
richten, doen het lastgevings- en het machtigingsmodel tekort aan de aard van het vertegenwoordigen en de aard van het parlement. ${ }^{105}$ De aard van het vertegenwoordigen heeft daarbij betrekking op de rolopvatting van de individuele volksvertegenwoordiger met betrekking tot de vraag of hij zich al dan niet laat leiden door de wil van zijn achterban; de aard van het parlement betreft de rolopvatting met betrekking tot de vraag welk belang door de vertegenwoordiger behoort te worden behartigd. De begrippen aard van het vertegenwoordigen en aard van het parlement zijn synoniemen voor de twee dimensies van het vertegenwoordigingsbegrip zoals Burke die impliciet onderscheidde in zijn toespraak in Bristol, de stijl van vertegenwoordiging, respectievelijk de focus van vertegenwoordiging. ${ }^{106}$

Ten aanzien van de stijl van vertegenwoordiging kunnen drie mogelijke rolopvattingen van vertegenwoordigers worden onderscheiden ${ }^{107}$ :

a. die van de 'delegates', de lasthebbers. Deze categorie volksvertegenwoordigers laat zich leiden door de opvattingen die zij (meent te) vertegenwoordigen;

b. die van de 'trustees', de gemachtigden. Deze volksvertegenwoordigers huldigen het standpunt dat zij in hun stemgedrag zoveel mogelijk hun eigen mening moeten volgen;

c. die van de 'politico's'. Dit betreft de restcategorie van volksvertegenwoordigers die het antwoord op de vraag of zij al dan niet als lasthebber van de kiezers moeten optreden van geval tot geval beoordelen.

Deze indeling is gebaseerd op onderzoeken waarbij werd getracht meer inzicht te krijgen in de opvattingen van de volksvertegenwoordigers zelf, al

105. Idem.

106. In tegenstelling tot de juridische literatuur bestaat er in de politicologische literatuur allerminst overeenstemming over de te hanteren begrippen ter benaming van de verschillende vertegenwoordigingstheorieën. Dit heeft tot gevolg dat een bepaalde theorie onder verschillende benamingen bekend kan staan. Geheel andere benamingen voor de hier genoende theorieën worden bijvoorbeeld gehanteerd door M.P.C.M. van Schendelen, Parlementaire informatie, besluitvorming en vertegenwoordiging, Rotterdam 1975, pp. 6-13.

107. Vergl. onder meer: Hoogerwerf, a.w., p. 9/10; Kooiman, a.w., p. 96; N.L. Schwartz, The blue guitar: political representation and community, Chicago 1988, pp. 24-26. 
kan niet ontkend worden dat deze empirische rolopvattingen ook aansluiting vinden bij de hierboven genoemde normatieve mandaatstheorieën.

Ook bij de focus van vertegenwoordiging kan een drietal rolopvattingen worden onderscheiden. Waar Burke in dit verband doelde op de tegenstelling tussen de belangen van het eigen kiesdistrict en de belangen van de hele natie, kan de focus van vertegenwoordiging thans ook van toepassing zijn op andere aanwijsbare belangen, zoals die van een (niet regionaal gebonden) belangengroepering of een politieke partij. ${ }^{108}$ Ten aanzien van deze rolopvattingen geldt dat bij alle drie een spanning bestaat tussen theorie en praktijk, tussen norm en werkelijkheid, zij het op verschillende wijze. In de tegenwoordige staatkundige en politieke verhoudingen is de focus ten aanzien van de partij wel de belangrijkste. Partijen spelen in de relatie tussen kiezer en gekozene in het politieke systeem van de meeste westerse landen een zeer belangrijke, zo niet dominante rol. Zij zijn een welhaast onmisbaar intermediair tussen de kiezers en de volksvertegenwoordigers geworden. $\mathrm{Zij}$ kanaliseren niet alleen de recrutering, maar ook prograrnmatisch en bij de regeringsvorming beheersen zij het toneel. Slechts in enkele zeer uitzonderlijke gevallen hebben zich restverschijnselen van directe democratie weten te handhaven, terwijl ook andere soorten organen dan partijen als schakel tussen vertegenwoordigden en vertegenwoordigers in de politiek uitzondering zijn gebleven. ${ }^{109}$

Aan de directe vertegenwoordiging van de kiezer wordt zowel in normatieve zin als de realiteit van het parlementaire bestaan wel aandacht geschonken, maar in feite stelt deze focus van vertegenwoordiging weinig tot niets meer voor. Daarnaast kan nog groeps- of sectorvertegenwoordiging als focus van vertegenwoordiging worden beschouwd. Deze vorm wordt als norm moeilijk aanvaard, maar wordt toch sterk gepraktiseerd. ${ }^{110}$

Bij focus van vertegenwoordiging wordt een aantal modellen onderscheiden. De twee modellen die hierbij in eerste instantie zijn te onderscheiden worden aangeduid als het integratiemodel en het differentiatiemodel. Zij worden ook wel als het eenheidsmodel respectievelijk het verscheidenheids-

108. Vergl. Thomassen, a.w., p. 173.

109. Kooiman (a.w., p. 97) noernt de discussie over een eventueel op corporatieve basis samengestelde Eerste Kamer hier als voorbeeld.

110. Kooiman, a.w., p. 97. 
model aangeduid. Het eenheidsmodel ziet het parlementslid als vertegenwoordiger van het hele volk; het verscheidenheidsmodel beschouwt hem als vertegenwoordiger van een bepaalde territoriale, sociale of politieke groepering. Bij deze modellen is de focus dus gericht op de persoon van de kiezer.

Naast deze twee modellen kunnen nog twee andere modellen worden onderscheiden, die beide als een species van het verscheidenheidsmodel zijn te beschouwen, $\mathrm{nl}$. het partijmodel en belangengroepenmodel. Het partijmodel ziet de volksvertegenwoordiger als de vertegenwoordiger van een politieke partij en sluit daarmee aan bij de theorie van het electorale mandaat. Wanneer die partij een ongeorganiseerde politieke stroming is, zal het partijmodel vaak gecombineerd zijn met het machtigingsmodel; is de partij daarentegen een moderne, georganiseerde partij, die -anders dan de individuele kiezer- in staat is de volksvertegenwoordiger te belonen of te straffen, dan gaat het partijmodel veelal samen met het lastgevingsmodel. De partij-organisatie, of althans de leiding daarvan, is dan de lastgever van het parlementslid. ${ }^{111}$

In het belangengroepenmodel is de volksvertegenwoordiger een vertegenwoordiger van een pressie- of belangengroepering. Ook dit model kan zowel met het machtigings- als met het lastgevingsmodel samengaan; deze combinatie varieert al naargelang vertegenwoordiger, politiek issue en politiek actieve belangengroepering. Deze vorm van vertegenwoordiging wordt, met uitzondering van vertegenwoordiging van regionale belangen, niet altijd even legitiem gevonden. ${ }^{112}$

111. Hoogerwerf, a.w., p. 15.

112. Kooiman, a.w., p. 98. 


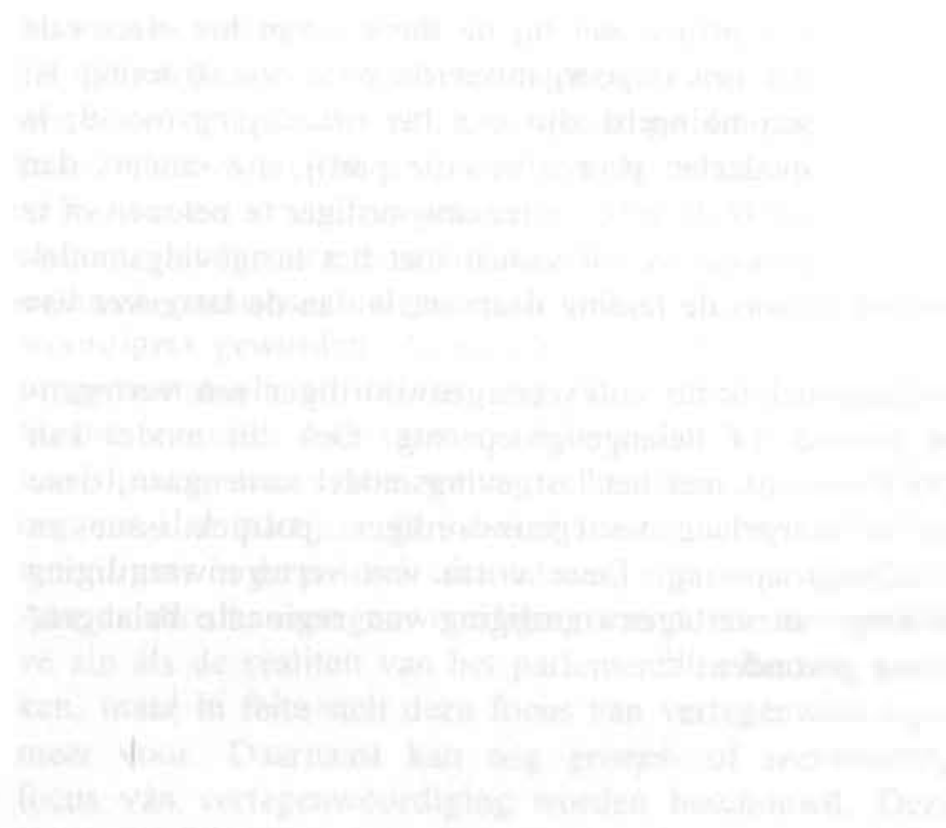

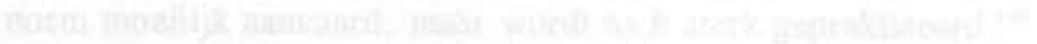

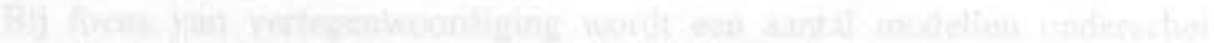

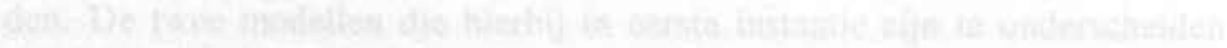

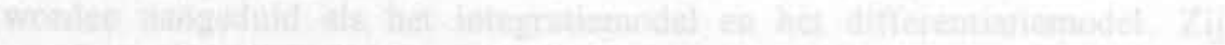

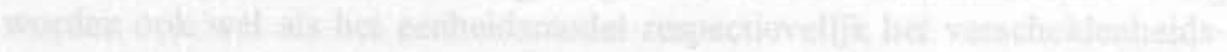

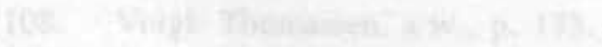

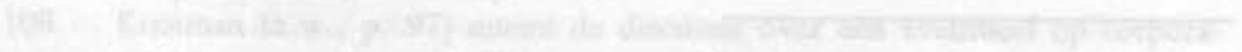

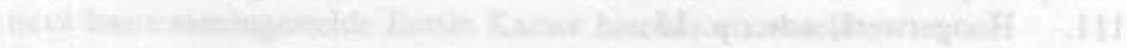

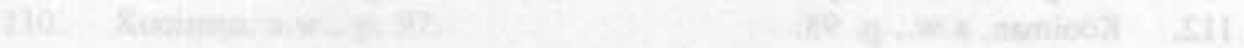




\section{STAATSRECHTELIJKE \\ VERTEGENWOORDIGING \\ IN NEDERLAND}

\subsection{Inleiding}

In dit hoofdstuk staat de ontwikkeling van de relatie tussen volksvertegenwoordiger en kiezer en de relatie tussen volksvertegenwoordiger en partij in Nederland centraal. Zoals hiervoor reeds vermeld is, speelt het vrije mandaat, vormgegeven in het verbod van last (en ruggespraak) hierbij een belangrijke rol. De ontwikkeling en de betekenis van deze verbodsbepaling in het Nederlandse staatsrecht komt dan ook in dit gedeelte uitgebreid aan bod.

Een beschouwing over de verbodsbepaling is echter slechts dan zinnig wanneer haar ontstaansgeschiedenis centraal wordt gesteld. De keuze voor het waarborgen van de onafhankelijkheid van de leden van de StatenGeneraal door het opnemen in de Grondwet van een uitdrukkelijk verbod van last en ruggespraak is namelijk geheel historisch bepaald. Gesteld kan zelfs worden dat er eigenlijk geen sprake is geweest van een keuze, in die zin dat bij de constitutie van de Nederlandse eenheidsstaat nooit enig alternatief voor de verbodsbepaling overwogen is; met name de ontwikkelingen in de tweede helft van de $18 \mathrm{e}$ eeuw leidden welhaast onontkoombaar tot de keuze van het verbod van last en ruggespraak als waarborg voor de onafhankelijkheid van de individuele volksvertegenwoordiger. Deze ontwikkelingen worden in hoofdzaak beheerst door twee factoren. De eerste factor is gelegen in de beïnvloeding door de ontwikkelingen in Frankrijk aan het einde van de $18 \mathrm{e}$ eeuw en draagt dus een extern karakter. Daarnaast is er een uiterst belangrijke interne factor, die wordt gevormd door het stelsel van besluitvorming op centraal niveau in het tijdperk voorafgaand aan het ontstaan van de Nederlandse eenheidsstaat, het tijdperk van de Republiek der Verenigde Nederlanden ( \pm 1581-1795).

Het stelsel van besluitvorming onder de Republiek der Verenigde Nederlanden werd in hoge mate beheerst door het gebod van last en ruggespraak, de verplichting voor de afgevaardigden van de Gewestelijke Staten in de Staten-Generaal bij stemmingen te stemmen volgens de van te voren door de Gewestelijke Staten gegeven opdracht (last). Wanneer de last niet in het 
aan de orde zijnde onderwerp voorzag, moesten de afgevaardigden, alvorens hun stem uit te brengen, teruggaan naar hun committenten teneinde na overleg (ruggespraak) een hernieuwde last te ontvangen. De ervaringen met deze wijze van besluitvorming op centraal niveau waren -zeker in de tweede helft van de $18 \mathrm{e}$ eeuw- dusdanig negatief dat bij de constitutie van de Nederlandse eenheidsstaat de keuze voor het verbod van last en ruggespraak als logische tegenhanger van het gebod van last en ruggespraak voor de hand lag.

Aandacht voor de praktijk van het gebod van last en ruggespraak is daarom gewenst teneinde de overgang naar het verbod van last en ruggespraak te verklaren. In de nauwe samenhang tussen beide bepalingen is de reden gelegen dat in dit hoofústuk aan de beschouwing over de verbodsbepaling, een beschouwing over de gebodsbepaling vooraf gaat. Als vertrekpunt dient daarvoor de situatie ten tijde van de vestiging van de Republiek der Verenigde Nederlanden.

Daarbij dient te worden opgemerkt dat dit niet betekent dat het stelsel van last en ruggespraak pas in deze periode ontstaan is. Integendeel, het ontstaan van het stelsel van het gebod van last en ruggespraak, gaat aannemelijk verder terug, zij het dat het exacte tijdstip niet kan worden aangegeven. Dit wordt in hoge mate veroorzaakt door het feit dat de gebodsbepaling oorspronkelijk een regel van gewoonterecht was. De gewoonte van het gebod van last en ruggespraak kan echter nooit eerder ontstaan zijn dan ten tijde van de eerste vergadering van een vertegenwoordigend lichaam; in dit geval niet zozeer een volksvertegenwoordigend lichaam maar een standenvertegenwoordigend lichaam. Omdat in de middeleeuwen lange tijd volstrekt geen sprake was van besluitvorming op centraal niveau, is het mogelijk het ontstaan van de praktijk van het gebod van last en ruggespraak in het besluitvormingsproces op centraal niveau te dateren. Oorspronkelijk werden de Gewestelijke Staten van het rijk steeds afzonderlijk door de landsheer geraadpleegd. Dat veranderde echter in 1464 toen Philips de Goede de Staten van het Bourgondische rijk bijeenriep om hen te horen over zijn plannen met een groot leger ter kruistocht te gaan. In verband hiermee werd overleg gepleegd over zijn vervanging gedurende zijn afwezigheid. Tevens zouden enkele muntkwesties en enkele stedelijke grieven aan de orde komen. Deze bijeenkomst, die op 9 januari 1464 in Brugge plaatsvond, wordt vrij algemeen beschouwd als de eerste bijeenkomst van de zgn. Algemene Staten, de voorloper van de huidige Staten-Generaal. Deze vergadering droeg reeds kenmerken in zich van wat 
later als de Staten-Generaal zou worden aangeduid. ${ }^{1}$ Voor deze vergadering hadden de afgevaardigden van de gewesten een instructie meegekregen van de Statenvergadering die hen had afgevaardigd.

Ten aanzien van het besluitvormingsproces op centraal niveau kan het ontstaan van de praktijk van het gebod van last en ruggespraak dus tamelijk exact worden gedateerd. Moeilijker ligt dit bij het bepalen van het ontstaan van de gebodsbepaling op lagere niveau's. Hier was al veel langer (d.i. voor 1464) sprake van zekere overlegstructuren, waarvan het tijdstip van ontstaan (en dus ook het ontstaan van het gebod) niet bekend is. Zo kwamen de standen van een gewest -al dan niet in persoon- bijeen in de vergadering van de Gewestelijke Staten. Bij deze vergadering berustte de beslissingsbevoegdheid; afzonderlijk hadden de standen slechts én of enkele stemmen. De afgevaardigden van een stand waren in de vergadering gebonden aan de instructies die zij van hun committenten hadden meegekregen. Het ontbreken van een exact tijdstip van het ontstaan van het gebod van last en ruggespraak is echter niet al te bezwaarlijk. Voor de in dit onderzoek centraal staande problematiek is het louter bestaan van de gebodsbepaling als uitgangspunt voldoende. Wel is het, alvorens met een beschrijving van het stelsel van besluitvorming onder de Republiek te beginnen, zinvol enige aandacht te besteden aan de staatkundige situatie ten tijde van de vestiging van de Republiek der Verenigde Nederlanden. Dat is de inhoud van paragraaf 2 . In paragraaf 3 zullen de belangrijkste actoren binnen het besluitvormingsproces in de Republiek aan de orde komen: de respectievelijke Gewestelijke Staten van de provincies van de Republiek. Paragraaf 4 richt zich vervolgens op de positie die de Staten-Generaal hierbij innam. In paragraaf 5 zal de ontwikkeling van het gebod van last en ruggespraak op centraal niveau worden besproken, terwijl in paragraaf 6 de invloed van het gebod op het besluitvormingsproces nader zal worden aangegeven. Paragraaf 7 beschrijft de periode van de Bataafse Republiek; deze vormt de overgang van het gebod van last en ruggespraak naar het verbod van last en ruggespraak. De ontwikkeling en functie van de verbodsbepaling vanaf de vestiging van de Nederlandse eenheidsstaat is de

1. Hierover C. van de Kieft, De Staten-Generaal in het Bourgondisch-Oostenrijkse tijdvak (1464-1555), in: S.J. Fockema Andreae/H. Hardenberg (red.), 500 jaren Staten-Generaal in de Nederlanden. Van Statenvergadering tot volksvertegenwoordiging. Assen 1964, p. 1. 
rode draad in de volgende paragrafen, die steeds een periode tussen de belangrijkste grondwetsherzieningen sinds 1814 bestrijken.

\subsection{De staatkundige situatie rond 1581}

De vestiging van de Republiek der Zeven Verenigde Nederlanden laat zich niet exact dateren. Als tijdstip van ontstaan worden wel genoemd 23 januari 1579 (de totstandkoming van de Unie van Utrecht), 22 juli 1581 (de afzwering Philips II), 1588 (toen de staten -bij gebrek aan een nieuwe landsheer- de soevereiniteit overnamen) en 1595 (toelating Stad en Lande als zevende gewest tot de Staten-Generaal). De Republiek kwam voort uit het grotere staatkundige verband van de Republiek der Zeventien Provinciën. Deze had zich gevormd door de geleidelijke vereniging van de betrokken gewesten onder de Bourgondische en Habsburgse landsheren. Deze vereniging is voor een groot deel toe te schrijven aan Philips de Goede (1419-1467). Hij was immers de landsheer die de uitbreidingspolitiek van het Bourgondische Huis, ingezet in 1384, voortzette en de meeste gewesten onder zijn scepter wist te verenigen. Hij wist het bewustzijn van de onderlinge belangengemeenschap te bevorderen en nam -zij het langzaam en gematigd- enkele maatregelen op het gebied van de financiële administratie en de rechtsbedeling, die een nadere eenheid van de gewesten konden voorbereiden. ${ }^{2}$ Op grond van zijn actief centraliserende beleid, kan hij als grondlegger van de Nederlandse en Belgische staten worden beschouwd. ${ }^{3}$ Het is echter de vraag of Philips niet slechts fungeerde als katalysator van een ontwikkeling die zich hoe dan ook zou hebben voorgedaan. De eenmaking van de 'Lage Landen bi der See' tussen 1384 en 1593 was immers ook een gevolg van de verzwakking van de middeleeuwse feodaliteit als internationaal politiek systeem. En ook als intern-staatkundige basis voldeden de feodale kaders niet meer voor de nieuwe nationale staten, waar de voormalige vazallen c.q. leenmannen waren uitgegroeid tot

2. Vergl. I.H. Gosses, Handboek tor de staatkundige geschiedenis der Nederlanden, deel 1, 4e druk, bewerkt door R.R. Post, 's-Gravenhage 1959, p. 220.

3. Vergl. J.P. de Monté VerLoren, Hoofdlijnen uit de ontwikkeling der rechterlijke organisatie in de Noordelijke Nederlanden tot de Bataafse omwenteling, 6e druk, bewerkt door J.E. Spruit, Deventer 1982, p. 196. 
monarchale landsheren die volgens 'nieuwe' staatsrechtelijke doctrines wilden regeren. ${ }^{4}$

Ondanks hun streven naar eenheid, integriteit en onafhankelijkheid bezaten noch de Bourgondische hertogen, noch (later) Karel V en Philips II voor de Nederlanden een algemene rechtstitel van koning, heer of wat dan ook. Staatsrechtelijk werd door de eenmaking van de Lage Landen geen eenheidsstaat gevormd, maar een personele unie van vorstendommen, die alle eigen rechtssystemen hadden. Er ontstond een statenbond waarvan alle leden én en dezelfde soeverein hadden. Daardoor was deze bij zijn troonsbestijging verplicht zich in elk van de gewesten als hertog, graaf of heer te laten erkennen.

Binnen de Nederlanden was er nog weinig integratie van de gewesten. Elk vorstendom had eigen politieke en juridische tradities en instellingen. Aan de in 1579 gesloten Unie van Utrecht, die min of meer noodgedwongen zou uitgroeien tot de constitutie van de Republiek der Verenigde Nederlanden, lag allerminst de bedoeling ten grondslag de uit de late middeleeuwen overgeleverde bestuursstructuren aan te tasten. Ook de afzwering van de landsheer in 1581 bracht daarin geen verandering. De opstand die tot de afzwering had geleid, was vooral juist een strijd geweest voor het behoud van de middeleeuwse privileges en gewoonten en tegen het vorstelijk centralisatiestreven. Toen aan de bestuursinrichting van de nieuwe staat een meer concrete vorm moest worden gegeven, waren eerbied voor de overgeleverde rechten en vrijheden van de standen en behoud van de gewestelijke en lokale instellingen natuurlijk dwingende geboden. ${ }^{5}$ Nieuwe competenties voor de reeds bestaande instellingen ontstonden dan ook slechts als gevolg van de nieuwe staatkundige structuur van de in het kader van de Republiek verenigde onafhankelijke gewesten, waarbinnen de landsheer was weggevallen. ${ }^{6}$

4. Vergl. H. de Schepper, De burgerlijke overheden en hun permanente kaders 1480-1579, in: Algemene Geschiedenis der Nederlanden, dee! 5 , Haarlem 1980, p. 312.

5. A.J.C.M. Gabriēls, De heren als dienaren en de dienaar als heer. Het stadhouderlijk stelsel in de tweede helft van de achtiende ceuw, "s-Gravenhage 1990 , p. 13.

6. Vergl. De Monte VerLoren/Spruit, a.w., p. 219. 
De grondslag van de regeringsvorm in de geünieerde gewesten bleef echter die van een standenstaat, zij het een onthoofde standenstaat. ${ }^{7}$ Het wegvallen van de landsheer betekende het einde van het oude dualisme van de landsheerlijke staat waarin vorst en standvertegenwoordiging tegenover elkaar stonden. In staatkundig opzicht had dit verreikende gevolgen. De staatsvorm van de verbonden gewesten werd door het wegvallen van de landsheer niet alleen die van een republiek, maar ook die van een statenbond. ${ }^{8}$ De macht van de landsheer werd door de vertegenwoordigers van de standen, de Staten van de afzonderlijke gewesten, overgenomen. Daarmee kwam de soevereiniteit binnen de republiek, zo niet de jure, dan toch de facto te berusten bij de Statenvergaderingen van de in het bondgenootschap verenigde provincies.?

\subsection{De functie van de Gewestelijke Staten}

In de middeleeuwen berustte oorspronkelijk alle macht bij de landsheer; zijn absolute macht werd door geen enkel constitutioneel orgaan beperkt. In de late middeleeuwen, toen het leenstelsel op instorten stond, kwam echter een beweging op die de absolute macht van de landsheer enigszins aan banden legde. Vooral in de $14 \mathrm{e}$ eeuw, toen de ambities van de landsheren als gevolg van hun centralisatie-streven toenamen en door de stijgende welvaart en de daarmee verband houdende toenemende geldcirculatie 'het spel van territoriale expansie' intensiever en met grotere risico's werd gespeeld, moesten de landsheren steeds meer rekening houden met de draagkracht van hun onderdanen en moesten zij zich van enige instemming met hun politiek verzekeren. ${ }^{10}$ Vandaar dat zij ertoe overgingen vertegenwoordigers van die onderdanen op te roepen: de Staten van de afzonderlijke gewesten. Daaronder werden verstaan de standen: de geboorteadel, de hoge geestelijkheid en de 'derde stand'. Deze laatste stand bestond over het

7. Gabriëls, a.w., p. 13.

8. Behalve de 7 gewesten die hieronder nader zullen worden beschouwd omvatte de Republiek der Verenigde Nederlanden ook de landschap Drente en de zgn. Generaliteitslanden. Drente kende wel een eigen bestuur, maar behoorde -evenals de Generaliteitslanden- niet tot de stemhebbende gewesten.

9. Vergl. Gabriëls, a.w., p. 13.

10. Van de Kieft, a.w., p. 3. 
algemeen uit afgevaardigden namens de zogenaamde 'goede' steden; in feite vertegenwoordigden zij het stadspatriciaat, de handeldrijvende burgerij. Het proletariaat uit de stedelijke en landelijke industriële centra had geen afgevaardigden in de Staten. De plattelandsbevolking werd op diverse wijzen geacht vertegenwoordigd te zijn; dit verschilde nogal van gewest tot gewest. Ook de geestelijkheid was in de Nederlandse gewesten niet overal vertegenwoordigd. Bovengenoemd samenstellingspatroon was overigens allerminst uniform voor alle gewesten. ${ }^{11}$

De Staten werden doorgaans geraadpleegd over zaken van groot en algemeen belang, die in overleg en met medewerking van het volk geregeld dienen te worden. ${ }^{12}$ De bevoegdheid om als stand in een statenvergadering vertegenwoordigd te zijn berustte niet op een regel van publiek recht (in de eigenlijke betekenis van het woord), maar op een deel van de soevereiniteit, door de vorst aan de standen geschonken. De rechten die tezamen de landsheerlijkheid vormden, behoorden tot het vermogen van de landsheer; deze kon geheel vrijelijk daarover beslissen. ${ }^{13}$ De vertegenwoordigingsbevoegdheid van de standen was dus in vele opzichten privaatrechtelijk van karakter: de standen hielden als het ware het hen geschonken deel van de soevereiniteit in eigendom. ${ }^{14}$ Dit kwam vooral tot uitdrukking in de vrije beschikking die de standen over de wijze van uitoefening van deze bevoegdheid hadden. Wanneer zij deze niet in persoon wilden uitoefenen, konden zij haar door een lasthebber doen waarnemen of de uitoefening ervan zelfs geheel laten rusten. Het is daarom onjuist het vertegenwoordigingsbegrip geheel van het privaatrecht te abstraheren. Temidden van de privaatrechtelijke sfeer van de middeleeuwen is de vertegenwoordiging ontstaan, ook al heeft zij niet direct die vorm aangenomen die thans als staatsrechtelijke vertegenwoordiging wordt gezien. Hieruit is te verklaren dat toen het vertegenwoordigingsbegrip in het staatkundig leven ontstond, dit geheel volgens privaatrechtelijke beginselen werd geconstrueerd; de

11. Uitvoeriger over de samenstelling van de besturen van de gewesten: Gabriëls, a.w., pp. 17-35.

12. Zie voor een opsomming van de aangelegenheden waarin de landsheer de Gewestelijke Staten placht bijeen te roepen: R. Fruin, Geschiedenis der staatsinstellingen in Nederland tot den val der Republiek, bewerkt door H.T. Colenbrander, 2e druk, 's-Gravenhage 1922, p. 48.

13. Vergl. De Monté VerLoren/Spruit, a.w., p. 139.

14. Vergl. P.A. Ramaer, De verhouding der volksvertegenwoordigers tot hunne committenten in de constitutionele monarchie, Leiden 1868, p. 13 en p. 62. 
eerste volksvertegenwoordigers werden gezien als lasthebbers, die voor de uitvoering van hun opdracht aan hun committenten verantwoording schuldig waren, en die bovendien optraden als 'procureurs' van een privaatrechtelijke groep (de standen), niet van een staatkundige eenheid. ${ }^{15}$

Ook in de Nederlanden ontstonden de 'Staten' als de vertegenwoordiging van de verschillende standen tegenover de landsheer. Elk gewest had een eigen statenvergadering. De oorsprong van deze vertegenwoordiging van de standen was hun economische macht. Hieruit is hun politieke macht, later zelfs politiek recht, gegroeid. De economische macht van de adel was aanzienlijk ouder dan die van de steden. Oorspronkelijk werd dan ook alleen de adel door de vorst gehoord. Toen enkele Hollandse steden zo machtig waren geworden dat het gevaarlijk werd niet ook hen te horen, gingen Willem II en Floris $\mathrm{V}$ er toe over ook deze te rade te roepen, te 'dagvaarden'. De hierbedoelde steden waren de reeds genoemde 'goede steden', d.w.z. die steden die waren ontstaan op gebied waarover de graaf zijn volle rechten uitoefende. ${ }^{16}$ De medewerking van deze economisch machtige en welvarende steden, die overigens op hun beurt alle belang hadden bij een evenwichtig en krachtig bestuur, werd voor de landsheer onmisbaar. Niet alleen omdat de steden met hem een aantal belangen tegen de adel gemeen hadden, maar ook vanwege de financiële en militaire machtsmiddelen die zij hem konden verschaffen.

De Staten vertegenwoordigden echter niet alleen de verschillende standen: tezamen vertegenwoordigden zij het gehele volk tegenover de landsheer. Hun representativiteit voor de gehele bevolking is naar hedendaagse begrippen misschien een fictie, omdat de leden van de 'volksvertegenwoordiging' allen behoorden tot de invloedrijke sociale klassen. Niettemin beschouwden de standen zelf zich uitdrukkelijk als representatief en het is vrijwel zeker dat zij ook door de onderdanen als zodanig zijn aanvaard. ${ }^{17}$ De wezenlijke macht van de Staten was gelegen in de bevoegdheid bij een verzoek van de landsheer om financiële bijstand de zgn. vrijwillige beden

15. Vergl. H.R. Nord, Hisrorische ontwikkeling en beteekenis van de representariegedachte in her staatsrecht, Leiden 1941, p. 36.

16. Vergl. Fruin/Colenbrander, a.w., p. 45.

17. Deze hadden trouwens geen andere keuze; vergl. De Schepper, a.w., p. 323. 
al of niet toe te staan. ${ }^{18}$ Wanneer zij deze bevoegdheid niet zouden hebben bezeten, zou het bijeenroepen van de Staten waarschijnlijk geheel in ongebruik zijn geraakt. De Staten beschouwden zich dan ook als de voorstanders van de algemene vrijheid, op welke de plicht rustte voor het behoud van de privileges te waken. ${ }^{19}$ De grotere frequentie van de vorstelijke verzoeken om financiële bijstand bracht voor de landsheer politieke implicaties mee, zodat de geregelde samenroeping van de Staten zoniet een erkenning de jure, dan toch de facto inhield. Door hun instemming aan politieke voorwaarden te koppelen in 'acten presentatie' -door de vorsten geheel of gedeeltelijk ingewilligd in 'acten acceptatie'- werden zij geformaliseerde pressiegroepen, die in zekere mate inspraak verwierven in het regeringsbeleid. ${ }^{20}$ Deze ontwikkeling verliep -vanzelfsprekend- niet zonder tegenstand van de landsheer. Pas na dikwijls gevaarlijke crises en twisten, waarbij het bestaan van land en landsheer soms op het spel stond, werd een toestand van evenwicht bereikt. Een zekere mate van samenwerking bij het landsbestuur tussen vorst en standen was het gevolg.

In de regel kwamen de Staten niet ongeroepen bijeen. Behoudens enige uitzonderlijke omstandigheden en enkele revolutionaire perioden hebben de landsheren, vanaf het moment dat de Staten bijeengeroepen worden, het recht tot samenroeping stevig aan zich kunnen houden, hoewel het wel eens is voorgekomen dat steden en edelen (of steden onderling) ter regeling van huishoudelijke zaken uit eigen beweging bijeenkwamen. Een recht tot

18. De verzoeken om financiële bijstand door de landsheer moeten worden onderscheiden in traditionele en vrijwillige beden. De traditionele beden vormden een fundamenteel bestanddeel van de landsheerlijke rechten; de Staten waren dan ook verplicht een verzoek om een dergelijke bede in te willigen. De vrijwillige beden konden daarentegen pas door de landsheer worden geheven na toestemming van de Staten. Deze hadden dus de bevoegdheid vrijwillige beden al dan niet toe te staan. Dikwijls werden deze beden pas toegestaan tegen verlening van nieuwe privileges, of onder de voorwaarde dat ook de overige gewesten een bijdrage zouden leveren. De landsheer trachtte daarom dan ook zoveel mogelijk beslissingen uit te lokken van alle gewesten tegelijk; vergl. De Monté VerLoren/Spruit, a.w., pp. 120-123.

19. Vergl. Fruin/Colenbrander, a.w., p. 53 en het daar genoemde schrijven van de Staten van Holland en Zeeland.

20. De Schepper, a.w., p. 326. 
eigenmachtige bijeenkomst hebben de Staten niet bezeten, al maakten zij er wel aanspraak op.

In hun relatie tot de landsheer hielden de Staten het traditionele dualisme van de verdragsmonarchie aan; met name dat $\mathrm{zij}$-als tegenwicht in de 'balance of powers'- over rechten en vrijheden van de onderdanen in de respectieve landsdelen dienden te waken en deze moesten verdedigen. Derhalve meenden zij dat beslissingen over belangrijke aangelegenheden als troonswisselingen, muntzaken, oorlog en vrede, en wijzigingen in het vigerende recht, zelfs op publiek terrein, niet zonder hun medewerking of instemming genomen konden worden.

\subsubsection{De Gewestelijke Staten in de Republiek}

Onder de Republiek der Verenigde Nederlanden worden de Gewestelijke Staten oppermachtig. Bijna nergens in Europa hebben de statenvergaderingen in een grotere machtspositie verkeerd dan in de gewesten van de Republiek. Na de afzwering van Philips II waren de Staten (na enkele tevergeefse pogingen de soevereiniteit aan een andere landsheer op te dragen) getreden in diens rechten. $\mathrm{Zij}$ waren de soevereinen geworden, in die zin dat geen vergadering grotere bevoegdheden had dan de Staten. Bij hen berustte de volledige wetgevende en bestuurlijke macht, zowel op wereldlijk als kerkelijk terrein, met inbegrip van het recht van belastingheffing. Strikt genomen berustte de soevereiniteit niet bij de vergadering, maar bij het gehele lichaam van de Staten, waarvan de vergadering slechts een afvaardiging vormde. De eigenlijke Staten waren zoals gezegd de standen, die de afgevaardigden hadden gestuurd. Hierbij moet worden aangetekend dat onder de Republiek de geestelijkheid -behoudens een kleine, hier onder te bespreken uitzondering- niet meer als stand werd vertegenwoordigd.

Binnen het eigen gewest waren de gezamenlijke standen soeverein; wanneer zij in de Statenvergadering bijeen waren, vertegenwoordigden zij de bevolking van het gewest. ${ }^{21}$ Ridderschap en vroedschap waren daarentegen soeverein in hun rechtskringen, het platteland respectievelijk de steden. Deze corporaties waren aan niemand verantwoording schuldig; zij kozen zelf uit hun midden de nieuwe leden en zaten veelal voor het leven in

21. Vergl. C.H.E. de Wit, De strijd russen aristocratie en democratie in Nederland, 1780-1848, Heerlen 1965, p. 16. 
ridderschap en vroedschap. ${ }^{22}$ In een enkel geval doorkruiste weliswaar de stadhouder die coöptatie door zijn rechten van recommandantie en nominatie, maar deze rechten waren slecht omschreven; zij zouden vanaf het midden van de achttiende eeuw een van de belangrijkste oorzaken worden van het verzet van de standen tegen de stadhouder. Deze stadhouderlijke invloed beperkte de macht van ridderschap en vroedschap niet, maar verdeelde de regenten wel in voor- en tegenstanders van het stadhouderschap. $^{23}$

Gezien de soevereinteit van de standen waren hun afgevaardigden in bijna alle Gewestelijke Staten logischerwijs gebonden aan het gebod van last en ruggespraak. In de regel waren de afgevaardigden slechts gemachtigd tot kennisneming van de regeringsvoorstellen; verder moesten zij in elk stadium van de besluitvorming voor overleg of een bindend mandaat terugvallen op hun opdrachtgevers. Dit gold vooral voor de afgevaardigden van de stedelijke stand. De steden konden immers, wanneer zij van hun recht gehoord te worden gebruik wilden maken, niet in persoon verschijnen, terwijl het afvaardigen van het gehele stedelijk bestuur, ook al gezien de andere taken die dit college had te vervullen, moeilijk en omslachtig zou zijn. Alleen de stad Groningen werd in de vergadering van de Gewestelijke Staten door de gehele raad vertegenwoordigd; de overige steden stuurden afgevaardigden. Deze afgevaardigden waren slechts de dragers van het recht dat aan de steden zelf toebehoorde en waarover de steden dus geheel vrij konden beschikken. ${ }^{24}$

De Gewestelijke Staten waren niet permanent bijeen. Met uitzondering van Holland en Zeeland hielden de gewesten slechts én à twee vergaderingen per jaar. Als dagelijks bestuur fungeerden commissies uit de Staten: de Gedeputeerde Staten (in Holland en Zeeland Gecommitteerde Raden genoemd). De Gedeputeerde Staten vervingen de Staten bij hun afwezigheid en zorgden dat zij beschreven werden. Zij zorgden onder meer voor de voorbereiding en de uitvoering van de besluiten van de Staten en het beheer van de financiën. Elk college van Gedeputeerde Staten had een instructie waarin zijn taak nader was omschreven.

22. Vergl. Gabriëls, a.w., p. 14/15.

23. De Wit, a.w., p. 16.

24. Vergl. J.T. Buijs, De Grondwet, toelichting en kritiek, deel 1, Arnhem 1883 , p. 451. 
De statenvergaderingen vertonen zowel wat betreft hun samenstelling als de wijze van stemmen onderling grote verschillen. Gelderland, als hertogdom het eerste gewest in rang onder de Unie van Utrecht, kende een bestururvorm die sterk afweek van die van de overige gewesten. Het gewest bestond uit drie kwartieren, elk met eigen Staten, die op sommige gebieden (zoals de financiën) zelfstandig waren, en vormde aldus in mindere mate een eenheid dan de andere gewesten. ${ }^{25}$ De statenvergadering was een verenigde zitting van de Staten van de kwartieren van Nijmegen, Zutphen en Arnhem. Er werd kwartiersgewijs gestemd. In elk kwartier hadden zowel de adel (in het totaal maximaal zestig leden) als de (dertien) stemhebbende steden één stem. Feitelijk had de adel echter een overwicht, doordat leden van de ridderschappen in de stadsbesturen zitting konden nemen en veelvuldig van deze mogelijkheid gebruik maakten. ${ }^{26}$ Op de vergaderingen van de Staten van Gelderland moesten de afgevaardigden van de steden van instructies voorzien zijn. Dit gold echter niet voor de afvaardiging van de stad waar de vergadering gehouden werd. Gezien de geringe afstand tussen de betrokken afgevaardigden en het stedelijk bestuur werd een instructie niet nodig geacht: het bestuur kon immers dagelijks tegenover de afgevaardigden van zijn wil blijk geven. ${ }^{27}$

In Holland, in rang het tweede, maar in maatschappelijk en economisch opzicht het eerste gewest onder de Unie, waren als vanouds slechts de adel en de steden in de Staten vertegenwoordigd. De adel, een gesloten college dat zich door coöptatie aanvulde, vertegenwoordigde de edelen en het platteland. De adel had slechts én stem, tegenover achttien van de steden, maar daar hij in de vergadering het voorzittende en eerst-adviserende lid was, was zijn invloed toch aanzienlijk. ${ }^{28}$

Voor de beschrijving van het stelsel van besluitvorming binnen de Staten van Holland zijn een drietal ordonnanties van belang. De meest curieuze is die van 1 februari 1574 waarin (tijdelijk) een einde werd gemaakt aan de ook in Holland van oudsher bestaande praktijk van het gebod van last en

25. Vergl. Fruin/Colenbrander, a.w., p. 228; Gabriëls, a.w., p. 24.

26. Vergl. S.J. Fockema Andreae, De Nederlandse Staat onder de Republiek, 10 druk, Amsterdam 1985, p. 40/41. Zie ook: P.L. Muller, Onze gouden ceuw. De Republiek der Vereenigde Nederlanden in haar bloeitijd, Leiden 1896, p. 136; Gabriëls, a.w., p. $26 / 27$.

27. Vergl. Ramaer, a.w., p. 63.

28. Vergl. Fockema Andreae, a.w., p. 43; Muller, a.w., p. 137; Gabriēls, a.w., p. 17. 
ruggespraak. Deze ordonnantie, tot stand gekomen onder zware druk van Willem van Oranje, legde de afgevaardigden de verplichting op te zweren dat zij in "alle des gemeene lands zaaken" zouden
"(...) adviseeren en besluiten sulx zyluiden, na haarluider verstand en regte conscientie, tot de gemeene beste en welvaaren bevinden sullen te dienen, sonder affectie, gunst of ongunst tot eenige stee- den of persoonen in ' $t$ particulier". ${ }^{20}$

Vanaf 1577 echter weten de vroedschappen de macht weer aan zich te trekken en neemt de zelfstandigheid van de Staten geleidelijk af. De ordonnantie van 17 maart 1581 betekende een terugkeer naar de praktijk van het gebod van last en ruggespraak. De Staten werden (wederom) verplicht te zweren
"(...) in de saaken van beschryving te helpen besluiten en advisee- ren, sulx zyluiden by hunne principalen sullen syn gelast, en voorts op alle voorvallende saaken, als sysluiden na haar verstand in goede conscientie tot het algemeene best en welvaaren, vinden sullen dienen". ${ }^{30}$

In een ordonnantie van 12 maart 1585 werd uitdrukkelijk voorgeschreven dat de afgevaardigden met een bepaalde last moesten komen voor alle zaken die in de brief van beschrijving vermeld waren. Eigenlijke discussie kon dus niet meer plaats vinden, al was het gebruikelijk dat de afgevaardigden in minder belangrijke zaken hun toestemming gaven, onder voorbehoud van de goedkeuring van hun committenten. ${ }^{31}$

De samenstelling van de Staten van Zeeland was vrijwel gelijk aan die van Holland. Ook de Zeeuwse adel had slechts én stem, tegenover zes van de steden. De adel werd echter niet vertegenwoordigd door een college, maar door de eerste edele, de prins van Oranje, die deze functie steeds door een vertegenwoordiger liet vervullen. ${ }^{32}$ Gedurende de stadhouderloze perioden bestonden de Zeeuwse Staten alleen uit stedelijke afgevaardigden. Opvallend bij de samenstelling van de Zeeuwse Staten was voorts dat in de Staten twee steden (Vlissingen en Veere) waren vertegenwoordigd die geen 'gegoede' steden waren. De afgevaardigden van de steden in de Gewestelijke Staten hadden een imperatief mandaat, welk de steden verplicht waren

29. S. van Slingelandt, Staatkundige geschrifien, deel 1, Amsterdam 1784, p. 114; zie ook Ramaer, a.w., p. 54.

30. Ramaer, a.w., p. 56/57.

31. Vergl. Fruin/Colenbrander, a.w., p. 235.

32. Vergl. hierover Gabriëls, a.w., p. 20/21. 
onmiddellijk na beschrijving door de Gecommitteerde Raden te geven. Wanneer de afgevaardigden verhinderd waren ter vergadering te verschijnen, konden zij bij volmacht stemmen. Voorwaarde daarbij was dat zij een behoorlijk (speciaal) mandaat aan een lid van de Gecommitteerde Raden, aan de raadspensionaris, of aan de secretaris van de Staten hadden gegeven. Indien dit verzuimd was, gold de beslissing van de meerderheid. ${ }^{33}$

De afgevaardigden hadden de bevoegdheid over de behandelde zaken onmiddellijk een beslissing te nemen; het stond hen echter ook vrij de zaak aan te houden teneinde overleg met hun committenten te plegen. Dit diende binnen vier weken te geschieden. ${ }^{34}$ Ook was het mogelijk een stem onder voorbehoud van goedkeuring van de committenten uit te brengen. In dit geval moest binnen tien dagen aan de Staten, dan wel bij hun afwezigheid aan de Gecommitteerde Raden, worden medegedeeld in hoeverre het gevoelen van de committenten overeenstemde met dat van de afgevaardigden. Bij overschrijding van deze termijn werd er vanuit gegaan dat de toestemming van de committenten was verkregen. ${ }^{35}$

De Staten van Utrecht bestonden -als vanouds- uit de geestelijkheid (t.w. de vijf kapittels van de Utrechts hoofdkerken), de adel en de stad Utrecht (met de kleinere steden). Waar in de andere gewesten na de opstand de geestelijkheid uit de statenvergadering was verbannen, bleef zij in Utrecht, althans naar de vorm, vertegenwoordigd. Dit geschiedde door het college van geëligeerden, dat bestond uit afgevaardigden uit de kapittels. Elk lid had én stem; de geëligeerden, bij wie het voorzitterschap van de vergadering berustte, stemden eerst. De adel bracht de tweede stem uit, de steden de derde. Overigens werd het recht van de kleinere steden ter vergadering te verschijnen, door de stad Utrecht regelmatig betwist; zij maakte aanspraak op het monopolie als stad te worden beschreven. ${ }^{36}$

Binnen de Staten van Utrecht was het college van geëligeerden niet gebonden aan het gebod van last en ruggespraak; zij mocht zich bij het uitbrengen van haar (ene) stem slechts laten leiden door "Gods eer en 's lands

33. Vergl. Ramaer, a.w., p. 61.

34. Door de stemmen van vijf statenleden kon deze termijn worden beperkt tot twee weken; zes stemmen maakten verdere beperking van de termijn mogelijk.

35. Vergl. Ramaer, a.w., p. 62.

36. Vergl. Fruin/Colenbrander, a.w., p. 245/255; Gabriëls, a.w., p. 23; Ramaer, a.w., p. 62. 
welvaart". ${ }^{37}$ De afgevaardigden van de steden waren daarentegen wel gehouden aan het gebod van last en ruggespraak. Daar echter de (ene) stem van de stedelijke stand afhing van Utrecht, de stad waar de vergadering werd gehouden, veroorzaakte de praktijk van het gebod van last en ruggespraak in dit gewest weinig tijdverlies.

Net als in Gelderland stemde ook de Staten van Friesland kwartiersgewijs. Er waren vier kwartieren. Oostergo, Westergo en Zevenwolden vormden de drie plattelandskwartieren waarnaar de vertegenwoordigers van dertig grietenijen in de landdag (de statenvergadering) gegroepeerd waren. De (elf) Friese steden vormden sinds de opstand een vierde kwartier, waarin elke stad twee afgevaardigden had.

Ten aanzien van het stelsel van besluitvorming nemen de Staten van Friesland een bijzondere plaats in. De afgevaardigden mochten namelijk geen last van hun committenten ontvangen, terwijl ook het houden van ruggespraak met hen verboden was. Daar echter de afgevaardigden jaarlijks door de committenten werden gekozen, waren zij in zekere zin toch van hen afhankelijk. ${ }^{38}$ In feite was de landdag dan ook niet soeverein; het kwam er op neer dat hij jaarlijks de soevereiniteit van de committenten opgedragen kreeg. ${ }^{39}$ Ook hier werd kwartiersgewijs gestemd. De stem van een kwartier werd bepaald door meerderheid van de leden.

In Overijssel was de statenvergadering samengesteld uit de adel en de afgevaardigden uit de drie grote steden (Deventer, Kampen en Zwolle). De steden hadden ieder é́n stem, de adel (gewoonlijk veertig edelen) stemde hoofdelijk. Maar omdat de adellijke stemmen werden geacht op te wegen tegen de drie stedelijke stemmen, ontstonden ter vergadering regelmatig meningsverschillen over de vraag of naar aanleiding van een bepaalde stemming nu wel of niet een meerderheid van stemmen was verkregen. ${ }^{40}$ Deze geschillen werden op min of meer willekeurige wijze beslist, hetgeen steevast verzet van de overstemde partij uitlokte en niet zelden tot (tijdelijke) scheuringen aanleiding gaf. ${ }^{41}$

37. Ramaer, a.w., p. 62.

38. Vergl. Muller, a.w., p. 163: zij werden niet gevolmachtigd, als de committenten niet zeker van hen waren.

39. A.Th. van Deursen, Staatsinstellingen in de Noordelijke Nederlanden 1579. 1780, in: Algemene Geschiedenis der Nederlanden, a.w. (deel 5), p. 383.

40. Vergl. Gabriëls, a.w., p. 27. Zie over de -niet geheel duidelijke- regeling op dit punt: Fruin/Colenbrander, a.w., p. 253.

41. Muller, a.w., p. 167. 
Binnen de Staten van Overijssel werd het gebod van last en ruggespraak in het algemeen streng gehandhaafd. Zonder uitdrukkelijke last mochten de afgevaardigden van de steden niets beslissen. Doorgaans gingen de Staten, na voorschriften te hebben ontvangen, gewoonlijk voor een a twee weken op reces. Zelfs in minder belangrijke zaken hadden de afgevaardigden nauwelijks enige zelfstandige beslissingsbevoegdheid, daar deze zaken gewoonlijk schriftelijk werden afgedaan in de zgn. 'brieven van omzending' aan de committenten. ${ }^{42}$

De Staten van het gewest Stad Groningen en Ommelanden (Stad en Lande) bestonden uit twee leden tussen welke een nauwelijks verholen vijandschap bestond. Aan de ene kant stond de stad Groningen, die zoals gezegd in de statenvergadering vertegenwoordigd werd door de gehele raad, aan de andere kant stond de vertegenwoordiging van de Ommelanden. Deze werd gevormd door de adellijke en niet-adellijke grondeigenaren (de eigenerfden) en de zgn. volmachten. Deze volmachten vertegenwoordigden de plattelandsgemeenten waar de eigenerfden ontbraken. Elk lid had één stem, zij het dat de stad een zeker overwicht had. ${ }^{43}$

In Stad en Lande speelde het gebod van last en ruggespraak een enigszins beperkte rol. De stedelijke stand verscheen immers 'in persoon', zodat een bepaling inzake last en ruggespraak overbodig was. De afgevaardigden van de Ommelanden konden echter eerst hun beslissing kenbaar maken nadat zij op reces waren gegaan om hun committenten te raadplegen. Vervolgens dienden de drie kwartieren die tesamen de vertegenwoordiging van de Ommelanden vormden nog een (meerderheids)beslissing te nemen, alvorens het besluit kon worden vergeleken met dat van de stad Groningen. ${ }^{44}$

\subsection{De positie van de Staten-Generaal}

Reeds lang voor de vestiging van de Republiek was Philips de Goede teneinde het provincialisme, zoals dat via de Gewestelijke Staten tot uiting kwam te ontlopen, overgegaan tot geregelde samenroeping van de zogenaamde Algemene Staten. Daarbij speelde ook het centralisatie-streven een rol: de Algemene Staten als centraal controlelichaam van de standen

42. Vergl. Ramaer, a.w., p. 64.

43. Vergl. Fockema Andreae, a.w., p. 66; Gabriëls, a.w., p. 29/30.

44. Hierover: Ramaer, a.w., p. $68 / 69$. 
zouden een bindmiddel zijn om de eenheid van de Nederlanden te versterken. ${ }^{45}$ De Algemene Staten werden geacht 'het land' tegenover de landsheer te vertegenwoordigen. De bijeenkomsten van dit orgaan, die uitsluitend plaats vonden op bevel van de vorst, waren dus volksvertegenwoordigingen, zij het dan niet op de grondslag van (hedendaagse) democratische verkiezingsprincipes. Integendeel, de vergaderingen hadden een sterk aristocratisch, zoniet oligarchisch karakter. ${ }^{46}$ Vanaf de eerste vergadering van deze voorloper van de huidige Staten-Generaal in 1464 tot 1576 zouden de Algemene Staten regelmatig bijeenkomen, echter steeds op bevel, c.q. verzoek van de vorst die hen over bestuurlijke aangelegenheden wilde raadplegen. De in de vergadering behandelde onderwerpen kwamen, voorzover zij de gewesten gezamenlijk betroffen, overeen met de aangelegenheden waarvoor de Staten afzonderlijk geraadpleegd werden. Met name onder Karel V, die zoveel mogelijk de eenheid van de gewesten wilde bevorderen, kwamen de Algemene Staten regelmatig bijeen.

Oorspronkelijk werden de vergaderingen van de Algemene Staten tegen de zin van de Gewestelijke Staten gehouden; zij werden liever afzonderlijk geraadpleegd. ${ }^{47}$ Gaandeweg zagen zij in de bijeenkomsten echter steeds meer een machtsmiddel om de algemene politiek van de vorst en zijn regering te bekritiseren. De Algemene Staten groeiden van een gemeenschappelijk orgaan van gewestelijk particularisme uit tot een forum van steeds scherpere en sterker verenigde oppositie van de gewesten tegen het vorstelijk absolutisme. ${ }^{48}$ Noch het ene, noch het andere kwam overeen met de oorspronkelijke bedoelingen. Vandaar dat Philips II, bevreesd als hij was voor de -tegenstand van de Algemene Staten, de bijeenroeping van deze zoveel mogelijk vermeed en rechtstreekse onderhandelingen met de Gewestelijke Staten prefereerde.

De Algemene Staten hadden geen beslissingsmacht. Stemmingen vonden dan ook niet plaats. Behalve een enkele afvaardiging die eens over 'plain en ample povoir' beschikte, hadden de afgevaardigden van de gewesten in de regel alleen een volmacht om de verzoeken van de landsheer zelf of van een regeringscommissaris aan te horen. Wel konden zij met de woordvoerders van de vorst, zo ook onderling, van gedachten wisselen. Hoewel de

45. De Schepper, a.w., p. 326.

46. Van de Kieft, a.w., p. 3.

47. Vergl. Fruin/Colenbrander, a.w., p. 105.

48. De Schepper, a.w., p. 328. 
centrale overheid beoogde de Algennene Staten te laten optreden in plaats van de Gewestelijke Staten, zijn deze laatste er toch niet voor gezwicht de Algemene Staten ook maar de minste beslissingsmacht te delegeren. De afgevaardigden aldaar konden pas antwoorden na ruggespraak met hun committenten, de respectieve Gewestelijke Staten. Bij hen berustte de beslissingsbevoegdheid. Na het aanhoren van de verzoeken van de regering gingen de afgevaardigden dan ook onmiddellijk op reces om hun committenten te raadplegen, hetgeen soms lange tijd in beslag nam. Om het besluitvormingsproces niet al te zeer te vertragen werd soms bepaald dat de afgevaardigden op een vastgesteld tijdstip met de beslissing van hun committenten in de Algemene Staten moesten terugkeren. ${ }^{49}$ Daarin teruggekeerd, lieten de afgevaardigden het besluit van hun opdrachtgevers aan de vorst weten. De Staten van de minderheid, noch de afwezige Staten werden door het antwoord van de meerderheid gebonden.

Onder de Republiek der Verenigde Nederlanden onderging dit stelsel nauwelijks veranderingen in vergelijking met de situatie voor de vestiging van de Republiek. Deze was immers -min of meer per toeval- geschied naar aanleiding van een strijd voor het behoud van de oude vrijheden, waarop de landsheer (Philips II) inbreuk had gemaakt. Het verzet tegen de landsheer beoogde een terugkeer tot de vroegere toestand, zoals die geweest was voor de absolutistische, centraliserende maatregelen door Philips II genomen. De opstand en alles wat daaruit is voortgevloeid, zoals de Unie van Utrecht en de 'verlaetinge' van de landsheer, droegen dus een reactionair karakter. ${ }^{50}$ Door het wegvallen van de landsheer was de Unie van Utrecht de enige band die de zeven gewesten bijeenhield. Deze bondsakte kon echter onmogelijk als grondslag dienen voor een gemeenschappelijke regering van de nieuwe confederatie. De gewesten die haar destijds waren aangegaan, hadden daarbij slechts de wederzijdse handhaving van hun gezamenlijk grondgebied beoogd en allerminst de oprichting van een nieuwe staat. De grondleggers van de Republiek waren daarom genoodzaakt terug te grijpen op de oude instellingen uit de landsheerlijke periode. Maar omdat deze instellingen belangrijke instrumenten waren geweest van het vorstelijk centralisatiestreven, konden zij niet zonder meer worden

49. Vergl. Ramaer, a.w., pp. 70-72.

50. Vergl. De Monté VerLoren/Spruit, a.w., p. 218/219. 
overgenomen. Daarom werden zij naar aard en bevoegdheid aangepast en aangevuld tot bruikbare regeringscolleges voor de nieuwe statenbond.

Daarom ondergaat ook het karakter van de Staten-Generaal, zoals de Algemene Staten dan worden genoemd, onder de Republiek enige verandering. De Staten-Generaal worden dan een vergadering van de afgevaardigden van staten van de verenigde gewesten. Nu het waarborgen van een zo groot mogelijke soevereiniteit van de afzonderlijke gewesten de grondslag van de Unie vormde, was het in wezen onvermijdelijk dat de StatenGeneraal het hoogste regeringscollege binnen de Republiek zou worden. Dat betekende echter niet dat zij ook het belangrijkste regeringscollege werden; zoals reeds is vermeld was dit predikaat voorbehouden aan de Gewestelijke Staten, waar de facto het oppergezag berustte.

Niet doelbewust, maar als gevolg van een geleidelijke ontwikkeling werden de Staten-Generaal een vanaf 1593 permanent vergaderend lichaam, waarvan de bevoegdheid die aangelegenheden onvatte die door de Unie van Utrecht tot gemene zaak waren gemaakt. ${ }^{51}$ In de Staten-Generaal geschiedde de besluitvorming aan de hand van zgn. 'poincten van reces', punten van beschrijving die doorgaans aan het einde van de vergadering werden vastgesteld om op de volgende te worden behandeld. Daar de beslissingsbevoegdheid in de meeste zaken nog steeds bij de Gewestelijke Staten berustte, konden de afgevaardigden in de Staten-Generaal niet zelfstandig en naar eigen inzicht beslissen. Alleen in zaken van secundair belang en in de zogenaamde 'voorvallende zaken's2, alsmede in de gevallen die bij de Unie van Utrecht aan de soevereiniteit van de Gewestelijke Staten waren onttrokken ${ }^{53}$ kohden zij zelfstandig beslissingen nemen. Doorgaans was echter de toestemming van hun committenten (de respectieve Gewestelijke Staten) vereist, welk vereiste vorm werd gegeven door het gebod van last en ruggespraak.

51. Vergl. Gabriëls, a.w., p. 40.

52. Zie hierover P. Paulus, Verklaring der Unie van Utrecht, deel 3, Utrecht 1775-1777, pp. 132-145 en Ramaer, a.w., pp. 80-82.

53. Zie hierover Fruin/Colenbrander, a.w. pp. 188-197. 


\subsection{De ontwikkeling van het gebod van last en ruggespraak}

De oorspronkelijke vorm van de gebodsbepaling is het ongeschreven gebod van last en ruggespraak. Voor de Staten-Generaal onder de Republiek was handhaving van het (ongeschreven) gebod, gezien het reactionaire karakter van de opstand tegen Philips II, niet meer dan een logische voortzetting van de praktijk voor de vestiging van de Republiek. Bij de vorming van de Republiek der Verenigde Nederlanden moesten de tot dan toe nog steeds soevereine gewesten omwille van de vereniging iets van hun onafhankelijkheid prijsgeven, maar het was de gewesten er alles aan gelegen het verlies aan gewestelijke zelfstandigheid zoveel mogelijk te beperken. In dat verband is het begrijpelijk dat het gebod van last en ruggespraak werd gehandhaafd. Nu de praktijk met de gebodsbepaling in ongeschreven vorm voorheen nooit moeilijkheden had veroorzaakt, oordeelden de Gewestelijke Staten het oorspronkelijk ook na 1581 niet nodig hun afgevaardigden een instructie te geven: het ongeschreven gebod van last en ruggespraak bleef voorlopig onverkort van kracht.

Gaandeweg ondervonden de Gewestelijke Staten echter dat naleving van de ongeschreven gebodsbepaling niet meer in bevredigende mate kon worden afgedwongen. De afgevaardigden in de Staten-Generaal bleken steeds vaker zaken die in de vergadering aan de orde kwamen, zonder last van (c.q. ruggespraak met) hun committenten af te doen. Hierdoor kon het voorkomen dat in de vergadering van de Staten-Generaal besluiten werden genomen, die haaks op de opvattingen van de Gewestelijke Staten stonden. ${ }^{54}$ Dit vormde een ernstige bedreiging voor de positie van de Gewestelijke Staten als soevereine macht van de Republiek.

Deze ontwikkeling werd in de hand gewerkt door de grote afstand die de meeste afgevaardigden van hun gewest scheidde, alsmede doordat zij soms jaren achtereen in de Staten-Generaal verbleven, alvorens weer door hun committenten ontboden te worden. Sommige afgevaardigden waren zelfs

54. Vergl. J. Wagenaar, Vaderlandsche historie, deel XI (1625-1648), Amsterdam 1793 , p. $343 / 344$. 
voor het leven benoemd, hetgeen hun onathankelijkheid ten opzichte van hun committenten vergrootte. ${ }^{55}$

De belangrijkste oorzaak van het tanend gezag van de Gewestelijke Staten was echter dat de afgevaardigden meer en meer onder invloed van de prinsen van Oranje waren geraakt. ${ }^{56}$ Met name Frederik Hendrik had een groot overwicht, ook al door zijn erkenning als Eerste Edele in de Ridderschap van Holland (1637). ${ }^{57}$ De Gewestelijke Staten ondervonden dat de afgevaardigden alles deden om de prins ter wille te zijn, "de eene uyt vreese, de ander om particuliere interesten ende voordelen". ${ }^{58}$ Volgens de Staten van Holland had dit tot gevolg dat de meeste staatszaken werden afgedaan door de prins en enkele hem toegewijde afgevaardigden. ${ }^{59} \mathrm{Het}$ spreekt voor zich dat de Gewestelijke Staten met deze gang van zaken niet erg waren ingenomen. Er ontstond dan ook behoefte aan het uitdrukkelijk vastleggen en herbevestigen van het gebod van last en ruggespraak, om zo de invloed van de prins op de afgevaardigden in de Staten-Generaal te beperken en om te voorkomen dat in de vergadering van de Staten-Generaal besluiten zonder hun instemming konden worden genomen. Bijkomend argument om juist rond 1640 tot codificatie van de gebodsbepaling over te gaan was de bij de gewesten bestaande vrees dat de afgevaardigden (ook) besluiten, tegengesteld aan de opvatting van de Gewestelijke Staten, zouden nemen over op dat moment actuele en voor de Gewestelijke Staten nogal belangrijke onderwerpen als de relatie met Engeland (de Staten zagen in de door Frederik Hendrik aangegane huwelijksalliantie tussen het Oranjehuis en de Stuarts een grote bedreiging voor hun soevereiniteit) en de aanstaande vredesonderhandelingen (die later zouden leiden tot de Vrede van Munster) ${ }^{\infty}$

55. Om dit te voorkomen waren de Staten van Holland dan ook gewoon hun afgevaardigden te benoemen voor een periode van ten hoogste drie jaren; vergl. Ramaer, a.w., p. 76.

56. Vergl. Wagenaar, a.w., p. 343 en L. van Aitzema, Saken van Staet en Oorlogh, in ende omtrent de Vereenighde Nederlanden, deel 2 (16331644), 's-Gravenhage 1669 , p. 911.

57. Vergl. J.H. Kluiver, De Republiek na het bestand 1621-1650, in: Algemene Geschiedenis der Nederlanden, deel 6, Haarlem 1979, p. 361.

58. Van Aitzema, a.w., p. 911.

59. Idem, p. 914.

60. Vergl. Wagenaar, a.w., p. 344 en Van Aitzema, a.w., p. 938. 


\subsubsection{Vormgeving van de instucties}

In de praktijk is door de tijden heen op verschillende wijzen getracht aan de gebodsbepaling vorm te geven. Hierbij kan een onderscheid worden gemaakt. tussen het gebod van last en ruggespraak in ongeschreven vorm (zie hierboven) en het gebod van last en ruggespraak in geschreven vorm. De laatste categorie kan daarbij als volgt onderverdeeld worden:

- een uniforme algemene instructie: én instructie die voor de afgevaardigden van alle gewesten geldt en die aangeeft hoe zij in het algemeen dienen te handelen;

- een afzonderlijke algemene instructie: een instructie die voor de afgevaardigden van één gewest geldt en die aangeeft hoe deze in het algemeen dienen te handelen;

- een bijzondere instructie: deze geeft aan hoe de afgevaardigden van één gewest in een bepaald, in de instructie omschreven geval dienen te handelen. In tegenstelling tot de algemene instructies heeft de bijzondere instructie dus slechts betrekking op én bepaald onderwerp.

Een voor elk gewest identieke instructie (uniforme algemene instructie) voor de afgevaardigden in de vergadering van de Staten-Generaal heeft nooit bestaan. Wel zijn enkele pogingen ondernomen om tot een dergelijke instructie te komen. De eerste poging dateert van 1643, toen de Staten van Holland, verontrust door de hierboven geschetste ontwikkeling, de overige Gewestelijke Staten hebben voorgesteld een uniforme algemene instructie op te stellen. Deze poging mislukte; de daartoe door de Staten van Holland ontworpen instructie, in 1643 door hen aanvaard, vond weinig instemming; alleen de Staten van Gelderland (1643) en van Overijssel (1652) namen haar over.

Het is echter de vraag of in dit geval inderdaad moet worden gesproken van een poging om tot een uniforme algemene instructie te komen. In de literatuur bestaat hierover geen eensluidende opvatting. Volgens Paulus, daarin gevolgd door Ramaer, hadden de Staten van Holland wel degelijk de intentie een instructie op te stellen die de andere gewesten tot voorbeeld zou strekken. ${ }^{61}$ Anderen nemen echter aan dat de reden voor het rond deze tijd overgaan van enkele andere gewesten tot het opstellen van een instructie, is gelegen in de aard van de omstandigheden en niet in een

61. Vergl. Paulus, a.w., p. 91; Ramaer, a.w., p. 76; Gabriëls, a.w., p. 305 (noot 17). 
vermeende voorbeeldfunctie van de Staten van Holland. Ook deze gewesten zagen zich door het optreden van de prins in hun soevereiniteit bedreigd en namen maatregelen. ${ }^{62}$ Het feit dat de overige gewesten niet overgingen tot het opstellen van een instructie laat zich eveneens verklaren uit hun houding tegenover de prins: zij waren bang door het opstellen van een instructie de sympathie van de prins te verspelen. Met name in Stad en Lande, waar de Staten onderling zeer verdeeld waren, was deze overweging de reden om niet tot het geven van een instructie over te gaan. ${ }^{63}$

Een latere poging om tot een uniforme algemene instructie te komen mislukte eveneens. Een voorstel van de Staten-Generaal dd. 30 mei 1671 aan de Gewestelijke Staten, om tot een uniforme algemene instructie te komen, vond bij de laatsten geen steun. Volgens Paulus gebeurde dit omdat de Gewestelijke Staten bevreesd waren dat een dergelijke instructie hun onafhankelijkheid zou bedreigen. ${ }^{64}$ De meeste Gewestelijke Staten hadden toen overigens -vermoedelijk juist vanwege dit onafhankelijkheidsaspectreeds uit eigen beweging een afzonderlijke algemene instructie voor hun afgevaardigden in de Staten-Generaal vastgesteld; een uniforme algemene instructie had dus eigenlijk geen zin meer.

Een dergelijke afzonderlijke algemene instructie is door de Gewestelijke Staten van vijf van de zeven provincies die onder de Republiek verenigd waren voor hun afgevaardigden in de vergadering van de Staten-Generaal opgesteld en voor kortere of langere tijd van kracht geweest.

Bij de Staten van Holland is de door hen zelf opgestelde instructie uit 1643 niet lang van kracht geweest. Vast staat dat zij reeds in 1669 zijn overgegaan tot de vaststelling van een nieuwe, uit negentien artikelen bestaande instructie, die heeft gegolden tot het einde van de Republiek. ${ }^{65}$ Daarmee is niet gezegd dat de instructie uit 1643 tot 1669 heeft gegolden. Waarschijnlijk is zij slechts enkele jaren van kracht geweest. Reeds in 1653 namen de Staten van Holland een resolutie aan, waarin werd bepaald dat geen afgevaardigde "ter Generaliteyt sal mogen verschynen sonder speciale Resolutie en Commissie van haer Edele Groot Mogentheden". ${ }^{\infty}$ Deze

62. Vergl. o.a. Van Aitzema, a.w., p. 938; Fruin/Colenbrander, a.w., p. $184 / 185$.

63. Vergl. Van Aitzema, a.w., p. 899; Wagenaar, a.w., p. 344.

64. Paulus, a.w., p. 131.

65. Instructie van 23 juli 1669 , Groot Placaethoek, deel 3, p. 89.

66. Resolutie van 22 augustus 1653, Groot Placaetboek, a.w., p. 51. 
instructie zou overbodig zijn geweest indien de instructie van 1643 op dat moment nog van kracht was; deze bevatte namelijk een bepaling van dezelfde strekking. ${ }^{67}$ Het aannemen van de instructie past echter wel in een situatie waarin de afgevaardigden niet aan een dergelijke bepaling gebonden waren, dus wanneer zij geen algemene instructie meer kenden. Dat de instructie van 1643 zo kort van kracht is geweest kan wellicht ook worden verklaard uit het feit dat de adel, die geheel van de prins afhankelijk was, geen voorstander van een instructie was; een enkeling weigerde zelfs de eed op de instructie te doen. ${ }^{68}$ Er werd dan ook beweerd -waarschijnlijk door de adel- dat de prins de instructie "ongeern" zag. ${ }^{\oplus}$ Opmerking verdient dat de Staten van Holland, voordat zij ertoe overgingen hun afgevaardigden een algemene instructie te geven, al sinds 1638 gewoon schijnen geweest deze van een bijzondere instructie te voorzien. ${ }^{70}$

Zoals hierboven reeds is opgemerkt zijn de Staten van Gelderland eveneens in 1643 overgegaan tot het geven van een algemene instructie aan hun afgevaardigden in de Staten-Generaal. Ook voor dit tijdstip kenden de afgevaardigden al instructies, maar deze hadden een incidenteel karakter. ${ }^{71}$ Het besluit om tot de algemene instructie over te gaan dateert in feite reeds uit 1641, toen op de op vijftien juni van dat jaar gehouden Landdag werd besloten het Hof van Gelderland te belasten met het opstellen van een ontwerp-instructie. Dit ontwerp, waarin verschillende incidentele instructies, uitgebreid en aangevuld, waren samengevoegd, werd door de Landdag op 21 maart 1643 aanvaard. $^{2}$ Het is daarom niet waarschijnlijk dat de

67. Art. II. De tekst van de instructie uit 1643 is opgenomen bij Van Aitzema, a.w., p. $910 / 911$.

68. Vergl. Van Aitzema, a.w., p. 911; Wagenaar, a.w., p. 346.

69. Van Aitzema, a.w., p. 914.

70. Vergl. Fruin/Colenbrander, a.w., p. 184. Bevestigend: Van Slingelandt, a.w. (deel 2), p. 148 (noot a).

71. L. Driessen/A.J. Maris, De instructiën voor de Gedeputeerden van Gelderland ter Generaliteit, in: Bijdragen en mededelingen "Vereeniging Gelre", deel 54, Amhem 1954, p. 333.

72. De tekst van de instructie is opgenomen bij Van Aitzema, a.w. p. 938 en bij Driessen/Maris, a.w., p. 336-340. De afwijkingen tussen deze bronnen (verschillende nummering en enkele geringe tekstuele verschillen) worden veroorzaakt door het feit dat Van Aitzema de tekst van instructie zoals die in het Landdagreces is geïnsereerd gebruikt, terwijl Driessen/Maris uitgaan van het door het Hof opgestelde concept. 
Staten van Gelderland in 1643 de door de Staten van Holland opgestelde instructie hebben overgenomen. Merkwaardig daarbij is, dat de eed die de Gelderse afgevaardigden op de instructie moesten doen, afgezien van enkele redactionele verschillen, wel identiek is aan de eed die de Hollandse afgevaardigden op hun instructie moesten doen. In november 1686 werd tot herziening van de instructie besloten. Het duurde echter tot 1709 voordat de Landdag daadwerkelijk tot actie overging. Op 28 maart van dat jaar besloot hij tot het uitvaardigen van een nieuwe instructie, die in 1710 werd ontworpen en door de Landdag op 1 oktober 1711 werd aanvaard. ${ }^{73}$ Volgens Paulus zijn de Staten van Gelderland in 1750 (op 17 oktober) nogmaals overgegaan tot het vaststellen van een nieuwe instructie, die zestien artikelen bevatte en nooit uitdrukkelijk is afgeschaft. ${ }^{74}$ Daar de door Paulus genoemde instructie vrijwel identiek is aan de instructie van 1711, gaat het hier vermoedelijk slechts om een herbevestiging van laatstgenoemde instructie. De reden voor deze nieuwe bekrachtiging van de instructie van 1711 is waarschijnlijk gelegen in het feit dat deze noodzakelijk was geworden nadat op 14 oktober 1750 het oude regeringsreglement voor Gelderland -met enkele wijzigingen van ondergeschikt belang- opnieuw was vastgesteld. ${ }^{75}$

Van de Staten van Utrecht waren in 1643 zowel de geëligeerden als de adel tegen aanvaarding van de door de Staten van Holland opgestelde instructie. Het duurde tot 1668 voordat de Staten van Utrecht overgingen tot het instrueren van hun afgevaardigden. Op 9 april van dat jaar hebben zij een algemene, elf artikelen tellende instructie vastgesteld, die heeft gegolden tot $1795 .^{76}$ Een op 15 juli 1690 door de Staten aangenomen resolutie zorgde voor aanvulling door de Utrechtse afgevaardigden het recht toe te kennen in zaken, die geen uitstel konden dulden, zonder ruggespraak te beraadslagen en te beslissen, onder de voorwaarde dat zij hun committenten zo spoedig mogelijk zouden inlichten." Ook hier geldt dat de afgevaardigden voordat de algemene instructie werd opgesteld, incidentele instructies kenden. Een resolutie van de Staten van Utrecht d.d. 19 augustus 1618

73. Driessen/Maris, a.w., p. 333.

74. Paulus, a.w., p. 92.

75. Vergl. C.W. van der Pot, Bestuurs- en rechtsinstellingen der Nederlandse Provinciën, Zwolle 1949, p. 95.

76. Vergl. Paulus, a.w., p. 109; Ramaer, a.w., p. 78.

77. Zie voor de tekst van deze resolutie: Utrechts Placaetboek, deel 1, p. 328. 
verwijst namelijk naar een blijkbaar reeds bestaand 'point van Beschryvinge'. $^{78}$

De Staten van Overijssel hebben, volgens de in de literatuur gangbare opvatting, in 1652 de 'Hollandse instructie' overgenomen. Of zij voor dit tijdstip al een instructie voor hun afgevaardigden in de Staten-Generaal hadden ontworpen is onbekend. De 'Hollandse instructie' heeft voor hen waarschijnlijk tot 1707 gegolden. Op 16 juli van dat jaar is door de Staten van Overijssel een nieuwe instructie vastgesteld. Deze omvatte dertien artikelen. Op 29 maart 1708 werd een veertiende artikel aan de instructie toegevoegd, die sindsdien ongewijzigd van kracht is gebleven tot het einde van de Republiek. ${ }^{79}$

Over de Staten van Stad en Lande is reeds opgemerkt dat zij in 1643 geen voorstander van een instructie waren. Volgens Paulus zijn de Staten echter kort daarop (28 februari 1644) wel overgegaan tot het geven van een algemene instructie aan hun afgevaardigden in de Staten-Generaal gegeven. ${ }^{80}$ Dat deze instructie daadwerkelijk heeft bestaan kan worden afgeleid uit een resolutie van 7 maart 1644, waarin wordt verwezen naar "de nieuwe Instruktie voor de Heeren, wegens deze Provincie gekommitteerd ter Vergaderinge van Hun Hoog Mogenden". ${ }^{81}$ Toch zou de hier bedoelde instructie niet lang van kracht zijn geweest, omdat in latere jaren (o.m. in 1672,1673 en 1678) bijzondere instructies gegeven zijn, zonder dat in die instructies werd verwezen naar een eerdere, algemene instructie. Dit rechtvaardigt volgens Paulus de conclusie dat de afgevaardigden van dit gewest toen al geen algemene instructie (meer) kenden. ${ }^{82}$ Ter nadere adstructie voert hij hierbij aan, dat in zijn tijd $( \pm 1775)$ de betrokken afgevaardigden ook geen 'vast Berigtschrift' hadden om naar te handelen. Daarom waren zij

"(...) dus wederom tot 't zelfde verpligt, waartoe zij, voor die Instruktie, gehouden waren. Maar toen waren ze (..) stilzwygend verpligt, alles over te nemen, waarbij hunne Provincie eenigszins geïnteresseerd was. Zij zijn dus, schoon niet door uitgedrukte

78. Zie voor de tekst van deze resolutie: Utrechrs Placaetboek, a.w., p. 327.

79. Vergl. Paulus, a.w., p. 114; Ramaer, a.w., p. 78/79.

80. Paulus, a.w., p. 91. Van Aitzema en Wagenaar laten zich hierover niet uit.

81. Paulus, a.w., p. 129.

82. Idem, p. 122. 
woorden, als nog, omtrent, gehouden aan ' $t$ gene by de voors, in ongebruik geraakte Instruktie bepaald was". ${ }^{83}$

Aan de andere kant zouden de bijzondere instructies een -al dan niet tijdelijke- aanvulling kunnen zijn van de algemene instructie uit 1644, daar de gevallen waarin bovengenoemde bijzondere instructies voorzien niet worden genoemd in de algemene instructie van 1644 .

De Staten van Zeeland en van Friesland hebben nooit algemene of bijzondere instructies aan hun afgevaardigden gegeven. In Zeeland is in 1597 een poging ondernomen om tot een algemene instructie te komen, doch het is bij een concept-instructie gebleven. Voor de Friese afgevaardigden naar de vergadering van de Staten-Generaal gold waarschijnlijk enige tijd een Kommissie (opdracht). Bekend is een Kommissie dd. 1 mei 1662 aan Egbert van Baerdt, Grietman van Hasterland, waarin hem wordt opgedragen niet te "resolveren dan op behagen van ons of onze Gedeputeerden". Deze bewoordingen doen vermoeden dat een Kommissie min of meer gelijk is te stellen met een bijzondere instructie.

Vast staat echter dat rond 1770 noch de afgevaardigden van Zeeland, noch die van Friesland aan enige instructie gebonden waren. Deze afgevaardigden bleven echter gehouden aan de algemene, ongeschreven regel van het gebod van last en ruggespraak. De afgevaardigden van deze twee gewesten waren dus

"(...) stilzwijgend tot al het zelve gehouden, waartoe de Gedeputeerden van andere Provinciën uitdrukkelyk verpligt zyn. En 't verzuim daarvan zou hun al zoo kwalijk genomen worden, als of hun zulks met name was voorgeschreven". ${ }^{84}$

\subsubsection{De inhoud van de instructies}

De hierboven genoemde instructies vertonen inhoudelijk veel overeenkomsten. Dit doet vermoeden dat wellicht toch de ontwerp-instructie van de Staten van Holland als voorbeeld heeft gediend. De vraag blijft dan waarom de meerderheid van de overige Gewestelijke Staten weigerachtig bleef deze instructie geheel over te nemen. De vele overeenkomsten zouden echter ook kunnen worden verklaard vanuit de gedachte dat het hier de codificatie van in de diverse gewesten onderling nauwelijks uiteenlopende gewoontes betrof.

83. Idem, p. 130.

84. Idem, p. 109 en p. 114. 
In de uitwerking van de hoofdlijnen vertonen de instructies wel enige verschillen. Sommige instructies zijn op sommige punten meer gedetailleerd of spreken zich uitdrukkelijker over bepaalde onderwerpen uit dan andere. Dit is waarschijnlijk terug te voeren op het feit dat de staten van het desbetreffende gewest van oordeel waren dat deze zaken van een dusdanig groot belang waren, dat zij een uitvoerige regeling vereisten. Wellicht speelt ook de afstand tot de committenten een rol. Wanneer de gecommitteerden hun committenten vrij dicht in de buurt wisten, was het vrij eenvoudig snel onderling overleg te plegen of een boodschap over te (laten) brengen. Was de afstand groter, dan was dit vanzelfsprekend moeilijker en kon een (meer) uitvoerige instructie mogelijke onnodige vertraging voorkomen.

Alle instructies bevatten in ieder geval bepalingen over:

- de eisen, aan de persoon van een afgevaardigde gesteld;

- de wijze waarop de committenten op de hoogte moesten worden gehouden van hetgeen in de vergadering van de Staten-Generaal werd besproken;

- de wijze waarop de afgevaardigden in het algemeen en in met name genoemde bijzondere gevallen dienden te handelen.

In de eerste categorie behoren de bepalingen die voorschreven dat de afgevaardigden moesten behoren tot de "gekwalifiçeerdsten en bekwaamsten" burgers van het betreffende gewest. Ook mochten zij in geen andere dienstbetrekking staan dan in die met de Staten van het gewest. De redactie van deze bepalingen vormt overigens een duidelijk bewijs voor de stelling dat het opstellen van de instructies slechts de codificatie van reeds lang bestaand gewoonterecht was; dit blijkt uit de herhaaldelijk voorkomende zinsnede "volgens voorgaande gebruik".

De bepalingen uit de tweede categorie benadrukken nogmaals de soevereiniteit van de Gewestelijke Staten. Meestal reppen de instructies m.b.t. deze categorie van een rapportage- en een correspondentie-verplichting voor de gecommitteerden in de Staten-Generaal. Hierdoor konden de committenten zich een beeld vormen over hetgeen in de Staten-Generaal aan de orde kwam en konden zij, wanneer zij dit nodig achtten, de afgevaardigden van een last te voorzien, dan wel ruggespraak met hen houden. Ook de vrijwel in alle instructies voorkomende bepaling dat bij een plenaire vergadering van de Gewestelijke Staten steeds minimaal én afgevaardigde bij de vergadering van de Staten-Generaal moest achterblijven, kan in deze categorie worden ondergebracht. Alleen in de instructie van de Staten van 
Holland (1669) ontbreekt een bepaling in deze zin. Waarschijnlijk werd een dergelijke bepaling, vanwege de geringe afstand tussen committenten en gecommitteerden, niet nodig geacht.

De derde categorie valt uiteen in twee delen. Allereerst de bepalingen die als algemene opdracht beschouwd kunnen worden. De bepaling die de gecommitteerden verplichtte de bevelen van hun committenten op te volgen en de belangen van hun gewest te beschermen spreekt in dit verband voor zich. Opvallender is de steeds weer terugkerende bepaling die de gecommitteerden verplichtte de Unie van Utrecht (en alle daarop gegronde regelingen en resoluties) trouw na te volgen. Volgens Paulus is de reden van deze bepaling gelegen in het feit dat de afgevaardigden moesten zorgen dat in de vergadering van de Staten-Generaal niets werd besloten of ondernomen dat strijdig zou zijn met de Unie van Utrecht. De bepaling verplichtte de afgevaardigden ook te waken tegen inbreuken op het Unieverdrag, waarbij blijkbaar vooral werd gedacht aan het vereiste van eenparigheid van stemmen van art. 9 van de Unie van Utrecht. ${ }^{85}$ Dat de Unie van Utrecht in alle instructies als een algemene opdracht aan de afgevaardigden gegeven is, bewijst wederom dat het Unieverdrag, zij het min of meer toevallig, de grondwet van de Republiek der Verenigde Nederlanden was geworden en ook als zodanig door de soevereine Gewestelijke Staten werd beschouwd.

Als laatste algemene opdracht dient nog te worden genoemd de bepaling die de gecommitteerden verplichtte de "ware gereformeerde Religie" te beschermen.

Belangrijker zijn echter de bepalingen die de afgevaardigden voorschrijven in met name genoemde gevallen niet te handelen zonder voorafgaand overleg (ruggespraak) of zonder de goedkeuring van hun committenten: de speciale of bijzondere last. ${ }^{86}$ Deze bepalingen vormen naar hun aard de kern van de algemene instructie. Op het punt van de speciale last kennen de meeste instructies dezelfde constructie. $\mathrm{Er}$ is een hoofdartikel waarin een opsomming wordt gegeven van de onderwerpen waarin voorafgaand overleg (ruggespraak) nodig is teneinde tot concrete lastgeving (wel of niet bewilligen in het voorstel) te komen.

85. Vergl. Paulus, a.w.,p. 131.

86. Niet te verwarren met de speciale of bijzondere instructie. 
De lengte van de opsomming in het hoofdartikel suggereert dat zij uitputtend beoogt te zijn. De instructies laten echter na de opsomming de zinsnede "eenige diergelyke wigtige materien" volgen. De opsomming in het hoofdartikel is dus niet limitatief. Ook in andere, niet expliciet in het hoofdartikel genoemde gevallen zijn de afgevaardigden verplicht tot overleg met hun committenten. In dit kader kan ook de in vrijwel alle instructies voorkomende bepaling dat de interpretatie van de instructie en het geven van nadere regels is voorbehouden aan de Gewestelijke Staten, worden geplaatst.

Naast het hoofdartikel bevatten de instructies nog artikelen met betrekking tot speciale gevallen waarin de gecommitteerden op een bepaalde, in de instructies omschreven wijze moesten handelen. Dit zijn veelal door de Gewestelijke Staten belangrijk geachte onderwerpen die nooit door de afgevaardigden in de Staten-Generaal beslist mogen worden voordat nader advies bij de committenten is ingewonnen. De speciale last is hierbij een extra controle teneinde het overleg tussen afgevaardigden en committenten -en daarmee de lastgeving- te verzekeren. Soms behelzen de bepalingen een uitdrukkelijk verbod tot besluiten, en zo dit toch door de meerderheid van de vergadering van de Staten-Generaal mocht geschieden, moesten de afgevaardigden tegenstemmen. Deze bepalingen werden waarschijnlijk ingegeven door de opvatting van de Gewestelijke Staten dat, gezien de bevoegdheidstoedeling in het Unieverdrag, de beslissingsmacht in die aangelegenheden bij hen berustte.

\subsection{De invloed van het gebod op het besluitvormingsproces}

Van alle vormen van staatsinrichting die het huidig grondgebied van Nederland door de eeuwen heen heeft gekend, is die van de Republiek der Verenigde Nederlanden waarschijnlijk het meest bekritiseerd. ${ }^{87}$ Deze kwalijke reputatie is vooral gebaseerd op het oordeel over het toenmalige stelsel van besluitvorming op centraal niveau. Als gevolg van de soevereiniteit van de afzonderlijke gewesten hadden de afgevaardigden in de StatenGeneraal nauwelijks enige zelfstandige beslissingsbevoegdheid en waren zij

87. Bijvoorbeeld door Thorbecke, die de Republiek beschouwde als "het onhandelbaarste staatswezen waarin zich immer een volk of eene mogendheid bewoog" (Historische schersen, $2 \mathrm{e}$ druk, 's-Gravenhage 1872, p. 2). 
dusdanig strikt gebonden aan hun committenten, dat de besluitvorming op centraal niveau slechts uiterst traag en moeizaam tot stand kon komen.

De praktijk van het gebod van last en ruggespraak was daarvan de belangrijkste, doch niet de enige oorzaak. Zij makte deel uit van een complex van drie factoren, die thans funest voor het adequaat functioneren van een dennocratische rechtsstaat zouden zijn, maar die indertijd -uit het oogpunt van het waarborgen van de soevereiniteit van de afzonderlijke gewesten- beschouwd werden als de 'ware palladia der vrijheid'. ${ }^{88}$ Als zodanig werden opgevat:

1. de verplichting voor de afgevaardigden om volgens een last te stemmen;

2. het recht om in een aantal zaken eenstemmigheid te eisen;

3 . het recht van de minderheid zich niet te schikken in de wil van de meerderheid.

De verplichting voor de afgevaardigden om volgens een last te stemmen, vormgegeven in het gebod van last en ruggespraak, was zoals gezegd de belangrijkste oorzaak van de vertraging en frustratie van het besluitvormingsproces. Dit kon vooral geschieden als gevolg van de interpretatie van art. 19 van de Unie van Utrecht. Dit artikel was het handvat voor de gewesten om het behoud van hun autonomie en onafhankelijkheid zoveel mogelijk te waarborgen. Verder dan enige samenwerking op gebieden als financiën, buitenlandse zaken en defensie wilden zij dan ook beslist niet gaan. Dat was overigens bij het sluiten van de Unie van Utrecht ook uitdrukkelijk de bedoeling geweest: de gewesten streden immers juist voor het behoud van hun oude vrijheden waarop de landsheer inbreuk had gemaakt. De veranderde staatkundige situatie maakte echter in de $17 \mathrm{e}$ en vooral- de $18 \mathrm{e}$ eeuw ver(der)gaande samenwerking noodzakelijk. Het strikt vasthouden aan de Unie van Utrecht door de gewesten teneinde hun zelfstandigheid zoveel mogelijk te handhaven, maakte in die tijd de Republiek onbestuurbaar. In de vergadering van de Staten-Generaal kon vrijwel niets worden besloten zonder de instemming van de Gewestelijke Staten. Alleen in de zaken die bij de Unie van Utrecht uitdrukkelijk aan de beslissingsmacht van de Gewestelijke Staten waren onttrokken, alsmede in de voorvallende zaken hadden de afgevaardigden in de Staten-Generaal enige zelfstandige beslissingsbevoegdheid. Voor het overige waren zij, uitdrukkelijk dan wel stilzwijgend, gehouden aan het gebod van last en

88. Muller, a.w., p. 143. 
ruggespraak. De vergadering van de Staten-Generaal had meer het karakter van een congres van afgezanten dan van wetgevende vergadering. ${ }^{89}$ Wanneer de last van de afgevaardigden van de verschillende gewesten uiteenliep, vond schorsing van de vergadering plaats om de afgevaardigden in staat te stellen ruggespraak te plegen met hun staten. Het proces van ruggespraak en de daaropvolgende hernieuwing van de lastbrief werd pas beëindigd wanneer de Staten-Generaal een unanieme beslissing konden realiseren.

Het recht om in een aantal zaken eenstemmigheid te eisen was een bijkomende complicerende factor in het besluitvormingsproces. Hoewel de Unie van Utrecht bepaalde dat alleen over oorlog en vrede, over financiële consenten en over het aannemen van nieuwe bondgenoten met algemene stemmen diende te worden besloten, gold in de praktijk de regel van volstrekte unanimiteit voor de rechtsgeldigheid van alle belangrijke beslissingen. Deze praktijk was een rechtstreeks gevolg van de machtspositie die Holland innam. Holland was het machtigste gewest binnen de Republiek; er gebeurde niets van belang of het werd eerst in de Staten van Holland behandeld, alvorens in de Staten-Generaal ter tafel te komen. ${ }^{0}$ De overige gewesten hanteerden de regel van eenparigheid van stemmen om de macht van Holland enigszins te beperken; indien zij niet aan deze regel hadden vastgehouden, zou dat tot gevolg hebben gehad dat de soevereiniteit bij de Staten van Holland was komen te berusten.

In relatie tot het vereiste van volstrekte unanimiteit voor alle belangrijke beslissingen kon het gebod van last en ruggespraak uitgroeien tot een parlementair obstructiemiddel, zeker nu in de kleinere gewesten de Gewestelijke Staten slechts eenmaal per jaar bijeenkwamen. Uit motieven die de politieke macht in de regio wilden houden werd het gebod gehanteerd om een centrale besluitvorming te frustreren. Waar de lastverhouding strikt werd toegepast manifesteerden zich vetogroepen, die krachtig genoeg waren om beslissingen op een ander niveau te verhinderen, maar die niet in staat waren om maatschappelijke en politieke conflicten op te lossen. Het gebod was nauw verbonden met een traditioneel consensusdenken, met regionalisme, immuniteiten en privileges. ${ }^{\text {II }}$

89. Vergl. Fnin/Colenbrander, a.w., p. 183; Van Slingelandt, a.w. (deel 2), p. 149.

90. Vergl. Muller, a.w., p. 142.

91. D.J. Elzinga, De politieke partij en het constitutionele recht, Nijmegen 1982, p. 92. 
Ook het recht dat de minderheid van de gewesten had om zich niet te schikken in de wil van de meerderheid was een complicerende factor in het besluitvormingsproces. De invloed van deze regel was echter, nu het vereiste van volstrekte uniformiteit voor vrijwel alle belangrijke beslissingen gold, beperkt.

Door de Gewestelijke Staten, of, indien deze afwezig waren, de Gedeputeerde Staten, werd streng toegezien op strikte naleving van het gebod. Dat gold vooral voor de afgevaardigden van het gewest Holland, die hun committenten nooit ver van zich verwijderd wisten en voortdurend in alle zaken aan een streng toezicht waren onderworpen. De Staten van de andere gewesten waren in het algemeen iets soepeler. Soms traden echter ook zij streng op. Zo kwam een afgevaardigde van Stad en Lande in de problemen door het vredesverdrag met Portugal (1661). De Staten van Stad en Lande waren tegen dit verdrag en hadden besluiten van deze strekking genomen. Uit de verhouding tussen gecommitteerden en hun committenten vloeit voort dat de eersten op de hoogte moesten zijn van de besluiten, door de laatsten genomen, zelfs indien een uitdrukkelijke instructie ontbrak. Een afgevaardigde van Stad en Lande, een zekere J. Schuilenburg (Schulenborch), gaf, zonder overleg met zijn committenten, zijn goedkeuring aan bovengenoemd vredesverdrag. De Staten van Stad en Lande waren woedend; Schuilenburg werd uit zijn ambt ontzet en onbekwaam verklaard ooit nog enig ambt te bekleden. Tot verdere maatregelen schijnt het niet gekomen te zijn omdat Schuilenburg gesteund werd door (de Staten van) Holland, een uitgesproken voorstander van het vredesverdrag. ${ }^{22}$ Als gevolg van Schuilenburgs populariteit werd de beslissing van de Staten van Stad en Lande later door és der leden (de stad Groningen) grotendeels herroepen. ${ }^{93}$

Soms werd ook ten onrechte kritiek uitgeoefend op afgevaardigden. Toen Everard van Weede, Heer van Dyckveld, afgevaardigde namens Utrecht op de Statenvergadering van 24 mei 1684 rapport had uitgebracht over hetgeen in de voorgaande vergadering van de Staten-Generaal was behandeld en besloten, beklaagde hij zich bij zijn committenten over het feit dat hij door leden van de 'Stadtsregeringe' (de vroedschap van de Stad Utrecht) werd beschuldigd zonder last en machtiging van de Staten van Utrecht met een

92. Vergl. Wagenaar, a.w., (deel XIII), p. 16/17.

93. Ramaer, a.w., p. 83. 
resolutie van de Staten-Generaal te hebben ingestemd. Toen staande de vergadering door vergelijking van genoemde resolutie en die van de Staten van Utrecht over hetzelfde onderwerp, bleek dat de beschuldiging onjuist was, werden de afgevaardigden namens de stad Utrecht in de Gewestelijke Staten door de overige leden verzocht na te gaan wie voor deze onjuiste beschuldiging verantwoordelijk waren. Tevens kregen zij de opdracht te overwegen op welke wijze tegen de verantwoordelijken maatregelen moesten worden genomen. Daarbij dienden zij ook aan te geven welke (vorm van) genoegdoening de ten onrechte beschuldigde afgevaardigde Van Weede moest krijgen. ${ }^{94}$ Enige tijd later kwam het gedrag van dezelfde afgevaardigde wederom in een vergadering van de Staten van Utrecht ter discussie te staan. In de Staten-Generaal was hem door een burgemeester van Amsterdam verweten zijn last te buiten te gaan door in te stemmen met een besluit in de Staten-Generaal genomen. Weliswaar gaf Van Weede toen als antwoord dat hijzelf het beste wist wat zijn last behelsde, maar in de vergadering van de Staten van Utrecht werd vervolgens door de afgevaardigden namens de stad Utrecht een uitspraak van de Staten verlangt of Van Weede "wel, off qualyck" had gehandeld. ${ }^{95}$

\subsubsection{De Republiek in verval}

Dat het besluitvormingsproces van de Republiek funest was voor een adequaat functioneren van het staatsbestel werd niet alleen in de $19 \mathrm{e}$ eeuw, maar ook reeds ten tijde van het bestaan van de Republiek zelf erkend. Vooral toen vanaf het begin van $18 \mathrm{e}$ eeuw de economische situatie verslechterde en verschillende gewesten hun aandeel in de financiering van de lasten van de Republiek niet meer konden of wilden opbrengen, kwamen de gebreken duidelijk aan het licht. De Staten-Generaal hadden geen middelen om de onwillige gewesten tot betaling te dwingen. Elk gewest kon immers de besluitvorming binnen de Staten-Generaal belemmeren. En als er al een besluit van de Staten-Generaal voorlag, ontbrak het veelal aan gezag om dit uit te voeren. Niet ten onrechte stelde de raadspensionaris Van Slingelandt dat het niet zo zeer een wonder was dat de Republiek in

94. Extract uit de resoluties van de Staten van Utrecht, 24 mei 1684, opgenomen bij G.W. Vreede, Inleiding tot eene geschiedenis der Nederlandsche diplomatie, deel 1, Utrecht 1856, bijlagen p. 41/42.

95. Extract uit de resoluties van de Staten van Utrecht, 5 juli 1684, opgenomen bij Vreede, a.w., bijlagen p. 42/43; vergl. ook Ramaer, a.w., p. 83. 
verval was, maar wel dat zij nog bestond. ${ }^{*}$ De toestand van regeringsloosheid was overigens niet alleen een kenmerk van de regering op centraal niveau. Ook binnen de gewesten zelf manifesteerde zij zich. Ook daar werd elke belangrijke aangelegenheid beslist "op het welbehagen der principalen" en werden alvorens te besluiten eerst de committenten (de standen) geraadpleegd.

Toen duidelijk werd dat effectieve en efficiënte besluitvorming op centraal niveau vrijwel niet meer mogelijk was, werden verschillende voorstellen ter verbetering gedaan. Als gevolg van het strikt vasthouden aan de soevereiniteit van de afzonderlijke gewesten waren deze pogingen echter tot mislukken waren gedoemd.

Zo zag bijvoorbeeld Van Slingelandt het ontbreken van een vaste instructie voor de afgevaardigden in de Staten-Generaal als "een groot gebrek in de constitutie van de generale Regeering". ${ }^{n 7}$ Een dergelijke instructie was volgens Van Slingelandt nodig als duidelijke afbakening van de bevoegdheden van de Staten-Generaal ten opzichte van die van de Gewestelijke Staten. ${ }^{98}$ Zijn pleidooi vond echter geen gehoor. En hoewel ook de Raad van State in de eerste helft van de $18 \mathrm{e}$ eeuw nog tweemaal voorstellen van soortgelijke strekking deed, stuitte elke poging dit fundamentele gebrek binnen het besluitvormingsproces uit de weg te ruimen op de onwil van de Gewestelijke Staten. Het gebod van last en ruggespraak werd zo een van de vele uitvloeisels van de soevereiniteit van de Gewestelijke Staten, die meer toevallig dan volgens een bepaald plan ontstaan was, maar die, toen zij eenmaal bestond, onmogelijk bleek te kunnen worden afgeschaft omdat elk gewest belang had bij de instandhouding ervan. ${ }^{90}$ Zo had Holland reeds in $17 \mathrm{e}$ eeuw aan de eenparigheid van stemmen, juist op het belangrijke punt van de consenten van de gewvesten, vastgehouden, omdat het overstemming door de andere gewesten vreesde. ${ }^{100}$ Een andere kwestie die in dit kader tot controverses leidde, was de vraag waar de beslissingsmacht van de Staten-Generaal ophield en die van de Gewestelijke Staten begon. In tal van zaken betwistten de Gewestelijke Staten de bevoegdheid tot beslissen van

96. Geciteerd bij J. de Bosch Kemper, De staatkundige geschiedenis van Nederland tot 1830, Amsterdam 1868, p. 186.

97. Van Slingelandt, a.w. (deel 2), p. 256.

98. Idem, p. 259.

99. Ramaer, a.w., p. 84.

100. Vergl. J. Hovy, Institutioneel onvermogen in de $18 \mathrm{e} \mathrm{ecuw,} \mathrm{in:} \mathrm{Algemene}$ Geschiedenis der Nederlanden, deel 9, Haarlem 1980, p. 132. 
de Staten-Generaal. In de discussies over deze kwestie stonden twee partijen tegenover elkaar: de 'bondsstaatspartij' die van mening was dat het gezag van de voormalige landsheer was overgegaan op de Staten-Generaal, en de 'statenbondpartij' die het standpunt huldigde dat met het wegvallen van het landsheerlijke gezag ook de persoonlijke band tussen de gewesten was verdwenen en de enige nog resterende binding tussen deze nog bestond uit hetgeen de Unie van Utrecht hierover bepaalde.

Een oplossing voor de problemen was moeilijk te vinden. De Unie bood daarvoor geen enkel aanknopingspunt. Weliswaar is getracht door het beleggen van een tweede Grote Vergadering van de voltallige Gewestelijke Staten (november 1716) een einde te maken aan de bestuurlijke malaise, maar het vertrouwen bij de gewesten onderling en tegenover de stadhouder was te gering om zelfs maar tot een bescheiden herziening van het verouderde en door de staatkundige werkelijkheid achterhaalde Unieverdrag te komen. De tweede Grote Vergadering ging na negen maanden uiteen na slechts ten aanzien van de sterkte van het leger een besluit genomen te hebben. ${ }^{101}$

De mede door de miserabele wijze van besluitvorming veroorzaakte zwakte van de Republiek werd voor allen zichtbaar toen zij in 1747 betrokken raakte bij de Oostenrijkse successie-oorlog na de verovering door Frankrijk van de Waalse gewesten, die een barrière vormden tussen Frankrijk en de Republiek. De bevolking kwam in opstand tegen de regenten en de democratische partij maakte haar opwachting. Haar 'programma' was echter te vaag om tot een belangrijke staatkundige herziening te kunnen bijdragen. De toenmalige stadhouder Willem IV was tot een dergelijke herziening ook niet bereid. In de daaruit voortvloeiende afscheiding door de democraten van de Oranjepartij lag de kiem voor de aanstaande omwenteling, die (onder meer) een definitief einde zou maken aan het door het stelsel van het gebod van last en ruggespraak gefrustreerde besluitvormingsproces in de Republiek. Onder stadhouder Willem V verscherpte de tegenstelling tussen de stadhouderlijke (orangistische) partij en de anti-stadhouderlijke (Patriotten) partij zich. De democratische beweging kreeg een belangrijke impuls door de ontwikkelingen in de Verenigde Staten en -vooral- Frankrijk. Vele patriotten vluchtten naar het revolutionaire Frankrijk en keerden in 1795 terug toen het Franse leger de Republiek binnenviel. $\mathrm{Zij}$ noemden

101. Over deze vergadering: De Bosch Kemper, a.w., pp. 186-188. 
zich Bataven en gaven daarmee uiting van hun afkeer van de oude bestuursinstellingen, die zij, dankzij de steun van de Fransen, spoedig drastisch zouden hervormen. ${ }^{102}$

\subsection{Van gebod naar verbod: de Bataafse Republiek}

De vestiging van de Bataafse Republiek maakte een einde aan het verlammende stelsel van besluitvorming van de Republiek der Verenigde Nederlanden. In de gedachtengang van de nieuwe machthebbers was geen plaats meer voor soevereine provincies; het gebod van last en ruggespraak diende dan ook te verdwijnen. $\mathrm{Zij}$ wilden af van het confederaal bestel van de Republiek. De Staten-Generaal moesten ervan worden doordrongen dat zij niet tot onderhandeling over wederzijdse belangen, maar tot gezamenlijke beraadslaging en besluitvorming waren geroepen en zich op de belangen van het geheel hadden te richten.

De Bataafse Omwenteling (de 'fluwelen revolutie') begon op 19 januari 1795 toen, een dag na het vertrek van stadhouder Willem V, de stedelijke regeringen van Leiden, Amsterdam en Haarlem werden vervangen door aanhangers van de patriotten. Andere steden volgden spoedig en reeds een week later beschikte de opstandsbeweging over de meerderheid van de mandaten in de Staten van Holland: 12 van de 18 stemmen waren 'omgegaan'. Op 26 januari 1795 vond de eerste zitting plaats van de provisionele representanten van het volk van Holland en werd officieel de standenstaat afgeschaft. ${ }^{103}$ Voorzitter van de vergadering was Pieter Paulus, in een grijs verleden een warm voorstander van de Unie, maar thans bekeerd tot de beweging van de patriotten. Naarmate de Franse troepen hun opmars voortzetten, volgden ook overige gewesten het voorbeeld van Holland, zodat op 16 februari de revolutionairen de meerderheid in de StatenGeneraal gevormden.

De beginselen van de revolutie, in hoofdzaak uit Frankrijk afkomstig, vroegen nu om uitwerking. Op de eerste plaats waren daar de opvattingen over de volkssoevereiniteit en de staatseenheid. In een land dat eeuwenlang

102. Uitvoeriger over de gebeurtenissen in de laatste decennia van de Republiek o.a.: Fruin/Colenbrander, pp. 321-362; De Wit, a.w., pp. 26-28 en vooral- pp. 32-49; De Bosch Kemper, a.w., pp. 212-244.

103. Vergl. De Wit, a.w., p. 113. 
een aristocratische regentenmaatschappij was geweest waarin de gewestelijke soevereiniteit een absoluut goed was, wekten de nieuwe opvattingen merkwaardigerwijs weinig opschudding. Op gewestelijk niveau werden het stadhouderschap en alle andere erfelijke ambten afgeschaft en werd de oude wijze van stemmen per stand vervangen door hoofdelijke stemmingen. In de plaats van de oude statenvergaderingen kwamen provisionele representanten. Vooral in Holland heerste de opvatting dat het oude besluitvormingsstelsel met de nieuwe (aard van) volksvertegenwoordiging onverenigbaar was: er werd over dit punt zelfs geen discussie gevoerd. ${ }^{104}$

Op centraal niveau liepen de zaken iets minder voorspoedig. De uiteindelijke beslissing over de eenwording van de gewesten moest hier worden genomen; zolang die beslissing uitbleef bleef de gewestelijke soevereiniteit bestaan. Aanvankelijk bleef op centraal niveau het oude besluitvormingsstelsel volgens het gebod van last en ruggespraak dan ook van kracht. Met uitzondering van Holland bleven de gewesten vasthouden aan hun soevereiniteit; eenheid en ondeelbaarheid van de staat werd door hen vooral gevreesd omdat dit het amalgameren van de schulden tot gevolg zou kunnen hebben. ${ }^{105}$ Nadat alle gewesten -al dan niet gedwongen- accoord waren gegaan met het voorstel de gewestelijke soevereiniteit in een eenheidsstaat te doen opgaan, organiseerden de Staten-Generaal, die na de omwenteling de oppermacht van het Nederlandse volk aanvaard hadden, de verkiezingen voor haar opvolger, de Nationale Vergadering, die tot taak zou krijgen een grondwet te ontwerpen. Zolang de Nationale Vergadering nog geen staatsregeling had vastgesteld, gold het in Reglement voor de Nationale Vergadering als voorlopige constitutie voor de Bataafse Republiek. Dit Reglement was een in november 1795 bereikte compromis tussen het unitarische voorstel van de democraten en het confederale voorstel van aristocraten. Het schiep een federatie van een nogal zwakke structuur en liet in het midden waar de soevereiniteit gelegen was. De Nationale Vergadering diende weliswaar het volk van de republiek te representeren, maar tegelijkertijd handhaafden andere bepalingen in feite de gewestelijke soevereiniteit, vooral op het gebied van de burgerbewapening en de financiën. ${ }^{10 \%}$

104. Vergl. Ramaer, a.w., p. 150 en de aldaar in noot 1 genoemde bron.

105. De Bosch Kemper, a.w., p. 260.

106. De Wit, a.w.. p. 120 en p. 142. 
Artikel 76 van het reglement betekende echter het einde van het oude stelsel van besluitvorming op centraal niveau. Het artikel bepaalde dat de leden van de Nationale Vergadering geen bijzondere betrekkingen met de gewesten meer hadden en niet als gecommitteerden van een gewest in het bijzonder, maar als representanten van het gehele Bataafse volk in de Vergadering zitting hadden. Een verbod van last en ruggespraak voor de leden van de Vergadering was van dit uitgangspunt een logisch gevolg:

"Zij zullen dus geene Provinciale Resolutiën, Instructiën of Revocatiēn of wat iets meer van dien aart is, onderworpen zijn, doch bij eene hoofdelyke stemming, zonder eenige ruggespraak, alle de gemeenschappelyke belangen der geheele Republicq regelen en besluiten $(\ldots)^{n} .^{107}$

Artikel 76, dat gezien kan worden als voorloper en historische basis van de huidige artikelen 50 en 67 lid 3 Grondwet, is eerst na grote moeilijkheden en veel onenigheid in de Reglement opgenomen. Hoewel het zijn grondslag vond in de algemene onvrede met het stelsel van besluitvorming onder de Republiek en het door velen gevoelde verlangen naar staatkundige eenheid, stuitte het toch op grote weerstand bij de gewesten Friesland, Groningen en Zeeland, die de 'een- en ondeelbaarheid' van de nieuwe Republiek zoveel mogelijk trachtten tegen te houden. ${ }^{108}$ In de Staten-Generaal ontstond een felle discussie over bovengenoemd principe. Scheuring in de Unie dreigde nu daarvan het gevolg te worden. Onder sterke druk van Frankrijk, dat immers alle belang had bij de Republiek als trouwe bondgenoot teneinde een aanvalsbasis tegen Engeland te hebben en daarom de omvorming tot solide eenheidsstaat van de losse verzameling van heterogene gewesten voorstond, werden de weerspannige gewesten echter gedwongen hun goedkeuring aan het Reglement te hechtten. ${ }^{109}$ Het zou tot januari 1798 als voorlopige constitutie van kracht blijven.

Bepalingen zoals die van art. 76 van het Reglement konden furore maken toen in de Franse Revolutie en haar nasleep, de parlementen zich niet langer als standenvergadering gingen beschouwen, maar als vertegenwoor-

107. Art. 76 lid 2 van het Reglement. Dit artikel vond mede zijn grond in de opvattingen over staatsrechtelijke vertegenwoordiging in Frankrijk ten tijde van de Franse Revolutie; zie hfdst. 2.

108. Hierover uitvoeriger: Ramaer, a.w., pp. 151-160.

109. Vergl. De Wit, a.w., p. $120 / 121$. 
digers van het volk, en -tegen de alom latente denkbeelden van Rousseau, waarin de volkswil zich niet laat delegeren- moesten verantwoorden dat zij de leiding van zaken hadden en dat op hun gezag werd geregeerd en bestuurd. ${ }^{110}$ De omwenteling van 1795 heeft ook Nederland dit vertegenwoordigingsbegrip gebracht. Zo was art. 10 van de Burgerlijke en Staatkundige Grondregels van 1798 geheel op Montesquieu geïnspireerd. ${ }^{111}$

"Het Bataafsche Volk, zijne belangen in persoon niet kunnende waarnemen, verkiest daartoe, bij onderlinge overeenkomst, eene geregelde Staats-form en wel eene Volks-regeering bij Vertegenwoordiging."

Deze staatkundige principes komen in de elkaar snel opvolgende staatsregelingen van de Bataafse Republiek steeds weer terug: de afgevaardigden van het volk vertegenwoordigen geen bijzondere groepen, maar het volk in zijn geheel, en beschikken daarbij over een vrij mandaat. Waar deze Staatsregelingen de woorden 'het volk' gebruiken, drukken zij "(...) een wettig begrip uit. Het beteekende een juridischen persoon, ja den souverein." ${ }^{112}$ In de eerst na jaren van moeizaam vergaderen tot stand gekomen Staatsregeling van 1798 zijn deze principes terug te vinden in de artt. 30 en 31 :

"Het Vertegenwoordigend Lichaam is datgene, welk het geheele volk vertegenwoordigt, en, in deszelfs naam, wetten geeft, overeenkomstig het voorschrift der Staatsregeling."

"Geen lid van dit Lichaam vertegenwoordigt, immer, eenig afzonderlijk gedeelte des Volks, noch ontvangt eenen bijzonderen Lastbrief."

In de Staatsregeling des Bataafschen Volks van 1801 ontbrak een bepaling van deze strekking. Wel werd bepaald dat de leden van het 'Wetgevend Lichaam' een belofte moesten afleggen, dat zij aan niets zouden medewerken dat zou afwijken van de "(..) gronden eener volksregeering bij vertegenwoordiging". ${ }^{113}$ Aangenomen mag worden dat, analoog aan het ontbreken van een verbodsbepaling in enige oude Franse constituties, het

110. C.W. van der Pot/A.M. Donner, Handboek van het Nederlandse Staatsrecht, 12e druk, bewerkt door L. Prakke (e.a.), Zwolle 1989, p. 417.

111. Vergl. Nord, a.w., p. 100.

112. J.R. Thorbecke, Aanteekening op de Grondwet, deel 1, (nieuwe) $2 \mathrm{e}$ druk, 's-Gravenhage 1906, p. 205.

113. Belofte voor de Leden van het Wetgevend Lichaam ex Staatsregeling 1801. 
ontbreken daarvan in deze Staatsregeling niet betekent dat het verbod van last en ruggespraak niet gegolden zou hebben. ${ }^{114}$

De Staatsregeling van 1805 echter bevat de bepaling weer in haar oude vorm:

"De leden van de Vergadering van Hun Hoog Mogenden brengen hoofdelijk hunne stem uit, zonder eenigen last te ontvangen van, of ruggespraak te houden met hun Departement. Zij zijn wegens hun gedrag, in de Vergadering van Hun Hoog Mogenden gehouden, aan de Departementale Besturen geene verantwoording schuldig. ${ }^{\text {n115 }}$

De Constitutie voor het Koningrijk Holland van 1806, ontstaan nadat Lodewijk Napoleon door zijn broer tot koning was gemaakt, bracht een nieuwe inrichting van de volksvertegenwoordiging, die evenwel de relatie tussen de afgevaardigden en hun committenten ongewijzigd liet:

"De leden der Vergadering van Hun Hoog Mogenden brengen hoofdelijk hunne stem uit, en stemmen zonder eenigen last, van wie het ook zij, te ontvangen." ${ }^{116}$

Aan bovengenoemde staatkundige principes lag vooral de bestaande afkeer van de staatkundige praktijk onder de Republiek der Verenigde Nederlanden ten grondslag. De theoretische fundering was niet geheel doordacht. Dat in het nieuwe stelsel het probleem bestond waaraan een vergadering van 'voor zichzelf' stemmende leden de legitimatie ontleende om 'het gehele Nederlandse volk' te vertegenwoordigen, werd niet beseft. ${ }^{117}$

\subsection{Staatsrechtelijke vertegenwoordiging 1814-1848}

Ook na het einde van het Bataafse tijdvak (1795-1813) bleef het besef dat de praktijk van het gebod van last en ruggespraak en de vergaande invloed van de Gewestelijke Staten ten tijde van de Verenigde Republiek niet meer terug diende te keren, aanwezig. Ook G.K. van Hogendorp, de geestelijk vader van de eerste grondwetten van het Koninkrijk der Nederlanden en een voorstander van zoveel mogelijk restauratie van historische

114. Vergl. C. Müller, Das imperative und freie Mandat. Überlegungen zur Lehre von der Reprüsentation des Volkes, Leiden 1966, p. 51.

115. Art. 24 Staatsregeling 1805.

116. Art. 56 Constitutie voor het Koninkrijk Holland.

117. Vergl. Van der Pot/Donner/Prakke, a.w., p. 418. 
instellingen (dus met een gedecentraliseerd bestuur, zij het nu met een 'Souverein Vorst' in plaats van een stadhouder), stelde zich op dit standpunt. Reeds lange tijd voordat hij zich eind 1813 in zijn hoedanigheid als voorzitter van de grondwetscommissie weer officieel aan staatszaken wijdde, had hij zijn gedachten laten gaan over de manier waarop na de Franse overheersing de Nederlandse staatsinrichting er uit zou moeten zien. Daarbij zocht hij vooral naar mogelijkheden om de gebreken van de oude staatsinrichting weg te nemen, waarbij aanvankelijk zijn streven naar een verbeterde Unie van Utrecht voorop stond. Een eerste aanzet daartoe gaf hij in 1795 in zijn Memorie ${ }^{118}$. Een van de verbeteringen van het hoofdgebrek in de Unie -"de zwakheid der algemeene Regeering"119- zag hij in het verbreken van alle banden tussen de afgevaardigden in de vergadering van de Staten-Generaal en hun committenten, de Provinciale Staten, al hield hij de mogelijkheid open dat de afgevaardigden na enkele jaren konden worden teruggeroepen. ${ }^{120}$ Dezelfde gedachte is terug te vinden in de door hem in 1799 opgestelde herziene versie van de Unie van Utrecht. ${ }^{121}$ De bepalingen over de Staten-Generaal amendeerde Van Hogendorp als volgt:

"De Provintien zullen Gedeputeerden zenden in Vergadering der Staaten Generaal naar maate van haare volkrijkheid (...). In deeze Vergadering worden alle de zaaken van haar ressort bij meerderheid van stemmen afgedaan (...). De leden van dezelve en van alle de verdere Generaliteits Collegien zijn geen verantwoording schuldig aan, noch ontvangen eenigen last van hunne committenten, maar kunnen door dezelve bij het uiteinde hunner commissie al of niet gecontinueerd worden, naar goedvinden ". ${ }^{12}$

118. Te vinden in Brieven en gedenkschriften van Gijsbert Karel van Hogendorp, deel 3, 's-Gravenhage 1876, p. 87 ev. Over de memorie: C.W. van der Pot, Geschiedenis der wetenschap van het Nederlandse staatsrecht seder 1813. Amsterdam 1957, pp. 134-137, alsmede H.T. Colenbrander, Ontstaan der Grondwet, deel 1, 's-Gravenhage 1908, pp. XXIV/XXV.

119. Van Hogendorp, Memorie, a.w., p. 91.

120. Idem, p. 103.

121. G.K van Hogendorp, De Unie van Utrecht herzien, in: Brieven en gedenkschriften, a.w., pp. 171-183. Over dit stuk: Van der Pot, Geschiedenis der wetenschap van het Nederlandse staatsrecht, a.w., p. 137/138 en Colenbrander, a.w., p. XXV/XXVI.

122. Van Hogendorp, De Unie van Utrecht herzien, a.w., p. 178. 
Later liet hij de gedachte van een herziene versie van de Unie van Utrecht Ios, zonder echter verder op zijn eerdere denkbeelden terug te komen.

De basis van de Grondwet van 1814 wordt gevormd door een drietal door Van Hogendorp in de periode 1812-1813 opgestelde schetsen van een

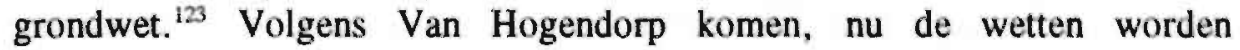
gemaakt door Koning en Staten-Generaal gezamenlijk, het hoofd van de Staat en de natie door haar vertegenwoordigers als het ware samen, om de algemene belangen van de maatschappij te regelen en de grondslag te leggen voor het bestuur van de Staat. Een onafhankelijke Kamer behoort tot de eerste vereisten van de vertegenwoordiging. Om deze onafhankelijkheid te realiseren is de verbodsbepaling ontworpen. Elk lid van de Kamer moet zich beschouwen als vertegenwoordiger van de gehele natie, hetgeen ook in de eed tot uitdrukking komt. In dit verband merkt hij over de verbodsbepaling op:

"Dit artikel sluit inzonderheid en bij name uit, den last van, of ruggespraak met de vergadering, door welke een lid benoemd is. Dit zijn de staten der provinciën; deze benoemen de leden, maar zij hebben geenen last, hoegenaamd, aan dezelve te geven; daar moet geen ruggespraak van de leden met de staten der provinciën plaatshebben. Hiermede zijn al de leden in volmakte onafhankelijkheid gesteld, en kunnen zich geheel en al gedragen naar de inspraak van hun geweten, ter betrachting van eed en pligt. ${ }^{124}$

De grondwetscommissie van 1814 was het inzake het verbod van last en ruggespraak unaniem met Van Hogendorps opvattingen eens. ${ }^{125}$ De Grondwet voor de Vereenigde Nederlanden van 1814 verklaarde dan ook in artikel 62:

"Alle leden der Staten-Generaal stemmen voor zichzelven en zonder last of ruggespraak met de vergadering door welke zij benoemd zijn. "

123. De derde schets, die door de grondwetscommissie in 1814 tot uitgangspunt is genomen is, tezamen met een toelichting, te vinden in Brieven en gedenkschriften, a.w. (deel 6, 's-Gravenhage 1902), pp. 47-72. Over de schetsen van Van Hogendorp: Colenbrander, a.w., p. XXIX ev. en B.D.H. Tellegen, Overzicht van het tot stand komen der Grondwet van 1814, Groningen 1912, pp. 4-9.

124. G.K. van Hogendorp, Bijdragen tot de huishouding van staat in het Koningrijk der Nederlanden, deel 8, 2e druk, Amsterdam 1864, p. 263.

125. Vergl. Tellegen, a.w., p. 56. 
De als gevolg van de vereniging met. België noodzakelijke grondwetsherziening in 1815 beperkte zich, op voorstel van Van Hogendorp, slechts tot de als gevolg van de vereniging noodzakelijke wijzigingen. ${ }^{126}$ De verhouding van de leden van de Staten-Generaal met hun kiezers (toegespitst op de relatie tussen Staten-Generaal en Provinciale Staten) stond daarom allerminst in de belangstelling. Wel veranderde als gevolg van de invoering van het tweekamerstelsel de grondslag van de bepaling dat de Staten-Generaal het gehele Nederlandse volk vertegenwoordigen. In de verdeling van de Staten-Generaal in twee Kamers moet de vertegenwoordiging worden gezien van het aristocratisch en het democratisch beginsel, die beide in de maatschappij voorhanden zijn en derhalve in de nationale vertegenwoordiging moeten worden opgenomen. ${ }^{127}$ De Eerste Kamer vertegenwoordigt daarbij het aristocratisch beginsel, de Tweede Kamer vertegenwoordigt het democratisch beginsel.

In de grondwetscommissie werd slechts een korte discussie gewijd aan de bepaling betreffende het verbod van last en ruggespraak. Het Belgische lid J.J. Raepsaet merkte op, dat de woorden 'recevoir ni mandat, ni instruction' die in de franstalige versie van het voorliggende grondwetsontwerp waren gebruikt, elke betrekking tussen de afgevaardigde in de StatenGeneraal en de Staten van zijn provincie schenen uit te sluiten, maar dat deze totale uitsluiting niet scheen te volgen uit de nederlandstalige versie van het ontwerp, waarvan volgens hem de woorden 'zonder ruggespraak' alleen de gehele afhankelijkheid zoals zich die vroeger had gemanifesteerd uitsloten. Hierop werd geantwoord dat bepaling uitdrukkelijk bedoeld was te verbieden dat een lid van de Staten-Generaal een instructie krijgt van de Provinciale Staten: "(..) geene mandaten of ruggespraak komt hier aan te pas; zij stemmen geheel vrij, maar willen zij een vriend raadplegen, omnino licet. ${ }^{n 28}$ In het verlengde hiervan werd wel betoogd dat niets belette dat een afgevaardigde een inlichting vroeg aan de Staten van zijn provincie. $^{129}$

Met deze uitspraak wordt nogmaals tot uiting gebracht dat het verbod van last en ruggespraak zich op de eerste plaats richtte tot de Provinciale Staten; hoewel het niet expliciet is gesteld, mag worden aangenomen dat de

126. Een overzicht daarvan is te vinden in Brieven en gedenkschriften, a.w. (deel 6), pp. 211-228.

127. Van Hogendorp, Bijdragen tot de huishouding van staat, a.w., p. 337.

128. Colenbrander, a.w. (deel 2), p. 173.

129. Vergl. Ramaer, a.w., p. 196. 
verbodsbepaling wel degelijk beoogde ook ruggespraak tussen de afgevaardigde en zijn committenten te verbieden, vanwege de uit het verleden overgeleverde vrees van frustering van het besluitvormingsstelsel op centraal niveau. Ten aanzien van de woorden 'zonder ruggespraak' beweerden overigens enkele Hollandse leden van de grondwetscommissie dat deze het raadplegen van leden van de Provinciale Staten of zelfs van het gehele college niet uitsloten, maar deze opvatting moet toch als onjuist worden beoordeeld omdat zij lijnrecht tegen de bedoeling van het verbod van last en ruggespraak ingaat. ${ }^{130}$

Het werk van de commissie leidde slechts tot verandering van de verbodsbepaling voorzover de instelling van de Eerste Kamer dat noodzakelijk maakte. Nu de leden van deze Kamer door de Koning zouden worden benoemd, was het verbod van last en ruggespraak niet op hen van toepassing. De verbodsbepaling werd daarom geplaatst in de afdeling van de Grondwet die (alleen) over de Tweede Kamer handelde. Als artikel 83 bepaalde zij nu:

"De leden dezer Kamer stemmen voor zichzelven en zonder last of ruggespraak met de vergadering door welke zij benoemd zijn."

Ten tijde van de grondwetsherziening van 1840, noodzakelijk als gevolg van de scheiding met België, zijn geen nieuwe opvattingen over het vertegenwoordigingsbegrip en de problematiek van het verbod van last en ruggespraak verkondigd. Na een zeer lange aanloop (de eerste aanzetten voor de herziening dateerden reeds van 1831) werd uiteindelijk besloten tot een zeer beperkte herziening; afgezien van de grondwetsbepalingen die wijziging behoefden op grond van de inkrimping van het territorium van het Koninkrijk en de invoering van de (vooralsnog tot het strafrechtelijke aspect beperkte) ministeriële verantwoordelijkheid, bleef de Grondwet, behoudens de vernummering van de meeste artikelen, ongewijzigd.

\subsection{Grondwet 1848}

$\mathrm{Na}$ de afscheiding van België en de daarmee samenhangende marginale grondwetsherziening van 1840 was de rust op het constitutionele vlak slechts van korte duur. Net als in het laatste decennium van de

130. Vergl. Thorbecke, Aanteekening, a.w., p. 236. 
achttiende eeuw leidden ontwikkelingen in het buitenland tot een ongecontroleerde en 'buitenproportionele' reactie in Nederland. De nieuwe koning Willem II liet zich door deze ontwikkelingen nogal snel uit het veld slaan en ging binnen een nacht overstag voor de druk uit de Tweede Kamer om tot ingrijpende grondwetswijzigingen over te gaan.

Toch waren niet alleen de ontwikkelingen in het buitenland oorzaak van de snelle en vergaande wijziging van de Grondwet. Vermoedelijk zou Willem II niet overstag zijn gegaan, wanneer de ontwikkelingen slechts tot het buitenland beperkt zouden zijn gebleven. Maar ook in Nederland zelf werd de roep om een meer radicale wijziging van de Grondwet na 1840 steeds sterker. De Tweede Kamer drong reeds in haar antwoord op het troonrede van 1843 (wederom) aan op herziening van de grondwet. Toen de koning daar naar haar mening niet adequaat genoeg op reageerde leidde dat in de periode 1845-1849 tot enkele initiatiefvoorstellen uit de Tweede Kamer. Zowel de voorstellen van de Negenmannen, als een later ingediend voorstel van het lid Nedermeijer van Rosenthal vonden geen genade in de ogen van de meerderheid van de Tweede Kamer. ${ }^{131}$

De ontwikkelingen in het buitenland trokken de meerderheid van de StatenGeneraal en de Koning over de streep. Aldus werd de herziening van de grondwet in 1848 (betrekkelijk onverwacht) de meeste belangrijke en ingrijpende in de constitutionele geschiedenis van het Koninkrijk der Nederlanden. Het jaar 1848 betekent een cesuur in de Nederlandse politieke ontwikkeling; het markeert echter niet een radicale breuk. ${ }^{132}$

De bepalingen betreffende de taak van de Staten-Generaal en betreffende last en ruggespraak krijgen bij de herziening nauwelijks aandacht. In de vertegenwoordigingsbepaling wordt de hoofdletter in het woord 'Volk' vervangen door een kleine letter; ten aanzien van de bepalingen over last en ruggespraak worden slechts de bewoordingen gewijzigd. De zinsnede 'voor zichzelven' uit 1815/1840 wordt nu 'elk volgens eed en geweten'. In de nieuwe grondwet kwam de bepaling, thans opgenomen in artikel 82, als volgt te luiden:

131. Zie over de voorgeschiedenis van de Grondwet 1848 o.m. G.W. Bannier, Grondwetten van Nederland, Zwolle 1936, pp. 394-401; J.C. Boogman, Rondom 1848. De politieke onwikkeling van Nederland 1840-1858, Haarlem 1978, pp. 50-63.

132. Boogman, a.w., p. 61 en p. 63. 
"De leden stemmen, elk volgens eed en geweten, zonder last van of ruggespraak met hen, die benoemen."

De verbodsbepaling werd ook nu weer geplaatst in de paragraaf handelend over de Tweede Kamer. Door middel van een schakelbepaling werd de bepaling van het verbod van last en ruggespraak nu ook op de Eerste Kamer van toepassing verklaard. ${ }^{133}$ De plaatsing van de verbodsbepaling was niet echt gelukkig: daar zij ook van toepassing was op de leden van de Eerste Kamer, had de bepaling terecht moeten komen bij het hoofdstuk betreffende de Staten-Generaal en niet bij het hoofustuk dat over de Tweede Kamer afzonderlijk handelde. ${ }^{134}$

Naast deze wijzigingen werd in de eed die de leden van de Staten-Generaal moesten afleggen de belofte om zich zonder aanzien van provinciale of andere bijzondere belangen op de onafhankelijkheid van de staat te richten geschrapt; als gevolg van de wijzigingen in het kiesstelsel was de herinnering dat men geen vertegenwoordiger van de provincies was maar een vertegenwoordiger van het geheel, overbodig geworden.

In het licht van de ingrijpende wijzigingen die de grondwetswijziging van 1848 bracht, is het begrijpelijk dat aan de bepalingen van de huidige artikelen 50 en 67 lid $3 \mathrm{Gw}$. weinig aandacht werd besteed. Toch zijn er tijdens de parlementaire behandeling van de herziening sporadisch enkele opmerkingen over de bepalingen gemaakt. Zo wordt in de memorie van toelichting bij het ontwerp van wet dat op de Staten-Generaal betrekking had over de vertegenwoordigingsbepaling (art. 79 Grondwet 1840), opgemerkt:

"De bepaling van art. 79 der Grondwet, dat de Staten-Generaal het geheele Nederlandsche volk vertegenvoordigen, is behouden, maar van eene wettelijke fictie tot eene waarheid gemaakt. De StatenGeneraal blijven ook in twee Kamers gesplitst; doch in de zamenstelling dezer Kamers zijn aanmerkelijke wijzigingen gebragt. ${ }^{135}$

De passage over de veranderde betekenis van art. 79 wordt verder niet toegelicht, maar het ligt voor de hand te veronderstellen dat de regering bedoelde aan te geven dat door de uitbreiding van het kiesrecht de bepaling dat de Staten-Generaal het gehele Nederlandse volk vertegenwoordigen aan

133. Art. 86 Grondwet 1848.

134. Vergl. J. Heemskerk, De prakijk onzer Grondwet, deel 1, Utrecht 1881, p. 137.

135. Handelingen van de Regering en de Staten-Generaal over de herziening der Grondwet, 1847-1848, deel 1, 's-Gravenhage 1848, p. 341. 
waarde zou winnen; in vergelijking met de oude Grondwet zou nu een groter gedeelte van de bevolking door de Staten-Generaal vertegenwoordigd worden, een gedeelte dat omvangrijk genoeg en dusdanig samengesteld was om te stellen dat thans iedereen daadwerkelijk vertegenwoordigd werd. De opvatting van de regering lijkt te impliceren dat zij de op de nieuwe leest geschoeide Staten-Generaal als een goede afspiegeling van het Nedelandse volk beschouwde.

Blijkens het voorlopig verslag bleken de leden van de Tweede Kamer niet erg ingenomen met de door de Regering in de memorie van toelichting gedane uitlating omtrent de 'fictie-vertegenwoordiging'. Het voorlopig verslag begint op dit punt met op te merken dat men zich onthoudt om nogmaals opmerkingen te maken over de voorgestelde regelingen t.a.v. het stelsel van verkiezingen; bij de algemene opmerkingen was dat immers al geschied. ${ }^{136}$ Het verslag vervolgt dan met te stellen dat ook de StatenGeneraal in hun oude vorm het gehele Nederlandse volk vertegenwoordigen en de uitlating van de regering in feite betekende dat de Tweede Kamer incompetent zou zijn:

"Men onthoudt zich daarvan te liever, omdat het onder de bestaande omstandigheden ongepast zou oordeelen met de Regering in eenen woordenstrijd te treden over de stelling, die zij in hare memorie van toelichting tot dit ontwerp op de voorgrond plaatst, dat namelijk door hare voorstellen het grondwettig voorschrift, dat de Staten-Generaal het geheele Nederlandsche volk vertegenwoordigen, van eene wettelijke fictie tot eene waarheid wordt gemaakt. Men zal daaromtrent alleen aanmerken, dat zulk eene veroordeling van eene vertegenwoordiging, die uit kracht der bepalingen van eene plegtig bezworene Grondwet bestaat, hier niet noodzakelijk was en zelfs de strekking zou kunnen hebben, om eenigermate het gezag te ontnemen aan hetgeen door die vertegenwoordiging nog zal worden tot stand gebragt; terwijl daarenboven de stelling zelve geenszins boven tegenspraak verheven is. Indien toch in de schatting van den steller der memorie van toelichting de fictie daarin gelegen was, dat tot nu toe niet alle burgers van den Staat regtstreeks tot de verkiezing der volksvertegen-

136. Deze opmerkingen kwamen er op neer dat de meerderheid van de Kamer niet tegen het voorgestelde stelsel van verkiezingen was -zij het dat zij eerder voorstanders tegen wil en dank waren- maar dat voorgestelde regeling t.a.v. de inrichting en wijze van verkiezing van de Eerste Kamer te weinig garanties bevatte om daadwerkelijk zoals beoogd als 'bolwerk voor de Kroon' te kunnen fungeren, dat daarmee het eindoordeel over het ontwerp negatief uitviel; vergl. Handelingen, a.w., p. 439. 
woordiging medewerken, dan zal eene dergelijke fictie ook na het invoeren van het voorgedragen kiesstelsel blijven bestaan. ${ }^{n 137}$

In de memorie van beantwoording doet de regering geen enkele moeite de opvatting van de Tweede Kamer als zou het voorgestelde stelsel van vertegenwoordiging even goed een fictie zijn als het oude stelsel te weerleggen. Zij merkt slechts op dat zij aan die opvatting geen aandacht hoeft te besteden. "Wanneer toch eene wettelijke fictie is daargesteld, moet die worden geëerbiedigd. " 138 Pas in tweede lezing, bij de behandeling van de wetsontwerpen in de vergadering van de Tweede Kamer in dubbele getale, wordt door de regering, in de persoon van de tijdelijke minister van Justitie, weer een uitspraak over wie de Staten-Generaal geacht worden te vertegenwoordigen, gedaan. Over de 'nieuwe' vertegenwoordiging wordt geheel in de geest van Burke- gezegd:

"Wij zullen eene Vertegenwoordiging krijgen, die diep zal gevoellen, welke hare pligten zijn, en die wetten zal helpen tot stand brengen, die de uitdrukking zijn van de meening van het verstandig gedeelte des volks. " 139

Daarvoor was al door hem te kennen te geven dat de regering tegenstander was van een door enkele leden geopperd (nog) meer algemeen kiesrecht dan voorgesteld. De allerlaagste klassen van de maatschappij zouden volgens hem niet behoren mee te werken aan het kiezen van een volksvertegenwoordiging. ${ }^{140}$

Tijdens de algemene beschouwingen wordt de kritiek op de opmerkingen over de 'fictie-vertegenwoordiging' hier en daar herhaald. Door Telting wordt o.a. opgemerkt dat het voorgestelde stelsel van verkiezingen gebrekkig is

"(...) omdat het, uitgaande van het denkbeeld, dat de vertegenwoordiging moet uitvloeijen van den volkswil, inderdaad niet geeft wat het belooft, wanneer de overgroote meerderheid des volks door een hoogen census van de wilsopenbaring wordt uitgesloten, en het

137. Handelingen, a.w. (deel 1), p. 460.

138. Idem, p. 543.

139. Handelingen van de Regering en de Staten-Generaal over de herziening der Grondwet, 1847-1848, deel 3, 's-Gravenhage 1849, p. $358 / 359$ (cursivering RK).

140. Idem, p. 357. 
dus eene zeer tastbare onwaarheid is, dat dit stelsel de vertegenwoordiging van eene wettelijke fictie tot eene waarheid zoude maken. " ${ }^{141}$

De klaarblijke onwaarheid van de opvatting van de regering over de vertegenwoordigingsbepaling in het ontwerp van de Grondwet wordt door sommige leden gebruikt om aan te tonen dat het oude stelsel aangaande vertegenwoording zeer wel behouden kan blijven omdat ook dat (door de getrapte verkiezingen van de Tweede Kamer door de Provinciale Staten) garandeerde dat in de Staten-Generaal het gehele volk vertegenwoordigd werd. Zo merkt Nap over rechtstreekse verkiezingen (waarvan hij tegenstander is) op:

"Iedere vertegenwoordiging of procuratie-geving, ook slechts van één persoon, door éénen gevolmachtigde, of ook van meer personen, die eenparig denzelfden vertegenwoordiger hebben verkregen, is reeds eene fictio juris. Maar deze regts-fictie wordt nog grooter wanneer de minderheid zich aan de volstrekte meerderheid moet onderwerpen; nog grooter wanneer zij dit moet doen aan de betrekkelijke meerderheid; nog grooter bij eene volkskeuze, wanneer alle vrouwen en minderjarigen, d.i. $3 / 4$ of misschien wel $4 / 5$ der geheele bevolking, geacht worden of in het geheel geen wil te hebben, als kunnende niet met kennis des onderscheids handelen, of hunnen wil door over hen gestelden uit te drukken. Maar nog oneindig grooter wordt die fictie wanneer men door het bepalen van eenen census, welke dan ook, nog weder eene willekeurige grens gaat trekken en een groot deel der meerderjarige mannen afsnijdt, als onbekwaam, om een politischen wel uit te drukken, ondat zij niets of iets minder dan de willekeurig bepaalde som in zekere belasting betalen. Men spreke dus niet van waarheid, dáár, waar men slechts de eene fictie voor de andere geeft en waar de waarheid de treurigste werkelijkheid zoude zijn, wanneer namelijk het volk in massa in de zaal des wetgevers optreedt, om zich zelf de wetten te schrijven. ${ }^{\mathrm{i} \omega 2}$

Ook het regeringsvoorstel is volgens Nap een fictie, maar dan een valse, omdat de meeste stemgerechtigden juist niet met het oordeel des onderscheids zullen (kunnen) handelen. Het beste stelsel is daarom volgens hem

141. Handelingen van de Regering en de Staten-Generaal over de herziening der Grondwet, 1847-1848, deel 2, 's-Gravenhage 1849, p. 69.

142. Idem, p. 327 (cursivering in origineel). 
dat met van een getrapte verkiezing. Dat is weliswaar een fictie, maar het is een fictie
"(...) die het vermoeden van waarheid voor zich heeft, omdat allen, die tot het daarstellen daarvan hebben medegewerkt of hebben moeten medewerken, geacht moeten worden met kennis des onder- scheids te hebben kunnen handelen. ${ }^{143}$

\subsection{Staatsrechtelijke vertegenwoordiging $1848-1900$}

De nieuwe Grondwet van 1848 was geheel het werk van Thorbecke geweest. Hoewel hij noch deel uit maakte van de regering die de wetsontwerpen betreffende de grondwetsherziening in de Staten-Generaal verdedigde, noch van de Kamer die aan die herziening haar fiat gaf, waren het in hoofdzaak zijn opvattingen, in de door hem bij de voorbereidingen aangegeven vorm, die in de nieuwe Grondwet tot uitdrukking werden gebracht. Dit maakt de geringe andacht voor de theoretische onderbouwing van het vertegenwoordigingsbegrip en -in mindere mate- van het verbod van last en ruggespraak in de nieuwe Grondwet nog moeilijker verklaarbaar, daar Thorbecke in zijn geschriften blijk geeft een duidelijke opvatting over deze problematiek te hebben.

Thorbecke verwierp zowel het monarchale absolutisme zoals zich dat onder Lodewijk XIV in Frankrijk manifesteerde, als de reactie op dat absolutisme, de leer van de volkssoevereiniteit verkondigd door Rousseau. Beide opvattingen waren volgens Thorbecke elkaars gelijke, in zoverre dat beide de staatsmacht belichamen en niets van doen hebben met recht, maar slechts met macht als hoofdbeginsel. Desalniettemin vindt Thorbecke's staatsidee zijn grondslag in de leer van de volkssoevereiniteit; het is echter een aangepaste versie, door hem bepleit als het in de gegeven omstandigheden enig bereikbare om nieuwe revoluties te voorkomen.

In Thorbecke's opvattingen berust de soevereiniteit noch bij de koning, noch bij het volk; zij komt echter tot gelding in een zelfstandig functionerende volksvertegenwoordiging. De soevereiniteit is opgesloten in het staatsbestel, zij behoort aan koning noch volk toe maar blijkt eerst door het

143. Idem, p. 328. 
functioneren van dit bestel. ${ }^{144}$ Deze opvatting wordt door Thorbecke verkondigd in de tweede druk van zijn Aantekening; de woorden 'het volk' in de vertegenwoordigingsbepaling betekenen

"(...) tegenover de Statengeneraal en den Koning gesteld, een feit; die menigte van individus, bijzondere leden van het Staatsgenootschap, die, te zamen de bevolking van Nederland uitmakende, wel als nationaal geheel buiten de Vertegenwoordiging aanzijn heeft; doch staatsregtelijke persoonseenheid eerst in en door de Vertegenwoordiging zelve erlangt."

Over de inhoud van het vertegenwoordigingsbegrip en het karakter van de Staten-Generaal houdt Thorbecke er een volgens Nord vaderlijke opvatting op na. ${ }^{146}$ Het 'gronddenkbeeld' van de vertegenwoordiging is dat zal worden meegeregeerd door de

"(...) bijzondere leden van het Staatsgenootschap, door de wardigsten zoo men wil (...). Een zeker getal van ingezetenen wordt ten deele door de Kroon, ten deele buiten haar, gekozen om, vitsluitend afgaande op de Grondwet en eigen inzigt van het algemeene best, gezamenlijk met de Kroon de algemeene wetgeving en eenige andere regten van souvereine regeermagt te oefenen. ${ }^{n 147}$

Bij het vervullen van hun taak hebben de Staten-Generaal de opdracht de belangen van het Nederlandse volk in zijn geheel te behartigen en niet dat van een gedeelte daarvan. ${ }^{148}$ Dat betekende echter niet dat de StatenGeneraal hun taak van het vertegenwoordigen van het gehele Nederlandse volk moesten interpreteren als het openbaren van de wil van het volk. In de visie van Thorbecke over een "Vrijgekozen Volksvertegenwoordiging, zelf-

144. Vergl. F.L. van Holthoon, De genese van Thorbeckes organische staatsleer, in: Bijdragen en mededelingen betreffende de geschiedenis der Nederlanden, deel 101 (1986), p. 198.

145. Thorbecke, Aanteekening, a.w., p. 206 (cursivering in origineel). Met deze opvatting volgde Thorbecke overigens een andere benadering over het begrip "het volk" dan in de eerste druk van zijn Aanteekening, zie daarover: Van Holthoon, a.w., p. 198 en H.H. Zwager, De motivering van het algemeen kiesrecht in Europa, Groningen 1958, p. 161/162.

146. Nord, a.w., p. 102. Zie ook p. 103/104 waar Nord de ontwikkeling in Thorbeckes opvattingen over het vertegenwoordigingsbegrip weergeeft.

147. Thorbecke, Aanteekening, a.w., p. 206.

148. Idem, p. 207. 
standig, naar eigen inzigt en oordeel besluitende, zonder eenigen band met de kiezers" ${ }^{149}$, was die interpretatie uitgesloten.

Bij het verbod van last en ruggespraak komt Thorbecke terug op het begrip 'vertegenwoordigen'. Hij ziet in het verbod

"(...) de voorwaarde van 't geen art. 79 instelt, dat de Statengeneraal het geheel vertegenwoordigen. Den afgevaardigde, die het gansche volk moet vertegenwoordigen, kan niet, wat hij heeft te doen, door een deel des volks worden voorgeschreven. "150

Het volkomen vrij functioneren van de leden van de Staten-Generaal was voor Thorbecke een absoluut vereiste. Hij beweerde (in 1841) dat het verbod dusdanig strikt geïnterpreteerd diende te worden, dat ook de leden van de Eerste Kamer -die toen nog door de Koning benoemd werden- geen ruggespraak met de Koning mochten houden. ${ }^{151}$

De opvatting van Thorbecke dat de volksvertegenwoordiger de grootst mogelijke zelfstandigheid diende te bezitten en onafhankelijk van het inzicht van zijn kiezers diende te beslissen, was in belangrijke mate gegrond op zijn afkeer van het stelsel van besluitvorming van de oude Republiek met het gebod van last en ruggespraak. Het besluitvormingsproces onder de Republiek karakteriseerde hij als "eigenlijk geene beraadslaging", maar eerder een "twisten niet met redenen, maar met vaste en vooraf uitgebragte (lees: bepaalde) stemmen" waarbij eigenbelang en onderlinge naijver de boventoon voerden. Het door hem verachte besluitvormingsstelsel van de Republiek indachtig bepleitte Thorbecke het kiezen als kamerleden van personen met algemene bekwaamheid, die zich vertegenwoordigers van de gehele staat dienden te voelen, niet van een bepaalde landsstreek of provincie. Eenmaal gekozen was de gekozene vertegenwoordiger van het gehele Nederlandse volk; elke relatie tot bepaalde kiesdistricten hield op te bestaan.

Behalve door Thorbecke zijn ook door de Leidse hoogleraar Buijs uitvoerige beschouwingen aan staatsrechtelijke vertegenwoordiging gewijd. Zijn opvattingen wijken niet veel af van die van Thorbecke. De beschouwingen die Buijs aan het begrip 'vertegenwoordiging' en aan het verbod van last en

149. J.R. Thorbecke, Narede, in: Parlementaire redevoeringen, Deventer 1870, p. 12/13. Zie hierover: Zwager, a.w., p. 165.

150. Thorbecke, Aanteekening, a.w., p. 235 (cursivering in origineel).

151. Idem, p. 236. 
ruggespraak wijdt zijn echter aanmerkelijk uitvoeriger, maar daarnaast ook minder rigoreus en minder coherent dan die van Thorbecke. Zo geeft Buijs zich heel wat meer moeite dan Thorbecke om het begrip 'vertegenwoordiging' duidelijk te maken. Daar waar Thorbecke zich over de vraag wie of wat vertegenwoordigd wordt niet al te druk wil maken -van hem mag men er desnoods ook "enkel een vleijend opschrift in zien van een nieuwen vorm van aristocratie"152 - geeft Buijs uitvoerig aan hoe de desbetreffende grondwetsbepaling juridisch-dogmatisch moet worden opgevat en welke invloed de politieke werkelijkheid voor de betekenis van deze bepaling heeft.

Ten aanzien van de betekenis van de vertegenwoordigingsbepaling merkt Buijs op, dat de bedoeling van de (grond)wetgever duidelijker zou zijn geweest wanneer hij deze bepaling in onmiddellijk verband had gebracht met het verbod van last en ruggespraak:

"Immers dan zou gebleken zijn, dat: shet geheele nederlandsche volk vertegenwoordigen • en *stemmen volgens eed en geweten, zonder lastgeving of ruggespraak - twee uitdrukkingen waren voor één zelfde gedachte en dat beide te zamen ten doel hadden het groote punt van verschil tusschen den middeleeuwschen en den modernen Staat in het licht te stellen. "153

Analoog aan de bepalingen in de diverse Staatsregelingen van de Bataafse Republiek zou Buijs dan ook beide bepalingen in én grondwetsartikel tot uitdrukking gebracht zien. ${ }^{154} \mathrm{Nu}$ echter de vertegenwoordigingsbepaling op zichzelf staat, is zij voor tweeërlei uitleg vatbaar. De eerste uitleg wordt bepaald door het historische karakter van de bepaling; zij geeft niet de oorsprong van de Staten-Generaal aan, maar hun doel. De vertegenwoordigingsbepaling bevat de opdracht aan de Staten-Generaal het algemeen belang van het gehele volk te behartigen. Voor vertegenwoordiging van bijzondere belangen is geen plaats. Sterker nog: het terzijde stellen van die bijzondere belangen is de conditio sine qua non van de Staten-Generaal. ${ }^{155}$ Een modern parlement vertegenwoordigt immers

"(...) het eenige wat op het gebied van het publieke recht voor vertegenwoordiging vatbaar is, te weten al de bijzondere begrippen en denkbeelden, welke omtrent de eischen van het algemeen belang

152. Idem, p. 206.

153. Buijs, a.w. (deel 1) p. 384/385.

154. Idem, p. 449/450.

155. Idem, p. 373. 
in de menschelijke samenleving voorkomen. Al die verschillende inzichten in hunne bonte verscheidenheid in én brandpunt samen te voegen, opdat zij daar, onderling strijdende over de beste middelen orn het door allen gewilde doel te verwezenlijken, eindelijk den juisten weg vinden, welke naar dat doel henenleidt, ziedaar de natuurlijke roeping van de moderne volksvertegenwoordiging. " 156

Of het volk daarbij enige invloed kan uitoefenen op de samenstelling van de Staten-Generaal is niet belangrijk; de opdracht geldt onder alle omstandigheden.

"De. Staten-Generaal vertegenwoordigen het geheele nederlandsche volk zooals de voogd den minderjarige, geheel onafhankelijk van de vraag hoe en door wiens tusschenkomst de voogd aan zijn mandaat gekomen is. ${ }^{\text {"157 }}$

De tweede uitleg van de vertegenwoordigingsbepaling beweert het tegendeel van de eerste. De bepaling beoogt dan juist aan te geven wat de oorsprong van de Staten-Generaal is: een afspiegeling van het gehele volk, die door haar samenstelling de getrouwe weergave van de onder het volk levende denkbeelden, behoeften en wensen is.

"Het groote verschil tusschen beide opvattingen valt in het oog: de Staten-Generaal kunnen het volk vertegenwoordigen in laatstgenoemden zin en toch het algemeen belang verwaarlozen, even als zij omgekeerd onder de leus *alles vóór, niets door het volk*, dat belang getrouwelijk kunnen dienen en dus in waarheid voor het geheele nederlandsche volk optreden zonder dat er toch van eenig verband met dat volk sprake is. ${ }^{n 158}$

Van de twee mogelijke opvattingen over de uitleg van de vertegenwoordigingsbepaling -de Staten-Generaal komen op voor het gehele volk, of de Staten-Generaal komen voort uit het gehele volk- gaat Buijs' voorkeur uit naar de eerste omdat het, gezien het uiterst beperkte kiesrecht ten tijde van het ontstaan van de bepaling, onzinnig zou zijn te veronderstellen dat de twee uitleg de bedoeling van de wetgever zou zijn geweest. Op grond van deze keuze meent Nord in Buijs een aanhanger van het oneigenlijke vertegenwoordigingsbegrip te zien. ${ }^{159} \mathrm{Hij}$ verliest daarbij uit het oog dat

156. Idem, p. $373 / 374$..

157. Idem, p. 384.

158. Idem, p. 385.

159. Nord, a.w., p. 190. 
op grond van de door Buijs gevolgde historische interpretatie deze niets anders kon, dan zijn voorkeur voor de eerste uitleg van het vertegenwoordigingsbegrip uit te spreken en dat die historische interpretatie nu juist een keuze voor het eigenlijke vertegenwoordigingsbegrip onmogelijk maakt. Hoewel niet ontkend kan worden dat Buijs' opvattingen wel eens aristocratische elementen bevatten, heeft hij zich desondanks nooit een tegenstander van het eigenlijke vertegenwoordigingsbegrip getoond. Wanneer, zoals bij Nord, de vraag of de volksvertegenwoordigers al dan niet door het volk worden gekozen beslissend wordt geacht voor het onderscheid tussen eigenlijke en oneigenlijke staatsrechtelijke vertegenwoordiging, is het onmogelijk Buijs als aanhanger van de oneigenlijke vertegenwoordiging te zien.

Daarnaast miskent Nord dat Buijs wel degelijk oog heeft gehad voor de uitbreiding van de regeling ten aanzien van het kiesrecht, met alle gevolgen voor de betekenis van het vertegenwoordigingsbegrip van dien. Buijs' eindoordeel over de betekenis van de bepaling anno de tweede helft van de negentiende eeuw komt namelijk allerminst overeen met zijn historisch bepaalde keuze. In navolging van de voorstellen tot grondwetsherziening van de Negenmannen lag aan de Grondwet van 1848 de bedoeling ten grondslag

"(...) om de Staten-Generaal zooveel mogelijk tot een zuiver orgaan te maken van het nederlandsche volk, althans van dat gedeelte ' $t$ welk tot uitoefening van het kiesrecht wordt opgeroepen. ${ }^{n 160}$

De op grond van de nieuwe grondwet gewijzigde regelingen van het kiesrecht vormen volgens Buijs duidelijk het bewijs dat het in 1848 inderdaad de bedoeling van de grondwetgever was deze (nieuwe) betekenis aan de vertegenwoordigingsbepaling toe te kennen.

Dat in deze gewijzigde betekenis de Staten-Generaal het gehele volk vertegenwoordigen betekent echter nog niet dat de individuele volksvertegenwoordiger dat ook doet. Op hem rust inderdaad ook de opdracht het algemeen belang te behartigen, maar over de aard en inhoud van dat algemeen belang bestaan verschillende opvattingen. Daarom moeten de Staten-Generaal volgens Buijs,

"(...) zullen zij in waarheid Volksvertegenwoordiging kunnen heeten, al die verschillende opvattingen van het groote algemeen belang uitdrukken en wel liefst met dezelfde betrekkelijke kracht,

160. Buijs, a.w. (deel 1), p. 388. 
waarmede elk dier opvattingen zich in het volksleven pleegt te openbaren. De afgevaardigde wordt dus de vertegenwoordiger van zijn district, dat wil niet zeggen de man die (...) aan de bijzondere belangen van zijn district de groote algemeene belangen opoffert, welker behartiging hem alleen werd opgedragen, maar die in zijn publiek leven omtrent de eischen van het algemeen belang dezelfde denkbeelden koestert, dezelfde beginselen belijdt en toepast als de meerderheid van de kiezers die hem afvaardigde. ${ }^{161}$

Het door Buijs gemaakte onderscheid tussen 'de Staten-Generaal vertegenwoordigen het gehele Nederlandse volk' en 'de individuele volksvertegenwoordigers moeten de in Nederland levende opvattingen betreffende het algemeen belang tot uitdrukking brengen' is uit het oogpunt van de theorie bijzonder aantrekkelijk. Op deze manier wordt er aan de ene kant een duidelijke relatie gelegd tussen de volksvertegenwoordiging en datgene wat er onder het volk leeft, terwijl aan de andere kant de individuele volksvertegenwoordigers toch dienaren van het algemeen belang blijven. ${ }^{162}$ In dit opzicht bestaat er een nauwe relatie met Burke's beroemde uitspraak over de taak van het parlement.

Ook over het verbod van last en ruggespraak geeft Buijs een uitvoerige beschouwing. Het verbod heeft volgens hem vooral historische betekenis. Voor Europa in het algemeen geeft het de grenslijn tussen het middeleeuwse en het moderne recht aan; voor Nederland in het bijzonder vormt het de breuk met het staatsrecht van de Republiek. Als de Staten-Generaal hun wetgevende functie uitoefenen, maken zij thans gebruik van een publiek recht. Dit in tegenstelling tot vroeger, toen zij een burgerlijk recht hadden dat aan hen door hun kiezers was afgestaan, en zij aan die kiezers verantwoording over het gebruik van dat recht moesten afleggen. De taak van de kiezers is beperkt tot het aanwijzen van degenen die de dragers van het staatsgezag zullen zijn. Zodra deze gekozen zijn, eindigt de invloed van de kiezers. De macht die de gekozenen uitoefenen ontvangen zij echter van boven (de staat) en niet van beneden (het volk), vandaar dat lastgeving verboden is. Het verbod van last en ruggespraak gebiedt de vertegenwoordiger immers naar eigen overtuiging te stemmen en verbiedt daarom niet

161. Idem.

162. Vergl. F.H. van der Burg, Overheid en onderdaan in een representatieve democratie (preadvies VAR), Haarlem 1970, p. 13. 
alleen dat hij een lastbrief van zijn kiezers met zich brengt, maar ook dat hij, eenmaal gekozen, zich tot zijn kiezers wendt om met deze te overleggen hoe hij behoort te handelen.

Dit betekent volgens Buijs echter niet dat er volgens de grondwet geen enkele band tussen kiezers en gekozenen bestaat. De Staten-Generaal moeten immers een afspiegeling zijn van de politieke denkbeelden onder het volk. Buijs wil dan ook niet weten van de in de eerste jaren na 1848 verkondigde opvatting dat het afleggen van een politieke geloofsbelijdenis door een kandidaat-volksvertegenwoordiger een zedelijke band met de kiezers tot gevolg zou hebben, die niet te verenigen zou zijn met de vrijheid van handelen die hij later als afgevaardigde moest hebben. Volgens Buijs moet die zedelijke band er juist zijn, "althans wanneer die politieke geloofsbelijdenis niet meer behelst dan in de regel het geval pleegt te zijn". ${ }^{163}$ Die programma's en belijdenissen zijn immers het motief dat tot de benoeming door de kjezers leidt. Naarmate het politieke leven zich ontwikkelt verlangt de kiezer ook meer te weten van de kandidaat. Maar de band tussen kiezers en vertegenwoordigers mag niet zover gaan dat laatstgenoemden door middel van lastgevingen worden gebonden. Zelfs zonder een uitdrukkelijke verbodsbepaling zou dit een schending van de grondwet betekenen omdat de kiezer door zijn lastgevingen tracht zich meester te maken van de wetgevende macht, terwijl deze niet aan hem, maar aan de Koning en de Staten-Generaal is opgedragen. ${ }^{164}$

De ontwikkeling van het politieke blijkt uit het juist in die tijd opkomende partijenstelsel met zijn staatkundige programma's. Ook aan dat verschijnsel wijdt Buijs een beschouwing:

"(...) hoe grooter de zelfstandigheid is van een candidaat en hoe grondiger zijne kennis van ons staatsbestuur, hoe zeldzamer het zal gebeuren dat hij volkomen kan instemmen niet enkel met de algemeene beginselen maar ook met al de bijzondere bepalingen van een uitvoerig programma. (...) Naarmate de eigen kracht van het kiezersvolk toeneernt, vermenigvuldigen zich de aanvallen op de zelfstandigheid van de volksvertegenwoordigers en kost het deze meer moeite datgene te blijven wat de Grondwet wil dat zij zijn zullen. ${ }^{n 165}$

163. Buijs, a.w. (deel 1), p. 454.

164. Idem, p. 453.

165. Idem, p. 455. 
Buijs ziet daarom partijvorming als een ernstige bedreiging voor het individuele gehalte van de vertegenwoordiging en concludeert dat, wanneer op de ingeslagen weg van de partijvorming wordt voortgegaan, het beginsel van het verbod van last en ruggespraak uiteindelijk vernietigd zal worden. ${ }^{166}$

\subsection{Staatsrechtelijke vertegenwoordiging 1900-1945}

Vanaf het midden van de $19 \mathrm{e}$ eeuw raakte het staatkundig leven in vele landen van Europa in een stroomversnelling. Door de invoering van het algemeen kiesrecht nam het aantal kiesgerechtigden dusdanig toe, dat alleen door middel van een buitenparlementaire organisatie als een politieke partij naar hun gunst kon worden gedongen. Om deze gunst niet te verspelen was het vervolgens noodzaak ook binnen het parlement als partij op te treden, teneinde de partijstandpunten (te trachten) te verwezenlijken. Deze geleidelijke ontwikkeling in de richting van de partijenstaat manifesteerde zich in ons land aan het begin van deze eeuw. Aanvankelijk werd zij zeer wantrouwend gevolgd, als al niet ontkend werd dat zij zelfs bestond. Zo verdedigde De Savornin Lohman de 'ouderwetse' opvatting dat er een "zedelijke band" behoorde te bestaan tussen kiezers en gekozenen, waarin voor de partijen eigenlijk geen rol is weggelegd. ${ }^{167}$ Een juiste toepassing van de verbodsbepaling bepaalde volgens hem voor een groot deel de werking van de constitutie van het Koninkrijk: wanneer de volksvertegenwoordigers niet de vrijheid zouden hebben om geheel naar eigen inzichten te stemmen, "wordt de constitutie in haar wezen verkracht". ${ }^{168}$ Ook Krabbe ging niet uit van het bestaan van partijen en daaraan ondergeschikte volksvertegenwoordigers-partijleden, maar van de relatie tussen de individuele volksvertegenwoordiger en zijn kiezer en de daarmee samenhangende theorie van het vrije mandaat. Hij beoordeelde het verbod van last en ruggespraak "als een ijdel en machteloos woord"16s, maar gaat vervolgens in zijn betoog tot een aanzienlijke nuancering van dit oordeel

166. Idem, p. 456.

167. J.C. de Savornin Lohman, Onze constitutie, 2e druk, Utrecht 1907, p. 397.

168. Idem, p. $397 / 398$.

169. H. Krabbe, De moderne staatsidee, 's-Gravenhage 1915, p. 55. 
over. De kiezers mochten zijn inziens hun kiesrecht ook gebruiken om zich uit te spreken over de inhoud van rechtsnormen;

"(...) en voorzover zij dat doen, staat de volksvertegenwoordiger niet meer vrij tegenover de wetsontwerpen waarin zulke hoofdpunten zijn belichaamd. Het gezag van den volksvertegenwoordiger ligt in de waarde die zijn rechtsbewustzijn voor de uitvaardiging van normen bezit, en die waarde is ontleend aan de rechtsovertuiging van de meerderheid der kiezers. ${ }^{170}$

Met die rechtsovertuiging moet de individuele volksvertegenwoordiger dus rekening houden, tenminste voorzover deze hem bekend is. Het is immers, volgens Krabbe's staatsidee, het in de kiezer aanwezige rechtsbewustzijn dat de basis van zijn kiesrecht vormt; het is het fundament van de verbindbaarheid van de wet en moet daarom in de gekozene doorwerken ondat deze juist op grond van "zijn politieke gezindheid van bepaalde gebieden van het recht" is gekozen. ${ }^{171}$ Dit houdt volgens Krabbe echter niet in, dat de volksvertegenwoordiger blijvende ruggespraak met de kiezers behoort te hebben. Aan de onathankelijkheid van de individuele volksvertegenwoordiger ten opzichte van zijn kiezers moet worden vastgehouden,

"(...) om der wille van de beteekenis van het recht, als een norm die door de reactie van het rechtsbewustzijn tot rechtsnorm wordt gestempeld (...). Want geeft men die zelfstandigheid geheel of ten deele prijs, dan laat men het rechtsbewustzijn van andere personen, dan van hen wier rechtsovertuiging normatieve kracht bezit, beslissen en wordt dus de beteekenis van de verkiezing, die er op gericht is een selectie van rechtsbewustzijn te verkrijgen, vervalscht. "172

Volgens Van den Broek beschouwt Krabbe het verbod van last en ruggespraak als ijdel en machteloos op grond van het imperatief mandaat dat van de politieke partijen zou uitgaan ${ }^{173}$, maar dat lijkt, zeker gezien het tijdsbeeld waarin Krabbe's betoog moet worden geplaatst, wat vergezocht. Aannemelijker is dat het betoog gericht is tegen al te vergaande invloed van de kiezers en niet van de politieke partijen op de volksvertegenwoordigers.

170. Idem.

171. Idem, p. 56.

172. Idem, p. $57 / 58$.

173. A.C.P. van den Broek, Recallrecht in het licht van de representatie, 'sGravenhage 1978, p. 25. 
Nord komt in zijn proefschrift na een grondig onderzoek van de ontwikkeling van het vertegenwoordigingsbegrip min of meer tot dezelfde conclusie als Krabbe. De kiezers hebben door hun keuze slechts te kennen gegeven dat de gekozen volksvertegenwoordiger, en niemand anders, in de hem voorgelegde gevallen zijn mening moet uiten, gebaseerd op de algemene beginselen die hen tot hun keuze hebben genoopt. Binnen dat kader is de individuele volksvertegenwoordiger geheel onafhankelijk; hij heeft slechts zijn eigen rechtsbewustzijn, zijn eigen overtuiging en zijn eigen geweten tot maatstaf.

"Het is in strijd met het karakter der moderne representatie dat de volksvertegenwoordigers onherroepelijk gebonden zijin aan den wil van hun kiezers. De vertegenwoordiger is geen lasthebber; en door een te sterke binding zou het representatieve stelsel veranderen in een directe democratie. Het beginsel der representatieve volksregeering houdt in, dat een klein aantal burgers de groote politieke beslissingen neemt; wanneer zij echter degenereeren tot afgezanten van bepaalde groepen, wier eenige functie ligt in het overbrengen van een beslissing die door de groepen reeds is genomen, dan komt men met dat beginsel in strijd. ${ }^{\text {174 }}$

Waar de literatuur in deze periode weinig aandacht voor de staatkundige ontwikkelingen toont, heeft de grondwetgever deze wel doorgrond. De Grondwet van 1917 bracht de 'package deal' van de onderwijspacificatie, de invoering van het algemeen kiesrecht en de vervanging van het geldende districtenstelsel door een zeer geperfectioneerd systeem van evenredige vertegenwoordiging. ${ }^{175}$ Door de invoering van dit systeem werd de persoonlijke band tussen kiezers en afgevaardigden grotendeels verbroken, al moet de intensiteit van het contact dat ten tijde van het districtenstelsel tussen de afgevaardigde en zijn district plaatsvond ook weer niet overdreven worden.

Ten aanzien van de betekenis van de vertegenwoordigingsbepaling en het verbod van last en ruggespraak bracht de grondwetsherziening schijnbaar geen verandering; beide bepalingen bleven ongewijzigd. Toch zijn bij de parlementaire behandeling van de herziening enkele in dit kader relevante opmerkingen gemaakt. In de memorie van toelichting wordt onder meer

174. Nord, a.w., p. 207/208.

175. Van der Burg, Representatie en participatie, a.w., p. 16. 
opgemerkt dat de ontwikkeling van het parlementaire stelsel invoering van het stelsel van evenredige vertegenwoordiging nodig maakt.

"In tweeërlei opzicht. Vooreerst is de partijvorming belangrijk gewijzigd. De partijen en hare fractiën zijn niet meer groeperingen van kiezers die de leiding aanvaarden van bekende staatslieden; het zijn geworden groepeeringen van kiezers die zelve de richting van het staatsbeleid bepalen. (...) Ten andere zijn de partijen veel meer dan voorheen geworden nationale partijen. De vertegenwoordigers zijn minder vertrouwensmannen van districtkiezers dan vertegenwoordigers van partijen. ${ }^{n 176}$

Bij de mondelinge behandeling in de Tweede Kamer wordt het stelsel wel zeer concreet door Cort van der Linden weergegeven:

"Het stelsel dat ik heb verdedigd is zeer in het kort dit. Het algemeen kiesrecht is gebouwd op de feitelijke indeling der natie in grote politieke groepen; om die politieke groepen tot hun recht te doen komen in de volksvertegenwoordiging is noodig de evenredige vertegenwoordiging. ${ }^{m}{ }^{177}$

Cort van der Linden wilde de invloed van de politieke partijen beperken tot het leidinggeven aan de rechtsovertuiging van het volk zoals die op het moment van verkiezing van de Tweede Kamer bestond. Hij meende hiermee "het overdreven partijwezen" te bestrijden. ${ }^{178}$ De opvatting van de tegenstanders van het stelsel van evenredige vertegenwoordiging dat het partijwezen juist zou worden versterkt door het stelsel, werd door hem niet gedeeld. ${ }^{170}$

Hoewel ook de Grondwet van 1917 bepaalde dat de Staten-Generaal het gehele Nederlandse volk vertegenwoordigen en dit opzicht de tekst van de bepaling dus niet afweek van haar voorgangster in de grondwet van ruim honderd jaar daarvoor, betekende de grondwetsherziening van 1917 wel dat er wederom een nieuwe betekenis aan de bepaling werd toegekend. Werd

176. Handelingen over de herziening der Grondwet, deel 1, 's-Gravenhage 1916, p. $344 / 345$.

177. Handelingen over de herziening der Grondwet, deel 2, 's-Gravenhage 1917. p. 880.

178. Vergl. W.J. van Welderen Rengers/C.W. de Vries, Schets eener parlementaire geschiedenis van Nederland, deel 4, 4e druk, 's-Gravenhage 1955, p. 153.

179. Vergl. F.J.A. Huart, Grondwetsherziening 1917 en 1922, Arnhem 1925, pp. 176-179; Van Welderen Rengers/De Vries, a.w., p. 184. 
in 1814 in de vertegenwoordigingsbepaling de vestiging van de eenheidsstaat tot uitdrukking gebracht als duidelijke reactie op de praktijken onder de Republiek, in 1848 was de eenheidsstaat voldoende geïnstitutionaliseerd dat het tot uitdrukking brengen van deze functie in de vertegenwoordigingsbepaling door de praktijk en de veranderingen in de Grondwet overbodig werd gemaakt. De betekenis van de bepaling evolueerde dan ook tot het aangeven van de grondslag van de Staten-Generaal, in 1848 gelegen in het vormen van een afspiegeling van (het kiesgerechtigde gedeelte van) de bevolking. Na de grondwetsherziening van 1917 gaf de bepaling weliswaar nog steeds de grondslag van de Staten-Generaal aan, maar was de grondslag gewijzigd in het vormen van een afspiegeling van de politieke partijen. Voor het verbod van last en ruggespraak betekende dit dat het vrije mandaat vooral de functie kreeg om de binding van de individuele volksvertegenwoordiger aan zijn partij niet te groot te laten worden.

\subsection{Staatsrechtelijke vertegenwoordiging na 1945}

In tegenstelling tot de periode $1900-1945$ is in de naoorlogse literatuur wel herhaaldelijk aandacht besteed aan de in het licht van de staatkundige ontwikkelingen veranderende betekenis van de vertegenwoordigingsbepaling en het daarmee samenhangende verbod van last en ruggespraak. Zo heeft volgens Donner de invoering van het stelsel van evenredige vertegenwoordiging er toe geleid dat de Staten-Generaal een goede afspiegeling vormen van de bevolking, zoals zij naar politieke richtingen is verdeeld. ${ }^{180}$ De betekenis van de vertegenwoordigingsbepaling is dus volgens Donner inderdaad zoals die door de regering bij de grondwetsherziening van 1917 verkondigd werd. De betekenis van de bepaling is in hoge mate afhankelijk van de aard van het kiesstelsel. Een stelsel van evenredige vertegenwoordiging leidt tot een volksvertegeriwoordiging die een getrouwe afspiegeling is van de onder het volk bestaande opvattingen op de dag van de verkiezingen; het districtenstelsel leidt tot

"(...) een parlement, dat in staat is een bepaalde politieke wil tot uitdrukking te brengen. Dat laatste stemt meer overeen met de ge-

180. A.M. Donner, De plaats van de Staten-Generaal in het hedendaagse staatsrecht (Preadvies Calvinistische Juristenvereniging 1961), in: Tussen het echte en het gemaakie, Zwolle 1986, p. 126. 
dachte aan een "volksvertegenwoordiging", die de openbare zaak actief beheert en beslist. Beoogt men een parlement, dat de volkswil uitdrukt, dan ligt het voor de hand een kiesstelsel te aanvaarden, dat die wilsvorming bevordert en naar de vorming van een duidelijke meerderheid streeft. Nederland had zulk een kiesstelsel voor 1917. (...) Het tegenwoordige stelsel is anders. Het representeert het volk niet in zijn streven naar bepaalde programmapunten, maar het toont ons dat volk in zijn volstrekte verscheidenheid. Het geeft inderdaad een afspiegeling van de stromingen en partijen, maar ziet af van elk middel om het in zijn énheid en samenhang op te roepen. ${ }^{n 181}$

De klassieke theorie dat de individuele volksvertegenwoordiger geacht wordt het algemeen belang te behartigen en dat hij van zijn kiezers of van zijn partij geen lastgevingen heeft te aanvaarden, is volgens Donner weliswaar nog van kracht, maar heeft door de invoering van het algemeen kiesrecht aan zeggingskracht verloren. ${ }^{182}$ In de praktijk worden de kiezers veel eerder op één lijn gesteld met het te vertegenwoordigen volk, dan vroeger (onder het oude kiesstelsel) voorstelbaar was. Het begrip 'volk' is met andere woorden geconcretiseerd, het is geen abstracte grootheid meer. De oudere optiek waarin de individuele volksvertegenwoordiger het gehele Nederlandse volk vertegenwoordigt staat naast de realiteit waarin de volksvertegenwoordiger zich in de eerste plaats als partij-vertegenwoordiger manifesteert. De metamorfose van het vertegenwoordigen van het volk naar het vertegenwoordiger van de kiezer is volgens Donner in hoge mate te verklaren uit de invloed van de politieke partijen. Vooral wanneer een volksvertegenwoordiger een bepaalde groep binnen een partij vertegenwoordigt en als zodanig door de partij wordt gekandideerd, zal hij de neiging vertonen zich met de opvattingen en belangen van die groep zeer ver te identificeren. ${ }^{183}$

Oud heeft in zijn beschouwingen merkwaardigerwijs wel aandacht voor de invloed van politieke opinie-peilingen en de vermeende noodzaak van een

181. Idem, p. 126/127.

182. Idem, p. 128.

183. Idem, p. 129. Donner spreekt in dit verband van de bezetter van een kwaliteitszetel; beter ware het wellicht om -analoog aan Birch- het begrip 'symbolische vertegenwoordiger' te hanteren. 
referendum, maar schijnbaar geen oog voor de invloed van politieke partijen op de positie van de individuele volksvertegenwoordiger. In zijn beschouwingen over de betekenis van de vertegenwoordigingsbepaling en het verbod van last en ruggespraak gaat hij slechts uit van de relatie tussen volksvertegenwoordiger en kiezer. In deze relatie kan volgens hem niet van een mandaat of lastgeving gesproken worden omdat daarbij uitgegaan wordt van het feit dat de lasthebber (beter: de vertegenwoordiger) de wil verklaart van de lastgever (de vertegenwoordigde). ${ }^{184}$ Het kiezerscorps heeft geen -algemene- wil, het parlement kan die wil dus ook niet verklaren. Het kiezerscorps is een orgaan van de Staat, zodat een met meerderheid van stemmen genomen besluit hoogstens als orgaanwil beschouwd kan worden. Daarbij is wil dan nog in oneigenlijke zin gebruikt. De werkelijke wil van het kiezerscorps zou mogelijk alleen in de vorm van een referendum tot uiting kunnen komen, maar deze vorm van directe democratie is behoudens een facultatief referendum- volgens Oud in strijd met de gedachte van het vertegenwoordigend stelsel. ${ }^{185}$

Wanneer de functie van volksvertegenwoordiger als de uitvoering van een mandaat wordt omschreven, wordt dit woord in een oneigenlijke betekenis gebruikt, vandaar dat Oud niets wil weten van enige mandaatstheorie. Als men de verhouding kiezers-parlement zou willen beschrijven, dan zou men haar het best kunnen vergelijken met de verhouding tussen minderjarige en voogd, waarbij de voogd (het parlement) weliswaar verantwoording dient af te leggen aan de minderjarige (het electoraat), maar in geen enkel opzicht aan hem ondergeschikt is. ${ }^{186}$ Tussen de afgevaardigden en de kiezers bestaat geen juridische, maar hooguit een zedelijke band. Op dit punt volgt Oud dus de opvattingen van (o.a.) Burke en Buijs. Oud huldigde dan ook het standpunt dat ruggespraak met niemand is toegelaten. Last en ruggespraak waren volgens hem onverbrekelijk met elkaar verbonden. De verbodsbepaling zag op het raadplegen van anderen met het doel "bepaaldelijk hun aanwijzingen in ontvangst te nemen". ${ }^{187}$ Overleg met anderen

184. P.J. Oud, Het constitutioneel recht van het Koninkrijk der Nederlanden, deel 1, Zwolle 1947, p. 429.

185. Oud, a.w., p. $430 / 431$ en p. 653 ev.

186. Al acht Oud ook deze analogie niet helemaal juist; het vraagstuk van de volksvertegenwoordiging is volgens hem eigenlijk een vraagstuk sui generis (p. 431).

187. P.J. Oud, Handboek voor het Nederlands gemeenterecht, deel 1, Zwolle 1956, p. 240. 
in de zin van advies was naar zijn mening wel geoorloofd, zo niet onmisbaar om een lid van een vertegenwoordigend lichaam in staat te stellen zijn taak met behoorlijke kennis van zaken te vervullen.

De vraag naar de betekenis van de vertegenwoordigingsbepaling en van het verbod van last en ruggespraak in het licht van de invloed van de politieke partijen op de volksvertegenwoordiger is eerst na 1960 aan de orde gesteld. De vertegenwoordigingsfiguur waarbij de kiezers via de partij vertegenwoordigd worden, wordt door Van den Broek partijrepresentatie genoemd. ${ }^{188}$ De partij vertegenwoordigt de kiezers die op haar gestemd hebben. De kiezer kiest de partij, de partij wijst de vertegenwoordiger in het parlement aan op grond van zijn plaats op de kandidatenlijst, waarbij de mogelijkheid dat iemand met voorkeurstemmen wordt gekozen hooguit voor kleine correcties kan zorgen. Wanneer dit partijmodel, dat in de verhouding kiezer-partij zowel elementen van machtiging als lastgeving bevat, gecombineerd wordt met het lastgevingsmodel in de verhouding partij-vertegenwoordiger, waarbij de partij de lastgever is, valt de term partijrepresentatie samen met het de theorie van het electorale mandaat. ${ }^{189}$ Echter:

"Het lijkt ons dat in dit systeem het partijmodel op gespannen voet staat, zo niet in strijd is met het grondwettelijk voorschrift dat de Staten-Generaal het gehele Nederlandse volk vertegenwoordigen; het al eerder genoemde eenheidsmodel. Wij zouden het begrip partijrepresentatie willen reserveren voor de combinatie van partijmodel met machtigingsmodel. Het electoraat verleent de politieke partijen mandaat vertegenwoordigers aan te wijzen in het parlement; de partij machtigt haar vertegenwoordigers het program waarop ze gekozen zijn naar eigen inzicht (geweten) uit te voeren. ${ }^{\text {190 }}$

Volgens Van den Broek is in deze visie een coëxisteren van het grondwettelijke eenheidsmodel en het feitelijk bestaande partijmodel mogelijk en worden tevens optimale voorwaarden geschapen voor een effectieve besluitvorming. Dit is nu zeer de vraag, daar het door hem geschetste model de politieke werkelijkheid allerminst weergeeft: de individuele volksvertegenwoordiger is niet onathankelijk van zijn partij en voert niet

188. Van den Broek, a.w., p. 26.

189. Zie hiervoor, hoofdstuk 2.

190. Van den Broek, a.w., p. 26 (cursivering in origineel). 
zozeer een partij-c.q. verkiezingsprogramma uit, maar een regeerakkoord. De coalitie staat centraal, niet het belang van de afzonderlijke partij. Daarnaast is Van den Broeks visie moeilijk te begrijpen in het licht van zijn opvatting over het verbod van last en ruggespraak. Dit ziet volgens hem niet op de relatie tussen volksvertegenwoordiger en partij, maar op de relatie tussen kiezer en gekozene, "want al spelen de politieke partijen via kandidaatstelling een grote rol, het blijven de kiezers die de afgevaardigden benoemen". ${ }^{191}$ Nog afgezien van de tegenspraaen opzichte van zijn eerdere beweringen, miskent ook deze opvatting de werkelijkheid waarin de kiezers een kandidaat benoemen die door de partij naar voren is geschoven. Ook wordt niet duidelijk welke garantie het model van Van den Broek, nu het verbod van last en ruggespraak slechts ziet op de relatie kiezer-gekozene, bevat dat de volksvertegenwoordiger zijn taak inderdaad volgens eigen inzicht kan vervullen. Als er in werkelijkheid al sprake is van een van de door Van den Broek genoemde modellen, dan is dat het model dat ten grondslag ligt aan de theorie van het electorale mandaat.

Dat laatste is niet het geval bij de opvatting van Thomassen. Volgens hem ligt aan het Nederlandse systeem van politieke vertegenwoordiging een tweetal normatieve theorieën ten grondslag. ${ }^{192}$ Allereerst is dat de reeds eerder vermelde liberale theorie van de representatieve democratie. De aanwezigheid in de grondwet van de bepalingen van art. 50 en 67 lid 3 toont volgens Thomassen aan dat de liberale theorie het uitgangspunt is van het systeem van politieke vertegenwoordiging in ons land.

De tweede normatieve theorie over politieke vertegenwoordiging die volgens Thomassen mede ten grondslag ligt aan het in Nederland geldende systeem van evenredige vertegenwoordiging, legt een relatie tussen representatie en representativiteit. Een representatieve democratie betekent volgens deze opvatting dat het parlement de opvattingen van het electoraat zo goed mogelijk moet weerspiegelen. De nadruk op de representativiteit van de volksvertegenwoordiging is niet noodzakelijk in strijd met de liberale beginselen van de democratie, volgens welke de leden van volksvertegenwoordiging stemmen zonder last (of ruggespraak), het algemeen

191. Idenn.

192. J.J.A. Thomassen, Politieke strijdpunten en coalitievoorkeuren, in: M.P.C.M. van Schendelen, J.J.A. Thomassen en H. Daudt (red.), 'Leden van de Staten-Generaal...', 's-Gravenhage 1981, pp. 207-210. 
belang dienen, en op basis van een afweging van belangen in het parlement tot besluitvorming komen. Dat het parlement een zo getrouw mogelijke afspiegeling van de kiezers moet zijn, impliceert niet dat de leden van het parlement gebonden zouden zijn aan instructies van hun kiezers. Integendeel, de nadruk op afspiegeling suggereert dat de leden van het parlement, juist door hun eigen mening te volgen, zo veel mogelijk overeenkomstig de opvattingen van hun kiezers zullen handelen.

De meest geaccepteerde uitleg van de huidige functie en betekenis van de artikelen 50 en 67 lid $3 \mathrm{Gw}$. is gegeven door Elzinga. ${ }^{193} \mathrm{Hij}$ verklaart de hardnekkigheid waarmee de huidige artt. 50 en 67 lid $3 \mathrm{Gw}$. zich hebben weten te handhaven uit de tweesporigheid van het klassieke representatiebegrip. Het klassieke representatiebegrip omvat enerzijds het vrije mandaat als organisatieprincipe ('pragmatisch-technisch instrument') bij de constituering van de nationale eenheidsstaat, en anderzijds het vrije mandaat als regulerend beginsel van democratie.

"Terwijl de klassiek-liberale democratieopvatting -met haar kiesrechtuitsluitingen en betrekkelijk elitaire benadering van de verhouding kiezer-gekozene- plaats maakte voor andere opvattingen, heeft het instrumentele aspect van het vrije mandaat zijn aantrekkingskracht behouden. Nog steeds worden de mogelijke blokkeringseffecten van het gebonden mandaat naar voren gehaald om aan te tonen, dat een zelfstandige volksvertegenwoordiger voonwaarde is voor een adequaat functionerende (centrale) besluitvorming. Nu niet langer als instrument om regionalisme en privileges uit te bannen, maar als een middel om een te vergaande invloed van politieke partij-organen of maatschappelijke organisaties te voorkomen". ${ }^{194}$

Deze functie is de restfunctie van het vrije mandaat. ${ }^{195}$ De bepalingen van art. 50 en art. 67 lid $3 \mathrm{Gw}$. hebben in ieder geval tot gevolg dat noch aan de kiezers, noch aan politieke partijen of andere groeperingen juridische middelen ter beschikking staan om een volksvertegenwoordiger tot zetelaf-

193. Elzinga, a.w., pp. 91-113. Zie ook D.J. Elzinga/C. Wisse, De parlementaire fracties (Nederlands Parlementsrecht, deel 5), Groningen 1988, pp. 167-189.

194. Elzinga, a.w., p. 94.

195. Elzinga, a.w., p. 103; Elzinga/Wisse, a.w., p. 185. 
stand te dwingen. De facto betekent dit dat aanvaarding van de benoeming tijdens de zittingsperiode alleen door volksvertegenwoordiger zelf teniet kan worden gedaan. Welke wijze van beïnvloeding of binding ook door het interne partijrecht en/of door fractiereglementen tot stand wordt gebracht, in vrijwel alle gevallen zal het effectueren van statutaire, huishoudelijke of fractieregelingen uiteindelijk afhangen van de eigen beslissing van de volksvertegenwoordiger om al dan niet aan te blijven. In de mogelijkheid van het nemen van die eigen beslissing schuilt de restfunctie van de verbodsbepaling.

Bij de grondwetsherziening van 1983 is door de regering aangegeven welke waarde thans aan de bepalingen moet worden toegekend. Volgens haar duiden de woorden 'het gehele Nederlandse volk' uit art. $50 \mathrm{Gw}$. op "een nadere karakterisering en taakomschrijving van de Staten-

Generaal en haar leden die immers gezamenlijk inderdaad héél het

Nederlandse volk moeten vertegenwoordigen". ${ }^{.96}$

Onder uitdrukkelijke verwijzing naar de historische betekenis van het artikel, achtte de regering het van belang het artikel ook thans in de Grondwet vast te leggen als een opdracht voor de Staten-Generaal. In het licht van het voorgaande doet deze opvatting vreemd aan. De regering lijkt immers geheel voorbij te gaan aan de staatkundige ontwikkelingen sinds 1814 en verkondigt het uit die tijd daterende standpunt over de betekenis van de vertegenwoordigingsbepaling, een betekenis die toendertijd werd ingegeven door de afkeer van de staatsinrichting van de Republiek der Verenigde Nederlanden.

Aan het verbod van last is tijdens de parlementaire behandeling de nodige aandacht besteed, al blonk de gedachtenwisseling niet bepaald door helderheid uit. Door de leden van de CDA-fractie in de Tweede Kamer werd gevraagd of met het verbod van last wel werd vastgelegd dat elk bindend mandaat aan een lid van de Staten-Generaal nietig is. $\mathrm{Zij}$ gaven aan dat naar hun mening juist in de praktijk een verontrustende grensvervaging van het (niet nader geadstrueerde) begrip 'bindend mandaat' viel waar te nemen. ${ }^{197}$ De regering antwoordde dat het lastverbod de voorwaarde inhoudt die moet bewerkstelligen dat de Staten-Generaal inderdaad het gehele Nederlandse volk vertegenwoordigen, een opvatting die overigens

196. Tweede Kamer 1976-1977, 14 222, nr. 3, p. 9.

197. Tweede Kamer 1978-1979, 14 224, nr. 5, p. 4. 
op Thorbecke terug gaat en daarmee dus ook al niet bepaald een nieuw gezichtspunt betekende. ${ }^{198}$ Volgens de regering is elk bindend mandaat (waarbij niet werd aangegeven wanneer daarvan sprake is) van een lid van de Staten-Generaal nietig; het resultaat van een in de Kamer gehouden stemming kan niet worden aangevochten op grond van het feit dat een lid zich aan de fractiediscipline heeft onttrokken. ${ }^{199}$ Dit standpunt is volgens Kortmann in zoverre juist dat een bindend mandaat geen publiekrechtelijke gevolgen -met name inzake het uitbrengen van de stem en het bezetten van de zetel- kan hebben. Doch of elk bindend mandaat ook nietig is in burgerrechtelijke zin, valt volgens hem te betwijfelen. "Het is niet uitgesloten dat het handelen in strijd met een bindend mandaat tot burgerrechtelijke gevolgen leidt (royement van het partijlidmaatschap bijvoorbeeld). "200 $\mathrm{De}$ door de regering aangebrachte koppeling tussen een bindend mandaat en de uitslag van een in de Tweede Kamer gehouden stemming is overigens nogal ongelukkig en weinig overtuigend. Het omgekeerde van de redenering is immers ook waar: het resultaat van een stemming kan ook niet worden aangevochten wanneer een of meer leden van de kamerfractie door hun partij of fractie gedwongen zijn om tegen hun eigen overtuiging te stemmen. In dit opzicht vormt het vrije mandaat niet bepaald een garantie voor de onafhankelijkheid van de individuele volksvertegenwoordiger.

De regering erkende dat er wel een politieke gebondenheid van een kamerlid aan het verkiezingsprogramma van zijn partij bestaat. Dit gebeurde bij de parlementaire behandeling van het wijzigingsvoorstel in de Tweede Kamer toen door de VVD-fractie de vraag gesteld werd of de verplichting tot het uitvoeren van een verkiezingsprogramma als een last kan worden aangemerkt. ${ }^{21}$ De regering antwoordde:

"Kamerleden hebben zich, door zich kandidaat te laten stellen door een partij, akkoord verklaard met het verkiezingsprogram van die partij. De kiezers hebben hem grond van dat programma gekozen. Het kamerlid is daarom politiek gebonden zowel tegenover de kie-

198. Tweede Kamer 1978-1979, 14 224, nr. 6, p. 6. Vergl. Thorbecke, Aanteekening, a.w., p. 235.

199. Tweede Kamer $1978-1979,14224$, nr. 6, p. 6.

200. C.A.J.M. Kortmann, De Grondwetshercieningen 1983 en 1987, 2e druk, Deventer 1987, p. 224. In dezelfde zin: P.P.T. Bovend'Eert, Regeerakkoorden en regeringsprograms, 's-Gravenhage 1988, p. 156/157.

201. Tweede Kamer 1978-1979, 14224, nr. 5, p. 4. 
zers, als tegenover zijn politieke partij, zich aan dat programma te houden. Hij behoudt daarbij echter zijn onafhankelijkheid en zelfstandigheid als volksvertegenwoordiger. In die zin is het zich houden aan het verkiezingsprogramma niet te zien als een last. " 202

De politieke verplichting om zich te houden aan een verkiezingsprogramma kan volgens de regering echter niet worden gesanctioneerd. Enkele politieke partijen hebben overwogen dit wel te doen door o.a. het terugroepingsrecht, het recht van terugroeping van op de partijlijst gekozen afgevaardigden in vertegenwoordigende lichamen nadat het vertrouwen in hen is opgezegd door (organen van) de partij. Hoewel ook dit recht hoogstens privaatrechtelijke gevolgen kan hebben, legt het toch een grote druk op het kamerlid in zijn kwaliteit van volkswertegenwoordiger. De regering maakte dan ook terecht bezwaar tegen een tussentijds terugroepingsrecht van politieke partijen.

"Ten aanzien van het zogenaamde terugroepingsrecht merken wij op, dat politieke partijen een dergelijk recht niet bezitten. Van een bindend mandaat zou inderdaad sprake zijn indien een politieke partij een formeel terugroepingsrecht zou kunnen uitoefenen voor het geval kamerleden het verkiezingsprogramma van die partij niet ten uitvoer brengen. De werkelijkheid is, dat een gekozene in de uitoefening van zijn lidmaatschap niet juridisch gebonden is aan de besluiten van politieke partijen. Een politieke partij heeft niet de bevoegdheid een einde te maken aan het lidmaatschap van de kamer en het verlies van vertrouwen van zijn politieke partij betekent niet dat hij zijn zetel in het vertegenwoordigend lichaam waarin hij gekozen is opgeeft. Er bestaan geen wettelijke bepalingen waarin het verlies van het vertrouwen van een politieke partij als grond van het verlies van het kamerlidmaatschap wordt vermeld. Wel kan een politieke partij een kamerlid uitnodigen tot een gedachtenwisseling als er twijfel over zou bestaan of het verkiezingsprogram voldoende zou worden gevolgd. . ${ }^{\text {2013 }}$

Hieruit leidde de regering af dat een terugroepingsrecht niet tegen de wil van de betrokkene kan worden uitgeoefend.

Opvallend is dat in de discussie geen aandacht is besteed aan binding van de fracties c.q. de leden daarvan aan een regeeraccoord. Gezien het belang

202. Tweede Kamer 1978-1979, 14224, nr. 6, p. 7.

203. Tweede Kamer 1978-1979, 14224, nr. 6, p. 7. 
dat sinds de Tweede Wereldoorlog in toenemende mate aan het regeeraccoord wordt toegekend, was daarvoor voldoende reden aanwezig. In de parlementaire geschiedenis is herhaaldelijk betoogd dat de staatsrechtelijke positie van volksvertegenwoordigers zich niet verdraagt met de bindende afspraken van een regeeraccoord. ${ }^{204}$ Het regeeraccoord verplicht de betrokken fracties steun te verlenen aan het kabinet en aan de uitvoering van het accoord zelf. Maar daar volgens de Grondwet en de Reglementen van Orde van de Kamers niet de fracties, maar de individuele leden afzonderlijk of de Kamers als geheel taken en bevoegdheden uitoefenen inzake wetgeving en parlementaire controle op het regeringsbeleid, bestaat er een wezenlijk verschil tussen de fractie als geheel en haar individuele leden, waardoor uit de binding van de fractie aan het regeeraccoord niet automatisch voortvloeit dat ook de afzonderlijke fractieleden tegen hun zin worden gebonden. Integendeel, ook hier voorkomt het lastverbod dat deze consequentie kan intreden. De binding van individuele volksvertegenwoordigers aan besluiten van hun fracties heeft slechts een beperkte werking: hoe strikt de fractiereglementen ook mogen zijn en de handelingsvrijheid van de individuele volksvertegenwoordiger beperken, nooit kan deze worden belet in strijd met het fractiebesluit en/of het fractiereglement zich te uiten of naar eigen inzicht te stemmen. ${ }^{205}$ Publiekrechtelijke gevolgen voor de geldigheid van stemmingen heeft een afwijking van fractiebesluiten niet. Intern, dus binnen de fractie zelf, kan een dergelijk afwijkend stemgedrag echter wel gevolgen hebben: nu de fracties zich hebben verbonden tot uitvoering van het regeeraccoord, rust op hen de verplichting deze uitvoering te waarborgen, desnoods door disciplinaire maatregelen te nemen tegen individuele fractieleden. ${ }^{206}$

In de huidige Grondwet is bij de herziening van 1983 de zinsnede 'van of ruggespraak met hen die benoemen', vervallen. Ten aanzien van het verbod tot het houden van ruggespraak merkte de regering op dat de zinsnede overbodig was en nog slechts een historische betekenis had. Bovendien zou zij de onjuiste indruk wekken dat het voeren van overleg met de achterban verboden is. ${ }^{207}$ Met deze uitleg ging de regering echter voorbij aan de van

204. Zie de voorbeelden genoemd door Bovend'Eert, a.w., p. 155.

205. Vergl. Bovend'Eert, a.w., p. 157; Elzinga, a.w., p. 106.

206. Bovend'Eert, a.w., p. $159 / 160$.

207. Tweede Kamer $1976-1977,14224$, nr. 3, p. 6. 
oudsher bestaande nauwe band tussen last en ruggespraak. Het houden van ruggespraak diende immers om de afgevaardigden van een nieuwe last te voorzien. Zeker gezien de verwijzing naar de historische betekenis van het verbod van ruggespraak, is de door de regering gegeven reden voor het schrappen van dit verbod weinig gelukkig.

De regering stelde daarnaast dat het schrappen van de zinsnede 'hen die benoemen' bedoeld was om uitdrukkelijk vast te stellen dat elk bindend mandaat van een lid van de Staten-Generaal nietig is. ${ }^{208}$ Onder de oude tekst van de bepaling zou staande kunnen worden gehouden dat alleen de kiezers als benoemende instantie fungeren en dat het verbod zich alleen tot hen en niet tot partijen, fracties en andere groeperingen zou richten. Naar de geest zag het verbod echter ook onder deze redactie op deze instanties. ${ }^{209} \mathrm{Nu}$ de grondwet zwijgt over het bestaan van politieke partijen moeten zij worden gezien als een verzameling van kiezers, waardoor ook de partijen onder de werking het (oude) verbod vielen. Dit had historisch bezien immers niet alleen op de individuele kiezer, maar ook op groepen daarvan betrekking.

Gezien het door de regering aangehaalde voorbeeld dat het resultaat van een gehouden stemming niet kan worden aangevochten op grond van het feit dat een lid zich aan de fractie-discipline heeft onttrokken en anders heeft gestemd dan in de fractie was overeengekomen, moet zeker onder de huidige redactie de verbodsbepaling geacht worden zich juist in het bijzonder op de problematiek van de gebondenheid van leden van de StatenGeneraal aan lastgeving van de fracties van de politieke partijen te richten. Daarmee lijkt het lastverbod vooral nog tot een interne functie (de uitslag van stemmingen in het parlement) te zijn beperkt.

208. Idem.

209. Vergl. Elzinga, a.w., p. 104; Kortmann, a.w., p. 224 (noot). 


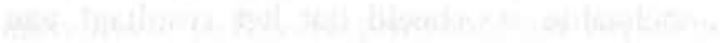

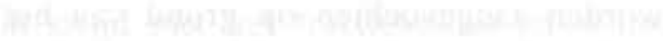

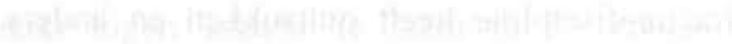

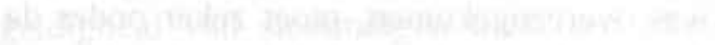

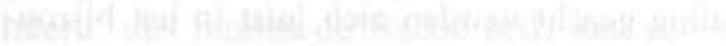

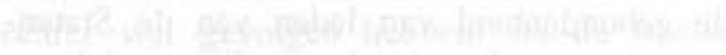

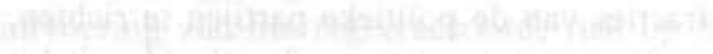

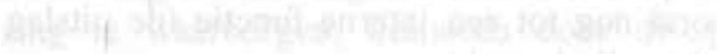

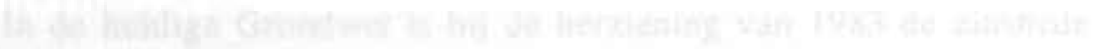

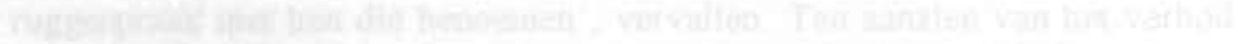

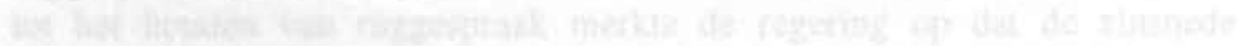

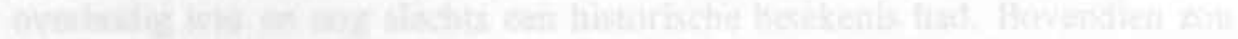

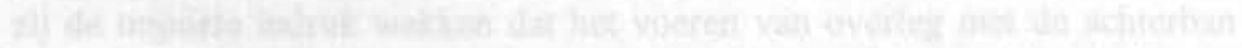

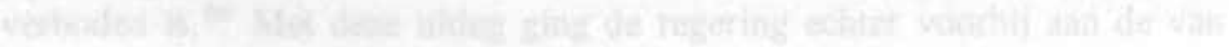

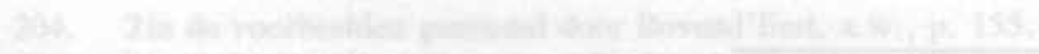

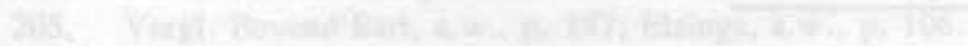

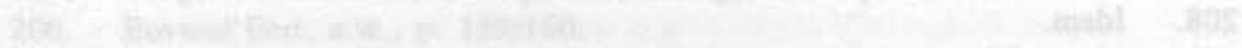

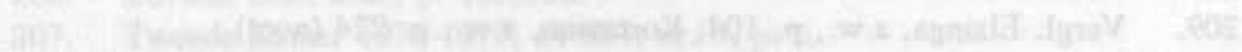




\section{DE ONAFHANKELIJKHEID VAN DE VOLKSVERTEGENWOORDIGER IN DUITSLAND}

\subsection{Inleiding}

Het grondwettelijk kader van de positie van de individuele volksvertegenwoordiger in Duitsland wordt bepaald door de artikelen 20, 21 en 38 van het Grundgesetz (GG). Voor zover hier van belang luiden deze:

\section{Art. 20 GG:}

1. Die Bundesrepublik Deutschland ist eine demokratischer und sozialer Bundesstaat.

2. Alle Staatsgewalt geht vom Volke aus. Sie wird vom Volke in Wahlen und Abstimmungen und durch besondere Organe der Gesetzgebung, der vollziehenden Gewalt und der Rechtsprechung

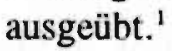

\section{Art. 21 GG:}

1. Die Parteien wirken bei der politischen Willensbildung des Volkes mit. Ihre Gründung ist frei. Ihre innere Ordnung muß demokratischen Grundsätzen entsprechen. Sie müssen über die Herkunft und Verwendung ihrer Mittel sowie über ihr Vermögen öffentlich Rechenschaft geben.

2. Parteien, die nach ihren Zielen oder nach dem Verhalten ihrer Anhänger darauf ausgehen, die freiheitliche demokratische Grundordnung zu beeinträchtigen oder zu beseitigen oder den Bestand der Bundesrepublik Deutschland zu gefährden, sind

1. Voor het overige bepaalt het artikel:

3. Die Gesetzgebung ist an die verfassungsmäßige Ordnung, die vollziehende Gewalt und die Rechtsprechung sind an Gesetz und Recht gebunden.

4. Gegen jeden, der es unternimmt, diese Ordnung zu beseitigen, haben alle Deutschen das Recht zum Widerstand, wenn andere Abhilfe nicht möglich ist. 
verfassungswidrig. Über die Frage der Verfassungswidrigkeit entscheidet das Bundesverfassungsgericht.

3. Das Nähere regeln Bundesgesetze.

Art. 38 GG:

1. Die Abgeordneten des Deutschen Bundestages werden in allgemeiner, unmittelbarer, freier, gleicher und geheimer Wahl gewählt. Sie sind Vertreter des ganzen Volkes, an Aufträge und Weisungen nicht gebunden und nur ihrem Gewissen unterworfen.

2. Wahlberechtigt ist, wer das achtzehnte Lebensjahr vollendet hat; wählbar ist, wer das Alter erreicht hat, mit dem die Volljährigkeit eintritt.

3. Das Nähere bestimmt ein Bundesgesetz.

Waar het tweede lid van artikel $20 \mathrm{GG}$ tot uitdrukking brengt dat de staatsinrichting van de Bondsrepubliek is gegrond op het beginsel van de representatieve democratie door te bepalen dat alle staatsmacht vanuit het volk door bijzondere organen wordt uitgeoefend, bepaalt artikel $38 \mathrm{GG}$ dat de vertegenwoordigers van het volk in die organen het gehele volk vertegenwoordigen en daarbij een vrij mandaat hebben. Artikel 21 geeft aan dat ook de politieke partijen in dit kader een specifieke taak hebben: zij worden geacht mee te werken bij de politieke wilsvorming van het volk. De in deze drie bepalingen vastgelegde beginselen zijn niet alleen bepalend voor de staatsrechtelijke positie van de Bondsdagafgevaardigden, maar vormen tevens de drie grondnormen van de Duitse parlementaire democratie. ${ }^{2}$ Daarbij doet zich het merkwaardige fenomeen voor dat twee van deze grondnormen lijken te botsen. De opdracht in art. $21 \mathrm{GG}$ aan de politieke partijen om mee te werken aan de politieke wilsvorming van het volk, wordt in hoge mate uitgevoerd door de vertegenwoordigers van deze partijen in de Bondsdag. Tegelijkertijd zijn deze vertegenwoordigers ingevolge art. 38 GG ook onafhankelijke vertegenwoordigers van het gehele volk. De tegenstelling tussen deze twee artikelen van het Grundge-

2. Vergl. P. Badura, Die parlamentarische Demokratie, in: J. Isensee/P. Kirchhof, Handbuch des Staatsrecht der Bundesrepublik Deutschland, deel 1. Heidelberg 1987, p. 956; H.-P. Schneider, Commentaar op art. 38 GG, in: E. Denninger e.a. (red.), Kommentar zum Grundgesetz für die Bundesrepublik Deutschland, deel 2, Neuwied/Darmstadt 1984, p. 256. 
setz staat centraal in paragraaf 6 van dit hoofdstuk. Daaraan voorafgaand wordt in de paragrafen 3 tot en met 5 de huidige inhoud en betekenis van de drie grondnormen aan een nadere beschouwing onderworpen en geeft paragraaf 2 een beschrijving van hun ontwikkeling in het Duitse staatsrecht.

\subsection{De ontwikkeling van het vrije mandaat in het Duitse staatsrecht}

De staatkundige situatie van het Duitse rijk aan het einde van de middeleeuwen is wel getypeerd als een "unregelmaßiges Staatsgebilde, das seines Gleichen auf der ganzen Welt nicht hat". ${ }^{3}$ Een grondwet bestond niet. Voor enkele zaken bestonden specifieke juridische regelingen, zoals de uit 1356 daterende 'Goldene Bulle', die de verkiezing van de koning (door de paus vervolgens tot keizer te kronen) regelde. In de andere gevallen werd de besluitvorming bepaald door de bestaande machtsverhoudingen of door concreet overleg.

Het is zelfs twijfelachtig of het Duitse rijk in deze periode wel als een staat kan worden beschouwd. Waar in de meeste andere West-Europese landen aan het einde van de middeleeuwen de gecentraliseerde en unitaire nationale staat zijn gezag vestigde ten koste van het regionale en het standsparticularisme, maakte Duitsland juist een ontwikkeling in de omgekeerde richting door. ${ }^{4}$ Nadat vanaf de $13 \mathrm{e}$ eeuw het voormalige Heilige Roomse Rijk uiteenviel in een particularistische standenstaat, verbleekte de rijkseenheid gaandeweg tot een schaduwbestaan. ${ }^{5}$ De macht van de geestelijke en wereldlijke vorstendommen en grote steden nam toe, terwijl het centrale

3. S. von Pufendorf, Die Verfassung des Deutschen Reiches, Leipzig 1877, p. 110. De oorspronkelijke, Latijnse uitgave van dit boek (De statu imperii Germanici, 1667) repte zelfs van een "onregelmatig lichaam gelijk aan een monster"; vergl. R.C. van Caenegem, Geschiedkundige inleiding tot het publiekrecht, Gent 1985, pp. 108. Zie ook: O. Model, Grundgesetz für die Bundesrepublik Deutschland, 10e druk, bewerkt door K. Müller, Köln 1987, p. 3.

4. Vergl. Van Caenegem, a.w., p. 108.

5. Vergl. M.C. Burkens, De Bondsrepubliek Duitsland, in: L. Prakke/C.A.J.M. Kortmann (red.), Het staatsrecht van de landen der Europese Gemeenschappen, 3e druk, Deventer 1988, p. 115. 
gezag verviel tot een symbool. Het bleef een zichtbaar bindmiddel tussen de steden en de vorstendommen, maar had geen effectieve rechtstreekse controle over deze gebieden. Het rijk had geen eigen leger, geen eigen bestuursapparaat en bijna geen eigen financiën (met name geen belastinginkomsten), waardoor het onmogelijk was zich naar de bevolking als staat te manifesteren. Voor het verkrijgen van financiële en militaire steun was de koning, als een van de grote Duitse landheren, genoodzaakt te putten uit de middelen die het bezit van zijn eigen vorstendom hem verschafte.

Bovendien stonden de privileges van de ook in het Duitse rijk bestaande standen een uitbreiding van het centrale gezag in de weg. Het Duitse rijk telde vier standen: de wereldlijke vorsten, de geestelijke vorsten, de graven en baronnen en de steden. De eerste twee standen leverden de keurvorsten, die belast waren met de verkiezing van de koning. De standen kwamen sinds de tweede helft van de $15 \mathrm{e}$ eeuw op gezette tijden bijeen in de Rijksdag. Zij werden daartoe door de keizer opgeroepen. In de Rijksdag waren zij niet naar stand georganiseerd, maar verenigd in een drietal raden (c.q. colleges): de raad van de keurvorsten, de raad van de overige vorsten, de graven en de baronnen en de raad van de steden. ${ }^{6}$ De wereldlijke vorsten, de geestelijke vorsten en de graven en baronnen verschenen meestal niet in persoon: de beraadslaging in de Rijksdag lieten zij over aan agenten, die veelal namens meerdere standen tegelijk optraden. ${ }^{7}$ De vierde stand, die van de steden, kon vanzelfsprekend niet anders dan door middel van zijn afgevaardigden zijn stem in de Rijksdag laten horen. Deze afgevaardigden waren steevast gebonden aan een imperatief mandaat. Dit mandaat werd aanvankelijk vormgegeven door een algemene instructie waarin de hoofdlijnen werden aangeven voor hun stemgedrag; later werden de afgevaardigden vrijwel altijd verplicht over alle zaken die in de Rijksdag aan de orde kwamen ruggespraak te houden met hun committenten. ${ }^{8}$

De Rijksdag vergaderde aanvankelijk niet op een vaste vergaderplaats, terwijl ook de duur van de vergadering aan verandering onderhevig was.

6. Over deze raden: P. Moraw, Hofiag und Reichstag von den Anfängen im Mittelalter bis 1806, in: H.-P. Schneider/W. Zeh (red.), Parlamentsrecht und Parlamentspraxis in der Bundesrepublik Deutschland, Berlijn 1989, pp. $17 / 18$ en $28-30$ en D. Willoweit, Deutsche Verfassungsgeschichte, München 1990, p. 163/164.

7. Vergl. Moraw, a.w., p. 40.

8. Vergl. P.A. Ramaer, De verhouding der volksvertegenwoordigers tot hunne committenten in de constiturionele monarchie, Leiden 1868, p. 22. 
Vanaf 1663 was de Rijksdag echter een 'ewiger Reichstag' omdat hij in de vergadering van dat jaar in Regensburg niet in staat bleek tot besluiten te komen en daarom besliste permanent in Regensburg te blijven zetelen. Tot een factor van politiek belang zou hij nooit uitgroeien: de rechten van de standen en de ondergeschiktheid van de wetten van de Rijksdag aan de plaatselijke en regionale wetten verhinderden dit. De (wetgevende) macht van de Rijksdag was daarom in deze tijd de facto erg beperkt. De belangstelling van de standen voor de werkzaamheden van de Rijksdag nam dan ook steeds meer af. De steden volstonden uiteindelijk met één enkele afgevaardigde, die van Regensburg, om namens hen op te treden, terwijl de andere standen zich veelal beperkten tot het geven van schriftelijk commentaar. ${ }^{9}$

\subsubsection{Het Duitse rijk in de 19e exuw}

De revolutionaire gebeurtenissen in Europa aan het einde van de $18 \mathrm{e}$ eeuw betekenden een geleidelijke ontwikkeling naar meer Duitse eenheid. ${ }^{10}$ Deze ontwikkeling werd versneld door het formele einde van het oude Duitse rijk in 1806. Drie verloren oorlogen met Frankrijk leidden tot de annexatie van het Duitse grondgebied aan de linkeroever van de Rijn door Frankrijk (Verdrag van Luneville, 1801) en het ontstaan van de Rijnbond. In de Rijnbond werden de onderling zeer verdeelde resterende Duitse vorstendommen aan de rechteroever van de Rijn verenigd onder het protectoraat van Frankrijk (juli 1806). De leden van de Rijnbond verklaarden op 1 augustus 1806 op de formeel nog steeds voortdurende Rijksdag in Regensburg dat zij uit het Duitse rijk traden. Zes dagen later abdiceerde de keizer, daartoe onder druk gezet door Napoleon. Daarmee verdween het keizerschap en ook het Duitse rijk als zodanig. ${ }^{11}$

Door deze verdwijning van het Duitse rijk ontstond na de Franse nederlaag in 1813 een machtsvacuüm. Het congres van Wenen loste dit op door in 1815 de oude territoria en de rechten van de standen grotendeels te herstellen. In de Duitse 'Bundesakte' van 1815 verenigden de Duitse vorsten, de vrije steden, de keizer van Oostenrijk en de koning van Pruisen alle voormalige gebiedsdelen van het Duitse rijk in de Duitse Bond tot een

9. Idem, p. $25 / 26$.

10. Zie over de factoren die tot deze ontwikkeling bijdroegen: R. Wahl, Die Entwicklung des deutschen Verfassungsstaates bis 1866, in: Isensee/Kirchhof, a.w. (deel 1), pp. 7-12.

11. Vergl. Moraw, a.w., p. 45. 
statenbond. Ook de koningen van Denemarken en van Nederland waren partij bij de akte (respectievelijk voor Holstein en Luxemburg). Afgezanten van de lidstaten kwamen onder voorzitterschap van Oostenrijk bijeen in de Bondsvergadering ('Bundesversammlung') in Frankfurt am Main. Ook van deze vergadering waren de bevoegdheden beperkt. Naar de aard van de statenbond konden geen uniforme wetten tot stand worden gebracht, maar moest elke lidstaat eigen wetgeving tot stand brengen.

De Duitse Bond kende geen grondwet. Art. 13 van de Bundesakte bepaalde dat in alle lidstaten een afzonderlijke grondwet diende te worden ontworpen: "In allen Bundesstaaten wird eine landständische Verfassung stattfinden." Over de uitleg van het begrip 'landständische Verfassung' bestond nogal wat onenigheid. ${ }^{12}$ De verschillende opvattingen op dit punt leidden in de praktijk tot zeer gedifferentieerde grondwetten, waarvan vooral die van de Zuidduitse staten een voor die tijd zeer liberaal karakter hadden. ${ }^{13}$ Enkele daarvan beschouwden de afgevaardigden in de Landdag uitdrukkelijk als volksvertegenwoordigers, die een voor die tijd aanzienlijk vacatiegeld genoten teneinde hun onafhankelijkheid te garanderen. ${ }^{14}$ Toch waren ook op dit niveau de bevoegdheden van de vertegenwoordigende organen beperkt. Zij bezaten geen wetgevende bevoegdheid, maar slechts een instemmingsrecht ten aanzien van het uitvaardigen, veranderen of intrekken van wetten. ${ }^{15}$ Daarmee waren de lidstaten eigenlijk beperkte constitutionele monarchieën waarin de (meeste) vorstelijke prerogatieven bleven bestaan. Dat de onathankelijkheid van de vertegenwoordigers in de Landdagen door een verbod van last werd gewaarborgd, was daarom slechts van

12. Hierover: H. Reuss, Zur Geschichte der Repräsentativverfassung in Deutschland, in: H. Rausch, Zur Theorie und Geschichse der Repräsentation und Repräsentativverfassung, Darmstadt 1968, pp. 6-14, alsmede K. Stern, Das Staatsrecht der Bundesrepublik Deutschland, deel 1, 2e druk, München 1984, p. 66/67; J.-D. Kühne, Volksvertretungen im monarchischen Konstitutionalismus, in: Schneider/Zeh, a.w., p. $49 / 50$ en pp. 54-56; Willoweit, a.w., p. 209/210.

13. Uitvoeriger over de inhoud van de diverse grondwetten (m.n. die van Pruisen): Ramaer, a.w., pp. 208-215.

14. Vergl. N. Achterberg, Parlamentsrecht, Tübingen 1984, p. 22; Stern, a.w., p. 1049/1050; Kühne, a.w., p. 74.

15. Vergl. Mode!/Müller, a.w., p. 7; Badura, a.w., p. 966/967; Willoweit, a.w., p. 212; Kühne, a.w., p. 57/58. Uitvoeriger: O. Kimminich, Der Bundesstaat, in: Isensee/Kirchhof, a.w. (deel 1), p. 1129-1134. 
symbolische betekenis. Overigens kenden niet alle grondwetten een dergelijke verbodsbepaling: zeker in de beginjaren van de Duitse Bond kon het voorkomen dat de afgevaardigden in een Landdag (veelal die van de kleinere Landen) aan een imperatief mandaat gebonden waren. ${ }^{16}$

Hoewel door de besluiten van het Congres van Wenen de heersende wensen ten aanzien van de vereniging van de Duitse staten tot én rijk zo goed als onvervuld waren gebleven, vielen na 1815 toch enige aanzetten in deze richting te bespeuren. Vooral inzake douane-aangelegenheden was dit het geval; zo ontstonden vanaf 1818 enkele douane-unies tussen staten. Ook de meest succesvolle poging om tot enige eenheid te geraken -het zgn. 'Zollverein', een algemeen tolverbond dat in 1834 in werking trad- had op dit terrein betrekking.

De revolutionaire tendenzen in West-Europa in de jaren veertig van de vorige eeuw hadden ook voor Duitsland gevolgen, die op nationaal niveau in de richting van meer eenheid en de constitutionele verankering van de liberale theorie van de representatieve democratie zouden leiden. Na maart 1848 waren bijna overal de conservatieve regeringen vervangen door een meer liberaal ingesteld bestuur. Deze wisseling had ook gevolgen voor de samenstelling van de Bondsvergadering in Frankfurt am Main. ${ }^{17}$ In de nieuwe, progressieve samenstelling riep zij de lidstaten op verkiezingen voor een nationale vergadering uit te schrijven op grond van door haar opgestelde regels. De nieuw gekozen nationale vergadering, naar haar vergaderplaats ook wel 'Paulskirchenversammlung' genoemd, zag het ontwerpen van een grondwet voor het gehele Duitse grondgebied als haar hoofdtaak. Dit ontwerp, de 'Paulskirchenverfassung', dat qua inhoud zeer progressief was, werd door 28 bondsstaten aanvaard. ${ }^{18}$ Desondanks bleef de inmiddels tot Duitse keizer gekozen Pruisische koning weigeren deze verkiezing te aanvaarden, onder meer omdat Pruisen zelf de grondwet niet had aanvaard. Daarop riepen verschillende bondsstaten 'hun' afgevaardigden in de nationale vergadering terug, een handeling die duidelijk in strijd was met de zojuist aangenomen grondwet. Deze bepaalde namelijk ten aanzien van de status van de afgevaardigden dat zij vertegenwoordigers

16. Vergl. Kühne, a.w., p. 73.

17. Vergl. Willoweit, a.w., p. 225.

18. Over de Paulskirchenverfassung: Wahl, a.w., pp. 17-20. 
van het Duitse volk waren (en dus geen gedelegeerden namens de Duitse landen), die niet aan instructies gebonden konden worden. ${ }^{19}$

Door het optreden van het leger kwam in juni 1849 een einde aan de inmiddels naar Stuttgart verhuisde nationale vergadering en daarmee aan de eerste poging tot Duitse eenheid te geraken. De Duitse Bond bleef daarentegen formeel nog intact tot de Pruisisch-Oostenrijkse oorlog in 1866. Omdat art. 11 van de Bondsakte onderlinge oorlogsvoering uitsloot, betekende de korte, door Pruisen gewonnen oorlog de facto het einde van de Duitse Bond. Het op 23 augustus 1866 in Praag gesloten vredesverdrag bevestigde dit. Onder leiding van Pruisen werd daarop door de Noordduitse staten de Noordduitse Bond gevormd. In tegenstelling tot de Duitse Bond was deze een bondsstaat. De door Bismarck ontworpen grondwet voor de Noordduitse Bond anticipeerde reeds op de toetreding van de overige (zuidelijke) staten. Deze toetreding was in 1870 na de Duitse overwinning in de Frans-Duitse oorlog (waarin de noordelijke en zuidelijke staten in onderlinge 'Schutz- und Trutzbündnisse' samenwerkten) een feit. De Noordduitse Bond werd tot het Duitse rijk uitgebreid; zijn grondwet werd, met enkele wijzigingen, als grondwet voor het gehele rijk overgenomen, de 'Reichsverfassung' (RV) van 16 april $1871 . .^{20}$ Grondslag van dit Duitse rijk was niet het beginsel van de volkssoevereiniteit, maar de soevereiniteit van de aangesloten staten. De Koning van Pruisen was als 'Duits keizer' (niet: 'Keizer van Duitsland') staatshoofd van de bondsstaat; de wetgevende macht berustte bij de 'Bundesrat' (de vergadering van de vorsten van de lidstaten c.q. hun vertegenwoordigers) en de 'Reichstag' tezamen. Hoewel beide organen een eigen taak in het wetgevingsproces hadden, lag het zwaartepunt bij de 'Bundesrat'. ${ }^{21}$ De Rijksdag kon geen wetgeving totstandbrengen zonder de instemming van de Bondsraad, die nogal conservatief was ingesteld. Een actieve rol in het staatsbestuur was dan ook niet voor de Rijksdag weggelegd, ook al omdat hij geen eigen recht van

19. Hoofdstuk IV, art. II, $\$ 93$ Paulskirchenverfassung: "Das Volkshaus besteht aus den Abgeordneten des deutschen Volkes." Art. IV van hetzelfde hoofdstuk bepaalde in \$96: "Die Mitglieder (...) können durch Instruktionen nicht gebunden werden."

20. Hierover, uitgebreid: E.R. Huber, Das Kaiserreich als Epoche verfassungsstaatlicher Entwicklung, in: Isensee/Kirchhof, a.w. (deel 1), pp. 3583, m.n. pp. 36-51. Zie ook: Willoweit, a.w., pp. 254-258.

21. Hierover: Huber, a.w., pp. 63-68; Willoweit, a.w., p. 256/257; Model/Müller, a.w., p. 11. 
vergadering had, maar door de keizer bijeengeroepen diende te worden. De afgevaardigden in Rijksdag waren de vertegenwoordigers van het gehele volk, gekozen bij directe verkiezingen en gehouden aan het verbod van last en ruggespraak. ${ }^{22}$

\subsubsection{De Republiek van Weimar en het Hitlerregime}

Bovengenoemde staatsvorm bleef behouden tot het einde van de Eerste Wereldoorlog. Het matrozenoproer in Kiel zette een ontwikkeling in die in november 1918 leidde tot de vlucht van keizer Wilhelm II naar Nederland en het uitroepen van de republiek door Scheidemann, waarbij de oude grondwet van het Duitse rijk niet formeel opgeheven, maar door een "revolutionären Akt" verwijderd werd. $^{23}$ De gebeurtenissen vonden hun grond in een volksbeweging die zich weinig gelegen liet liggen aan de grenzen van de diverse staten van het Duitse rijk en een unitaristische opbouw van het rijk nastreefde. In januari 1919 vonden algemene verkiezingen plaats voor een grondwetgevende nationale vergadering, die vanwege de voortdurende onrust in de hoofdstad Berlijn Weimar als vergaderplaats koos. De Republiek van Weimar was geboren.

De nieuwe grondwet, de 'Weimarer Reichsverfassung' (WRV), naar een ontwerp van Preuß ${ }^{24}$, was gebaseerd op het beginsel van de volkssoevereiniteit. Hij creëerde een representatieve democratie in de vorm van een republiek. Daarnaast werd een presidentiële democratie gevormd, als hulpmiddel voor het geval dat de eerste staatsvorm niet zou functione-

22. Art. 29 RV 1871: "Die Mitglieder des Reichstages sind Vertreter des gesamten Volkes und an Aufträge und Instruktionen nicht gebunden".

23. Uitvoeriger over de gebeurtenissen in de laatsie maanden van 1918 en de totstandkoming van de grondwet: W. Carr, A history of Germany, 18151985, 3e druk, Londen 1987, pp. 237-252; F. Stier-Somlo, Die Verfassung des Deutschen Reichs vom 11. August 1919, Bonn 1919, pp. 1-71. Zie ook: Willoweit, a.w., pp. 276-283.

24. H. Preuß (1860-1925), hoogleraar in Berlijn en later minister in de eerste regering van de Republiek van Weimar, stond in het toenmalige Duitsland bekend als de meest links georiënteerde staatsrechtgeleerde. Over zijn persoon en zijn werkzaamheden t.a.v. de grondwet: Carr, a.w., p. 254/ 255. Uitvoerig over het ontwerp: Stier-Somlo, a.w., pp. 27-39. 
ren. ${ }^{25}$ Weliswaar bleven -op aandringen van de Duitse landen- elementen van het federatieve stelsel behouden, maar in het algemeen vertoonde het ontwerp sterke unitaristische trekken (hetgeen bijvoorbeeld ook tot uiting kwam in het hernoemen van de 'Staaten' in Lander). De nieuwe grondwet kende de staatsmacht toe aan een viertal organen: de Rijksdag, de Rijksraad, de Rijkspresident en de Rijksregering. ${ }^{26}$ In tegenstelling tot de Rijksdag van het vroegere keizerrijk kwam aan de nieuwe Rijksdag wel wetgevende bevoegdheid toe (art. $68 \mathrm{f} \mathrm{WRV).} \mathrm{De} \mathrm{afgevaardigden} \mathrm{werden} \mathrm{in}$ algemene, geheime en rechtstreekse verkiezingen gekozen door de stemgerechtigde vrouwen en mannen. Evenals in de oude situatie waren de afgevaardigden de vertegenwoordigers van het gehele volk en hadden zij een vrij mandaat. Naast een gewijzigde redactie onderscheidde de desbetreffende grondwetsbepaling zich ook van haar voorganger in de Reichsverfassung van 1871 doordat thans voor het eerst ook werd bepaald dat de afgevaardigde slechts aan zijn eigen geweten onderworpen was. ${ }^{27}$

De Rijksraad vormde een federatief element in de overwegend unitaristische Duitse staat. Hij bestond uit afgevaardigden van de regeringen van de Duitse landen; deze afgevaardigden hadden een imperatief mandaat. ${ }^{28} \mathrm{De}$ Rijksraad behartigde de belangen van de Duitse landen bij de wetgeving en het bestuurlijk handelen van het Rijk. Op het gebied van de wetgeving bezat hij een beperkt vetorecht, in die zin dat de Rijksraad een door de Rijksdag aangenomen wetsvoorstel in eerste instantie kon tegenhouden. Dit veto kon echter vervolgens weer door de Rijksdag met gewone meerderheid van stemmen worden verworpen. Ook het grondwettelijk vereiste van instemming van de Rijksraad bij het indienen van wetsvoorstellen door de Rijksregering (art. 69 lid 1 WRV) was niet absoluut. Wanneer deze instemming niet werd verkregen, kon de regering desalniettemin tot

25. Over de grondwet: H. Schneider, Die Reichsverfassung vom 11. August 1919, in: Isensee/Kirchhof, a.w. (deel 1), pp. 85-142, m.n. pp. 99-108 en pp. 113-126. Zie ook: Van Caenegem, a.w., pp. 223-225; Willoweit, a.W., pp. 283-286.

26. De zgn. 'Reichswirtschaftsrat' blijft hier buiten beschouwing.

27. Art. 21 WRV: "Die Abgeordneten sind Vertreter des ganzen des Volkes. Sie sind nur ihrem Gewissen unterworfen und an Aufträge nicht gebunden."

28. Vergl. H. Schneider, a.w., p. 93. 
indiening van het voorstel bij de Rijksdag overgaan, mits de afwijkende mening van de Rijksraad daarbij werd vermeld. ${ }^{20}$

Binnen het staatsbestel van de Republiek van Weimar had de -gekozenRijkspresident veel macht, hetgeen o.a. tot uitdrukking kwam in de hem toekomende bevoegdheid tot het benoemen van de leden van de regering, tot ontbinding van de Rijksdag en tot het uitschrijven van een (facultatief) referendum..$^{30}$ De grote macht van de rijkspresident werd nog vergroot door het staatsnoodrecht. Ingevolge art. 48 WRV kon de rijkspresident, bij aanzienlijk gevaar voor de openbare orde en veiligheid, noodzakelijk geachte maatregelen (zoals het maken van noodverordeningen of het inzetten van het leger) treffen. Het begrip openbare orde en veiligheid werd daarbij ruim geïnterpreteerd; d.m.v. van noodverordeningen werden (onder andere) regelingen op het gebied van belastingrecht, ambtenarenrecht, vennootschapsrecht, sociaal zekerheidsrecht tot stand gebracht.

De Republiek van Weimar was geen lang leven beschoren. Vele factoren hebben hiertoe bijgedragen, zoals de zware financiële lasten, opgelegd door het Vredesverdrag van Versailles, het falen van het staatkundig systeem en het gebrek aan aanhankelijkheid van de bevolking voor de republiek, ${ }^{31}$ Mede ten gevolge van de economische crisis aan het begin van de jaren dertig en de opkomst van Hitlers NSDAP kwam de Republiek van Weimar in toenemende mate in een situatie van onbestuurbaarheid te verkeren. Doordat in de Rijksdag geen meerderheid tot stand kon worden gebracht, werden steeds kabinetten benoemd die alleen het vertrouwen van de Rijkspresident hadden. Na de verkiezingen voor de Rijksdag van 1932 werd Hitler in januari 1933 als leider van de grootste fractie in de Rijksdag (de NSDAP) door rijkspresident Von Hindenburg tot regeringsleider ('Reichskanzler') benoemd, nadat pogingen om een ander tot kanselier te benoemen mislukt waren. $\mathrm{Na}$ het overlijden van Von Hindenburg nam Hitler ook diens functie over, aldus de functies van president en kanselier

29. Vergl. Model/Müller, a.w., p. 14; H. Schneider, a.w., p. 116.

30. Vergl. de mogelijkheid van het uitschrijven van een wetgevingsreferendum die de president van Frankrijk in het huidige staatsbestel heeft. Zie daartoe o.m. P.C. Gilhuis, Het referendum, Alphen aan den Rijn 1981, hfdst. 4.

31. Vergl. Burkens, a.w., p. 115; Van Caenegem, a.w., p. 222; Model/Müller, a.w., p. 15/16; H. Schneider, a.w., p. 136/137, alsmede Th. Ellwein/J.J. Hesse, Das Regierungssystem der Bundesrepublik Deutschland, 6 e druk, Opladen 1987, p. 130. 
in één persoon verenigend. Hij ging een coalitie aan met de Duitse Nationale Volkspartij (DNV), ontbond de Rijksdag en schreef nieuwe verkiezingen uit. Deze werden door de NSDAP gewonnen, al bleef de steun van de DNV ter verkrijging van een meerderheid in de Rijksdag noodzakelijk. Door middel van noodverordeningen, die onder meer de grondrechten buiten werking stelden, en door middel van het 'Gesetz zur Behebung der Not von Volk und Reich' (het 'Ermächtigungsgesetz' van 24 maart 1933), werd de dictatuur gevestigd. Aan de werking van de WRV werd echter formeel geen einde gemaakt. Door de machtigingswet werd het recht tot wetgeving aan de regering overgedragen. Deze wetgeving, vast te stellen en bekend te maken door de rijkskanselier, mocht zelfs in strijd zijn met de grondwet, zolang zij maar de bevoegdheden van de rijkspresident niet veranderde en de samenstelling van de Rijksdag en Rijksraad intact liet. Een week later werd door het 'Gesetz zur Gleichschaltung der Länder mit dem Reich' (het 'Gleichschaltungsgesetz' van 31 maart 1933) de werkingssfeer van de machtigingswet ook tot de lagere overheden uitgebreid. Later, in januari 1934, zou het 'Gesetz über den Neuaufbau des Reiches' leiden tot het opheffen van de landelijke volksvertegenwoordigingen, de overdracht van de nog bestaande heerlijkheidsrechten van de Duitse landen aan het Rijk en het onderwerpen van de landsregeringen aan de rijksregering. Deze wet behoort tot de slechts zeven wetten waartoe tijdens het Derde Rijk door de Rijksdag zelf werd besloten. Voor het overige functioneerde deze vooral als "Akklamationsorgan". ${ }^{32}$ Het 'Gesetz über den Neuaufbau des Reiches' betekende het einde van de zelfstandigheid van de Duitse landen. Zij werden provincies van het rijk. Het 'Neuaufbaugesetz' bevatte voorts een machtiging aan de Rijksregering om nieuw constitutioneel recht te ontwerpen. Hierdoor werd de laatste hindernis die de machtigingswet tegen een dictatuur had opgeworpen (de bepaling dat de inrichting van Rijksdag en Rijksraad in stand moest blijven), omzeild. De Rijksraad werd dientengevolge dan ook spoedig ontbonden. De Rijksdag, hoewel overbodig geworden, bleef daarentegen bestaan. ${ }^{33}$

Reeds in de zomer van 1933 waren reeds alle partijen behalve de NSDAP geliquideerd of tot zelfontbinding overgegaan. Het oprichten van nieuwe partijen was verboden. In steeds sterkere mate wist het Hitlerregime zich

32. Willoweit, a.w., p. 305.

33. Over de resterende 'functie' van de Rijksdag in deze periode: Achterberg, a.w., p. $30 / 31$. 
als totalitaire dictatuur door te zetten. Staat en partij versmolten, waardoor het staatsapparaat onder gezag van de partij kwam te staan.

\subsubsection{Duitsland na de Tweede Wereldoorlog}

Aan het dictatoriale staatsbestel van het Hitlerregime kwam met de nederlaag in de Tweede Wereldoorlog een einde. Op 8 mei 1945 volgde in Berlijn de onvoorwaardelijke capitulatie. In de jaren 1945-1949 is door de Duitse staatsrechtgeleerden een felle discussie gevoerd over de staatsrechtelijke c.q. volkenrechtelijke status van Duitsland in deze periode. Aan de ene kant werd beweerd dat de onvoorwaardelijke overgave had geleid tot de -staatsrechtelijke zeldzame- situatie waarin de Duitse statelijkheid in feite had opgehouden te bestaan en aan alle handelingen c.q. uitingen van Duitsland als staat een einde was gekomen (de zgn. 'Untergangslehren'), aan de andere kant werd juist het tegendeel beweerd (de $\mathrm{zgn}$. 'Fortbestandslehren'). ${ }^{34}$ Daar beide opvattingen een kern van waarheid bevatten is het moeilijk aan te geven welke in deze de juiste is; ook het constitutionele hof (het Bundesverfassungsgericht) heeft zich er niet eenduidig over uitgelaten. ${ }^{35}$ Hoewel de gehele discussie inmiddels door de geschiedenis

34. Zie voor een overzicht van de discussie: M. Stolleis, Besatzungsherrschaft und Wiederaufbau deutscher Staatlichkeit 1945-1949, in: Isensee/Kirchhof, a.w. (deel 1), pp. 187-191; Th. Maunz/R. Zippelius, Deutsches Staatsrecht, 27e druk, München 1988, p. 7/8.

35. Zie BVerfG 31 juli 1973, BVerfGE 36,1 (16) en de daar genoemde eerdere uitspraken van het Bundesverfassungsgericht. Het standpunt van het hof over het al dan niet voortbestaan van de vooroorlogse Duitse staat is nogal ambivalent. Gesteld wordt dat zowel uit de preambule van de grondwet als uit het Grundgesetz zelf blijkt dat het Duitse rijk de breuk van 1945 heeft overleefd en noch door de capitulatie noch door de tijdelijke uitoefening van de staatsmacht door de geallieerden ondergegaan is:

"Das Deutsche Reich existiert fort (...), besitzt nach wie vor Rechtsfähigkeit, ist allerdings als Gesamtstaat mangels Organisation, insbesondere mangels institutionalisierter Organe selbst nicht handlungsfähig. (...) Mit der Errichtung der Bundesrepublik Deutschland wurde nicht ein neuer westdeutscher Staat gegnündet, sondern ein Teil Deutschlands neu organisiert." Kan dit nog gezien worden als het onderschrijven van de 'Forthestandslehre', het beeld wordt echter weer diffuus als het hof hier meteen eryptisch op laat volgen dat de Bondsrepubliek geen rechtsopvolger van het oude Duitse rijk is, maar als staat identiek is met de staat van het oude Duitse rijk, zij het slechts voor een deel (!). 
grotendeels is achterhaald, is het, gezien de ambivalente houding die het Bundesverfassungsgericht op dit punt ten toon heeft gespreid, zaak enige terughoudendheid te betrachten ten aanzien van die schrijvers die zich min of meer onomwonden voor een bepaalde opvatting uitspreken. ${ }^{36}$

Overeenkomstig een besluit van de Conferentie van Potsdam ( 2 augustus 1945) werd het overheidsgezag als het ware van onderen naar boven opgebouwd, d.w.z. beginnend op communnaal niveau (waar de capitulatie, in ieder geval in praktijk, relatief weinig gevolgen had gehad voor het bestuur) en van daaruit op bondsniveau. De keuze voor opbouw van onderen af werd ingegeven door de wens van de geallieerden de nieuwe Duitse staat geen centraal geregeerde staat te laten worden die de vrijheid van zijn burgers en aangrenzende staten zou bedreigen. ${ }^{37}$ De lopende zaken op centraal niveau werden vooralsnog, ingevolge een daartoe strekkend besluit van de Conferentie van Potsdam, afgehandeld door de zogenaamde 'Kontrollrat'. Hierin hadden de bevelhebbers van de vier bezettingszones zitting. Vervolgens kwamen de regionale verbanden -aanvankelijk met verschillende benamingen, maar spoedig toch weer Länder genoemd- weer tot leven. In 1948 besloten de westelijke geallieerde mogendheden, overeenkomstig de resultaten van een in Londen gehouden conferentie met de Benelux-landen, te beginnen met de wederopbouw van het Duitse staatsbestel op centraal niveau. ${ }^{38}$ Een eerdere poging daartoe, tijdens een conferentie in München in 1947 van de minister-presidenten van de Duitse landen en vertegenwoordigers van de vier bezettingsmachten,

36. Zoals Burkens, a.w., p. 115 en Maunz/Zippelius, a.w., p. 2 die beiden (een variant van) de Untergangslehre verkondigen of Model/Müller, a.w., p. 18 die het tegendeel beweert.

37. Vergl. Maunz/Zippelius, a.w., p. 3, alsmede: K. von Beyme, Wandlungen des Parlamentarismus: Von Weimar nach Bonn, in: Schneider/Zeh, a.w., p. 111.

38. Zie uitvoerig over de staatsrechtelijke wederopbouw: R. Mußgnug, Zustandekommen des Grundgesetzes und Entstehen der Bundesrepublik Deutschland, in: Isensee/Kirchhof, a.w. (deel 1), pp. 219-258; E. Denninger, Inleidend hoofdstuk, in: Denninger, a.w. (deel 1), pp. 63-85; B. SchmidtBleibtreu/F. Klein, Kommentar zum Grundgesetz für die Bundesrepublik Deutschland, 6e druk, Neuwied/Darmstadt 1983, pp. 89-104, P. Badura, Staatsrecht. Systematische Erläuterung des Grundgesetzes für die Bundesrepublik Deutschland, München 1986, pp. 17-23 en pp. 29-33 en R. Weber-Fas, Das Grundgesetz, Berlijn 1983, pp. 17-21. 
mislukte als gevolg van de toenemende tegenstellingen tussen oost en west.

Het feit de dat de Sovjet Unie niet was uitgenodigd voor de conferentie in Londen, leidde tot het vertrek van haar vertegenwoordiger in de 'Kontrollrat'. Dit had uiteindelijk de splitsing van het Duitse rijk in twee delen en de totstandkoming van twee zelfstandige staten tot gevolg. In het westelijk deel kregen de minister-presidenten van de Duitse landen de opdracht een grondwetgevende vergadering bijeen te roepen. $\mathrm{Na}$ een aanvankelijke aarzeling namen zij deze opdracht aan. Omdat zij de hoop op een 'gesamtdeutschen Lösung' nog niet hadden opgegeven, stond hen voor West-Duitsland slechts een provisorische regeling voor ogen. Dit voorlopig karakter van de grondwet werd niet alleen in haar benaming tot uitdrukking gebracht (Grundgesetz in plaats van Verfassung, waarmee overigens aan het begrip Grundgesetz een volledig afwijkende betekenis werd toegekend dan tot dan toe gebruikelijk ${ }^{39}$, maar ook in haar totstandkomingsprocedure. In plaats van besluitvorming door een nationale grondwetgevende vergadering geschiedde het opstellen van de grondwet door vertegenwoordigers van de landen, de daaropvolgende goedkeuring door de parlementen van de landen. ${ }^{40}$

In augustus 1948 kwam een door de minister-presidenten benoemde commissie van deskundigen met een ontwerp van een grondwet voor de elf Westduitse landen. Dit was het zgn. 'Herrenchiemser Entwurf', ook wel 'Verfassungskonvent von Herrenchiemsee' genoemd. Intussen waren door de Landdagen van de elf landen vertegenwoordigers voor een grondwetgevende Parlementaire Raad gekozen. Deze raad, onder voorzitterschap van Adenauer, stelde in mei 1949 de definitieve tekst van de grondwet vast, die vervolgens -behoudens enkele artikelen- door de drie bezettingsmachten werd goedgekeurd. Hierna werd zij door tien van de elf landdagen aangenomen, waarmee werd voldaan aan de door de bezettingsmachten gestelde eis dat de grondwet door tenminste twee derde van de landdagen moest worden aanvaard. Bayern wees de grondwet af omdat deze te veel centralistische tendensen bevatte, maar verklaarde wel tot de Bondsrepubliek te

39. Hierover: K. Hesse, Grundzüge des Verfassungsrechts der Bundesrepublik Deurschland, 17e druk, Heidelberg 1990, p. $32 / 33$.

40. W. Alfert e.a., Staats- und Verfassungsrecht der Bundesrepublik Deutschland, 6e druk, Witten 1989, p. 23. 
willen behoren. De grondwet werd op 23 mei 1949 afgekondigd en trad daags daarna in werking.

De notulen van de Parlementaire Raad tonen aan dat de raad zich vaak liet leiden door de ervaringen (zowel de positieve als de negatieve) die met de WRV opgedaan waren. Vooral de fouten van deze regeling wilde hij vermijden: vandaar bijvoorbeeld de versterkte positie van de regering onder de huidige grondwet (als gevolg van de remmende werking van het zgn. 'konstruktives Mißtrauensvotum' van art. $67 \mathrm{GG}^{41}$ ), de zwakkere positie van de president en de mogelijkheid om 'staatsgevaarlijke' politieke partijen te verbieden (art. 21 lid 2 GG). Enkele grondwetsartikelen kunnen worden gezien als een reactie op de praktijken ten tijde van het nationaalsocialisme. Zo moet de bepaling die wijziging van enkele basisprincipes van het Grundgesetz ontoelaatbaar verklaart (art. 79 lid $3 \mathrm{GG}$ ), worden gezien als een bescherming tegen een soortgelijke (legale) grondwetswijziging als teweeggebracht door het 'Ermächtigungsgesetz' in 1933. In dit verband wordt wel gesproken over Duitsland als streitbare Demokratie: een democratie dient strijdbaar te zijn, teneinde haar eigen voortbestaan te kunnen garanderen en niet lijdzaam te hoeven toezien dat pogingen worden gedaan haar omver te werpen. ${ }^{42}$ Ondanks deze vergaande beschermingsconstructie is de grondwet, zoals gezegd, een tijdelijke regeling. Het voorlopig karakter van de grondwet -en in feite ook van de voormalige Bondsrepubliek zelf- beoogde aan te geven dat de Bondsrepubliek slechts een deel van het Duitse rijk omvatte. Volgens de preambule van het Grundgesetz zou het voor andere Duitse landen mogelijk zijn om tot de Bondsrepubliek toe te treden, waarbij met name werd gedacht aan de in 1949 nog bestaande vijf landen in het toenmalige grondgebied van de

41. Art. $67 \mathrm{GG}$ :

1. Der Bundestag kann dem Bundeskanzler das Mißtrauen nur dadurch aussprechen, daß er mit der Mehrheit seiner Mitglieder einen Nachfolger wählt und den Bundespräsidenten ersucht, den Bundeskanzler zu entlassen. Der Bundespräsident muß dem Ersuchen entsprechen und den Gewählten ernennen.

2. Zwischen dem Antrage und der Wahl müssen achtundvierzig Stunden liegen.

42. Over dit begrip en zijn implementatie in het Duitse staatsrecht: J. Becker, Die wehrhafte Demokratie des Grundgesetzes, in: Isensee/Kirchhof, a.w. (deel 7, Heidelberg 1992), pp. 309-359, m.n. pp. 332-350. 
DDR. Art. $146 \mathrm{GG}$, het slotartikel van het Grundgesetz, bepaalt dan ook dat de grondwet zijn gelding verliest op de dag waarop een grondwet in werking treedt waartoe het gehele Duitse volk vrijelijk heeft besloten. De vereniging van Oost- en West-Duitsland heeft deze dag inmiddels zeer nabij gebracht. Toch is het onwaarschijnlijk dat de nieuwe grondwet ingrijpende wijzigingen ten opzichte van het Grundgesetz zal ondergaan. Bij de ontwikkeling van een nieuwe 'gesamtdeutschen Verfassung' voor Duitsland kan niet aan het huidige Grundgesetz voorbij worden gegaan. Hoewel zijn benaming slechts een voorlopige rechtstoestand bedoelt aan te geven, kan gesteld worden dat het Grundgesetz zich in praktijk dusdanig bewezen heeft dat het als Verfassung kan worden beschouwd.

\subsection{De norm van art. $20 \mathrm{GG}$}

Het grondwettelijk kader van de positie van de individuele volksvertegenwoordiger in Duitsland wordt in de eerste plaats bepaald door art. 20 GG, het artikel dat de kernbepalingen bevat voor de inrichting van het Duitse staatsbestel. In dit kader zijn vooral de eerste twee leden van dit artikel van belang. Inhoudelijk verschillen deze enigszins van hun tegenhangers in de WRV. Artikel 1 WRV omschreef de staatsvorm van het Duitse rijk eenvoudigweg als republiek, zonder het bijvoeglijk naamwoord 'democratisch'; het beginsel van de volkssoevereiniteit werd in hetzelfde artikel tot uitdrukking gebracht door de zin: "Die Staatsgewalt geht vom Volke aus". In het Herrenchiemser-ontwerp ontbraken deze bepalingen, maar toedoen van de Parlementaire Raad kwamen ze weer in de Duitse grondwet terecht. ${ }^{43}$

Het democratische principe dat in eerste lid van dit artikel wordt verankerd en vervolgens in het tweede lid, alsmede in de artikelen 21 en 38 GG op wezenlijke punten wordt geconcretiseerd en in art. 28 lid 1 GG van toepassing wordt verklaard op de lagere overheden, bevat "Fundamentalaussagen des GG zum Staatsaufbau und zur Staatswillensbildung der Bundesrepublik Deutschland". ${ }^{44}$ De andere twee basisprincipes van art. 20

43. Vergl. E. Stein, commentaar op art. $20 \mathrm{GG}$ (2e hoofdstuk), in: Denninger, a.w. (deel 1), p. 1267/1268.

44. Th. Maunz/G. Dürig (e.a.), Kommentar zur Grundgesetz (losbladig), München, Commentaar op art. $20 \mathrm{GG}, 2 \mathrm{e}$ hoofdstuk, randnummer 1. 
lid 1 GG (het 'Bundesstaatsprinzip' en het 'Sozialstaatsprinzip') zijn, hoe fundamenteel ook, niet gelijkwaardig aan het eerste: zij zijn vooral statische begrippen, die een begrenzing vormen van het democratische principe. Het democratische principe vormt het centrale grondwetsbegrip: "Sie ist der dominierende politische Kraftfactor, den das Grundgesetz unmittelbar für die staatliche Willensbildung akzeptiert". ${ }^{45}$ Deze 'staatliche Willensbildung' dient strikt te worden onderscheiden van de 'Willensbildung des Volkes' waarvan in -het hieronder te bespreken- art. 21 GG sprake is. Het eerste proces betreft de uiting van de mening of de wil van een staatsorgaan op officiële wijze; deze moet ingevolge art. 20 lid 2 GG terug te voeren zijn op de staatsmacht van het volk, dan wel een uiting van het volk zelf zijn. ${ }^{46}$ Het proces van de 'Willensbildung des Volkes' betreft de (politieke) wilsvorming van het volk, die in de publieke opinie gevormd wordt. Alleen wanneer het volk als staatsorgaan optreedt en zelf de staatsmacht uitoefent, dus bij 'Wahlen und Abstimmungen', vallen beide begrippen samen. ${ }^{47}$

De kwalificatie van Duitsland in art. 20 lid $1 \mathrm{GG}$ als een democratische en sociale bondsstaat is een kernpunt van de grondwettelijk vastgelegde staatsorde. ${ }^{43}$ Dit kernpunt kan zelfs niet door middel van een grondwetswijziging aangetast worden. Art. 79 lid 3 GG bepaalt in dit kader dat een grondwetswijziging die beoogt de onderverdeling van de bond in landen, de principiële medewerking van de landen bij de wetgeving en/of de in art. 1 GG (onaantastbaarheid van de waarde van de mens) of art. $20 \mathrm{GG}$ vastgelegde beginselen aan te tasten, ontoelaatbaar is. Hieruit blijkt dat het Grundgesetz ontworpen is vanuit bepaalde uitgangspunten die van doorslaggevende betekenis kunnen worden geacht voor het karakter van het staats-

45. H. Meyer, Die Stellung der Parlamente in der Verfassungsordnung des Grundgesetzes, in: Schneider/Zeh, a.w., p. 119.

46. Vergl. BVerfG 30 juli 1958, BVerfGE 8, 104 (113).

47. Vergl. BVerfG 30 juli 1958, BVerfGE 8, 104 (113) en BVerfG 19 juli 1966, BVerfGE 20, 56 (98).

48. Vergl. Burkens, a.w., p. 118; Maunz/Dürig, a.w., hoofdstuk 1, randnummers 1-59, m.n. nrs. 7 en 8; F.E. Schnapp, Commentaar op art. 20 GG, in: I. von Münch/Ph. Kunig (red.), Grundgesetz-Kommentar, deel 1, 4e druk, München 1992, p. 1039/1040. 
bestel van Duitsland. ${ }^{49}$ In de rechtspraak en in de literatuur wordt aangenomen dat de voorschriften van het Grundgesetz tesamen een waardenstelsel vormen, dat als zodanig medebepalend is voor de interpretatie van de afzonderlijke bepalingen. ${ }^{\text {so }}$

Voor de bepaling van de grondwettelijke positie van de individuele volksvertegenwoordiger is vooral de eerste volzin van art. 20 lid 2 GG van belang. Binnen de grenzen van de overige bepalingen van de eerste twee leden van dit artikel vormt hij een letterlijk te interpreteren gebodsbepaling: de staatsmacht kan slechts van het volk uitgaan c.q. moet daarop terug te voeren zijn. ${ }^{51}$ Het Bundesverfassungsgericht merkte, in navolging van eerdere uitspraken, in 1987 over het artikel op:

"Alle Organe und Vertretungen, die Staatsgewalt ausüben, bedürfen hierfür einer Legitimation, die sich auf die Gesamtheit der Bürger als Staatsvolk zurückführen läßt. Das demokratische Prinzip erstreckt sich nicht nur auf bestimmte, sondern auf alle Arten der Ausübung von Staatsgewalt. Die verfassungsrechtlich notwendige demokratische Legitimation erfordert eine ununterbrochene Legitimationskette vom Volk zu den mit staatlichen Aufgaben betrauten Organen und Ambtswaltern. Die Legitimation muß jedoch nicht in jedem Fall durch unmittelbare Volkswahl erfolgen. In aller Regel genügt es, daß sie sich mittelbar auf das Volk als Träger der Staatsgewalt zurückführen läßt. "52

De bepaling van art. 20 lid 2, eerste volzin GG sluit uit dat anderen drager van de staatsmacht kunnen zijn: alle uitoefening van de staatsmacht moet van het volk uitgaan en tot het volk te herleiden zijn. Onder 'volk' wordt in dit verband verstaan: "die Aktivbürgerschaft als Gesamtheit aller wahlberechtigten Bürger". ${ }^{53}$ Het volk staat in deze bepalingen dus gelijk

49. Vergl. P. Kirchbof, Die Ideniität der Verfassung in ihren unabänderlichen Inhalsen, in: Isensee/Kirchhof, a.w. (deel 1), pp. 775-814, m.n. pp. 788792 en 802-813, alsmede Maunz/Dürig, a.w., randnummers 24-29 van het le hoofdstuk bij art. 20; Weber-Fas, a.w., pp. 31-34.

50. Vergl. onder meer: Burkens, a.w., p. 118; Badura, Staatsrecht, a.w., p. 171; Kirchhof, a.w., p. 803/804 en pp. 809-813.

51. Vergl. Stein, a.w., p. 1271/1272; Meyer, a.w., p. 152; Schnapp, a.w., p. 1054.

52. BVerfG 1 oktober 1987, BVerfGE 77, 1 (40).

53. Schnapp, a.w., p. 1054. 
aan het totaal van de kiesgerechtigden en niet het gehele volk (zoals in art. $38 \mathrm{GG}$, zie hieronder). Deze beperking wordt echter niet in strijd geacht met het in art. 20 lid 1 GG vastgelegde democratische principe. ${ }^{54}$ Het volk, als 'Aktivbürgerschaft', is op grond van de bewoordingen van art. 20 lid 2, tweede volzin GG niet alleen een 'Verfassungsorgan' omdat het bij de 'Wahlen und Abstimmungen' een grondwettelijke functie vervult, het is zelfs het 'oberste Bundesorgan'. ${ }^{55} \mathrm{Nu}$ alle staatsmacht van het kiesgerechtigde volk uitgaat, is het noodzakelijk dat periodiek verkiezingen worden gehouden; alleen op deze manier verkrijgen de leden van de Bondsdag de voor hun hoedanigheid als volksvertegenwoordiger noodzakelijke democratische legitimatie. ${ }^{56}$ Deze periodieke verkiezingen zijn bepalend voor de politieke wilsvorming van het volk; daarnaast verzekeren zij dat de Bondsdagafgevaardigden naar het volk toe verantwoordelijk blijven. ${ }^{57}$

Met de kernbepaling dat alle staatsmacht uitgaat van het volk verankert het Grundgesetz de leer van de volkssoevereiniteit als bindend uitgangspunt voor de staatsinrichting van Duitsland. ${ }^{58}$ De $2 \mathrm{e}$ volzin van het artikel maakt een driedeling van de staatsmacht volgens de Trias-leer en geeft aan hoe het volk de hem toekomende staatsmacht uitoefent: doorgaans niet zelf, maar door (staatsrechtelijke) vertegenwoordiging in 'besondere Organe'. Met bijzondere organen worden zowel de volksvertegenwoordiging op

54. Vergl. (o.a.) Th. Schramm, Staatsrecht, deel 1, 4e druk, bewerkt door J. Schmidt-Troje, Köln 1987, p. $6 / 7$.

55. Tenminste wanneer dit begrip in ruime zin wordt opgevat: vergl. BVerfG 11 juli 1961, BVerfGE $13,54(85,87)$.

56. BVerfG 1 oktober 1987, BVerfGE 77, 1 (40). Zie ook: H. Hofmann/H.

Dreier, Repräsentation, Mehrheitsprinzip und Minderheitenschurz, in: Schneider/Zeh, a.w., p. 178/179.

57. Vergl. C. Starck, Grundrechtliche und demokratische Freiheitsidee, in: Isensee/Kirchhof, a.w. (deel 2, Heidelberg 1987), p. 18; Stern, a.w. (deel 1), p. 605/606; Schmidt-Bleibtreu/Klein, a.w., p. 422. Zie ook BVerfG 2 maart 1977, BVerfGE 44, 125 (139) en BVerfG 1 oktober 1987, BVerfGE $77,1(40)$.

58. Vergl. Maunz/Dürig, a.w., randnr. 1 van het 20 hoofdstuk bij art. 20; Alfert, a.w., p. 38; Badura, Staatsrecht, a.w., p. 173 en E.-W. Böckenförde, Demokratie als Verfassungsprinzip, in: Isensee/Kirchhof, a.w. (deel 1), p. 888 . 
centraal niveau (de Bondsdag) als die van de Duitse landen zelf (meestal Landdag geheten) bedoeld. Doordat deze vertegenwoordigingen door het volk worden gekozen, verkrijgen deze de legitimatie voor hun status als zelfstandig beslissend en handelend orgaan van de staat (c.q. van het afzonderlijke land), waarvan de rechten en plichten in het Grundgesetz resp. de Landesverfassungen zijn omschreven.

Van de bijzondere organen is de Bondsdag het enige dat als zodanig zijn legitimatie van het gehele volk krijgt. ${ }^{59}$ Toch is de Bondsdag niet de enige volksvertegenwoordiging. Naast de volksvertegenwoordigingen op het niveau van de landen wordt het gehele Duitse volk op centraal niveau ook vertegenwoordigd in de Bondsraad, maar deze instantie ontleent haar democratische legitimatie aan verkiezingen voor de Landdagen. ${ }^{\infty}$ Gesteld kan worden dat in de Bondsdag de bevolking van het Duitse rijk wordt vertegenwoordigd en in de Bondsraad de bevolking van de Duitse landen. ${ }^{61}$

Op het stelsel van staatsrechtelijke vertegenwoordiging in Duitsland bestaan enkele uitzonderingen. Art. 20 lid 2, 2e volzin GG bepaalt dat de uitoefening van de staatsmacht door het volk zelf geschiedt bij 'Wahlen und Abstimmungen'. Dat, uitgaande van het beginsel van de volkssoevereiniteit, uitoefening van de staatsmacht door het volk zelf geschiedt door middel van verkiezingen is een noodzakelijke uitzondering, die tot het "Wesen jeder Demokratie" 62 behoort; minder noodzakelijk is de mogelijkheid als volk zelf (een aspect van) de staatsmacht uit te oefenen door middel van een referendum. Het Grundgesetz bepaalt dat bij een nieuwe territoriale indeling van de BRD het daartoe benodigde wetsontwerp door middel van een referendum moet worden bekrachtigd. ${ }^{6}$ Een referendum over dit onderwerp kan ook op initiatief van (een deel van) het volk worden gehouden (art. 29 lid 4 GG). Daarnaast sluit het grondwetsartikel

59. Vergl. Maunz/Dürig, a.w., hfdst. 2, randnr. 76; Stein, a.w., p. 1279.

60. Kritisch over de vraag of de leden van de Bondsraad het gehele volk vertegenwoordigen: M. Drath, Die Entwicklung der Volksrepräsentation, in: Rausch, a.w., pp. 318-322.

61. Vergl. Maunz/Dürig, a.w. randnr. 5 bij art. 38 .

62. BVerfG 23 oktober 1952, BVerfGE 2, 1 (11).

63. Art. 29 lid 2 GG: "Maßnahmen zur Neugliederung des Bundesgebietes ergehen durch Bundesgesetz, das der Bestätigung durch Volksentscheid bedarf. Die betroffen Länder sind zu hören." 
niet uit dat referenda worden gehouden over andere onderwerpen, al is deze mogelijkheid erg geclausuleerd. ${ }^{\omega}$

Het Grundgesetz heeft daarmee gekozen voor de uitoefening van de staatsmacht door de bijzondere organen, m.a.w. voor het stelsel van de indirecte democratie. ${ }^{65}$ Deze voorkeur heeft -naast de voor de hand liggende praktische reden- ook een historisch motief. Bij de totstandkoming van het Grundgesetz speelden, zoals reeds werd vermeld, de ervaringen in de jaren 1933-1945 een belangrijke rol. Op grond van deze ervaringen overheerste bij de Parlementaire Raad het besef dat het Duitse volk niet beschikte over voldoende 'politieke rijpheid', zodat het opnemen van veel plebiscitaire elementen in het Grundgesetz niet was gerechtvaardigd. ${ }^{60}$

\subsection{De onafhankelijke volksvertegenwoordiger: art. 38 GG}

De typering van de afgevaardigden in de Bondsdag als 'Vertreter des ganzen Volkes, an Aufträge und Weisungen nicht gebunden und nur ihrem Gewissen unterworfen' in de tweede volzin van art. 38 lid 1 GG vormt de kernbepaling voor diens onafhankelijkheid. Met deze bepaling spreekt het Grundgesetz zich uit voór het vrije en tegen het imperatieve mandaat. Daarmee wordt aangesloten bij de ook in Duitsland gevestigde constitutionele traditie van het verbod van last. Hoewel door de tijden heen de redactie van de verbodsbepaling niet altijd hetzelfde is geweest, komt aan de verschillende redacties eenzelfde betekenis toe. ${ }^{67}$

Zoals hiervoor reeds is aangegeven is art. 38 lid 1, 2e volzin GG niet de enige bepaling in het Grundgesetz waarin het beginsel van de representatieve democratie is vastgelegd. $\mathrm{Zij}$ moet beschouwd worden als een nadere invulling van de formulering 'durch besondere Organe der Gesetzgebung,

64. Vergl. Model/Müller, a.w., p. 254; Maunz/Dürig, a.w., hfdst. 2, randnr. 42. Zie ook: Schnapp, a.w., p. 1054/1055; Stein, a.w., p. 1281/1282.

65. Vergl. Alfert, a.w., p. 43.

66. Vergl. Maunz/Dürig, a.w., hfdst. 2, randnr. 39; Stein, a.w., p. 1268; Weber-Fas, a.w., p. 53.

67. Vergl. Model/Müller, a.w., p. 385; Hofmann/Dreier, a.w., p. 178. Dit neemt niet weg dat de functie van de bepaling door de tijden heen niet hetzelfde geweest: zie $\$ 6$ van dit hoofdstuk. 
der vollziehenden Gewalt und der Rechtsprechung' in de 2e volzin van art. 20 lid 2 GG. $^{68}$

Art. 38 lid 1, 2e volzin gaat terug op art. 46 van het 'Herrenchiemser Entwurf'. Daarover werd in de grondwetgevende Parlementaire Raad van de zijde van Bayern opgemerkt dat de afgevaardigden alleen daarom al geen vertegenwoordigers van het gehele volk konden zijn omdat zij hun mandaat slechts aan hun kiezers, en dus slechts aan een gedeelte van het volk (de 'Aktivbürgerschaft') te danken hadden. Een grote meerderheid in de raad was echter van mening dat de 'klassieke' formulering behouden diende te worden. Er werd een 'gute Wirkung' van verwacht, zodat de afgevaardigden zich niet al te zeer als vertegenwoordiger van een bepaalde belangengroepering zouden beschouwen. Door de CDU werd de vraag opgeworpen of de in art. 46 van het ontwerp vastgelegde onafhankelijkheid en gewetensvrijheid van de individuele volksvertegenwoordiger nog wel te rijmen viel met de politieke werkelijkheid van de democratische partijenstaat en niet als 'hohle Deklamation' moest worden beschouwd. ${ }^{69}$ Deze kritiek werd door een enkele SPD-vertegenwoordiger beaamd: afgevaardigden die het fractiestandpunt niet zouden overnemen, alsmede politieke 'Einzelgänger' zouden door de bepaling niet erg veel bescherming genieten. De kritiek op de inhoud van de bepalingen werd door de meeste afgevaardigden in de raad niet gedeeld. Als argumenten werden onder meer aangevoerd dat het verbod van binding aan 'Aufträge und Weisungen' gelijk te stellen was met het beginsel dat rechters onathankelijk dienden te zijn, en dat het vrije mandaat zich niet richtte tegen het bestaan van partijen, maar slechts de heerschappij van het partij-apparaat over de individuele volksvertegenwoordiger uitsloot, en dus vooral diende ter bescherming tegen partijdwang. ${ }^{70}$

Opgemerkt dient te worden dat de bepalingen van art. 38 lid 1 GG slechts betrekking hebben op de leden van de Bondsdag; zij gelden niet voor de leden van de volksvertegenwoordigingen op de lagere niveaus, noch voor voormalige of toekomstige Bondsdagafgevaardigden. In de jurisprudentie is bepaald dat art. 38 GG "seinem Wortlaut wie seinem Sinngehalt nach nur für Abgeordnete, d.h. für diejenigen, die bereits Mitglieder des Deutschen

68. Vergl. Maunz/Dürig, a.w., Commentaar bij art. 20, hfdst. 2, randnr. 63.

69. Vergl. H.-P. Schneider, a.w., p. 257.

70. Idem, p. $257 / 258$. 
Bundestages sind" geldt. ${ }^{71}$ Het mandaat moet dus eerst verkregen zijn en vervolgens voortduren. Het verkrijgen van het mandaat geschiedt niet onmiddellijk door de vaststelling van de verkiezingsuitslag, maar pas wanneer de gekozene tegenover de bevoegde kiesraad schriftelijk heeft verklaard zijn verkiezing aan te nemen. Daarbij moet ook de zittingsduur van de vorige Bondsdag verstreken zijn. Omdat deze zittingsduur pas eindigt bij het aantreden van de nieuwe Bondsdag, wordt het mandaat eerst op dat moment, dus bij de constituerende vergadering van de nieuwe Bondsdag, verkregen.

\subsubsection{Vertreter des ganzen Volkes}

Naar de letterlijke tekst van art. 38 lid 1, 2e volzin GG zijn de afgevaardigden de vertegenwoordigers van het gehele volk; het artikel bepaalt dus niets omtrent de individuele volksvertegenwoordiger. Het Bundesverfassungsgericht heeft bepaald dat ook de individuele volksvertegenwoordiger weliswaar als vertegenwoordiger van het gehele volk is te beschouwen, maar eerst door zijn werkzaamheden in parlementsverband, "im Sinne der Gesamtheit seiner Mitglieder", daadwerkelijk vertegenwoordiger wordt. ${ }^{2}$ Dit is een logisch gevolg van de relatie tussen tussen art. $38 \mathrm{GG}$ en art. $20 \mathrm{GG}$ : niet de individuele afgevaardigde, maar het parlement als geheel is op te vatten als een van de bijzondere organen in de zin van art. 20 lid 2 GG die de bij het volk berustende staatsmacht uitoefenen. ${ }^{73}$

Artikel $38 \mathrm{GG}$ heeft betrekking op alle afgevaardigden in hun hoedanigheid als leden van een parlementaire vertegenwoordiging en daarom op de Bondsdag als geheel. Uitgangspunt van het artikel is daarmee niet de persoonlijke (identieke) vertegenwoordiging, zoals die bijvoorbeeld in het burgerlijk recht bestaat, maar vertegenwoordiging in de betekenis van staatsrechtelijke vertegenwoordiging, d.i. "als Aufgabe, das rechtsabwesende Volk gegenwärtig zu machen". ${ }^{74}$ De verhouding tussen de volksvertegenwoordiging en het volk wordt daarbij niet bepaald door een delegatie-figuur waarin de rechten van het volk worden overgedragen op de volksvertegenwoordiging, noch door volmachtverlening in privaatrechtelij-

71. BVerfG 3 juli 1957, BVerfGE 7, 63 (73). Zie ook: BVerfG 15 februari 1978, BVerífE 47, 253 (269).

72. BVerfG 10 mei 1977, BVerfGE 44, 308 (3!6).

73. Idem.

74. Maunz/Dürig. a.w., randnr. 1 bij art. 38 . 
ke zin. Het mandaat en de daaraan verbonden rechten en plichten van de volksvertegenwoordigers volgen rechtstreeks uit de grondwet. ${ }^{75}$ Hoewel alle macht van het volk uitgaat, wordt ingevolge de grondwet de relatie tussen volk en Bondsdag overheerst door de laatste. Als vertegenwoordigingsorgaan handelt de Bondsdag bij uitoefening van zijn taken uit eigen recht. De besiissingen die hij neemt worden, net zoals de beslissingen van de overige (volks)vertegenwoordigende organen, het volk toegerekend: de wil van het parlement geldt als (hypothetische) volkswil. Het volk zelf kan niet beschikken over de door de grondwet aan de Bondsdag toegekende bevoegdheden; het heeft bij het uitoefenen van de staatsmacht, slechts de beschikking over de hem grondwettelijk toegekende bevoegdheden en is slechts in dit kader tot handelen als staatsorgaan bevoegd. ${ }^{76}$ Het volk heeft slechts een constitutionele taak voorzover het Grundgesetz deze taak uitdrukkelijk formuleert.

Hoewel art. 38 lid 1 GG niet gericht is tot de individuele volksvertegenwoordiger, volgt uit het feit van de 'totaalvertegenwoordiging' (Universalvertretung) noodzakelijkerwijs dat de afgevaardigden ook individueel een staatsrechtelijke status hebben. Zij hebben een vrij mandaat en dienen het algemeen belang te behartigen. De aan deze status verbonden grondwettelijke rechten kan hij langs juridische weg afdwingen in een 'Organstreitverfahren'. ${ }^{7}$ Dit is een procedure bij het Bundesverfassungsgericht betreffende de grondwetsinterpretatie bij 'Organstreitigkeiten', d.w.z. geschillen over de omvang van rechten en plichten tussen hoogste staatsorganen op bondsniveau. ${ }^{78}$

Door zijn staatsrechtelijke status heeft de afgevaardigde een openbaar ambt, op grond waarvan hij (een deel van de) staatsmacht uiteefent. Het beroep van Bondsdagvertegenwoordiger is een hoog staatsambt; de leden van de Bondsdag zijn echter geen ambtenaren in dienst van de bond. Er zijn -in de bewoordingen van het Bundesverfassungsgericht- "grundlegende statusrechtliche Unterschiede" tussen de afgevaardigden in de Bondsdag en

75. Vergl. H.-P. Schneider, a.w., p. 258; MaunziDürig, a.w., randnr. 1 bij art. 38; Stem, a.w. (deel 2, le druk München 1980), p. 38.

76. Vergl. H.H. Klein, Aufgaben des Bundestages, in: Isensee/ Kirchhof, a.w. (deel 2), p. 342; Stern, a.w. (deel 2), p. 39. Kritisch: Meyer, a.w., p. $120 / 121$.

77. Vergl. art. 93 lid 1 sub 1 GG.

78. Vergl. Burkens, a.w., p. 153. 
ambtenaren. ${ }^{79}$ De afgevaardigden worden beroepen door het vertrouwen dat de kiezers in hen stellen. Zij hebben een 'repräsentativen Status' en oefenen hun mandaat in onafhankelijkheid uit; de rol van de politieke partijen verandert daaraan niets. Het vervullen van enig ander ambt in publieke dienst wordt op grond van de grondwettelijke machtenscheiding zelfs onverenigbaar geacht met het lidmaatschap van de Bondsdag. Er bestaat een incompatibiliteit van ambt en mandaat, met uitzondering van het ambt van regeringsleider, minister of staatssecretaris. Het feit dat de Bondsdagafgevaardigde geen ambtenaar is, betekent dat het aannemen van geschenken als beloning voor handelen volgens, of juist tegen zijn plicht niet valt onder omkoping van een ambtenaar. Het is daarom, hoewel strijdig met de grondwet, niet als een strafbaar feit aan te merken.

De status van vertegenwoordiger van het hele volk sluit uit dat hij als vertegenwoordiger van deelbelangen optreedt. De volksvertegenwoordiger representeert de gehele bevolking van de bond, dus "die staatsbürgerliche Gesellschaft als einheitlicher und weder regional noch ständisch-korporativ aufgesplitterter 'Träger' der Staatsgewalt." 80 Een Bondsdagafgevaardigde vertegenwoordigt dus ook niet een enkel kiesdistrict (bijv. dat waar hij gekozen is) en zelfs niet (alleen) alle kiesgerechtigden van het volk, maar het gehele volk in alle kiesdistricten. De inhoud van het begrip 'volk' in art. $38 \mathrm{GG}$ reikt dus verder dan de inhoud van hetzelfde begrip in art. 20 GG. ${ }^{81}$

Een en ander neemt niet weg dat het de afgevaardigde is toegestaan bij zijn taak de belangen van zijn district (de z.gn. 'Wahlkreisbetreuung') of een (andere) groep binnen de bevolking in het oog te houden, zolang hij maar naar geweten deze belangen als belangrijk voor het gehele volk kan beschouwen. ${ }^{82}$ In de praktijk is hiermee ongeveer eenderde van de arbeidstijd van de afgevaardigde in de Bondsdag gemoeid. De toelaatbaarheid van het -in zekere mate- rekening houden met bijzondere belangen blijkt reeds uit het bestaan van verschillende politieke partijen (c.q. de grondwet-

79. BVerfG 30 september 1987, BVerfGE 76, 256 (341).

80. Vergl. I. von Münch, Commentaar op art. $38 \mathrm{GG}$, in: I. von Münch (red.) Grundgesetz-Kommentar, deel 2, 2e druk, München 1981, p. 489.

81. Vergl. hiervoor bij art. 20 ( $\$ 3$ ). Zie voorts: S. Landshut, Der politische Begriff der Repräsentation, in: Rausch, a.w., p. $488 \mathrm{ev}$.

82. Maunz/Dürig, a.w., randnr. 11. Vergl. ook: Maunz/Zippelius, a.w., p. 263; Schramm, a.w., p. 88. 
telijke erkenning daarvan), welk bestaan (ook) door art. 38 GG aangenomen wordt. Maar ook het feit dat 'de belangen van gehele volk' bestaan uit (conflicterende) deelbelangen rechtvaardigt aandacht voor een of meer specifieke deelbelangen. ${ }^{83}$ Maar nu art. 38 GG de behartiging van de belangen van het gehele volk vooropstelt, kan hij niet worden gedwongen tot behartiging van deelbelangen. Hij kan zich daartoe ook niet -al dan niet vrijwillig- verplichten. Verplichtingen die hij, mondeling of schriftelijk, uitdrukkelijk of stilzwijgend, aangaat zijn nietig en de afgevaardigde kan er dan ook zonder meer van af wijken. Deze regel vloeit voort uit het Duitse equivalent van het verbod van last: het verbod van binding door middel van 'Aufträge und Weisungen'.

\subsubsection{Aufträge und Weisungen}

De afgevaardigden in de Bondsdag zijn ingevolge art. $38 \mathrm{GG}$ niet gebonden aan 'Aufträge und Weisungen'. Over de concrete uitleg van dit begrippenpaar bestaat in de literatuur enig verschil van mening. De aanvulling 'Weisungen' is bij de totstandkoming van het GG door de Parlementaire Raad toegevoegd aan de reeds in art. 21 WRV genoemde en in het Herrenchiemser-ontwerp overgenomen 'Aufträge'. De raad stelde dat de reikwijdte van het begrip 'Weisung' groter was dan van het begrip 'Auftrag': "Eine Weisung kann nur jemand empfangen, der sich daran gebunden fühlt. Der Auftrag hat mehr ein zivilrechtliches Gepräge." ${ }^{84}$ Een andere opvatting stelt dat 'Aufträge' betrekking hebben op gedragingen in het algemeen, waar 'Weisungen' op een concrete gedraging ziet. Daarnaast bestaat de opvatting dat 'Aufträge' afkomstig zijn van 'buitenparlementaire' organisaties of personen, terwijl 'Weisungen' juist van parlementaire instanties (m.n. fracties, maar ook andere instanties binnen het parlement) komen. In deze opvatting heeft het verschil tussen parlementaire organen ('Weisungen') en niet-parlementaire organen ('Aufträge') tot gevolg dat Weisungen reeds op grond van het Grundgesetz ontoelaatbaar zijn, terwijl Aufträge wel grondwettelijk toelaatbaar zijn, maar ingevolge het burgerlijk recht onverbindend zijn.

Tegenwoordig wordt er van uitgegaan dat het doel van dit gedeelte van art. $38 \mathrm{GG}$ is de onafhankelijkheid van de volksvertegenwoordigers tegenover

83. Vergl. Von. Münch, a.w., p. 489/490. Zie voorts: Maunz/Dürig, a.w., randnr. 11 bij art. 38 en H.-P. Schneider, a.w., p. 267.

84. Geciteerd bij Von Münch, a.w., p. 490. 
elke wijze van beïnvloeding te garanderen, ongeacht of deze beïnvloeding nu plaats vindt door een constitutioneel of maatschappelijk orgaan en ongeacht de vraag wat het juridische gevolg van een dergelijke beïnvloeding is. De eerdergenoemde zienswijzen worden dan ook als onjuist beschouwd: de enige juiste interpretatie is het beschouwen van 'Aufträge' en 'Weisungen' als een tautologie. Met de toevoeging van 'Weisungen' wordt de onafhankelijkheid van de individuele volksvertegenwoordiger slechts versterkt; aan het begrip komt geen zelfstandige betekenis toe. ${ }^{85}$ In deze opvatting bestaat dus duidelijk verschil met Nederland waar het (oude) verbod van last en ruggespraak op twee verschillende, zij het aan elkaar gerelateerde situaties zag. Wel is in deze opvatting het verbod om 'Aufträge' en 'Weisungen' aan te nemen gelijk te stellen met het verbod van last. ${ }^{86}$

Het verbod ziet op de eerste plaats op het uitvoeren van 'Aufträge und Weisungen'. Daarnaast wordt ook het geven van lastgeving ontoelaatbaar geacht. Toezeggingen van, of overeenkomsten met een afgevaardigde zijn in strijd met $\S 134 \mathrm{BGB}$, de Duitse pendant van art. 3:40 BW. ${ }^{87}$ De plaatsing van dit artikel in het Duitse BW neemt niet weg, dat het ook buiten het burgerlijk recht werking heeft:

"Im übrigen kommt es nicht darauf an, ob ein Verbotgesetzes verfassungsrechtlicher, privatrechtlicher, strafrechtlicher oder verwaltungsrechtlicher Natur ist; ebensowenig ist es erheblich, ob das Verbotsgesetz im Bundesrecht oder im Landesrecht enthalten ist. " ${ }^{88}$

85. Vergl. Von Münch, a.w., p. 490; H.-P. Schneider, a.w., p. 278.

86. Waar in het vervolg sprake is van het begrip lastgeving is dit als synoniem voor 'Aufträge und Weisungen' gebruikt.

87. \$134 BGB: "Ein Rechtsgeschāft, das gegen ein gesetzliches Verbot verstößt, ist nichtig, wenn sich nicht aus dem Gesetz ein anderes ergibt." Aangenomen wordt dat dit artikel (anders dan art. 3:40 BW) slechts betrekking heeft op de inhoud van de rechtshandeling: vergl. het commentaar van Th. Mayer-Maly in: F.J. Säcker (red.), Münchener Kommentar zum Bürgerlichen Gesetzbuch, algemeen deel, 3e druk, München 1993, p. 1087.

88. J. von Staudinger, Kommentar zum Bürgerlichen Gesetzbuch, deel 1, 12e druk, bewerkt door H. Dilcher, Berlijn 1980, p. 413. 
In de literatuur wordt aangenomen dat het gevolg van een dergelijke strijdigheid in het geval van art. 38 GG inderdaad nietigheid ten gevolge heeft. ${ }^{89}$

In de tegenwoordige tijd fungeert het verbod van last vooral als garantie tegen binding aan lastgeving, beginselen of programma's van de partij van wier fractie de afgevaardigde deel uit maakt. Hij is en blijft gehouden aan zijn vrije mandaat. Daar dit mandaat zich ook uitstrekt tot zijn stemgedrag, kan de individuele volksvertegenwoordiger tijdens de zittingsperiode niet door zijn partij worden teruggeroepen (geen recall-recht) of verplicht worden zijn zetel ter beschikking te stellen (geen rotatie). Wanneer een politieke partij tijdens de zittingsduur het vertrouwen in een van haar afgevaardigden in de Bondsdag zou opzeggen heeft dat slechts een politieke, maar geen juridische betekenis. Het is van generlei invloed op zijn onafhankelijke positie als lid van de volksvertegenwoordiging. Er bestaat geen verplichting voor de individuele volksvertegenwoordiger om zich te conformeren aan het standpunt van de partij c.q. fractie. Volgens de meeste schrijvers is fractiedwang zelfs in strijd met de grondwet. ${ }^{90}$ Wel kan de partij of fractie de betrokken onwillige afgevaardigde uit de partij (c.q fractie) stoten, maar dat heeft geen mandaatsverlies tot gevolg. Dat neemt niet weg dat de partij natuurlijk over het relatief $z$ ware pressiemiddel beschikt de afgevaardigde te dreigen met een onverkiesbare plaats op de kandidatenlijst voor de volgende verkiezingen. Ook een wisseling van partij c.q. fractie of het gaan innemen van een onafhankelijke, niet-partijgebonden positie binnen de Bondsdag leidt niet tot verlies van het mandaat, dat hij op grond van zijn plaats op de kandidatenlijst van een (andere) partij heeft gekregen. Het mandaat dient wel te worden opgegeven wanneer de partij waarvan de volksvertegenwoordiger deel uitmaakt, door het Bundesverfassungsgericht wordt verboden. ${ }^{\text {it }}$

De door sommige partijen aangehangen praktijk dat de afgevaardigde voor zijn verkiezing een verklaring dient te onderschrijven dat hij zijn mandaat zal opgeven wanneer hij -bijvoorbeeld- het programma van zijn partij niet

89. Vergl. Von Münch, a.w., p. 490; H.-P. Schneider, a.w., p. 267, alsmede Säcker, a.w., p. 1094.

90. Vergl. Maunz/Dürig, a.w., randnr. 12 bij art. 38 en de daar genoende literatuur.

91. BVerfG 23 oktober 1952, BVerfGE 2, 1 (74). Deze reden voor mandaatsverlies is later in de Duitse kieswet opgenomen (zie hieronder). 
meer onderschrijft, is eveneens nietig. Deze nietigheid vloeit echter niet voort uit art. 38 lid $1 \mathrm{GG}$ omdat deze bepaling, zoals reeds werd aangegeven, slechts betrekking heeft op de positie van de afgevaardigde in de Bondsdag. De nietigheid bestaat ingevolge $\S 134 \mathrm{BGB}$. Het zelfde geldt voor een door een afgevaardigde ondertekende blanco-verklaring van het opgeven van zijn mandaat, die de partij op een door haar gewenst moment kan inroepen. Weliswaar kan de afgevaardigde zelf op elk door hem gewenst tijdstip zijn mandaat neerleggen, maar een dergelijke blancoverklaring is in feite een verplichting tot het neerleggen van het mandaat en daarom in strijd met het Grundgesetz omdat ook dit indruist tegen het recht om (vrijwillig) de zetel in de Bondsdag op te geven. ${ }^{2}$ Over de relatie tussen de volksvertegenwoordiger en zijn partij is wel opgemerkt dat een juridische binding van de eerste aan besluiten c.q lastgeving van zijn partij alleen al daarom onmogelijk ('systemwidrig') is, omdat de volksvertegenwoordiger zijn mandaat niet van de partij, maar van zijn kiezers krijgt. ${ }^{93}$ Deze opvatting is echter te formeel; zij miskent het praktische monopolie van de politieke partij bij de kandidaatstelling.

Over de uitoefening van het ambt van Bondsdagvertegenwoordiger kunnen tussen afgevaardigde en partij overeenkomsten worden gesloten; bijvoorbeeld dat de afgevaardigde onder bepaalde omstandigheden zijn mandaat zal opgeven, of, in het geval dat hij dit nalaat, andere handelingen (zoals het betalen van een door de partij vast te stellen boete) dient te verrichten. Ook dit zou indruisen tegen het vrije mandaat en is daarom nietig op grond van de reeds eerder genoemde bepaling uit het BGB. ${ }^{94}$ De Bondsdagafgevaardigde kan alleen worden gedwongen zijn mandaat op te geven wanneer er sprake is van een van de in $\$ 46$ lid 1 van het 'Bundeswahlgesetz' genoemde redenen voor het verlies van de zetel in de Bondsdag. ${ }^{95}$

92. Vergl. Drath, a.w., p. 262; Schmidt-Bleibtreu/Klein, a.w., p. 588.

93. Vergl. Maunz/Zippelius, d.w., p. 262.

94. Vergl. H.H. Klein, Status des Abgeordneten, in: Isensee/Kirchhof, a.w. (deel 2), p. 376.

95. Dit artikel luidt (voor zover hier van belang):

"Ein Abgeordneter verliert die Mitgliederschaft im Deutschen Bundestag bei

1. Ungültigkeit des Enwerbs der Mitgliedschaft,

2. Neufeststellung des Wahlergebnisses,

3. Wegfall einer Voraussetzung seiner jederzeitigen Wählbarkeit,

4. Verzicht, 
De onafhankelijkheid van de volksvertegenwoordiger leidt er natuurlijk niet toe dat hij volledig onverantwoordelijk is voor zijn handelen. Zoals hiervoor is opgemerkt kan hij weliswaar niet voor zijn 'politiek' gedrag (in het parlement of daarbuiten) ter verantwoording worden geroepen door middel van 'instrumenten' als 'recall' en 'rotation', maar staatsrechtelijk blijft hij verantwoording schuldig aan zijn kiezers. Dit uit zich in het al dan niet vernieuwen van zijn mandaat bij de volgende verkiezingen.

Het Grundgesetz bevat geen bepaling die uitsluit dat een Bondsdagvertegenwoordiger ook lid van de regering is. De praktijk is dan ook dat de meeste ministers en staatssecretarissen tevens lid van de Bondsdag zijn. Een dergelijke cumulatie van functies is, hoewel zij om andere redenen als ongewenst moet worden beschouwd, ${ }^{96}$ voor de onafhankelijkheid van de betrokkenen niet problematisch; zij laat het vrije mandaat van de Bondsdagvertegenwoordiger onverlet.

Het kan dus voorkomen een afgevaardigde tegen een wet stemt, die hij in zijn hoedanigheid als lid van de regering (mede) heeft ontworpen. Wat hiervoor is opgemerkt over ontoelaatbare (stem)dwang vanuit partij of fractie geldt hier ook voor de bondsregering. Wel kan in een dergelijke situatie de partij hem aanraden zijn zetel op te geven en kan de bondskanselier de president verzoeken de minister te ontslaan. De mogelijkheid van een dergelijk ontslag is echter ook buiten het bestaan van een dergelijk stemconflict aanwezig (vergl. art. 64 lid 1 GG). Het vrije mandaat van de afgevaardigde in de Bondsdag verzet zich echter tegen het gebruik van een dergelijk pressiemiddel in een situatie als hierboven beschreven. Wel komt het voor dat een Bondsdagafgevaardigde, die tot de regering toetreedt, voor de duur van zijn aanstelling, zijn mandaat tijdelijk opgeeft ('Ruhen des Mandats'). Wanneer hij weer uit de regering treedt, neemt hij zijn mandaat weer op, waardoor de afgevaardigde die hem in Bondsdag verving (de 'Mandatsverwalter') moet terugtreden. Omdat de onafhankelijkheid van de

5. Feststellung der Verfassungswidrigkeit der Partei oder Teilorganisation einer Partei, der er angehört, durch das Bundesverfassungsgericht nach Artikel 21 Abs. 2 Satz 2 des Grundgesetzes.

Verlustgründe nach anderen gesetzlichen Vorschriften bleiben unberührt."

96. Daarover: Meyer, a.w., pp. 129-134. 
tijdelijke vervanger bij deze praktijk zeer in het gedrang komt, wordt zij grondwettelijk ongewenst, en veelal zelfs ontoelaatbaar geacht. ${ }^{97}$

Daar art. 38 lid $3 \mathrm{GG}$ bepaalt dat een bondswet de bepalingen van de eerste twee leden van art. $38 \mathrm{GG}$ nader uitwerkt, is het in theorie mogelijk dat bij bondswet wordt bepaald dat een afgevaardigde zijn mandaat verliest wanneer hij uit eigen beweging zijn partij verlaat of gedwongen wordt de partij te verlaten. De toelaatbaarheid van een dergelijke bepaling is omstreden. ${ }^{98}$ Over het algemeen wordt geoordeeld dat het wetsvoorbehoud in art. 38 lid 3 GG ziet op een nadere invulling van het beginsel van het vrije mandaat, maar niet van een beperking daarvan. ${ }^{99}$ Om deze zelfde redenen wordt het onmogelijk geacht een op art. 38 lid $3 \mathrm{GG}$ gebaseerde bondswet te laten bepalen dat toetreding tot de bondsregering (of de regering van een land) tot mandaatsverlies leidt.

\subsection{3 ... nur ihrem Gewissen unterworfen}

De onathankelijkheid van de volksvertegenwoordigers in de Bondsdag wordt tenslotte onderstreept door het feit dat zij 'nur ihrem Gewissen unterworfen' zijn. Wanneer het Grundgesetz spreekt van 'Gewissen' moet daaraan volgens het Bundesverfassungsgericht de betekenis van het begrip in het algemeen spraakgebruik worden toegekend. ${ }^{100}$ In dit spraakgebruik dient het begrip 'Gewissen' te worden beschouwd als een "real erfahrbares seelisches Phänomen (...), dessen Forderungen, Mahnungen und Warnungen für den Menschen unmittelbar evidente Gebote unbedingten Sollens sind". ${ }^{101}$ De concrete invulling hiervan is sterk subjectief. In het Grundgesetz wordt het begrip 'Gewissen' dan ook niet in objectieve zin gebruikt; de laatste zinsnede van art. 38 lid $1 \mathrm{GG}$ is daarom bijvoorbeeld niet geschikt om vermeend onjuist handelen van een afgevaardigde te veroordelen als zijnde strijdig met het geweten. Wanneer een afgevaardigde beweert slechts naar eigen geweten te handelen, hoeft hij dat niet nader te verklaren en is dat een weliswaar niet te bewijzen, maar ook niet tegen te spreken

97. Vergl. Klein, Status des Abgeordneten, a.w., p. 377; Stern, a.w. (deel 1). p. $1053 / 1054$.

98. Vergl. H.-P. Schneider, a.w., p. 270.

99. Vergl. Maunz/Dürig, a.w., randnr. 16 bij art. 38.

100. BVerfG 20 december 1960, BVerfGE 12, 45 (54). Deze uitspraak had betrekking op art. $4 \mathrm{GG}$, dat het recht van gewetensvrijheid waarborgt.

101. BVerfG 20 december 1960, BVerfGE 12, 45 (54). 
vermoeden van zijn goede trouw. In verband hiermee wordt wel gepleit een beroep op het geweten te beperken tot "seltene Extremsituationen", teneinde een devaluatie van het beroep op het geweten te voorkomen. ${ }^{102}$ Een en ander neemt vanzelfsprekend niet weg dat de afgevaardigde ook gehouden is de wetten na te leven en in acht te nemen. De zinsnede beoogt niet de onderwerping aan het eigen geweten aan te geven, maar andere mogelijke invloeden (van buiten, van kiezers, belangengroepen, partijen enz.) uit te sluiten; het accent ligt m.a.w. op het woordje nur. ${ }^{103}$ Daarnaast maakt de zinsnede het mogelijk beïnvloeding van de individuele volksvertegenwoordiger (door bijvoorbeeld stemdwang van de partij of de fractie) niet alleen af te doen als in strijd met het beginsel van het vrije mandaat, maar ook een morele dimensie aan het verweer te geven. Met de onderwerping aan het geweten is verenigbaar dat een eigen, afwijkende mening omwille van de 'Fraktionssolidariät' toch ondergeschikt wordt gemaakt aan het standpunt van de fractie. ${ }^{104}$ In een dergelijke situatie laat de betrokkende zich vrijwillig leiden door de noodzaak als fractie zoveel mogelijk als eenheid op te treden.

\subsection{De rol van de politieke partijen: art. 21 GG}

In tegenstelling tot de meeste grondwetten van andere (West--) Europese staten erkent het GG het bestaan van politieke partijen. Door art. 21 GG zijn zij constitutioneel geïncorporeerd. Hierdoor wordt de moderne democratische partijenstaat gelegaliseerd. ${ }^{105} \mathrm{De}$ integratie van de politieke partijen in de constitutionele orde maakt hen tot een belangrijke factor bij de bepaling van de staatsrechtelijke positie van de individuele volksvertegenwoordiger. In de optiek van het Grundgesetz zijn de politieke partijen publiekrechtelijk erkende en gereguleerde organisaties die zich kenmerken door hun specifieke taak binnen het staatsbestel.

102. Zie: H.-P. Schneider, a.w., p. 279.

103. Vergl. Von Münch, a.w., p. 491; Maunz/Dürig, a.w., randnr. 17 bij art. 38 GG. Kritisch: Alfert, a.w., p. 166: "Indem das Grundgesetz den Abgeordneten nur seinem Gewissen gegenüber verantwortlich macht, lassen sich subjektive Elementen nicht ausschalten."

104. Vergl. Von Mūnch, a.w., p. 491; H.-P. Schneider, a.w., p. 279.

105. Vergl. Schramm, a.w., p. 41. 
Art. 21 GG wordt beschouwd als een van de belangrijkste bepalingen uit de Duitse grondwet. ${ }^{106}$ In tegenstelling tot de voorgaande grondwetten van het Duitse rijk -en de meeste tegenwoordige grondwetten van andere landen- erkent het Grundgesetz dat in de moderne staat het bestaan en functioneren van politieke partijen een noodzakelijke voorwaarde is voor het democratisch en effectief functioneren van het staatsbestel. ${ }^{107}$ Zoals hiervoor is aangegeven is art. 21 GG een nadere invulling van het democratisch principe van art. $20 \mathrm{GG}$ en het daarin voorziene systeem van het parlementaire, representatieve regeringsstelsel. Hoewel art. 79 lid $3 \mathrm{GG}$ artikel 21 GG niet uitdrukkelijk vermeldt, moet daarom ook dit artikel worden geacht deel uit te maken van de bepalingen waarop het wijzigingsverbod van art. 79 lid 3 GG betrekking heeft. ${ }^{108}$ Ook art. 21 GG is een "Grundnorm für das politische Leben in der Bundesrepublik Deutschland überhaupt". ${ }^{109}$

Uit de bewoordingen van de eerste volzin van art. 21 lid $1 \mathrm{GG}$ valt op te maken dat de grondwetgever niet slechts het bestaan van verscheidene partijen heeft willen erkennen, maar ook het meerpartijenstelsel heeft willen constitutionaliseren. ${ }^{110}$ Samen met de in de tweede volzin verankerde oprichtingsvrijheid en het algemene discriminatieverbod van art. 3 GG (te vergelijken met art. 1 van de Nederlandse grondwet) impliceert dit tevens dat alle partijen gelijk behandeld dienen te worden. Dit is de zgn. 'Wettbewerbsgleichheit' of 'Chancengleichheit': alle partijen dienen door de overheid op voet van gelijkheid behandeld te worden. Een verschillende behandeling van politieke partijen is alleen te rechtvaardigen op grond van enkele bijzonder dwingende (doelmatigheids-)gronden, zoals de noodzaak om het functioneren van het parlement niet te belemmeren door partijversplintering. Het beginsel van de 'Chancengleichheit' betekent daarom geen absolute gelijkstelling van alle partijen: "Insoweit verpflichtet der

106. Vergl. Von Münch, a.w., p. 1.

107. Idem. In dezelfde zin: K. Doehring. Das Staatsrecht der Bundesrepublik Deutschland, 3e druk, Frankfurt am Main 1984, p. 153; Stern, a.w. (deel 1), p. 435/436; Maunz/Dürig, a.w., randnr. 5 bij art. 21 GG.

108. Vergl. Alfert, a.w., p. 182.

109. Von Münch, a.w., p. 1.

110. U.K. Preuß, Commentaar op art. 21 GG, in: Denninger, a.w. (deel 2), p. 12/13; Von Miünch, a.w., p. 12; Stern, a.w. (deel 1), p. 457; Maunz Dürig, a.w., randnrs. 35 en 135. 
Grundsatz der Chancengleichheit politischer Parteien den Staat zu einer rechtlichten, nicht aber zu einer tatsächlichen Gleichstellung"."11

De operatievrijheid van het partijwezen verhindert ook dat (alle) activiteiten van politieke partijen door de overheid worden gefinancierd: alleen op het moment dat volkswil en staatswil samenvallen -dus ten tijde van de verkiezingen- is overheidsfinanciering toegestaan. ${ }^{112}$

De tweede volzin van art. 21 lid $1 \mathrm{GG}$ bevat het recht van vereniging voor politieke partijen. Dit grondrecht bevestigt ten aanzien van de politieke partijen hetgeen art. 9 lid $1 \mathrm{GG}$ voor verenigingen en vennootschappen in het algemeen garandeert en is daaĩnee een lex specialis van dit artikel. ${ }^{113}$ Ten aanzien van politieke partijen geldt echter wel dat slechts natuurlijke personen ervan deel kunnen uitmaken (vergl. hieronder), waar art. 9 GG ook toelaat dat rechtspersonen zich verenigen.

Naar hun rechtsvorm zijn de politieke partijen in Duitsland verenigingen (meestal zonder rechtspersoonlijkheid) in de zin van het burgerlijk recht. Hun betekenis, rechten en plichten gaan echter veel verder dan die van de 'gewone' burgerrechtelijke vereniging. De staatsrechtelijke positie van de politieke partijen wordt dan ook niet bepaald door hun rechtsvorm. Alleen al de plaatsing van art. 21 GG in het hoofdstuk over 'Der Bund und die Länder' en de aansluiting op art. $20 \mathrm{GG}$, dat de uitoefening van de staatsmacht regelt, onttrekt de politieke partijen aan het burgerlijk recht en geeft hen een eigen, grondwettelijke status. ${ }^{114}$

111. Alfert, a.w., p. 58. Zie ook: dez. p. 193/194.

112. Het beginsel van de "Chancengleichheit" is vastgelegd in hoofdstuk $1, \$ 5$ PartG. Over het begrip "Chancengleichheit" en de daarop gebaseerde rechtspraak: D.Th. Tsatsos/M. Morlok, Parteienrecht. Eine verfassungsrechiliche Einführung, Heidelberg 1982, pp. 85-101 en Ph. Kunig, Parteien, in: Isensee/Kirchhof, a.w. (deel 2), pp. 132-136. Zie voorts: D.J. Elzinga, De politicke partij en het constitutionele recht, Nijmegen 1982, p. 55/56; Von Münch, a.w., pp. 13-20; Preuß, a.w., pp. 32-36; Model/Müller, a.w., pp. 281-283.

113. Art. 9 lid 1 GG: "Alle Deutschen haben das Recht, Vereine und Gesellschaften zu bilden." Over de verhouding tussen art. 9 GG en art. 21 GG: Schramm, a.w., p. 36/37; Maunz/Dürig, a.w., randnr. 38.

114. Vergl. Von Münch, a.w., p. 10/11; Maunz/Dürig, a.w., randnrs. 44-46. Zie ook: Elzinga, a.w., pp. 56-58. 


\subsubsection{Historische ontwikkeling van de politieke partijen}

"Die politischen Parteien haben (...) nur dort eine Stätte, wo es um Repräsentation (...) geht. "115 Het is daarom niet verwonderlijk dat ook in Duitsland de opkomst van het partijwezen samenhangt met de opbouw van de representatieve democratie, al is dit niet de enige factor die tot partijvorming bijgedragen heeft. ${ }^{116}$ Een beschrijving van de rol van de politieke partijen in Duitsland dient dan ook verder terug te gaan dan het jaar van hun grondwettelijke erkenning.

De politieke partijen in Duitsland hadden al een (ongeveer) honderdjarig verleden achter zich voordat zij na de Tweede Wereldoorlog grondwettelijke erkenning kregen. De eerste aanzet tot vorming van politieke partijen dateert van $1848 / 1849$, toen in de nationale vergadering in Frankfurt am Main fracties werden gevormd, die hun ontstaan vonden in de bestaande politieke tegenstellingen. Daarbij werden de eerste pogingen ondernomen om tot interne fractie-organisatie te komen, maar deze strandden op het grote verloop onder de fractie-leden; (mede) als gevolg van de sterke fractie-discipline kwamen herhaaldelijk afsplitsingen voor. ${ }^{117}$ Door middel van de fracties, die vanwege hun aantal en hun afsplitsingen niet met hun politieke richting, maar naar het café waar zij plachtten te vergaderen werden aangeduid, was ongeveer tweederde van de afgevaardigden georganiseerd. ${ }^{118}$ Ondanks het geringe succes van deze pogingen (ook al omdat de Paulskirchenversammlung geen lang leven beschoren was) geldt deze gebeurtenis als de geboorte van het Duitse partijwezen. ${ }^{19}$

De ontwikkeling van de politieke partijen in de periode 1849-1949 is wel beschreven als een ontwikkeling "aus dem Bereich des 'Dubiosen', des 'Fragwürdigen', des mit dem 'staatlichen Ethos' Unvereinbaren in die Richting der Anerkennung und der Legalität". ${ }^{120}$ Partij- c.q. fractievorming werd lange tijd als ongepast beschouwd: waar het streven gericht was op het tot stand brengen van enige staatkundige eenheid was de vorming van een systeem van georganiseerde contrasten met dit streven onverenigbaar. ${ }^{121}$ Het constitutionele denken was toegespitst op de tegenstelling

115. H. Krïger, Allgemeine Staatslehre, 2e druk, Stuttgart 1966, p. 368.

116. Vergl. Preuß, a.w., p. 7/8.

117. Vergl. Willoweit, a.w., p. 227.

118. Idem, p. $227 / 228$.

119. Vergl. Alfert, a.w., p. 181.

120. Tsatsos/Morlok, a.w., p. 7.

121. Model/Mäller, a.w., p. 276. Vergl. ook: Alfert, a.w., p. 181. 
tussen regering en 'volks'vertegenwoordiging; daarin was geen plaats voor een opdeling van de volkswil naar fracties of partijen.

Daarnaast vormde de grote territoriale verdeeldheid van het Duitse rijk een complicerende factor voor het doorzetten van de partijvorming. Na het mislukken van de nationale vergadering verdwenen de partij- en fractiestructuren dan ook weer. In de volksvertegenwoordigingen van de Duitse landen zette de partijvorming zich wel door, zij het zeer aarzelend. Geabstraheerd van plaatselijke bijzonderheden stonden hier een conservatieve stroming en een liberale stroming tegenover elkaar. In Pruisen vormde de linkervleugel van de liberale stroming in de volksvertegenwoordiging, samen met de 'Nationalliberale Partei' (een afscheiding van de liberale stroming) en andere, niet in het parlement vertegenwoordigde groepen in 1861 de 'Deutsche Fortschrittspartei', die op basis een programma afgevaardigden en hun aanhang verenigde, zich naar de kiezers toe als eenheid manifesteerde en niet pas achteraf door parlementaire groepsvorming door individuele afgevaardigden tot stand kwam. Op grond hiervan wordt zij als de eerste moderne partij in Duitsland beschouwd, al was ook hier de relatie tussen fractie en buitenparlementaire aanhang zeer labiel. ${ }^{122}$

Ook in de Rijksdag van het keizerrijk, dus op centraal niveau, viel gaandeweg een ontwikkeling tot partijvorming te bespeuren. ${ }^{123}$ Dit leidde echter niet tot grondwettelijke erkenning van de rol van de politieke partijen. Uiteindelijk vielen vier hoofdstromingen te onderscheiden, waartoe meerdere partijen behoorden: de liberale, de conservatieve, de katholieke en de socialistische. In de Rijksdag en de Landdagen groeiden deze vier hoofdstromingen van het Duitse politieke leven uit tot een meerpartijensysteem, dat zonder al te veel veranderingen tot het einde van de republiek van Weimar stand hield. Sedert de jaren zeventig van de vorige eeuw steunden de partijen op een uitgebreid verenigings- en afdelingswezen, dat er voor zorgde dat vooral economische en sociaal-politieke onderwerpen politieke aandacht kregen. Aan het begin van de eeuw waren de politieke partijen -in verschillende mate- verworden tot massaorganisaties met een relatief vaste structuur, eigen inkomsten door contributie heffing en (betaalde) werknemers. De aanzet daartoe was gegeven door de SPD, uit concurrentieoverwegingen waren de overige partijen gevolgd. ${ }^{124}$

122. Vergl. Preuß, a.w., p. 8/9.

123. Hierover: Model/Müller, a.w., p. 275; Willoweit, a.w., p. 262/263.

124. Vergl. Preuß, a.w., p. 10. 
Met de invoering van het parlementaire stelsel en het evenredig kiesrecht zou de WRV met haar liberale strekking de constitutionele voorwaarden voor een staatkundig systeem scheppen, dat in feite op de werkzaamheid van de politieke partijen berustte. Hoewel de politieke partijen niet expliciet als elementen van dit systeem werd genoemd, was hun praktische betekenis op zijn minst even groot als thans. De WRV bevatte ten aanzien van politieke partijen slechts een "distanzierende Erwähnung" ${ }^{125}$ in art. 130, door te bepalen dat ambtenaren "Diener der Gesamtheit, nicht einer Partei" waren. Deze bepaling was inhoudelijk uitermate tegenstrijdig nu zij enerzijds de rol van politieke partijen veroordeelde als bedreigend voor de eenheid van de staat, maar anderzijds wel impliciet bevestigde dat politieke partijen noodzakelijk waren voor de politieke wilsvorming. Toch werd de merkwaardige opvatting van de WRV op het punt van de politieke partijen in wetenschappelijke kring in het algemeen onderschreven. Zo ontkende Jellinek dat het begrip 'politieke partij' in het staatsrecht thuishoorde. In zijn ogen waren de politieke partijen slechts "gesellschaftliche Bildungen (...) die als solche nicht Gegenstand der Staatsrechtslehre selbst sind." ${ }^{126}$ Het verzwijgen van de rol van politieke partijen is terug te voeren op het in die tijd heersend concept over het begrip democratie. Dit concept verzette zich tegen aantasting van de vrije wil van het individu en de wil van het, uit het totaal der individuen bestaande gehele volk, zoals die door de vertegenwoordigers van het gehele volk in het parlement werd gerepresenteerd, door de erkenning van het bestaan van groepen die het in dit concept van democratie geldende proces van politieke wilsvorming konden denatureren. ${ }^{127}$ Deze houding had wel tot gevolg dat er spanning ontstond tussen de WRV en de politieke werkelijkheid waarin tal van partijen opereerden. Het gebrek aan een regeling betreffende de politieke partijen maakte het ook onmogelijk de anti-democratisch ingestelde partijen aan te pakken, waardoor uiteindelijk het meerpartijensysteem vervangen zou worden door een partijmonopolie; een van de oorzaken van de ondergang van de Republiek van Weimar. ${ }^{128}$

125. Weber-Fas, a.w., p. 57 (noot).

126. G. Jellinek, Allgemeine Staatslehre, 3e druk, bewerkt door W. Jellinek, Berlijn 1929, p. 114.

127. Vergl. BVerfG 23 oktober 1952, BVerfGE 2, 1 (10). Zie ook: SchmidtBleibtreu/Klein, a.w., p. 437.

128. Vergl. Ellwein/Hesse, a.w., p. 179. 


\subsubsection{Het begrip 'politieke partij'}

Bij de totstandkoming van het GG werd op het punt van de politieke partijen vooral beoogd een einde te maken aan de spanning tussen grondwet en grondwettelijke praktijk. In het Herrenchiemser-ontwerp was dan ook voorzien in een bepaling omtrent de politieke partijen (art. 47). Na door de Parlementaire Raad enigszins te zijn gewijzigd, kwam deze uiteindelijk als art. 21 in het GG terecht. ${ }^{129}$ Het Grundgesetz was echter niet de eerste grondwet waarin het bestaan en de functie van politieke partijen werd erkend. Die eer viel te beurt aan de grondwet van Baden. De Badische Landesverfassung van 22 mei 1947 voorzag in de artikelen 118121 in een uitvoerige regeling voor het functioneren van politieke partijen. ${ }^{130}$

In vergelijking hiermee is de aandacht van het Grundgesetz voor de politieke partijen summier. Art. $21 \mathrm{GG}$ liet vele vragen over de grondwettelijke status van de politieke partijen open. Het was aan de rechtspraak van het Bundesverfassungsgericht en het op grond van art. 21 lid 3 GG vereiste, maar pas na veel te lange tijd tot stand gekomen 'Parteiengesetz' (PartG) van 24 juli 1967 om hierin duidelijkheid te brengen. Deze wet, die ook voor de Duitse landen verbindend is, maakte ook een einde aan de discussie omtrent de inhoud van het in het GG niet gedefinieerde begrip van de politieke partij. $\S 2$ lid 1 van het PartG omschrijft deze als volgt:

Parteien sind Vereinigungen von Bürgern, die dauernd oder für längere Zeit für den Bereich des Bundes oder eines Landes auf die politische Willensbildung Einfluß nehmen und an der Vertretung des Volkes im Deutschen Bundestag oder einem Landtag mitwirken wollen, wenn sie nach dem Gesamtbild der tatsächlichen Verhältnisse, insbesondere nach Umfang und Festigkeit ihrer Organisation, nach der Öffentlichkeit eine ausreichende Gewähr für die Ernsthaftigkeit dieser Zielsetzung bieten. Mitglieder einer Partei können nur natürliche Personen sein.

129. Uitvoeriger over de ontstaansgeschiedenis van art. 21 GG: Preuß, a.w., p. $10 / 11$.

130. De tekst van deze artikelen is opgenomen bij Stern, a.w. (deel 1), p. $438 / 439$. 
Deze definitie behoort tot het 'gewone' recht van de bond; het is geen grondwettelijke definitie. ${ }^{131}$ Door het ontwerpen van een bondswet kan de wetgever geen authentieke interpretatie van een in de grondwet gebruikt begrip geven, zelfs niet wanneer de grondwet -zoals in dit geval in art. 21 lid $3 \mathrm{GiG}$ - de nadere regeling aan hem overlaat. ${ }^{132}$ Daarom is het denkbaar dat het Bundesverfassungsgericht uit art. $21 \mathrm{GG}$ (in samenhang met de overige bepalingen van de grondwet) een andere definitie van dit begrip zou afleiden. In de praktijk is echter juist het tegendeel het geval: het constitutionee! hof heeft juist bepaald dat de definitie van het PartG overeensternt met art. 21 lid $1 \mathrm{GG}$ en grondwettig is. ${ }^{133}$

\subsubsection{De functie van de politieke partij}

Ook ten aanzien van de taak van politieke partijen houdt het Grundgesetz zich op de vlakte. Het PartG geeft in $\$ 1$ van het eerste hoofdstuk een nadere invulling:

1. Die Parteien sind ein verfassungsrechtlich notwendiger Bestandteil der freiheitlichen demokratischen Grundordnung. Sie erfüllen mit ihrer freien, dauernden Mitwirkung an der politischen Willensbildung des Volkes eine ihnen nach dem Grundgesetz obliegende und von ihm verbürgte öffentliche Aufgabe.

2. Die Parteien wirken an der Bildung des politischen Willens des Volkes auf allen Gebieten des öffentlichen Lebens mit, indem sie insbesondere auf die Gestaltung der öffentlichen Meinung Einfluß nehmen, die politische Bildung anregen und vertiefen,

die aktive Teilnahme der Bürger am politischen Leben fördern, zur Übernahme öffentlicher Verantwortung befähigte Bürger heranbilden,

sich durch Aufstellung von Bewerben an den Wahlen in Bund, Ländern und Gemeinden beteiligen,

auf die politische Entwicklung in Parlament und Regierung Einfluß nehmen,

131. Uitvoeriger over het begrip 'politieke partij" (o.a.): Maunz/Dürig, a.w., randnrs. 7-31; Model/ Müller, a.w., p. $277 / 278$; Von Münch, a.w., pp. 2-10; Tsatsos/Morlok, a.w., pp. 20-24; Preuß, a.w., pp. 19-26; Kunig, a.w., pp. 106-109.

132. Vergl. Von Münch, a.w., p. 2/3, alsmede: Kunig, a.w., p. $109 / 110$.

133. BVerfG 14 februari 1978, BVerfGE 47, 198 (222). 
die von ihnen erarbeiteten politische Ziele in den Prozeß der staatlichen Willensbildung einführen und

für eine ständige lebendige Verbinding zwischen dem Volk und dem Staatsorganen sorgen.

3. Die Parteien legen ihre Ziele in politischen Programmen nieder.

Uit de omschrijving van het begrip politieke partij in het PartG is af te leiden dat de politieke partij een vereniging van burgers is. Deze vereniging moet de beïnvloeding van de politieke wilsvorming als hoofddoel hebben. In deze optiek vervullen de politieke partijen de functie van -onmisbare- schakel tussen volk en staat. ${ }^{134}$ Door middel van de partijen kan de wil van het volk worden omgezet in de wil van de staat, terwijl de partijen op hun beurt weer de volkswil (kunnen) beïnvloeden. Hoewel art. 21 lid 1, le volzin GG alleen de laatste functie lijkt weer te geven, staat vast dat ook de eerste functie een taak van de politieke partijen is. ${ }^{135}$ De partijen zijn daarmee bindmiddel tussen staat en volk, in beide richtingen. Dit heeft weer tot gevolg dat zij zich zowel op het maatschappelijk als het constitutionele vlak dienen te ontplooien. Zij zijn geen 'Verfassungsorgan', maar vallen (t.a.v. enkele aspecten) wel onder de werking van de grondwet (politieke partijen als 'verfassungsrechtlichen Institutionen') en kunnen partij zijn in een 'Organstreitverfahren'.

In de functietypering van het meewerken aan de politieke wilsvorming worden zowel de waarborg van, als ook de grens aan het functioneren van politieke partijen verwoord. De waarborg is gelegen in de taak van de partijen zoals die in de definitie van het begrip politieke partij opgesloten ligt. $\mathrm{Nu}$ met name het meewerken aan, c.q. het beïnvloeden van de politieke wilsvorming van het volk een essentieel onderdeel vormt van het wezen van een politieke partij, is de omschrijving in art. 21 lid 1 , eerste volzin GG strikt genomen overbodig. De grens aan het functioneren van de politieke partijen is gelegen in het meewerken c.q. beïnvloeden. Art. 21 GG sluit dus een monopolie van politieke partijen bij de politieke wilsvorming uit. Iedere groepering, al dan niet georganiseerd, en ieder individuele burger heeft daartoe (ook) het recht.

134. Vergl. Model/Müller, a.w., p. 276; Von Münch, a.w., p. 11: Alfert, a.w., p. 182.

135. Dit valt af te leiden uit: BVerfG 19 juli 1966, BVerfGE 20, 56 (101). 
Dat de politieke partijen meewerken bij de politieke wilsvorming dient ruim te worden geïnterpreteerd: elke vorm van beïnvloeding van de politieke wilsvorming is toegestaan, zolang hij maar legaal is. Het PartG geeft in $\S 1$ lid 2 een niet-limitatieve opsomming van mogelijkheden. Dit artikel wordt in de literatuur overwegend negatief beoordeeld, omdat het bol staat van de gemeenplaatsen en vanzelfsprekendheden. ${ }^{136}$ Toch komt aan het artikel enige betekenis toe omdat er in feite een uitbreiding van de functie van de politieke partijen in te lezen is. Naast het bijdragen aan de politieke wilsvorming van het volk, werken de partijen ook mee aan de vorming van de wil van staat. Dit ligt besloten in de vier als laatste genoemde taken in het artikel. ${ }^{137}$

Het begrip politieke wilsvorming is in tegenstelling tot de meeste overige bepalingen over de politieke partijen ook niet in het PartG uitgewerkt. Preuß definieert het als volgt:

"Politische Willensbildung ist der Prozeß der Formung, Artikulierung und Geltendmachung von Bedürfnissen, Interessen und Meinungen in bezug auf die Erhaltung, Veränderung oder Beseitigung der für das Gemeinwesen konstitutiven Herrschaftsverhältnisse. Politische Willensbildung ist gleichbedeutend mit der Politisierung sozialer Konflikte. ${ }^{n 138}$

Of een partij zich in voldoende mate inlaat met de (beïnvloeding van de) politieke wilsvorming om als politieke partij in de zin van het Grundgesetz en het PartG aangemerkt te worden, wordt beoordeeld aan de hand van het partijprogramma, dat zoveel mogelijk politieke thema's moet bevatten. ${ }^{139}$ Zo waren bijvoorbeeld de Groenen in hun beginfase geen politieke partij in de zin van het Grundgesetz. omdat zij slechts én programmapunt (het milieu) hadden.

Belangrijk, zo niet het belangrijkste onderdeel van de politieke wilsvorming zijn de 'Wahlen und Abstimmungen' (art. 20 lid 2 GG). Hierdoor handelt het volk zelf direct als staatsvolk en als politieke groepering. Met betrekking tot dit aspect van de politieke wilsvorming nemen de politieke partijen een bijzondere positie in omdat, afgezien van individuele kiesgerechtigden,

136. Vergl. Von Münch, a.w., p. 20/21; Kunig, a.w., p. 110.

137. Vergl. Maunz/Zippelius, a.w., p. 76.

138. Preuß, a.w., p. 20. Zie voorts over de inhoud van dit begrip: Kunig, a.w., p. 112 .

139. Vergl. Alfert, a.w., p. 183. 
alleen zij bevoegd zijn tot het stellen van kandidaten. Om hun status als politieke partij te behouden zijn zij zelfs verplicht regelmatig aan verkiezingen deel te nemen, ongeacht het resultaat. Het PartG bepaalt dat een politieke partij haar status verliest wanneer zij zes jaar lang niet aan verkiezingen voor de Bondsdag of de Landdagen heeft deelgenomen.

Politieke wilsvorming van het volk heeft betrekking op het gehele, nietgeorganiseerde volk. Daarvan dient te worden onderscheiden de wilsvorming van de staat ex art. 20 lid 2, die zoals hiervoor bij de bespreking van art. $20 \mathrm{GG}$ reeds werd aangegeven slechts betrekking heeft op de 'Aktivbürgerschaft'.

\subsubsection{De positie van de fracties}

De fractie is de vertegenwoordiger van de politieke partij in de Bondsdag. Zij is echter niet alleen een deel van de partij, maar tegelijkertijd ook "als Gliederung des Bundestages der organisierten Staatlichkeit eingefügt". ${ }^{140}$ In dat opzicht kan de fractie worden beschouwd als het belangrijkste onderdeel van de Bondsdag. In de fracties zijn de leden van de Bondsdag naar politieke richting verenigd. Zij hebben een belangrijk aandeel bij de menings- en wilsvorming van de afgevaardigden en daarmee van het gehele parlement. ${ }^{141}$ Het Bundesverfassungsgericht ziet de fractie als "notwendige Einrichtungen des Verfassungslebens", toegerust met eigen rechten, om een ordelijke werkwijze van het parlement te verzekeren. Dit brengt mee dat zij gerechtigd zijn tot het instellen van een 'Organstreitverfahren'.

Hoewel fracties voor de werkzaamheden van het parlement onontbeerlijk zijn, bevat de Duise grondwet geen nadere regeling voor hun functioneren. ${ }^{142}$ De fracties vinden hun juridische grondslag in de 'Geschäftsordnung des Deutschen Bundestages' (GeschO BT), het Reglement van Orde van de Bondsdag, dat in $\S 10$, lid 1 de in art. 21 lid 1 , eerste volzin

140. Badura, Staatsrecht, a.w., p. 310.

141. Vergl. W. Zeh, Gliederung und Organe des Bundestages, in: Isensee/ Kirchhof, a.w. (deel 2), p. 393 en p. 397.

142. De vermelding van fracties als maatstaf voor berekening van het aantal bondsdagafgevaardigden in de zgn. "Gemeinsamer Ausschu $\beta$ " voor defensie-aangelegenheden van Bondsdag en Bondsraad (art. 53a GG, in 1968 ingevoegd) is in dit kader niet van belang. 
GG besloten liggende nauwe samenhang tussen politieke partijen en fracties zichtbaar maakt: ${ }^{143}$

Die Fraktionen sind Vereinigungen von mindestens fünf vom hundert der Mitglieder des Bundestages, die derselben Partei oder solchen Parteien angehören, die aufgrund gleichgerichteter politischer Ziele in keinem Land miteinander im Wettbewerb stehen. Schließen sich Mitglieder des Bundestages abweichend von Satz 1 zusammen, bedarf die Anerkennung als Fraktion der Zustimmung des Bundestages.

Deze redactie van de bepaling omtrent de fracties is in 1969 ontstaan. Voordien (d.i. sinds de inwerkingtreding van de GeschO BT in 1952) bepaalde het reglement slechts dat leden van de Bondsdag die tot dezelfde partij behoorden, een fractie konden vormen. Hierdoor konden de leden van de CDU en CSU (de CDU-exponent in Bayern) alleen met toestemming van de gehele Bondsdag een fractie vormen; door de huidige redactie is dit niet meer nodig.

De huidige definitie is niet zonder kritiek gebleven. Met name op het punt van de vorming van fracties blinkt zij niet in helderheid uit. Los van het feit dat de definitie geen regels bevat over de toelating tot of het verlaten van een fractie, wekt de term 'Vereinigungen' de indruk dat het ieder lid van de Bondsdag vrij zou staan om al dan niet tot een fractie toe te treden. Daarnaast impliceert de definitie dat alleen leden van een partij een fractie kunnen vormen; daarmee gaat zij voorbij aan het feit dat onder het Duitse kiesstelsel het niet vereist is dat iemand daadwerkelijk lid is van een bepaalde politieke partij, om voor deze kandidaat te staan. ${ }^{144}$

Ook geeft de definitie geen uitsluitsel over de vraag of de fracties een orgaan van de Bondsdag zijn of eenvoudigweg een politieke indeling daarvan. De heersende leer kiest, zij het aarzelend, voor het eerste. ${ }^{145}$ Deze keuze is gebaseerd op de in $\$ 10$ Gescho besloten liggende relatie tussen fractie en partij. Hieruit wordt afgeleid dat de fracties, door het 'vertegenwoordigen' van de wil van hun politieke partij in de Bondsdag, een parlementaire functie vervullen. Ook het feit dat de fracties partij

143. Vergl. Hesse, a.w., p. 226: Zeh, a.w., p. 393. In dezelfde zin: D.J. Elzinga/C. Wisse, De parlementaire fracties (Nederlands parlementsrecht, deel 5), Groningen 1988, p. 82.

144. Vergl. Meyer, a.w., p. 154/155.

145. Vergl. Schramm, a.w., p. 58. 
kunnen zijn in een 'Organstreitverfahren' pleit voor deze opvatting. Aanhangers van de tegengestelde opvatting erkennen dat de fracties weliswaar onderdelen van de politieke partij zijn en aan de partijen de legitimatie ontlenen om aan de politieke wilsvorming deel te nemen, maar dit betekent niet dat zij -anders dan de Bondsdag in zijn geheel- het gehele volk vertegenwoordigen en namens het volk handelen. ${ }^{146}$ Daarnaast staat dan nog de opvatting dat het, vooral als gevolg van het ontbreken van jurisprudentie van het $\mathrm{BVerfG}$, niet mogelijk is het karakter van de fracties aan te geven. ${ }^{147}$ In ieder geval hebben de fracties een eigen karakter: zij zijn bijvoorbeeld geen commissie ('Ausschuß') van de Bondsdag in de zin van art. $43 \mathrm{GG} .^{148}$

Het feit dat de fractie deel is van het parlement heeft o.m. tot gevolg dat op haar het parlementsrecht en niet het partijrecht van toepassing is. De in de partijwetgeving (m.n. de laatste twee volzinnen van art. 21 lid 1 GG) aangelegde normen voor de (interne) organisatie van de partij, zijn daarom niet van toepassing. Hoewel noch het $\mathrm{GG}$, noch de GeschO van de Bondsdag regels omtrent de organisatie van de fractie bevatten, betekent dit niet dat het functioneren van de fracties geheel vrij is. De status van de fractie als (deel-)orgaan van het parlement ontdoet haar niet van haar in het Grundgesetz en de GeschO -al dan niet expliciet- verwoorde en door het Bundesverfassungsgericht erkende functie als parlementair vertegenwoordiger van de partijwil. ${ }^{149}$ Het uitoefenen van deze functie kan niet geschieden zonder bij de vorming en organisatie van fracties enige elementaire democratische beginselen in acht te nemen. ${ }^{150}$ Deze eis geldt ook voor regelingen betreffende het interne functioneren van de fractie. ${ }^{151}$

De fracties en niet de partijen zijn de drager van de binnenparlementaire wilsvorming en werkzaamheden; zij zijn bestanddelen van de staatsorgani-

146. Vergl. Maunz/Dürig, a.w., randnr. 14 bij art. 40 GG.

147. Vergl. Zeh, a.w., p. 394/395. Uitvoerig: Achterberg, a.w., pp. 275-278; Stern, a.w. (deel 1), pp. 1025-1027.

148. Vergl. Schmidt-Bleibtreu/Klein, a.w., p. 611.

149. Vergl. Tsatsos/Morlok, a.w., p. 215.

150. Vergl. Klein, Status des Abgeordneten, a.w., p. 373, die spreekt van "das Gebot innerfraktioneller Demokratie".

151. Over de interne structuren van de fracties: Achterberg, a.w., pp. 283-290; Ellwein/Hesse, a.w., pp. 251-257; Elzinga/Wisse, a.w., pp. 83-85. 
satie, niet van de organisatie van de partij. ${ }^{152}$ Voor de bepaling van hun staatsrechtelijke positie moet daarom worden aangesloten bij art. $38 \mathrm{GG}$. Toch vinden de fracties hun bestaansgrond impliciet ook in art. $21 \mathrm{GG}$. Zij zijn als 'partijen' in het parlement het noodzakelijke bemiddelingsorgaan van de partij-invloed in het parlement. Daarom is de politieke partij, als buiten-parlementaire organisatie, genoodzaakt een van haar wil afwijkend standpunt van haar Bondsdagfractie van buiten te beïnvloeden. De toelaatbaarheid van deze beïnvloeding vindt, evenals de toelaatbaarheid van benvloeding van individuele fractieleden, haar grens in art. 38 GG: ook de fractie is niet gebonden aan lastgeving c.q. besluitvorming van de partij(organen). ${ }^{153}$

Hieraan verwant is de vraag of een meerderheid binnen de fractie of de fractieleiding de individuele volksvertegenwoordiger kunnen binden. Het antwoord op deze vraag luidt ontkennend voorzover er sprake is van fractiedwang. De fractie kan een fractielid niet verplichten het fractiestandpunt over te nemen. Een juridische binding is, zoals in de vorige paragraaf reeds is uiteengezet, onverenigbaar met art. $38 \mathrm{GG}$. Fractiediscipline (in de vorm van een politieke, dus morele verplichting voor afgevaardigde) wordt daarentegen in overeenstemming met de -ook door art. 21 GG erkenderealiteit van de partijenstaat geacht. ${ }^{154}$ Sommigen achten fractiediscipline zelfs noodzakelijk voor een goed functionerend parlement. ${ }^{155}$ Voorwaarde daarbij is wel dat "die Unterwerfung unter Programm und Satzung freiwillig erfolgt und eine Lösung aus der freiwillig übernommenen Bindung jederzeit durch Austritt aus der Partei möglich ist". ${ }^{156}$

152. Vergl. Preuß, a.w., p. 37.

153. Vergl. Tsatsos/Morlok, a.w., p. 215; Ellwein/Hesse, a.w., p. 257; Zeh, a.w., p. 398; Badura (Staatsrecht), a.w., p. 310. Volledig tegengesteld, maar niet overtuigend: Preuß, a.w., pp. 37-39.

154. Tsatsos/Morlok, a.w., p. 216; Schramm, a.w. p. 93; Badura, Staatsrecht, a.w., p. 307. Anders: Achterberg, a.w., p. 218/219.

155. Vergl. Stern, a.w. (deel 1), p. 1075/1076; Ellwein/Hesse, a.w., p. 243.

156. Maunz/Dürig, a.w., randnr. 67; vergl. ook dez., randnr. 96 en Hesse, a.w., p. 233. In dezelfde zin: Schramm, a.w., p. 93. 


\subsection{Partijenstaat versus representatieve democratie: het Spannungsverhältnis tussen art. 21 en art. 38 GG}

Het GG verankert in art. 38 lid 1 het 'klassieke' systeem van staatsrechtelijke vertegenwoordiging waarin de volksvertegenwoordigers het vrije mandaat bezitten, door te bepalen dat de door het volk (c.q. het daartoe gerechtigde deel daarvan) gekozen afgevaardigden het gehele volk vertegenwoordigen, niet gebonden zijn aan 'Aufträge und Weisungen', en slechts aan hun geweten onderworpen zijn. Tegelijkertijd lijkt het GG in art. 21 de reeds ten tijde van de Republiek van Weimar ontstane (en later door Leibholz verfijnde) partijenstaat-gedachte en de daaraan verbonden leer van het electorale mandaat te bevestigen door in lid 1 te bepalen dat de politieke partijen meewerken bij de politieke wilsvorming van het volk. Hoewel uit art. 21 GG niet expliciet een verdere ontwikkeling van de moderne parlementaire democratie als partijenstaat valt af te leiden, is de heersende opvatting in de literatuur dat deze ontwikkeling wel degelijk door het GG beoogd wordt. Ook het Bundesverfassungsgericht heeft dit geleidelijk aan erkend: met de grondwettelijke erkenning van de politieke partijen "ist von Bundesverfassungs wegen der moderne demokratische Parteienstaat legalisiert worden". 157

Het is echter de vraag of het wel mogelijk is de moderne partijenstaatdemocratie naast de representatieve parlementaire democratie te stellen en deze twee concepten van het begrip 'democratie' te combineren:

"In Wirklichkeit schließt nämlich das Bekenntnis zur modernen parteienstaatlichen Massendemokratie das gleichzeitige Bekenntnis zu den Grundsätzen des liberalen parlamentarisch-repräsentativen Demokratismus aus, weil es sich hier dem Prinzip nach um verschiedene Strukturtypen der Demokratie handelt. ${ }^{n 158}$

Weliswaar heeft de wetgever later gepoogd de tegenstelling tussen beide concepten weg te nemen door in het PartG de rol van de partijen te verdui-

157. BVerfG 12 juli 1960, BVerfGE 11, 266 (273). In eerdere uitspraken hanteerde het Bundesverfassungsgericht op dit punt mindere stellige bewoordingen; zie bijvoorbeeld BVerfG 16 maart 1955, BVerfGE 4, 144 (155).

158. G. Leibholz, Parteienstaut und repräsentative Demokratie. Eine Betrachtung zu Art. 21 und 38 des Bonner Grundgesetzes, in: Rausch, a.w., p. 236 (cursivering RK). 
delijken, maar de daarin gehanteerde formuleringen zijn dusdanig vaag dat zij niets veranderen aan de "Unentschiedenheit der Normen". ${ }^{159}$

Het Bundesverfassungsgericht heeft reeds vrij spoedig nadat het met zijn werkzaamheden begonnen was, een uitspraak moeten doen omtrent het spanningsveld tussen het vrije mandaat van de individuele volksvertegenwoordiger ex art. $38 \mathrm{GG}$ en de opdracht van art. 21 GG dat de politieke partijen meewerken bij de politieke wilsvorming van het volk en de hieruit voortvloeiende tegenstelling tussen de afgevaardigde als onafhankelijk volksvertegenwoordiger en de afgevaardigde als exponent van zijn partijorganisatie. Het Bundesverfassungsgericht overwoog daarbij onder meer dat het GG de politieke werkelijkheid recht doet door uitdrukkelijk te erkennen dat de politieke partijen meewerken bij de politieke wilsvorming van het volk. Door de grondwettelijke dubbelfunctie van de afgevaardigden als vertegenwoordigers van het gehele volk en als exponenten van een politieke partij, maakt de grondwet een 'Spannungsverhältnis' tussen art. 21 GG en art. 38 GG zichtbaar. Deze artikelen laten zich theoretisch moeilijk met elkaar in overeenstemming brengen. Een uitweg uit deze tegenstelling is volgens het Bundesverfassungsgericht te vinden wanneer bedacht wordt dat

"(..) es bei Art. 38 GG um einem Satz aus dem gesicherten ideologischen Bestand des Verfassungsrechts der liberalen Demokratie handelt, den der Verfassungsgesetzgeber als herkömmlich und daher unbedenklich übernommen hat, ohne daß ihm dabei die prinzipielle Unvereinbarkeit mit Art. 21 GG voll deutlich geworden wäre. Immerhin hat sich die Auslegung mit der in diesen positiven Normen des Grundgesetzes in Erscheinung tretenden Spannungslage auseinanderzusetzen. Die Lösung kann nur so erfolgen, daß ermittelt wird, welches Prinzip bei der Entscheidung einer konkreten verfassungsrechtlichen Frage jeweils das höhere Gewicht hat. ${ }^{-1 \omega}$

Deze uitspraak is wel bekritiseerd om de historische context waarin art. 38 GG door het Bundesverfassungsgericht werd geplaatst en om het ontbreken

159. W. Rudzio, Das politische System der Bundesrepublik Deutschland, Opladen 1983, p. 103.

160. BVerfG 23 oktoher 1952, BVerfGE 2, 1 (72/73). In dezelfde zin: BVerfG 16 maart 1955, BVerígE 4, 144 (151). 
van een theoretische grondslag van de parlementaire partijdemocratie. ${ }^{161}$ Door de keuze voor een pragmatische oplossing van het Spannungsverhältnis zijn uit het oordeel van het Bundesverfassungsgericht geen criteria af te leiden ten gunste van welk artikel in concrete gevallen de beslissing dient te luiden. Een antwoord op vragen als de omvang en grenzen van fractiediscipline of de gevolgen van het al dan niet gedwongen uittreden van de afgevaardigde uit partij of fractie, wordt daarmee in hoge mate arbitrair.

Naar aanleiding van bovengenoemde uitspraak van het Bundesverfassungsgericht en de kritiek daarop is in de doctrine getracht wel te komen tot een onderlinge afstemming van de in art. $21 \mathrm{GG}$ en art. $38 \mathrm{GG}$ vastgelegde beginselen. Daarbij wordt in het algemeen niet ontkend dat beide artikelen 'Strukturtypen' bevatten, die moeilijk met elkaar te verenigen zijn. Slechts een enkeling ontkent het bestaan van een 'Spannungsverhältnis' door te stellen dat alleen art. 21 GG een 'Strukturtyp' vastlegt, gezien de nauwe aansluiting op art. 20 en de plaatsing van het artikel in het hoofdstuk in het Grundgesetz over de bond en de landen. Art. 38 GG is in deze opvatting geen 'Strukturtyp', maar regelt slechts de verkiezingen en de gevolgen daarvan. Nu art. 38 GG geen norm bevat, is er dus ook geen spanningsveld van normen. ${ }^{162}$ Ook is wel beweerd dat het gegeven dat de afgevaardigden in politieke zin van hun partij en fractie afhankelijk zijn, niets heeft uit te staan met de juridische constructie van het vrije mandaat. De betreffende grondwetsbepalingen zijn daarom niet "prinzipiell unvereinbar, sondern ergänzen sich, indem sie verschiedene Aspekte desselben Problems regeln". ${ }^{163}$

De heersende opvatting is echter dat aan art. 38 GG een zelfstandige betekenis toekomt. Het is geen lex specialis van art. $21 \mathrm{GG}^{1+4}$ Evenmin

161. Vergl. onder meer H.-P. Schneider, a.w., p. 281 en D. Rauschning, Das parlamentarische Regierungssystem des Grundgesetzes in der Rechtsprechung des Bundesverfassungsgerichts, in: Ch. Starck (red.), Bundesverfassungsgericht und Grundgesetz, deel 2, Tübingen 1976, p. 220.

162. Preuß, a.w., p. 40.

163. Hofmann/Dreier, a.w., p. 185.

164. Vergl. Achterberg, a.w., p. 218; Schramm, a.w., p. 90. Anders: Von Münch, a.w, p. 495, die de mening toegedaan is dat in ieder geval het element van de gewetensvrijheid uit art. 38, lid 1, tweede volzin GG lex specialis van art. $21 \mathrm{GG}$ is. 
is het een bepaling van louter technisch recht, maar bevat het in de tweede volzin van het eerste lid een positief-rechtelijk voorschrift. Het GG heeft zich in art. 38 uitgesproken voor het vrije mandaat, niet voor het electorale mandaat. Zowel art. $21 \mathrm{GG}$ als art. $38 \mathrm{GG}$ leggen een grondwettelijke norm vast, waardoor wel degelijk een 'Spannungsverhältnis' ontstaat. ${ }^{165}$ Dit kan echter worden opgelost door de huidige functie en samenhang van beide bepalingen te beschouwen in plaats van uit te gaan van een historisch bepaalde, principiële tegenstelling tussen partijenstaat en representatieve democratie. In de tegenwoordige tijd kan een democratie niet zonder een effectief functionerend parlement, dat de vele problemen waarvoor het zich gesteld ziet kan oplossen. Dit functioneren wordt vooral mogelijk gemaakt door de politieke partijen, die door hun vertegenwoordigers aan de werkzaamheden van het parlement deelnemen en daarmee uitvoering geven aan de hun door het Grundgesetz gegeven opdracht aan de politieke wilsvorming van het volk mee te werken. Het parlement wordt door het Grundgesetz niet gezien als een vergadering van een onafhankelijke, als afzonderlijke eenheden gekozen (elite)groep; veel meer worden de afgevaardigden gezien in hun relatie tot hun partijen. In dit verband wordt wel gesproken van de "Parteibezogenheit des freien Mandats". ${ }^{166}$ De politieke partijen moeten niet beschouwd worden als een belemmering van de onafhankelijkheid van de individuele volksvertegenwoordiger, maar juist als belangrijke voorwaarde voor hun functioneren:

"Das Grundgesetz macht gerade in den Bestimmungen der Art. 21 und 38 Abs. 1 Satz 2 deutlich, daß die Stellung des Abgeordneten nicht ohne das Wirken der politischen Parteien verstanden werden kann und daß umgekehrt für die Mitwirkung der politischen Parteien im Parlament das freie Mandat des Abgeordneten wesentlich ist" ${ }^{167}$

Wanneer de politieke partijen door de parlementaire werkzaamheden van hun afgevaardigden aan de politieke wilsvorming deelnemen (c.q. meewerken), dienen zij het vrije mandaat van de individuele volksvertegenwoordiger ex art. 38 lid 1, tweede volzin GG, te respecteren. Dit mandaat beoogt niet de afgevaardigde volledig onafhankelijk van zijn partij of fractie te maken: art. $38 \mathrm{GG}$ is geen uitzondering op art. $21 \mathrm{GG}$ in die zin

165. Vergl. Schramm, a.w., p. 90.

166. Vergl. H.-P. Schneider, a.w., p. 281; Schramm, a.w., p. 89.

167. Hesse, a.w., p. 233. 
dat de politieke partijen op generlei wijze hun afgevaardigden in Bondsdag zouden mogen beïnvloeden. Beînvloeding van volksvertegenwoordigers door de politieke partijen is juist een van de manier waarop de partijen hun grondwettelijke taak van het meewerken aan de politieke wilsvorming kunnen uitvoeren. Art. 38 GG verhindert echter dat de uiterste consequentie van de partijenstaat-gedachte kan intreden, door een monopolie van de politieke partijen bij de wilsvorming van het volk te verbieden. Net zoals in Nederland heeft het vrije mandaat in het Duitse staatsrecht dan ook vooral een restfunctie:

"Das freie Mandat begrenzt die Bindungen des Abgeordneten an sein Partei und Fraktion, indem es diesen Bindungen die rechtliche Sanktion vorenthält. Kein Abgeordneter kann deshalb rechtlich zu einem bestimmten Verhalten im Parlament gezwungen werden $(\ldots)^{n 168}$

Ook de rechtspraak van het Bundesverfassungsgericht lijkt geleidelijk de opvatting van de doctrine te volgen en, zij het nogal aarzelend, in de richting van de restfunctie-opvatting te gaan. Zonder het voortbestaan van het 'Spannungsverhältnis' te ontkennen, wordt de betekenis van art. 38 GG meer en meer tot de restfunctie gereduceerd:

"Es mag in der Konsequenz eines idealtypisch zu Ende gedachten Parteienstaates liegen, daß sich die Willensbildung des Volkes nur durch das Medium der Parteien vollzöge und die gleichberechtigte Teilnahme der Aktivbürger an der Auslese der Wahlbewerber insbesondere nur in dem von den politischen Parteien beherrschten Raum erfolgen könnte. Diese Konsequenz wird jedoch van Grundgesetz auf Bundesebene durch das Bekentnis zum repräsentativen Status der Abgeordneten in Art. 38 GG verfassungskräftig abgewerht. "169

Tot een uitdrukkelijke herroeping van de pragmatische oplossing van de uitspraak van 1952 is het in de meer recente jurisprudentie van het Bundesverfassungsgericht (nog) niet gekomen. Daartoe ontbreekt overigens ook de noodzaak nu het ontbreken van een concrete oplossing van de tegenstellingen tussen de 'Strukturtypen' van art. 21 GG en art. 38 GG in de praktijk nog niet tot noemenswaardige problemen heeft geleid. Uit de jurisprudentie over het 'Spannungsverhältnis' valt af te leiden, dat voor de beantwoording

168. Idem.

169. BVerfG 9 maart 1976, BVerfGE 41, 399 (416). In dezelfde zin reeds: BVerfG 12 juli 1960, BVerfGE 11, 266 (273). 
van de vraag ten gunste van welk artikel in een specifiek geval dient te worden beslist, twee randvoorwaarden gelden. Allereerst kan de staatsrechtelijke positie van een volksvertegenwoordiger niet los worden gezien van zijn relatie tot de politieke partij; de benoeming tot volksvertegenwoordiger heeft de afgevaardigde in hoge mate, zo niet geheel aan zijn betrokkenheid tot de partij te danken. Gevolg van het vrije mandaat is echter dat de staatsrechtelijke positie van de individuele volksvertegenwoordiger niet slechts door zijn relatie met zijn partij wordt bepaald; het verschaft hem een zelfstandige status. Voorts geldt als uitgangspunt dat de politieke partijen, wanneer zij trachten hun afgevaardigden in het parlement te beïnvloeden, daarmee slechts de opdracht vervullen die hen in art. 21 GG is gegeven. Beïnvloeding van afgevaardigden is derhalve toelaatbaar, maar art. 38 lid 1, tweede volzin GG verhindert dat deze beïnvloeding zover gaat dat zij afbreuk doet aan de zelfstandige positie van de afgevaardigden. Hierdoor zal de beslissing veelal in het voordeel van art. $38 \mathrm{GG}$ uitvallen, zelfs wanneer dit artikel gehanteerd wordt in zijn restfunctie in de partijenstaat. In een enkel geval zal de beslissing ten gunste van art. $21 \mathrm{GG}$ uitvallen. Dit zal bijvoorbeeld het geval zijn wanneer een fractie zou besluiten een weerspannig lid te verbieden het woord te voeren in, of terug te roepen uit een parlementaire commissie waarin hij namens de fractie zitting heeft. Het recht daartoe ontleent de fractie aan het feit dat aan het lidmaatschap van een parlementaire commissie een besluit van de fractie ten grondslag ligt, en niet een -openbare- verkiezing. ${ }^{170}$ Art. 38 GG staat aan een dergelijk besluit van de fractie niet in de weg omdat de parlementaire rechten van de betrokkene afgevaardigde (en dus zijn zelfstandigheid) hierdoor in principe niet worden geschonden: hij kan immers in het plenaire debat alsnog zijn opvattingen kenbaar maken. ${ }^{171}$

170. Dit voorbeeld is ontleend aan Model/Müller, a.w., p. 388. Zie voor een ander voorbeeld: Schramm, a.w., p. 94.

171. Vergl. BVerfG 13 juni 1989, BVerfGE 80, 188 (225). 


\section{IE ONAFHANKELIJKHEID VAN DE VOLKSVERTEGENWOORDIGER IN HET VERENIGD KONINKRIJK}

\subsection{Inleiding}

Het is een feit van algemene bekendheid dat het Verenigd Koninkrijk geen geschreven grondwet heeft. Er is geen 'basiswet' die de grondslag vormt voor de inrichting van de Britse staat, zijn rechtsorde en de bevoegdheden van de staatsorganen. Een dergelijke wet heeft in het Verenigd Koninkrijk nooit bestaan. De verklaring voor het ontbreken ervan is vooral een historische: de geleidelijke en ononderbroken ontwikkeling van het Britse staatsbestel van monarchie (in de strikte betekenis van het woord) naar parlementaire democratie. Waar andere staten overgingen tot het opstellen van een grondwet om een nieuwe start te maken en/of een basis te creëren voor de uitoefening van hun gezag, deed deze behoefte zich in het Verenigd Koninkrijk niet of nauwelijks gelden. Daarnaast zijn ook andere factoren oorzaak van het ontbreken van een grondwet: de geïsoleerde geografische ligging, een relatief grote homogeniteit, een tolerante en pragmatische benadering van religieuze en politieke conflicten, het geringe enthousiasme onder politici voor een beperking van hun handelingsvrijheid wanneer zij aan het bewind zijn, en "a widely diffused acceptance of traditional forms, gradualism and parliamentary methods". ${ }^{1}$

Waar hiervoor voor Nederland en de Bondsrepubliek Duitsland een beschouwing over de relevante artikelen uit de grondwet het logische vertrekpunt vormden voor de beschrijving van de positie van de individuele volksvertegenwoordiger en de rol van het vrije mandaat daarbij, is dat bij het ontbreken van een grondwet voor het Verenigd Koninkrijk onmogelijk. Het is daarom zaak enige aandacht te besteden aan de bronnen en beginselen van het Britse staatsrecht, voorzover deze relevant zijn voor de bepaling van de positie van de volksvertegenwoordigers. Deze bronnen en beginselen staan centraal in paragraaf 2 . Nu zij vooral historisch bepaald zijn, zal vervolgens in paragraaf 3 een beschrijving worden gegeven van de

1. S.A. de Smith, Constitutional and administrative law, 6e druk, bewerkt door R. Brazier, Londen 1989, p. 9/10. 
ontwikkeling van de positie van de volksvertegenwoordiger in het Verenigd Koninkrijk en de aard van hun mandaat, waarbij ook (summiere) aandacht zal worden besteed aan de algemene constitutionele geschiedenis van het Verenigd Koninkrijk. Aan de hand hiervan zal in paragraaf 4 het huidige formele kader van de onafhankelijkheid van de 'Member of Parliament' (MP) aan de orde worden gesteld, waarna in de volgende paragrafen de invulling hiervan in de praktijk zal worden beoordeeld. In paragraaf 5 staat daarbij de relatie tussen de MP en zijn centrale en parlementaire partijorganisatie centraal, in paragraaf 6 zijn relatie met zijn lokale partijorganisatie en zijn kiezers.

\subsection{Beginselen en bronnen van het Britse staatsrecht}

Het ontbreken van een geschreven grondwet voor het Verenigd Koninkrijk neemt vanzelfsprekend niet weg dat ook dit land belangrijke constitutionele beginselen kent. Iets minder vanzelfsprekend is het antwoord op de vraag of deze beginselen impliceren dat er een constitutie voor het Verenigd Koninkrijk bestaat. Tegen de bevestigende beantwoording van deze vraag door de meerderheid van de Britse staatsrechtgeleerden is wel aangevoerd dat het zinloos is te beweren dat er een constitutie voor het Verenigd Koninkrijk bestaat, nu het, bij ontstentenis van een geschreven kader, onmogelijk is te bepalen welke beginselen wel en welke niet tot die constitutie behoren. ${ }^{2}$ Toch wordt vrijwel algemeen aanvaard dat aan de (materiële) constitutie van het Verenigd Koninkrijk drie basisprincipes ten grondslag liggen, die in de loop der tijden tot ontwikkeling zijn gekomen.

Het overheersende basisprincipe van de Britse constitutie is het beginsel van de juridisch onbeperkte competentie van de formele wetgever, de sovereignty of parliament. ${ }^{3}$ In het Britse staatsrecht bestaat geen hoger

2. Vergl. F.F. Ridley, There is no British constitution: a dangerous case of the emperor's clothes, in: Parliamentary Affairs, vol. 41 (1988), pp. 340361 .

3. Vanwege de vele betekenissen die aan het begrip soevereiniteit toekomen prefereren sommige auteurs de term '(legislative) supremacy of parliament', maar met De Smith/Brazier (a.w., p. 64/65) moet worden toegegeven dat dit eigenlijk lood om oud ijzer is. 
recht dan de formele wetgeving, neergelegd in de Acts of Parliament. De rechterlijke macht is belast met het uitleggen en toepassen van de Acts of Parliament, maar zij is door het ontbreken van enige geschreven bepaling die de bevoegdheden van het parlement op enigerlei wijze beperkt, niet bevoegd de wetten formeel te toetsen. Het begrip parliament moet in dit verband gelezen worden als de 'Queen in Parliament', d.i. het staatshoofd en de beide huizen van het parlement. ${ }^{4}$

De soevereiniteit van het parlement geldt als de hoeksteen van het Britse staatsrecht; als zodanig speelt zij in het Verenigd Koninkrijk de rol die in (de meeste) andere westerse landen door grondwettelijke bepalingen wordt

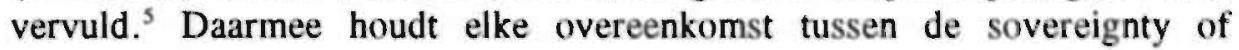
parliament en een grondwet op: omdat een grondwet een beperking van de macht van de formele wetgever impliceert, sluiten de begrippen elkaar uit. Zij kunnen niet naast elkaar bestaan. Desalniettemin wordt vrijwel unaniem erkend dat het mogelijk is in het Verenigd Koninkrijk op enigerlei wijze te komen tot de opstelling van een grondwet die ook de wetgever bindt, waarmee ook een einde zou worden gemaakt aan de sovereignty of parliament. ${ }^{6}$ Overigens dient het staatsrechtelijke principe van de sovereignty of parliament niet te worden verward met de vraag naar de feitelijke machtsverdeling. Dat regering en parlement het soms moeten afleggen tegen de druk van georganiseerde maatschappelijke krachten doet in geen enkel opzicht afbreuk aan hun rechtens onbeperkte bevoegdheid. Wel wordt het beginsel van de juridische soevereiniteit van het parlement de laatste tijd niet meer zo overtuigd beleden als vroeger wel eens het geval was, hetgeen

4. Aan het begrip parlement komt in het Britse staatsrecht een drietal betekenissen toe. Naast de hier gebezigde betekenis kan zij ook beperkt zijn tot beide huizen van het parlement of zelfs slechts tot het Lagerhuis. In deze paragraaf wordt met het parlement steeds de 'Queen in Parliament' bedoeld.

5. Vergl. E.C.S. Wade/A.W. Bradley, Constitutional and administrative law, 10 e druk, Londen 1985, p. 7.

6. Vergl. L. Prakke, Het Verenigd Koninkrijk van Groot-Britannië en NoordIerland, in: L. Prakke/C.A.J.M. Kortmann (red.), Het staatsrecht van de landen der Europese Gemeenschappen, 3e druk, Deventer 1988, p. 681. 
voornamelijk is toe te schrijven aan de toetreding van het Verenigd Koninkrijk tot de EEG. ${ }^{?}$

Waar andere staten in hun grondwet (c.q. de preambule daartoe) zich tot het beginsel van de volkssoevereiniteit verklaren, is dit in het Verenigd Koninkrijk niet het geval. De reden hiervoor is niet zozeer het ontbreken van een geschreven grondwet, maar de sovereignty of parliament. Als gevolg hiervan wordt in het Verenigd Koninkrijk daarom niet tot uitgangspunt genomen dat het volk soeverein is. Het volk is weliswaar in de huidige constellatie door zijn functie bij de verkiezingen als politiek soeverein aan te merken, maar omdat de juridische soeverein (theoretisch) niet aan deze verkiezingen hoeft vast te houden, kan gezegd worden dat in laatste instantie het parlement de enige soeverein is ${ }^{8}$ In de woorden van Ridley:

"Britain never developed this idea of popular sovereignty in constitutional terms, even if we sometimes talk of the sovereignty of the electorate in political terms. Even if the latter were true, it would merely allow the people to choose their government: it does not base the governmental order, the British 'constitution', on their authority and thus gives them only half their right. (Moreover, since a parliamentary majority can change that order, prolong its own life, alter the franchise or reform the electoral system, even the political rights of the electorate depend on Parliament.) What we have, instead, is the sovereignty of Parliament. Parliament determines -and alters- the country's system of government. If we ask where that power comes from, the answer is broadly that Parliament claimed it and the courts recognised it. The people never came into the picture. The liberal (middle-class) democracies established in Europe had, despite their generally limited franchise, to base their constitutions on the principle that ultimate authority

7. Vergl. Prakke, a.w., p. 681. Over de sovereignty of parliament in het algemeen: De Smith/Brazier, a.w., pp. 70-82; Wade/Bradley, a.w., pp. 60-75. Zie voorts: O. Hood Philips, Constitutional and administrative law, 7e druk, bewerkt door P. Jackson, Londen 1987. pp. 41-58; T. Koopmans, Vergelijkend publiekrecht, 2e druk, Deventer 1986, pp. 25-41.

8. C.W. van der Pot/A.M. Donner, Handboek van het Nederlandse staatsrecht, $12 \mathrm{e}$ druk, bewerkt door L. Prakke (e.a), Zwolle 1989, p. 60. 
was vested in the people. Britain seerns to be the sole exception to this democratic path. "9

Het ontstaan van de sovereignty of parliament is historisch bepaald, met name door de gebeurtenissen in de $17 \mathrm{e}$ eeuw. ${ }^{10}$ Aanvankelijk had het beginsel vooral een praktische functie ter regulering van de verhouding tussen parlement en Kroon. In deze betekenis kan het thans nog worden gezien als een belangrijke, maar ook enigszins onnauwkeurige uitdrukking van het democratische beginsel dat het parlement, de (gekozen) volksvertegenwoordiging, meer staatsmacht hoort toe te komen dan andere (overheids)organen. ${ }^{11}$

Naast de oorspronkelijke praktische functie kreeg het beginsel van de sovereignty of parliament vanaf de $19 \mathrm{e}$ eeuw ook een theoretische betekenis. In die hoedanigheid groeide het onder invloed van het werk van A.V. Dicey uit van een beschrijvende tot een normatieve theorie. ${ }^{12}$ Ondanks de vele politieke en maatschappelijke veranderingen die zich sindsdien hebben voorgedaan, en de vele, doorgaans kritische aandacht die het beginsel in de literatuur heeft gekregen, heeft de sovereignty of parliament zijn "absolute and immutable character" 13 behouden. Ook voor het stelsel van staatsrechtelijke vertegenwoordiging in het Britse staatsrecht is de sovereignty of parliament in theorie van belang. Dicey maakte bij de sovereignty of parliament een onderscheid tussen de juridische en de politieke soevereiniteit: de juridische soevereiniteit berust bij het parlement, de politieke bij het electoraat. ${ }^{14}$ De gedachte verbinding tussen het electoraat en het parlement berust op het feit, dat het parlement het volk vertegenwoordigt en dus zijn wil tot uitdrukking moet brengen. ${ }^{15}$ Zolang de juridische

9. Ridley, a.w., p. 344/345.

10. Zie C.R. Munro, Studies in constitutional law, Londen 1987, pp. 79-81, en hieronder ( $\$ 3$ ).

11. Vergl. A.W. Bradley, The sovereignty of Parliament - in Perpetuity?, in: J.L. Jowell/A.D.H. Oliver, The changing constitution, $2 \mathrm{e}$ druk, Oxford 1989 , p. 25.

12. Vergl. Koopmans, a.w., p. 16.

13. Bradley, a.w., p. 26.

14. A.V. Dicey, Introduction to the study of the law of the constitution, 8e druk, Londen 1915, pp. 70-74 en pp. 424-434.

15. J. van der Hoeven, De plaats van de grondwet in het constitutionele recht, Zwolle 1988 (aangevulde heruitgave), p. 70 (cursivering in origineel). 
soeverein, het parlement, vasthoudt aan periodieke verkiezingen, is hij afhankelijk van de politieke soeverein, het electoraat:

"the essence of representative government is, that the legislature should represent or give effect to the will of the political sovereign, i.e. of the electoral body, or the nation". ${ }^{16}$

Behalve de sovereignty of parliament kent het Britse staatsrecht nog een tweetal andere basisprincipes, die echter in dit kader minder relevant zijn, de separation of powers en de rule of law. De separation of powers omvat het beginsel van de scheiding van de staatsmachten, zoals dat in de meeste westerse democratieën algemeen wordt aanvaard. Hoewel de Engelse situatie model heeft gestaan voor de denkbeelden van Montesquieu, geldt ook hier dat in het Verenigd Koninkrijk de machtenscheiding allerminst strikt is doorgevoerd. ${ }^{17}$ Ook in het Verenigd Koninkrijk heeft het parlement naast zijn (mede)wetgevingsfunctie tevens een controlerende functie. Daarnaast is aan een strikte machtenscheiding nog minder de hand gehouden dan in de meeste westerse landen, nu het hoogste rechtscollege van het land (de 'lawlords') deel uit maakt van het House of Lords.

Het andere basisprincipe van het Britse staatsrecht, de rule of law is geen vastomlijnd begrip. In het algemeen wordt het zo uitgelegd dat de uitoefening van de staatsmacht een wettige basis dient te hebben en dat de wet zowel formele als materiële minimumwaarborgen voor gerechtigheid behoort te bieden. ${ }^{18}$

Naast deze constitutionele beginselen zijn ook de bronnen van het Britse staatsrecht van belang. De volgende bronnen kunnen worden onderscheiden:

16. Dicey, a.w., p. 425. In dezelfde zin: J. Harvey/L. Bather, The British constitution and politics, Se druk, Londen 1983, p. 492.

17. Vergl. De Smith/Brazier, a.w., pp. 19-22; Wade/Bradley, a.w., pp. 53-59; Hood Philips, a.w., pp. 29-31; Harvey/Bather, a.w., pp. 355-360. Zie voorts: J. Kingdom, Government and politics in Britain, Cambridge 1991, pp. $38-40$.

18. Vergl. De Smith/Brazier, a.w., p. 18/19; Hood Philips, a.w., pp. 33-39; Harvey/Bather, a.w., p. 11/12 en pp. 382-392; Kingdom, a.w., p. 40/41. Zie voorts: J. Jowell, The rule of law today, in: Jowell/Oliver, a.w., pp. 3-23. 
1) Wetgeving. Dit is verreweg de belangrijkste bron van het Britse constitutionele recht. Hieronder vallen allereerst de Acts of Parliament (zoals de Bill of Rights 1689, de Act of Settlement 1701, de European Communities Act 1972) die "rules of major importance in the history of the constitution"19 bevatten. Ook de wetten die betrekking hebben op het kiesstelsel en de samenstelling en de functie van het parlement (zoals de Representation of the People Acts) behoren hiertoe. Gedelegeerde wetgeving ('subordinate legislation') geldt ook als bron van constitutioneel recht. ${ }^{20}$

De formele wetgever is de reeds genoemde 'Queen in Parliament', het staatshoofd en beide kamers het parlement, samenwerkend volgens een bepaalde procedure. De wetgevingsprocedure zelf is slechts gedeeltelijk wettelijk geregeld; voor het overige ligt zij vast in de reglementen van orde van de beide huizen en in de common law.

2) Common law. Deze bron is op te vatten als een systeem van jurisprudentieel gewoonterecht. In het Verenigd Koninkrijk geldt zij in vele opzichten als de rechtsbron bij uitstek, vooral voor het privaatrecht. De common law is echter ook van betekenis voor het staatsrecht: het basisprincipe van het Britse staatsrecht, de sovereignty of parliament, behoort tot de common law. ${ }^{21}$ Daarnaast liggen ook de wetgevingsprocedure en de grondslag van de bevoegdheden van de Kroon in de common law besloten. ${ }^{22}$

3) Gewoonte. Hiertoe behoort niet het in de loop van eeuwen door de Engelse rechters op basis van gewoontes opgebouwde recht (dat behoort tot de common law-bron), maar gewoonterecht waaraan de rechter (doorgaans) nog niet te pas is gekomen. In dit kader is vooral de law and custom of Parliament van belang. Hieronder vallen de regels en gebruiken die betrekking hebben op het functioneren, de werkwijze, de privileges en de immuniteiten van beide huizen en die het onbelemmerd functioneren van het parlement mogelijk moeten maken. Een klein deel van deze regels is neergelegd in de wet, een nog kleiner deel berust op jurisprudentie. Het merendeel is echter te vinden in resoluties van de huizen van het parlement, in de handelingen (Hansard) en voor enkele belangrijke onderwerpen in de reglementen van orde. Een deel van de law and custom of Parliament

19. De Smith/Brazier, a.w., p. 23.

20. Hierover: De Smith/Brazier, a.w., p. 23/24 en Prakke, a.w., p. 682/683.

21. Vergl. Wade/Bradley, a.w., p. 17; Prakke, a.w., p. 683.

22. Vergl. De Smith/Brazier, a.w., p. 24/25. 
is nergens als zodanig vastgelegd omdat zij berust op "informal understandings or practices." 23

4) Conventions. Deze bron is voor het Britse staatsrecht van groot belang. Wanneer de conventions (ook wel non-legal rules of the constitution genoemd) buiten beschouwing zouden worden gelaten, zou een volstrekt vertekend beeld worden verkregen. Hood Philips omschrijft conventions als: "Rules of political practice which are regarded as binding by those to whom they apply, but which are not laws as they are not enforced by the courts or by the Houses of Parliament." 24 Conventions kunnen zowel een plicht als een recht impliceren; bijvoorbeeld de plicht voor het House of Lords om het beleid van de gekozen regering, met een meerderheid in het House of Commons, niet te belemmeren of het recht van het staatshoofd om -onder omstandigheden- zijn goedkeuring te onthouden aan een voordracht van de premier tot ontbinding van het Lagerhuis. De voorbeelden geven al aan dat conventions in het algemeen slechts in zeer algemene bewoordingen zijn geformuleerd, hetgeen hun (h)erkenning en toepassing er niet gemakkelijker op maakt. ${ }^{25}$

De hierboven aangehaalde verbinding tussen volk (c.q. het electoraat) en het parlement, die door Dicey in het kader van de sovereignty of parliament werd onderscheiden, krijgt vorm in wat misschien wel gezien kan worden als de belangrijkste convention in het Britse staatsrecht: de convention van het responsible government. Volgens deze convention is het bestuur verantwoording verschuldigd aan het parlement -en daarmee in laatste instantie aan het electoraat- voor de manier waarop het zijn bevoegdheden uitoefent. Brengt het bestuur niet de wil van het electoraat tot uitdrukking, dan kan ontbinding van het parlement en een beroep op de kiezers noodzakelijk zijn. Tijdens de zittingsperiode van het parlement is de regering aan het parlement verantwoording verschuldigd; bij verkiezingen moeten de regering en haar aanhang in het parlement echter verantwoording afleggen aan het electoraat. De kiezers kunnen dan hun instemming betuigen met het gevoerde beleid door de regering een nieuwe

23. De Smith/Brazier, a.w., p. 25 en p. 262/263. Vergl. ook: Wade/Bradley, a.w., p. 30. Uitvoeriger: Th. Erskine May, (Treatise on) The law, privileges, proceedings and usage of Parliament (Parliamentary practice), 20e druk, bewerkt door Ch. Gordon e.a., Londen 1983, pp. 207-216.

24. Vergl. Hood Philips, a.w., p. 113.

25. Vergl. G. Marshall, Constiturional conventions. The rules and forms of political accountability, Oxford 1984, p. $4 / 5$ en p. 210. 
termijn te gunnen of juist dit beleid afkeuren door de concurrerende partij aan de macht te helpen. ${ }^{26}$

De onderkenning van het belang van de conventions voor het politieke en staatkundige leven in het Verenigd Koninkrijk is ook een verdienste van Dicey geweest. Hoewel hij niet de eerste was die het fenomeen aan een grondig onderzoek onderwierp, kan hij gezien worden als de gangmaker voor latere schrijvers. ${ }^{27}$ Dicey onderscheidde twee soorten regels:

"The one set of rules are in the strictest sense 'laws,' since they are rules which (...) are enforced by the Courts; these rules constitute 'constitutional law' in the proper sense of that term, and may for the sake of distinction be called collectively 'the law of the constitution.'

The other set of rules consist of conventions, understandings, habits, or practices which, though they may regulate the conduct of the several members of the sovereign power, of the Ministry, or of other officials, are not in reality laws at all since they are not enforced by the Courts. This portion of constitutional law may, for the sake of distinction, be termed the 'conventions of the constitution,' or constitutional morality. ${ }^{28}$

De conventions zijn "the critical morality of the Constitution"; zij bevatten "the rules that the political actors ought to feel obliged by, if they have considered the precedents and reasons correctly. ${ }^{29}$ De (subjectieve) opvatting van deze politieke actoren is voor het bestaan van de conventions niet van doorslaggevende aard.

Bij vergelijking van Dicey's definitie met de eerdergenoemde definitie van Hood Philips valt op dat Dicey slechts regels die niet door de rechter kunnen worden afgedwongen tot conventions rekent. De uitbreiding tot regels die (ook) niet door een van de beide huizen kunnen worden afgedwongen is echter nodig ter onderscheiding van de regels die wèl door een

26. A.H. Birch, The British system of government, 8e druk, Londen 1990, p. 22.

27. Vergl. A.H.M. Dölle, Over ongeschreven staatsrecht, Groningen 1988, pp. 69-84.

28. Dicey, a.w., p. 23. Op deze passage en de kritiek erop wordt uitvoerig ingegaan door Munro, a.w., pp. 35-60.

29. Marshall, a.w., p. 12 (cursivering in origineel). 
van de huizen kunnen worden afgedwongen; deze laatste behoren tot de 'law and custom of parliament', hoewel er een zekere overlap met de conventions kan zijn. ${ }^{30}$ De reglementen van orde nemen daarbij een bijzondere plaats in: "(..) on analysis they will be found to consist partly of law, partly of mere practice, and only to a small extent of convention. ${ }^{n 1}$

Ook in een ander opzicht wordt Dicey's definitie als minder correct beschouwd, nl. op het punt waar hij ontkent dat conventions rechtsregels zijn. Dit standpunt, vooral aangehangen in de wat oudere literatuur, is thans veelal verlaten. Meer recente literatuur kwalificeert conventions als regels die wel tot het constitutioneel recht behoren, zij het dat deze daarbinnen in sommige opzichten een aparte plaats innemen. ${ }^{32}$ Daarbij dient vooral te worden gedacht aan het niet in rechte afdwingbaar zijn van conventions. Dit laatste betekent overigens allerminst dat conventions niet bindend zouden zijn: "Doubtless all conventions are binding, but some are more binding than others". ${ }^{33}$ Schending ervan brengt een eigen sanctie mee, die niet minder effectief behoeft te zijn dan een beroep op de rechter. Te denken valt aan het afstemmen van een wetsvoorstel, het ontslag van een minister (of zelfs van de hele regering) en -vooral- aan de publieke verontwaardiging, die bij overtreding van een belangrijke convention zeker niet zou uitblijven. ${ }^{34}$

5) Europees gemeenschapsrecht. Ook voor het Verenigd Koninkrijk geldt dat EEG-wetgeving prevaleert boven nationale wetten. Over de vraag in hoeverre dit beginsel een uitzondering vormt op de sovereignty of parliament lopen de meningen uiteen. ${ }^{35}$ Vooral vanuit de Conservative Party wordt regelmatig betoogd dat maatregelen in het kader van de voortschrij-

30. Vergl. Hood Philips, a.w., p. 115.

31. Idem.

32. Vergl. Dölle, a.w., p. 73.

33. De Smith/Brazier, a.w., p. 45.

34. Vergl. Prakke, a.w., p. 684; Dölle, a.w., pp. 73-75. Uitvoerig: Dicey, a.w., pp. 413-468.

35. Vergl. De Smith/Brazier, a.w. p. 26/27 en -vooral- pp. 79-82: "And so this unique Act (de European Communities Act 1972, RK) is a fascinating excercise in equivocation, a wilful manifestation of legislative schizophrenia." (p. 82). Zie voorts: Hood Philips, a.w., pp. $72-74$ en p. 81/82; Bradley, a.w., pp. 35-43; Koopmans, a.w., p. 36/37. 
dende Europese eenwording leiden tot "the greatest abdication of national and parliamentary sovereignty in our history". ${ }^{36}$

6) Doctrine. Deze rechtsbron heeft slechts "persuasive authority". ${ }^{37}$ Ten aanzien van de staatsrechtelijke positie van de individuele volksvertegenwoordiger valt op, dat zowel in de Britse staatsrechtelijke als in de meer politicologisch getinte literatuur relatief weinig aandacht wordt besteed aan vertegenwoordigingstheorieën in relatie met het parlementair stelsel van het Verenigd Koninkrijk. Evenmin kan worden gezegd dat er veel aandacht wordt geschonken aan de relatie tussen de individuele leden van het Lagerhuis en hun kiezers c.q. achterban.

\subsection{De ontwikkeling van het vrije mandaat in het Britse staatsrecht}

Het Verenigd Koninkrijk was -tenminste waar het Engeland betreft $^{38}$ - de eerste staat waar de feodale standenvertegenwoordiging is uitgegroeid tot een echte nationale vertegenwoordiging, gevormd door van hun kiezers onafhankelijke afgevaardigden, die bijeenkomen om de bestuurlijke aangelegenheden van het land te bespreken. Deze ontwikkeling verliep in twee fasen: eerst wist het parlement zijn onafhankelijkheid ten opzichte van de Kroon te bewerkstelligen, om vervolgens door de geleidelijke uitbreiding van het kiesrecht uit te groeien tot een volksvertegenwoordigend or-

36. Aldus de (toenmalige) MP Thatcher in de vergadering van het House of Commons van 26 juni 1991, geciteerd in The Guardian van 27 juni 1991.

37. De Smith/Brazier, a.w., p. 27.

38. Het voert te ver in dit kader uitvoerig in te gaan op de totstandkoming van het Verenigd Koninkrijk in zijn huidige vorm, zie daarvoor bijvoorbeeld Prakke, a.w., pp. 677-679. Het Verenigd Koninkrijk is een eenheidsstaat in die zin dat er voor de vier onderdelen (Engeland, Wales, Schotland en Noord-lerland) slechts één regering en éen parlement is. Dat neemt niet weg dat er tussen de constituerende delen in tal van opzichten belangrijke verschillen bestaan, bijvoorbeeld op de terreinen van de verhouding kerk en staat, rechterlijke organisatie, privaat- en strafrecht, regionaal en plaatselijk bestuur en het onderwijs. Het Verenigd Koninkrijk kent zodoende een aanzienlijke mate van rechtsverscheidenheid binnen een kader van politiek-bestuurlijke eenheid, die echter geen grote verschillen teweeg brengt in de positie van de individuele volksvertegenwoordiger. 
gaan. ${ }^{39}$ De uitgroei van de middeleeuwse representatieve instellingen tot die van de tegenwoordige tijd is in het Verenigd Koninkrijk met tamelijk weinig schokken gepaard gegaan. Waar in andere landen (zoals Frankrijk) een revolutie nodig was om staatsrechtelijke desiderata te realiseren, geldt voor het Verenigd Koninkrijk dat er sprake is van een ononderbroken continuilteit tussen de (laat)middeleeuwse representatieve instellingen en die van de tegenwoordige tijd..$^{40}$ Overigens dient te worden bedacht dat het staatkundig stysteem van het Verenigd Koninkrijk niet zozeer is uitgedacht, maar gegroeid. Het is eerder een bestel dan een stelsel. Pas achteraf zijn de beschrijvers van dat bestel het gaan rechtvaardigen en schematiseren en hebben zij voor al het goede dat zij vonden, veel mooiere en diepzinniger motieven aangegeven dan die waaraan de instellingen hun ontstaan in werkelijkheid te danken hebben. ${ }^{41}$

\subsubsection{Ontstaan van het Engelse parlement}

Vanaf zijn ontstaan is het Engelse parlement een combinatie geweest van 'volks'vertegenwoordiging en gerechtshof; vele van zijn functies zijn op dit laatste aspect terug te voeren. Hierin ligt een fundamenteel verschil met de continentale parlementen (zoals dat van Frankrijk). ${ }^{42}$ De historische oorsprong van het Engelse parlement ligt vooral in de zittingen van het hof van de koning ter afdoening van rechtszaken; in mindere mate is hij gelegen in de feodale vergaderingen die later in standenvergaderingen zijn overgegaan. ${ }^{43}$ Van oudsher had het parlement twee taken. Zijn juridi-

39. Vergl. D. Kavanagh, British politics: continuities and change, $2 \mathrm{e}$ druk, Oxford 1990, p. 213.

40. Prakke, a.w., p. 679; Van der Pot/Donner/Prakke, a.w., p. 57; R.C. van Caenegem, Geschiedkundige inleiding tot het publiekrecht, Gent 1985, p. 71.

41. Van der Pot/Donner/Prakke, a.w., p. 58.

42. Vergl. R. Fawtier, Das Englische Parlament und die Französischen Generalstände im Mintelalter, in: H. Rausch (ed.), Die geschichtlichen Grundlagen der modernen Volksvertretung, deel 1, Darmstadt 1980, p. 346.

43. Uitvoeriger over de oorsprong van het Engelse parlement: D. Pasquet, The origins of the House of Commons, Londen 1964. Zie voorts: H.R. Nord, Historische ontwikkeling en beteekenis van de representatiegedachte in het staatsrecht, Leiden 1941, pp. 51-57; C.P. Ilbert, Parliament: its history, constitution and practice, 3e druk, bewerkt door C. Carr, Londen 1948, pp. 1-20; G.O Sayles, The functions of the medieval parliament of En- 
sche taak kwam tot uiting in het rechtspreken van de curia regis, zijn politieke functie kwam tot uiting in de feodale bijeenkomsten, waar de koning-leenheer over alle belangrijke zaken overleg pleegde met zijn vazallen, die hem hun consilium verschuldigd waren. ${ }^{44}$ Dit overleg vloeide voort uit het reeds in deze tijd aanvaarde, uit het Romeins recht overgeleverde principe dat de vorst in belangrijke aangelegenheden niet mocht handelen zonder "counsel and consent". Dit principe ("Quod omnes tangit ab omnibus approbetur') gaf uitdrukking aan het recht van de betrokkenen om zich bij monde van hun vertegenwoordigers uit te spreken over wat hen raakt. ${ }^{46}$ De macht van dit overlegorgaan van vorst en leenmannen, dat vanaf ongeveer de $13 \mathrm{e}$ eeuw parlement genoemd werd, was oorspronkelijk erg beperkt. Wetgeving werd vooral als een privé-aangelegenheid van de koning gezien. Bij de Magna Carta (1215; volledige naam Magna Carta Libertatum), een feodaal privilege, wisten de leenmannen de vorst gunstige voorrechten af te dwingen, waaronder de bepaling in art. 12 dat bijzondere feodale heffingen niet opgelegd mochten worden zonder voorafgaande toestemming. ${ }^{67}$

Toen het feodale stelsel in de $13 \mathrm{e}$ eeuw minder belangrijk werd en zijn rol als bindmiddel in een tijd van politieke verdeeldheid verzwakte, vond een grote verandering plaats. Twee nieuwe klassen, die geen plaats in het feodale verband hadden, kwamen op: de 'knights' en de 'burgesses'. Omdat de vorst in financiële zaken gedwongen was deze nieuwe klassen te raadplegen wanneer hij zijn onderdanen verzocht om het afdragen van gelden waartoe zij volgens feodale regels niet verplicht waren, verschenen afgevaardigden in het parlement die niet in een leenrechtelijke verhouding tot de koning stonden, maar behoorden tot niet-feodale klassen of gemeen-

gland, Londen 1988, pp. 1-58; Fawtier, a.w., pp. 346-358 (mn. pp. 351355).

44. Van Caenegem, a.w., p. 71. Vergl. ook P.A. Ramaer, De verhouding der volksvertegenwoordigers tot hunne committenten in de constitutionele monarchie, Leiden 1868, p. 38.

45. Vergl. Ilbert, a.w., p. 2; M. Prestwich, English politics in the thirteenth century, Basingstroke 1990, p. 20.

46. Vergl. F.H. van der Burg, 'Quod omnes tangit ab omnibus approbetur', in: M.C. Burkens/R. Crince Le Roy, Burger en overheid, 's-Gravenhage 1984, p. 68.

47. Zie voor een overzicht van de bepalingen van de Magna Carta: Van Caenegem, a.w., p. 70; Prestwich, a.w., p. 22/23. 
ten. Aanvankelijk (vanaf 1254) werden alleen afgevaardigden van de graafschappen (de 'counties' of 'shires') in de vergadering opgeroepen. Later, voor het eerst in 1265 , werden ook vertegenwoordigers van de steden ('boroughs') uitgenodigd; vanaf 1295 zou dit regelmatig het geval zijn. ${ }^{48}$ $\mathrm{Na} 1327$ werd geen parlement meer bijeengeroepen waarvoor niet ook afgevaardigden namens de shires en de boroughs waren uitgenodigd. De bijeenroeping van het parlement geschiedde door de koning door middel van een 'writ of summons'. Deze bevatte een uitvoerige opgave van de aangelegenheden waarover vergaderd zou worden, of slechts een algemene omschrijving als "belangrijke aangelegenheden van Staat en Kerk". ${ }^{49}$ Het aantal afgevaardigden dat daadwerkelijk aan de uitnodiging voor de vergadering gehoor gaf, was overigens niet al te hoog, met uitzondering van de vergadering van 1295 . De maatregelen waarmee de afgevaardigden hun instemming moesten betuigen kostten de shires en boroughs veelal slechts geld, terwijl ook de verblijfskosten voor de afgevaardigden hoog waren. Wanneer de boroughs wel gehoor gaven aan de uitnodiging was hun rol in de vergadering bovendien vrijwel te verwaarlozen: ten opzichte van de 'mighty lords' waren zij in deze periode dusdanig onbeduidend dat hun aanwezigheid eigenlijk in het geheel niet opviel. ${ }^{\text {so }}$

Het middeleeuwse parlement bestond dus uit twee groepen: allereerst een aantal personen dat uit eigen hoofde een eenheid van het land vertegenwoordigde, en daarnaast een aantal vertegenwoordigers van de gemeenschappen (de 'communitates'). De eerste groep (gevormd door graven en baronnen) hoorde in beide 'soorten' van het parlement thuis; de tweede (gevormd door ridders, burgers en lage geestelijkheid) alleen in de standenvergadering, niet in het gerechtshof. Uit de tegenstelling Parlement-Hof en Parlement-Standenvergadering zou uiteindelijk die van Hogerhuis en Lagerhuis groeien. Zowel de graven en baronnen, die op persoonlijke titel werden opgeroepen, als de ridders en burgers die door verkiezing in aanmerking kwamen, trachtten zoveel mogelijk aan de representatie te ontsnappen. Representatie werd, met name sedert de regering van Edward

48. Uitvoeriger hierover: M. McKisack, The parliamentary representation of the English boroughs during the Middle Ages, Londen 1932, pp. 8-11 en p. 24.

49. Vergl. E. Coke, The institures of the laws of England, deel IV (Concerning the jurisdiction of courts), Londen 1817, p. 4/5; Ramaer, a.w., p. 39.

50. Vergl. Sayles, The functions of the medieval parliament of England, a.w., p. 43; Prestwich, a.w., p. 142. 
II (1307-1327), niet beschouwd als een recht met de daaraan eventueel verbonden voordelen, maar als een onaangename plicht. Er zijn gevallen bekend waarin de afgevaardigden zelfs naar het buitenland vluchtten teneinde deze plicht te ontlopen. ${ }^{51}$

Omdat zowel de ridders als de burgers een gemeenschap vertegenwoordigden (en niet een persoonlijk belang of het belang van een stand) werd niet getracht deze vertegenwoordiging evenredig te maken aan het bevolkingsaantal van deze gemeenschap of de omvang van het electoraat. ${ }^{52}$ Elke county zond twee ridders; elke borough zond twee burgers, met uitzondering van de stad Londen: zij zond vier vertegenwoordigers. De vereisten voor het actief kiesrecht waren voor elke county gelijk; het stemrecht kwam (sedert 1430) slechts toe aan "all freeholders whose tenements had an annual value of 40 shillings". ${ }^{33}$ Voor de steden bestond een grote pluriformiteit aan vereisten; een situatie die tot aan de Reform Act van 1832 zou voortduren. ${ }^{54}$

De bepaling van de Magna Carta over de benodigde instemming van het land voor de heffing van belastingen kreeg onder Edward I (1272-1307) grote betekenis doordat de Koning het recht van toestemming door het parlement voor nieuwe belastingen moest erkennen. Toen ook, vanaf 1295 , vergaderde het parlement te Westminster in plaats van in de steeds wisselende verblijfplaats van de koning. Omdat Westminister later de vaste vergaderplaats van het parlement zou worden, wordt de vergadering van 1295 wel aangeduid als het Modelparlement. In dit Modelparlement van 1295 onder Edward I was de vertegenwoordiging uit de gemeenschapen volledig; aanwezig waren prelaten, magnaten, twee knights namens elke county, twee burgesses namens elke stad en de lagere geestelijkheid, een groep die later als afzonderlijke groep uit het parlement zou verdwijnen. Overigens moet de benaming Modelparlement niet verstaan worden in die

51. Vergl. A.F. Pollard, The evolution of Parliament, 2e druk, Londen 1934, p. 154.

52. Vergl. P.G.J. Pulzer, Political representation and elections in Britain, 3e druk, Londen 1978, p. 13/14.

53. Idem, p. 14.

54. Uitvoeriger over de vereisten voor het kiesrecht in de periode voor 1832: J.R. Pole, Political representation in England and the origins of the American Republic, Londen 1966, pp. 397-401. 
zin dat de functies van het huidige Engelse parlement van zijn voorganger van 700 jaar geleden zijn afgeleid.

Onder Edward III (1327-1377) kwam de splitsing van het parlement in twee huizen tot stand. Tot het Hogerhuis behoorden de prelaten en de hoge adel, tot het Lagerhuis de ridders en de burgers. Tevens ontstond in deze tijd de gewoonte dat de bijeenroeping van het parlement minimaal eenmaal per jaar diende te geschieden. Hoewel voor de raadpleging van het parlement de bestaande feodale vormen werden gebruikt, was er toch sprake van een nieuwe vertegenwoordiging, die voor het eerst een element van keuze bevatte, al berustte zij niet op enig bewustzijn van volkssoevereiniteit of democratie: "Probably the earliest sense in which they (ridders en burgers, RK) acted 'for' their boroughs and shires was in performing a duty for which the whole shire or borough was responsible." ${ }^{\text {55 }}$ De afgevaardigden van de gemeenten en de graafschappen hadden namens deze in het parlement zitting en gaven voor deze hun instemming met de besluiten van de koning. Deze in de dertiende eeuw ontstane opvatting kreeg een eeuw later een nadere uitwerking toen de rechters in hun beslissingen aanvoerden dat onbekendheid met een wet geen reden was voor het nietnaleven ervan omdat iedereen geacht werd van de handelingen van het parlement op de hoogte te zijn. "Everyone was taken to know the law because everyone was considered ('intended') to be present there, either personally or 'by procuration'". 36

Hieruit ontstond in de vijftiende eeuw de doctrine dat de vergadering van het parlement een substituut was voor de fysiek gezien onmogelijke vergadering van alle inwoners van het rijk. Deze doctrine is wel beschouwd als een
"(...) sort of usable tautology. As all British subjects owed allgian- ce to, and recieved protection form the Crown, so all were present, or represented in, the legislature, To have denied that one was represented in Parliament would have been tantamount to a denial obligation to obey the laws, which was sedition. ${ }^{\text {57 }}$

Deze gedachte was echter evenmin democratisch. De opvatting dat iedereen door de ridders en de burgers in het parlement aanwezig werd gemaakt "had nothing to do with any demand for accuracy of correspon-

55. H.F. Pitkin, The concept of representation, Berkely 1967, p. 85. Zie ook: Van Caenegem, a.w., p. 71.

56. Pitkin, a.w., p. 85 (met nadere literatuurverwijzingen in noot).

57. Pole, a.w., p. 388. 
dence between legislature and nation, nor with the democratic idea that each man has a right to be present and participate in his government, so that representation is a substitute for direct democracy". .58

Dit 'democratic idea' zou pas later opgeld doen; het is langzaam en met schokken gegroeid.

De nieuwe afgevaardigden waren oorspronkelijk gebonden aan een strikt imperatief mandaat. Hun voornaamste taak was het toestaan van belastingen, al werd op dit op de Magna Carta gebaseerde instemmingsrecht wel eens inbreuk gemaakt. Ten aanzien van de belasting-aangelegenhedlen staat vast dat de afgevaardigden gehouden waren aan een vorm van last en ruggespraak ${ }^{59}$. Voor de overige aangelegenheden, waaronder de belangrijke taak om te beslissen op verzoekschriften uit de bevolking waarin 'local grievances' naar voren werden gebracht, is dit minder zeker, al zijn er wel gevallen van bekend. ${ }^{60}$ Het oudst bekende voorbeeld is de opdracht die in de oproep van de vorst tot de parlementsvergadering van 1268 aan de afgevaardigden werd gegeven om brieven ('letters patent') mee te brengen, waarin de gemeenschappen die zij vertegenwoordigden moesten verklaren dat zij "für angenommen und bindend halten, was auch immer die Männer in ihrem Auftrag beschließen würden". ${ }^{61}$ Deze omschrijving duidt op een constructie in de zin van een gebod van last en ruggespraak. ${ }^{62}$ In de oproepen voor eerdere parlementsvergaderingen waren dergelijke bewoordingen voordien niet gebezigd, terwijl zij ook na 1268 aanvankelijk geen vaste plaats in de oproep voor een parlementsvergadering hadden. Vanaf

58. Pitkin, a.w., p. 86. In dezelfde zin; Pole, a.w., p. 388.

59. Zo schreef Coke, a.w., p. 14 (omstreeks 1623): "It is also the law, and custome of the parliament, that when any new device is moved on the kings behalf, in parliament for his aid, or the like, the commons may answer, "that they tendred the king estate, and are ready to aid the same, only in this new device they dare not agree without conference with their countries": whereby it appeareth that such conference is warrantable by the law and custom of parliament." (cursivering RK)

60. Vergl. Ramaer, a.w., p. 41.

61. Aldus H.M. Cam, Theorie und Proxis der Repräsentation im mintelalterlichen England, in: Rausch (deel 2), a.w., p. 338 (cursivering RK).

62. G.O. Sayles, Representation of cities and boroughs in 1268, in: English Historical Review, vol. 40 (1925), p. 581. 
1290 was dit echter wel regelmatig het geval. ${ }^{63}$ Een andere lastgevingsconstructie is te vinden in de 'commission' die in 1304 door de 'mayor' en de 'sheriffs' te Londen aan de afgevaardigden werd meegegeven, geschreven op de achterkant van de uitnodiging door de vorst.

Nadat in 1377 de verdeling van het parlement in twee huizen definitief was, heeft het Lagerhuis zich meer en meer van het stelsel van de imperatieve mandaten weten te ontslaan. Aan het einde van de $14 \mathrm{e}$ eeuw werd het recht van het parlement om deel te nemen aan de wetgeving voor altijd vastgesteld en erkend; als gevolg daarvan veranderde de werkwijze van de vergadering. Deze verandering had ook gevolg voor de relatie tussen de afgevaardigden in het parlement en degenen die hen benoemden. ${ }^{*}$ Dit leidde er weer toe dat ten aanzien van de wetgevende functie van het parlement gezegd kan worden dat het in ieder geval vanaf het begin van de $15 \mathrm{e}$ eeuw onafhankelijk van zijn committenten was ${ }^{65}$. In belasting-aangelegenheden bleef het mandatenstelsel echter nog betrekkelijk lang bestaan, althans de iure. Vanaf de $16 \mathrm{e}$ eeuw raakte ook in dit opzicht de praktijk van last en ruggespraak in ongebruik. Alleen wanneer het parlement een reden nodig had om door de regering gevraagde financiële steun te weigeren, werd er nog een beroep op gedaan. ${ }^{\star}$ Formeel is de regel echter nooit afgeschaft.

Naarmate de middeleeuwen hun einde naderden werd ook de afkeer om vertegenwoordigd te worden minder. Vanaf \pm 1445 nam het aantal steden dat afgevaardigden zond, aanzienlijk toe. Het verzoek om vertegenwoordiging kwam nu van de andere kant, vanuit de bevolking: zij begon het als een eer te beschouwen in het parlement vertegenwoordigd te zijn. Zij begreep ook dat het parlement een machtsmiddel in haar handen was, dat met succes tegen de Kroon kon worden gebruikt. Vertegenwoordiging werd

63. Vergl. Sayles, Representation of cities and boroughs in 1268, a.w., p. 582 . Zie ook Prestwich, a.w., p. 141.

64. Uitvoeriger: Ramaer, a.w., p. 44/45.

65. Vergl. bijv. Coke, a.w., p. 14, die op de hiervoor (noot 59) geciteerde passage laat volgen: "And is to be observed, though one be chosen for one particular county or borough, yet when he is returned, and sits in parliament, he serveth for the whole realm, for the end of his coming thiter, as in the writ of his election appeareth, is generall." Als de afgevaardigden een algemeen doel dienden, is lastgeving erg onwaarschijnlijk.

66. Vergl. Ramaer, a.w., p. 49. 
van last tot voorrecht; de leden van de vergadering zagen zich niet meer als de afgevaardigden van hun stand, maar als die van het gehele land. ${ }^{67}$ Het parlement begon zijn middeleeuws karakter te verliezen. Het kreeg de nieuwe functie van mede-wetgever en daarmee van mede-uitoefenaar van het staatsgezag. Uiteindelijk zou het zelf uitgroeien tot soeverein. Deze machtsuitbreiding was overigens wel een geleidelijk proces, dat eeuwen duurde.

\subsubsection{Opkomst parlementair stelsel}

In de ontwikkeling van de huidige positie van de individuele volksvertegenwoordiger in het Verenigd Koninkrijk hebben theorie en praktijk elkaar wederzijds benvloed. Afgevaardigden van de "communitates' werden reeds voor overleg met de koning beroepen voordat de vertegenwoordigingsgedachte in moderne zin bestond. Naarmate echter de afgevaardigden meer geregeld bijeenkwamen, kwam deze gedachte op, niet scherp, maar scherp genoeg om te worden toegepast. Zo zijn vorm en gedachte, steunend op elkaar, samen gegroeid in de richting van de moderne praktijk. ${ }^{68}$ In deze uitgroei naar zijn nieuwe functie bereikte het Engelse parlement reeds in de $15 \mathrm{e}$ eeuw een voorlopig hoogtepunt, toen het de nationale wetgevende bevoegdheid (het vaststellen van de Acts) samen met de koning uitoefende. Het bleef formeel deze taak vervullen in de $16 \mathrm{e}$ eeuw, hoewel zijn effectieve invloed als gevolg van de opkomst van het klassiek absolutisme sterk werd gereduceerd en het ene volgzame parlement na het andere de wetten goedkeurde die door de oppermachtige Tudors werden gewenst. Onder de Tudors (1485-1603) beleefde het Engelse parlement de meeste onderdanige fase van zijn bestaan en stemde het in met de meest tegenstrijdige wetten, al naargelang het grillige verloop van de wil van de monarch. Diens wil was wet; het parlement "became perverted into instruments of tyranny". ${ }^{*}$ Niet alleen ter zake van belangrijke politieke wendingen, maar ook de minder politiek geladen wetgeving in burgerlijke aangelegenheden gaf het parlement blijk van weinig initiatief. $^{70}$

67. Vergl. Pollard, a.w., p. 159. Zie ook: Pitkin, a.w., p. 245.

68. G.B. Adams, Constitutional history of England, 6e druk, bewerkt door R.L. Schuyler, Londen 1938, p. 173.

69. E.A. Freeman, The growth of the English constitution from the carliest times, 3e druk, Londen 1890, p. 103.

70. Vergl. Van Caenegem, a.w., p. 79 en p. 88/89; Freeman, a.w., p. 104. 
Ten aanzien van de positie van de individuele volksvertegenwoordiger werd het ondanks -of misschien wel dankzij- de geringe betekenis van het parlement steeds meer een vanzelfsprekendheid dat een afgevaardigde niet meer voor zijn plaatselijke 'kiezers' in het parlement zat, maar een meer omvangrijke taak had. Hij was "a publick, a Councellor to the whole State". ${ }^{71}$ Het duidelijkst komt deze opvatting naar voren in een veel geciteerde uitspraak van Sir Thomas Smith, die de basis vormt voor het gehele denken over staatsrechtelijke vertegenwoording in het Verenigd Koninkrijk. ${ }^{72}$ Het parlement, zo schreef Smith omstreeks 1565 ,

"(..) representeth and hath the power of the whole realme both the head and the bodie. For everie Englishman is entended to be there present, either in person or by procuration and attornies, of what preheminence, state dignitie, or qualitie soever he be, from the Prince (be he King or Queene) to the lowest person of Enlande. And the consent of Parliament is taken to be everie mans consent. "73

Wanneer de afgevaardigden zich deze opvatting eigen gemaakt hebben is niet exact aan te geven; wel geldt dat zij reeds tamelijk ver terug gaat, in ieder geval verder dan op het continent het geval was. Bedacht dient te worden dat de opvatting overigens lang niet betekent dat daarmee reeds in de $16 \mathrm{e}$ eeuw het moderne (staatsrechtelijke) vertegenwoordigingsbegrip zijn intrede in het Verenigd Koninkrijk had gedaan.

Het parlement trad in de 17e eeuw uit zijn onbelangrijkheid en bond de strijd aan met het absolutisme van de Stuarts (1603-1688). De strijd om de macht tussen Koning en parlement zou uiteindelijk met de Glorious Revolution eindigen in een overwinning van het parlement. Bij de troonsbestijging van Willem van Oranje werden door de Bill of Rights (13 februari 1689) de grondslagen van de huidige constitutie van het Verenigd Konink-

71. Cam, a.w., p. 345. Vergl, ook: Pitkin, a.w., p. 248: "In 1641 the Commons refer to themselves as "the Representative Body of the whole Kingdom", as distinct form the Lords, who are only "particular Persons'". Deze karaterisering van het Lagerhuis zou later zelfs door de conservatieve koning Charles I worden gebruikt.

72. P.A. Gibbons, Ideas of political representation in Parliament, 1660-1832, Oxford 1914, p. 55.

73. Th. Smith, De Republica Anglorum: a discourse on the commonwealth of England, Cambridge 1906 (eerste uitgave 1583), p. 49. 
rijk vastgesteld, alle vroegere machtsoverschrijdingen van de koningen onwettig verklaard en nieuwe waarborgen gegeven voor de rechten van het parlement. De theoretische grondslag van de constitutionele monarchie was gelegd, de praktijk van de sovereignty of parliament werd gevestigd. De rechtstitel van de Kroon kreeg een parlementair karakter: de aanspraak hierop stond ter beoordeling van het parlement. De vorst was niet langer de Soeverein in de staat, maar werd een staatsorgaan. ${ }^{74}$ De uitoefening van zijn prerogatieven werd vanaf nu beperkt door de sovereingty of parliament.

De Stuart-periode leidde tot de constitutionele beperking van de Engelse monarchie en de politieke overheersing door het parlement. De neerslag hiervan is te vinden in aantal beroemde grondwettelijke teksten, geschreven elementen van de in hoofdzaak ongeschreven Britse constitutie. Te denken valt hierbij aan de Petition of Right van 1628, waarvan een van belangrijkste bepalingen inhield dat de onderdanen niet mochten worden gedwongen tot het betalen van belastingen die niet 'by common consent' waren opgelegd, de Habeas Corpus Act van 1679, de Act of Settlement (1701) en de beroemdste tekst uit deze periode, de eerdergenoemde Bill of Rights van 1689. ${ }^{75}$

De Bill of Rights is een belangrijke schakel in de keten die van de Magna Carta heeft geleid tot de mensenrechtenverklaringen in onze tijd. ${ }^{76}$ Haar belangrijkste bepalingen bevatten enkele fundamentele principes van de rechtsstaat, zoals de bepaling dat de koning geen wetten mocht schorsen zonder instemming van het parlement (artt. 1 en 2), het verbod op strafrechtelijke willekeur (art. 10) en de garantie van vrije verkiezingen. Ook de bepaling over de belastingheffing door de koning (vergl. art. 12 van de Magna Carta) is in de Bill of Rights terug te vinden.

Maar niet alleen de inhoud, ook de vorm van de Bill of Rights is in dit kader van belang: zij doet zich namelijk voor als een verklaring van aloude rechten en vrijheden, opgesteld door de Lords en de Commons, sprekend in hun hoedanigheid van een 'full and free representation of this nation'. Door de Bill of Rights kreeg het Lagerhuis een overwicht op de Kroon. Tevens werd de band tussen het Lagerhuis en het volk losser. Was het

74. Vergl. P. Ritterbusch, Parlamentssouveränität und Volkssouveränität in der Staats- und Verfassungsrechtslehre England, Leipzig 1929, p. 4/5.

75. Uitvoeriger over deze teksten: v. Caenegem, a.w., pp. 97-99.

76. Idem, p. 98. 
vroeger regel geweest, dat het lidmaatschap van de afgevaardigden jaarlijks werd bekrachtigd door de graafschappen en gemeenten die zij vertegenwoordigden, vanaf 1695 was de zittingsduur van de afgevaardigden drie jaar geworden. Dit was in overeenstemming met de lange(re) duur van de parlementen in de praktijk. Onder het Huis van Hannover (sedert 1714), werd het gezag van het parlement uitgebreid, doordat aan de Koning het recht werd ontnomen gratie te schenken aan ministers die door het parlement in staat van beschuldiging waren gesteld. Verder maakte het besluit om de begroting niet langer voor de regeringsperiode van de Koning, maar slechts voor één jaar vast te stellen, een jaarlijkse bijeenroeping van het parlement onvermijdelijk.

Sedert het einde van de $17 \mathrm{e}$ eeuw waren twee politieke bewegingen, de Whigs en de Tories actief, zij het alleen binnen het parlement. Het 'lidmaatschap' deze groeperingen berustte meer op traditie, persoonlijke voorkeuren en rivaliteiten dan op politieke overtuiging. Buiten het parlement bestonden geen politieke organisaties. De groeperingen in het parlement hadden deze ook niet nodig: door de invloed van de adellijke grootgrondbezitters en het veelvuldig omkopen van kiezers, soms zelfs van de gehele borough kwamen zij toch wel aan hun zetels. Onder George I (1714-1727) werd de zittingsduur van het parlement op zeven jaar werd gesteld (Septenial Act van 1715). George I, een Duitser die gebrekkig Engels sprak, had meer belangstelling voor het bestuur van zijn (echte) vaderland en zat nog maar zelden de vergaderingen van de ministers voor. Deze ontwikkelden zich van onzelfstandige adviseurs van de vorst tot aan het parlement verantwoordelijke bewindslieden. Dit droeg bij tot het ontstaan van het moderne systeem van een homogeen kabinetsbeleid, een beleid waarop in toenemende mate de leider van de meerderheidspartij als Prime Minister zijn stempel zou gaan drukken. ${ }^{7}$ In de loop van de $18 \mathrm{e}$ eeuw ontstond de gewoonte dat ministers na een wantrouwensvotum aftraden.

Belangrijk voor de steeds groter wordende rol van het House of Commons was niet alleen dat het zowel de lage adel als de stedelijke burgerij bevatte (in tegenstelling tot het Europese vasteland, waar de adel en de burgerlijke derde stand gescheiden vergaderden en stemden), maar ook het in de $18 \mathrm{e}$ eeuw geformuleerde principe dat de leden niet in het parlement zetelden

77. Vergl. Prakke, a.w., p. 679: Van Caenegem, a.w., p. 103. 
om lokale belangen te verdedigen. De afgevaardigden werden geacht alleen het nationaal belang op het oog te hebben, want ze waren "the attorneys of the people of England". ${ }^{78}$ Een imperatief mandaat (door middel van 'instructions") was daarom onaanvaardbaar. De in vroeger tijden sporadisch verkondigde opvatting dat het imperatief mandaat aan het Engelse recht vreemd was, groeit in deze eeuw door de denkbeelden van de Whigs uit tot de heersende doctrine. ${ }^{79}$

Maar waar de ontwikkeling van het parlement in Engeland langzaam en geleidelijk verliep, en dikwijls het oude naast het nieuwe bleef voortbestaan, kon het voorkomen dat (ook) de oude ideeën omtrent de verhouding tussen de afgevaardigden en hun kiezers nog lang hebben nagewerkt. Door de vestiging van het parlementaire stelsel eisten de vertegenwoordigden meer inspraak. Gedurende enige tijd kende de praktijk van het imperatieve mandaat een opleving. In de $17 \mathrm{e}$ en de $18 \mathrm{e}$ eeuw waren bindende instructies van de kiezers aan hun vertegenwoordigers in het House of Commons weer een algemeen verschijnsel. ${ }^{80}$ Zo werden in de tweede helft van de $18 \mathrm{e}$ eeuw door de kiezers bij verkiezingen veelvuldig uitspraken van kandidaten verlangd over politieke hangijzers als de Amerikaanse onafhankelijkheidsoorlog of de noodzaak en aard van parlementaire hervormingen. $\mathrm{Er}$ ontstond de gewoonte dat van kandidaten geëist werd verklaringen te ondertekenen waarin zij zich voor of tegen "the leading measures of the time" uitspraken. ${ }^{81}$ Het onmiddellijke gevolg hiervan was dat verscheidende leden van het parlement niet werden herkozen omdat zij weigerden een dergelijke verklaring te ondertekenen. Onder degenen die weigerden was Edmund Burke, die desalniettemin toch gekozen werd voor het district Bristol. Nadat de uitslag van zijn verkiezing bekend was geworden, hield hij de toespraak over de positie van de afgevaardigden in het parlement

78. Aldus een (ministeriële) verklaring, in 1745 in het parlement afgelegd; vergl. Van Caenegem, a.w., pp. 103/104.

79. Zie hiervoor, hoofdstuk 2 .

80. Hierover uitvoerig: E. Porritt/A.G. Porritt, The unreformed House of Commons: parliamentary representation before 1832, deel 1, Cambridge 1903, pp. 263-271.

81. Th. Erskine May, The constitutional history of England since the accesion of George the third, deel 1 (1760-1860), 4e druk, bewerkt door F. Holland, Londen 1912, p. 355. Vergl. ook Ramaer, a.w., p. 172 en de voorbeelden genoemd door Ritterbusch, a.w., p. 159. 
waarin hij de terugkeer van de oude mandaten bestreed als zijnde in strijd met de constitutie.

Mede onder invloed van de opvattingen van Burke raakten de bindende (schriftelijke) instructies voor leden van het Lagerhuis in de laatste twee decennia van de $18 \mathrm{e}$ eeuw in onbruik. Zij maakten plaats voor andere manieren waarop de kiezers hun opvattingen over politieke aangelegenheden aan de leden van de het Lagerhuis kenbaar maakten. Vooral de praktijk van een nieuwe, lossere binding aan de kiezers, de 'pledges to constituents', nam een hoge vlucht. ${ }^{82}$ De inhoud van deze beloften verschilde nogal per kiesdistrict, evenals de mate van binding aan de beloften. Met name in de districten waar de roep om parlementaire hervormingen het grootst was, kon het voorkomen dat de belofte zoveel betekende als de aanvaarding door de afgevaardigden in het Lagerhuis van de verplichting om bij stemmingen de bevelen van de kiezers op te volgen en zich naar hun wensen te schikken, waarmee eigenlijk de praktijk van de instructies bleef gehandhaafd. ${ }^{83}$

De gebeurtenissen aan het einde van de $17 \mathrm{e}$ eeuw hadden een periode van "stable government and gradual constitutional evolution"84 ingeluid, die zonder verdere noemenswaardige (wets)wijzigingen tot de Reform Act van 1832 (zie hieronder) in stand zou blijven. De Britse $18 \mathrm{e}$ eeuwse constitutie was er een waarin de massa slechts weinig directe invloed had. Het was een regeringssysteem waarin plaats was voor slechts een kleine 'ruling class', hoewel het zich bijvoorbeeld door de grote individuele vrijheden ook in dit opzicht onderscheidde van zijn tegenhangers op het Europese vasteland. Het toenmalige regeringssystem was zowel constitutioneel als parlementair van aard, maar het was beslist geen democratie:

"Parliament in the eighteenth century was based on the medieval principle that consent to taxation should be given by representatives of the three 'estates of the realm', the nobility, the clergy and the commons. The nobility and clergy had their representatives in the House of Lords while the rest of the population were represented

82. Vergl. Ritterbusch, a.w., p. 160; Porrit, a.w., p. 271.

83. Zie de voorbeelden genoemd door Porrit, a.w., p. 272. Vergl. ook: Pole, a.w., p. 429.

84. Birch, The British system of government, a.w., p. 30 . 
by the 'knights of the shires' and the members for 'parliamentary boroughs' who sat in the House of Commons. ${ }^{85}$

Het kiesrecht voor het House of Commons was erg beperkt. Mede hierdoor kon het voorkomen dat tijdens verkiezingen corruptie en omkoping veelvuldig voorkwam. Misstanden bij verkiezingen manifesteerden zich reeds sedert lange tijd in het Verenigd Koninkrijk. ${ }^{86}$ Aan het einde van de $17 \mathrm{e}$ eeuw vervalsden vorsten als Charles II en James II (beiden uit het huis Stuart) verkiezingsuitslagen om zodoende hun (afnemende) invloed op het Lagerhuis te behouden. Toen in de $18 \mathrm{e}$ eeuw het parlement steeds machtiger werd, waren verkiezingsfraude en omkoping nog de enige middelen waardoor het gezag van de vorst. kon worden versterkt. ${ }^{87}$

\subsubsection{Het Verenigd Koninkrijk in de 19e eeuw}

De kardinale beslissingen waren in het Verenigd Koninkrijk reeds voor de $19 \mathrm{e}$ eeuw gevallen: de nationale eenheidsstaat, de constitutionele monarchie, de sovereignty of parliament waren verworvenheden van vorige eeuwen, die thans niet meer ter discussie stonden. Uit het thans gevestigde concept van 'responsible parliamentary government' kon zich nu 'representative democracy' gaan ontwikkelen: "Once Parliament had established its claims to control government, the next stage was to make it representative of the population". ${ }^{88}$ De belangrijkste ontwikkeling in het Verenigd Koninkrijk in de $19 \mathrm{e}$ eeuw is dan ook de modernisering en zeer geleidelijke democratisering van het parlement. Deze ontwikkeling is echter beperkt tot het Lagerhuis, want het Hogerhuis heeft zijn traditionele samenstelling van erfelijke adel c.q. grootgrondbezitters en enkele bisschoppen van de staatskerk weten te behouden, terwijl het tot het begin van $20 \mathrm{e}$ eeuw ook zijn traditionele machtspositie naast het Lagerhuis wist te bewaren. De Parliament Acts van 1911 en 1949 hebben deze machtspositie verzwakt

85. Idem, p. 32.

86. Vergl. hierover: C. O'Leary, The elemination of corrupt practices in British elections, 1868-1911, Oxford 1962, pp. 5-13.

87. Vergl. Gibbons, a.w., p. 8.

88. Kavanagh, a.w., p. 4. 
door de vroeger onberkte bevoegdheid tot het afstemmen van wetsontwerpen te reduceren tot een suspensief veto. ${ }^{89}$

Een zeer belangrijk gebeurtenis was de totstandkoming, in 1832, van de Representation of the People Act. Deze wet, ook wel de (eerste) Reform Act genoemd, bracht een uitbreiding van het kiesrecht en een wijziging van de indeling in kiesdistricten. Hierdoor kreeg het Lagerhuis een groter representief karakter. Het Britse kiesstelsel veranderde

"(...) from an historic to a rational basis. The right to vote and, to a lesser degree, the distribution of constituencies were now derived not from tradition but from first principles." 90

De noodzaak van de veranderingen werd in de preambule van de Act expliciet aangegeven; zij verklaarde dat de bedoeling van de wet was een einde te maken aan de misbruiken die zich tot die tijd bij de verkiezing van leden van het Lagerhuis manifesteerden. ${ }^{91}$ Dit doel schoot de Reform Act echter grotendeels voorbij. Hooguit leidde deze wet tot een meer alerte houding van het Lagerhuis ten aanzien van de bestrijding van deze misstanden. ${ }^{2}$

In 1867 werd een volgende en relatief radicale stap gezet door de tweede Reform Act, die tegemoet kwam aan de eis het cijnsvereiste dusdanig te verlagen dat een aanzienlijk deel van de arbeiders stemrecht zou verwerven. Door deze wet nam het totaal aantal kiesgerechtigden dan ook meteen met $88 \%$ toe. ${ }^{9}$ De bevoordeling van de stedelijke bevolking door de tweede Reform Act werd spoedig gevolgd door een analoge maatregel ten faveure van de plattelandsarbeiders in 1884 (derde Reform Act), in 1885 en 1888 gevolgd door een algemene herziening van de kiesdistricten (Redistribution of Seats Acts). Na deze veranderingen was ongeveer 60\% van de volwassen mannelijke bevolking kiesgerechtigd. ${ }^{94}$ Voor algemeen kiesrecht moest worden gewacht tot 1918 toen alle mannen van 21 jaar en

89. Vergl. Kingdom, a.w., p. 256/266. Overigens is het bestaansrecht van de Lords nog steeds een omstreden zaak, vooral in kringen van Labour; vergl. Kavanagh, a.w., p. 232/233.

90. Pulzer, a.w., p. 31.

91. Vergl. Erskine May, Parliamentary practice, a.w., p. 10. Zie ook: Pulzer, a.w., pp. 15-17.

92. O'Leary, a.w., pp. 13-26.

93. Idem, p. 44. Zie ook Kingdom, a.w., p. 165.

94. Vergl. Pulzer, a.w., p. 31. 
ouder en alle vrouwen van 30 jaar en ouder kiesgerechtigd werden. Dit verschil in leeftijdsvereiste voor mannen en vrouwen werd in 1928 opgeheven.

Toch hadden deze radicale veranderingen slechts een zeer trage weerslag op de nationale politiek. De arbeidersbeweging beperkte zich er voorlopig toe als een pressiegroep binnen de liberale partij op te treden; pas in het begin van de $20 \mathrm{e}$ eeuw werd resoluut overgegaan tot eigen partijvorming en afzonderlijk optreden in het Lagerhuis.

Door de toenemende invloed van de kiezers is bovengenoemde praktijk van kiezersbeloften blijven voortbestaan, al werd er sporadisch tegen geprotesteerd. Vooral na de Reform Act van 1832 is dit het geval geweest. In de periode voor de Reform Bill waren de 'pledges' tamelijk algemeen van aard en weinig frequent, na de Reform Bill werd de praktijk van de 'pledges' uitgebreid als gevolg van de toename van het kiezerscorps. Om haar in werking te laten treden werd het parlement ontbonden. Het feit dat het volk een groter aandeel in de samenstelling van het Lagerhuis had gekregen, maakte dat het zijn macht gebruikte om zoveel mogelijk invloed op de beslissingen van het Lagerhuis uit te oefenen. Op vele plaatsen werden uitdrukkelijke beloften, veelal in een specifiekere vorm (d.i. betrekking hebbend op eén bepaald onderwerp) dan voorheen, van de kandidaten geëist. De meesten van hen gaven deze ook, slechts een enkeling verzette zich nog tegen deze praktijk. ${ }^{95}$ Het afleggen van beloften door de kandidaten werd veelal gezien als een wezenlijk bestanddeel van het verkiezingsproces, vooral in tijden dat een bepaald vraagstuk de kiezers in hun ban hield. Volgens Erskine May heeft het kiesstelsel zoals dat sedert de Reform Act gestalte heeft gekregen de praktijk van de 'pledges' meer in overeenstemming met de Engelse constitutie gebracht. ${ }^{\%}$ Hij huldigt het standpunt dat deze gewoonte voor rechtmatig moet worden gehouden omdat kiezers, gezien hun toegenomen 'political education', het recht hebben te weten waar een kandidaat voor staat en de kandidaten, gezien de uitbreiding van electoraat, niet anders kunnen dan zich duidelijker dan voorheen voor of tegen bepaalde politieke hangijzers uit te spreken. Dat

95. Uitvoeriger: Ramaer, a.w., p. 175/176. Zie ook: Ritterbusch, a.w., p. 160: "Diese Form der Bindung des Volksvertreters an den Willen seiner Wähler ist bis auf den heutigen Tag (d.i. 1929, RK) in Übung."

96. Erskine May, Constitutional history, a.w., p. 356. 
betekent echter niet dat de kandidaat volledig afhankelijk dient te zijn van het electoraat: "A member once elected, is free to act upon his own convictions and conscience." In hoeverre deze uitspraak thans nog correct is, zal hieronder worden nagegaan.

\subsection{De vertegenwoordigingsgedachte in het Britse staatsrecht: de mandate doctrine}

Het concept dat in het Verenigd Koninkrijk aan het stelsel van staatsrechtelijke vertegenwoordiging ten grondslag ligt, wijkt enigszins af van het concept van staatsrechtelijke vertegenwoordiging in Nederland en Duitsland. Hoewel in de Bondsrepubliek Duitsland de politieke partijen grondwettelijke erkenning hebben gekregen en in Nederland niet, is het concept van staatsrechtelijke vertegenwoordiging in beide landen toch in hoge mate identiek. In beide landen vormt de liberale theorie van de representatieve democratie nog steeds de basis van het stelsel van staatsrechtelijke vertegenwoordiging. Ondanks het bestaan en, in Duitsland, de grondwettelijke erkenning van de politieke partijen is de vertegenwoordigingsgedachte in het Nederlandse en Duitse staatsrecht daarom nog steeds gebaseerd op een individueel concept over staatsrechtelijke vertegenwoordiging, zoals dit in de theorie van het vrije mandaat en haar tegenhanger, de theorie van het imperatief mandaat, tot uiting komt. Kernpunt bij deze theorieën is immers de mate waarin de wil van de kiezers het (stem)gedrag van de afzonderlijke leden van een volksvertegenwoordiging bepaalt.

De vertegenwoordigingsgedachte in het staatsrecht van het Verenigd Koninkrijk is daartegen niet (meer) gebaseerd op een individueel concept over staatsrechtelijke vertegenwoordiging. ${ }^{98}$ Juist in het Verenigd Koninkrijk wordt staatsrechtelijke vertegenwoordiging nauw in verband gebracht met het opereren van de politieke partijen, het uit het kiesstelsel voortvloeiende twee-partijenstelsel en de daarmee samenhangende enge verbondenheid tussen regering en meerderheidspartij in het House of Commons. De flexibiliteit van de Britse constitutie en de in het Verenigd Koninkrijk heersende opvatting dat ervaring en praktisch inzicht prevaleren boven

97. Idem, p. 357.

98. Vergl. I. Budge/D. McKay (ed.), The changing British political system: into the 1990s, $2 \mathrm{e}$ druk, Londen 1988, p. 63. 
theoretische concepten, hebben de liberale theorie van de representatieve democratie naar de achtergrond gedrongen ten koste van een theory of party representation'. Deze erkent de praktijk van de rol van de politieke partijen met hun sterke interne partijdiscipline die tot gevolg heeft dat de individuele MPs hun stemgedrag richten naar de opvattingen van de partij of fractie. MPs zijn door hun partij kandidaat gesteld vanwege hun steun en instemming aan het beleid van de partij(-top). Daarom zullen zij zich ook in de meeste gevallen bij het uitbrengen van stemmen laten leiden door de standpunten van hun partij:

"It is a two-way street, and it is perhaps more accurate to see MPs as only having any power at all because they are members of political parties than saying that their parties limit their power." 9 ?

De politieke partijen vormen daardoor een belangrijke factor in het staatsrecht van het Verenigd Koninkrijk, al geldt ook hier dat de wetgever zich zelden met politieke partijen inlaat of zelfs maar hun bestaan erkent. ${ }^{100}$

Voor het stelsel van staatsrechtelijke vertegenwoordiging betekent de 'theory of party representation' dat in het Verenigd Koninkrijk niet de individuele volksvertegenwoordiger wordt geacht een mandaat van de kiezers te hebben gekregen, maar de regeringspartij. De politieke partijen worden geacht bij de verkiezingen met duidelijke voorstellen over het te voeren beleid te komen; voor de uitvoering van deze voorstellen krijgen zij, wanneer zij de verkiezingen winnen, een mandaat van kiezers. Dit is de mandate doctrine: "The government is expected to carry out the policy (...) indicated at the last general election and is not expected to act contrary to that policy (...)." ${ }^{101}$

Het concept van de mandate doctrine is door de jaren heen aan verandering onderhevig geweest; tot op heden bestaat geen eensgezindheid over de concrete inhoud ervan. De Conservative Party ziet de doctrine in hoofdzaak als een bevoegdheid van de regering haar verkiezingsbeloften, al dan niet in een verkiezingsprogramma vastgelegd, te realiseren. De Labour Party ziet haar veel meer als een verplichting om het verkiezingsprogramma uit te voeren. Wanneer bij algemene verkiezingen een bepaald onder-

99. P. Silk/R. Walters, How Parliament works, 2e druk, Londen/New York 1989, p. 44.

100. Vergl. Prakke, a.w., p. 707.

101. Hood Philips, a.w., p. 56. In dezelfde zin: Budge/McKay, a.w., p. 63; Koopmans, a.w., p. 174; W.I. Jennings, Cabinet Government, 3e druk, Cambridge 1959, p. 503/504. 
werp (zoals economische hervormingen) de verkiezingsstrijd beheerst, wordt de mandate doctrine ook wel zo uitgelegd dat de uitkomst van de verkiezingen een duidelijke indicatie vormt voor het ten aanzien van dit onderwerp te voeren beleid. Zo nu en dan is ook wel gesteld -bijna altijd door de partij(en) die in de oppositie verkeerde(n)- dat de mandate doctrine betekent dat de regering geen recht heeft om zonder toestemming van de kiezers een bepaald beleid door te voeren. Alvorens dit beleid te realiseren, moeten de opvattingen van de kiezers gepeild worden.

Zoals wel vaker in de Britse constitutionele geschiedenis is ook de mandate doctrine uitgegroeid van een pragmatisch tot een normatief beginsel. De normatieve waarde van de doctrine is echter geringer dan bijvoorbeeld de sovereignty of parliament. In de loop van de $19 \mathrm{e}$ eeuw ontstond geleidelijk de gedachte dat het electoraat de regering een mandaat geeft om een bepaald beleid tot stand te brengen. De algemene verkiezingen van mei 1831, met als inzet de (noodzaak van) parlementaire hervormingen, waren de eerste verkiezingen waarbij de kiezers niet alleen een uitspraak deden over de samenstelling van de regering, maar ook over de hoofdlijnen van het door deze te voeren beleid. Reeds in 1885 was de mandate doctrine uitgegroeid tot een constitutioneel beginsel, getuige de weerstand die Gladstone in zijn eigen partij ondervond toen hij, enkele maanden na de verkiezingen, de Ierse eis voor Home Rule wilde inwilligen: betoogd werd dat een dergelijke ingrijpende maatregel niet doorgevoerd kon worden zonder raadpleging van het electoraat. Omdat bij de vorige verkiezingen de Home Rule-kwestie niet aan de orde was geweest, had de regering op dit punt geen mandaat van de kiezers gekregen om tot een dergelijke maatregel over te gaan. ${ }^{102}$ Binnen het jaar zag Gladstone zich genoodzaakt het parlement te ontbinden en de zaak aan de kiezers voor te leggen. Later, in het eerste decennium van deze eeuw, werd de mandate doctrine door de conservatieven aangewend om hun tegenstand in het House of Lords tegen de maatregelen van de Liberals te rechtvaardigen. ${ }^{103}$

Hoewel de mandate doctrine inhoudelijk nogal vaag is en evenmin onomstreden, speelt zij tot op de dag van vandaag nog een belangrijke rol in het

102. Vergl. Harvey/Bather, a.w., p. 492.

103. Zie voor andere voorbeelden: Jennings, a.w., p. 505/506; Nord, a.w., p. 65. 
staatsrecht van het Verenigd Koninkrijk: "The doctrine is (...) of importance. Though it must be necessarily vague and its operation a matter of dispute, it is recognised to exist. " ${ }^{104}$

Maar ondanks de erkenning van de mandate doctrine verschilt het gewicht dat aan de doctrine wordt toegekend per partij. Noch de Conservative Party noch (voorheen) de Liberal Party hebben zich uitdrukkelijk op het standpunt gesteld dat een partij zich bij een verkiezing naar het electoraat toe dient te presenteren met concrete voorstellen die, vooropgezet dat de partij de verkiezingen wint, zij ook daadwerkelijk dient te realiseren. Hun opvatting over de mandate doctrine was (en is binnen de Conservative Party nog steeds) veel vager en vrijblijvender. ${ }^{105} \mathrm{Zij}$ zien het mandaat dat de kiezers de regeringspartij geven vooral als een vrijbrief. De partij die de verkiezingen wint, heeft een 'mandate to govern', d.w.z. dat het de partij vrij staat "to pursue whatever policies it thinks appropriate". ${ }^{106}$ Alleen in de (zeldzame) situatie waarin de verkiezingen door een enkel onderwerp werden gedomineerd is het mandaat minder vrijblijvend. De kiezers worden dan geacht bij de verkiezingen vooral een uitspraak te hebben gedaan over dat onderwerp, waardoor de beperking van het mandaat zich in hoofdzaak richt tot de aangegeven uitvoering van het beleid ten aanzien van dat onderwerp.

In de mandate doctrine heeft een regering strikt genomen niet het recht om een ingrijpende beleidsverandering tot stand te brengen zonder de kiezers in de gelegenheid te stellen hun opvattingen hierover kenbaar te maken. Met name op dit punt is de mandate doctrine uitermate vaag en omstreden. Door conservatieve en liberale regeringen is daarom de doctrine naar willekeur toegepast; zij beriepen zich op een mandaat wanneer hen dit geschikt voorkwam, maar negeerden het wanneer zij zich niet gebonden wilden voelen aan hun (verkiezings)programma. ${ }^{107}$ De mandate doctrine

104. Jennings, a.w., p. 505.

105. De huidige erfgenamen van de Liberal Party, de Liberal Democrats, lijken op dit punt thans een minder vrijblijvende opvatting te huldigen. Maar daar de 'Lib Dems' voortdurend in de oppositie verkeren, staat nog niet vast dat zij in de praktijk ook volgens deze nieuwe opvatting zullen handelen.

106. A.H. Birch, Representative and responsible government, 7e druk, Londen 1979, p. 117.

107. Zie de voorbeelden genoemd door Birch, Representative and responsible government, a.w., p. 117. 
wordt hier niet gezien als een verplichting voor een politieke partij ten opzichte van het electoraat om een concreet beleid te realiseren:

"They maintain that the government should judge each issue on its merits and in relation to the opinions expressed in Parliament and in the country, and should not feel that its hands are tied by pledges made some time previously in the possibly different circumstances of an election campaign." 108

Binnen de Labour Party zijn de opvattingen over de mandate doctrine nogal afwijkend. Met name de aan de Labour Party gelieerde vakbonden huldigen van oudsher het standpunt dat leiders en afgevaardigden (namens de vakbonden) aan een uitdrukkelijk imperatief mandaat van de leden gebonden dienen te zijn. ${ }^{109}$ Labour-politici met een vakbond-achtergrond neigen ertoe dit principe ook van toepassing te laten zijn voor de afgevaardigden van de partij in het parlement. In hun optiek betekent de mandate doctrine dat MPs gedelegeerden van de partij zijn en in concrete gevallen onderworpen dienen te zijn aan lastgeving van de partij of van aan de partij gelieerde organisaties. ${ }^{10}$

Deze afwijkende opvatting over de mandate doctrine en de rol van de individuele MPs daarbij is grotendeels een gevolg van het relatief late ontstaan van de Labour Party. Door de geleidelijke uitbreiding van het kiesrecht in de $19 \mathrm{e}$ eeuw waren de van oudsher bestaande partijen genoodzaakt zich ook buiten het parlement als partij te manifesteren om hun kiezers aan zich te binden en zo hun positie in het parlement te consolideren en te versterken. De lokale partijorganisaties die als gevolg hiervan ontstonden waren bedoeld ter ondersteuning van de parlementaire partij. "' De Labour Party daarentegen ontstond in 1900 juist uit de arbeidersbeweging buiten het parlement, met het doel deze (de 'working class') in het parlement te vertegenwoordigen. Vandaar ook dat vanuit de basis werd getracht de afgevaardigden in het parlement zoveel mogelijk door lastgevingen aan zich te binden en te controleren. Vanaf de beginjaren van

108. Birch, Representative and responsible government, a.w., p. 117.

109. Vergl. A. Young, The reselection of MPs, Londen 1983, p. 124.

110. Vergl. D. Oliver, The parties and parliament, in: Jowell/Oliver, a.w., p. 126: L. Radice/E. Vallance/V. Willis, Member of Parliament: the job of a backbencher, 20 druk, Londen 1990, p. 5.

111. Vergl. Radice/Va!lance/Willis, a.w., p. 5. Uitvoeriger: E.J. Evans, Political parties in Britain 1783-1867, Londen 1985, pp. 34-45. 
de Labour Party hebben partij-activisten en parlementsleden op dit punt tegenover elkaar gestaan:

"Underlying the tension between activists and parliamentarians was the former's fear that the Labour Group in Parliament would, if were not strictly controlled, backslide into opportunism, manoeuvre and compromise, and the latter's easy assumption that manoeuvre and compromise were inherent in their situation and essential to the furtherance of Labour's immediate aims. " ${ }^{112}$

Daarnaast hebben Labour-politici, anders dan die van de oudere partijen, het bedrijven van politiek nooit beschouwd als een constant proces van geven en nemen, van compromissen en veranderingen. In de opvatting van de oudere partijen is het bedrijven van politiek een activiteit die noodzakelijkerwijs een mate van onafhankelijkheid vereist ten behoeve van degenen die zich met deze activiteit inlaten. Binnen de Labour Party wordt daarentegen de opvatting gehuldigd dat Labour-afgevaardigden worden gekozen om de maatschappij te hervormen. Hierbij is politiek niet een zaak van het vinden van een compromis tussen tegengestelde belangen en opvattingen, maar een zaak van het streven naar een voorafbepaald doel. De mandate doctrine wordt binnen de partij dan ook uitgelegd als een verplichting om bij algemene verkiezingen het electoraat een programma voor te leggen waarin het beleid staat omschreven dat de partij, mits de verkiezingen worden gewonnen, de komende regeerperiode wil gaan verwezenlijken. ${ }^{113}$ De opvatting is dat de partij, wanneer zij de verkiezingen wint, een mandaat heeft on dit programma te realiseren en naar de kiezers toe gehouden is dat ook daadwerkelijk te doen, tenzij onvoorziene omstandigheden tot een afwijkend beleid nopen. De strenge partij-discipline binnen Labour is dan ook voor een deel gebaseerd op deze uitleg van de mandaat-gedachte. ${ }^{114}$

Hoewel de mandate doctrine door alle politieke partijen wordt onderschreven -zij het dat niet altijd een even sterke binding aan het van de kiezers gekregen mandaat aanwezig wordt geacht- en ook in de literatuur het bestaan ervan wordt erkend, is de doctrine niet zonder kritiek gebleven.

112. R. Miliband, Parliamentary socialism: A study in the politics of Labour, Londen 1961, p. 26. Zie ook Young, a.w., p. 47 en p. 117 die constateert dat in dit opzicht weinig binnen de Labour Party is veranderd.

113. Vergl. Birch, Representative and responsible government, a.w., p. 118.

114. Idem, p. 121. 
De voornaamste reden hiervoor is dat ook hier de (politieke) werkelijkheid aanmerkelijk gecompliceerder is dan de theorie van de mandate doctrine suggereert. Door de omvang en de gedetailleerdheid van het partij- c.q verkiezingsprogramma is het tegenwoordig zo goed als onmogelijk te bepalen welke van de in het programma omschreven punten door de kiezers onderschreven worden en welke niet, al zijn er sporadisch verkiezingen waarin duidelijk een onderwerp de overige zaken overheerst. Tevens maakt de veelheid aan onderwerpen dat de gemiddelde kiezer geen idee heeft van alle opvattingen waar de partij waarop hij stemt voor staat. Daarnaast kan niet worden uitgesloten dat (tenminste een deel van) het electoraat niet in staat is een duidelijke mening te geven omtrent gecompliceerde en technische beleidspunten; dit geldt met name voor de te voeren economische politiek. Ook is de doctrine moeilijk toe te passen wanneer een parlement van meer dan twee partijen tot stand komt, zonder dat een ervan de meerderheid -en dus een duidelijk mandaat- heeft. Evenmin kan de mandate doctrine worden toegepast wanneer er zich omstandigheden voordoen die ten tijde van de verkiezingen niet bekend waren. Het is echter algemeen aanvaard dat in een dergelijk geval het de regering is toegestaan van het mandaat af te wijken. ${ }^{115}$

Tenslotte is wel aangevoerd de mandate doctrine geen rekening houdt met het feit dat het mandaat waarover een regering beschikt, niet gedurende de gehele periode waarin een regering aan de macht is gelijke kracht heeft, omdat omstandigheden en opvattingen aangaande het te voeren beleid (c.q. een bepaald deel daarvan) gedurende deze periode aan verandering onderhevig kunnen zijn. ${ }^{116}$ In deze opvatting zou het mandaat dus in de loop van de regeringsperiode zwakker worden naarmate de tijd na de verkiezingen verstrijkt en de regering langer aan de macht is. Dit laatste punt van kritiek komt echter zeer vergezocht voor. Wanneer deze opvatting zou worden aanvaard, betekent dat een terugkeer naar het imperatief mandaat. Immers, alleen wanneer bij een bepaald beleidspunt steeds een last van de kiezers wordt verkregen, dan wel dat met hen ruggespraak gehouden wordt, kan gezegd worden dat het mandaat een accurate en actuele momentopname is en de gehele regeerperiode door dezelfde waarde heeft.

115. Vergl. Jennings, a.w., p. 506; Hood Philips, a.w., p. 56.

116. Harvey/Bather, a.w., p. 493/494. 
De mandate doctrine vertoont veel overeenkomsten met de theorie van het electoraal mandaat. Zoals hiervoor (hoofdstuk 2) reeds is aangegeven geeft de kiezer in de theorie van het electoraal mandaat evenmin een mandaat aan de individuele volksvertegenwoordiger. Waar in de theorie van electoraal mandaat de kiezer een (vrij) mandaat geeft aan de politieke partij van zijn keuze die het vervolgens (zij het met een meer imperatief karakter) doorgeeft aan haar afgevaardigden in het parlement, is ook in de mandate doctrine de individuele volksvertegenwoordiger vooral een afgevaardigde van de partij:

"He is a party man, indeed a party delegate. If he belongs to the majority party, his task is to carry out the party program, for it is through program that the voters have given party a mandate to govern. (...) This mandate, however, is not a local mandate. Party has distilled the interests and aspirations of a class into a comprehensive social philosophy. The program deriving from this philosophy, while favoring one class over another, is conceived to be in the long-run interests of the whole nation. It makes sure that the voter (...) asks himself 'the right question', ruling out merely local representations and giving the voter only a choice between two national viewpoints. Thus, the old problem of whether the MP should represent his constituency of the nation is given a new solution. The function of representing the national interest, once attributed to the Sovereign and later to Parliament, is now performed by party". ${ }^{117}$

De mandate doctrine kan worden gezien als een species van het electoraal mandaat: als gevolg van het Britse kiesstelsel gaat het mandaat aan de politieke partij min of meer automatisch over de regering, mits zij de verkiezing wint. ${ }^{118}$ Gezien het twee-partijenstelsel heeft doorgaans immers steeds een van de grote partijen de meerderheid en kan zij zonder problemen de regering vormen en daarmee vervolgens haar partijprogramma c.q. verkiezingsprogramma ten uitvoer brengen. In Nederland en Duitsland moet steeds een coalitie gevormd worden teneinde een regeringsmeerderheid te krijgen, waarmee het mandaat dat de kiezers de partijen bij de verkiezingen hebben gegeven verzwakt raakt als gevolg van de noodza-

117. S.H. Beer, Modern British politics. Parties and pressure groups in the collectivist age, 3e druk, Londen 1982, p. 87/88.

118. De afgevaardigden van de verliezende partijnen hebben strikt genomen wel een electoraal mandaat. 
kelijke compromissen. De mandate doctrine is daarom, vanwege de verwachting -zo niet het vereiste- dat het partijprogramma (zo veel mogelijk) zal worden omgezet in beleid, strikter dan de leer van het electoraal mandaat. Daarnaast kan worden gezegd dat zij van de Britse politici en academici meer erkenning heeft gekregen dan de leer van het electoraal mandaat door hun collegae op het vastenland, al kan enig opportunisme ten aanzien van de aanwending ervan de betrokken politici niet worden ontzegd: "In short, the doctrine of the mandate is part of the political cant. It is a stick used by the Opposition to beat the Government". ${ }^{119}$

Ondanks alle kritiek is de mandate doctrine niettemin van belang als grondslag voor de staatsrechtelijke vertegenwoordiging in het Verenigd Koninkrijk. Daarnaast is het een uitdrukking van het fundamentele democratische vereiste dat uitspraken die ten tijde van de verkiezingen worden gedaan in grote lijnen moeten worden waargemaakt. ${ }^{120} \mathrm{Nu}$ het vooral de politieke partij is die dergelijke uitspraken doet, al dan niet schriftelijk in de vorm van een programma, is de partij al eerste gebonden deze zo veel mogelijk uit te voeren. Voor de afgevaardigden van de partij in het parlement heeft dit tot gevolg dat ook zij zich op die uitspraken kunnen beroepen en eventueel, als gevolg van hun interpretatie van de betreffende uitspraak, tot een afwijkend standpunt komen. In dit opzicht voorkomt de mandate-doctrine het intreden van de uiterste consequentie van de partijenstaat: de absolute afhankelijkheid van de individuele volksvertegenwoordiger aan zijn partij en fractie. Zij verhindert dat partijen naar willekeur de afgevaardigden kunnen binden.

De mate van onafhankelijkheid van de individuele volksvertegenwoordiger binnen de mandate-doctrine is echter beduidend minder dan in de liberale theorie van de representatieve democratie. Om deze reden heeft de liberale theorie dan ook nog niet geheel voor het Britse staatsrecht afgedaan. In voorkomende gevallen (d.i. wanneer het de politici zo uitkomt) wordt er nog wel een beroep op gedaan, vooral wanneer een volksvertegenwoordiger in conflict dreigt te geraken met zijn partij. ${ }^{121}$

119. Jennings, a.w., p. 505.

120. Vergl. Harvey/Bather, a.w., p. 494.

121. Vergl. Kingdom, a.w., p. 158. 


\subsection{De relatie tussen de MP en de centrale en parlementaire partijorganisatie ${ }^{122}$}

De leden van het Lagerhuis ontlenen hun status van volksvertegenwoordiger tegenwoordig vooral aan de Representation of the People Act (1983) en de House of Commons Act ${ }^{123}$ (1949, sindsdien herhaaldelijk gewijzigd); beide wetten vinden strikt genomen hun oorsprong in de Reform Act van 1832. Toch is de huidige staatsrechtelijke positie van de leden van het Britse parlement slechts in zeer beperkte mate uit deze wetten af te leiden. Zij bevatten voornamelijk -naast de materiële regeling van het actief en passief kiesrecht- formeelrechtelijke bepalingen (te vergelijken met de inhoud van de Nederlandse Kieswet). ${ }^{124}$ Hiervoor is reeds angegeven dat de positie van de MPs vooral door de conventions bepaald wordt. Hieronder zal worden uiteengezet in hoeverre deze conventions doorwerken in de relatie tussen de MP en zijn partij en in de relatie tussen de MP en zijn kiezers c.q. achterban.

Net zoals de kiesstelsels van de meeste westerse staten vormt ook het Britse kiesstelsel tegenwoordig een grote belemmering voor het verwerven van een zetel in het Lagerhuis als onafhankelijk, niet partij-gebonden kandidaat. De (schaarse) gevallen waarin de laatste decennia personen erin zijn geslaagd als 'onafhankelijken' in het Lagerhuis te komen, betroffen veelal reeds in het Lagerhuis zitting hebbende MPs die na onenigheid uit hun partij waren gestapt (c.q. gezet) en op grond van hun populariteit in hun district waren herkozen. Bijna zonder uitzondering werden zij bij de

122. De kwalificatie als vertegenwoordiger van het volk c.q. lid van het parlement ('Member of Parliament') heeft in het Verenigd Koninkrijk slechts betrekking op de leden van het Lagerhuis; de leden van het Hogerhuis worden geacht "no one but themselves" te vertegenwoordigen. Waar in deze paragraaf het woord parlement wordt gebruikt is dat als synoniem voor het Lagerhuis en niet (meer) als de Queen in Parliament.

123. Ook wel bekend als Redistribution of Seats Act. Naast de hier genoemde wetten zijn er nog andere Acts die bepalingen t.a.v. het kiesrecht bevatten, zoals de House of Commons Disqualification Act 1975, die bekleders van een aantal openbare ambten van het passief kiesrecht uitsluit (vergl. Hood Philips, a.w., pp 179-182; De Smith/Brazier, a.w., p. 251/252).

124. Vergl. Erskine May, Parliamentary practice, a.w., pp. 20-54; Prakke, a.w., pp. 702-705. 
volgende verkiezing echter verslagen door een partijgebonden kandidaat. Nadat een antal (in meerderheid) Labour MPs zich tijdens de parlementszirting van 1979-1983 van de partij afscheidden en de Social Democratic Party vormden, verloren bij de algemene verkiezingen van 1983 meer dan twintig van hen hun zetel, hetgeen duidelijk illustreert dat hun oorspronkelijke verkiezing niet gebaseerd was op hun persoonlijke populariteit, maar op die van hun (voormalige) partij. Regel is daarom dat kandidaten worden gekozen en in het parlement zitting hebben vanwege hun binding aan een politieke partij.

Evenals de meeste andere Europese landen zijn ook in Groot-Brittanië politieke partijen als zodanig een betrekkelijk recent verschijnsel. Sinds het verval van de Liberal Party in de periode 1914-1935 wordt de Britse politiek gedomineerd door twee grote politieke organisaties, de Conservative Party (de erfgenamen van de 17e eeuwse Tories) en de Labour Party. Deze laatste partij werd pas in 1900 opgericht, maar was reeds in 1922 de Liberal Party voorbijgestreefd. Sindsdien zijn het de Conservative Party en de Labour Party die elkaar de macht betwisten. Alleen deze twee partijen zijn in staat geweest om bij algemene verkiezingen voldoende aanhang te verwerven om hun leiders in staat te stellen het land te besturen, dan wel 'Her Majesty's Loyal Opposition' te voeren.

De ontwikkeling van dit enigszins rigide twee-partijensysteem hangt samen met verschillende veranderingen in de Britse parlementaire democratie. De oorsprong van het twee-partijensysteem gaat terug tot het einde van de $17 \mathrm{e}$ eeuw toen de macht betwist werd door de Tories en de Whigs. ${ }^{125}$ In de tweede helft van de $19 \mathrm{e}$ eeuw evolueerden de partijen tot massa-partijen met oligarchische structuren en een professioneel bestuursapparaat. De oorzaak hiervan was gelegen in de tweede Reform Act. De uitbreiding van het kiesrecht die deze Act teweegbracht, dwong de politieke partijen zich tot hechte(re) verbanden te organiseren en een verbinding met de achterban te creëren. Tot die tijd waren de politieke partijen niet meer geweest dan parlementaire groeperingen, weliswaar met enige organisatiestructuren binnen het parlement, maar niet daarbuiten. Lokale afdelingen bestonden niet. Evenmin bestond de mogelijkheid dat de kiezers lid werden van de partij. De verkiezingen zelf waren zaak van individuen, niet van partijorganisaties. Bij de verkiezingen van 1880 kandideerden de meeste kandi-

125. Vergl. hiervoor ( $\$$ 3). Zie tevens: Van Caenegem, a.w., p. 103; Pulzer, a.w., p. $37 / 38$. 
daten nog op persoonlijke titel; de volgende verkiezingen, in 1885 , werden echter reeds gedomineerd door de binding van de kandidaten aan een politieke partij. ${ }^{126}$

Analoog aan de versterkte organisatie van de politieke partijen werd ook de partij-discipline sterker; in de 20e eeuw zou zij een 'logische constante' worden. De toename van de partij-discipline komt tot uitdrukking in de afname van het aantal kabinetten dat (vervroegd) moest aftreden als gevolg van onenigheid in de partij: in de $18 \mathrm{e}$ en $19 \mathrm{e}$ eeuw was dit een veelvuldig voorkomend verschijnsel, in de $20 \mathrm{e}$ eeuw daarentegen was het uiterst zeldzaam. Hieraan verwant is de geleidelijke toename van de partijeenheid zoals die zich bij stemmingen in het Lagerhuis manifesteerde. ${ }^{127}$ De periode 1945-1970 wordt dan ook gekenmerkt door de verkiezing van MPs die niet of nauwelijks bereid zijn het risico te nemen om hun oppositie tegen het beleid van de eigen partij openbaar te maken. "This significant occurence in British politics reinforced the tendency to rigidity in the British political system and marked the final stage in the history of party discipline in which Britsh party leaders could obtain obedience from their followers in divisions, in other parliamentary activities, and, to a lesser degree, outside parliament". 128

Vanaf 1970 valt echter een kentering in deze ontwikkeling waar te nemen (zie hieronder).

\subsubsection{De rol van de centrale partijorganisatie}

Hoewel elk lid van het parlement een zekere speelruimte heeft om zich tegen bepaalde aspecten van het beleid van de partij te verzetten, geldt

126. Vergl. O'Leary, a.w., p. 183.

127. Zie hierover bijv. H. Berington, MPs and their constituents in Britain: The history of the relationship, in: V. Bogdanor (ed.), Representatives of the people? Parliamentarians and constituents in western democracies, Aldershot 1985, p. 26/27; R.J. Jackson, Rebels and Whips. An analysis of dissension, discipline and cohesion in British political parties, Londen 1968, p. 4; Birch, The British system of government, a.w., p. 38/39; Budge/McKay, a.w., p. 60.

128. Jackson, a.w., p. 4. Onder het begrip partij-discipline wordt in dit kader niet alleen (de mate van) eenheid binnen een politieke partij aangegeven, maar ook de methoden die door die partij c.q. de leiding daarvan worden gebruikt om de partijeenheid te bewaren. 
dat zij hun status van MP ontlenen bij de gratie van de partij. Burke's klassieke opvatting dat een eenmaal gekozen MP bij zijn beslissing over de in het parlement aanhangige zaken geheel onafhankelijk diende te zijn, is daarom ook in het Verenigd Koninkrijk nauwelijks nog in overeenstemming met de hedendaagse praktijk. Een enkele keer, vooral bij ethisch geladen kwesties als abortus of de doodstraf, zal de partij geen stemdwang toepassen, maar in de meeste gevallen waarover het Lagerhuis dient te beslissen zijn de MPs in de eerste plaats verantwoording schuldig aan hun partij; in gemiddeld $90 \%$ van de stemmingen in het Lagerhuis zal de partij de MPs aangeven hoe zij dienen te stemmen. ${ }^{129}$ Mocht een MP zich aan de partij-discipline onttrekken dan kan ook hier de MP niet (tussentijds) door zijn partij worden gedwongen zijn zetel op te geven. In dit opzicht bestaat ook in het Verenigd Koninkrijk de restfunctie van het vrije mandaat. Toch zal deze onafhankelijkheid voor de MP slechts tijdelijk blijken te zijn: het is praktisch gesproken onmogelijk zich als MP te verzekeren van een herverkiezing wanneer niet de partij-lijn wordt gevolgd.

Hoewel strikt persoonlijke kandidaturen alleszins mogelijk zijn en ook wel eens voorkomen, is de kandidaatstelling vooral een zaak van de politieke partijen. Hierbij spelen zowel de centrale partij-organisatie als de plaatselijke afdeling een rol. Nu de wet ook op dit punt ten aanzien van politieke partijen zwijgt, is de selectie van kandidaten binnen de partij "wholly unregulated by rules of strict law, and depends on extra-legal party-rules and practices". ${ }^{130}$ MPs worden gekozen door de partij-organisatie in het district dat zij (gaan) vertegenwoordigen volgens de interne, vaak gedetaileerde regels voor de selectie van kandidaten zoals die door de centrale partij-organisatie zijn opgesteld. De centrale partij-organisatie heeft een beperkt vetorecht: $z i j$ kan een door de lokale partij voorgedragen kandidaat afwijzen, maar mag niet zelf in een vervanging voorzien. ${ }^{131}$ De centrale partij-organisatie (bij Labour het dagelijks bestuur, het National Executive Committee (NEC), bij de Conservatives het Conservative Central Office) maakt slechts sporadisch van dit vetorecht gebruik. Dit wordt mede veroor-

129. Vergl. Silk/Walters, a.w., p. 44.

130. De Smith/Brazier, a.w., p. 254.

131. Vergl. Kavanagh, a.w., p. 73 en p. 125/126. Zie ook: M. Rush, Political recruitment, representation and participation, in: J.P. Mackintosh (ed.), People and Parliament, Westmead 1978, p. 18/19. 
zaakt door de angst voor een afsplitsing van de lokale partij-organisatie bij het gebruiken van het veto.

De rol van de centrale partij-organisatie is voor het overige beperkt tot het opstellen van lijsten van mogelijke kandidaten. Zowel de Labour Party als de Conservative Party hebben centrale lijsten van geschikte ('approved') kandidaten. De nominatie van aspirant-MPs voor een dergelijke lijst geschiedt binnen de Labour Party door de plaatselijke (wijk)afdelingen en aan de partij verwante organisaties (doorgaans de vakbonden). Het dagelijks bestuur van de lokale partij-organisatie stelt een (summiere) voordracht op; de daadwerkelijke verkiezing geschiedt, behoudens het veto van het dagelijks bestuur van de Labour Party, in een vergadering van een in elk kiesdistrict in te stellen kiescollege. In dit college hebben afgevaardigden van de vakbonden $40 \%$ van de stemmen, de overige leden ('ordinary members') $60 \%$. $^{132}$

De selectieprocedure binnen de Conservative Party is in grote lijnen identiek aan die van Labour. Aspirant-MPs voor de conservatieven worden onderworpen aan een twee dagen durende selectie alvorens zij als 'approved candandidate' op de centrale lijst worden geplaatst. Bij de Conservative Party kan de selectiecommissie van ieder district elke door haar gewenste kandidaat aanwijzen, ongeacht of deze nu wel of niet op de centrale lijst voorkomt; de daadwerkelijke verkiezing geschiedt in een vergadering van de plaatselijke partij. In praktijk echter worden doorgaans slechts kandidaten van de lijst aangewezen. ${ }^{133}$

\subsubsection{De Whips en the whip}

Is een MP voor zijn kandidaatstelling (mede) afhankelijk van de centrale partijorganisatie, wanneer hij eenmaal gekozen is en als backbencher in het Lagerhuis belandt, is hij in hoge mate afhankelijk van de fractie. Binnen de parlementaire fracties van de politieke partijen vormen de Whips een belangrijk en uniek fenomeen. Elke in het Lagerhuis vertegenwoordigde politieke partij heeft de aanwezigheid van een of meer Whips noodzakelijk geoordeeld voor een goed functioneren van haar fractie in het parlement. Het verschijnsel van de Whips is in die zin geînstitutionaliseerd dat de Whips van de regeringspartij (thans veertien in getal) 'ministers of the Crown' zijn; van de oppositie krijgen de drie 'senior

132. Vergl. De Smith/Brazier, a.w., p. 254/255.

133. Vergl. Silk/Walters, a.w., p. 12. 
official opposition Whips' zelfs een salaris; naast de leider van de oppositie zijn zij de enige leden van de oppositie die van rijkswege een salaris ontvangen. Elk van de grote partijen kent een Chief Whip, een Deputy Chief Whip en verschillende junior Whips. De benoemingsprocedure van de Whips verschilt per partij. ${ }^{12}$

De Whips hebben tot taak de communicatie binnen de fractie te verzekeren, teneinde te bewerkstelligen dat "the parliamentary party system is used to convert political aims into political achievements through the use of MP's votes, cast on a party basis". ${ }^{135} \mathrm{Zij}$ vormen min of meer het kanaal waarlangs de communicatie tussen partijleiding en leden van het Lagerhuis (en dan met name de backbenchers) verloopt; zij doen aanbevelingen omtrent promotie van backbenchers en dragen (mede) zorg voor handhaving van de fractiediscipline. ${ }^{136}$ Daarnaast hebben zij tot taak de onder de leden levende opvattingen, voorzover van belang voor de partijleiding, te signaleren en naar de laatste toe te verwoorden. ${ }^{137}$ Mede hierom zorgt elke partij ervoor dat bij elke zitting van het Lagerhuis (c.q. een commissie daaruit) steeds een Whip aanwezig; het is een convention dat geen van hen er het woord zal voeren. De Whips zijn voorts verantwoordelijk voor het efficiënt functioneren van het pairing system. Hierbij wordt getracht bij stemmingen in het Lagerhuis (vooral bij de zgn. 'two-line whip', zie hieronder) de afwezigheid van MPs van de eigen partij te neutraliseren door met Whips van andere partijen overeen te komen dat een evenredig aantal MPs van andere partijen eveneens afwezig zal zijn. De afwezige MP van de eigen partij wordt dan min of meer gepaard aan een afwezige MP van de andere partij. Elke partij kent daartoe een Pairing Whip, die bijhoudt welke MP een pair heeft, welke van plan is bij een stemming verstek te laten gaan en wat de reden voor deze afwezigheid is. Na elke stemming gaat de Pairing Whip na hoe de MPs van zijn partij hebben gestemd en of geen van hen zonder (geldige) reden bij stemming verstek heeft laten gaan. ${ }^{138}$

134. Hierover: Jackson, a.w., p. 35; Kingdom, a.w., p. 284.

135. Silk/Walters, a.w., p. 48.

136. Vergl. R. Brazier, Constiturional practice, Oxford 1988, p. 168; J.A.G. Griffith/M. Ryle, Parliament. Functions, practice and procedures, Londen 1989, p. 113/114; O. McDonald, Parliament at work, Londen 1989, p. 116; De Smith/Brazier, a.w., p. 266/267; Budge/McKay, a.w., p. 62.

137. Vergl. Jackson, a.w., p. 35.

138. Idem, p. 42. 
De taak van de Whips komt het duidelijkst tot uiting in het zenden van the whip, de agenda waarop de onderwerpen staan vermeld die op korte termijn in het Lagerhuis aan de orde zullen komen. Hoewel de whip naar de letter slechts een oproep tot aanwezigheid is, stijgt de betekenis in de praktijk hier ver boven uit: de whip bevat ook de uitdrukkelijke instructie voor de MPs zich bij het stemgedrag te richten naar de partij-lijn. ${ }^{130}$ Door middel van onderstreping van de onderwerpen vermeld in de whip (een enkelvoudige, dubbele of drievoudige onderstreping), wordt aangegeven in welke mate de partij-leiding aan een bepaald onderwerp hecht. Een enkelvoudige onderstreping ('one-line whip') geeft in het algemeen aan dat over het desbetreffende onderwerp geen stemming zal plaatsvinden. Een 'two-line whip' wordt gebruikt om openlijke rebellie van MPs bij controversiële onderwerpen te vermijden: de dubbel onderstreepte whip stelt een MP die aangaande het betreffende onderwerp kritisch ten opzichte van het partijstandpunt staat, in de gelegenheid een pair te vormen en bij de stemming verstek te laten gaan.

Wanneer een 'three-line whip' uitgaat, geeft de partijleiding de MPs te kennen dat van hen verwacht wordt dat zij bij de bespreking van het desbetreffende onderwerp in het Lagerhuis aanwezig zijn en hun stem uitbrengen (op de door de partijleiding gewenste wijze). Wanneer een MP een 'threeline whip' zonder geldige reden naast zich neer legt, dient dit veelal opgevat te worden als een verzetsdaad tegen de partijleiding. Een 'threeline whip' wordt zo belangrijk geacht dat in het buitenland verblijvende MPs (doorgaans op eigen kosten) terug dienen te keren wanneer een dergelijke whip uitgaat. ${ }^{140}$ Normaliter zullen de meeste MPs zonder meer gehoor geven aan de 'three-line whip'; in het -schaarse- geval waarin zij het oneens zijn met hetgeen van hen verwacht wordt, treden de Whips op als intermediair tussen de betrokken MP(s) en de partijleiding. Van een MP die om hem moverende reden in een bepaald geval bij een 'three-line whip' het partijstandpunt niet kan onderschrijven, wordt verwacht dat hij contact opneemt met een van de Whips van de partij om zijn zaak uiteen te zetten. De Whip zal dan een bijeenkomst met de betrokken MP en iemand van de

139. Vergl. Brazier, a.w., p. 168; Jackson, a.w., p. 39.

140. Een enkele keer wordt erg ver gegaan met het realiseren van deze verwachting: het is voorgekomen dat een (conservatieve) premier een lijnschip naar de Verenigde Staten beval midden in de oceaan te stoppen om een backbencher te laten overstappen op een ander schip dat richting Engeland voer; vergl. Jackson, a.w., p. 39. 
partijleiding beleggen; deze laatste zal uitleggen waarom de steun van de MP gewenst is en zal hem proberen op andere gedachten te brengen. Wanneer dit laatste geen resultaat mocht opleveren, hebben de Whips zelf geen middelen tot hun beschikking om de betrokken MP weer in het gareel te krijgen of hem te straffen. De toepassing van dergelijke middelen is voorbehouden aan de partij c.q. fractie. Naast eventuele problemen met de lokale partij-organisatie (die geen direct effect zullen hebben op het functioneren als MP) dient de MP in een dergelijk geval vooral de centrale partij-organisatie te vrezen. Deze beschikt over de ultieme sanctie van uitstoting uit de partij. ${ }^{141}$ Daarnaast kan de fractie de betrokken MP een waarschuwing geven of gedurende enige tijd schorsen. Wanneer zij een zwaardere sanctie tegen een weerspannige MP nodig oordeelt, kan zij deze de whip ontnemen (withdrawal of the whip). Dit laatste staat gelijk aan uitstoting uit de fractie: de betrokken MP mag geen vergaderingen van de partij meer bezoeken, ontvangt geen whip en raakt verstoken van alle parlementaire informatie en steun, waardoor hij voortaan in het House of Commons vrijwel geheel op zichzelf aangewezen is. ${ }^{142}$

Naast de Whips als parlementaire organen waarlangs de communicatie tussen partijleiding en backbenchers verloopt, kennen de politieke partijen in het Lagerhuis nog andere organen die voor de backbenchers van belang zijn. Vooral de Conservative Party en de Labour Party kennen in dit opzicht een formeel kader; de overige partijen kennen, mede als gevolg van hun geringere zetelaantal, een lossere structuur. De Conservative Party heeft hiertoe het 'Conservative Private Members Committee', een commissie die echter bekender is onder de naam 1922 Committee. $^{143}$ In deze commissie hebben alle MPs van de partij zitting, met uitzondering van die MPs die tevens lid zijn van de regering, of -in voorkomende gevallen-van het schaduwkabinet. De Whips van de partij wonen de vergaderingen van de commissie wel bij, maar hebben geen stemrecht. Het 1922 Committee is

141. Over de andere, mindere ingrijpende sancties die een partij voorts nog ter beschikking staan: Jackson, a.w., pp. 23-34.

142. Vergl. De Smith/Brazier, a.w., p. 267; MeDonald, a.w., p. 118; Kingdom, a.w., p. 285.

143. Deze naam is afgeleid van de vergadering van conservatieve MPs in de Carlton Club in oktober 1922 die leidde tot de val van Chamberlain als partijleider en het uiteenvallen van de conservatief-liberale coalitieregering onder leiding van Lloyd George. 
een belangrijke opiniebron, wier opvattingen de partijtop in hoge mate respecteert, maar zij is niet betrokken bij het formuleren van het beleid van de partij. ${ }^{144}$

Alle Labour MPs, maken deel uit van de in 1923 opgerichte Parliamentary Labour Party (PLP), die qua functie vergelijkbaar is met het 1922 Commiltee, zij het dat de PLP zich naar de partijleiding formeler -en soms zelfs agressiever- opstelt. Beide organen spelen ook een belangrijke rol bij de verkiezing van de partijleider, waarbij aan het 1922 Committee meer macht toekomt dan aan de PLP. ${ }^{145}$ Als gevolg van het feit dat de activiteiten van eerstgenoemde commissie zich veelal buiten de publiciteit voltrekken (in tegenstelling tot haar Labour-tegenhanger), heeft het 1922 Committee onderhand een legendarische naam gekregen, die door zijn rol bij de perikelen rond het aftreden van Mrs Tatcher slechts is versterkt.

Gezien het bovenstaande kan worden gesteld dat de invloed van de politieke partijen op hun afgevaardigden in het parlement ook in het Verenigd Koninkrijk aanzienlijk is. In de relatie tussen MP en de centrale en de parlementaire partijorganisatie (de fractie) resteert voor eerstgenoemde weinig onafhankelijkheid. Zeker binnen de Labour Party is dit uitdrukkelijk het geval. In een 1968 opgestelde, thans nog steeds van kracht zijnde 'Code of Conduct' voor de leden van de PLP wordt de bewegingsvrijheid van de MPs tot een minimum beperkt:

"While the Party recognises the right of Members to abstain from voting in the House on matters of deeply held personal conviction, this does not entitle Members to vote contrary to a decision of a Party Meeting, or to abstain from voting on a Vote of Confidence in a Labour Government. "146

De andere partijen in het Lagerhuis hebben nooit een code met een dergelijke bepaling opgesteld. Maar zeker binnen de Conservative Party heeft de praktijk geleerd dat de MPs bij stemmingen geacht worden volgens een zelfde regel te handelen.

144. Vergl. R.T. McKenzie, British political parties. The distribution of power within the Conservative and Labour parties, 2e druk, Londen 1964, p. 59; Kingdom, a.w., p. 282.

145. De regels van de belangrijkste politieke partijen voor de verkiezing van de partijleider zijn opgenomen bij Brazier, a.w., pp. 260-266.

146. Opgenomen bij Griffith/Ryle, a.w., p. 114/115. 
Hoewel door deze strikte binding voor het vrije mandaat nog hooguit slechts een restfunctie is weggelegd, blijkt dat zolang er over de hoofdlijnen van het te voeren beleid eensgezindheid bestaat, partijen wel bereid zijn te accepteren dat er binnen zekere marges ruimte is voor afwijkende opvattingen over (aspecten van) dat beleid. Analyses van het stemgedrag in het Lagerhuis laten zien dat MPs in toenemende mate van hun afkeuring over het beleid van de partij blijk geven door tegen de partij(-lijn) te stemmen zonder dat dit tot sancties leidt. Vooral onder de Labour-regering van $1974^{147}$ is deze ontwikkeling in een stroomversnelling geraakt; in een half jaar tijd werd de regering Wilson maar liefst zeventien maal weggestemd. De Labour-regering van 1974-1979 overkwam het tweëenveertig maal, alvorens in maart 1979 door een motie van wantrouwen getroffen te worden. ${ }^{148}$ Ter vergelijking: de regering Heath (1970-1974) werd, ondanks een Lagerhuismeerderheid van 30 zetels, in haar regeringsperiode zes maal weggestemd, waarvan drie keer zelfs bij een 'three-line whip'. Deze ontwikkeling heeft ook een zekere preventieve werking: het te verwachten negatieve stemgedrag van de eigen MPs aangaande een bepaald onderwerp zal de regering ervan weerhouden terzake met (wets)voorstellen te komen. ${ }^{149}$

Voor de regeringspartij geldt dat de mate waarin afwijkend stemgedrag van de eigen MPs het regeringsbeleid kan doorkruisen ook samenhangt met de grootte van de meerderheid die zij in het Lagerhuis bezit. In de laatste regeerperiode van Mrs. Tatcher, toen de regeringspartij de grootste meerderheid sinds 30 jaar binnen het Lagerhuis had, konden 'dissenting votes', ondanks hun toegenomen aantal, het regeringsbeleid niet snel in gevaar brengen, al is het ook in deze regeerperiode wel eens voorgekomen

147. Hiermee wordt gedoeld op de (tweede) Labour-regering onder leiding van Harold Wilson, die na de verkiezingen van februari 1974 aan de macht kwam. Bij deze verkiezingen werd Labour weliswaar de grootste partij, maar slaagde er niet in de absolute meerderheid te behalen. Wilson schreef daarom voor oktober 1974 nieuwe verkiezingen uit, die ditmaal Labour wel de absolute meerderheid brachten ( 319 van de 635 zetels).

148. Brazier, a.w., p. 175. Zie ook Kavanagh, a.w., p. 227; Budge/McKay, a.w., p. 61 en pp. 64-66.

149. Vergl. Silk/Walters, a.w., p. 63. 
dat de regering haar plannen afgestemd zag. ${ }^{150}$ Maar zelfs wanneer dit 'gevaar' niet dreigt, kan het voorkomen dat MPs van de regeringspartij van hun onenigheid met het regeringsbeleid blijk geven. Echter, dit geldt niet voor alle MPs: de ministers, de staatssecretarissen, de Whips en de 'parliamentary private secretaries' mogen niet tegen de partij-(lijn) stemmen; zij vormen de payroll vote die op grond van de conventions verplicht is de regering met zijn stem te steunen.

\subsection{De relatie tussen de MP en zijn lokale partij en kiezers}

Het is opvallend dat (aspirant) MPs geen enkele formele band met het district behoeven te hebben. Een praktische uitzondering vormen Schotland en Wales, waar de kandidaten in ieder geval van Schotse, respectievelijk Welse afkomst moeten zijn, terwijl in Yorkshire de lokale partijen zelden een kandidaat aanzoeken die niet in het graafschap woonachtig is. In het algemeen wordt echter noch van kandidaten noch van de MPs verwacht dat zij in het district woonachtig zijn. De kandidaten van de beide grote partijen zijn zelfs meestal geen 'local men'. Wel wordt door de plaatselijke afdelingen van de toekomstige kandidaten verwacht dat zij zich vertrouwd maken met de problemen van het district. En als onderdeel van dit proces van nursing the constituency kan ook van hen gevraagd worden zich, nadat zij als MP zijn verkozen, in het district te vestigen. Een 'prospective candidate' mag aan deze kennismaking met het district zoveel geld besteden als hij wil, maar voor de eigenlijke campagne, die begint wanneer de Prime Minister de verkiezingsdatum bekend maakt, geldt een maximumbedrag, vastgelegd in de Representation of the People Act. ${ }^{151}$ Om niet serieus bedoelde kandidaatstellingen tegen te gaan dient door of vanwege iedere kandidaat een waarborgsom van $£ 500$ te worden gestort, die wordt verbeurd als de kandidaat niet minstens $5 \%$ van de uitgebrachte stemmen

150. Zie de voorbeelden genoemd door Brazier, a.w., p. 176, Kingdom, a.w., p. 285 en Budge/McKay, a.w., p. 60 . Meest spectaculaire voorbeeld is wel het in tweede lezing sneuvelen (in 1986) van het wetsontwerp dat de openingstijden van winkels op zondag moest uitbreiden: ondanks het uitgaan van een 'three-line whip' stemden 72 MPs van de Conservative Party, de meesten van hen onder aanzienlijke druk van hun districten, tegen het wetsontwerp.

151. Vergl. De Smith/Brazier, a.w., p. 257. 
op zich verenigt. Deze waarborgsom wordt, evenals de meeste andere uitgaven van de kandidaat ten behoeve van zijn verkiezingscampagne, door de lokale partij betaald. ${ }^{152}$ Oolk in dat opzicht is er dus een grote afhankelijkheid van de partij.

\subsubsection{Constituency surgery}

Waar Burke de opvatting huldigde dat een eenmaal gekozen MP niet zi.jn district, maar het hele land diende te vertegenwoordigen, hebben in de tegenwoordige tijd nog maar weinig MPs een dergelijke afstandelijke houding tegenover hun kiesdistrict. Ook voor het Verenigd Koninkrijk geldt dat de toenemende staatsbemoeienis met de maatschappij, de belangstelling van de media voor de politiek en het parlement en het verminderde respect voor de gevestigde instellingen hebben geleid tot toenemende druk vanuit de kiesdistricten op hun MP om hun belangen te behartigen. Uit een in 1985 gepubliceerd onderzoek, waaraan ongeveer tweederde van alle toenmalige MPs deelnamen, blijkt dat MPs hun taak als woordvoerders voor lokale aangelegenheden als belangrijk tot zeer belangrijk beschouwen $(88,1 \%)$; hetzelfde geldt voor de taak van lokale ombudsman $(82,9 \%)$, terwijl de taakopvatting van de MP als maatschappelijk werker van het district door zo'n driekwart van de ondervraagden werd onderschreven $(72,2 \%)$. $^{153}$

De wijze waarop de meeste MPs functioneren in relatie tot hun achterban wordt wel constituency surgery genoemd; dit vanwege de overeenkomsten die het bezoeken van de lokale MP vertoont met het bezoeken van een arts. ${ }^{154}$ Net als laatstgenoernde houden de MPs spreekuur op een van te voren bekend gemaakte plaats en tijd, meestal wekelijks of tweewekelijks op vrijdagmiddag of zaterdagochtend. Afhankelijk van de grootte van het kiesdistrict kan een MP meerdere spreekuren hebben. De inwoners van het kiesdistrict zoeken contact met hun MP aangaande alle denkbare problemen, maar het zijn vooral problemen met betrekking tot huisvesting en sociale voorzieningen die frequent aan de MPs worden voorgelegd.

152. Vergl. Silk/Walters, a.w., p. 12; MacDonald, a.w., p. 64.

153. Silk/Walters, a.w., p. 54. De uitkomsten van dit onderzoek hevestigen die van eerdere onderzoeken; zie daarover J. Jeger, The image of the MP, in: Mackintosh, a.w., pp. 11-13.

154. Vergl. Silk/Walters, a.w., p. 54. Illustratief voor de inhoud van deze 'surgery' is de bijdrage van de MP Brian Gould, The MP' and constituency cases, in: Mackintosh, a.w., pp. 84-94. 
De surgeries vinden hun oorsprong in een van de oudste functies van het Engelse parlement, 'the redress of grievances'. De surgeries zijn een nieuwe uitingsvorm hiervan. Als zodanig zijn zij lange tijd door de MPs verwaarloosd. Tussen beide wereldoorlogen begonnen Labour MPs zich deze functie weer eigen te maken, maar het duurde tot na de Tweede Wereldoorlog vooraleer de surgeries beschouwd werden als onderdeel van de taken die een MP hoort te vervullen. ${ }^{155}$ Vooral de backbenchers zien zichzelf in toenemende mate als 'good constituency members', enerzijds omdat zij dit zelf als hun belangrijkste rol beschouwen, anderzijds omdat hun kiezers dit als de spilfunctie van de werkzaamheden van een MP zien. ${ }^{156}$ Daarbij kan een onderscheid gemaakt worden tussen MPs die als 'welfare officer' fungeren en MPs die als 'local promoter" optreden. De laatsten zien zichzelf meer als belangbehartiger van lokale en regionale belangen, waar de eerstgenoemden vooral begaan zijn met het lot van de individuele kiezer. ${ }^{157}$

De MP wordt door zijn achterban beschouwd als een machtige bondgenoot, die als een soort advocaat kan optreden voor de belangen van zijn kiezers, niet alleen wanneer de 'tegenpartij' een overheidslichaam is, maar ook tegenover privaatrechtelijke rechtspersonen, of het nu een locale werkgever betreft of de Britse PTT. MPs zullen zich niet inlaten met persoonlijke conflicten tussen kiezers; evenzo zullen zij trachten geen invloed op de rechtspraak uit te oefenen. Behalve deze twee uitzonderingen zullen zij zich doorgaans inzetten voor alle zaken die de achterban hen voorlegt, zelfs wanneer deze formeel niet tot de verantwoordelijkheid van de MP behoren. Bij constituency surgery zal de politieke voorkeur van de bezoekende kiezer voor de inzet van de MP onbelangrijk zijn, wellicht met uitzondering van de -schaarse- gevallen waarin onderwerpen van partij-politieke

155. Vergl. D.D. Searing, The role of the good constituency member and the practice of representation in Britain, in: Joumal of Politics, vol. 47 (1985), p. 350. Zie ook: Ph. Norton, Parliament in perspective, Hull 1987, p. 9 en J.W. Marsh, Representational changes: the constituency MP, in: Ph. Norton (ed.), Parliament in the 1980s, Oxford 1985, p. 69.

156. Vergl. Radice/Vallance/Willis, a.w., p. 49.

157. Uitvoeriger: Searing, a.w., pp. 357-360. 
aard door de kiezer worden aangedragen. In dat geval kan de onpartijdige opstelling van de MP in het gedrang komen. ${ }^{158}$

De kiezers verwachten dan ook in toenemende mate van hun MPs dat zij zich regelmatig in het district vertonen. Ook in dit opzicht bestaat er dus een duidelijk verschil met de opvattingen van Burke. Het werk dat de MP in zijn district verricht is veelal van ceremoniële aard, hetgeen niet weg neemt dat het een belangrijk gedeelte van zijn tijd in beslag neemt. Een MP voor de Conservative Party omschreef het zo:

"The MP must be alvailable. He will be expected to respond to invitations to lunch, to dine and to speak, and to pay visits to local institutions, such as hospitals, police and fire stations."

Daarnaast moet de MP natuurlijk ook nog de activiteiten van zijn lokale partij bijwonen. Zo verklaarde bovengenoemde MP hierover:

"The MP's relations with the local party are every bit as important.

This will mean that Fridays (when the House is not sitting) and weekends (all the year, save for August during which politics takes a holiday) can be taken up with wine and cheese parties, fêtes and fayres, the annual general meetings of ward association, and a plethora of Christmas parties. These can be tiresome, but are more often entertaining. I seem to have spent the best part of my life drawing the raffle. ${ }^{159}$

Naast de sociale verplichtingen ten opzichte van de lokale partij heeft de MP ook politieke verplichtingen. Eenmaal gekozen als lid van het parlement zijn de MPs van de Labour Party automatisch onderworpen aan mandatory reselection (athankelijk van de uitkomst van de procedure ook wel deselection genoemd), een beoordelingsprocedure door de lokale partij die sinds 1980 door de Labour Party wordt gehanteerd om de invloed van de leden van de partij te vergroten. Gedurende de zittingsperiode van het parlement dient elke Labour MP eenmaal het proces van reselection te ondergaan teneinde te beoordelen of de MP bij de volgende verkiezing gehandhaafd wordt als de kandidaat van de lokale partij. ${ }^{100}$ Reselection kan

158. Vergl. I. Crewe, MPs and their constituents in Britain: How strong are the links?, in: Bogdanor, a.w., p. 55.

159. Silk/Walters, a.w., p. 55.

160. Hierover: De Smith/Brazier, a.w., p. 255; Silk/Walters, a.w., p. 12; Kavanagh, a.w., p. 73; Birch. The British systern of government, a.w., p. 69. 
daarom (indirect) uiteindelijk tot gevolg hebben dat de betrokken MP zijn zetel verliest. In de praktijk verloopt de reselection voor de meeste Labour MPs zonder problemen. In de zeldzame gevallen waarin deselection is toegepast was verwaarlozing van de belangen van het eigen district veelal het excuus, maar had de werkelijke reden andere oorzaken. ${ }^{161}$ De automatische reselection is niet onomstreden.Betoogd is dat zij gevaarlijk dicht in de buurt komt van de situatie waarin afgevaardigden worden gebonden door lastgevingen van hun kiezers. ${ }^{162}$ Het proces betekent immers dat Labour MPs moeten zorgen voor een goede relatie met de lokale partij, willen zij ook bij de volgende verkiezing hun kandidaat zijn. Het uitvoeren van lastgevingen zou een manier kunnen zijn om tot een dergelijke relatie te komen. De manier waarop de MP zijn surgeries verricht kan hem echter een sterkere en onafhankelijkere positie ten opzichte van de lokale partij verschaffen. Wanneer hij deze taak tot tevredenheid van de kiezers van het district verricht, zal de lokale partij het minder snel op een conflict met de betrokken MP laten aankomen.

Ook binnen de Conservative Party is deselection geen onbekend verschijnsel. Anders dan bij Labour is dit binnen de Conservative Party echter geen mogelijk gevolg van het automatisme van een reselection-procedure. Eenmaal verkozen als MP kunnen de MPs van de Conservative Party er normaliter van uitgaan dat zij de nominatie van hun partij behouden; slechts de algemene (leden)vergadering van de lokale partij kan tot deselection van de eigen MP overgaan. Dit gebeurt vrijwel nooit, al wordt er wel eens door de lokale partij mee gedreigd. ${ }^{163}$ Daarom geldt ook voor MPs van deze partij dat het niet aan te bevelen is de wensen van de lokale partij van het kiesdistrict te negeren.

Het hierboven geschetste beeld van de surgeries behoeft enige nuancering. De frequentie en inhoud van de contacten met de MP worden bepaald door

161. Vergl. Crewe, a.w., p. 51.

162. Vergl. Young, a.w., p. 9.

163. In de laatste decennia is deselection (op grond van afwijkende politieke inzichten tussen lokale partij en MP) binnen de Conservative Party slechts één keer voorgekomen: in januari 1990 werd Sir Anthony Meyer, MP namens Clwyd NW, door zijn lokale partij verstoten, ironisch genoeg omdat hij het had gewaagd het leiderschap van Mrs. Tatcher te betwisten. Had Meyer dit 10 maanden later gedaan, dan had het hem wellicht een ministerspost opgeleverd .... 
de aard en omvang van het kiesdistrict. Ook de functie van de betreffende MP speelt een rol. Zo zal een MP die tegelijkertijd lid van de regering is, de contacten met zijn district veelal (moeten) overlaten aan iemand van de lokale partij-organisatie of een andere afgevaardigde, hetgeen tot gevolg heeft dat hij zijn 'constituency duties' minder effectief kan vervullen dan een nauwgezette backbencher. ${ }^{164}$ Daarnaast heeft een MP natuurlijk nog andere taken te vervullen. Naast zijn parlementaire werkzaamheden kunnen dat bijvoorbeeld ook taken zijn die voortvloeien uit de relatie -in welke vorm dan ook- die de MP met een bepaalde belangengroepering onderhoudt: "In Britain (...) it has always been regarded as healthy for all the interests and views that exist within society to have their spokesmen in the national Parliament." 165

Toch blijkt uit onderzoek dat een groot deel van de tijd die een MP beschikbaar heeft, wordt besteed aan het onderhouden van contacten met de achterban. In het hierboven reeds genoemde onderzoek uit 1985 bleek dat in de maanden waarin het Lagerhuis zitting hield een kleine meerderheid van de ondervraagden, $52,1 \%$, acht tot twaalf dagen per maand in het kiesdistrict doorbracht; $20,9 \%$ was zelfs meer dan dertien dagen aanwezig. Genoemde percentages zijn gerelateerd aan de maanden waarin het Lagerhuis zitting heeft, doorgaans worden dan op meer dan twintig dagen vergaderingen gehouden. Gevoegd bij de grote afstanden tussen sommige districten en Londen en de (bijbehorende) moeilijke bereikbaarheid, geven de getallen duidelijk aan dat de betrokkenheid tot de achterban bij de (meeste) MPs groot is.

Een en ander laat overigens onverlet dat het onderhouden van de contacten ook van de kiezers zelf uitgaat. Te denken valt hier bijvoorbeeld aan de vele brieven die MPs (al dan niet via hun lokale partij) dagelijks ontvangen. Hoewel onderzoek aantoont dat het effect daarvan betrekkelijk gering is ${ }^{166}$-behalve soms als aanwijzing voor de MPs over welke onderdelen van het beleid bij de kiezers de meeste ontevredenheid heerst-, bestaat bij de kiezers een rotsvast vertrouwen dat het helpt, hetgeen weer tot gevolg heeft dat de waardering voor de betrokken MP stijgt. ${ }^{167}$ Het kiesstelsel,

164. Vergl. Crewe, a.w., p. 46.

165. Birch, Representative and responsible government, a.w., p. 141.

166. Vergl. bijvoorbeeld Jeger, a.w., p. 14/15.

167. Vergl. Norton, a.w., p. 10; Marsh, a.w., p. 75. 
dat deze al dan niet vermeende band tussen kiezer en gekozene mogelijk maakt, draagt er aldus toe bij het representatieve stelsel te versterken. ${ }^{10}$ Daarnaast wordt de MP niet alleen in het kiesdistrict zelf bezocht. Ook wanneer hij zich in Londen bevindt weten de kiezers hem te vinden. Door middel van de zgn. 'green card' laten zij via een bode de MP weten dat zij op hem wachten in centrale hal van het Lagerhuis (voor iedereen toegankelijk tijdens de zittingen). De MP is niet verplicht het verzoek om een onderhoud in te willigen, maar doorgaans zal hij dat toch doen en niet alleen vanwege het feit dat de betrokken kiezer zoveel moeite heeft gedaan hem te bezoeken. Hij is immers voor zijn herverkiezing mede van hem afhankelijk.

Uit de intensieve relatie tussen MP enerzijds en kiezers en lokale partij anderzijds volgt dat van de MP verwacht wordt altijd de belangen van zijn district te behartigen. Waar in andere landen (bijv. Duitsland) dit veelal een bijkomstigheid is en zeker niet als verplichting wordt gezien, is dit in het Verenigd Koninkrijk wel het geval. Wanneer een MP van district verandert, heeft dat tot gevolg dat hij zijn politieke aandachtsgebieden moet aanpassen aan de belangen van het district. De sterke binding aan het district betekent ook dat -in ieder geval in de opvatting van de kiezers- het belang van het district prevaleert boven dat van de (centrale) partij. ${ }^{169}$

De daadwerkelijke invloed van de kiezers is ondanks alles zeer gering. Als uitvloeisel van het twee-partijensysteem zal de aanwijzing door de partijen van hun officiële kandidaat in de regel bepalen wie de zetel zal gaan bezetten; de rol van de kiezers is daarmee eigenlijk beperkt tot het betuigen van hun instemming voor de kandidaat. ${ }^{170}$ Dat de uitkomsten van de verkiezingen voor het House of Commons vanaf de jaren zeventig lijken te wijzen op een ontwikkeling in de richting van een drie-partijensysteem doet hieraan niets af. Het groeiende cynisme van de kiezers ten aanzien van het functioneren van de politieke partijen, zoals dat uit onderzoek naar voren

168. Koopmans, a.w., p. 251.

169. Vergl. Silk/Walters, a.w., p. 57; Crewe, a.w., pp. 48-51; Jeger, a.w., p. $12 / 13$.

170. Vergl. De Smith/Brazier, a.w., p. 254. In dezelfde zin: J.P. Mackintosh, Attitudes to the representative role of Parliament (introduction) en $\mathrm{P}$. Paterson, Primaries: reforming the candidate selection proces, beiden in: Mackintosh, a.w., p. 2 resp. p. 30. 
$\operatorname{komt}^{171}$, kan moeilijk los worden gezien van een verdere verzwakking van de positie van de kiezers.

Nu de selectie van de kandidaten is voorbehouden aan de partijen, is de Britse MP veeleer afhankelijk van zijn lokale partij dan van de lokale kiezers. Deze selectie, genormeerd door interne partijregels, kent weliswaar enige lokale democratische controle binnen de partijen, maar deze contolerende taak is doorgaans voorbehouden aan een kleine groep kiezers, tevens partijleden, het selectoraat:

"Candidate selection (...) is in the hands of a small, often tiny, knot of party activists, whose political position is usually unrepresentative of the party's ordinary supporters in the constituency". 172

Dit heeft een enkeling al doen concluderen dat de meeste MPs tegenwoordig door minder personen worden aangewezen dan in de periode voor de Reform Act van 1832. ${ }^{173}$

171. Vergl. R. Topf, Political change and political culture in Britain, 1959-87, in: J.R. Gibbins (ed.), Contemporary political culture, Londen 1989, p. $59 / 60$.

172. Crewe, a.w., p. 62.

173. R. Rose, The problem of party government, Harmondsworth 1976, p. 252. 


\section{HET VRIJE MANDAAT IN HET HEDENDAAGSE STAATSRECHT}

\subsection{Inleiding}

In dit slothoofdstuk staat de waarde en de functie van het vrije mandaat in het hedendaagse staatsrecht centraal. Allereerst komen in de volgende twee paragrafen de theorie (paragraaf 2) en de praktijk (paragraaf 3) van het vrije mandaat aan bod, toegespitst op de relaties die de volksvertegenwoordiger met zijn partij c.q. fractie en met zijn kiezers onderhoudt. Deze relaties zijn in de hiervoor besproken landen in grote lijnen identiek, vandaar dat de aandacht zich hier op alle drie de landen richt. Vervolgens zal in de resterende twee paragrafen de aandacht worden verlegd naar het Nederiandse staatsrecht. Hierbij komt niet alleen de huidige, vrij algemeen aanvaarde restfunctie van het vrije mandaat aan de orde (paragraaf 4 ), maar zal ook worden ingegaan op de andere functies die aan het vrije mandaat kunnen en moeten worden toegekend (paragraaf 5).

\subsection{Onafhankelijkheid als constitutionele norm}

Hiervoor (hoofdstuk 2) is beschreven hoe de opvattingen over de relatie tussen volksvertegenwoordigers en hun kiezers zoals die in de $18 \mathrm{e}$ eeuw het meest eloquent door Edmund Burke werden verwoord, als de liberale theorie van de representatieve democratie zijn uitgegroeid tot de heersende doctrine. In deze theorie zijn de leden van een vertegenwoordigend lichaam geen lasthebbers (meer) van hun kiezers, maar treden zij op als hun onafhankelijke gevolmachtigden. $\mathrm{Zij}$ zijn geen vertegenwoordigers van deelbelangen, maar dienen het algemeen belang van de natie te behartigen. Wat dit algemeen belang precies inhoudt is moeilijk te bepalen en zal van geval tot geval bekeken moeten worden; in ieder geval sluit het uit dat uitsluitend belangen van bepaalde groepen van de natie worden vertegenwoordigd.

In het vertegenwoordigend lichaam, het parlement, komen de vertegenwoordigers van het volk bijeen om door uitwisseling van argumenten en met inachtneming van het algemeen belang tot een rationele oplossing van 
de hen voorgelegde vraagstukken te komen. Deze oplossing wordt niet ontleend aan de wil of de opvattingen van de kiezers, maar komt voort uit redelijk parlementair overleg.' Het besluit van het parlement wordt het volk toegerekend; pas hierdoor krijgt dit volk een wil. Zonder vertegenwoordiging kan er geen uitdrukking worden gegeven aan de volkswil: deze wil bestaat pas vanaf het ogenbiik dat de leden van het parlement hem hebben geformuleerd. ${ }^{2}$ Via het systeem van staatsrechtelijke vertegenwoordiging worden verlangens van het volk door de volksvertegenwoordiging gezeefd en gefilterd totdat ze passen binnen de politiek van het mogelijke. Spontane reacties van de bevolking worden door de volksvertegenwoordiging getransformeerd tot datgene wat binnen de maatschappelijke werkelijkheid en binnen het rechtssysteem aan veranderingen gerealiseerd kan worden. ${ }^{3}$ Dat dit leidt tot enige verwijdering tussen kiezer en gekozene moet op de koop toe genomen worden: het moderne vertegenwoordigend stelsel impliceert nu eenmaal reductie en vervreemding. ${ }^{4}$ De politieke realiteit kan tot gevolg hebben dat de gekozenen beslissingen moeten nemen waarin de kiezers hun voorkeuren steeds minder herkennen.

Het is duidelijk dat de volksvertegenwoordiging aan de liberale theorie een bijzonder essentiële rol in het staatkundig bestel ontleent. De volkswil bestaat pas als de volksvertegenwoordigers de inhoud ervan hebben bepaald en geconcretiseerd. De volksvertegenwoordiging brengt dus allerminst een reeds bestaande wilsuiting over, maar formuleert deze. Deze wil is geldig voor de hele volk. Door het deelnemen aan parlementaire debatten en het totstandbrengen van wetten, geven de volksvertegenwoordigers uiting aan de eengemaakte volkswil die samenvalt met het algemene belang. ${ }^{5}$ Het zijn daarom dan ook slechts personen die door eigendomsverwerving, intellec-

1. Vergl. J.J.A. Thomassen, Politieke representatie, in: J.J.A. Thomassen (red.), Hedendaagse democratie, Alphen aan den Rijn 1991, p. 170.

2. E. Witte, Politiek en democratie. Omtrem de werking van de westerse democratieën in de 19de en 20ste cenw, Brussel 1990, p. 29. Zie cok: A.M. Donner, Over representatie, in: De mens in het recht (bundel W.F. Prins), 's-Gravenhage 1975, p. 106.

3. M.C. Burkens/H.R.B.M. Kummeling/B.P. Vermeulen, Beginselen van de democratische rechtsstaat. Inleiding tot de grondslagen van het Nederlandse staats- en bestuursrecht, 2e druk, Zwolle 1992, p. 27.

4. Vergl. F.H. van der Burg, Overheid en onderdaan in een representarieve democratie (preadvies VAR), Haarlen 1970, p. 25.

5. Vergl. Witte, a.w., p. 29. 
tueel vermogen en/of bekwaamheid een vooraanstaande plaats in de samenleving bekleden die zich met dit algemene belang mogen inlaten: waar het volk zelf de kennis en het inzicht mist om tot een zinnige afweging te komen, beschikken zij over de eigenschappen die hen geschikt maken om de volkswil te verwoorden en het algemeen belang te herkennen. ${ }^{6}$ De onafhankelijkheid van deze volksvertegenwoordigers staat dan ook centraal. Bij het formuleren van de volkswil moeten ze immers volkomen autonoom een beroep doen op de ratio, zonder enige band met het volk of groepen daaruit. Vandaar ook dat zij parlementaire onschendbaarheid genieten en geen imperatief mandaat kennen.

Door de geleidelijke uitbreiding van het kiesrecht in de $19 \mathrm{e}$ en $20 \mathrm{e}$ eeuw is de behartiging van het algemeen belang niet meer uitsluitend voorbehouden aan een elitaire groep. Deze uitbreiding en de hiermee gepaard gaande opkomst van de politieke partijen en andere groeperingen (zoals vakbonden) geschiedde echter binnen de contouren van de liberale staat. De principes en instellingen van deze staat veranderden daarom niet. Ondanks de uitbreiding van het aantal kiesgerechtigden was er formeel gezien sprake van continuteit, hetgeen vooral te verklaren is uit het feit dat deze uitbreiding uitermate geleidelijk geschiedde en via de conflictregulerende technieken van het parlementair systeem (discussies, het vertrouwen in de rede) werd geïntegreerd en gedisciplineerd. ${ }^{7}$ De toetreding van de massa had echter wel een wijziging van de concrete werking van het liberale systeem tot gevolg. Het vertegenwoordigend stelsel berustte in feite niet meer op vertegenwoordiging van het onbepaalde begrip volk, maar op vertegenwoordiging van de verschillende sociale groeperingen. Extra-constitutionele organen zoals politieke partijen, vakbonden en andere belangengroepen waren voortaan van groot belang voor de (efficiënte) werking van het parlementaire regeringsstelsel. ${ }^{\overline{8}}$

Deze ontwikkeling liet de bovengenoemde principes voor het overige echter onverlet, hoewel de politieke praktijk hen tot een formeel kader heeft herleid. De hoofdkenmerken van de liberale theorie van de representatieve democratie zijn nog altijd formeel of materieel in de meeste constituties van de westerse democratieën geïncorporeerd. Uitgangspunt is nog steeds dat het parlement (c.q. een deel daarvan) door het volk wordt

6. Vergl. Thomassen, a.w., p. 170; Witte, a.w., p. 29.

7. Vergl. Witte, a.w., p. 65.

8. Idem, p. 66. 
gekozen om dat volk bij het nemen van besluiten te vertegenwoordigen. De handelingen van het vertegenwoordigend lichaam worden niet aan de leden daarvan persoonlijk, maar aan het volk toegerekend: het volk is gebonden aan de besluiten van het vertegenwoordigend lichaam.

Het begrip volk is in dit verband enigszins dubbelzinnig. Aan de ene kant heeft de term betrekking op allen die volgens het recht van een staat tot de burgers ervan worden gerekend; dit is de ruime uitleg van het begrip. In engere betekenis ziet de term slechts op hen, die het recht hebben in de samenwerking tussen overheid en volk een actieve rol te spelen, ook al is die actieve rol doorgalans beperkt tot het aanwijzen van vertegenwoordigers (de 'Aktivbürgerschaft'). ${ }^{9}$ In de huidige Nederlandse staat, alsmede in de ons omringende landen bestaat het volk in deze laatste, enge betekenis dus uit de kiesgerechtigden. De beide betekenissen van het begrip volk moeten scherp van elkaar worden onderscheiden. Hoewel in een moderne democratie de beide betekenissen elkaar dicht benaderen -het aantal kiesgerechtigden beslaat immers een groot deel van het volk in ruime zin-, zijn de begrippen geen synoniemen. Het volk in ruime zin kan nooit identiek zijn aan het volk in enge zin.

\subsubsection{Onafhankelijkheid blijvende noodzaak}

Wanneer gezegd wordt dat de leden van het parlement het gehele volk vertegenwoordigen, wordt daarmee het volk in de ruime betekenis van het woord bedoeld. Zij worden echter gekozen door het volk in enge zin. Mede hierom is de onafhankelijkheid van de individuele volksvertegenwoordiger een vereiste. Dat is echter niet de belangrijkste reden voor het onafhankelijkheidsvereiste. Het vereiste is in de eerste plaats historisch bepaald.

Het vereiste hangt nauw samen met het ontstaan van de moderne staat. Met het nationaal besef groeit de overtuiging dat de volksvertegenwoordigers ook het belang van de hele natie dienen te behartigen en niet dat van een regio of een bepaalde groepering (stand). Het is deze taak van de volksvertegenwoordiger in de moderne staat die zijn onathankelijkheid noodzakelijk maakt. Daarnaast geldt nog het praktische argument dat vertegenwoordiging in het huidige staatsbestel vrijwel de enige manier ter verwe-

9. Vergl. P.W.A. Immink, Beschouwingen over de ontwikkeling van de begrippen volk en vertegenwoordiging, in: Publiekrechtelijke opstellen (bundel C.W. van der Pot), Zwolle 1950, p. 120/121. 
zenlijking van (enige) democratie is, zolang de mogelijkheid tot het houden van een referendum ontbreekt of -zoals in Duitsland- erg beperkt is. De onafhankelijkheid van de individuele volksvertegenwoordiger is bij staatsrechtelijke vertegenwoordiging essentieel voor het functioneren van het besluitvormingsproces. De geschiedenis heeft immers aangetoond dat een stelsel waarin de afgevaardigden gebonden zijn aan een imperatief mandaat door middel van een gebod van last en ruggespraak, het recht van veto en het vereiste van eenparigheid van stemmen niet functioneert. In de tegenwoordige tijd, met de toegenomen taken van de overheid zou een dergelijk stelsel daarom ook volstrekt ondenkbaar zijn.

De noodzakelijke onafhankelijkheid voor de individuele volksvertegenwoordiger heeft gestalte gekregen in het vrije mandaat. Dit mandaat, in het algemeen geformuleerd als een verbod van last, is in de meeste westerse democratieën een constitutioneel beginsel. De keuze voor het constitutioneel incorporeren van het verbod van last is voornamelijk toe te schrijven aan historische motieven. Het markeert doorgaans een breekpunt in de geschiedenis van de betreffende staat. Waar voorheen de leden van de vertegenwoordigend lichamen in een sterke afhankelijkheidsrelatie tot degenen die hen benoemden stonden, leidde het ontstaan van de moderne staat tot een taakverandering voor de volksvertegenwoordigers -het behartigen van het algemeen belang- die het noodzakelijk maakte de oude bindingen met hun committenten te verbreken. Dat betekende echter niet dat er geen bindingen overbleven: het vrije mandaat beoogt niet alle contact tussen de volksvertegenwoordigers en hun achterban te verbieden. De liberale theorie van de representatieve democratie veronderstelt echter een zeer losse binding, die de individuele volksvertegenwoordiger alle handelingsvrijheid laat. Dit werd reeds door Burke onderkend:

"To deliver an opinion is the right of all men; that of constituents is a weighty and respectable opinion, which a representative ought always to rejoice to hear; and which he ought always most seriously to consider. But authoritative instructions, mandates issued, which the member is bound blindly and implicitly to obey, to vote, and to argue for, though contrary to the clearest conviction of his judgment and conscience, -these are things utterly unkown to the 
laws of this land, and which arise from a fundamental mistake of the whole order and tenor of our constitution. ${ }^{10}$

Van de landen waarvan de onafhankelijkheid van de individuele volksvertegenwoordiger hiervoor aan een nadere beschouwing is onderworpen geldt dat in Nederland en Duitsland het vrije mandaat (formeel) grondwettelijk is verankerd. In het Verenigd Koninkrijk is dit logischerwijs niet het geval, maar ook hier geldt dat de onafhankelijkheid van de individuele volksvertegenwoordiger norm is, zij het in mindere sterke mate dan in de overige twee landen het geval is. " Dit is een gevolg van de 'mandate doctrine' die de liberale theorie van de representatieve democratie naar de achtergrond heeft gedrongen, al wordt ook in het Verenigd Koninkrijk in voorkomende gevallen nog wel een beroep op haar gedaan. Evenmin speelt een rol dat de kiesstelsels van de desbetreffende landen onderling nogal verschillen. Voor de afgrenzing van de onathankelijkheid van de individuele volksvertegenwoordiger is de aard van het kiesstelsel niet relevant: het is zijn taak in het moderne staatsbestel die zijn onathankelijkheid ten opzichte van andere individuen en groeperingen tot een essentieel vereiste maakt.

Dat het vereiste van de onafhankelijkheid van de individuele volksvertegenwoordiger wordt ingegeven door de taak die hij in het staatsbestel vervult, is ook de reden dat de ontwikkelingen die zich hebben voorgedaan sinds het vrije mandaat als constitutioneel beginsel werd erkend en die van invloed waren op het functioneren van de volksvertegenwoordiging (waarbij met name moet worden gedacht aan de opkomst van de politieke partijen), eigenlijk nog niet eens van zoveel invloed zijn geweest op het constitutioneel kader. Daarmee wordt niet bedoeld dat constitutionele erkenning van die ontwikkelingen veelal is uitgebleven. Dat is in dit kader minder relevant: ook in de weinige gevallen waar dit wel is geschied (Duitsland) is de onafhankelijkheid van de individuele volksvertegenwoordiger als zelfstandig constitutioneel vereiste blijven bestaan. Maar ook in de landen waar een formele regeling op het punt van de politieke partijen ontbreekt, is het functioneren en de invloed van de politieke partijen nog steeds begrensd door het vrije mandaat. Het bestaan van politieke partijen noopte weliswaar tot een aanvulling van het theoretisch kader van het

10. E. Burke, Speech to the electors of Bristol (3 november 1774), in: The works of the Right Honourable Edmund Burke (deel 2), Londen 1906/1907, p. 165 (cursivering in origineel).

11. Zie hieronder, $\$ 3$. 
vertegenwoordigend stelsel in de moderne democratie (de theorie van het electoraal mandaat), maar doet niets af aan het vereiste van de onafhankelijkheid van de individuele volksvertegenwoordiger. Het functioneren van de politieke partijen ten opzichte van hun kandidaten voor de vertegenwoordigende lichamen, hun praktische monopolie bij de kandidaatstelling etc. hebben het vereiste van de onafhankelijkheid van de laatsten juist alleen maar aan belang doen toenemen. De onafhankelijkheid van de individuele volksvertegenwoordiger geldt eens te meer als constitutionele norm.

De liberale theorie van de representatieve democratie is daarom in theoretisch opzicht nog steeds van waarde bij de bepaling van de staatsrechtelijke positie van de individuele volksvertegenwoordiger. In de meeste (westerse) landen vormt zij het uitgangspunt voor het stelsel van staatsrechtelijke vertegenwoordiging. De rol van de politieke partijen doet, zoals gezegd, weinig af aan de liberale theorie c.q. de taak die de volksvertegenwoordiger daarin vervult: hij dient nog steeds niet een deelbelang (i.c. het belang van de partij), maar het algemeen belang te behartigen. In dit opzicht heeft de constitutionele norm van het verbod van last zijn normerende werking tot op de dag van vandaag behouden. ${ }^{12}$

\subsection{Beperkte onafhankelijkheid als staatkundige praktijk}

De onafhankelijkheid van de individuele volksvertegenwoordiger ten opzichte van anderen vormt een essentieel, zo niet het doorslaggevende element bij de plaatsbepaling van diens staatsrechtelijke positie. Zijn primaire taak -het vertegenwoordigen van het gehele volk, waarbij het algemeen belang als criterium dient- kan hij alleen dan effectief vervullen wanneer hij niet afhankelijk is van anderen. Deze onafhankelijkheid is eveneens noodzakelijk voor het effectief functioneren van het totaal van de volksvertegenwoordigers, het parlement. Aan de andere kant kan een democratisch staatsbestel in de huidige constellatie ook niet functioneren zonder het intermediair van de politieke partij, terwijl parlementaire werkzaamheden alleen in fractieverband effectief kunnen worden verricht. De hieruit voortkomende relaties tussen volksvertegenwoordiger en partij en

12. Vergl. D.J. Elzinga/C. Wisse, De parlementaire fracties (Nederlands Parlementsrecht, deel 5), Groningen 1988, p. 169. 
tussen volksvertegenwoordiger en fractie impliceren noodzakelijkerwijs een vermindering van de onathankelijkheid van de individuele volksvertegenwoordiger. Daarnaast heeft het ontstaan van deze relaties tot gevolg gehad dat de relatie tussen volksvertegenwoordiger en kiezer aan belang heeft ingeboet. Door de intensiteit van de relaties tussen volksvertegenwoordiger en partij en volksvertegenwoordiger en fractie is de relatie tussen kiezer en gekozene vrijwel non-existent geworden: alleen bij verkiezingen is zij nog waarneembaar. Waar echter er van uitgegaan moet worden dat in de huidige democratie het primaat nog steeds bij het volk (in de ruime betekenis van het woord) berust -het beginsel van de volkssoevereiniteit ligt in alle westerse democratieën wel in de een of andere vorm ten grondslag aan de (materiële) constitutie- en de volksvertegenwoordiger de intermediair is tussen volk en bestuur, maakt de verzwakking van de relatie tussen kiezer en gekozene de discrepantie tussen theorie en praktijk alleen maar groter.

Opgemerkt dient te worden dat een volksvertegenwoordiger tegenwoordig naast de hierboven genoemde relaties bij de vervulling van zijn staatsrechtelijke taak ook relaties onderhoudt met anderen groeperingen en individuen, zoals belangengroeperingen en vakbonden. Van dergelijke relaties kan gezegd worden dat zij afgeleiden zijn, d.w.z. zij bestaan naast (een van) de drie genoemde relaties. Een volksvertegenwoordiger is nooit alleen maar afgevaardigde namens een dergelijke groepering. De aard van deze afgeleide relaties en de mate van onafhankelijkheid daarin laat zich moeilijk in algemene bewoordingen weergeven. Omdat het afgeleiden zijn, zal er zelden sprake zijn van een grote afhankelijkheid. Alleen voor de MPs van de Labour Party in het parlement van het Verenigd Koninkrijk liggen de zaken enigszins anders. Vanwege de nauwe band tussen de vakbonden en de Labour Party (een deel van de MPs van de partij wordt door de vakbonden gesponsord) is in de relatie tussen de MP en de betrokken vakbond sprake van een relatief grote afhankelijkheid.

\subsubsection{Relatie volksvertegenwoordiger - kiezer}

De relatie tussen volksvertegenwoordiger en kiezer is van de drie hier centraal staande relaties de oudste; zij bestaat vanaf het moment dat vertegenwoordigende lichamen voor het eerst bijeengeroepen worden. Het bestaan van een dergelijk lichaam impliceerde echter allerminst dat het regeringsstelsel van de betreffende staat viel te typeren als een regeringsvorm waarbij die vertegenwoordigende lichamen een doorslaggevende functie factor vormden in het besluitvormingsproces, in die zin dat vrijwel geen belangrijke (politieke) verandering kon worden doorgevoerd die niet 
de instemming had van dat lichaam. ${ }^{13}$ Een dergelijk regeringsstelsel ontstond eerst in de 17e eeuw in het Verenigd Koninkrijk door de vestiging van de sovereignty of parliament na 1688. Later, aan het einde van de $18 \mathrm{e}$ eeuw volgden Frankrijk en de Verenigde Staten, terwijl andere Europese staten, onder invloed van de Franse revolutie, de daaropvolgende eeuw volgden.

De vertegenwoordigende lichamen waren daarom aanvankelijk geen volksvertegenwoordigingen in de moderne betekenis van het woord, maar overlegorganen waarin afgevaardigden van de standen bijeenkwamen om met de landsheer of vorst overleg te plegen. De relatie tussen deze vertegenwoordigers en hun committenten werd geheel beheerst door regels van privaatrecht. De afgevaardigden waren lasthebbers, die voor de uitvoering van hun opdracht aan hun committenten verantwoording schuldig waren; zij traden op als procureurs van hun stand, niet van een staatkundige eenheid. ${ }^{14}$ Handelingen van de vertegenwoordigers werden geacht door de lastgever (de standen) te zijn verricht. Wanneer de vertegenwoordiger naar de mening van de lastgever zijn taak niet goed uitoefende, kon hij door deze worden teruggeroepen, of uit zijn vertegenwoordigingsbevoegdheid worden ontzet. Als gevolg van het gebod van last en ruggespraak stonden de vertegenwoordigers in een sterke afhankelijkheidsrelatie ten opzichte van degenen die hen benoemden.

De huidige, op onathankelijkheid gebaseerde relatie tussen volksvertegenwoordiger en kiezer ontstaat in de 17e eeuw in Engeland; later, als gevolg van de Franse revolutie, raakt zij ook over het Europese vasteland verspreid. Deze relatie is sindsdien door de tijden heen gekenmerkt door een relatief grote onafhankelijkheid van volksvertegenwoordiger ten opzichte van de kiezer. Deze onafhankelijkheid is uitgegroeid tot constitutioneel vereiste. Dat is te verklaren uit het feit dat de (grond)wetgever zich bij het opstellen van de bepalingen die de onafhankelijkheid van de individuele volksvertegenwoordiger moesten garanderen, zijn onafhankelijkheid in de relatie met zijn kiezers voor ogen had. Deze bepalingen vinden immers hun bestaansgrond in het voorkomen van de situatie waarin de afgevaardigde in een afhankelijkheidsrelatie stond ten opzichte van degenen die hem benoemden. Daarnaast speelde het groeiend besef dat een vertegenwoordi-

13. Vergl. A.H. Birch, Representation, Londen 1971, p. 30.

14. H.R. Nord, Historische ontwikkeling en beteekenis van de representatiegedachte in het staatsrecht, Leiden 1941, p. 36. 
gend lichaam het gehele volk diende te vertegenwoordigen een rol, een besef dat doorgaans ook in de constitutie werd opgenomen.

Deze bepalingen zijn daarom van historisch belang. In Nederland markeren zij de totstandkoming van de eenheidsstaat en de breuk met de praktijk van besluitvorming ten tijde van de Republiek der Verenigde Nederlanden. De bepalingen waren dan ook vooral bedoeld om de leden van de StatenGeneraal te beschermen tegen (te) vergaande beïnvloeding van buitenaf, waarmee bij de constituering van het Koninkrijk der Nederlanden met name werd gecloeld op beïnvloeding door de provincies, die immers aanvankelijk (tot 1848) de leden van de Staten-Generaal kozen. In Duitsland valt een soortgelijke ontwikkeling waar te nemen. De constitutionele verankering van de beginselen van de liberale theorie van de representatieve democratie in de loop van de $19 \mathrm{e}$ eeuw past ook hier in het streven naar meer staatkundige eenheid en een vermindering van de invloed van de Duitse landen. In het Verenigd Koninkrijk is, ondanks het ontbreken van een geschreven grondwet, hetzelfde het geval. Ook daar waren de afgevaardigden van de counties en de boroughs aanvankelijk lasthebbers van hun kiezers. Eerder dan in Nederland hebben zij zich echter aan hun lastgeving weten te onttrekken en zijn zij zich zelf uitdrukkelijk gaan beschouwen als vertegenwoordigers van het gehele volk. Waar de liberale theorie van de representatieve democratie op het Europese vasteland zouden uitgroeien tot het (theoretisch) kader voor de staatsrechtelijke positie van de volksvertegenwoordiger in de moderne staat, was zij in het Verenigd Koninkrijk slechts de weerslag van de praktijk, al verzetten plaatselijk kiezers zich tegen de vermindering van hun invloed die hiervan het gevolg was. De staatkundige ontwikkelingen gingen in het Verenigd Koninkrijk nu eenmaal sneller dan in de rest van Europa.

Voor alle drie landen geldt dat een bewustzijn van de gevaren die schuilden in een te grote athankelijkheid van de individuele volksvertegenwoordiger ten opzichte van zijn kiezers aanwezig was. De geleidelijke uitbreidingen van het kiesrecht vormden slechts nieuwe signalen om die onafhankelijkheid te blijven waarborgen: het gevaar dat een groter wordend aantal kiezers de onafhankelijkheid van de volksvertegenwoordigers onder druk zou kunnen gaan zetten, werd allerminst denkbeeldig geacht.

De taak van de kiezer -en daarmee zijn invloed- is in het algemeen slechts beperkt tot het regelmatig uitbrengen van zijn stem. Alleen van dat deel van het kiezerscorps dat lid is van een politieke partij, kan gezegd worden dat de functie en invloed groter zijn, al verschilt dit per partij en zal zeker 
ten aanzien van de (aanwijzing van) kandidaten voor het volksvertegenwoordigend lichaam op centraal niveau de invloed beperkt zijn. Recent onderzoek naar de kandidaatstellingsprocedures binnen de Nederlandse politieke partijen leert bijvoorbeeld dat de invloed van afdelingen erg beperkt is. ${ }^{15}$ En alleen via deze afdelingen kunnen de leden enige invioed op de besluitvorming uitoefenen.

Voor het overige is er alleen bij het moment van de verkiezingen sprake van enige afhankelijkheid van de volksvertegenwoordiger. De lage frequentie van het contact tussen volksvertegenwoordiger en kiezer leidt weliswaar tot een ook in de praktijk relatief grote onafhankelijkheid van de eerste, maar heeft ook tot gevolg dat er een steeds grotere verwijdering tussen kiezer en gekozene optreedt. Of er daarom nog gesproken kan worden van een relatie tussen volksvertegenwoordiger en kiezer is zeer de vraag. Eerstgenoemde is weliswaar van de laatste afhankelijk om voor (her)verkiezing in aanmerking te komen (zij het dat de politieke partijen hier voor een eerste schifting zorgen), maar de facto is de invloed van de individuele kiezer dusdanig beperkt dat zijn taak tot een symbolische handeling is gereduceerd, die hooguit als meerwaarde heeft dat zij de concrete machtsverhoudingen tussen de politieke partijen voor een aantal jaren vaststelt. ${ }^{16}$ Alleen in het Verenigd Koninkrijk liggen de zaken enigszins anders (zie hieronder).

Een en ander neemt niet weg dat er ook tussentijds contact tussen volksvertegenwoordiger en kiezer voorkomt, maar dit contact is van een andere aard. Anders dan bij een verkiezing is hierbij geen sprake van een beoordeling of meningsuiting door de kiezer waarbij de (kandidaat-)vertegenwoordiger afhankelijk is van de kiezers. Het is veeleer andersom: de kiezer is bij dit tussentijds contact afhankelijk van de goede wil van de volksvertegenwoordiger om zijn belang, hoe specifiek ook, te behartigen dan wel op enige andere wijze daaraan aandacht te besteden.

In het Verenigd Koninkrijk lijkt -naast een onverminderd sterke binding aan de centrale partijorganisatie (vooral bij Labour) en de fractie- ook de onafhankelijkheid voor de MP in relatie met zijn lokale partij en kiezers nog beperkter te zijn dan voor zijn collega's in Nederland en Duitsland.

15. Vergl. R. Hillebrand, De antichambre van het parlement. Kandidaatstelling in Nederlandse politieke partijen, Leiden 1992, m.n. hoofdstuk 7.

16. Vergl. Elzinga/Wisse, a.w., p. 176. 
Toch lijkt dit de werking van het parlementair stelsel niet noemenswaardig te frustreren. De tevredenheid over de MPs is -tenminste voor degenen die als 'good constitueny MP' functioneren- groter dan de waardering die hun collega's in Nederland en Duitsland ontvangen. Dat de waardering hoger is, zegt echter niet dat daadwerkelijk het functioneren van de Britse MP beter is, maar geeft wel een indicatie. De hierboven gesignaleerde verzwakking van de relatie tussen volksvertegenwoordiger en kiezer ten faveure van de overige twee relaties lijkt zich in het Verenigd Koninkrijk daarom ook niet te manifesteren. Dit wordt in hoge mate veroorzaakt door het kiesstelsel. Onder het Britse districtenstelsel kan vanwege de meer persoonlijke band tussen kiezer en vertegenwoordiger (de surgeries) het contact makkelijker en vaker frequenter plaatsvinden.

\subsubsection{Relatie volksvertegenwoordiger - politieke partij}

Hoewel het besef dat de individuele volksvertegenwoordiger bij de uitoefening van zijn staatsrechtelijke taak een onafhankelijke positie dient in te nemen dateert van voor de opkomst van het partijenstelsel, en zich daarom eerder richtte tegen de binding van een afgevaardigde aan een stands- of regionale groepering dan tegen een binding aan een politieke partij, moet de problematiek van de relatie tussen volksvertegenwoordiger en partij vanwege de vele overeenkomsten met de oude problematiek beoordeeld worden in het licht van de problemen die vroeger speelden in de verhouding tussen de volksvertegenwoordiger en de stands- of regionale groepering die hem naar het parlement afvaardigde. In beide gevallen is immers sprake van een bedreiging van de vrijheid tot het nemen van zelfstandige beslissingen van de volksvertegenwoordiger door mogelijke of zelfs reeds bestaande instructies, afkomstig van derden.

De mate van onafhankelijkheid in de relatie tussen volksvertegenwoordiger en zijn partij is nogal ambivalent. Op het moment van de kandidaatstelling is de volksvertegenwoordiger vrijwel volledig afhankelijk van zijn partij, om er vervolgens tijdens de duur van zijn mandaat als volksvertegenwoordiger relatief onathankelijk van te zijn. De afhankelijkheid bij de kandidaatstelling is echter van grote invloed op het gedrag dat de volksvertegenwoordiger in deze periode zal vertonen. Waar de mate van onafhankelijkheid in de relatie tussen de volksvertegenwoordiger en zijn fractie veelal door de beslotenheid van de fractie verborgen blijft, komt in de relatie tussen de volksvertegenwoordiger en zijn partij de discrepantie tussen de theoretische onathankelijkheid en praktische afhankelijkheid van de indivi- 
duele volksvertegenwoordiger het meest waarneembaar aan de oppervlakte.

Aan de verkiezing van de individuele volksvertegenwoordiger door de kiezers gaat in de praktijk de -noodzakelijke- kandidaatstelling door de politieke partijen vooraf. Mede hierdoor heeft de praktijk geleid tot een steeds sterkere band tussen volksvertegenwoordiger en zijn partij, terwijl de band tussen hem en zijn kiezers relatief los bleef en zelfs verzwakte. Door de uitbreiding van het antal kiezers was een persoonlijke benadering van de kiezers uitgesloten en deden de politieke partijen met hun landelijk opgestelde lijsten en gecentraliseerde partijpropaganda hun intrede. Ter handhaving van de partijlijn ontstond de praktijk van de partij- en fractiediscipline, soms uitmondend in partij- c.q. fractiedwang. De later ontstane praktijk van het opstellen van partijprogramma's en regeeraccoorden versterkte deze ontwikkeling. In het huidige staatsbestel kan de volksvertegenwoordiger zich moeilijk aan de invloed van zijn partij onttrekken omdat zijn parlementaire werkzaamheden slechts in teamverband (de fractie) en met (technische) ondersteuning van partijorganen, dan wel andere instanties die door de partij worden betaald, efficient kunnen worden verricht. Desondanks kan een volksvertegenwoordiger die zich aan de partijdiscipline onttrekt daarop staatsrechtelijk niet worden aangesproken, zelfs niet wanneer hij de partij verlaat c.q. moet verlaten. Meer dan een zuiver morele verplichting voor de volksvertegenwoordiger zijn mandaat ter beschikking te stellen -en een daarmee corresponderend (moreel) recht voor zijn partij om dat te eisen- is er niet. Vandaar dat door sommigen gezocht is naar andere wegen om greep op de dissidente afgevaardigde te krijgen, zoals recall of rotatie. Deze middelen zijn echter, zo zij al constitutioneel toelaatbaar kunnen worden geacht, in de praktijk onwerkbaar gebleken.

Aan de andere kant is partijdiscipline noodzakelijk in een staatkundig bestel waarin een functionele samenhang bestaat tussen partijen en het parlementaire regeringssysteem. ${ }^{17}$ Willen de politieke partijen hun geloofwaardigheid behouden, dan moet er immers sprake zijn van een min of meer consequent volhouden van de partijlijn. De volksvertegenwoordigers geven bij hun parlementaire werkzaamheden gestalte aan de politieke denkbeelden van hun partij. Vandaar dat juist op dit niveau de onafhankelijkheid van de individuele volksvertegenwoordiger in het geding kan komen.

17. Vergl. P.J. Boukema, Vragen van partijrecht, Alphen aan den Rijn 1968, p. 14. 
Het partijprogramma, dat de afgevaardigde al dan niet bij aanvang van zijn lidmaatschap heeft moeten onderschrijven, en het daarop gebaseerde verkiezingsprogramma, dat veelal wel expliciet voor de verkiezingen door de kandidaten moet worden onderschreven, kunnen niet zonder meer als een vorm van lastgeving worden opgevat. Beide vormen veeleer een globale opdracht, die de afgevaardigde zich naar eigen inzicht en geweten gesteld heeft: zijn toetreding tot de partij is immers vrijwillig geschied. Er ontstaat weliswaar een politieke binding, zowel tegenover de kiezers, als tegenover de politieke partij, zich aan het partijprogramma te houden, maar de (staatsrechtelijke) onafhankelijkheid en zelfstandigheid als volksvertegenwoordiger blijft behouden. In die zin is deze vrijwillige binding aan het partij- c.q. verkiezingsprogramma niet te zien als een last. ${ }^{18}$ Bovendien zijn deze programma's ook veelal te abstract en te statisch om als lastgeving te dienen. Het is immers onmogelijk te voorzien welke onderwerpen in de toekomst om een beslissing zullen vragen. Daarnaast kan het verkiezingsprogramma doorgaans nooit (volledig) getransformeerd worden tot regeerprogramma, zodat de opvattingen van de partij slechts in samenwerking met andere partijen gerealiseerd kunnen worden, waardoor concessies en compromissen noodzakelijk zijn; het Verenigd Koninkrijk vormt in dit opzicht een uitzondering. De programma's zijn te beschouwen als een richtlijn voor de afgevaardigde, die hij gemachtigd, zo niet verplicht is naar beste weten uit te voeren. ${ }^{19}$ Dat de politieke partijen op grond van interne partijregels (aspirant-)volksvertegenwoordigers laten verklaren dat zij zich verplichten het verkiezingsprogramma naar vermogen uit te voeren en daarbij verantwoording zullen afleggen aan partijorganen, is niet per definitie in strijd met het vrije mandaat van de volksvertegenwoordiger. Er zijn verschillende varianten van een dergelijke binding denkbaar, die lang niet altijd in strijd met de constitutionele norm van onafhankelijkheid zijn.

Wat geldt voor de partij- en verkiezingsprogramma's, geldt ook voor de eventuele overige partijrichtlijnen, waarbij hier in het bijzonder moet worden geacht aan regels omtrent de toewijzing en aanvaarding van zetels aan de kandidaten (verkiezingsafspraken). Dergelijke regels beogen een verandering aan te brengen in de staatsrechtelijk onathankelijke positie van de individuele volksvertegenwoordiger en zijn daarom nietig. Het partijkader (partijraad, partijbestuur) is niet bevoegd op te treden als lastgever van

18. Vergl. Tweede Kamer 1978-1979, 14224, nr. 6, p. 7.

19. Vergl. W.A. Bonger, Problemen der demokratie, Groningen 1934, p. 122. 
de volksvertegenwoordigers. Uit het feit dat de politieke partijen de volksvertegenwoordiger kandidaat stellen en voor de laatste een veel aansprekender en herkenbaarder achterban vormen dan 'de kiezer' met zijn onbepaalde identiteit, mag niet worden afgeleid dat de politieke partij de taak van de kiezers kan overnemen, laat staan omzetten in een strikt (bindend) mandaat.

Omdat partijprogramma's en andere richtlijnen van de politieke partijen niet gezien kunnen worden als lastgeving, heeft het verbod van last en ruggespraak daarop geen betrekking. Dit betekent dat het vrije mandaat de afgevaardigden niet verbiedt zich aan een partijprogramma te binden of uitvoering te geven aan de richtlijnen van de partijorganen wanneer zij dat willen. Het vrije mandaat verbiedt wel dat er staatsrechtelijk consequenties worden verbonden aan het feit dat een afgevaardigde zich niet (meer) gebonden wenst te achten aan dergelijke beïnvloeding door de partij. Dit houdt in dat een volksvertegenwoordiger nooit tegen zijn wil van zijn mandaat kan worden ontheven en dat hij evenmin verplicht zou kunnen worden zijn mandaat uit te voeren op een andere wijze dan hem goeddunkt. Zou immers de afgevaardigde tegen zijn wil door anderen (zijn partij) gedwongen kunnen worden zijn mandaat op een door dezen bepaalde wijze uit te oefenen of aan anderen ter beschikking te stellen op een niet door hem bepaald moment, dan zou dat de terugkeer van het imperatieve mandaat betekenen. En dat is juist hetgeen het verbod van last en ruggespraak beoogt te voorkomen.

\subsubsection{Relatie volksvertegenwoordiger - fractie}

De relatie tussen volksvertegenwoordiger en zijn fractie in het parlement is nogal diffuus. Dat is te wijten aan de merkwaardige positie die de fractie in het staatsbestel inneemt. Enerzijds is zij onderdeel van het parlement (hoewel niet altijd als dusdanig erkend in bijvoorbeeld de Reglementen van Orde), anderzijds is zij nauw met de partij verbonden. Werden fracties oorspronkelijk gevormd teneinde het parlement efficiënter te laten functioneren, tegenwoordig is partijbinding de bestaansgrond van de fractie. Toch moet echter formeel een onderscheid worden gemaakt tussen partij en fractie. Wanneer een besluit van de fractie in strijd zou zijn met richtlijnen van de partij, zal dat intern tot de nodige spanningen aanleiding kunnen geven; voor de besluitvorming binnen het vertegenwoordigend lichaam is echter slechts relevant wat door de fractie verklaard wordt. Ook in materieel opzicht is er verschil. De fractie is niet louter een uitvoerend orgaan van, of het hoogste orgaan binnen een politieke partij. In 
beide gevallen wordt voorbij gegaan aan het feit dat niet alleen de betrokken politieke partij verantwoordelijk is voor de grootte en de samenstelling van de fractie, maar ook de kiezers, die in meerderheid geen lid van de partij zijn. ${ }^{20}$ De relatie tussen beide verschilt per land (zo niet per partij), maar in het algemeen geldt dat niet kan worden gezegd dat de partij de fractie overheerst. Alleen in het Verenigd Koninkrijk lijkt de centrale partij-organisatie een overwicht over de fractie te hebben. Vooral binnen de Labour Party is dit het geval.

Wat hierboven is opgemerkt over de mate van afhankelijkheid in de relatie tussen volksvertegenwoordiger en politieke partij is mutatis mutandis van toepassing op de relatie tussen volksvertegenwoordiger en fractie. Is de volksvertegenwoordiger voor de verkrijging van zijn mandaat (de kandidaatstelling) erg afhankelijk van zijn politieke partij, gedurende de uitoefening ervan is hij erg afhankelijk van zijn fractie. De handelingsvrijheid voor de individuele volksvertegenwoordiger is binnen de fractie in het algemeen gering. ${ }^{21}$ Hierbij moet een onderscheid worden gemaakt tussen beperking van de onafhankelijkheid als gevolg van fractiedwang en beperking van de de onathankelijkheid als gevolg van fractiediscipline. Wanneer de fractieleiding of de meerderheid van de fractieleden een fractielid trachten te dwingen tot een bepaalde houding in het parlement, is dit in strijd met het vrije mandaat dat de betrokkene heeft. De beslissingsbevoegdheid van het parlement berust niet bij de fracties, maar bij (het totaal van) de individuele volksvertegenwoordigers. Wanneer deze verplicht zouden zijn hun (stem)gedrag naar de meerderheid van de fractie te richten, zou niet meer het parlement beslissen, maar de meerderheid van de regeringspartijen. $^{2}$ Wanneer een fractielid echter vrijwillig zijn van het fractiestandpunt afwijkende mening opzij zet in de overtuiging dat de fractie in het parlement zo veel mogelijk als eenheid dient te opereren, is dat geen ontoelaatbare dwang aan de kant van de fractie, maar een gevolg van de rol die de fracties in het staatkundig bestel vervullen. De fracties verwoorden de partijstandpunten in het parlement. Daarbij is het zaak dat

20. Vergl. Boukema, a.w., p. 17.

21. Vergl. Elzinga/Wisse, a.w., p. 177. In dezelfde zin: M.C. Burkens, Machtsvorming of representativiteit; cen commentaar op het rapport van de commissie-Deetman, in: Staatsrechtelijke vernieuwingen: commentaren op het rapport van de commissie-Deetman, Zwolle 1991, p. 10.

22. Vergl. Th. Schramm, Staatsrecht (deel 1), 4e druk, bewerkt door J. Schmidt-Troje, Köln 1987, p. 93. 
zij zoveel mogelijk als eenheid opereren. Om deze eenheid binnen de fractie te bewerkstelligen is fractiediscipline toegestaan, in die zin dat de fracties mogen trachten het gedrag van hun afgevaardigden te beïnvloeden. Hoewel ook in de relatie tussen de volksvertegenwoordiger en zijn fractie juridisch gezien slechts een morele binding aan besluiten van de fractie aanwezig is, kan gesteld worden dat een fractie zelfs meer effectieve dwangmiddelen heeft om een dissident lid tijdens de uitoefening van zijn mandaat weer in het gareel te krijgen dan de betrokken politieke partij. Te denken valt hierbij onder andere aan het ontnemen van woordvoerderschappen en commissielidmaatschappen of, meer specifiek, aan de withdrawal of the whip in het Verenigd Koninkrijk. In welke mate bij besluiten van of namens de fracties sprake is van loyaliteit, discipline of zuivere dwang onder de fractieleden is in de praktijk moeilijk vast te stellen. Een fractie zal niet gauw in alle openheid een weerspannig fractielid tot andere gedachten proberen te dwingen; veeleer zal zij door -al dan niet in bedekte termente dreigen met interne maatregelen dit doel trachten te bereiken. Daarnaast heeft de problematiek van fractiedwang en fractiediscipline aan belang ingeboet door de parlementaire praktijk. De gecompliceerdheid van de parlementaire werkzaamheden heeft de fractieleden gedwongen zich te specialiseren in een of meer beleidsonderdelen. Hierdoor heeft de individuele volksvertegenwoordiger nauwelijks nog een duidelijk beeld van de beleidsterreinen die buiten zijn specialisatie vallen, waardoor hij veelal gedwongen is af te gaan op het oordeel van de betreffende fractiespecialist. Ook dit vermindert de onafhankelijkheid van de individuele volksvertegenwoordiger. Op zijn eigen beleidsterrein heeft de betrokken afgevaardigde wel enige onathankelijkheid, al geldt ook hier dat hij door anderen zal worden gestuurd en gecontroleerd. ${ }^{23}$ Onontkoombaar lijkt dan ook de

23. Hierbij dient in eerste instantie aan de leiding van de partij gedacht worden. In Nederland lijkt echter de macht van de partijleiding gering te zijn. In de Tweede Kamer is momenteel de zgn. fractiecommissie het meest bepalende gremium van besluitvorming. In deze commissie, waarin gewoonlijk slechts enkele fractiespecialisten op een aanverwant terrein zitting hebben, worden de facto de standpunten van de fractie bepaald; vergl. M.P.C.M. van Schendelen, Fracties en kamercommissies, in:J.J.A. Thomassen/M.P.C.M. van Schendelen/M.L. Zielonka-Goei (red.), De geachte afgevaardigde ... Hoe kamerleden denken over het Nederlandse parlement, Muiderberg 1992, pp. 76-80. 
conclusie dat de norm van het vrije mandaat voor een belangrijk deel door fractierecht en fractiepraktijk is achterhaald. ${ }^{24}$

\subsection{De betekenis van het vrije mandaat voor het Nederlandse staatsrecht nader beschouwd}

In de $18 \mathrm{e}$ en $19 \mathrm{e}$ eeuwse representatieve democratie was de functie van het vrije mandaat tweeledig. In de eerste plaats werd het gehanteerd als een pragmatisch-technisch instrument ter realisering van nationale eenheid. ${ }^{25}$ Ook voor ons land gold dat staatsrechtelijke vertegenwoordiging, geheel in de lijn van de liberale theorie van de representatieve democratie, werd gezien als een van de belangrijkste instrumenten ter realisering van de moderne nationale eenheidsstaat. Het vrije mandaat lag in deze opvatting over staatsrechtelijke vertegenwoordiging besloten: het had tot functie de noodzakelijke onafhankelijkheid van de leden van de Staten-Generaal in de Nederlandse eenheidsstaat expliciet tot uitdrukking te brengen. Daarmee werd een terugkeer naar de praktijk onder de Republiek der Verenigde Nederlanden met haar strikte lastverhouding uitgesloten, in ieder geval in theorie.

Bij de vestiging van het Koninkrijk der Nederlanden werd het gevaar van een terugkeer van de bestuurspraktijk onder de Republiek bepaald niet ondenkbeeldig geacht. De gedwongen constitutie van de eenheidsstaat onder de Bataafse Republiek, gevolgd door de inlijving bij Frankrijk, was allerminst als onverdeeld positief ervaren, zodat een particularistisch, oligarchisch getint verzet tegen het uit de Franse tijd overgeleverde centralisme in aanleg aanwezig was. ${ }^{26}$ Een terugkeer naar het provincialisme en de privileges onder de Republiek was in deze situatie niet ondenkbaar. Daarbij hadden de oude Gewestelijke Staten niet al hun invloed verloren; de Grondwet bepaalde immers (tot 1848) dat de leden van de Tweede

24. Vergl. Elzinga/Wisse, a.w., p. 178.

25. Vergl. D.J. Elzinga, De politieke partij en het constitutionele recht, Nijmegen 1982, p. 91; Elzinga/Wisse, a.w., p. 168.

26. Vergl. H.T. Colenbrander, Ontstaan der Grondwet, deel 2, 's-Gravenhage 1909, p. LXXXIV. 
Kamer zouden worden gekozen door de Staten van de provincies. ${ }^{27}$ Deze waren op hun beurt uit de (oude) standen samengesteld: ondanks de gelijkheid voor de wet had de grondwetgever teruggegrepen naar het ancien régime voor het creëren van die standen. ${ }^{28}$ Het was in de eerste plaats aan de vereniging met België te danken dat de eenheidsstaat-gedachte behouden bleef. De gezamenlijke afkeer in de Noordelijke Nederlanden van de stelselmatige Belgische oppositie deed de roep om een terugkeer naar het regionalisme van de Republiek verstommen en maakte dat de Noordelijke Nederlanden eensgezind tegen de Belgen optraden. ${ }^{20}$ Hoewel de breuk met België sneller kwam dan verwacht, duurde de vereniging lang genoeg om de Nederlandse eenheidsstaat te institutionaliseren.

Naast het eenheidsmotief werd door het $19 \mathrm{e}$ eeuwse liberalisme aan het vrije mandaat een zelfstandige waarde toegekend als regulerend beginsel van democratie. ${ }^{30}$ Het klassiek-liberale vrijheidsbeginsel stelde de samenstelling van de vertegenwoordigende lichamen afhankelijk van vrije verkiezingen. Nadat deze verkiezingen zijn gehouden en kiezers hun legitimerende taak hebben volbracht diende, het vertegenwoordigingsbegrip van de liberale theorie van de representatieve democratie indachtig, een zo onafhankelijk mogelijke politieke besluitvorming plaats te vinden.

In de $19 \mathrm{e}$ eeuwse staat lieten deze twee functies van het vrije mandaat zich uitermate goed combineren. Door de verdere ontwikkeling kwam deze combinatie van functies evenwel onder druk te staan. De onafhankelijke positie van de individuele volksvertegenwoordiger werd in het bijzonder door de opkomst van de politieke partijen en door het verschijnsel fractievorming in belangrijke mate beperkt.

De vraag naar de betekenis van de vertegenwoordigingsbepaling en van het verbod van last en ruggespraak in het licht van de invloed van de politieke partijen en hun fracties op (de keuze van) de volksvertegenwoordiger is eerst in de meer recente literatuur aan de orde gesteld. Dat heeft wellicht te maken met de late erkenning van de rol van de politieke partijen en de

27. Art. 56 Gw. 1814 (toen gericht tot de Staten-Generaal i.p.v. Tweede Kamer); art. $79 \mathrm{Gw} .1815$; art. $81 \mathrm{Gw} .1840$.

28. Vergl. H.H. Zwager, De motivering van het algemeen kiesrecht in Europa, Groningen 1958, p. 161.

29. Vergl. Colenbrander, a.w., p. LXXXIV.

30. Vergl. Elzinga, a.w., p. 91/92; Elzinga/Wisse, a.w., p. 168. 
omvang van hun invloed. ${ }^{31}$ Nog lange tijd heeft in Nederland de $19 \mathrm{e}$ eeuwse opvatting doorgewerkt dat partijvorming slechts diende om beginselen uit te dragen en anderen daardoor te overtuigen. Deze opvatting is inmiddels achterhaald en hoewel het misschien te ver voert te beweren dat thans, in de partijenstaat, het imperatief mandaat tot sociologische werkelijkheid is geworden, kan in ieder geval gesteld worden dat de verhouding van de vertegenwoordigers tot hun kiezers zich onder het partijstelsel gewijzigd heeft. Het zijn niet meer de vertegenwoordigers, op wie de kiezer in eerste instantie zijn stem uitbrengt, maar de partijen waarvan de maatschappelijke functie is leiding te geven aan de meningsvorming en zo het vertrouwen van de kiezers te (ver)werven en te behouden. ${ }^{32}$ De partij stelt kandidaten, die haar beginselen en denkbeelden in de Kamer moeten vertegenwoordigen; door op de partij te stemmen verklaart de kiezer met deze denkbeelden in te stemmen.

De verkiezingen geven aan welke aanhang deze denkbeelden onder de kiezers hebben, dus welke invloed de partij in het land heeft. De partij is zo het middel om de opinie in het parlement in overeenstemming te brengen met de politieke opinie in den lande. Wanneer wordt beweerd dat de volksvertegenwoordigers afhankelijk zijn van de partij is dit juist, in die zin, dat zij door de partijen kandidaat worden gesteld en zij, wanneer zij de partijlijn niet (willen) volgen, een morele verplichting hebben om af te treden en in ieder geval niet meer kandidaat zullen worden gesteld bij de volgende verkiezingen. Daarnaast blijven zij, eenmaal gekozen, onderhevig aan de invloed van de partij en -vooral- de parlementaire fractie.

De partij vertegenwoordigt de kiezers, die op haar gestemd hebben. De kiezer kiest de partij, de partij wijst -behoudens het, ondanks de recente versoepeling nog steeds tamelijk zeldzame geval dat iemand met voorkeurstemmen wordt gekozen- de vertegenwoordiger in het parlement aan op grond van zijn plaats op de kandidatenlijst. De vertegenwoordiger vertegenwoordigt de kiezers door de partij. Door de ontwikkeling van de politieke partijen met hun hiërarchische organisatie, de steeds gedetail-

31. Zie bijvoorbeeld E.H. s'Jacob, Representatie en mandaat in het politiek bestel, Groningen 1966, p. 10, die dan nog stelt dat de Nederlandse politieke partijen lang niet zo markant zijn als hun buitenlandse tegenhangers, in die zin dat zij staan voor "leiderschap, sterk hiërarchisch opgebouwde organisatie, ondergeschiktheid van afgevaardigden en partijministers aan de richtlijnen die de partijleiding geeft."

32. Vergl. s'Jacob, a.w., p. 9. 
leerder wordende verkiezings- en partijprogramma's (die de aspirantvolksvertegenwoordigers van te voren dienen te onderschrijven), de strikt geformuleerde regeeraccoorden en de vergaande fractie-invloed op de individuele volksvertegenwoordiger, is deze zeer afhankelijk geworden van zijn partij. In een enkel geval is deze afhankelijkheid inmiddels als dusdanig vergaand ervaren, dat een beroep op de rechter werd gedaan teneinde de onafhankelijkheid van de volksvertegenwoordiger ten opzichte van zijn partij te herstellen. Zo werden in januari 1986 een tweetal zaken in kort geding gevoerd voor de Rb. 's-Gravenhage en de Rb. Rotterdam, tegen respectievelijk de (toenmalige) partijvoorzitter van het CDA en de voorzitter van de Tweede-Kamerfractie van die partij. De gedingen, beide malen aanhangig gemaakt door de Stichting "Miljoenen zijn tegen", werden gevoerd met het oog op het stemgedrag van de leden van de CDA-fractie tijdens de behandeling in de Tweede Kamer van het wetsvoorstel tot goedkeuring van het kruisrakettenverdrag. Eiseres stelde onder meer dat gedaagden zich dienden te onthouden van het uitoefenen van pressie op de leden van de CDA-fractie. Dergellijke pressie zou de fractieleden belemmeren in de hen grondwettelijk toekomende vrijheid van stemmen en daarom in strijd met de Grondwet zijn. In het geding tegen partijvoorzitter Bukman verklaarde de rechter zich onbevoegd:

"De eis strekt er toe dat de rechter zich mengt in de totstandkoming van een verdrag. Dat past echter niet in ons staatsbestel. De bevoegdheid om verdragen te sluiten is in ons staatsbestel voorbehouden aan de Koning en de St.-Gen. De rechter moet zich daar niet in mengen, ook niet op een niet-rechtstreekse wijze via een maatregel tegen een partij-voorzitter die niet zelf aan het besluitvormingsproces van Koning en Staten-Generaal deelneemt. ${ }^{\text {}}{ }^{33}$

De Rotterdamse rechter die over de vordering tegen de toenmalige fractievoorzitter De Vries moest oordelen hanteerde een minder strikte scheiding tussen bevoegdheid en ontvankelijkheid: de eis van de stichting kwam er volgens hem op neer dat de k.g.-rechter zich moest inlaten

"(...) met de vraag omtrent de grondwettigheid van een wet en tevens van een daarmee samenhangend verdrag door de wijze van totstandkoming van die wet te beoordelen. Het is de rechter evenwel niet toegestaan in een dergelijke beoordeling te treden. ${ }^{34}$

33. Rb. 's-Gravenhage 23 januari 1986, KG 1986, 107.

34. Rb. Rotterdam 29 januari 1986, KG 1986, 154. 
Eiseres werd niet-ontvankelijk verklaard, al had een onhevoegdverklaring ook hier meer voor de hand gelegen.

Naast de veranderingen in de relatie tussen volksvertegenwoordiger en partij heeft zich ook in de relatie tussen volksvertegenwoordiger en kiezer een verandering voorgedaan, zij het niet in die mate dat hierbij sprake zou zijn van een toegenomen afhankelijkheid van de volksvertegenwoordiger. Wel zijn de kiezers een grotere interesse gaan vertonen in het functioneren van de volksvertegenwoordiger. $\mathrm{Zij}$ willen hun rol niet meer beperkt zien tot het eens in de vier jaar uitbrengen van hun stem, maar ook tussentijds een zekere mate van participatie hebben. Deze grotere betrokkenheid bij de besluitvorming op centraal niveau leidt tot een toenemende controlerende activiteit door de kiezers; ze zijn mondiger geworden en vormen, zeker wanneer zij zich hebben georganiseerd in belangengroepen, een belangrijke factor waarmee de volksvertegenwoordiger bij het bepalen van zijn standpunt rekening moet houden. Vrijwillige tegemoetkoming aan bindingen en afspraken, beïnvloeding door overleg (ruggespraak) of belangenbehartiging zijn middelen om dit bereiken. De grondwettelijke norm van het lastverbod biedt geen concrete aanknopingspunten om uit te maken in welke gevallen wel en in welke gevallen geen sprake is van handhaving of opheffing van de onafhankelijkheid van de individuele volksvertegenwoordiger. Het verbod van last voorkomt echter dat de invloed van de kiezers zover gaat dat zij de volksvertegenwoordiger door een overeenkomst dwingend kunnen verplichten hun standpunten over te nemen. Juridische instrumenten om nakoming van een dergelijke overeenkomst af te dwingen zijn niet aanwezig.

Reeds in 1915 constateerde Krabbe dat het in de meeste constituties voorkomende verbod van last of ruggespraak een "ijdel en machteloos woord" was. ${ }^{35}$ Sindsdien hebben de ontwikkelingen in de staatkundige praktijk deze woorden slechts in waarde doen toenemen. Er is een spanning ontstaan tussen de grondwettelijk geboden zelfstandigheid van de volksvertegenwoordiger en de politieke praktijk, die van die zelfstandigheid weinig heeft overgelaten. Naast de -grondwettelijk vastgelegde- relatie tussen gekozene en kiezer, heeft de staatkundige praktijk gezorgd voor een relatie tussen gekozene en partij waarin de machtsverhoudingen zodanig zijn dat 
van de onafhankelijkheid van eerstgenoemde vrijwel nihil is. De zelfstandigheid van de volksvertegenwoordiger is thans niet meer dan een residu van hetgeen in de vorige eeuw werd beoogd. ${ }^{36}$ Door de discrepantie tussen theorie en praktijk, tussen formele zelfstandigheid en feitelijke onzelfstandigheid, hebben de bepalingen van de artt. 50 en 67 lid $3 \mathrm{Gw}$. hun feitelijke bestaansgrond verloren. Uitgaandie van de in Nederland nog steeds vrij algemeen aanvaarde opvatting over de grondwet als waarborg voor (onder meer) de positie en bevoegdheden van staatsorganen ${ }^{37}$, roept de hierboven gesignaleerde spanning tussen (grondwettelijke) norm en werkelijkheid de vraag op naar de functie van beide bepalingen in het hedendaagse staatsrecht.

Gesteld kan worden dat de bepalingen van de artt. 50 en 67 lid $3 \mathrm{Gw}$. in de praktijk van weinig waarde zijn. Volgens Kortmann is het dan ook zeer de vraag of de in beide bepalingen vervatte norm in praktijk (nog) overeenstemt met de door de regering bij de laatste grondwetsherziening verkondigde opvatting. Met name de ontwikkelingen in de relatie tussen volksvertegenwoordiger en partij en de daarin vervatte mogelijkheid dat partijbelang gesteld gaat worden boven het algemeen belang, brengt het gevaar met zich dat de grondwettelijke voorschriften verworden tot een lege huls. ${ }^{38}$

\subsubsection{Huidige betekenis: de restfunctie van het verbod van last}

De huidige artt. 50 en 67 lid $3 \mathrm{Gw}$. markeren de totstandkoming van Nederland als eenheidsstaat en beschermen de leden van de StatenGeneraal tegen (te) vergaande beïnvloeding van buitenaf, waarmee bij de constitutie van het Koninkrijk der Nederlanden met name werd gedoeld op beïnvloeding door de provincies. Het feit dat de onderhavige bepalingen vooral historisch bepaald zijn, neemt niet weg dat beide bepalingen sinds 1814 voortdurend in de grondwet zijn opgenomen. De bepaling van art. 50 $\mathrm{Gw}$. onderging daarbij nooit enige verandering; de bepaling van art. 67 lid Gw. kende tot aan de relatief ingrijpende wijziging in 1983 slechts enkele redactionele wijzigingen van ondergeschikt belang.

Dat de bepalingen qua redactie geen ingrijpende wijzigingen onderging, betekent niet dat de betekenis van de bepalingen ongewijzigd bleef. Hier-

36. Vergl. Elzinga/Wisse, a.w., p. 169.

37. Vergl. hierover A.H.M. Dölle, Over ongeschreven staatsrecht, Groningen 1988, pp. 228-232 (m.n. p. 230).

38. C.A.J.M. Kortmann, De Grondwetsherzieningen 1983 en 1987, 2e druk, Deventer 1987 , p. $198 / 199$. 
voor (hoofdstuk 3) is reeds aangegeven dat bij de belangrijkste grondwetsherzieningen een nieuwe betekenis aan de bepalingen werd toegekend, maar deze nieuwe betekenis niet in de formulering van de bepalingen tot uitdrukking werd gebracht. Werd in 1814 in de vertegenwoordigingsbepaling de vestiging van de eenheidsstaat tot uitdrukking gebracht als duidelijke reactie op de praktijken onder de Republiek, in 1848 was deze dusdanig geinstitutionaliseerd dat het tot uitdrukking brengen van deze functie in de vertegenwoordigingsbepaling door de praktijk en de veranderingen in de Grondwet overbodig werd gemaakt. De betekenis van de bepaling evolueerde dan ook tot het aangeven van de grondslag van de Staten-Generaal, in 1848 gelegen in het vormen van een afspiegeling van (het kiesgerechtigde gedeelte van) de bevolking. Het verbod van last en ruggespraak werd gehandhaafd uit vrees dat de kiezers of groepen daarvan, analoog aan de provincies ten tijde van de Republiek, de centrale besluitvorming door een te strikte binding van de volksvertegenwoordigers zouden frustreren. Na de grondwetsherziening van 1917 gaf de vertegenwoordigingsbepaling weliswaar nog steeds de grondslag van de Staten-Generaal aan, maar was deze gronusiag gewijzigd in het vormen van een atspiegeíng van de poítiéke partijen, waarbij het verbod van last en ruggespraak beoogde te veel invloed van de politieke partijen uit te sluiten.

Bij de grondwetsherziening van 1983 werd deze betekenis aangescherpt toen de regering aangaf welke waarde thans aan de bepalingen moet worden toegekend. Volgens haar duiden de woorden 'het gehele Nederlandse volk' uit art. $50 \mathrm{Gw}$. op "een nadere karakterisering en takomschrijving van de Staten-Generaal en haar leden die immers gezamenlijk inderdaad hél het Nederlandse volk moeten vertegenwoordigen". ${ }^{39}$ Onder uitdrukkelijke verwijzing naar de historische betekenis van het artikel, achtte de regering het van belang het artikel ook thans in de Grondwet vast te leggen als een opdracht voor de Staten-Generaal. Het verbod van last van art. 67 lid $3 \mathrm{Gw}$. dient daarbij om uitdrukkelijk vast te leggen dat elk bindend mandaat van een kamerlid nietig is ${ }^{40}$. Op een dergelijk mandaat kan derhalve nimmer een beroep worden gedaan. Hoewel de bepaling ziet op elke lastgevingsverhouding, wordt daarbij toch met name gedacht aan de gebondenheid van leden van de Staten-Generaal aan lastgeving van de fracties. Zo kan het resultaat van een gehouden stemming niet worden

39. Tweede Kamer 1976-1977, 14 222, nr. 3, p. 9.

40. Tweede Kamer 1976-1977, 14 224, nr. 3, p. 6. 
aangevochten op grond van het feit dat een lid zich aan de fractie-discipline heeft onttrokken en anders heeft gesternd dan in de fractie was overeengekomen. ${ }^{41}$

De aandacht in de uitleg van de regering voor de verhouding tussen volksvertegenwoordiger en politieke partij is een impliciete erkenning van de verschuiving van kiezersdemocratie naar partijendemocratie. Dit neemt echter niet weg dat op grond van deze uitleg van de bepalingen van de artt. 50 en 67 lid $3 \mathrm{Gw}$. kan worden geconcludeerd dat ook aspecten van de oude betekenis van de bepalingen zijn gehandhaafd. Dit is te verklaren uit de hierboven beschreven tweesporigheid van het klassieke representatiebegrip dat enerzijds het vrije mandaat als organisatieprincipe bij de constituering van de nationale eenheidsstaat beschouwde, en anderzijds als regulerend beginsel van democratie:

"Terwijl de klassiek-liberale democratieopvatting -met haar kiesrechtuitsluitingen en betrekkelijk elitaire benadering van de verhouding kiezer-gekozene- plaats maakte voor andere opvattingen, heeft het instrumentele aspect van het vrije mandaat zijn aantrekkingskracht behouden. Nog steeds worden de mogelijke blokkeringseffecten van het gebonden mandaat naar voren gehaald om aan te tonen, dat een zelfstandige volksvertegenwoordiger voorwaarde is voor een adequaat functionerende (centrale) besluitvorming. Nu niet langer als instrument om regionalisme en privileges uit te bannen, maar als een middel om een te vergaande invloed van politieke partij-organen of maatschappelijke organisaties te voorkomen" ${ }^{42}$

Dat deze veranderde betekenis van de bepalingen niet heeft geleid tot een formele herziening van de Grondwet laat zich verklaren uit het open stelsel van het Nederlandse constitutionele recht dat, evenals het stelsel van het Verenigd Koninkrijk, veel ruimte laat voor aanpassing aan zich wijzigende politieke en maatschappelijke verhoudingen, zonder dat de geschreven constitutie zelf ter discussie hoeft te staan of hoeft te worden gewijzigd. ${ }^{43}$ In de hedendaagse politieke en maatschappelijke verhoudingen, waarin de volksvertegenwoordiger functioneert binnen een strikt fractieverband en voor zijn verkiezing en verdere politieke carrière afhankelijk is van de partij-organisatie, is absolute onafhankelijkheid van de individuele volks-

41. Tweede Kamer 1978-1979, 14 224, nr. 6, p. 6.

42. Elzinga, a.w., p. 94.

43. Vergl. C.A.J.M. Kortmann, Constitutioneel recht, Deventer 1990, p. 131. 
vertegenwoordiger onvoorstelbaar. ${ }^{44}$ In het huidige staatsbestel wordt het vrije mandaat daarom veelal nog slechts een restfunctie toegekend. Het vrije mandaat heeft tot doel te verhinderen dat vrijwillige partijbinding ontaardt in onvrijwillige binding. ${ }^{45}$ In deze optiek hebben de bepalingen van art. 50 en art. 67 lid $3 \mathrm{Gw}$. tot gevolg dat kiezers, noch politieke partijen, noch anderen, juridische middelen ter beschikking staan om een volksvertegenwoordiger tot zetelafstand te dwingen. De facto betekent dit dat aanvaarding van de benoeming tijdens de zittingsperiode alleen door de volksvertegenwoordiger zelf teniet kan worden gedaan. Welke wijze van beïnvloeding of binding ook door het interne partijrecht en/of door fractiereglementen tot stand wordt gebracht, in vrijwel alle gevallen zal het effectueren van statutaire, huishoudelijke of fractieregelingen uiteindelijk afhangen van de eigen beslissing van de volksvertegenwoordiger om al dan niet aan te blijven. In de mogelijkheid van het nemen van die eigen beslissing schuilt de restfunctie van de verbodsbepaling.

De restfunctie van het vrije mandaat laat daarom in zekere mate binding aan besluiten van politieke partij en fractie toe en brengt daarmee theorie en praktijk dichter bijelkaar. Wanneer partijen en fracties verplicht zouden worden dergelijke bindingen achterwege te laten zou dat betekenen dat de partijen en fracties hun taak in het parlementaire systeem op geheel andere wijze zouden moeten gaan vervullen, hetgeen ongetwijfeld grote inbreuk zou maken op de oriëntatie- en organisatievrijheid van partijen en fracties. ${ }^{46}$ Deze vrijheid is van wezenlijke betekenis, omdat de mogelijkheid voor een ruime partijpolitieke verscheidenheid in de vertegenwoordigende lichamen éen van de belangrijkste waarden van het democratische systeem is. Het democratisch pluralisme komt beter tot zijn recht indien de verschillende politieke stromingen naar organisatie en oriëntatie herkenbaar kunnen doordringen in de statelijke organen. ${ }^{47}$ Een zekere autonomie van partijen en fracties om eigen organisatievormen en eigen regels te hanteren, vormt daarvan een belangrijk aspect.

Om de athankelijkheid van de volksvertegenwoordiger aan partij en fractie die hiermee gepaard gaat eenvoudigweg af te doen als strijdig met wet en grondwet, is een miskenning van de moderne parlementaire democratie.

44. Vergl. Elzinga, a.w., p. 108.

45. D.J. Elzinga, Partijbinding en politieke moraliteir, in: R.A. Koole (red.), Het belang van politieke partijen, Groningen 1984, p. 173.

46. Vergl. Elzinga/Wisse, a.w., p. 184.

47. Idem, p. 188. 
Omdat de Grondwet door het verbod van last een onpasseerbare grens trekt, is enige vrijmoedigheid ten aanzien van de overblijvende vrijheid toegestaan. ${ }^{48}$ Het gaat echter te ver uit het bestaan van de restfunctie af te leiden dat de volksvertegenwoordiger vrijwillig afstand kan doen van het grondwettelijke recht op zelfstandigheid. ${ }^{49}$ De bepalingen van de artt. 50 en 67 lid $3 \mathrm{Gw}$. bevatten niet een recht waarvan de volksvertegenwoordiger afstand kan doen; daarvoor is de opdracht van art. $50 \mathrm{Gw}$ te veel een plicht. Een (ongenormeerd en ongesanctioneerd) recht voor de volksvertegenwoordiger op onderwerping aan de partij an fractie valt er niet aan te ontlenen. Het verbod van last kan weliswaar gezien worden als een recht op zelfstandigheid voor de volksvertegenwoordiger, maar dit recht is vanwege de samenhang met de bepaling van art. $50 \mathrm{Gw}$. erg beperkt, in die zin dat daarvan geen afstand mag worden gedaan, omdat de volksvertegenwoordiger dan de kans loopt zijn grondwettelijke plicht te verzaken. De bindingen die een volksvertegenwoordiger met partij en fractie aangaat kunnen dus nooit zo worden geïnterpreteerd dat zij gezien moeten worden als het afstand doen van een recht. Het belang van de restfunctie is juist dat er geen afstand mag worden gedaan van een recht. De toelaatbaarheid van bindingen tussen volksvertegenwoordiger en zijn partij en fractie en de naleving ervan is gelegen in de sociaal-politieke sfeer, waar verenigingsrechtelijke regels, politieke moraliteit, vrijwillige binding aan maatschappelijke organisaties, gewetens-, oriëntatie- en organisatievrijheid leidende beginselen van handelen kunnen zijn. Daarvoor is het niet nodig afstand te doen van een grondwettelijk recht dat juist bedoelt aan te geven dat die beginselen zich buiten de sfeer van het constitutioneel recht ophouden. Juist omdat noch de Grondwet noch de Kieswet bepalingen bevatten inzake de politieke partijen en hun fracties in het vertegenwoordigend lichaam moet worden aangenomen dat de relatie tussen volksvertegenwoordiger en politieke partij en de relatie tussen volksvertegenwoordiger en fractie beheerst wordt door regels van privaatrechtelijke aard. De (grond)wetsartikelen inzake de staatsrechtelijke positie van de individuele volksvertegenwoordiger hebben betrekking op de persoon van de volksvertegenwoordiger in die hoedanigheid, niet op de persoon van de volksvertegenwoordiger als partijlid. In dit opzicht is de volksvertegenwoordiger in principe aan twee gescheiden rechtsregimes onderworpen: het publiekrechtelijke regime

48. Idem, p. 187.

49. Anders: Elzinga/Wisse, a.w., p. 186/187. 
in zijn hoedanigheid als volksvertegenwoordiger en het privaatrechtelijke in zijn hoedanigheid als partijlid. Deze rechtsorden kunnen in principe naast elkaar bestaan. Het betekent echter niet dat de (privaatrechtelijke) regels gericht tot een persoon in zijn hoedanigheid als partijlid, niet in strijd kunnen komen met de regels van de Grondwet en de Kieswet die de staatrechtelijke positie van de individuele volksvertegenwoordiger reguleren. Er bestaat een hiërarchie tussen beide rechtsorden: de publiekrechtelijke regels kunnen niet hun gelding verliezen wegens strijd met de privaatrechtelijke regels die de verhouding tussen partij en partijlid betreffen. ${ }^{50}$ Dit standpunt vindt in zoverre steun in de jurisprudentie dat de Afdeling Rechtspraak heeft bepaald dat de bepalingen van de Kieswet betrekking hebben op de publieke orde en van dwingend recht zijn, zodat daaraan niet bij overeenkomst de kracht kan worden ontnomen. ${ }^{51}$ Over de geldigheid van de overeenkomst deed de Afdeling (logischerwijs) geen uitspraak.

Met deze uitspraak heeft de Afdeling ook een -bevestigend- oordeel gegeven over de vraag of afspraken over het bezetten van een zetel in een vertegenwoordigend lichaam overeenkomsten zijn die de kracht ontnemen aan wetten die op de publieke orde of goede zeden betrekking hebben (art. 14 Wet AB). ${ }^{52}$ Deze vraag was, evenals de vraag of een dergelijke overeenkomst een ongeoorloofde oorzaak heeft wegens strijd met de Grondwet en andere publiekrechtelijke voorschriften, eerder niet in de rechtspraak beantwoord. In 1971 verklaarde de Hoge Raad zich inzake de beoordeling van verkiezingsafspraken onbevoegd, waardoor hij niet aan beantwoording van beide vragen toekwam. ${ }^{53}$

Meer recent heeft de Hoge Raad zich echter, met voorbijgaan aan de bevoegdheidsvraag, over beide vragen uitgelaten. ${ }^{54}$ Het betrof een Antillenzaak waarin de beoordeling van een verkiezingsafspraak tussen de Partido Democratico Aruba (PDA) en haar kandidaten voor de eilandsraad

50. Anders: C.A.J.M. Kortmann, De vijheid van interne organisatie van de politieke partij, in: Koole, a.w., p. 147.

51. Afd. Rechtspraak RvS 6 september 1982, AB 1983, 114 (verkiezingsafspraak Beesel).

52. Art. 14 Wet $\mathrm{AB}$ is bij de inwerkingtreding van het NBW op 1 januari 1992 komen te vervallen.

53. HR 26 maart 1971, AB 1971, 135; NJ 1971, 434 (verkiezingsafspraak Elsloo).

54. HR 18 november 1988, AB 1989, 185; NJ 1990, 564 (verkiezingsafspraak Aruba). 
van Aruba (later de Staten van Aruba genoemd) centraal stond. Deze afspraak omvatte de verplichting tot het afstand doen van een zetel in de Staten van Aruba bij verlies van het lidmaatschap van de partij die de zetel toegewezen had gekregen, alsmede de verplichting om bij verlies van het partijlidmaatschap een eventuele opvolgingsbenoeming niet te aanvaarden. Toen de situatie zich voordeed dat de PDA de nakoming van deze verpliclhtingen wilde afdwingen werd zij in eerste aanleg niet-ontvankelijk verklaard, waarna zij hoger beroep instelde bij het Gemeenschappelijk Hof van Justitie van de Nederlandse Antillen en Aruba.

Het Hof begon met de erkenning van de restfunctie van het vrije mandaat. Het ook in de Staatsregeling van Aruba vastgelegde vrije mandaat betekent onder meer

"dat fractiebinding noch partijlidmaatschap invloed kan hebben op het al dan niet aanblijven van een eenmaal gekozen en benoemd Statenlid en dat zullks uiteindelijk alleen te zijner eigen vrije beslissing is, voor zover de Staatsregeling niet tot aftreden dwingt, hetgeen met betrekking tot de zich thans mogelijk voordoende omstandigheid van een tot aftreden verplichtende overeenkomst met de betreffende politieke partij niet het geval is".

Vervolgens oordeelde het Hof over de verplichting van de verkiezingsafspraak tot het afstand doen van de zetel in de Staten van Aruba bij verlies van het partijlidmaatschap, dat "die overeenkomst nietig is zodat daarvan geen nakoming kan worden gevorderd (...)".5s Zijn beslissing baseerde het Hof op de stelling dat "een dergelijke overeenkomst strijdt met het in de Staatsregeling neergelegde beginsel van het vrije mandaat van het Statenlid, welk beginsel de publieke orde betreft". Opvallend hierbij is dat het Hof voor zijn motivering niet een privaatrechtelijke benadering koos door zich te beroepen op nietigheid van de overeenkomst ex art. 3:40 BW wegens ongeoorloofde oorzaak omdat de aanwijzing van kandidaten van vertegenwoordigende lichamen een zaak is van publieke orde. Evenmin volstond het Hof met verwijzing naar het toen nog van kracht zijnde art. 14 Wet $\mathrm{AB}$, maar grondde hij de nietigheid van de privaatrechtelijke overeenkomst op het vrije mandaat, een handelswijze die door de Hoge Raad werd gesauveerd. Daarmee werd aan de met de artt. 50 en 67 lid $3 \mathrm{Gw}$. corresponderende artikelen van de Arubaanse Staatsregeling een werking toegekend als waarborgnormen in partijrechtelijke relaties, waarmee ook

55. Dit citaat en het hierna volgende zijn de bewoordingen van het Hof zoals deze door de Hoge Raad werden samengevat. 
het eerder reeds door de Afdeling Rechtspraak erkende primaat van de publiekrechtelijke regels ten opzichte van de privaatrechtelijke (partij)regels werd bevestigd. Het vrije mandaat heeft daarmee een vergaande externe werking gekregen.

Bij de beoordeling van de tweede verplichting van de verkiezingsafspraak (de verplichting om bij verlies van het partijlidmaatschap een eventuele opvolgingsbenoeming niet te aanvaarden) volgde het Hof de motivering van de Afdeling Rechtspraak in haar uitspraak over de verkiezingsafspraak Beesel. De Hoge Raad nam ook hier het oordeel van Hof over, maar voegde daaraan toe dat uit het terechte oordeel van het Hof, dat de kiesrechtelijke bepalingen van publieke orde zijn zodat daaraan niet bij overeenkomst de kracht kan worden ontnomen, volgt dat die bepalingen geen ruimte laten voor een afspraak als hierbedoeld, zodat ook die afspraak als nietig moet worden beschouwd. De Hoge Raad ging hier dus verder dan het Hof, door uit diens motivering ook de gevolgen voor de privaatrechtelijke overeenkomst aan te geven. Ook hier erkende de Hoge Raad dus het bestaan van een hiërarchie tussen het publiekrechtelijke en het privaatrechtelijke rechtsregimes van regels betreffende de positie van de volksvertegenwoordiger.

\subsection{De meerwaarde van het vrije mandaat in het staatsrecht}

Uit hetgeen in de vorige paragraaf werd opgemerkt kan worden afgeleid dat het vrije mandaat in het Nederlandse staatsrecht tegenwoordig nog in ieder geval een tweetal functies moet worden toebedeeld. Naast de in de literatuur onderkende restfunctie van het vrije mandaat, heeft het vrije mandaat ook nog de functie zoals die door de regering bij de grondwetsherziening 1983 aangegeven is: elk bindend mandaat aan een volksvertegenwoordiger is nietig. Dit beeld behoeft echter enige nuancering: beide functies kennen het vrije mandaat een te beperkte rol in het huidige staatsrecht toe.

De formulering die door de regering bij de grondwetsherziening 1983 is gekozen om de functie van het vrije mandaat aan te geven is enigszins onnauwkeurig. Dat elk bindend mandaat aan de individuele volksvertegenwoordiger nietig is, zoals de regering stelde, is strikt genomen onjuist. Zoals hiervoor is opgemerkt kan het negeren van een dergelijk mandaat voor de betrokken volksvertegenwoordiger wel degelijk gevolgen hebben, 
zij het in het privaatrechtelijke regime waaraan de volksvertegenwoordiger in zijn hoedanigheid als partijlid onderworpen is. ${ }^{56}$ Het vrije mandaat beschermt de volksvertegenwoordiger bijvoorbeeld niet tegen een royement door de partij. Juist is de opvatting dat een dergelijk mandaat geen publiekrechtelijke gevolgen heeft. Dit is hetgeen de regering poogde aan te geven met de opmerking dat de geldigheid van stemmingen in de Staten-Generaal niet kan worden aangetast wanneer een volksvertegenwoordiger anders heeft gestemd dan te voren in de fractie was overeengekomen. Deze functie heeft louter een interne werking. Zij zegt niets over de toelaatbaarheid van lastgevingen en ziet daarom niet op relaties tussen volksvertegenwoordiger enerzijds en kiezers, partijen en fracties anderzijds. Het vrije mandaat heeft in deze opvatting slechts betrekking op de beoordeling van de geldigheid van stemmingen in het parlement. De vraag is of een dergelijke interne functie vermelding van het vrije mandaat in de Grondwet rechtvaardigt. Wanneer het vrije mandaat alleen deze functie zou toekomen lijkt vermelding in Reglementen van Orde meer gepast, omdat deze nu eenmaal de werking van het parlement (c.q. de Kamers daarvan) reguleren en daarom vooral interne werking hebben. ${ }^{57}$

De functie die de regering bij de behandeling van de grondwetswijziging 1983 het vrije mandaat toedichtte, heeft een interne werking; de in de literatuur onderkende restfunctie van het vrije mandaat heeft ook een externe werking. $\mathrm{Zij}$ ziet op de relaties tussen de volksvertegenwoordiger en anderen, ook buiten het parlement: het vrije mandaat als restfunctie heeft tot doel te voorkomen dat een volksvertegenwoordiger door wie dan ook tot zetelafstand wordt gedwongen. In dit opzicht absorbeert de restfunctie min of meer de functie die de regering in 1983 aan het vrije mandaat heeft toegekend. De verdienste van de restfunctie-gedachte is dat zij een constitutioneel vergelijk tussen de op het eerste gezicht onverenigbare grootheden van de kiezersdemocratie en de partijendemocratie mogelijk maakt. Toch doet ook de beperking tot de restfunctie het vrije mandaat te weinig eer aan. Het vrije mandaat heeft in het huidige staatsrecht niet

56. Vergl. Kortmann, De vrijheid van interne organisatie van de politieke partij, a.w., p. 148.

57. Een zekere mate van externe werking kan de Reglementen van Orde echter ook niet worden ontzegd; zie hierover: G.H. Hagelstein, De parlementaire commissies (Nederlands Parlementsrecht, deel 6), Groningen 1991, pp. 7779. 
alleen betrekking op de situatie waarin -door welke omstandigheid dan ook ${ }^{58}$ een volksvertegenwoordiger onvrijwillig zijn zetel dreigt op te moeten geven. Er is meer.

\subsubsection{Meer dan een restfunctie}

Naast de hierboven vermelde functies kan het vrije mandaat nog een aantal andere essentiële functies in het Nederlandse staatsrecht worden toebedacht, in ieder geval in normatieve zin. In de eerste plaats vormt het vrije mandaat een belangrijke waarborg voor het intern functioneren van de politieke partijen. In samenhang met de bepalingen van de artt. 50 en 60 $\mathrm{Gw}$. vormt het vrije mandaat een grens van openbare orde voor het interne organisatierecht van politieke partijen. Dit organisatierecht mag niet zodanig zijn dat afbreuk zou worden gedaan aan de genoemde artikelen. ${ }^{59}$ Deze functie is verwant aan de restfunctie, maar gaat tegelijkertijd verder. Het vrije mandaat heeft niet alleen een functie in de situatie waarin een politieke partij een volksvertegenwoordiger tot zetelafstand wil dwingen, maar in alle situaties waarin sprake is van (de dreiging van) een conflict tussen volksvertegenwoordiger en zijn partij. Daarbij hoeft niet meteen met de zware sanctie van zetelafstand te worden gedreigd. In dit opzicht is het vrije mandaat voor de volksvertegenwoordiger een middel zich binnen partijverband oppositioneel op te stellen. ${ }^{60}$ Daarnaast dient het ter voorkoming van het zich manifesteren van oligarchische tendensen binnen een politieke partij. $^{\text {i }}$

Het vrije mandaat mag echter niet dusdanig extensief geïnterpreteerd worden dat binding (aan besluiten van) politieke partijen daaronder valt. De beoordeling van deze vraag is, zoals gezegd, van een heel andere orde. Het verhindert wel dat die binding juridisch afgedwongen kan worden en dat langs deze weg het imperatief mandaat terugkeert.

58. Met de verkiezingen als logische uitzondering.

59. Kortmann, De vrijheid van interne organisatie van de politieke partij, a.w., p. 147.

60. Vergl. Elzinga, De politieke partij en het constitutionele recht, a.w., p. 111 .

61. Vergl. D. Grimm, Die politischen Parteien, in: E. Benda (e.a.), Handbuch des Verfassungsrechts der Bundesrepublik Deutschland, Berlijn 1983, p. 355; Schramm, a.w., p. 90/91 en -impliciet- Elzinga, De politieke partij en het constitutionele recht, a.w., p. 106. 
Daarnaast heeft het vrije mandaat ook een functie ten opzichte van het externe functioneren van de politieke partijen in het staatkundig bestel. Het vrije mandaat voorkomt vergaande beïnvloeding van de individuele volksvertegenwoordiger door zijn politieke partij en sluit daarmee een monopolie van de laatste binnen het politieke besluitvormingsproces uit. Het democratisch gehalte van een staat verzwakt wanneer de volksvertegenwoordigers zich bij het nemen van politieke besluiten teveel oriënteren naar de opvattingen die binnen hun partij leven. ${ }^{62}$ Van een effectieve parlementaire controle op het toch al weinig doorzichtige en sterk gefragmenteerde overheidsbeleid kan geen sprake zijn wanneer het parlement als instrument van de regeringspartijen meer aan de kant van de regering dan aan die van het volk komt te $\operatorname{staan}^{63}$. Het vrije mandaat vormt een bevestiging van de eigen taak en verantwoordelijkheid van de individuele volksvertegenwoordiger: het vertegenwoordigen van het hele volk. In de situatie waarin de politieke partijen grondwettelijk niet zijn erkend, en dus een bepaling in de zin van art. 21 uit het Duitse Grundgesetz ontbreekt, kan alleen een bepaling die het vrije mandaat garandeert de rol van de politieke partijen in het staatsbestel binnen de grenzen van het noodzakelijke en aanvaardbare houden.

Een variant op bovengenoemde functie is de betekenis van het vrije mandaat voor het functioneren van parlementaire fracties. De rol van het vrije mandaat is dit opzicht in grote lijnen identiek aan de rol van het vrije mandaat voor het (intern) functioneren van de politieke partijen. Door de eigen, prominente rol die de fracties in het staatsbestel vervullen en de centrale positie die zij binnen het vertegenwoordigend lichaam innemen, veelal tot erkenning komend in de Reglementen van Orde, beschikken zij echter over eigen middelen waarvan de toepassing de fractieleden in hun onafhankelijkheid zou kunnen bedreigen. Deze toepassing wordt echter beperkt door het vrije mandaat, al wordt zij niet geheel door het vrije mandaat onmogelijk gemaakt. De fractie kan een lid verbieden namens haar in een parlementaire commissie zitting te nemen; de fractie kan echter nooit voorkomen dat een lid (al dan niet op persoonlijke titel) zijn opvattingen in het parlement kenbaar maakt.

62. Grimm, Die politischen Parteien, a.w., p. 356.

63. Vergl. S.W. Couwenberg, Nieuwe hoop op staatkundige en bestuurlijke vernieuwing in het fin de siècle?, in: Staatsrechtelijke vernieuwingen, a.w., p. $24 / 25$. 
Het vrije mandaat fungeert voorts als organisatieprincipe voor het totaal van alle volksvertegenwoordigers in een vertegenwoordigend lichaam. Het garandeert de zelfstandigheid van dit collectief en stelt dit in staat om daadwerkelijk beslissingen te nemen, zonder obstructie van buitenaf. Het vrije mandaat is een onmisbare voorwaarde voor het functioneren van een beraadslagende en besluitende vergadering dat "erst recht unter den Bedingungen permanenten Entscheidungsbedarfs und hochkomplexer Entscheidungsmaterien nicht entbehrt werden kann". ${ }^{64}$

Deze functie is sterk historisch bepaald. De geschiedenis heeft geleerd dat een vertegenwoordigend lichaam niet kan functioneren wanneer het geen zelfstandige positie binnen het staatsbestel inneemt. In dit perspectief is het vrije mandaat ook thans nog van waarde: zonder (grondwettelijke) erkenning van het vrije mandaat loopt een dergelijk lichaam het gevaar een congres van gebonden afgevaardigden te worden, waarmee het toch al wankele evenwicht tussen kiezersdemocratie en partijendemocratie zou worden verstoord.

Van deze (externe) functie kan ook een intern organisatieprincipe worden afgeleid. Dit principe vertoont overeenkomsten met de uitleg die door de regering aan het vrije mandaat is gegeven, maar omvat meer dan de beoordeling van de geldigheid van stemmingen. In deze optiek fungeert het vrije mandaat als waarborg voor de werkwijze en communicatie binnen het vertegenwoordigend lichaam. De rechten die een volksvertegenwoordiger bij de uitoefening van zijn taak in het parlement toekomen, zoals de parlementaire onschendbaarheid, het recht van spreken, recht op informatie etc., worden alle ingegeven door de gedachte dat de volksvertegenwoordiger geen belemmeringen dient te ondervinden bij de vervulling van zijn taak. Het vrije mandaat vormt hiervoor de garantie.

Tenslotte creëert het vrije mandaat een verantwoordingsplicht naar de kiezers. Hoewel de relatie tussen kiezer en volksvertegenwoordiger onder het vrije mandaat beheerst wordt door het ontbreken van elke juridische binding, betekent dit niet dat de volksvertegenwoordiger niet ter verantwoording kan worden geroepen. Als democratie verwijst naar participatie door het volk, dan moet een representatieve democratie zorgen voor controlemechanismen die de burgers van een doorslaggevende invloed op

64. D. Grimm, Parlament und Parteien, in: H.-P. Schneider/W. Zeh, Parlamentsrecht und Parlamentspraxis in der Bundesrepublik Deutschland, Berlijn 1989, p. 205. Zie ook dez., Die politischen Parteien, a.w., p. 354. 
het proces van besluitvorming verzekeren. ${ }^{\text {os }}$ Volksvertegenwoordigers behoren verantwoording af te leggen aan het volk..$^{60}$

In een representatieve democratie zijn de periodieke verkiezingen het verantwoordingsmoment bij uitstek, al is enig 'voorwerk' reeds door de politieke partijen verricht als gevolg van hun praktisch monopolie bij de kandidaatstelling. Volksvertegenwoordigers die niet aan de verwachtingen van het volk hebben voldaan, lopen het risico niet herkozen te worden.

De functie van het vrije mandaat in dit kader is dat hierdoor de individuele volksvertegenwoordiger zich bij het verantwoordingsmoment van de verkiezingen niet achter zijn politieke partij en/of fractie kan verschuilen. Juist omdat het vrije mandaat garandeert dat de individuele volksvertegenwoordiger bij het nemen van politieke beslissingen geheel vrij is, is hijzelf verantwoordelijk voor zijn handelen: "Nur eine rechtlich freie Entscheidung setz under "Rechtfertigungszwang" und schaft damit Verantwortlichkeit". ${ }^{67}$ Wanneer de volksvertegenwoordiger trouw de partijlijn blijft volgen, moet hij de consequenties dragen wanneer een (regerings)partij door de kiezers wordt afgestraft voor het kennelijk impopulaire beleid van de partij. Niet voor niets hebben de laatste verkiezingen aangetoond dat juist de dissidente leden van een partij in een dergelijk geval op veel voorkeurstemmen kunnen rekenen.

\subsubsection{De praktische waarde van de functies}

De bovengenoemde functies van het vrije mandaat, hoe belangrijk ook, kunnen de aanwezigheid van een discrepantie tussen de constitutionele norm en de politieke werkelijkheid niet wegnemen. De reden hiervoor is dat deze functies vooral normatieve functies zijn die aan het vrije mandaat kunnen worden toegekend. De praktische waarde van deze functies lijkt vooralsnog niet zo groot te zijn. Hiervoor zijn een tweetal oorzaken aan te wijzen.

De eerste oorzaak voor de geringe praktische waarde van bovenvermelde functies van het vrije mandaat is gelegen in het niet of onvoldoende verwerken in het constitutioneel systeem van de relaties die de moderne

65. Vergl. W.H. Fortin/Th. Holterman, Democratie, in: Th. Holterman/C. Riezebos/L.J.J. Rogier/G.F.M. van der Tang (red.), Algemene begrippen staatsrecht, 3e druk, Zwolle 1991, p. 221.

66. Vergl. Burkens/Kummeling/Vermeulen, a.w., p. 136.

67. H. Hofmann/H. Dreier, Repräsentation, Mehrheitsprinzip und Minderheitenschutz, in: Schneider/Zeh, a.w., p. 185. 
volksvertegenwoordiger met zijn partij en fractie onderhoudt. De discrepantie tussen de constitutionele norm van het vrije mandaat en de politieke werkelijkheid vindt haar ontstaan in de historische ontwikkeling van de staatsrechtelijke positie van de individuele volksvertegenwoordiger en de mate van onafhankelijkheid die deze positie met zich brengt. Zoals hiervoor reeds is aangegeven, is steeds getracht de ontwikkelingen op het constitutioneel vlak in de bestaande mechanismen te integreren. Deze mechanismen zijn in Nederland en het Verenigd Koninkrijk ook gebruikt om bovengenoemde nieuwe relaties tussen volksvertegenwoordiger enerzijds en politieke partij en fractie anderzijds en de mate van onafhankelijkheid daarin te verklaren, in plaats van een nieuw concept te ontwerpen om zodoende het systeem aan te passen. En ook in Duitsland is na de Tweede Wereldoorlog niet zozeer een nieuw, allesomvattend concept bedacht teneinde theorie en praktijk meer met elkaar in overeenstemming te brengen. Aanpassing van het concept van het vrije mandaat heeft niet plaatsgevonden; dat is in zijn 'oude' gedaante gehandhaafd. Volstaan is slechts -de ervaringen van de Republiek van Weimar indachtig- met de afzonderlijke grondwettelijke erkenning van de rol van de politieke partijen. Zodoende kwamen er twee 'Strukturtypen' tegenover in elkaar te staan. Verzuimd is beide typen in és concept te verenigen.

De rol van de politieke partijen en hun fracties in het vertegenwoordigend lichaam heeft het vrije mandaat niet tot een restfunctie gedegradeerd. Vooral de rol van de partijen heeft juist geleid tot het ontstaan (c.q. de wenselijkheid) van de hierboven genoemde andere functies van het vrije mandaat. De functie die het vrije mandaat van oudsher vervulde is er niet door verminderd of aangetast. De van oudsher constitutioneel erkende relatie tussen volksvertegenwoordiger en kiezer kenmerkte zich immers reeds altijd al door een relatief grote onathankelijkheid voor de volksvertegenwoordiger. In de relatie tussen de volksvertegenwoordiger en zijn politieke partij is, in ieder geval ten tijde van het kandidaatstellingsproces, sprake van een sterke, zo niet absolute afhankelijkheid, terwijl de relatie tussen de volksvertegenwoordiger en zijn fractie in het parlement gekenmerkt wordt door een vrijwel constante afhankelijkheid. Zeker zolang het functioneren van de politieke partijen en hun fracties niet is vastgelegd in een (grond)wettelijke taakomschrijving, kan alleen het vrije mandaat bewerkstelligen dat de volksvertegenwoordigers voldoende onathankelijkheid behouden om hun grondwettelijke taak te vervullen. En zelfs wanneer een dergelijke taakomschrijving wel wordt gerealiseerd, zal het vrije 
mandaat een functie hebben om -net als in de Bondsrepubliek Duitslandeen monopolie van de partijen te verhinderen en het (interne) partij- en fractierecht te reguleren. De karakterisering van het verbod van last als de "ruggegraat van ons vertegenwoordigend stelsel op nationaal niveau" is dan ook beslist niet overdreven.

Het vrije mandaat dient vanwege de belangrijke functies die het in het Nederlandse staatsrecht vervult grondwettelijke gewaarborgd te blijven. De praktische werking ervan blijft echter ook in hoge mate afhankelijk van de mentaliteit van de individuele volksvertegenwoordiger en van de opvattingen die hij ten aanzien van zijn functie heeft. Daarmee is de tweede oorzaak van de geringe praktische waarde van de functies van het vrije mandaat genoemd. De mate van onafhankelijkheid van de volksvertegenwoordigers wordt bepaald door hun verwantschap met de partij en het gemeenschappelijke (partij)doel tot regeringspartij uit te groeien om zo (mede) het landsbestuur ter hand te nemen. Binnen deze brede marges wordt het handelen van een volksvertegenwoordiger ingegeven door zijn persoonlijkheid, de aard van zijn achterban en de zaken waarvoor hij een bijzondere belangstelling heeft. Te vaak hebben de volksvertegenwoordigers zich daarbij geschikt in de paternalistische houding van partij en fractie en zich tevreden gesteld met een (bescheiden) rol binnen de kudde van het stemvee. Uit recent onderzoek is duidelijk gebleken dat voor de meeste kamerleden staatsrechtelijke vertegenwoordiging nog steeds betekent dat zij uitdrukking geven aan de beginselen en het programma van hun partij. ${ }^{\circ}$ In de weinige zaken waarin zij de opvattingen van de kiezers (menen te) volgen, wordt dit niet ingegeven door de principiële overtuiging dat in een representatieve democratie aan de opvattingen van de kiezers een belangrijk gewicht toekomt, maar eerder uit een omgekeerde houding. Slechts in zaken van weinig fundamenteel belang zijn de volksvertegenwoordigers bereid de opvattingen van de kiezers te volgen. ${ }^{\text {T }}$

Voor een dergelijke opstelling bestaat eigenlijk geen rechtvaardiging. De volksvertegenwoordiger moet zijn positie en invloed binnen de eigen partij

68. G.H. Hagelstein, Het vertegenwoordigingsprincipe in de Wet Gemeenschappelijke Regelingen, in: Namens 1986, p. 381.

69. J.J.A. Thomassen/M.L. Zielonka-Goei, Het parlement als volksvertegenwoordiging, in: Thomassen/Van Schendelen/Zielonka-Goei, a.w., pp. 198202.

70. Idem, p. 202. 
niet onderschatten. De relatie met de partij maakt de volksvertegenwoordiger allesbehalve machteloos en onderworpen, al kan dit verschillen naargelang de aard van de partij en de positie van de betrokken volksvertegenwoordiger daarin. De volksvertegenwoordigers, die doorgaans toch enig aanzien genieten binnen de eigen partij, hebben voldoende mogelijkheden ervoor te zorgen dat de eigen opvattingen vertaald kunnen worden in die van de partij. ${ }^{71}$ Hoe hoger de positie van de betrokken volksvertegenwoordiger, hoe gemakkelijker dit te verwezenlijken is, maar ook de doorsnee volksvertegenwoordiger heeft daartoe de mogelijkheid door gebruik te maken van de media, partij-organen en parlementaire rechten.

Een meer onafhankelijke opstelling van de individuele volksvertegenwoordiger zou voor het staatsbestel een winstpunt zijn. Om het daadwerkelijk zo ver te laten komen zullen de volksvertegenwoordigers het besef moeten laten doordringen dat zij nog steeds geroepen zijn het algemeen belang (en dus het volk) te vertegenwoordigen en zich daadwerkelijk ook zo zouden gaan gedragen. Het algemeen belang, thans gereduceerd tot een formeel begrip, dat de politiek naar believen kan invullen en dat nog slechts gehandhaafd wordt vanwege zijn legitimerende werking, moet weer in zijn oude (normatieve) betekenis vorm krijgen. ${ }^{2}$

Een mentaliteitsverandering van de volksvertegenwoordigers past ook bij de betekenis van het verbod van last: niet alleen biedt dit een bescherming tegen (te) vergaande beïnvloeding door partijen en kiezers, maar ook verlangt het (door de samenhang met art. $50 \mathrm{Gw}$.) een bepaalde houding van de individuele volksvertegenwoordiger. Hij dient zich niet te beperken tot het trouw en kritiekloos navolgen van de partij- en fractielijn, maar daarentegen de taak van de Staten-Generaal tot uitgangspunt te nemen en niet de doelstellingen van zijn partij.

Deze opvatting van de taak van de individuele volksvertegenwoordiger werd reeds door Bonger verwoord:

"Het belangrijkste argument tegen het imperatieve mandaat ligt op karaktergebied. Een persoonlijkheid, iemand die in het leven getoond heeft iets te kunnen, laat zich niet door anderen, die noch in kennis noch in bekwaamheid zijn meerderen zijn, voorschrijven wat hij in een situatie doen moet, die hij kent, maar de anderen niet. (...) Afgevaardigden moet juist personen zijn met sterk verant-

71. Vergl. A. Adonis, Parliament today, Manchester 1990, p. 42.

72. Vergl. Couwenberg, a.w., p. 25. 
woordelijkheidsgevoel, in tegenstelling met de gewone burgers, die zich aan niemand verantwoordelijk voelen. "73

Deze opvatting is vrijwel identiek aan die van Burke (de liberale theorie), die immers de mening was toegedaan dat slechts de besten geroepen waren tot vertegenwoordiging van het volk. Deze elitaire opvatting is thans achterhaald in die zin dat niet enkel de besten tot het vertegenwoordigen van het volk zijn geroepen, maar in zekere zin is er wel een element van bewaard gebleven: volksvertegenwoordigers moeten karakterpersonen zijn.

Bij het bereiken van een dergelijke mentaliteitsverandering kunnen de discussies omtrent staatkundige vernieuwing die natar aanleiding van het werk van de commissie-Deetman worden gevoerd, wellicht behulpzaam zijn, al hangt het ook hier uiteindelijk af van de politieke wil van de volksvertegenwoordigers om deze vernieuwingen door te voeren. Er bestaat een nauwe band tussen staatkundige vernieuwing en het vrije mandaat. De roep om staatkundige vernieuwing wordt (mede) ingegeven door de constatering van de steeds wijder wordende kloof tussen kiezers en gekozenen. De relatie tussen kiezers en gekozenen is, naast de relatie tussen de kiezers en het openbaar bestuur, de rode draad die door het werk van de commissieDeetman, alsook van eerdere commissies die zich met dit onderwerp bezig hebben gehouden, loopt. ${ }^{74}$ Dat is ook wel logisch omdat dat in verbetering van deze relatie de oplossing van de door de commissies gesignaleerde problemen ligt. Staatkundige vernieuwing zal daarom moeten leiden tot een kiesstelsel waarin de afgevaardigde inderdaad de "verlangens van de kiezer representeert" en de kiezer "zich voor en tegen afgevaardigden-in-spé kan uitspreken". ${ }^{75}$

Een kiesstelsel dat bijdraagt tot een optimale relatie tussen kiezer en gekozene zal tot meer betrokkenheid van de burgers leiden, hetgeen een andere taakopvatting van de volksvertegenwoordigers tot gevolg zou moeten hebben. Zij zouden dan minder op de partij-politiek gericht moeten zijn en meer op de belangen van het volk. In dit opzicht zou staatkundige vernieuwing leiden tot een opwaardering van het vrije mandaat. Dat meer participatie als gevolg van staatkundige vernieuwing tot verzwakking van het vertegenwoordigend stelsel zal leiden, moge een juiste veronderstelling zijn. Bedacht dient echter te worden dat het vertegenwoordigend stelsel

73. Bonger, a.w., p. 122.

74. Vergl. Burkens, a.w., p. 4.

75. Idem, p. 9. 
geen doel op zich is, maar slechts een middel om het volk (in de ruime betekenis van het woord) enige invloed op het landsbestuur te geven. ${ }^{76}$ Andere middelen om het volk meer invloed te geven, zoals volksraadpleging of de mogelijkheid om (meer) overheidsfunctionarissen te kiezen, kunnen slechts dienen als een aanvulling op het vertegenwoordigend stelsel. Het vrije mandaat wordt er niet door aangetast. Zolang elementen van het vertegenwoordigend stelsel behouden blijven, kan het vrije mandaat niet worden gemist.

76. Vergl. Burkens/Kummeling/Vermeulen, a.w., p. 187. 


\section{SAMENVATTING}

Doelstelling van dit proefschrift is na te gaan welke functies thans nog aan het vrije mandaat kunnen worden toebedacht. Het vrije mandaat, dat de onafhankelijkheid van de afgevaardigden in het parlement garandeert, vormt het wezenlijke kenmerk van hun staatsrechtelijke positie. Hun taak om de gehele natie te vertegenwoordigen, kunnen de afgevaardigden immers slechts naar behoren uitoefenen wanneer zij niet van anderen afhankelijk zijn.

Het vrije mandaat makt deel uit van de liberale theorie van de representatieve democratie. Deze theorie ziet volksvertegenwoordigers niet als lasthebbers van hun kiezers, maar als gevolmachtigden. De volksvertegenwoordigers worden geacht -in samenwerking met het bestuur- het algemeen belang van de natie te behartigen en niet het bijzondere belang van bepaalde groepen of individuen. In het parlement komen zij bijeen om op basis van uitwisseling van gedachten tot besluitvorming te komen. Deze besluitvorming komt niet voort uit de wil of de opvattingen van de kiezers, maar uit redelijk parlementair overleg.

De liberale theorie van de representatieve democratie markeert het ontstaan van de moderne staat. Zij vindt haar oorsprong in de staatkundige opvattingen van de Whigs, een politieke stroming in het $18 \mathrm{e}$ eeuwse parlement van het Verenigd Koninkrijk. De theorie is het duidelijkst verwoord door de Britse staatsman en politiek filosoof Edmund Burke, een van de meest invloedrijke Whigs, in zijn rede tot zijn kiezers in Bristol (1774):

"Parliament is not a congress of ambassadors from different and hostile interests; which interests each much maintain, as an agent and advocate, against other agents and advocates; but Parliament is a deliberative assembly of one nation, with one interest, that of the whole; where, not local purposes, not local prejudices ought to guide, but the general good, resulting from the general reason of the whole."

Deze opvatting over de relatie tussen kiezers en gekozenen is uitgegroeid tot de heersende doctrine. In vrijwel alle moderne westerse staten kent de constitutie het uitgangspunt dat de afgevaardigden in het parlement beschikken over een vrij mandaat. Veelal is dit als een verbod van last in de grondwet opgenomen. Daarmee lijkt het vrije mandaat zijn bestaansrecht te hebben aangetoond. 
De constitutionele verankering van het vrije mandaat staat echter op gespannen voet met de staatkundige praktijk, die door de overheersende rol van de politieke partijen van de onafhankelijkheid van de afgevaardigden in het parlement weinig heeft overgelaten. De constitutionele norm dat de kiezers beslissen over de aanwijzing van volksvertegenwoordigers gaat schuil achter de praktijk, waarin de politieke partijen het kandidaatstellingsen verkiezingsproces beheersen en waarin de partijstandpunten prevaleren boven de opvattingen van de kiezers. Vooral in de relatie tot de eigen partij en fractie resteert er weinig onafhankelijkheid voor de volksvertegenwoordigers.

Deze ontwikkeling heeft grote gevolgen het functioneren van de volksvertegenwoordigers en daarmee ook voor hun staatsrechtelijke positie: niet langer vormen hun eigen oordeel en inzicht de doorslaggevende maatstaven voor de te nemen beslissingen, maar de opvattingen van de eigen partij en fractie. Overal waar de liberale theorie van de representatieve democratie onderdeel vormt van de constitutie manifesteert zich een waardevermindering van de betekenis van het vrije mandaat.

Ook in Nederland is dit het geval. Hier markeert het vrije mandaat de overgang van het regeringsstelsel van de standenstaat van de Republiek der Verenigde Nederlanden naar dat van de huidige eenheidsstaat van het Koninkrijk der Nederlanden. De constitutionele verankering van het vrije mandaat is een reactie op het besluitvormingsstelsel van de Republiek. Als gevolg van de afzwering van Philips II in 1581 waren de rechten van de landsheer overgenomen door de vertegenwoordigers van de standen, de Staten van de afzonderlijke gewesten. Daarmee kwam de soevereiniteit te berusten bij de Statenvergaderingen van de in het bondgenootschap verenigde gewesten. Afgevaardigden van de Gewestelijke Staten kwamen in de vergadering van de Staten-Generaal bijeen om besluiten te nemen over de zaken die in de Unie van Utrecht tot gemeenschappelijke zaak waren bestemd. Maar omdat de beslissingsbevoegdheid in de meeste zaken nog steeds bij de Gewestelijke Staten berustte, konden de afgevaardigden in de Staten-Generaal niet zelfstandig en naar eigen inzicht beslissen. Steeds stond voorop dat geen beslissingen mochten worden genomen die de autonome positie van de gewesten zouden aantasten. Daarom waren de afgevaardigden door hun committenten (de respectieve Gewestelijke Staten) gebonden aan imperatief mandaat, vormgegeven door het gebod van last en ruggespraak. Dit verplichtte de afgevaardigden van de Gewestelijke Staten in de Staten-Generaal bij stemmingen te stemmen volgens de van te voren 
door de Gewestelijke Staten gegeven opdracht (last). Wanneer de last niet in het aan de orde zijnde onderwerp voorzag, moesten de afgevaardigden, alvorens hun stem uit te brengen, teruggaan naar hun committenten teneinde na overleg (ruggespraak) een hernieuwde last te ontvangen.

Het gebod van last en ruggespraak was oorspronkelijk een regel van gewoonterecht. In die hoedanigheid is het ook ten tijde van de Republiek steeds van kracht geweest, al zijn enkele gewesten er toe overgegaan schriftelijke instructies voor hun afgevaardigden op te stellen teneinde meer duidelijkheid over hun (aan de Gewestelijke Staten ondergeschikte) positie te verschaffen.

Het gebod van last en ruggespraak was, zeker in de $18 \mathrm{e}$ eeuw, fataal voor het besluitvormingsproces in de Staten-Generaal. Het was de belangrijkste oorzaak van de uiterst trage en moeizame besluitvorming op centraal niveau. De gewesten bleven strikt vasthouden aan de Unie van Utrecht om zo hun zelfstandigheid zoveel mogelijk te handhaven. Dit makte de Republiek in feite onbestuurbaar. De vergadering van de Staten-Generaal had meer het karakter van een congres van afgezanten dan van wetgevende vergadering. In de vergadering van de Staten-Generaal kon vrijwel niets worden besloten zonder de instemming van de Gewestelijke Staten. Wanneer de last van de afgevaardigden van de verschillende gewesten uiteenliep, vond schorsing van de vergadering plaats om hen in staat te stellen naar hun Gewestelijke Staten terug te keren om ruggespraak te plegen. Het proces van ruggespraak en eventuele hernieuwing van de lastbrief werd pas beëindigd wanneer de Staten-Generaal tot een unanieme beslissing kwamen.

De vestiging van de Bataafse Republiek in 1795 maakte een einde aan de macht van de gewesten en daarmee aan het verlammende stelsel van besluitvorming in de Republiek der Verenigde Nederlanden. De soevereiniteit kwam thans bij de Staten-Generaal te berusten. De leden van de StatenGeneraal waren niet meer de losse verzameling van onderhandelaars waarin ieder slechts het eigen gewest vertegenwoordigde, maar een eenheid gericht op het behartigen van het belang van het hele land. Daarom hadden zij een vrij mandaat: zij moesten stemmen zonder last en ruggespraak. Onder invloed van de ontwikkeling in Frankrijk werden deze beginselen in 1798 in de eerste grondwet van de nieuwe staat opgenomen, waarmee de liberale theorie van de representatieve democratie haar intrede in het Nederlandse staatsrecht deed. Met uitzondering van de Staatsregeling van 1801 zijn sindsdien in elke grondwet c.q. staatsregeling de beginselen van deze 
theorie tot uitdrukking gebracht door bepalingen in de zin van de huidige artikelen 50 en 67 lid 3 Grondwet.

Hoewel dit niet in de formulering van deze bepalingen tot uitdrukking is gebracht, hebben zij sinds de vorming van het Koninkrijk der Nederlanden bij de belangrijkste grondwetsherzieningen steeds een nieuwe betekenis gekregen. In 1814 werd met de bepaling dat de Staten-Generaal het gehele Nederlandse volk vertegenwoordigen en het verbod van last en ruggespraak de vestiging van de eenheidsstaat bekrachtigd en een terugkeer naar de praktijken ten tijde van de Republiek der Verenigde Nederlanden voorkomen. Bij de grondwetswijziging in 1848 was de eenheidsstaat geïnstitutionaliseerd, zodat de vertegenwoordigingsbepaling als verwoording van de eenheidsstaat-gedachte door de praktijk en de veranderingen in de grondwet strikt genomen overbodig werd gemaakt. Haar betekenis evolueerde dan ook tot het aangeven van de grondslag van de Staten-Generaal: het vormen van een afspiegeling van de kiezers. Het verbod van last en ruggespraak werd gehandhaafd uit vrees dat de kiezers de centrale besluitvorming zouden frustreren door het opleggen van bindingen aan de volksvertegenwoordigers. Na de grondwetsherziening van 1917 gaf de vertegenwoordigingsbepaling weliswaar nog steeds de grondslag van de Staten-Generaal aan, maar deze veranderde in het vormen van een afspiegeling van de politieke partijen. De verbodsbepaling kreeg daarbij de functie vergaande invloed van de politieke partijen op de individuele volksvertegenwoordiger tegen te gaan. In 1983 is de functie van de verbodsbepaling -waaruit het ruggespraak-aspect werd geschrapt- vooral in verband gebracht met de rol van de parlementaire fracties. Hoewel het verbod ziet op elke lastgeving, is het accent komen te liggen op de gebondenheid van de leden van de Staten-Generaal aan besluiten van de fracties. Zo wordt het resultaat van een gehouden stemming niet benvloed wanneer een lid van de StatenGeneraal zich aan de fractiediscipline onttrekt en anders stemt dan in de fractie is overeengekomen.

In het Nederlandse staatsrecht overheerst de opvatting dat het verbod van last nog slechts een restfunctie heeft. Erkend wordt dat de individuele volksvertegenwoordiger zeer afhankelijk is geworden, met name van zijn partij en fractie, maar die afhankelijkheid gaat niet zo ver dat een volksvertegenwoordiger tot aftreden kan worden gedwongen. Dit is een beslissing voor de volksvertegenwoordiger zelf. In de mogelijkheid van het nemen van een eigen beslissing ligt de restfunctie van het verbod van last. 
In het Duitse staatsrecht valt een zelfde ontwikkeling van het vrije mandaat te onderkennen. Ook hier zijn in de loop van de 19e eeuw de beginselen van de liberale theorie van de representatieve democratie in de constitutie verankerd. De artikelen 20 en 38 van het Grundgesetz (GG) zijn hiervan de moderne exponenten. Met de kernbepaling dat alle staatsmacht afkomstig is van het volk verklaart het Grundgesetz in art. 20 lid 2 de leer van de volkssoevereiniteit tot uitgangspunt voor de staatsinrichting van Duitsland. Met de bepaling van art. 38 lid 1 GG dat de afgevaardigden in de Bondsdag "Vertreter des ganzen Volkes, an Aufträge und Weisungen nicht gebunden und nur ihrem Gewissen unterworfen" zijn spreekt het Grundgesetz zich uit voor het vrije mandaat. Daarmee wordt aangesloten bij de ook in Duitsland gevestigde constitutionele traditie van het verbod van last.

De bepaling van art. 38 lid GG geeft de afgevaardigden een eigen staatsrechtelijke status, waarvan vrijheid een van de kernbegrippen is. Dit wordt in het bijzonder benadrukt door de onafhankelijkheid en onvervreembaarheid van het mandaat. $\mathrm{Hij}$ is niet gebonden aan enige lastgeving en kan zich steeds op zijn gewetensvrijheid beroepen.

In tegenstelling tot de meeste grondwetten van andere landen erkent het Grundgesetz dat in de moderne verzorgingsstaat het bestaan en functioneren van politieke partijen een noodzakelijke voorwaarde is voor het democratisch en effectief functioneren van het staatsbestel. De politieke partijen vormen het intermediair tussen volk en staat. $\mathrm{Zij}$ hebben een specifieke taak, gelegen in het meewerken bij de politieke wilsvorming van het volk (art. $21 \mathrm{GG).} \mathrm{De} \mathrm{erkenning} \mathrm{van} \mathrm{de} \mathrm{rol} \mathrm{van} \mathrm{de} \mathrm{politieke} \mathrm{partijen} \mathrm{in} \mathrm{het}$ staatsbestel is in feite de erkenning van het bestaan van de moderne partijenstaat.

De opdracht in art. $21 \mathrm{GG}$ aan de politieke partijen om mee te werken aan de politieke wilsvorming van het volk, wordt in hoge mate uitgevoerd door de vertegenwoordigers van deze partijen in de Bondsdag. Tegelijkertijd zijn deze vertegenwoordigers ingevolge art. $38 \mathrm{GG}$ ook onafhankelijke vertegenwoordigers van het gehele volk. Daarmee creëert het GG een spanningsveld tussen de positie van de afgevaardigde als onafhankelijk volksvertegenwoordiger en de positie van de afgevaardigde als exponent van zijn partijorganisatie. Door deze grondwettelijke dubbelfunctie van de afgevaardigden als vertegenwoordigers van het gehele volk en als exponenten van een politieke partij, maakt het Grundgesetz een 'Spannungsverhältnis' tussen art. 21 GG en art. 38 GG zichtbaar. Dit kan worden opgelost door de huidige functie en samenhang van beide bepalingen te beschouwen. De 
politieke partijen moeten niet beschouwd worden als een belemmering van de onafhankelijkheid van de individuele volksvertegenwoordiger, maar juist als belangrijke voorwaarde voor hun functioneren. Wanneer de politieke partijen door de parlementaire werkzaamheden van hun afgevaardigden aan de politieke wilsvorming meewerken, dienen zij het vrije mandaat van de individuele volksvertegenwoordiger te respecteren. Dit mandaat beoogt niet de afgevaardigde volledig onathankelijk van zijn partij of fractie te maken. Art. $38 \mathrm{GG}$ is geen uitzondering op art. $21 \mathrm{GG}$ in die zin dat de politieke partijen op generlei wijze hun afgevaardigden in Bondsdag zouden mogen beïnvloeden. Beünvloeding van volksvertegenwoordigers door de politieke partijen is juist een van de manier waarop de partijen hun grondwettelijke taak van het meewerken aan de politieke wilsvorming kunnen uitvoeren. Art. 38 GG verhindert echter dat de uiterste consequentie van de partijstaat-gedachte kan intreden door een monopolie van de politieke partijen bij de wilsvorming van het volk te verbieden. Net zoals in Nederland heeft het vrije mandaat in het Duitse staatsrecht dan ook vooral een restfunctie.

Het Verenigd Koninkrijk geeft een enigszins ander beeld te zien, al geldt ook hier dat het vrije mandaat vooral tot zijn restfunctie beperkt schijnt te zijn. De vestiging van de eenheidsstaat liep hier (tenminste waar het Engeland en Wales betreft) ver vooruit op het ontstaan van de liberale theorie van de representatieve democratie, laat staan de constitutionele bevestiging daarvan. In het Verenigd Koninkrijk was het ontstaan van de liberale theorie dan ook vooral een reactie op de staatkundige praktijk. De notie dat de afgevaardigden in het Lagerhuis vertegenwoordigers van het gehele volk waren en beschikten over een vrij mandaat, bestond reeds geruime tijd voordat de Whigs haar als theorie zouden aanvaarden. Sinds de 15 e eeuw had deze opvatting een geleidelijke ontwikkeling doorgemaakt, alvorens eeuwen later, vooral door toedoen van Burke, tot de heersende doctrine uit te groeien.

De flexibiliteit van de Britse constitutie heeft echter de liberale theorie enigszins naar de achtergrond gedrongen. Vooral door de toegenomen invloed van de politieke partijen is in de loop van deze eeuw de vertegenwoordigingsgedachte in het Britse staatsrecht gewijzigd. Niet langer ligt hieraan een individueel concept over vertegenwoordiging in het staatsrecht ten grondslag, zoals dat door het vrije mandaat naar voren komt, maar wordt erkend dat het bestaan van de politieke partijen met hun sterke partijdiscipline tot gevolg heeft dat de individuele volksvertegenwoordiger zijn stemgedrag richt naar de opvatting van de partij. Deze 'theory of party 
representation' hangt nauw samen met de mandate doctrine, de opvatting dat de politieke partijen bij verkiezingen met duidelijke voorstellen over het te voeren beleid moeten komen: voor de uitvoering van deze voorstellen krijgen zij, wanneer zij de verkiezingen winnen, een mandaat van kiezers.

Door dit afwijkende, aan de staatkundige praktijk aangepaste concept over vertegenwoordiging in het staatsrecht resteert de Britse volksvertegenwoordiger nog minder onafhankelijkheid dan in Nederland en Duitsland. Vooral wanneer hij lid is van de regeringspartij is dit het geval. De fractie controleert door de Whips het functioneren van de afgevaardigde in het Lagerhuis. Dissidente leden kan door uitstoting uit de fractie het adequaat functioneren in het Lagerhuis vrijwel onmogelijk gemaakt worden. Daarnaast kunnen zij, als ultieme, door de centrale partijorganisatie op te leggen sanctie, uit de partij worden gestoten. Maar ook hier verhindert het vrije mandaat dat de afgevaardigde in het Lagerhuis door de partij kan worden gedwongen zijn zetel op te geven.

Ook ten opzichte van de lokale partijorganisatie is de afhankelijkheid groot. $\mathrm{Zij}$ beslist niet alleen over de kandidaatstelling, maar heeft ook tijdens de zittingsperiode van haar kandidaat in de reselection-procedure (c.q. de dreiging daarvan) een middel om de afgevaardigde aan zich te binden. Het is daarom in het eigen belang van de betrokken afgevaardigde om zo veel mogelijk rekening te houden met de belangen van zijn district. De rol van de kiezers hierbij is in feite beperkt tot het instemmen met de keuze van kandidaten die door de partijen is gemaakt, al leidt het fenomeen van de constituency surgery tot meer contact met de volksvertegenwoordiger en grotere tevredenheid over diens functioneren dan elders.

In het tegenwoordige staatsrecht lijkt het vrije mandaat van de afgevaardigde in de volksvertegenwoordigende lichamen van weinig waarde meer te zijn. De volksvertegenwoordiger functioneert binnen een strikt fractieverband en is voor zijn verkiezing en verdere politieke carrière afhankelijk van zijn partij. Absolute onafhankelijkheid van de volksvertegenwoordiger is daarom onvoorstelbaar. In het algemeen overheerst dan ook de indruk dat het vrije mandaat slechts een restfunctie toekomt. Het verhindert dat vrijwillige binding ontaardt in onvrijwillige binding; de volksvertegenwoordiger kan door niemand tot zetelafstand worden gedwongen.

De verdienste van de restfunctie-gedachte is dat zij door in zekere mate bindingen van de volksvertegenwoordiger toe te laten, de constitutionele 
theorie en de staatkundige praktijk dichter bijelkaar brengt. Een beperking tot de restfunctie doet het vrije mandaat echter te weinig eer aan. In de eerste plaats vormt het vrije mandaat een belangrijke grens van openbare orde voor het interne organisatierecht van politieke partijen. Het vrije mandaat ziet op alle situaties waarin sprake is van een (dreigend) conflict tussen volksvertegenwoordiger en zijn partij, zonder dat meteen de zware sanctie van zetelafstand wordt ingeroepen. Het biedt de volksvertegenwoordiger een middel zich binnen partijverband oppositioneel op te stellen. Daarnaast voorkomt het vrije mandaat dat zich binnen een politieke partij oligarchische tendensen manifesteren.

Daarnaast heeft het vrije mandaat ook een functie ten opzichte van het externe functioneren van de politieke partijen en hun parlementaire fracties. Het voorkomt vergaande benvloeding van de volksvertegenwoordiger door zijn partij en fractie en sluit daarmee uit dat deze in het besluitvormingsproces een monopoliepositie krijgen. Het vrije mandaat vormt een bevestiging van de eigen taak en verantwoordelijkheid van de volksvertegenwoordiger: het vertegenwoordigen van het hele volk.

Het vrije mandaat fungeert voorts als een organisatieprincipe voor het totaal van alle volksvertegenwoordigers in een vertegenwoordigend lichaam. Het garandeert de zelfstandigheid van dit collectief en stelt dit in staat om daadwerkelijk beslissingen te nemen, zonder obstructie van buitenaf. Zonder (grondwettelijke) erkenning van het vrije mandaat loopt een dergelijk lichaam het gevaar een congres van gebonden afgevaardigden te worden. Dit externe organisatieprincipe kent ook een interne variant: het vrije mandaat fungeert dan als waarborg voor de werkwijze en communicatie binnen het vertegenwoordigend lichaam. De rechten die een volksvertegenwoordiger bij de uitoefening van zijn taak in het parlement toekomen vinden hun ontstaan in de gedachte dat de volksvertegenwoordiger geen belemmeringen dient te ondervinden bij de vervulling van zijn taak. Het vrije mandaat vormt hiervoor de garantie.

Tenslotte creëert het vrije mandaat een verantwoordingsplicht naar de kiezers. Hoewel de relatie tussen kiezer en volksvertegenwoordiger onder het vrije mandaat beheerst wordt door het ontbreken van elke juridische binding, betekent dit niet dat de volksvertegenwoordiger niet ter verantwoording kan worden geroepen. In een representatieve democratie moeten controlemechanismen aanwezig zijn die de burgers invloed op het bestuur garanderen. De periodieke verkiezingen zijn het verantwoordingsmoment bij uitstek. Het vrije mandaat verhindert dat de volksvertegenwoordiger zich op dat moment achter zijn politieke partij en/of fractie kan verschui- 
len. Juist omdat het vrije mandaat garandeert dat de volksvertegenwoordiger bij het nemen van politieke beslissingen geheel vrij is, is hijzelf verantwoordelijk voor zijn handelen.

Het vrije mandaat is nog steeds een belangrijke waarborg voor de nodige onafhankelijkheid van de volksvertegenwoordiger. Het bestaan van politieke partijen en hun fracties in het vertegenwoordigend lichaam heeft het vrije mandaat niet louter tot een restfunctie gedegradeerd, maar juist voor een aantal nieuwe functies gezorgd. Zijn positie als ruggegraat van het vertegenwoordigend stelsel is daarmee alleen maar sterker geworden. Maar er zal vooral een mentaliteitsverandering van de volksvertegenwoordigers zelf voor nodig zijn, om het vrije mandaat in al zijn functies volledig tot zijn recht te laten komen. 


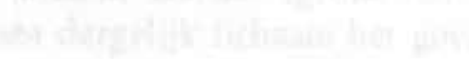

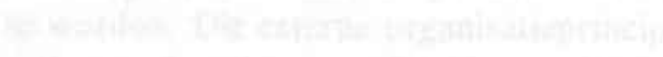

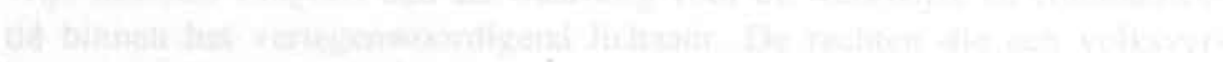
H:

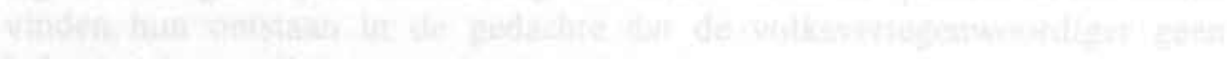

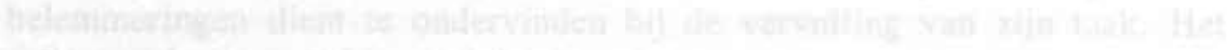

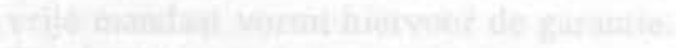

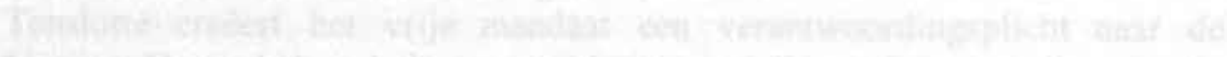

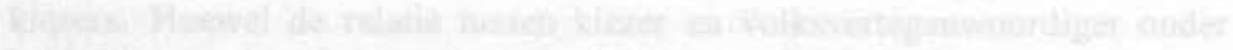

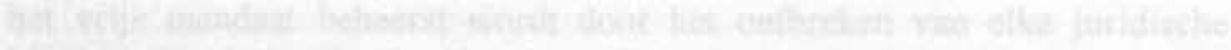

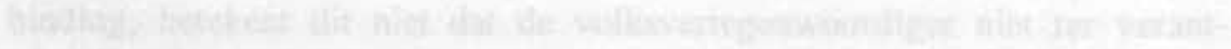

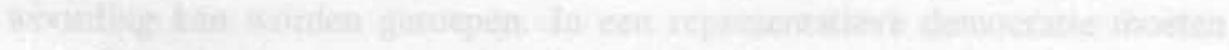

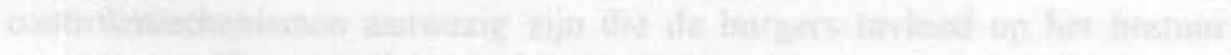

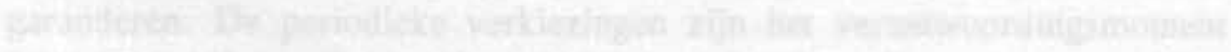

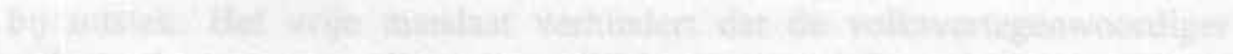
Eth the 


\section{ZUSAMMENFASSUNG}

Zielsetzung der vorliegenden Dissertation ist die Feststellung, welche Funktionen dem freien Mandat jetzt noch zugeschrieben werden können. Das freie Mandat, das die Unabhängigkeit der Abgeordneten im Parlament gewährleistet, ist das Wesensmerkmal ihrer staatsrechtlichen Position. Ihre Aufgabe zur Vertretung der gesamten Nation können die Abgeordneten ja nur dann ordnungsgemäß erfüllen, wenn sie nicht von anderen abhängig sind.

Das freie Mandat ist Bestandteil der liberalen Theorie der repräsentativen Demokratie. Diese Theorie betrachtet Volksvertreter nicht als Wählerbeauftragte sondern als Bevollmächtigte. Von den Volksvertretern wird erwartet daß sie -in Zusammenarbeit mit der Regierung- dem allgemeinen Interesse der Nation dienen und nicht dem besonderen Interesse bestimmter Gruppen oder Einzelpersonen. Im Parlament treten sie zusammen, um auf der Grundlage des Gedankenaustausches zur Beschlußfassung zu gelangen. Diese Beschlußfassung geht nicht aus dem Willen oder den Ansichten der Wähler hervor, sondern aus vernünftiger parlamentarischer Beratung.

Die liberale Theorie der repräsentativen Demokratie markiert das Entstehen des modernen Staates. Sie geht auf die Staatsauffassungen der Whigs zurück, einer politischen Bewegung in dem Parlament des Vereinigten Königreichs im 18. Jahrhundert. Die Theorie ist am deutlichsten von dem britischen Staatsmann und politischen Philosophen Edmund Burke in seiner Ansprache für die Wähler in Bristol (1774) dargelegt worden:

"Parliament is not a congress of ambassadors from different and hostile interests; which interests each much maintain, as an agent and advocate, against other agents and advocates; but Parliament is a deliberative assembly of one nation, with one interest, that of the whole; where, not local purposes, not local prejudices ought to guide, but the general good, resulting from the general reason of the whole."

Diese Ansicht über das Verhältnis zwischen Wählern und Gewählten ist zur herrschenden Lehre geworden. In nahezu allen modernen westlichen Staaten kennt die Verfassung den Ausgangspunkt, daß die Abgeordneten im Parlament ein freies Mandat haben. Häufig ist dies als ein Verbot des Auftrags im Grundgesetz vorgesehen. Damit scheint das freie Mandat seine Existenzberechtigung nachgewiesen zu haben. 
Die verfassungsmäßige Verankerung des freien Mandats aber steht auf gespanntem Fuß mit der politischen Praxis, die durch die vorherrschende Rolle der politischen Parteien von der Unabhängigkeit der Abgeordneten im Parlament wenig übrig gelassen hat. Die verfassungsmäßige Norm, daß die Wähler über die Ernennung von Volksvertretern entscheiden, tritt hinter die Praxis zurück, in der die politischen Parteien das Kandidatenund Wahlverfahren beherrschen und in der die Parteistandpunkte den Wähleransichten vorgehen. Namentlich in dem Verhältnis zur eigenen Partei und zur Fraktion bleibt den Volksvertretern wenig Unabhängigkeit. Diese Entwicklung hat große Folgen für das Funktionieren der Volksvertreter und damit auch für deren staatsrechtliche Position; nicht länger sind ihr eigenes Urteil und ihr eigenes Ermessen die entscheidenden Maßstäbe für die zu treffenden Entscheidungen, sondern die Ansichten ihrer eigenen Partei und der Fraktion. Ủberall dort, wo die liberale Theorie der repräsentativen Demokratie ein Teil der Verfassung ist, wird eine Wertminderung der Bedeutung des freien Mandats offensichtlich.

Auch in den Niederlanden ist dies der Fall. Hier markiert das freie Mandat den Übergang des Regierungssystems von dem Ständestaat der Republik der Vereinigten Niederlande zu dem des heutigen Einheitsstaates des Königreichs der Niederlande. Die verfassungsmäßige Verankerung des freien Mandats ist eine Reaktion auf das Beschlußfassungssystem der Republik. Nachdem im Jahre 1581 Philips II. abgeschworen war, waren die Rechte des Landesherrn von den Vertretern der Stände übernommen, den Staaten der einzelnen Regionen. Damit übernahmen die Staatenversammlungen der zu dem Bündnis vereinten Regionen die Souveränität. Abgeordnete der Regionalstaaten traten zur Versammlung der Generalstaaten zusammen, um über Angelegenheiten zu beschließen, die in der "Union von Utrecht" als gemeinschaftliche Angelegenheit ausgewiesen worden waren. Weil aber die Entscheidungsbefugnis in den meisten Angelegenheiten immer noch den Regionalstaaten zustand, konnten die Abgeordneten in den Generalstaaten nicht selbständig und nach eigenem Ermessen entscheiden. Immer galt vorrangig, daß keine Entscheidungen getroffen werden durften, die die autonome Position der Regionen beeinträchtigen könnten. Deshalb waren die Abgeordneten von ihren jeweiligen Kommittenten (den jeweiligen Regionalstaaten) an das imperative Mandat gebunden, das in dem Gebot von Auftrag und Rücksprache enthalten war. Dies verpflichtete die Abgeordneten der Regionalstaaten dazu, bei Abstimmungen in den Generalstaaten gemäß 
einer vorher von den Regionalstaaten erteiiten Anweisung (Auftrag) abzustimmen. Falls dieser Auftrag das zur Abstimmung stehende Thema nicht vorsehen sollte, mußten die Abgeordneten, bevor sie ihre Stimme abgaben, zu ihren Kommittenten zurückkehren, um nach Beratung (Rücksprache) einen neuen Auftrag zu erhalten.

Das Gebot von Auftrag und Rücksprache war ursprünglich eine Regel des Gewohnheitsrechts. In dieser Eigenschaft ist es auch zum Zeitpunkt der Republik immer in Kraft gewesen, wenn auch einige Regionen dazu übergegangen sind, für ihre Abgeordneten schriftliche Anweisungen zu erstellen, damit in bezug auf ihre (den Regionalstaaten untergeordnete) Position Deutlichkeit bestand.

Das Gebot von Auftrag und Rücksprache war, bestimmt im 18. Jahrhundert, fatal für das Beschlußfassungsverfahren in den Generalstaaten. Es war die wichtigste Ursache für die äußerst langsame und mühselige Beschlußfassung auf der Zentralebene. Die Regionen hielten weiterhin strikt fest an der Union von Utrecht, um auf diese Weise weitestgehend ihre Selbständigkeit zu wahren. Dies machte die Republik faktisch unregierbar. Die Versammlung der Generalstaaten hatte mehr den Charakter des Kongresses der Abgeordneten als der gesetzgebenden Versammlung. In der Versammlung der Generalstaaten konnte ohne das Einverständnis der Regionalstaaten fast nichts entschieden werden. Falls die Aufträge der Abgeordneten der einzelnen Regionen divergierten, erfolgte die Aussetzung der Versammlung, um es ihnen zu ermöglichen, zu ihren Regionalstaaten zurückzukehren um Rücksprache zu halten. Das Verfahren von Rücksprache und etwaiger Erneuerung des schriftlichen Auftrags wurde erst beendet, wenn die Generalstaaten zur einstimmigen Entscheidung gelangten.

Die Errichtung der Batavischen Republik im Jahre 1795 setzte der Macht der Regionen ein Ende und damit dem lähmenden System der Beschlußfassung in der Republik der Vereinigten Niederlande. Nunmehr erhielten die Generalstaaten die Souveränität. Die Mitglieder der Generalstaaten waren nicht mehr die lose Versammlung von Unterhändlern, in der jeder nur die eigene Region vertrat, sondern eine Einheit, die auf die Vertretung der Interessen des gesamten Staates ausgerichtet war. Aus diesem Grunde hatten sie ein freies Mandat: Sie mußten ohne Auftrag und Rücksprache abstimmen. Unter dem Einfluß der Entwicklungen in Frankreich wurden diese Grundsätze im Jahre 1798 in die erste Verfassung des neuen Staates 
aufgenommen, womit die liberale Theorie der repräsentativen Demokratie in das niederländische Staatsrecht eingetreten war. Mit Ausnahme der Staatsregelung von 1801 sind seitdem in jeder Verfassung beziehungsweise Staatsregelung die Grundsătze dieser Theorie durch Bestimmungen im Sinne der gegenwärtigen Artikel 50 und 67 Absatz 3 des niederländischen Grundgesetzes zum Ausdruck gebracht worden.

Obwohl dies nicht in der Formulierung dieser Bestimmungen zum Ausdruck gebracht worden ist, haben sie seit der Bildung des Königreichs der Niederlande bei den wichtigsten Grundgesetzänderungen immer eine neue Bedeutung erhalten. Im Jahre 1814 wurde mit der Bestimmung, daß die Generalstaaten das ganze niederländische Volk vertreten, und mit dem Verbot von Auftrag und Rücksprache die Errichtung des Einheitsstaates bestätigt und eine Rückkehr zu den Praktiken zur Zeit der Republik der Vereinigten Niederlande vermieden. Bei der Grundgesetzänderung des Jahres 1848 war der Einheitsstaat institutionalisiert, so daß die Vertretungsbestimmung als als Ausdruck des Einheitsstaatsgedankens von der Praxis und den Änderungen im Grundgesetz genaugenommen überflüssig gemacht wurde. Thre Bedeutung evolvierte denn auch zur Darlegung der Grundlage der Generalstaaten: Die Bildung einer Widerspiegelung der Wählerschaft. Das Verbot von Auftrag und Rücksprache wurde beibehalten, weil man befürchtete, daß die Wähler die zentrale Beschlußfassung beeinträchtigen würden, indem sie ihren Volksvertretern Bindungen auferlegen würden. Nach der Grundgesetzänderung des Jahres 1917 gab die Vertretungsbestimmung zwar immer noch die Grundlage der Generalstaaten an, doch änderte sich dies in die Bildung einer Widerspiegelung der politischen Parteien. Die Verbotsbestimmung bekam dabei die Funktion, weitgehender Einflußnahme der politischen Parteien auf den individuellen Volksvertreter entgegenzuwirken. Im Jahre 1983 ist die Funktion der Verbotsbestimmung -aus dem der Rücksprache-Aspekt gestrichen wurde- namentlich mit der Rolle der parlamentarischen Fraktionen in Zusammenhang gesetzt worden. Obwohl das Verbot jede Anweisung betrifft, hat sich der Schwerpunkt auf den Aspekt des Fraktionszwangs für die Mitglieder der Generalstaaten verlegt. So wird das Ergebnis einer abgehaltenen Abstimmung nicht beeinflußt, wenn sich ein Mitglied der Generalstaaten dem Fraktionszwang entzieht und anders abstimmt, als dies in der Fraktion vereinbart worden ist.

Im niederländischen Staatsrecht herrscht die Ansicht vor, daß das Verbot des Auftrags nur noch eine Restfunktion hat. Es wird anerkannt, daß der individuelle Volksvertreter sehr abhängig geworden ist, namentlich von 
seiner Partei und seiner Fraktion, jedoch geht diese Abhängigkeit nicht so weit, daß ein Volksvertreter zum Rücktritt gezwungen werden kann. Dies ist eine Entscheidung des Volksvertreters selbst. In der Möglichkeit, selbst eine eigene Entscheidung zu treffen, liegt die Restfunktion des Verbots des Auftrags.

Im deutschen Staatsrecht ist eine ähnliche Entwicklung des freien Mandats zu beobachten. Auch hier sind im Laufe des 19. Jahrhunderts die Grundsätze der liberalen Theorie der repräsentativen Demokratie in der Verfassung verankert. Die Artikel 20 und 38 des Grundgesetzes (GG) sind dafür die modernen Exponenten. Mit der Kernbestimmung "Alle Staatsgewalt geht vom Volke aus" erklärt das Grundgesetz in Artikel 20 Absatz 2 die Lehre der Volkssouveränităt zum Ausgangspunkt der deutschen Staatsordnung. Mit der Bestimmung des Artikel 38 Absatz 1 GG, daß die Bundestagsabgeordneten "Vertreter des ganzen Volkes, an Aufträge und Weisungen nicht gebunden und nur ihrem Gewissen unterworfen" sind, erklärt sich das Grundgesetz für das freie Mandat. Damit wird an die auch in Deutschland bestehende verfassungsmäßige Tradition des Verbots des Auftrags angeschlossen.

Die Bestimmung des Artikels 38 Absatz 1 GG erteilt den Abgeordneten einen eigenen staatsrechtlichen Status, bei dem die Freiheit einer der Kernbegriffe ist. Dies wird insbesondere mit der Unabhängigkeit und der Unübertragbarkeit des Mandats betont. Er ist nicht an irgendwelche Weisungen gebunden und kann sich jederzeit auf seine Gewissensfreiheit berufen.

Im Gegensatz zu den meisten Grundgesetzen anderer Staaten erkennt das deutsche Grundgesetz an, daß im modernen Versorgungsstaat das Bestehen und das Funktionieren der politischen Parteien eine notwendige Voraussetzung für das demokratische und effektive Funktionieren der Staatsordnung ist. Die politischen Parteien bilden die Mittlerstelle zwischen dem Volk und dem Staat. Sie haben eine spezifische Aufgabe, die in Jer Mitwirkung bei der politischen Willensbildung des Volkes gelegen ist (Art. 21 GG). Die Anerkennung der Rolle der politischen Parteien in der Staatsordnung ist faktisch die Anerkennung des Bestehens des modernen Parteienstaates.

Der Auftrag in Art. 21 GG für die politischen Parteien zur Mitwirkung bei der politischen Willensbildung des Volkes wird in erheblichem Umfange von den Vertretern dieser Parteien im Bundestag ausgeführt. Gleichzeitig 
sind diese Vertreter infolge der Bestimmungen des Paragraphen 38 GG auch unabhängige Vertreter des gesamten Volkes. Damit erzeugt das GG ein Spannungsfeld zwischen der Position des Abgeordneten als eines unabhängigen Volksvertreters und der Position des Abgeordneten als des Exponenten seiner Parteiorganisation. Durch diese verfassungsrechtliche Doppelfunktion der Abgeordneten als Vertreter des gesamten Volkes und als Exponenten einer politischen Partei macht das Grundgesetz ein Spannungsverhältnis zwischen Art. 21 GG und Art. 38 GG sichtbar. Dies kann gelöst werden, indem die heutige Funktion und den heutigen Zusammenhang der beiden Bestimmungen zu betrachten. Die politischen Parteien müssen nicht als eine Behinderung der Unabhängigkeit des einzelnen Volkswertreters angesehen werden, sondern gerade als eine wichtige Voraussetzung für deren Funktionieren. Wenn die politischen Parteien durch die parlamentarischen Tätigkeiten ihrer Abgeordneten bei der politischen Willensbildung mitwirken, müssen sie das freie Mandat des einzelnen Vertreters respektieren. Dieses Mandat bezweckt nicht, den Abgeordneten vollständig unabhängig von seiner Partei oder Fraktion zu machen. Art. $38 \mathrm{GG}$ ist keine Ausnahme von Art. $21 \mathrm{GG}$ in dem Sinne, daß die politischen Parteien in keiner Weise ihre Abgeordneten im Bundestag beeinflussen dürften. Die Beeinflussung von Volksvertretern durch die politischen Parteien ist nun gerade einer der Wege, auf denen die Parteien ihre verfassungsmäßige Aufgabe der Mitwirkung beider politischen Willensbildung ausführen können. Art. $38 \mathrm{GG}$ verhindert jedoch, daß die Extremkonsequenz des Parteienstaat-Gedankens eintreten kann, indem er ein Monopol der politischen Parteien bei der Willensbildung des Volkes untersagt. Wie in den Niederlanden hat das freie Mandat im deutschen Staatsrecht denn auch namentlich eine Restfunktion.

Das Vereinigte Königreich zeigt ein einigermaßen anderes Bild, obwohl auch hier gilt, daß das freie Mandat namentlich auf seine Restfunktion beschränkt zu sein scheint. Die Begründung des Einheitsstaates ging hier (wenigstens was England und Wales anbelangt) dem Entstehen der liberalen Theorie der repräsentativen Demokratie weit voraus, geschweige denn ihrer verfassungsmäßigen Bestätigung. Im Vereinigten Königreich war das Entstehen der liberalen Theorie denn auch namentlich eine Reaktion auf die politische Praxis. Die Ansicht, daß die Abgeordneten im Unterhaus Vertreter des ganzen Volkes waren und über ein freies Mandat verfügten, bestand bereits geraume Zeit, bevor die Whigs sie als Theorie annehmen sollten. Seit dem 15. Jahrhundert hatte diese Auffassung eine allmähliche 
Entwicklung erfahren, bevor sie Jahrhunderte später, namentlich durch den Einfluß von Burke, zur herrschenden Doktrin wurde.

Die Flexibilität der britischen Verfassung hat jedloch die liberale Theorie einigermaßen in den Hintergrund gedrängt. Narnentlich durch den gewachsenen Einfluß der politischen Parteien hat sich im Laufe dieses Jahrhunderts der Vertretungsgedanke im britischen Staatsrecht geändert. Dem liegt nicht länger ein individuelles Konzept über Vertretung im Staatsrecht zugrunde, wie dieses durch das freie Mandat zum Ausdruck kommt, sondern es wird anerkannt, dafi das Bestehen politischer Parteien mit ihrer starken Parteidisziplin zur Folge hat, daß der individuelle Volksvertreter sein Stimmverhalten auf die Ansicht der Partei ausrichtet. Diese 'theory of party representation' hängt eng mit der mandate doctrine zusammen, der Ansicht, daß die politischen Parteien bei Wahlen mit klaren Vorschlägen in bezug auf die zu betreibende Politik aufwarten müssen: Für die Ausführung dieser Vorschläge bekommen sie, wenn sie die Wahlen gewinnen, ein Mandat von den Wählern.

Durch dieses abweichende, der politischen Praxis angepaßte Konzept über die Vertretung im Staatsrecht bleibt dem britischen Volksvertreter eine noch geringere Unabhängigkeit als dem niederländischen oder deutschen. Namentlich wenn er Mitglied der Regierungspartei ist, ist dies der Fall. Die Fraktion kontrolliert durch die Whips das Funktionieren des Abgeordneten im Unterhaus. Dissidenten kann durch Ausschluß aus der Fraktion das adäquate Funktionieren im Unterhaus nahezu unmöglich gemacht werden. Darüber hinaus können sie als letztendliche von der zentralen Parteiorganisation aufzuerlegende Sanktion aus der Partei ausgeschlossen werden. Auch hier aber verhindert das freie Mandat, daß der Abgeordnete im Unterhaus von der Partei zum Rücktritt gezwungen werden kann.

Auch gegenüber der lokalen Parteiorganisation ist die Abhängigkeit groß. Sie entscheidet nicht nur über die Kandidatur, sondern hat auch während der Mandatsperiode ihres Kandidaten in dem 'reselection'-Verfahren (beziehungsweise mit deren Androhung) ein Mittel, den Abgeordneten an sich $z u$ binden. Es liegt deshalb im eigenen Interesse des betreffenden Abgeordneten, weitestgehend die Interessen seines Bezirks zu berücksichtigen. Die Rolle der Wähler ist dabei faktisch auf die Zustimmung zur Wahl der Kandidaten durch die Parteien beschränkt, obwohl des Phänomen der 'constituency surgery' zu größerem Kontakt zum Volksvertreter und zur größeren Zufriedenheit mit seinem Funktionieren leitet als dies anderswo der Fall ist. 
In dem gegenwärtigen Staatsrecht scheint das freie Mandat des Abgeordneten in den Volksvertretungsorganen kaum noch Wert zu haben. Der Volksvertreter funktioniert innerhalb eines strengen Fraktionsrahmens und ist für seine Wahl und seine weitere politische Laufbahn von seiner Partei abhängig. Absolute Unabhängigkeit des Volksvertreters ist deshalb unvorstellbar. Im allgemeinen herrscht denn auch der Eindruck vor, daß das freie Mandat nur eine Restfunktion erfüllt. Es verhindert, daß die freiwillige Bindung in eine unfreiwillige Bindung ausartet; der Volksvertreter kann von keinem zur Aufgabe seines Sitzes gezwungen werden.

Das Verdienst des Restfunktionsgedankens ist, daß dieser durch die Gestattung eines gewissen Maßes an Bindungen des Volksvertreters die verfassungsmäfige Theorie und die politische Praxis näher zueinander führt. Eine Beschränkung auf die Restfunktion wird dem freien Mandat jedoch ungenügend gerecht. Erstens bildet das freie Mandat eine wichtige Grenze der öffentlichen Ordnung für das interne Organisationsrecht der politischen Parteien. Das freie Mandat betrifft alle Situationen, in denen ein (drohender) Konflikt zwischen dem Volksvertreter und seiner Partei vorliegt, ohne daß sofort die schwere Sanktion des Rücktritts zur Geltung kommt. Es bietet dem Volksvertreter ein Mittel, sich innerhalb der Partei oppositionell zu verhalten. Darüber hinaus verhindert das freie Mandat, daß innerhalb einer Partei oligarchische Tendenzen eintreten.

Darüber hinaus hat das freie Mandat auch eine Funktion in bezug auf das externe Funktionieren der politischen Parteien und ihrer parlamentarischen Fraktionen. Es vermeidet weitgehende Beeinflussung des Volksvertreters durch seine Partei und Fraktion und schließt damit aus, daß diese in dem Beschlußfassungsverfahren eine Monopolstellung bekommen. Das freie Mandat bildet eine Bestätigung der eigenen Aufgabe und Verantwortung des Volksvertreters: Die Vertretung des gesamten Volkes. Das freie Mandat fungiert weiter als ein Organisationsprinzip für die Gesamtheit aller Volksvertreter in einem Vertretungsorgan. Es garantiert die Selbständigkeit dieses Kollektivs und ermöglicht es ihm, tatsächlich Entscheidungen zu treffen, ohne Behinderung von außen. Ohne die (verfassungsrechtliche) Anerkennung des freien Mandats läuft ein solches Organ Gefahr, ein Kongreß gebundener Abgeordneter zu werden. Dieses externe Organisationsprinzip kennt auch eine interne Variante: Das freie Mandat fungiert dann als Garantie für die Arbeitsweise und die Kommunikation innerhalb des vertretenden Organs. Die Rechte, die einem Volksvertreter bei der Erfullung seiner Aufgabe im Parlament zustehen, sind auf den Gedanken 
zurückzuführen, daß der Volksvertreter bei der Erfüllung seiner Aufgabe keine Behinderungen erfahren sollte. Das freie Mandat leistet dafür die Garantie. Zum Schluß erzeugt das freie Mandat eine Vertretungsverpflichtung gegenüber den Wählern. Obwohl das Verhältnis zwischen dem Wähler und dem Volksvertreter unter dern freien Mandat Jurch das Fehlen jeglicher rechtlichen Bindung beherrscht wird, bedeutet dies nicht, daß der Volksvertreter nicht zur Verantwortung gezogen werden kann. In einer repräsentativen Demokratie müssen Kontrollmechanismen vorliegen, die den Bürgern Einfluß auf die Regierung garantieren. Die regelmäßigen Wahlen sind das Verantwortungsmoment schlechthin. Das freie Mandat verhindert, daß sich der Volksvertreter zu dem Zeitpunkt hinter seiner politischen Partei und/oder Fraktion verstecken kann. Gerade weil das freie Mandat garantiert, daf der Volksvertreter bei der politischen Beschluffassung völlig frei ist, ist er selbst für sein Handeln verantwortlich.

Das freie Mandat ist immer noch ein wichtiger Garantie für die erforderliche Unabhängigkeit des Volksvertreters. Das Bestehen politischer Parteien und ihrer Fraktionen in dem Vertretungsorgan hat das freie Mandat nicht lediglich auf eine Restfunktion herabgesetzt, sondern gerade für eine Reihe neuer Funktionen gesorgt. Seine Position als das Rückgrat des Vertretungssystems ist damit nur noch stärker geworden. Es wird jedoch vor allem eine Mentalitätsänderung der Volksvertreter selbst erforderlich sein, um das freie Mandat in all seinen Funktionen in vollem Umfange zur Geltung kommen zu lassen. 


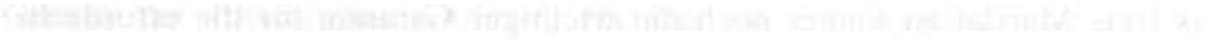

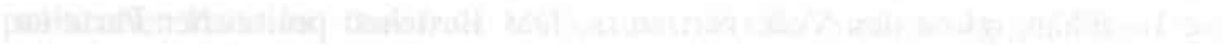

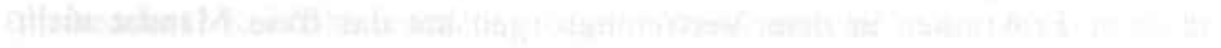

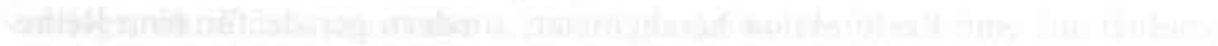

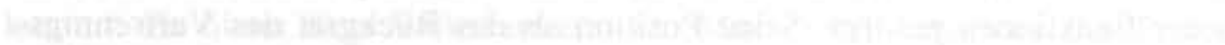

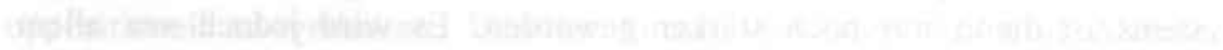

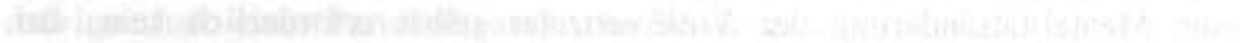

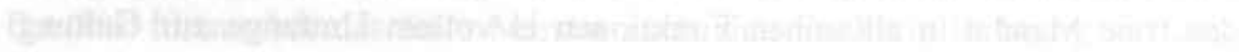

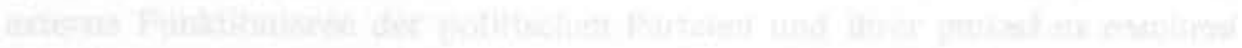

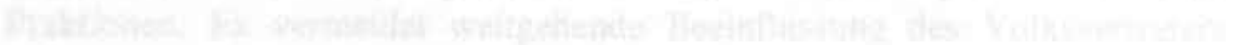




\section{SUMMARY}

The object of this dissertation is to determine what role(s) may still be ascribed to the free mandate. The free mandate, which guarantees the independence of representatives in parliament, forms the principal characteristic of their position in the constitution. The duty of representatives to represent the nation as a whole can only be exercised properly when they are not dependent upon others.

The free mandate is part of the liberal theory of representative democracy. This theory does not see the representatives of the people as mere delegates sent by their constituency, but as plenipotentiaries. The representatives of the people are expected -in cooperation with the executive- to represent the general interest of the nation and not the special interests of particular groups or individuals. In parliament they come together to take decisions on the basis of an exchange of views. This process of decision making does not ensue from the will or views of the voters, but arises from reasoned parliamentary deliberations.

The liberal theory of the representative democracy marks the coming into being of the modern state. It has its origin in the constitutional views of the Whigs, a political party in the British Parliament of the 18th century. The theory was most clearly represented by the British statesman and political philosopher Edmund Burke, one of the most influential Whigs, in his speech to the electors of Bristol (1774):

"Parliament is not a congress of ambassadors from different and hostile interests; which interests each much maintain, as an agent and advocate, against other agents and advocates; but Parliament is a deliberative assembly of one nation, with one interest, that of the whole; where, not local purposes, not local prejudices ought to guide, but the general good, resulting from the general reason of the whole."

This view of the relationship between the electors and the elected has developed into a pre-eminent doctrine. In virtually all modern western states it is a constitutional principle that representatives in parliament have a free mandate. Generally this is included the constitution as a prohibition on a mandate bound by instruction. This would appear to demonstrate the free mandate's right of existence. 
This free mandate enshrined in the constitution is however at odds with constitutional practice which, as a result of the dominant role of the political parties, leaves little independence to representatives in parliament. The constitutional norm that voters decide on the appointment of their representatives is obscured by practice in which political parties dominate nomination and election procedures for candidates and in which party viewpoints prevail over the views of the voters. There is little independence left for the representatives of the people vis a vis their own party or parliamentary party.

This development has far-reaching consequences for the way in which the representatives of the people do their job and also for their constitutional position. It is not longer the case that their own judgment and insight are decisive as the yardstick in taking decisions; it is rather the view of their own party and their parliamentary party which holds sway. In all countries where the liberal theory of representative democracy is a part of the constitution, there has been a devaluation of the free mandate.

This is also true in the Netherlands. In the Netherlands the free mandate marks the transformation of the system of government from the class-based society of the Republic of the United Netherlands to the current unitary state of the Kingdom of the Netherlands. The enshrinement in the constitution of the free mandate is a response to the decision-making system of the Republic. As a consequence of the renunciation of allegiance to Philip II in 1581 , the rights of the sovereign were assumed by the representatives of the classes, the States of the separate provinces. This meant that sovereignty devolved upon the Assembly of the States of the united provinces. The delegates of the Provincial States met at the Assembly of the State General to take decisions on matters that had been deemed common domain under the Union of Utrecht. However, because the authority to take decisions in most cases remained with the Provincial States, the delegates in the States General were not able to take decisions based on their own judgment independently. The first principle was that no decisions might be taken which would affect the autonomous position of the provinces. For that reason the delegates were bound by their principals (the respective Provincial States) to an imperative mandate which was a mandate bound by instruction and obligatory consultation. This obliged delegates to the Provincial States to vote according to the instructions given by the Provincial States beforehand in ballots of the States General. When these instructions did not take account of the subject under discussion, the 
delegates had to return to their principals before voting in order to receive new instructions following consultation.

The mandate bound by instruction and obligatory consultation was originally a rule deriving from customary law. In this context it was also still in force at the time of the Republic, although a number of provinces had gone on to issue written instructions to their representatives in order to provide increased clarity concerning their position (as subordinate to the Provincial States).

The mandate bound by instruction and obligatory consultation was, certainly in the 18 th century, fatal to the decision-making procedure in the States General. It was the most important reason for the extremely slow and difficult decision-making procedure at the central level. The provinces held strictly to the Union of Utrecht in order to retain their independence as far as possible. In fact, this made the Republic ungovernable. The assembly of the States General actually had more of the character of a conference of envoys rather than an assembly of law-makers. Virtually nothing could be decided in the conference of the States General, without the agreement of the Provincial States. When the interest of the representatives of the various provinces differed, there was a suspension of the assembly in order to give them the opportunity to return to the Provincial States for consultation. The procedure of returning for consultation and new instructions only came to an end when the States General arrived at a unanimous decision.

The establishment of the Batavian Republic in 1795 brought an end to the power of the provinces and consequently to the paralyzing system of decision-making obtaining in the Republic of the United Netherlands. The sovereignty fell to the States General. The members of the States General were no longer a loose assembly of negotiators in which each person only represented his own province but a unity; directed at promoting the interests of the country as a whole. For that reason they had a free mandate: they had to vote without instruction and consultation. These principles were included in the first constitution of the new state in 1798 under the influence of developments in France; thus the liberal theory of the representative democracy made its entrance in Dutch constitutional law. Since that time, with the exception of the constitution of 1801 , every constitution has given expression to the principles of this doctrine by provisions such as are found in the current articles 50 and 67 paragraph 3 of the Constitution. 
Since the formation of the Kingdom of the Netherlands, these provisions have, although this is not expressed in their wording, always acquired new meaning in the most important amendments to the constitution. In 1814, the provision that the States General represented the entire population of the Netherlands and the prohibition of a mandate bound by instruction and consultation gave force to the establishment of the unitary state and prevented the return to the practices of the period of the Republic of the United Netherlands. The unitary state was institutionalized in the amendment to the constitution of 1848 , so that the provision on representation, as an interpretation of the concept of the unitary state, was, strictly speaking, made superfluous by practice and the amendments to the constitution. This provision evolved to express the basic principle of the States General, i.e.: to reflect the views of the electorate. The prohibition on instruction and consultation was maintained out of fear that the voters would frustrate central decision-making by placing constraints on the representatives of the people. Following the constitutional revision of 1917 the provision on representation still expressed the basic principle of the States General, but it changed to become a reflection of the views of political parties. The prohibition was also to have the function of opposing the far-reaching influence of the political parties on the individual representative. In 1983 the working of the prohibition - from which the aspects of consultation had been removed - was primarily targeted at the role of the parliamentary party. Although the prohibition relates to any instruction, emphasis has come to bear on the restriction upon members of the States General resulting from being bound by the decisions of their parliamentary party. Accordingly, the result of a vote is not influenced when a member of the States General refuses party discipline and votes otherwise than was agreed in the parliamentary party. The dominant view in Dutch constitutional law is that the prohibition of a mandate bound by instruction only has a residual function. It is recognized that the individual representative has become very dependent, in particular, on his party and the parliamentary party, but the dependence does not go so far as to compel a representative to resign. That decision is up to the representative himself. It is in the option of taking a personal decision that the residual function of the prohibition of a bound mandate resides.

The same development can be detected in German constitutional law. Here too, in the course of the 19th century, the principles of the liberal theory of representative democracy were enshrined in the constitution. Articles 20 
and 38 of the constitution (Grundgesetz GG) are the contemporary exponents of this. With the central provision that all state power derives from the people, the constitution establishes in article 20 paragraph 2 the doctrine of the sovereignty of the people as the basis of the German constitution. With the provision in art. 38 paragraph $1 \mathrm{GG}$ that representatives in the German parliament are "Vertreter des ganzen Volkes, an Aufträge und Weisungen nicht gebunden und nur ihrem Gewissen unterworfen", the constitution puts itself on the side of the free mandate. This means adherence to the constitutional tradition (established in Germany too) of the prohibition of a bound mandate.

The provision in art. 38 paragraph 1 GG gives the representatives their own personal constitutional status, in which freedom is one of the central concepts. This is emphasized particularly by the independence and inalienability of the mandate. It is not attached to any instruction and can always appeal to freedom of conscience.

In contradistinction to most of the constitutions of other countries, the German constitution recognizes that, in the modern welfare state, the existence and operating of political parties is a necessary condition for the democratic and effective operation of the state system. The political parties are an intermediary between the people and the state. The have a specific task, in developing the political will of the people. The recognition of the role of the political parties in the state system is in fact the recognition of the existence of the modern party state.

The charge in article $21 \mathrm{GG}$ upon the political parties to work for the development of political education of the people, is largely implemented by the representatives of these parties in the German parliament. At the same time, pursuant to art. $38 \mathrm{GG}$, these representatives are also independent representatives of the whole people. This means that the constitution creates an area of tension between the position of the representative as independent representative of the people and the position of the representative as a member of his party organization. With this constitutional double role of the representatives as representatives of the whole people and of a political party, the constitution makes the 'Spannungsverhältnis' between art. $21 \mathrm{GG}$ and art. $38 \mathrm{GG}$ visible. This can be resolved by looking at the current role and relation of both provisions. The political parties must not be viewed as an obstacle to the independence of the individual representative, but rather as an important condition for their operation. When the 
political parties cooperate on the political education of the people through the parliamentary activities of their representatives, they should respect the free mandate of the individual representative. This mandate is not intended to make the representative entirely independent of his party or the parliamentary party: art. $38 \mathrm{GG}$ is no exception to art. $21 \mathrm{GG}$ and does not mean that political parties should not be able to influence their representatives in the German parliament in any way. One of the ways in which the parties implement their constitutional task of political education is precisely by influencing these representatives. Art. $38 \mathrm{GG}$ however prevents the extreme consequence of the party state idea by preventing the political parties from monopolizing political education. Just as is the case in the Netherlands, the free mandate also has a residual function in German constitutional law.

The situation in the United Kingdom is somewhat different; although, there too the free mandate would appear to be primarily reduced to a residual function. The establishment of the unitary state took place (at least as far as England and Wales is concerned) long before the coming into being of the liberal theory of representative democracy, let alone its constitutional confirmation. In the United Kingdom, the rise of liberal theory was also primarily a response to constitutional practice. The notion that members of the House of Commons represented the whole population and had a free mandate, existed long before the Whigs accepted it as a theory. This view had gradually developed since the 15th century; before, centuries later, primarily as a result of the activities of Burke, developing into the dominant doctrine.

The flexibility of the British constitution however puts liberal theory, to a degree, in the background. The concept of representation has been amended in the British constitution largely because of the increased influence of the political parties in the course of this century. An individual view of representation is no longer the foundation of the constitution here, as that is expressed in the free mandate. There is, however, a recognition that existence of political parties with their strong party discipline results in the individual representative voting in accord with the views of the party. This 'theory of party representation' relates closely to the mandate doctrine, the view that political parties in voting should come forward with clear proposals about the policy to be followed: they receive a mandate from the electorate when they win the elections to implement these proposals. 
As a result of this deviant concept of representation in constitutional law adjusted in terms of constitutional practice, the British representative is even less independent than those in the Netherlands and Germany; particularly when he is a member of the governing party. The parliamentary party organization controls the behaviour of the representatives in the House of Commons through the Whips. Expulsion from the parliamentary party can make it virtually impossible for dissident members to operate satisfactorily in the House of Commons. In addition as an ultimate sanction, they can be expelled from the party by the central party organization. But, here too, the free mandate prevents the representative from being forced to give up his seat in the House of Commons by the party.

Dependence on local party organizations is also considerable. The party organization not only nominates the candidates, but, during the period of government, it also has a means, in the reselection procedure (or the threat of it), to force the representative to do its will. It is therefore in the personal interest of the representative involved to pay as much attention as possible to the interests of his constituency. The role of the voters in this is in fact limited to agreeing with the choice of candidates made by the parties, although the phenomenon of the constituency surgery does lead to more contact with the representative of the people and more satisfaction about his role than elsewhere.

In contemporary constitutional law it would appear that the free mandate of the representative in those bodies representing the people has little remaining value. The representative operates under a strict party discipline and is entirely dependent for his election and further political career on the party. Absolute independence for the representative of the people is therefore inconceivable. In general there is also the impression that the free mandate has a mere residual function. It prevents voluntary association ending in involuntary association: the representative of the people can not be compelled to give up his seat by anyone.

The value of the residual function is that by allowing a certain degree of restriction on the representative it brings constitutional theory and constitutional practice closer to one another. Its limitation to the status of a residual function however is rather unfair to the free mandate. In the first place, the free mandate forms an important public order boundary in the internal organization of political parties. The free mandate applies in all situations where there is a question of a (threatening) conflict between the 
representative and his party, without recourse immediately being sought to the serious sanction of resignation. It offers the representative a means of playing an oppositional role within his party. In addition, the free mandate prevents oligarchic tendencies developing within political parties.

Furthermore, the free mandate also has a role in respect of the external operation of the political parties and the parliamentary parties. It prevents undue influence on the representative by his party and the parliamentary party and prevents them from acquiring a monopoly position in the decision-making process. The free mandate is a confirmation of the personal duty and responsibility of the representatives: to represent the whole people.

The free mandate operates as an organizational principle for all representatives in a representative body. It guarantees the independence of this collective and allows it to take real decisions, without obstruction from outside. Without (constitutional) recognition of the free mandate, such a body runs the danger of becoming a group of bound representatives. This external principle of organization also has an internal variant: the free mandate operating as a guarantee for methods and communication inside the representative body. The rights of the representative of the people in carrying out duties in parliament have their origin in the idea that the representative should not experience impediments to carrying out his duties. The free mandate is a guarantee for this.

Finally the free mandate creates a duty responsibility to the voters. Although the relationship between the voter and representative under the free mandate is not governed by any law. This does not mean that the representative cannot be called to account. In a representative democracy mechanisms of control must be present to guarantee the citizen influence upon government. The periodic elections are the moment of truth, par excellence. The free mandate prevents the representative from hiding behind his political party and/or parliamentary party at that time. Precisely because the free mandate guarantees that, in taking political decisions, the representative is entirely free, he is himself responsible for his activities.

The free mandate is still an important guarantee for the necessary independence of the representative of the people. The existence of political parties and their parliamentary groups in the representative body has not reduced the free mandate to a purely residual function, but has in fact brought a number of new roles into being. His position as the backbone of the representative system is thereby only made stronger. However, particularly 
a change of attitude among representatives will be necessary to ensure that the free mandate comes fully into its own. 


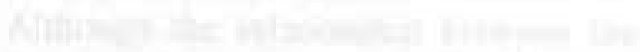

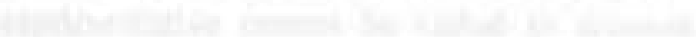




\section{GERAADPLEEGDE LITERATUUR}

Algemene bepalingen van administratief recht (rapport ABAR), 5e druk, Alphen aan den Rijn 1984

N. Achterberg, Parlamentsrecht, Tübingen 1984

G.B. Adams, Constitutional history of England, 6e druk, bewerkt door R.L. Schuyler, Londen 1938

A. Adonis, Parliament today, Manchester 1990

L. van Aitzema, Saken van Staet en Oorlogh, in ende omtrent de Vereenighde Nederlanden, deel 2, 's-Gravenhage 1669

W. Alfert (e.a.), Staats- und Verfassungsrecht der Bundesrepublik Deutschland, 6e druk, Witten 1989

C. Asser/W.C.L. van der Grinten, De vertegenwoordiging, deel 1, 7e druk, Zwolle 1990

J. d'Aulnis de Bourouill, De imperatieve mandaten der volksvertegenwoordigers, in: Themis 1882, pp. 416-433

P. Badura,

- Staatsrecht. Systematische Erlduterung des Grundgesetzes fü die Bundesrepublik Deutschland, München 1986

- Die parlamentarische Demokratie,

in: J. Isensee/P. Kirchhof, Handbuch des Staatsrecht der Bundesrepublik Deutschland, deel 1, Heidelberg 1987

G.W. Bannier, Grondwetten van Nederland, Zwolle 1936

J. Becker, Die wehrhafte Demokratie des Grundgesetzes,

in: J. Isensee/P. Kirchhof, Handbuch des Staatsrecht der Bundesrepublik Deutschland, deel 7, Heidelberg 1992

S.H. Beer, Modern British politics. Parties and pressure groups in the collectivist age, 3e druk, Londen 1982

H. Berington, MPs and their constituents in Britain: The history of the relationship,

in: V. Bogdanor (ed.), Representatives of the people? Parliamentarians and constituents in western democracies, Aldershot 1985 
K. von Beyme, Wandlungen des Parlamentarismus: Von Weimar nach Bonn,

in: H.-P. Schneider/W. Zeh, Parlamentsrecht und Parlamentspraxis in der Bundesrepublik Deutschland, Berlijn 1989

A.H. Birch,

- Representation, Londen 1971

- Representative and responsible government, 7e druk, Londen 1979

- The British system of government, 8e druk, Londen 1990

W. Blackstone, Commentaries on the laws of England, deel 1 (Of the rights of persons), 20e druk, Londen 1841

A.R. Bloembergen, Vertegenwoordiging, 3e druk, Alphen aan den Rijn 1986

W. Böckenförde, Demokratie als Verfassungsprinzip,

in: J. Isensee/P. Kirchhof, Handbuch des Staatsrecht der Bundesrepublik Deutschland, deel 1, Heidelberg 1987

V. Bogdanor, Introduction,

in: V. Bogdanor (ed.), Representatives of the people? Parliamentarians and constituents in western democracies, Aldershot 1985

W.A. Bonger, Problemen der demokratie, Groningen 1934.

J.C. Boogman, Rondom 1848. De politieke ontwikkeling van Nederland 1840-1858, Haarlem 1978

J. de Bosch Kemper, De staatkundige geschiedenis van Nederland tot 1830, Amsterdam 1868

P.J. Boukema, Vragen van partijrecht, Alphen aan den Rijn 1968

P.P.T. Bovend'Eert, Regeerakkoorden en regeringsprograms, 's-Gravenhage 1988

A.W. Bradley, The sovereignty of Parliament - in Perpetuity?, in: J.L. Jowell/A.D.H. Oliver, The changing constitution, $2 \mathrm{e}$ druk, Oxford 1989

R. Brazier, Constitutional practice, Oxford 1988

A.C.P. van den Broek, Recallrecht in het licht van de representatie, 'sGravenhage 1978

I. Budge/D. McKay (ed.), The changing British political system: into the 1990 s, 2 e druk, Londen 1988

J.T. Buijs,

- De Grondwet, toelichting en kritiek, Arnhem 1883

- De zelfstandigheid van het staatsrecht (rede 1876), in: Studien over staatkunde en staatsrecht, deel 2, Arnhem 1895 
F.H. van der Burg,

- Overheid en onderdaan in een representatieve democratie (preadvies VAR), Haarlem 1970

- Representatie en participatie, Deventer 1973

- Representatie, in: Werkboek staatkunde 1984-1985, Leiden 1984

- 'Quod omnes tangit ab omnibus approbetur', in: M.C. Burkens/R. Crince Le Roy, Burger en overheid, 's-Gravenhage 1984

E. Burke,

- The works of the Right Honourable Edmund Burke, 6 delen, Londen $1906 / 1907$

- An appeal from the new to the old Whigs in consequence of some late discussions in parliament relative to the reflections on the French revolution, in: Works (deel 5).

- Speech to the electors of Bristol (3 november 1774), in: Works (deel 2)

- Thoughts on the cause of the present discontents (1770), in: Works (deel 2)

- Reflections on the revolution in France and on the proceedings in certain societies in London relative to that event, in: Works (deel 4)

M.C. Burkens,

- De Bondsrepubliek Duitsland, in: L. Prakke/C.A.J.M. Kortmann (red.), Het staatsrecht van de landen der Europese Gemeenschappen, 3e druk, Deventer 1988

- Machtsvorming of representativiteit; een commentaar op het rapport van de commissie-Deetman,

in: Staatsrechtelijke vernieuwingen: commentaren op het rapport van de commissie-Deetman, Zwolle 1991

M.C. Burkens/H.R.B.M. Kummeling/B.P. Vermeulen, Beginselen van de democratische rechtsstaat, 2e druk, Zwolle 1992

R.C. van Caenegem, Geschiedkundige inleiding tot het publiekrecht, Gent 1985

H.M. Cam, Theorie und Praxis der Reprasentation im mittelalterlichen England,

in: H. Rausch (ed.), Die geschichtlichen Grundlagen der modernen Volksvertretung, deel 2, Darmstadt 1980

W. Carr, A history of Germany, 1815-1985, 3e druk, Londen 1987 
E. Coke, The institutes of the laws of England, deel IV (Concerning the jurisdiction of courts), Londen 1817 (herdruk 1985)

H.T. Colenbrander, Ontstaan der Grondwet (2 delen), 's-Gravenhage $1908 / 1909$

P.E. Converse/R. Pierce, Political representation in France, Cambridge 1986

S.W. Couwenberg, Nieuwe hoop op staatkundige en bestuurlijke vernieuwing in het fin de siecle?,

in: Staatsrechtelijke vernieuwingen: commentaren op het rapport van de commissie-Deetman, Zwolle 1991

I. Crewe, MPs and their constituents in Britain: How strong are the links?, in: V. Bogdanor (ed.), Representatives of the people? Parliamentarians and constituents in western democracies, Aldershot 1985

E. Denninger, Inleidend hoofdstuk,

in: E. Denninger e.a. (red.), Kommentar zum Grundgesetz für die Bundesrepublik Deutschland, deel 1, Neuwied/Darmstadt 1984

A.Th. van Deursen, Staatsinstellingen in de Noordelijke Nederlanden 1579 1780, in: Algemene Geschiedenis der Nederlanden, deel 5, Haarlem 1980.

A.V. Dicey, Introduction to the study of the law of the constitution, $8 \mathrm{e}$ druk, Londen 1915

K. Doehring, Das Staatsrecht der Bundesrepublik Deutschland, 3e druk, Frankfurt am Main 1984

A.H.M. Dölle, Over ongeschreven staatsrecht, Groningen 1988

A.M. Donner,

- De plaats van de Staten-Generaal in het hedendaagse staatsrecht (Preadvies Calvinistische Juristenvereniging 1961),

in: Tussen het echte en het gemaakte, Zwolle 1986

- Over representatie,

in: De mens in het recht (bundel W.F. Prins), 's-Gravenhage 1975

M. Drath, Die Entwicklung der Volksreprasentation,

in: H. Rausch (ed.), Zur Theorie und Geschichte der Repräsentation und Repräsentativverfassung, Darmstadt 1968

L. Driessen/A.J. Maris, De instructien voor de Gedeputeerden van Gelderland ter Generaliteit, in: Bijdragen en mededelingen "Vereeniging Gelre", deel 54, Arnhem 1954, pp. 333-348

Th. Ellwein/J.J. Hesse, Das Regierungssystem der Bundesrepublik Deutschland, 6e druk, Opladen 1987 


\section{D.J. Elzinga,}

- De politieke partij en het constitutionele recht, Nijmegen 1982

- Partijbinding en politieke moraliteit,

in: R.A. Koole (red.), Het belang van politieke partijen, Groningen 1984

D.J. Elzinga/C. Wisse, De parlementaire fracties (Nederlands Parlementsrecht, deel 5), Groningen 1988

Th. Erskine May,

- The constitutional history of England since the accesion of George the third, deel 1 (1760-1860), 4e druk, bewerkt door F. Holland, Londen 1912

- (Treatise on) The law, privileges, proceedings and usage of Parliament (Parliamentary practice), 20e druk, bewerkt door Ch. Gordon e.a., Londen 1983

E.J. Evans, Political parties in Britain 1783-1867, Londen 1985

R. Fawtier, Das Englische Parlament und die Franzosischen Generalstande im Mittelalter,

in: H. Rausch (ed.), Die geschichtlichen Grundlagen der modernen Volksvertretung, deel 1, Darmstadt 1980

S.J. Fockema Andreae, De Nederlandse Staat onder de Republiek, 10e druk, Amsterdam 1985

W.H. Fortin/Th. Holterman, Democratie, in: Th. Holterman/C.Riezebos/L.J.J. Rogier/G.F.M. van der Tang (red.), Algemene begrippen staatsrecht, 3e druk, Zwolle 1991

E.A. Freeman, The growth of the English constitution from the earliest times, 3e druk, Londen 1890

R. Fruin, Geschiedenis der staatsinstellingen in Nederland tot den val der Republiek, 2e druk, bewerkt door H.T. Colenbrander, 's-Gravenhage 1922 (herdruk 1980)

A.J.C.M. Gabriëls, De heren als dienaren en de dienaar als heer. Het stadhouderlijk stelsel in de tweede helft van de achttiende eeuw, 'sGravenhage 1990

P.A. Gibbons, Ideas of political representation in Parliament, 1660-1832, Oxford 1914

P.C. Gilhuis, Het referendum, Alphen aan den Rijn 1981

1.H. Gosses, Handboek tot de staatkundige geschiedenis der Nederlanden, deel 1, 4e druk, bewerkt door R.R. Post, 's-Gravenhage 1959 (herdruk 1979) 
B. Gould, The MP and constituency cases,

in: J.P. Mackintosh (ed.), People and Parliament, Westmead 1978

J.A.G. Griffith/M. Ryle, Parliament. Functions, practice and procedures, Londen 1989

D. Grimm,

- Die politischen Parteien,

in: E. Benda (e.a.), Handbuch des Verfassungsrechts der Bundesrepublik Deutschland, Berlijn 1983

- Parlament und Parteien,

in: H.-P. Schneider/W. Zeh, Parlamentsrecht und Parlamentspraxis in der Bundesrepublik Deutschland, Berlijn 1989

G.R.J. de Groot/A.A. van Rossum, Mandaat en volmacht, in: RM Themis 1993, pp. 127-141

G.H. Hagelstein,

- Het vertegenwoordigingsprincipe in de Wet Gemeenschappelijke Regelingen, in: Namens 1986, pp. 380-386

- De parlementaire commissies (Nederlands Parlementsrecht, deel 6), Groningen 1991

Handelingen van de Regering en de Staten-Generaal over de herziening der Grondwet, 1847-1848, 3 delen, 's-Gravenhage 1848/1849

Handelingen over de herziening der Grondwet, 3 delen, 's-Gravenhage 1916-1918

J. Harvey/L. Bather, The British constitution and politics, 5e druk, Londen 1983

J. Heemskerk, De prakijk onzer Grondwet, Utrecht 1881

K. Hesse, Grundzilge des Verfassungsrechts der Bundesrepublik Deutschland, 17e druk, Heidelberg 1990

J. Hijma/M.M. Olthof, Compendium van het Nederlands vermogensrecht, 4e druk, Deventer 1990

B.W. Hill, Edmund Burke. On government, politics and society, Brighton 1975

R. Hillebrand, De antichambre van het parlement. Kandidaatstelling in Nederlandse politieke partijen, Leiden 1992

J. van der Hoeven,

- De plaats van de grondwet in het consriturionele recht, Zwolle 1988

- De waarde van de grondwet, Zwolle 1962 
H. Hofmann/H. Dreier, Repräsentation, Mehrheitsprinzip und Minderheitenschutz,

in: H.-P. Schneider/W. Zeh, Parlamentsrecht und Parlamentspraxis in der Bundesrepublik Deutschland, Berlijn 1989

G.K. van Hogendorp,

- Brieven en gedenkschriften van Gijsbert Karel van Hogendorp, 7 delen, 's-Gravenhage 1866-1903

- Bijdragen tot de huishouding van staat in het Koningrijk der Nederlanden, 2e druk, Amsterdam 1864

F.L. van Holthoon, De genese van Thorbeckes organische staatsleer, in: Bijdragen en mededelingen betreffende de geschiedenis der Nederlanden, deel 101 (1986), pp. 177-201

O. Hood Philips, Constitutional and administrative law, 7e druk, bewerkt door P. Jackson, Londen 1987

A. Hoogerwerf, De geachte afgevaardigde. Over de vertegenwoordigende rol van het parlementslid, Meppel 1968

J. Hovy, Institutioneel onvermogen in de 18 eeuw, in: Algemene Geschiedenis der Nederlanden, deel 9, Haarlem 1980

F.J.A. Huart, Grondwetsherziening 1917 en 1922, Arnhem 1925

E.R. Huber, Das Kaiserreich als Epoche verfassungsstaatlicher Entwicklung,

in: J. Isensee/P. Kirchhof, Handbuch des Staatsrecht der Bundesrepublik Deutschland, deel 1, Heidelberg 1987

C.P. Ilbert, Parliament. Its history, constitution and practice, 3e druk, bewerkt door C. Carr, Londen 1948

P.W.A. Immink,

- Beschouwingen over de ontwikkeling van de begrippen volk en vertegenwoordiging,

in: Publiekrechtelijke opstellen (bundel C.W. van der Pot), Zwolle 1950

- Politieke vertegenwoordiging. Een begripsverkenning, in: Verspreide geschriften, Groningen 1967

R.J. Jackson, Rebels and Whips. An analysis of dissension, discipline and cohesion in British political parties, Londen 1968

E.H. s'Jacob, Representatie en mandaat in het politiek bestel, Groningen 1966

J. Jeger, The image of the MP, in: J.P. Mackintosh (ed.), People and Parliament, Westmead 1978 
G. Jellinek, Allgemeine Staatslehre, 3e druk, bewerkt door W. Jellinek, Berlijn 1929

W.1. Jennings, Cabinet Government, 3e druk, Cambridge 1959

J. Jowell, The rule of law today,

in: J.L. Jowell/A.D.H. Oliver, The changing constitution, 2e druk, Oxford 1989

D. Kavanagh, British politics: continuities and change, 2e druk, Oxford 1990

C. van de Kieft, De Staten-Generaal in het Bourgondisch-Oostenrijkse tijdvak (1464-1555),

in: S.J. Fockema Andreae/H. Hardenberg (red.), 500 jaren Staten-Generaal in de Nederlanden. Van Statenvergadering tot volksvertegenwoordiging, Assen 1964

O. Kimminich, Der Bundesstaat,

in: J. Isensee/P. Kirchhof, Handbuch des Staatsrecht der Bundesrepublik Deutschland, deel 1, Heidelherg 1987

J. Kingdom, Government and politics in Britain, Cambridge 1991

P. Kirchhof, Die Identitat der Verfassung in ihren unabanderlichen Inhalten,

in: J. Isensee/P. Kirchhof, Handbuch des Staatsrecht der Bundesrepublik Deutschland, deel 1, Heidelberg 1987

H.H. Klein,

- Aufgaben des Bundestages,

in: J. Isensee/P. Kirchhof, Handbuch des Staatsrecht der Bundesrepublik

Deutschland, deel 2, Heidelberg 1987

- Status des Abgeordneten,

in: J. Isensee/P. Kirchhof, Handbuch des Staatsrecht der Bundesrepublik Deutschland, deel 2, Heidelberg 1987

J.H. Kluiver, De Republiek na het bestand 1621-1650, in: Algemene Geschiedenis der Nederlanden, deel 6, Haarlem 1979

J. Kooiman, Over de Kamer gesproken, 's-Gravenhage 1976

T. Koopmans, Vergelijkend publiekrecht, 2e druk, Deventer 1986

C.A.J.M. Kortmann,

- De vrijheid van interne organisatie van de politieke partij, in: R.A. Koole (red.), Het belang van politieke partijen, Groningen 1984

- De Grondwetsherzieningen 1983 en 1987, 2e druk, Deventer 1987

- Constitutioneel recht, Deventer 1990

H. Krabbe, De moderne staatsidee, "s-Gravenhage 1915 
I. Kramnick, The rage of Edmund Burke. Portrait of an ambivalent conservative, New York 1977

H. Krüger, Allgemeine Staatslehre, 2e druk, Stuttgart 1966

J.-D. Kühne, Volksvertretungen im monarchischen Konstitutionalismus,

in: H.-P. Schneider/W. Zeh, Parlamentsrecht und Parlamentspraxis in der Bundesrepublik Deutschland, Berlijn 1989

Ph. Kunig, Parteien,

in: J. Isensee/P. Kirchhof, Handbuch des Staatsrecht der Bundesrepublik Deutschland, deel 2, Heidelberg 1987

S. Landshut, Der politische Begriff der Reprasentation,

in: H. Rausch (ed.), Zur Theorie und Geschichte der Reprasentation und Repräsentativverfassung, Darmstadt 1968

G. Leibholz,

- Das Wesen der Reprasentation und der Gestaltwandel der Demokratie im 20. Jahrhundert, 3e druk, Berlijn 1966

- Parteienstaat und repräsentative Demokratie. Eine Betrachtung zu Art. 21 und 38 des Bonner Grundgesetzes,

in: H. Rausch (ed.), Zur Theorie und Geschichte der Reprasentation und Reprasentativverfassung, Darmstadt 1968

J.P. Mackintosh, Attitudes to the representative role of Parliament (introduction),

in: J.P. Mackintosh (ed.), People and Parliament, Westmead 1978

C.B. Macpherson,

- Burke, Oxford 1980

- The political theory of possessive individualism, 13e druk, Oxford 1990

J.W. Marsh, Representational changes: the constituency MP,

in: Ph. Norton (ed.), Parliament in the 1980s, Oxford 1985

G. Marshall, Constitutional conventions. The rules and forms of political accountability, Oxford 1984

Th. Maunz/G. Dürig (e.a.), Kommentar zur Grundgesetz, losbladige uitgave, München

Th. Maunz/R. Zippelius, Deutsches Staatsrecht, 27e druk, München 1988.

O. McDonald, Parliament at work, Londen 1989

R.T. McKenzie, British political parties. The distribution of power within the Conservative and Labour parties, 2e druk, Londen 1964

M. McKisack, The parliamentary representation of the English boroughs during the Middle Ages, Londen 1932 
H. Meyer, Die Stellung der Parlamente in der Verfassungsordnung des Grundgesetzes,

in: H.-P. Schneider/W. Zeh, Parlamentsrecht und Parlamentspraxis in der Bundesrepublik Deutschland, Berlijn 1989

R. Miliband, Parliamentary socialism: A study in the politics of Labour, Londen 1961

J.S. Mill, Considerations concerning representative government, Londen 1861

O. Model, Grundgesetz fur die Bundesrepublik Deutschland, 10e druk, bewerkt door K. Müller, Köln 1987

J.P. de Monté VerLoren, Hoofdlijnen uit de ontwikkeling der rechterlijke organisatie in de Noordelijke Nederlanden tot de Bataafse omwenteling, $6 \mathrm{e}$ druk, bewerkt door J.E. Spruit, Deventer 1982

Montesquieu, De l'esprit des loix (deel 2), Parijs 1955

P. Moraw, Hoftag und Reichstag von den Anfägen im Mittelalter bis 1806 ,

in: H.-P. Schneider/W. Zeh (red.), Parlamentsrecht und Parlamentspraxis in der Bundesrepublik Deutschland, Berlijn 1989

P.L. Muller, Onze gouden eeuw. De Republiek der Vereenigde Nederlanden in haar bloeitij, Leiden 1896

C. Müller, Das imperative und freie Mandat. Überlegungen zur Lehre von der Reprasentation des Volkes, Leiden 1966

I. von Münch, Commentaar op art. $38 \mathrm{GG}$,

in: I. von Münch (red.) Grundgesetz-Kommentar (deel 2), 2e druk, München 1981

C.R. Munro, Studies in constitutional law, Londen 1987

R. Mußgnug, Zustandekommen des Grundgesetzes und Entstehen der Bundesrepublik Deutschland,

in: J. Isensee/P. Kirchhof, Handbuch des Staatsrecht der Bundesrepublik Deutschland, deel 1, Heidelberg 1987

H.R. Nord, Historische ontwikkeling en beteekenis van de representatiegedachte in het staatsrecht, Leiden 1941

Ph. Norton, Parliament in perspective, Hull 1987

C. O'Leary, The elemination of corrupt practices in British elections, 1868-1911, Oxford 1962 
D. Oliver, The parties and parliament,

in: J.L. Jowell/A.D.H. Oliver, The changing constitution, 2e druk, Oxford 1989

P.J. Oud,

- Handboek van het Nederlands gemeenterecht, Zwolle 1959

- Het constitutioneel recht van het Koninkrijk der Nederlanden, Zwolle 1947

D. Pasquuet, The origins of the House of Commons, Londen 1964

P. Paterson, Primaries: reforming the candidate selection proces, in: J.P. Mackintosh (ed.), People and Parliamem, Westmead 1978

P. Paulus, Verklaring der Unie van Utrecht, Utrecht 1775-1777

J.R. Pennock, Political representation: an overview, in: J.R. Pennock/J.W. Chapman, Representation, New York 1968 H.F. Pitkin, The concept of representation, Berkely 1967

J.R. Pole, Political representation in England and the origins of the American Republic, Londen 1966

A.F. Pollard, The evolution of Parliament, 2e druk, Londen 1934

E. Porritt/A.G. Porritt, The unreformed House of Commons: parliamentary representation before 1832, Cambridge 1903

C.W. van der Pot,

- Bestuurs- en rechtsinstellingen der Nederlandse Provincien, Zwolle 1949

- Geschiedenis der wetenschap van het Nederlandse staatsrecht sedert 1813, Amsterdam 1957

C.W. van der Pot/A.M. Donner, Handboek van het Nederlandse staatsrecht, 12e druk, bewerkt door L. Prakke (e.a), Zwolle 1989

L. Prakke, Het Verenigd Koninkrijk van Groot-Britannie en Noord-Ierland, in: L. Prakke/C.A.J.M. Kortmann (red.), Het staatsrecht van de landen der Europese Gemeenschappen, 3e druk, Deventer 1988

M. Prestwich, English politics in the thirteenth century, Basingstroke 1990 U.K. Preuß, Commentaar op art. 21 GG,

in: E. Denninger (red.), Kommentar zum Grundgesetz für die Bundesrepublik Deutschland, deel 2, Neuwied/Darmstadt 1984.

S. von Pufendorf, Die Verfassung des Deutschen Reiches, Leipzig 1877

P.G.J. Pulzer, Political representation and elections in Britain, 3e druk, Londen 1978

E. van Raalte, Het Nederlandse parlement, 7e druk, bewerkt door P.P.T. Bovend'Eert/H.R.B.M. Kummeling, 's-Gravenhage 1991 
L. Radice/E. Vallance/V. Willis, Member of Parliament: the job of a backbencher, 2e druk, Londen 1990

P.A. Ramaer, De verhouding der volksvertegenwoordigers tot hunne commintenten in de constitutionele monarchie, Leiden 1868

D. Rauschning, Das parlamentarische Regierungssystem des Grundgesetzes in der Rechtsprechung des Bundesverfassungsgerichts,

in: Ch. Starck (red.), Bundesverfassungsgericht und Grundgesetz, deel 2, Tübingen 1976

H. Reuss, Zur Geschichte der Reprasentativverfassung in Deutschland,

in: H. Rausch (ed.), Zur Theorie und Geschichte der Reprasentation und Reprdsentativverfassung, Darmstadt 1968

F.F. Ridley, There is no British constitution: a dangerous case of the emperor's clothes, in: Parliamentary Affairs, vol. 41 (1988), pp. 340-361

P. Ritterbusch, Parlamentssouveränitat und Volkssouveränitat in der Staats- und Verfassungsrechtslehre England, Leipzig 1929

R. Rose, The problem of party government, Harmondsworth 1976

J.-J. Rousseau, Du contract social ou principes du droit politique, Amsterdam 1762

W. Rudzio, Das politische System der Bundesrepublik Deutschland, Opladen 1983

M. Rush, Political recruitment, representation and participation, in: J.P. Mackintosh (ed.), People and Parliament, Westmead 1978

G.H. Sabine/Th.L. Thorson, A history of political theory, 4e druk, Hinsdale 1973

F.J. Säcker (red.), Münchener Kommentar zum Bürgerlichen Gesetzbuch, algemeen deel, 3e druk, München 1993

J.C. de Savornin Lohman, Onze constitutie, 2e druk, Utrecht 1907

G.O. Sayles,

- Representation of cities and boroughs in 1268, in: English Historical Review, vol. 40 (1925), pp. 580-585

- The functions of the medieval parliament of England, Londen 1988

M.P.C.M. van Schendelen,

- Parlementaire informatie, besluitvorming en vertegenwoordiging, Rotterdam 1975

- Over vertegenwoordiging en democratisch bestuur, in: Namens 1986, pp. 3-8. 
- Fracties en kamercommissies,

in: J.J.A. Thomassen/M.P.C.M. van Schendelen/M.L. Zielonka-Goei (red.), De geachte afgevaardigde ... Hoe kamerleden denken over het Nederlandse parlement, Muiderberg 1992

H. de Schepper, De burgerlijke overheden en hun permanente kaders 14801579, in: Algemene Geschiedenis der Nederlanden, deel 5, Haarlem 1980

B. Schmidt-Bleibtreu/F. Klein, Kommentar zum Grundgesetz für die Bundesrepublik Deutschland, 6e druk, Neuwied/Darmstadt 1983

F.E. Schnapp, Commentaar op art. 20 GG,

in: I. von Münch/Ph. Kunig (red.), Grundgesetz-Kommentar, deel 1, 4e druk, München 1992

H. Schneider, Die Reichsverfassung vom 11. August 1919,

in: J. Isensee/P. Kirchhof, Handbuch des Staatsrecht der Bundesrepublik Deutschland, deel 1, Heidelberg 1987

H.-P. Schneider, Commentaar op art. 38 GG,

in: E. Denninger e.a. (red.), Kommentar zum Grundgesetz für die Bundesrepublik Deutschland (deel 2), Neuwied/ Darmstadt 1984

Th. Schramm, Staatsrecht (deel 1), 4e druk, bewerkt door J. SchmidtTroje, Köln 1987

N.L. Schwartz, The blue guitar: political representation and community, Chicago 1988

D.D. Searing, The role of the good constituency member and the practice of representation in Britain, in: Journal of Politics, vol. 47 (1985), pp. 348-375

A. Sidney, Discourses concerning government, 3e druk, Londen 1751

P. Silk/R. Walters, How Parliament works, 2e druk, Londen/New York 1989

S. van Slingelandt, Staatkundige geschriften, Amsterdam 1784

S.A. de Smith, Constitutional and administrative law, 6e druk, bewerkt door R. Brazier, Londen 1989

Th. Smith, De Republica Anglorum: a discourse on the commonwealth of England, Cambridge 1906

C. Starck, Grundrechtliche und demokratische Freiheitsidee,

in: J. Isensee/P. Kirchhof, Handbuch des Staatsrecht der Bundesrepublik Deutschland, deel 2, Heidelberg 1987

J. von Staudinger, Kommentar zum Burgerlichen Gesetzbuch, deel 1, 12e druk, bewerkt door H. Dilcher, Berlijn 1980 
E. Stein, Commentaar op art. 20 GG (2e hoofdstuk),

in: E. Denninger (red.), Kommentar zum Grundgesetz für die Bundesrepublik Deutschland (deel 1), Neuwied/Darmstadt 1984

K. Stern, Das Staatsrecht der Bundesrepublik Deutschland (deel 1), 2e druk, München 1984 (deel 2, 1e druk München 1980)

F. Stier-Somlo, Die Verfassung des Deutschen Reichs vom 11. August 1919, Bonn 1919

M. Stolleis, Besatzungsherrschaft und Wiederaufbau deutscher Staatlichkeit 1945-1949,

in: J. Isensee/P. Kirchhof, Handbuch des Staatsrecht der Bundesrepublik Deutschland, deel 1, Heidelberg 1987

B.D.H. Tellegen, Overzicht van het tot stand komen der Grondwet van 1814 , Groningen 1912

J.J.A. Thomassen,

- Politieke strijdpunten en coalitievoorkeuren, in: M.P.C.M, van Schendelen, J.J.A. Thomassen en H. Daudt (red.), 'Leden van de Staten-Generaal...', 's-Gravenhage 1981

- Politieke representatie,

in: J.J.A. Thomassen (red.), Hedendaagse democratie, Alphen aan den Rijn 1991.

J.J.A. Thomassen/M.L. Zielonka-Goei, Het parlement als volksvertegenwoordiging,

in: J.J.A. Thomassen/M.P.C.M. van Schendelen/M.L. Zielonka-Goei (red.), De geachte afgevaardigde ... Hoe kamerleden denken over het Nederlandse parlement, Muiderberg 1992

J.R. Thorbecke,

- Narede, in: Parlementaire redevoeringen, Deventer 1870

- Historische schetsen, 2e druk, 's-Gravenhage 1872

- Aanteekening op de Grondwet, deel 1, (nieuwe) 2e druk, 's-Gravenhage 1906

R. Topf, Political change and political culture in Britain, 1959-87,

in: J.R. Gibbins (ed.), Contemporary political culture, Londen 1989

D.Th. Tsatsos/M. Morlok, Parteienrecht. Eine verfassungsrechtliche Einfiuhrung, Heidelberg 1982

G.W. Vreede, Inleiding tot eene geschiedenis der Nederlandsche diplomatie, Utrecht 1856 
E.C.S. Wade/A.W. Bradley, Constitutional and administrative law, 10e druk, Londen 1985

J. Wagenaar, Vaderlandsche historie, Amsterdam 1793

R. Wahl, Die Entwicklung des deutschen Verfassungsstaates bis 1866,

in: J. Isensee/P. Kirchhof, Handbuch des Staatsrecht der Bundesrepublik Deutschland, deel 1, Heidelberg 1987

R. Weber-Fas, Das Grundgesetz, Berlijn 1983

W.J. van Welderen Rengers/C.W. de Vries, Schets eener parlementaire geschiedenis van Nederland, deel 4, 4e druk, 's-Gravenhage 1955

H.D. van Wijk/W. Konijnenbelt, Hoofdstukken van administratief recht, 6e druk, Culemborg 1988

D. Willoweit, Deutsche Verfassungsgeschichte, München 1990

C.H.E. Wit, De strijd tussen aristocratie en democratie in Nederland, 1780-1848, Heerlen 1965

E. Witte, Politiek en democratie. Omtrent de werking van de westerse democratien in de 19de en 20ste eeuw, Brussel 1990

A. Young, The reselection of MPs, Londen 1983

W. Zeh, Gliederung und Organe des Bundestages,

in: J. Isensee/P. Kirchhof, Handbuch des Staatsrecht der Bundesrepublik Deutschland, deel 2, Heidelberg 1987

M.L. Zielonka-Goei, Werk in uitvoering: taken en werkzaamheden van kamerleden,

in: J.J.A. Thomassen/M.P.C.M. van Schendelen/M.L. Zielonka-Goei (red.), De geachte afgevaardigde ... Hoe kamerleden denken over het Nederlandse parlement, Muiderberg 1992

H.H. Zwager, De motivering van het algemeen kiesrecht in Europa, Groningen 1958 


\section{CURRICULUM VITAE}

René Kleijkers werd op 18 maart 1964 te Heerlen geboren. In 1982 behaalde hij het VWO-diploma aan het Romboutscollege te Brunssum. Vervolgens studeerde hij Nederlands Recht aan de Rijksuniversiteit Limburg, waar hij in 1983 aan de Algemene Faculteit het propaedeutisch diploma behaalde. In 1986 legde hij aan de Faculteit der Rechtsgeleerdheid het doctoraal examen af. Vervolgens was hij gedurende vijf jaren als Assistent in Opleiding (AIO) verbonden aan de vakgroep Publiekrecht van deze faculteit, waar hij zich ook bezighield met het onderzoek voor dit proefschrift. Na afloop van zijn AlO-aanstelling vervulde hij zijn militaire dienstplicht. Tijdens zijn parate diensttijd in 1992 diende hij bij het Nederlandse verbindingsbataljon dat onderdeel uitmaakt van de VN-vredesmacht in het voormalige Joegoslavië (UNPROFOR), waarvan drie maanden in Sarajevo. 


\section{NAWOORD}

In NJB 1992, p. 826 beklaagt de adjunct-secretaris van het blad zich over de droevige uitwerking die voorwoorden in proefschriften op haar hebben. Alle euforie aan de zijde van de promovendus over de voltooiing van het proefschrift "lijkt te pletter geslagen op de bodem van leed die in het voorwoord wordt ontvouwd". Die indruk, van een "treurig geploeter door moerassen van geleerdheid waarbij het een wonder mag heten dat betrokkene er nog redelijk intakt uitkomt ook", wil ik hier, al is het in een nawoord, vermijden. Ik zeg dan ook iedereen dank die op enigerlei wijze heeft bijgedragen aan de totstandkoming van dit proefschrift.

Het schrijven van een proefschrift is geen "Lijden", al zal ik op momenten wel de tegengestelde indruk hebben gewekt; ik klaag nu eenmaal graag. Een proefschrift behoort tot de meer triviale dingen van het leven. Als ik daarvan al niet tijdens mijn AIO-aanstelling doordrongen was, dan toch in ieder geval in de periode daarna. De waarde van een proefschrift wordt wel zeer relatief wanneer je in een oorlog terecht komt en je vervolgens machteloos moet toezien bij het leed dat wordt aangericht. En wanneer, na terugkeer in Nederland, maanden (jaren?) verstrijken waarin internationale organisaties zich slechts voortdurend een brevet van onvermogen geven door hun lafheid en volstrekte incompetentie en een aanvaardbare oplossing steeds moeilijker te bereiken lijkt, valt het moeilijk hiervan afstand te nemen en weer over te gaan tot de orde van dag. Wellicht dat daarom vandaag de euforie toch niet overheerst.

Maastricht, 30 augustus 1993

René Kleijkers 


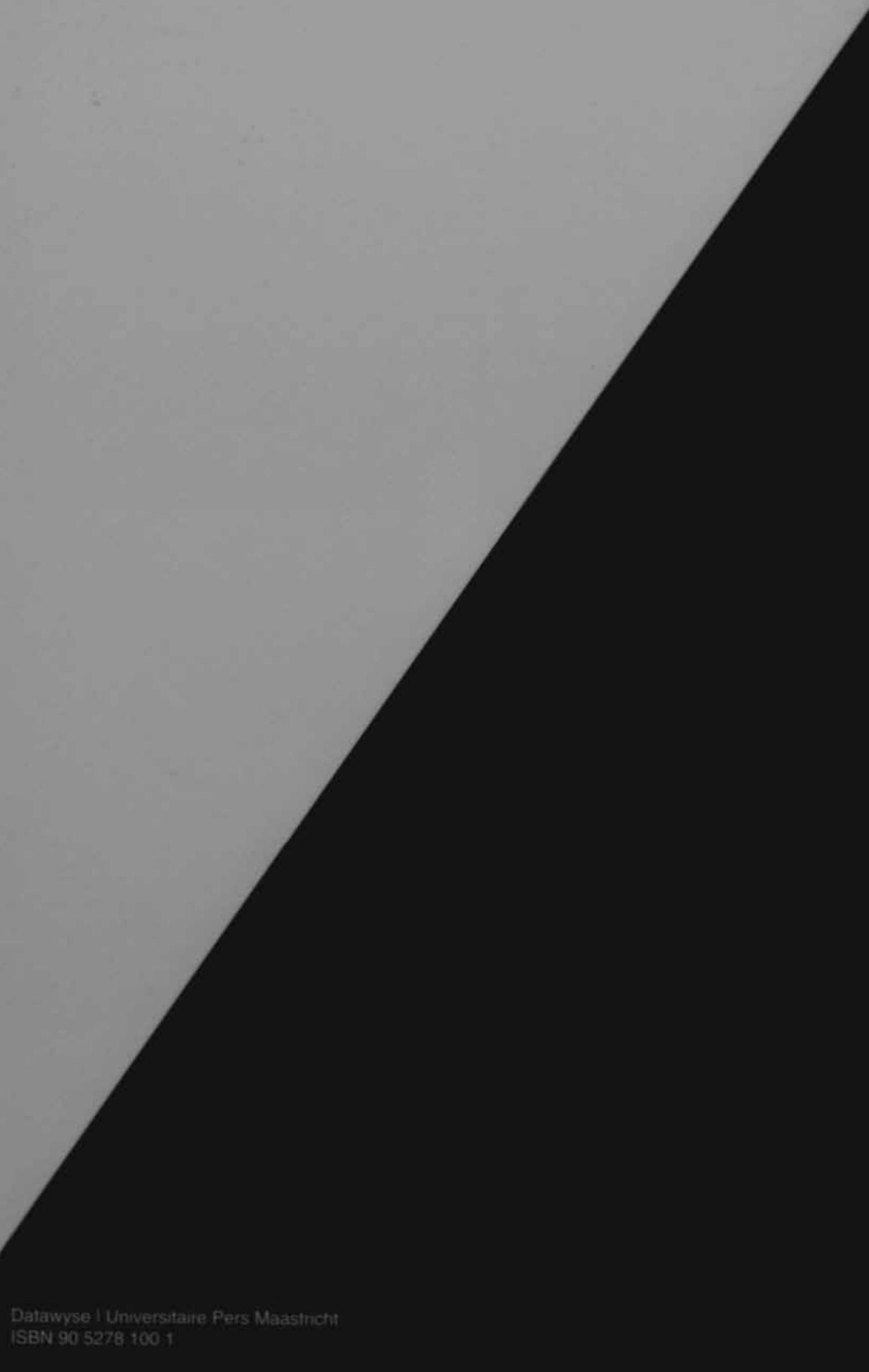

